\title{
RECORDS OF THE
}

AUSTRALIAN MUSEUM

Papers in Honour of Ken Aplin edited by

Julien Louys, Sue O'Connor and Kristofer M. Helgen
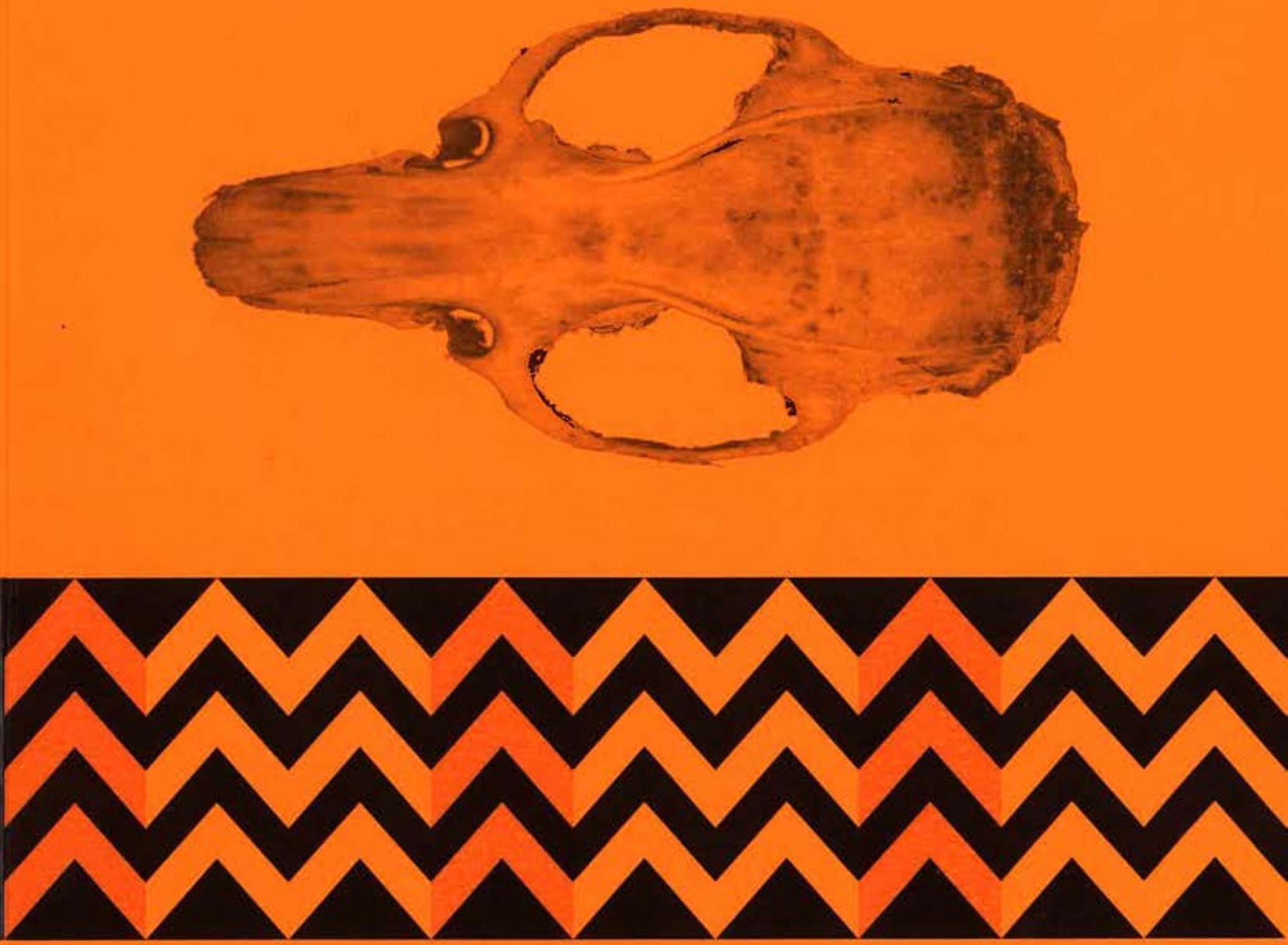


\section{Editorial Board}

Dr Shane Ahyong, ICZN COMMISSIONER

Dr Don Colgan

Dr Mark Eldridge

Dr Elena Kupriyanova

Dr Andrew Mitchell

Dr Amy Mosig Way

Dr Robin Torrence

Editor

Dr Shane McEvey

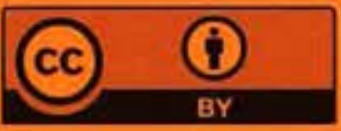

The works published by the Australian Museum in this issue are licensed under a Creative Commons Attribution 4.0 Intemational License (CC BY 4.0), which pernits unrestricted use, distribution, and reproduction in any medium, provided the original authors and source are credited.

\section{Volume 72 Number 5}

Published (print and online) 25 November 2020

Price: AU $\$ 120.00$

Printed by Roden Print \& Packaging, Sydney

ISSN 0067-1975 (print)

ISSN 2201-4349 (online)

The Australian Museum is a statutory authority of, and principally funded by, the NSW State Government.

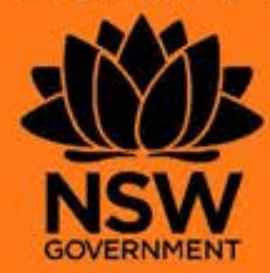

The Australian Museum houses some of the world's most important collections of Australian amimal, fossil and geological specimens and cultural objects. Research on these millions of specimens and artefacts yields insights into how our world changes through time and how its diversity can be classified, interpreted, and appreciated. This knowledge, when shared among the scientific and broader community-initially through publication-helps us understand the significance of the impact we have on our enviromment. The collections represent key research infrastructure that will have increasingly significant value through the rest of this century and into the future. From this resource, we come to know what reasonable steps society can take now for the well-being of future generations. Our responsibility is also to inspire the exploration of nature and cultures, our vision is a beautiful and sustainable natural world with vibrant and diverse cultures that we are able to see, appreciate and know deeply.

Since 1827, the results of studies on Australian Museum collections, or studies that more generally lead to a better understanding of nature and cultures in Australia and the Pacific, have been published by the Museum. Our leading science journal, Reconds of the Australian Museum, was first published in 1889. In 1999 we began releasing PDF of published articles through our open access website. In 2008 we adopted DOI registration for our online content to facilitate persistence and cross-linking in the scientific literature. In 2009 we digitized, articalized and DOI-registered the entire legacy of all science published by us since 1851 , and made that huge searchable resource permanently and freely available online. Since 2016 most authors are ORCID-registered. Since 2017 articles are ZooBank registered. PDF are extemally archived at NED (Australia's National edeposit), and, from 2019, works are licensed under a Creative Commons Attribution 4.0 International License (CC BY 4.0). To accelerate publication of peer-reviewed science we adopted (from volume 65,2014 ) a one-or severalarticle-per-issue model and we are limiting, but not abandoning, print production. There were five issues published in volume 70 (2018), seven in volume 71 (2019). All that is published in print is immediately and freely available online.

Authors are invited to submit manuscripts to the Editor. Manuscripts meeting subject and stylistic requirements outlined in the Instructions to Authors (see inside back cover) are peerreviewed by external referees to meet standards of excellence set by the Editorial Board

https://doi.org/10.3853/issn.2201-4349

Kenneth Peter Aplin (1958-2019) was one of Australia's leading vertebrate systematists, well known as an anatomist, mammalogist, herpetologist, palaeontologist, and archaeologist. Of all the many groups of animals that he studied, he was most passionate about the genus Rattus, among the most diverse and successful of all modern mammalian genera.

The cover image depicts the skull of one of the most recently described members of the genus, Rattus detentus (AM M.45608. the holotype), known only from the large and isolated island of Manus in the Admiralty Archipelago of Papua New Guinea. The species was named by Timm. Weijola, Aplin, Flannery, and Pine, in 2016. Little is known about the biology of the species, so far.

Ken developed an unusually acute "eye" for distinguishing taxa in vertebrate groups often considered very challenging to systematists, like Rattus. This skill was borne in part of extensive fieldwork, especially in New Guinea, Australia, and across Asia. This let him encounter many different groups of animals firsthand and to develop a remarkable ability for understanding them on their own ground. Where most mammalogists would bring rat traps, Ken would bring a shovel, and he would get to work in the landscape around him. digging burrows out of the ground to uncover rats that the trapper rarely sees. Of course, his careful work as a systematist and anatomist also sprang from a career spent within the world of natural history museums and their collections, the primary resource that biodiversity scientists use to develop their skills and undertake their work. From his earliest days as a scientist, he also showed an abiding interest in archaeology, and the study of faunal remains in archaeological contexts was a major strand that wove across his career. In this volume, the Australian Museum celebrates the career of an extraordinary fieldworker and muscum scientist who made enormous contributions to the study of Asia-Pacific biodiversity, present and past. 


\title{
Papers in Honour of Ken Aplin
}

\author{
edited by \\ Julien Louys, Sue O'Connor and Kristofer M. Helgen
}

Helgen, Kristofer M., Julien Louys, and Sue O'Connor. 2020. The lives of creatures obscure, misunderstood, and wonderful: a volume in honour of Ken Aplin 1958-2019

Armstrong, Kyle N., Ken Aplin, and Masaharu Motokawa. 2020. A new species of extinct False Vampire Bat (Megadermatidae: Macroderma) from the Kimberley Region of Western Australia

Cramb, Jonathan, Scott A. Hocknull, and Gilbert J. Price. 2020. Fossil Uromys (Rodentia: Murinae) from central Queensland, with a description of a new Middle Pleistocene species

Price, Gilbert J., Jonathan Cramb, Julien Louys, Kenny J. Travouillon, Eleanor M. A.

Pease, Yue-xing Feng, Jian-xin Zhao, and Douglas Irvin. 2020. Late Quaternary

fossil vertebrates of the Broken River karst area, northern Queensland, Australia

Theden-Ringl, Fenja, Geoffrey S. Hope, Kathleen P. Hislop, and Benedict J. Keaney.

2020. Characterizing environmental change and species' histories from

stratified faunal records in southeastern Australia: a regional review and a case

study for the early to middle Holocene

Brockwell, Sally, and Ken Aplin. 2020. Fauna on the floodplains: late Holocene culture and landscape on the sub-coastal plains of northern Australia

Hawkins, Stuart, Fayeza Shasliz Arumdhati, Mirani Litster, Tse Siang Lim, Gina Basile, Mathieu Leclerc, Christian Reepmeyer, Tim Ryan Maloney, Clara Boulanger, Julien Louys, Mahirta, Geoff Clark, Gendro Keling, Richard C. Willan, Pratiwi Yuwono, and Sue O'Connor. 2020. Metal-Age maritime culture at Jareng Bori rockshelter, Pantar Island, eastern Indonesia

Frankham, Greta J., Linda E. Neaves, and Mark D. B. Eldridge. 2020. Genetic relationships of Long-nosed Potoroos Potorous tridactylus (Kerr, 1792) from the Bass Strait Islands, with notes on the subspecies Potorous tridactylus benormi Courtney, 1963

Rowe, Kevin C., Helena A. Soini, Karen M. C. Rowe, Mark Adams, and Milos V. Novotny. 2020. Odorants differentiate Australian Rattus with increased complexity in sympatry

Louys, Julien, Michael B. Herrera, Vicki A. Thomson, Andrew S. Wiewel, Stephen C. Donnellan, Sue O'Connor, and Ken Aplin. 2020. Expanding population edge craniometrics and genetics provide insights into dispersal of commensal rats through Nusa Tenggara, Indonesia

Breed, William G., Chris M. Leigh, and Eleanor J. Peirce. 2020. Reproductive biology of the mice and rats (family Muridae) in New Guinea-diversity and evolution

Suzuki, Hitoshi. 2020. Evolutionary history of the subgenus Mus in Eurasia with special emphasis on the House Mouse Mus musculus

Richards, Stephen J., and Stephen C. Donnellan. 2020. Litoria aplini sp. nov., a new species of treefrog (Pelodryadidae) from Papua New Guinea

\section{Records of the Australian Museum \\ volume 72, issue no. 5 \\ 25 November 2020}

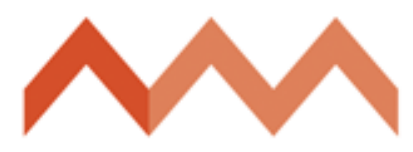





\title{
The Lives of Creatures Obscure, Misunderstood, and Wonderful: A Volume in Honour of Ken Aplin 1958-2019
}

\author{
Kristofer M. Helgen ${ }^{1,2} \mathbb{D}$, Julien Louys ${ }^{3} \mathbb{D}$, Sue O’Connor ${ }^{2,4} \mathbb{D}$ \\ ${ }^{1}$ Australian Museum Research Institute, Australian Museum, 1 William Street, Sydney, Australia \\ ${ }^{2}$ Australian Research Council Centre of Excellence for Biodiversity and Heritage, Canberra, Australia \\ ${ }^{3}$ Australian Research Centre for Human Evolution, Environmental Futures Research Institute, \\ Griffith University, Nathan Qld 4111, Australia \\ ${ }^{4}$ School of Culture, History, and Languages, College of Asia and the Pacific, \\ The Australian National University, Canberra, Australia
}

He was always a modest man, but Ken was a genius and the toughest man we knew. He was also extraordinarily generous of spirit. The way he gave of himself, his time, and his hard-won stores of knowledge, was legendary amongst his friends and colleagues. We admired him and we loved him. Ken was a world-renowned comparative anatomist, vertebrate systematist, palaeontologist, and zooarchaeologist. He was a problem solver like few we've ever met, and a fieldworker and world traveller par excellence. Ken's personal and professional outlook embraced the whole world, in all its true facets and flavours, its complexities and eccentricities - he took the world, and all of us in it, as we came. His intellectual reputation extended well beyond Australia and was known to thousands of colleagues who may never have had the chance to meet him.

Ken was funny. It was a sense of humour that helped guide him in all situations, borne in part of never taking himself, or anything else whatsoever, too seriously. Ken belonged to that rare breed of truly grounded people. To say he didn't tend to stand on ceremony is to say the least. He preferred things practical and simple. He had little or no tolerance of honours. He took things as they were, not as they purported or professed or pretended to be. His refusal to kowtow to trend could come off as rather contrarian: he scoffed at anti-malarials and smart phones, even if most of the rest of us decided they were actually pretty useful! As a scientist, a common pattern for Ken would be to produce work of the most extraordinary calibre, and then publish it in the most obscure possible places. He took a personal pride and pleasure in such things. We admired him for it, though it had the effect that his work often wasn't recognized as widely for its brilliance as it should have been. But Ken sought no glory, period. In proper Aussie style, he was a true champion of the battlers and the underdogs, wherever he found them. Even when it came to his study animals, the more despised they might be in the public eye, the more he loved them. Snakes? Good. Rats? Even better. And the bigger the better.

Ken received many accolades across a varied and deeply respected academic and professional career, which included serving as Curator of Herpetology at the Western Australian Museum and as a Research Scientist at the CSIRO. Among his honours were his appointments as Research Associate at the American Museum of Natural History in New York and the Smithsonian in Washington DC, as well as receiving the Lifetime Achievement Award of the Australian Museum, an award very rarely bestowed. Especially important were Ken's lasting contributions to the conservation of wild landscapes and wild creatures, especially in Southeast Asia and New Guinea-he understood acutely that the world was a grander place than any of us can realize in our short time here. Despite his humility, we in the scientific community could see Ken's greatness, we recognized it, and hope to honour it in a small way with this volume. We have tried to capture the truly dizzying breadth and depth of Ken's knowledge and interests with the contributions presented

Corresponding author: Kristofer M. Helgen Kris.Helgen@Australian.Museum

Received: 1 June 2020 Accepted: 26 October 2020 Published: 25 November 2020 (in print and online simultaneously)

Publisher: The Australian Museum, Sydney, Australia (a statutory authority of, and principally funded by, the NSW State Government)

Citation: Helgen, Kristofer M., Julien Louys, and Sue O'Connor. 2020. The lives of creatures obscure, misunderstood, and wonderful: a volume in honour of Ken Aplin 1958-2019. In Papers in Honour of Ken Aplin, ed. Julien Louys, Sue O'Connor, and Kristofer M. Helgen. Records of the Australian Museum 72(5): 149-160. https://doi.org/10.3853/j.2201-4349.72.2020.1734

Copyright: (c) 2020 Helgen, Louys, O'Connor. This is an open access article licensed under a Creative Commons Attribution 4.0 International License (CC BY 4.0), which permits unrestricted use, distribution, and reproduction in any medium, provided the original authors and source are credited. 


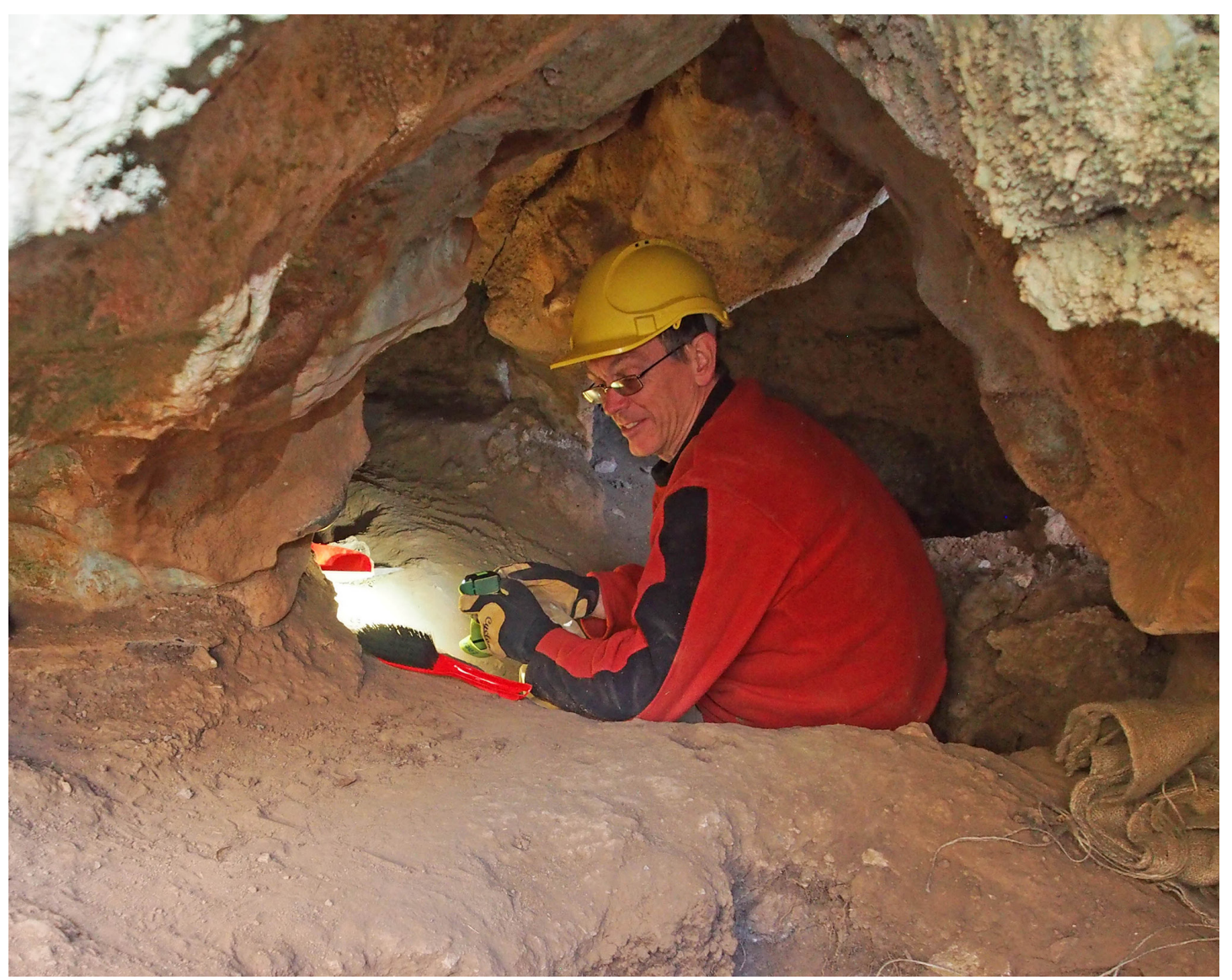

Figure 1. Ken Aplin in his element in 2016, digging a late Holocene faunal deposit in southeastern NSW. Photo courtesy of Brad Pillans.

in these pages. They describe new species of rodents, frogs, and bats, fossil and archaeological sites, and advances in rodent genetics and reproductive biology, amongst others. No topic was off bounds for Ken's piercing intellect, and even the smallest piece of scrappy bone or the tiniest crevice in a rock that harboured some animal remains was like finding treasure (Fig. 1).

Ken was a tough character. He chalked up most of the tropical diseases in the tropical disease textbook. Not the introductory textbook, but that massive reference book few physicians ever have to check out of the library. Malaria and typhus were long time traveling companions, and they came to know him as an opponent who gave as good as he got. A venomous snake bite and a broken back would not keep him down long, and were not to keep him from resuming the extraordinarily strenuous life of a New Guinea field biologist, a role he honed to perfection across four full decades of being ensconced in the natural and cultural worlds of that amazing island. So, literally backbreaking challenges could not tame him. When death stepped forward to introduce itself in his last phase of life, it did not at first realize the strength reflected straight back. Ken endured his final disease with the daunting Aplinian stoicism that all of us so admired. And that deep well of strength was to be seen not just in Ken, but in those around him who cared for him and loved him, most of all of course Ken's wife Angela and his children. It was painful for all of us to watch his fight, and his pain, but we came to be grateful for the miracle of more time than we might have had any right to expect from the man once sickness set in. We'll remember these final years with sadness but will also remember the many years when Ken was such a whirlwind of strength and verve that to be anywhere near him was to be pulled in close to a world as exciting as any that could be dreamed.

Ken left a mark that resonates deeply on so many, and in so many places around the world. In tropical forests all across the great Indonesian island of Sulawesi, there flies a fruit bat called Nyctimene cephalotes aplini. A small fruit bat, with camouflage spotted green and khaki wings, this beautiful little bat has scattered forest seeds throughout its rainforest home for millions of years. We remember too the world's smallest bandicoot, Microperoyctes aplini, an exquisite gem of an animal with dark chocolate brown stripes ornamenting soft, fluffy brown fur. This little beast haunts the edges of lakes that dot the mountain vistas of north-western New Guinea: Ken's kind of place. Other creatures, too, were named in Ken's honour, one of the highest forms of recognition in the world of natural history. When we remember Ken, we also remember these beautiful and rare creatures, and be reminded of what a rare and beautiful soul the man was. 


\section{Ken Aplin's Eponyms \\ $\dagger$ extinct taxa}

Nyctimene cephalotes aplini Kitchener, Packer, and Suyanto, 1995 (Chiroptera: Pteropodidae) Microperoyctes aplini Helgen and Flannery, 2004 (Peramelemorphia: Peramelidae)

$\uparrow$ Alormys aplini Louys, O’Connor, Mahirta, Higgins, Hawkins, and Maloney, 2018 (Rodentia: Muridae) $\uparrow$ Uromys aplini Cramb, Hocknull, and Price, 2020 (Rodentia: Muridae)

Litoria aplini Richards and Donnellan, 2020 (Anura: Pelodryadidae)

\section{Taxa Described by Ken Aplin \\ $\dagger$ extinct taxa}

\section{Ordinal group names}

Suborder Agreodontia Beck, Travouillon, Aplin, Godthelp, and Archer, 2013

Infraorder Phascolarctomorphia Aplin and Archer, 1987

Infraorder Vombatomorphia Aplin and Archer, 1987

\section{Family group names}

$†$ Family Holoclemensiidae Aplin and Archer, 1987

Family Acrobatidae Aplin, 1987

Tribe Apodemini Lecompte, Aplin, Denys, Catzeflis, Chades, and Chevret, 2008

Tribe Arvicanthini Lecompte, Aplin, Denys, Catzeflis, Chades, and Chevret, 2008

Tribe Millardini Lecompte, Aplin, Denys, Catzeflis, Chades, and Chevret, 2008

Tribe Malacomyini Lecompte, Aplin, Denys, Catzeflis, Chades, and Chevret, 2008

Tribe Praomyini Lecompte, Aplin, Denys, Catzeflis, Chades, and Chevret, 2008

\section{Genus group names}

$\dagger$ Watutia Flannery, Hoch, and Aplin, 1989

Lemdubuoryctes Kear, Aplin, and Westerman, 2016 (junior synonym of Peroryctes)

\section{Species group names}

$\dagger$ Dendrolagus noibano Flannery, Mountain, and Aplin, 1982

$\uparrow$ Protemnodon tumbuna Flannery, Mountain, and Aplin, 1982

$\uparrow$ Protemnodon nombe Flannery, Mountain, and Aplin, 1982

Litoria exophthalmia Tyler, Davies, and Aplin, 1986

Mallomys istapantap Flannery, Aplin, Groves, and Adams, 1989

Mallomys gunung Flannery, Aplin, Groves, and Adams, 1989

$\dagger$ Watutia novaeguineae Flannery, Hoch, and Aplin, 1989

Rattus timorensis Kitchener, Aplin, and Boeadi, 1991

Glaphyromorphus butlerorum Aplin, How, and Boeadi, 1993

Ramphotyphlops pilbarensis Aplin and Donnellan, 1993

Ramphotyphlops splendidus Aplin, 1998

Ramphotyphlops longissimus Aplin, 1998

Ramphotyphlops ganei Aplin, 1998

Diplodactylus klugei Aplin and Adams, 1998

Ctenotus maryani Aplin and Adams, 1998

Menetia surda cresswelli Aplin and Adams, 1998

$†$ Petauroides ayamaruensis Aplin, 1999

Dactylopsila kambuayai Aplin, 1999

Pseudantechinus roryi Cooper, Aplin, and Adams, 2000

Varanus bushi Aplin, Fitch, and King, 2007

Delma tealei Maryan, Aplin, and Adams, 2007

Delma desmosa Maryan, Aplin, and Adams, 2007

$\dagger$ Coryphomys musseri Aplin and Helgen, 2010

Microhydromys argenteus Helgen, Leary, and Aplin, 2010

Phascogale tapoatafa wambenger Rhind and Aplin, 2015

Phascogale tapoatafa kimberleyensis Aplin and Rhind, 2015

Aprasia wicherina Maryan, Adams, and Aplin, 2015

Delma hebesa Maryan, Brennan, Adams, and Aplin, 2015

Rattus detentus Timm, Weijola, Aplin, Flannery, and Pine, 2016

$\dagger$ Peroryctes aruensis (Kear, Aplin, and Westerman, 2016)

Halmaheramys wallacei Fabre, Reeve, Fitriana, Aplin, and Helgen, 2017

$\uparrow$ Macroderma handae Aplin and Armstrong, 2020 


\section{Ken Aplin's Bibliography}

\section{7}

Aplin, K. P. 1977. Preliminary faunal report. In Abercrombie Arch Shelter: An Excavation Near Bathurst, NSW, ed. I. Johnson. Australian Archaeology 6: 28-40.

https://doi.org/10.1080/03122417.1977.12093316

\section{1}

Aplin, K. P. 1981. The Kamapuk Fauna: A Late Holocene Vertebrate Faunal Sequence from the Western Highlands District, Papua New Guinea. B.A. (Hons.) thesis. The Australian National University, Canberra.

Aplin, K. P. 1981. Faunal remains from the archaeological sites in Mangrove Creek Catchment. In Mangrove Creek Dam Salvage Excavation Project, ed. V. Attenbrow, pp. 1-73. National Parks and Wildlife Service, New South Wales.

Aplin, K. P., R. Silcox, N. Stern, and E. Williams. 1981. An archaeological survey of the western shore of Lake Cawndilla, Kinchega National Park. In Darling Surveys 1, ed. J. Hope, pp. 70-88. Canberra: The Australian National University, Occasional Papers in Prehistory, Research School of Pacific Studies.

\section{3}

Aplin, K. P. 1983. Zygomaturus trilobus. A rhinoceran relative of the wombats and Euryzygoma dunense. Cheeky giant of the Pliocene. In Prehistoric Animals of Australia, ed. S. Quirk and M. Archer, pp. 58-61. Sydney: Australian Museum.

Flannery, T. F., M.-J. Mountain, and K. P. Aplin. 1983. Quaternary kangaroos (Macropodidae; Marsupialia) from Nombe Rockshelter, Papua New Guinea, with comments on megafaunal extinction in the New Guinea Highlands. Proceedings of the Linnean Society of New South Wales 107: 77-99.

\section{4}

Archer, M., and K. P. Aplin. 1984. Humans among primates: stark naked in a crowd. In Vertebrate Zoogeography and Evolution in Australasia, ed. M. Archer and G. Clayton, pp. 949-993. Perth: Hesperion Press.

Coutts, P. J. F., K. Aplin, and N. Taylor. 1984. Archaeological investigations at Captain's Point, Mallacoota. In Coastal Archaeology in Southeastern Victoria, ed. P. J. F. Coutts, pp. 1-184. Records of the Victorian Archaeological Survey, No.14.

\section{6}

Harding, H. R., K. P. Aplin, and C. D. Shorey. 1986. Cladistic analysis of marsupial sperm structure: methodological perspectives. Development, Growth and Differentiation Suppl. (1986): 70

Tyler, M. J., M. Davies, and K. Aplin. 1986. A new streamdwelling species of Litoria (Anura: Hylidae) from New Guinea. Transactions of the Royal Society of South Australia 110: 63-67.

\section{7}

Aplin, K. P. 1987. Basicranial anatomy of the early Miocene diprotodontian Wynyardia bassiana (Marsupialia: Wynyardiidae) and its implications for wynyardiid phylogeny and classification. In Possums and Opossums: Studies in Evolution, ed. M. Archer, pp. 369-391. Sydney: Royal Zoological Society of NSW.

Aplin, K. P., and M. Archer. 1987. Recent advances in marsupial systematics, with a new syncretic classification of marsupials. In Possums and Opossums: Studies in Evolution, ed. M. Archer, pp. xv-lxxii. Sydney: Royal Zoological Society of NSW.
Harding, H. R., K. P. Aplin, and C. D. Shorey. 1987. Parsimony analysis of marsupial sperm structure: a preliminary report. In New Horizons in Sperm Cell Research, ed. H. Mohri, pp. 375-385 Tokyo: Japan Science Society Press and New York: Garden and Breach Science Publishers.

Hughes, R. L., L. S. Hall, K. P. Aplin, and M. Archer. 1987. Organogenesis and fetal membranes in the New Guinea Pen-tailed Possum, Distoechurus pennatus (Acrobatidae: Marsupialia). In Possums and Opossums: Studies in Evolution, ed. M. Archer, pp. 715-724. Sydney: Royal Zoological Society of NSW.

\section{9}

Donnellan, S. C., M. Adams, and K. P. Aplin. 1989. A biochemical and morphological study of Rana (Anura: Ranidae) from the Chimbu Province, Papua New Guinea. Herpetologica 45(3): 336-343.

Donnellan, S. C., and K. P. Aplin. 1989. Resolution of cryptic species in the New Guinean lizard, Sphenomorphus jobiensis (Scincidae) by electrophoresis. Copeia 1989(1): 81-88. https://doi.org/10.2307/1445608

Flannery, T. F., K. P. Aplin, C. P. Groves, and M. Adams. 1989. Revision of the New Guinean murid genus Mallomys (Rodentia), with description of two new species from subalpine habitats. Records of the Australian Museum 41(1): 83-105. https://doi.org/10.3853/j.0067-1975.41.1989.137

Flannery, T. F., E. Hoch, and K. Aplin. 1989. Macropodines from the Pliocene Otibanda Formation, Papua New Guinea. Alcheringa 13: $145-152$. https://doi.org/10.1080/03115518908619048

\section{0}

Aplin, K. P. 1990. Basicranial Regions of Diprotodontian Marsupials: Anatomy, Ontogeny and Phylogeny. Unpublished $\mathrm{Ph} . \mathrm{D}$. thesis. University of New South Wales, Sydney.

Baverstock, P. R., T. F. Flannery, K. P. Aplin, J. Birrell, and M. Kreig. 1990. Albumin immunologic relationships of the bandicoots (Perameloidea: Marsupialia) - a preliminary report. In Bandicoots and Bilbies, ed. J. H. Seebeck, P. R. Brown, R. L. Wallis, and C. H. Kemper, pp. 13-18. Sydney: Surrey Beatty and Sons.

Harding, H. R., and K. P. Aplin. 1990. Phylogenetic affinities of the koala: a reassessment of the spermatozoal evidence. In Biology of the Koala, ed. A. Lee, K. Handasyde, and G. Sanson, pp. 1-31. Sydney: Surrey Beatty and Sons.

Hughes, R. L., L. S. Hall, M. Archer, and K. P. Aplin. 1990. Observations on placentation and development in Echymipera kalubu. In Bandicoots and Bilbies, ed. J. H. Seebeck, P. R. Brown, R. L. Wallis, and C. H. Kemper, pp. 259-270. Sydney: Surrey Beatty and Sons.

Kirsch, J. A. W., M. S. Springer, C. Krajewski, M. Archer, K. P. Aplin, and A. Dickerman. 1990. DNA/DNA hybridization studies of carnivorous marsupials. I. The intergeneric relationships of bandicoots (Marsupialia: Perameloidea). Journal of Molecular Evolution 30: 434-448. https://doi.org/10.1007/BF02101115

Springer, M. S., J. A. W. Kirsch, K. P. Aplin, and T. F. Flannery. 1990. DNA hybridization, cladistics and the phylogeny of phalangerid marsupials. Journal of Molecular Evolution 30: 298-311.

https://doi.org/10.1007/BF02100000 


\section{1}

Kitchener, D. J., K. P. Aplin, and Boeadi. 1991. A new species of Rattus from Gunung Mutis, south west Timor Island, Indonesia. Records of the Western Australian Museum 15: 445-461.

1992

Harding, H. R., and K. P. Aplin. 1992. Approaches to the study of structure-function relationships in spermatozoa. In Comparative Spermatology 20 Years After, ed. B. Baccetti, pp. 955-959. Italy: Serona Symposia Publications, Raven Press.

Mahony, M., S. C. Donnellan, and K. Aplin. 1992. Karyotypes of Australo-Papuan microhylid frogs (Anura Microhylidae). Herpetologica 48(2): 184-192.

Springer, M. S., G. McKay, K. P. Aplin, and J. A. W. Kirsch. 1992. Relationships among ringtail possums (Marsupialia: Pseudocheiridae) based on DNA hybridization. Australian Journal of Zoology 40: 423-435.

https://doi.org/10.1071/ZO9920423

\section{3}

Aplin, K. P., P. R. Baverstock, and S. C. Donnellan. 1993. Albumin immunological evidence for the time and mode of origin of the New Guinean terrestrial mammal fauna. Science in New Guinea 19: 131-145.

Aplin, K. P., and S. C. Donnellan. 1993. A new species of blindsnake, genus Ramphotyphlops, with a redescription of $R$. hamatus Storr 1982. Records of the Western Australian Museum 16: 243-256.

Aplin, K. P., and R. A. How. 1993. A window west: a perspective on Western Australian herpetology. In Herpetology in Australia. A Diverse Discipline, ed. D. Lunney and D. Ayers, pp. 337-345. Sydney: Royal Society of New South Wales. https://doi.org/10.7882/RZSNSW.1993.052

Aplin, K. P., R. A. How, and Boeadi. 1993. A new species of the Glaphyromorphus isolepis species group (Lacertilia: Scincidae) from Sumba Island, Indonesia. Records of the Western Australian Museum 16: 235-242.

Aplin, K. P., and P. A. Woolley. 1993. Notes on the distribution and reproduction of the Papuan Bandicoot, Microperoryctes papuensis (Peroryctidae, Peramelomorphia). Science in New Guinea 19: 109-112.

Colgan, D., T. F. Flannery, J. Trimble, and K. P. Aplin. 1993. Electrophoretic and morphological analysis of the systematics of the Phalanger orientalis (Marsupialia) species complex in New Guinea and the Solomon Islands. Australian Journal of Zoology 41: 355-378.

https://doi.org/10.1071/ZO9930355

\section{5}

Breed, W. G., and K. P. Aplin. 1995. Sperm morphology of murid rodents from New Guinea and the Solomon Islandsphylogenetic implications. Australian Journal of Zoology 43: $17-30$. https://doi.org/10.1071/ZO9950017

Harding, H. R., K. P. Aplin, and M. Mazur. 1995. Ultrastructure of spermatozoa of Australian Blindsnakes, Ramphotyphlops spp. (Typhlopidae, Squamata): first observations on the mature spermatozoon of scolecophidian snakes. In Advances in Spermatozoal Phylogeny and Taxonomy, ed. B. G. M. Jamieson and J.-L. Justine, pp. 385-396. Paris: Memoires Muséum nationale d'Histoire naturelle, vol. 166.

\section{6}

Burbidge, A. A., and K. P. Aplin. 1996. Endangered: marsupial moles. Landscope 11: 34.

\section{8}

Aplin, K. P. 1998. Three new blindsnakes (Squamata: Typhlopidae) from northwestern Australia. Records of the Western Australian Museum 19: 1-12.

Aplin, K. P. 1998. Vertebrate zoogeography of the Bird's Head of Irian Jaya, Indonesia. In Perspectives on the Bird's Head Peninsula of Irian Jaya, Indonesia: Proceedings of an Interdisciplinary Conference, ed. J. Miedema, C. Odé, and M. A. C. Dam, pp. 803-890. Leiden: Rodopi Publishers.

Aplin, K. P., and M. Adams. 1998. New species and subspecies of gekkonid and scincid lizards (Squamata) from the Carnarvon Basin region of Western Australia: morphological and genetic discrimination. Journal of the Royal Society of Western Australia 81: 201-223.

Pasveer, J. M. and K. P. Aplin. 1998. Late Pleistocene to Recent faunal succession and environmental change in lowland New Guinea: evidence from the Bird's Head of Irian Jaya, Indonesia. In Perspectives on the Bird's Head Peninsula of Irian Jaya, Indonesia: Proceedings of an Interdisciplinary Conference, ed. J. Miedema, C. Odé, and M. A. C. Dam, pp. 891-930. Leiden: Rodopi Publishers.

\section{9}

Aplin, K. P. 1999. “Amateur" taxonomy in Australian herpetology - help or hindrance? Monitor, Journal of the Victorian Herpetological Society 10 (2/3).

Aplin, K. P., and S. C. Donnellan. 1999. An extended description of the Pilbara Death Adder, Acanthophis wellsi Hoser (Serpentes: Elapidae), with notes on the Desert Death Adder, A. pyrrhus, Boulenger, and identification of a possible hybrid zone. Records of the Western Australian Museum 19: 277-298.

Aplin, K. P., J. M. Pasveer, and W. E. Boles. 1999. Late Quaternary vertebrates from the Bird's Head Peninsula, Irian Jaya, Indonesia, including descriptions of two previously unknown marsupial species. Records of the Western Australian Museum, Supplement no. 57: 351-387.

\section{0}

Aplin, K. P., A. Paino, and L. Sleep. 2000. Building Frog Friendly Gardens. Perth: Western Australian Museum.

Cooper, N. K., K. P. Aplin, and M. Adams. 2000. A new species of false antechinus (Marsupialia: Dasyuromorphia: Dasyuridae) from the Pilbara region, Western Australia. Records of the Western Australian Museum 20: 115-136.

Donnellan, S. C., K. P. Aplin, and P. J. Dempsey. 2000. Genetic and morphological variation in Australian Christinus (Squamata: Gekkonidae): preliminary overview with recognition of a cryptic species on the Nullarbor Plain. Australian Journal of Zoology 48: $289-315$. https://doi.org/10.1071/ZO98015

McKenzie, N. L., J. K. Rolfe, K. P. Aplin, M. A. Cowan, and L. A. Smith. 2000. Herpetofauna of the southern Carnarvon Basin, Western Australia. Records of the Western Australian Museum Supplement no. 61: 335-360. https://doi.org/10.18195/issn.0313-122x.61.2000.335-360

Withers, P. C., K. P. Aplin, and Y. L. Werner. 2000. Metabolism and evaporative water loss of Western Australian geckos (Reptilia: Sauria: Gekkonomorpha). Australian Journal of Zoology 48: 111-126.

https://doi.org/10.1071/ZO99007 


\section{1}

Aplin, K. P., N. K. Cooper, R. A. How, J. B. Hutchins, R. E. Johnstone, and L. A. Smith. 2001. Introduction to the checklists of vertebrates of Western Australia. Records of the Western Australian Museum Supplement no. 63: 1-7. https://doi.org/10.18195/issn.0313-122x.63.2001.001-007

Aplin, K. P., and S. Johnson. 2001. Community involvement in the detection, surveillance and management of frog diseases: a case study from Alcoa frogWAtch, southwest Australia. In Developing Management Strategies to Control Amphibian Diseases: Decreasing the Risks Due to Communicable Diseases, ed. R. Speare, p. 47. Townsville: School of Public Health and Tropical Medicine, James Cook University.

Aplin, K. P., and P. Kirkpatrick. 2001. In pursuit of the frog fungus. Landscope 16(3): 10-16.

Aplin, K. P., and P. Kirkpatrick. 2001. Chytridiomycosis in southwest Australia: historical sampling documents the date of introduction, rates of spread and seasonal epidemiology, and sheds new light on chytrid ecology. In Developing Management Strategies to Control Amphibian Diseases: Decreasing the Risks Due to Communicable Diseases, ed. R. Speare, p. 24. Townsville: School of Public Health and Tropical Medicine, James Cook University.

Aplin, K. P., and L. A. Smith. 2001. Checklist of the frogs and reptiles of Western Australia. Records of the Western Australian Museum Supplement no. 63: 51-74.

https://doi.org/10.18195/issn.0313-122x.63.2001.051-074

\section{2}

Jacob, J., P. R. Brown, K. P. Aplin, and G. R. Singleton. 2002. Ecologically-based management of pest rodents in rice-based agro-ecosystems in southeast Asia. In Proceedings, Twentieth Vertebrate Pest Conference, Silver Legacy Resort-Casino, Reno, Nevada, March 4-7, 2002, ed. R. M. Timm and R. H. Schmidt, pp. 67-74. Davis: University of California, Davis.

O'Connor, S., K. P. Aplin, M. Spriggs, P. Veth, and L. K. Ayliffe. 2002. From savannah to rainforest: changing environments and human occupation at Liang Lemdubu, Aru Islands, Maluku (Indonesia). In Bridging Wallace's Line: The Environmental and Cultural History and Dynamics of the Southeast AsianAustralian Region, ed. P. Kershaw, B. David, N. Tapper, D. Penny, and J. Brown, pp. 279-306, Advances in Geoecology Series, no. 34. Reiskirchen: Catena Verlag.

\section{3}

Aplin, K. P., P. R. Brown, J. Jacob, C. J. Krebs, and G. R. Singleton. 2003. Field methods for rodent studies in Asia and the IndoPacific. ACIAR Monograph no. 100, 223 pp. Canberra: Australian Centre for International Agricultural Research.

Aplin, K. P., T. Chesser, and J. ten Have. 2003. Evolutionary biology of the genus Rattus: profile of an archetypal rodent pest. In Rats, Mice and People: Rodent Biology and Management, ed. G. R. Singleton, L. A. Hinds, C. J. Krebs, and D. M. Spratt, pp. 487-498. ACIAR Monograph no. 96, 564 pp.

Aplin, K. P., A. Frost, N. P. Tuan, L. P. Lan, and N. M. Hung. 2003. Identification of rodents of the genus Bandicota in Vietnam and Cambodia. In Rats, Mice and People: Rodent Biology and Management, ed. G. R. Singleton, L. A. Hinds, C. J. Krebs, and D. M. Spratt, pp. 531-535. ACIAR Monograph no. 96, 564 pp.

Aplin, K. P., and G. R. Singleton. 2003. Balancing rodent management and small mammal conservation in agricultural landscapes: challenges for the present and the future. In Rats, Mice and People: Rodent Biology and Management, ed. G. R. Singleton, L. A. Hinds, C. J. Krebs, and D. M. Spratt, pp. 80-88. ACIAR Monograph no. 96, 564 pp.
Douangboupha, B., K. P. Aplin, and G. R. Singleton. 2003. Rodent outbreaks in the uplands of Laos: analysis of historical patterns and the identity of nuu khii. In Rats, Mice and People: Rodent Biology and Management, ed. G. R. Singleton, L. A. Hinds, C. J. Krebs, and D. M. Spratt, pp. 103-111. ACIAR Monograph no. 96,564 pp.

Khamphoukeo, K., B. Douangboupha, K. P. Aplin, and G. R. Singleton. 2003. Pest and non-pest rodents in the upland agricultural landscape of Laos: a progress report. In Rats, Mice and People: Rodent Biology and Management, ed. G. R. Singleton, L. A. Hinds, C. J. Krebs, and D. M. Spratt, pp. 284-289. ACIAR Monograph no. 96, 564 pp.

Lan, L.P., K. P. Aplin, N. M. Hung, N. V. Quoc, H. V. Chien, N. D. Sang, and G. R. Singleton. 2003. Rodent communities and historical trends in rodent damage in the Mekong Delta of Vietnam: establishing an ecological basis for effective pest management. In Rats, Mice and People: Rodent Biology and Management, ed. G. R. Singleton, L. A. Hinds, C. J. Krebs, and D. M. Spratt, pp. 290-296. ACIAR Monograph no. 96, 564 pp. Singleton, G. R, L. Smythe, G. Smith, D.M., Spratt, K. P. Aplin, and A. L. Smith. 2003. Rodent diseases in Southeast Asia and Australia: inventory of recent surveys. In Rats, Mice and People: Rodent Biology and Management, ed. G. R. Singleton, L. A. Hinds, C. J. Krebs, and D. M. Spratt, pp. 25-30. ACIAR Monograph no. 96, 564 pp.

\section{4}

Joshi, R. C., E. B. Gergon, K. P. Aplin, G. R. Singleton, A. R. Martin, J. C. Cabigat, A. Cayong, N. V. Desamero, and L. S. Sebastian. 2004. Rodents and other small mammals in Banaue and Hungduan rice terraces, Philippines. International Rice Research Notes 29(1): 44-46.

Mahirta, K. P. Aplin, D. Bulbeck, W. E. Boles, and P. Bellwood. 2004. Pia Hudale Rockshelter: a terminal Pleistocene occupation site on Roti Island, Nusa Tenggara Timur, Indonesia. In Quaternary Research in Indonesia, ed. S. Keates and J. M. Pasveer, pp. 361-380. Modern Quaternary Research in South East Asia No. 18. Rotterdam: A. A. Balkema.

Rabosky, D. L., K. P. Aplin, S. C. Donnellan, and S. B. Hedges. 2004. Molecular phylogeny of blindsnakes (Ramphotyphlops) from western Australia and resurrection of Ramphotyphlops bicolor (Peters, 1857). Australian Journal of Zoology 52: 531-548. https://doi.org/10.1071/ZO04045

Suzuki, H., T. Shimada, M. Terashima, K. Tsuchiya, and K. P. Aplin. 2004. Temporal, spatial, and ecological modes of evolution of Eurasian Mus based on mitochondrial and nuclear gene sequences. Molecular Phylogenetics and Evolution 33: 626-646. https://doi.org/10.1016/j.ympev.2004.08.003

\section{5}

Aplin, K., and J. Pasveer. 2005. Mammals and other vertebrates from late Quaternary archaeological sites on Pulau Kobroor, Aru Islands, eastern Indonesia. In Archaeology of the Aru Islands, ed. S. O'Connor, P. Veth, and M. Spriggs, pp. 41-62. Terra Australis 22. Canberra: Pandanus Press. https://doi.org/10.22459/TA22.2007.03

Chinen, A. M., H. Suzuki, K. P. Aplin, K. Tsuchiya, and S. Suzuki. 2005. Preliminary genetic characterization of two lineages of black rats (Rattus rattus sensu lato) in Japan, with evidence for introgression at multiple localities. Genes and Genetic Systems 80: $367-375$. https://doi.org/10.1266/ggs.80.367

Hope, G., and K. Aplin. 2005. Environmental change in the Aru Islands. In Archaeology of the Aru Islands, ed. S. O'Connor, P. Veth, and M. Spriggs, pp. 25-40. Terra Australis 22. Canberra: Pandanus Press. https://doi.org/10.22459/TA22.2007.02 
O’Connor, S., K. Aplin, J. Pasveer, and G. Hope. 2005. Liang Nabulei Lisa: a Late Pleistocene and Holocene sequence from the Aru Islands. In Archaeology of the Aru Islands, ed. S. O'Connor, P. Veth, and M. Spriggs, pp. 125-161. Terra Australis 22. Canberra: Pandanus Press. https://doi.org/10.22459/TA22.2007.07

O’Connor, S., K. Aplin, K. Szabó, J. Pasveer, P. Veth, and M. Spriggs. 2005. Liang Lemdubu, a Pleistocene cave site in the Aru Islands. In Archaeology of the Aru Islands, ed. S. O'Connor, P. Veth, and M. Spriggs, pp. 171-204. Terra Australis 22. Canberra: Pandanus Press.

https://doi.org/10.22459/TA22.2007.09

\section{6}

Aplin, K. P. 2006. Ten million years of rodent evolution in Australasia: phylogenetic evidence and a speculative historical biogeography. In Evolution and Biogeography of Australasian Vertebrates, ed. J. R. Merrick, M. Archer, G. M. Hickey, and M. S. Y. Lee, pp. 707-744. Oatlands, Sydney: Auscipub.

Aplin, K. P., P. R. Brown, G. R. Singleton, B. Douang Boupha, and K. Khamphoukeo. 2006. Rodents in the rice environments of Laos. In Rice in Laos, ed. J. M. Schiller, M. B. Chanphengxay, B. Linquist, and S. Appa Rao, pp. 291-308. Los Baños, Philippines: IRRI and Canberra: ACIAR.

Aplin, K. P., A. J. Fitch, and D. J. King. 2006. A new species of Varanus Merrem (Squamata: Varanidae) from the Pilbara region of Western Australia, with observations on sexual dimorphism in closely related species. Zootaxa 1313: 1-38.

https://doi.org/10.11646/zootaxa.1313.1.1

Douangboupha, B., P. R. Brown, K. Khamphoukeo, K. P. Aplin, and G. R. Singleton. 2006. Population dynamics of rodent pest species in upland farming systems of Lao PDR. The Lao Journal of Agriculture and Forestry Jan-June 2006: 109-121. Republished in Kasetsart Journal (Natural Science) 43: 125-131 (2009).

\section{7}

David, B., A. Fairbairn, K. Aplin, L. Murepe, M. Green, J. Stanisic, M. Weisler, D. Simala, T. Kokents, J. Dop, and J. Muke. 2007. OJP, a terminal Pleistocene archaeological site from the Gulf Province lowlands, Papua New Guinea. Archaeology in Oceania 42: 31-33. https://doi.org/10.1002/j.1834-4453.2007.tb00013.x

Hope, G. S., and K. P. Aplin. 2007. Palaeontology of Papua. In The Ecology of Papua. Part One. The Ecology of Indonesia Series. Volume V1, ed. A. J. Marshall and B. M. Beehler, pp. 246-254. Singapore: Periplus Editions.

Maryan, B., K. P. Aplin, and M. Adams. 2007. Two new species of the Delma tincta group (Squamata: Pygopodidae) with remarks on patterns of species endemism in northwestern Australia. Records of the Western Australian Museum 23: 273-305. https://doi.org/10.18195/issn.0312-3162.23(3).2007.273-305

O'Connor, S., and K. P. Aplin. 2007. A matter of balance: an overview of Pleistocene occupation history and the impact of the Last Glacial Phase in East Timor and the Aru Islands, eastern Indonesia. Archaeology in Oceania 42: 82-90. https://doi.org/10.22459/TA22.2007

Shimada, T., K. P. Aplin, P. Jenkins, and H. Suzuki. 2007. Rediscovery of Mus nitidulus Blyth (Rodentia, Muridae), an endemic murine rodent of the central basin of Myanmar. Zootaxa 1498(1): 45-68. https://doi.org/10.11646/zootaxa.1498.1.4

Shimada, T., K. P. Aplin, K. Jyogahara, K.-L. Lin, J.-P. Gonzalez, V. Herbreteau, and H. Suzuki. 2007. Complex phylogeographic structuring in a continental small mammal from East Asia, the rice field mouse, Mus caroli (Rodentia, Muridae). Mammal Study 32: 49-62.

https://doi.org/10.3106/1348-6160(2007)32[49:CPSIAC]2.0.CO;2
Singleton, G. R., P. R. Brown, J. Jacob, K. P. Aplin, and Sudarmaji. 2007. Unwanted and unintended effects of culling: a case for ecologically-based rodent management. Integrative Zoology 2: $247-259$.

https://doi.org/10.1111/j.1749-4877.2007.00067.x

Veth, P. M., K. P. Aplin, L. Wallis, T. Manne, T. Pulsford, A. White, and A. Chappell. 2007. The archaeology of Montebello Islands, Northwest Australia: late Quaternary foragers on an arid coastline. BAR, International Series, 1668. Oxford: Archaeopress.

https://doi.org/10.30861/9781407301037

\section{8}

Aplin, K., S. Donnellan, and J. Dell. 2008. The herpetofauna of Faure Island, Shark Bay, Western Australia. Records of the Western Australian Museum Supplement no. 75: 39-53. https://doi.org/10.18195/issn.0313-122x.75.2008.039-053

Lecompte, E., K. Aplin, C. Denys, F. Catzeflis, M. Chades, and P. Chevret. 2008. Phylogeny and biogeography of African Murinae based on mitochondrial and nuclear gene sequences, with a new tribal classification of the subfamily. BMC Evolutionary Biology 8: 199.

https://doi.org/10.1186/1471-2148-8-199

O'Connor, S., K. Aplin, and S. Collins. 2008. A small salvage excavation in Windjana Gorge, Kimberley, Western Australia. Archaeology in Oceania 43: 75-81.

https://doi.org/10.1002/j.1834-4453.2008.tb00032.x

\section{9}

Angelakis, E., K. Khamphoukeo, D. Grice, P. N. Newton, V. Roux, K. Aplin, D. Raoult, and J. M. Rolain. 2009. Molecular detection of Bartonella species in rodents from the Lao PDR. Clinical Microbiology and Infection 15 (s2): 95-97. https://doi.org/10.1111/j.1469-0691.2008.02177.x

Aplin, K. P. 2009. On the origin of rats. Australasian Science. April 2009: 28-31.

Shimada, T., J. J. Sato, K. P. Aplin, and H. Suzuki. 2009. Comparative analysis of evolutionary modes in Mc1r coat color gene in wild mice and mustelids. Genes and Genetic Systems 84: $225-231$. https://doi.org/10.1266/ggs.84.225

Sutton, A., M.-J. Mountain, K. Aplin, S. Bulmer, and T. Denham. 2009. Archaeozoological records for the highlands of New Guinea: a review of current evidence. Australian Archaeology 69: 41-58.

https://doi.org/10.1080/03122417.2009.11681900

\section{0}

Aplin, K. P., and K. M. Helgen. 2010. Quaternary murid rodents of Timor part I: new material of Coryphomys buehleri Schaub, 1937, and description of a second species of the genus. Bulletin of the American Museum of Natural History 341: 1-80. https://doi.org/10.1206/692.1

Aplin, K. P., and J. Lalsiamliana. 2010. Chronicle and impacts of the 2005-2009 mautam in Mizoram. In Rodent Outbreaks: Ecology and Impacts, ed. G. Singleton, S. Belmain, P. Brown, and B. Hardy. Los Baños, Philippines: International Rice Research Institute.

Aplin K., F. Ford, and P. Hiscock. 2010. Early Holocene human occupation and environment of the southeast Australian Alps: new evidence from the Yarrangobilly Plateau, New South Wales. In Altered Ecologies: Fire, Climate and Human Influence on Terrestrial Landscapes, ed. S. Haberle, J. Stevenson, and M. Prebble, pp. 187-212. Terra Australis 32. Canberra: ANU E Press. https://doi.org/10.22459/TA32.11.2010.11 
Aplin, K. P., K. M. Helgen, and D. P. Lunde. 2010. A review of Peroryctes broadbenti, the giant bandicoot of Papua New Guinea. American Museum Novitates 3696: 1-41. https://doi.org/10.1206/3696.2

David, B., J.-M. Geneste, K. Aplin, J.-J. Delannoy, N. Araho, C. Clarkson, K. Connell, S. Haberle, B. Barker, L. Lamb, J. Stanisic, A. Fairbairn, R. Skelly, and C. Rowe. 2010. The Emo site (OAC), Gulf Province, Papua New Guinea: resolving longstanding questions of antiquity and implications for the history of the ancestral Hiri maritime trade. Australian Archaeology 70: $39-54$.

https://doi.org/10.1080/03122417.2010.11681910

Donnellan, S. C., K. P. Aplin, and T. Bertozzi. 2010. Species boundaries in the Rana arfaki group (Anura: Ranidae) and phylogenetic relationships to other New Guinean Rana. Zootaxa 2496: 49-62.

Helgen, K. M., T. Leary, and K. P. Aplin. 2010. A revision of Microhydromys (Rodentia: Murinae), with description of a new species from southern New Guinea. American Museum Novitates 3676: 1-22.

https://doi.org/10.1206/632.1

Louys, J., K. P. Aplin, R. M. D. Beck, and M. Archer. 2010. Cranial anatomy of Oligo-Miocene koalas (Diprotodontia: Phascolarctidae): stages in the evolution of an extreme leaf-eating specialization. Journal of Vertebrate Paleontology 29: 981-992. https://doi.org/10.1671/039.029.0412

McNiven, I., B. David, K. Aplin, M. Pivoru, W. Pivoru, A. Sexton, J. Brown, C. Clarkson, K. Connell, J. Stanisic, M. Weisler. S. Haberle, A. Fairbairn, and N. Kemp. 2010. Historicising the present: late Holocene emergence of a rainforest hunting camp, Gulf Province, Papua New Guinea. Australian Archaeology 71(1): 41-56. https://doi.org/10.1080/03122417.2010.11689383

Murray, K., R. Retallick, K. R. McDonald, D. Mendez, K. Aplin, P. Kirkpatrick, L. Berger, D. Hunter, H. B. Hines, R. Campbell, M. Pauza, M. Driessen, R. Speare, S. J. Richards, M. Mahony, A. Freeman, A. D. Phillott, J. Hero, K. Kriger, D. Driscoll, A. Felton, R. Puschendorf, and L. F. Skerratt. 2010. The distribution and host range of the pandemic disease chytridiomycosis in Australia, spanning surveys from 1956-2007. Ecology 91: $1557-1558$. https://doi.org/10.1890/09-1608.1

Nunome, M., C. Ishimori, K. P. Aplin, K. Tsuchiya, H. Yonekawa, K. Moriwaki, and H. Suzuki. 2010. Detection of recombinant haplotypes in wild mice (Mus musculus) provides new insights into the origin of Japanese mice. Molecular Ecology 19(12): 2474-2489.

https://doi.org/10.1111/j.1365-294X.2010.04651.x

O’Connor, S., K. Aplin, E. St Pierre, and Y.-x. Feng. 2010. Faces of the ancestors revealed: discovery and dating of a Pleistocene-age petroglyph in Lene Hara Cave, East Timor. Antiquity 84: 649-665. https://doi.org/10.1017/S0003598X00100146

O'Connor, S., A. Barham, M. Spriggs, P. Veth, K. Aplin, and E. St Pierre. 2010. Cave archaeology and sampling issues in the tropics: a case study from Lene Hara Cave, a 42,000 year old occupation site in East Timor, Island Southeast Asia. Australian Archaeology 71: 29-40. https://doi.org/10.1080/03122417.2010.11689382

Shimada, T., K. P. Aplin, and H. Suzuki. 2010. Mus lepidoides (Muridae, Rodentia) of central Burma is a distinct species of potentially great evolutionary and biogeographic significance. Zoological Science 27: 449-459. https://doi.org/10.2108/zsi.27.449

Singleton, G. R., S. Belmain, P. R. Brown, K. Aplin, and N. M. Htwe. 2010. Impacts of rodent outbreaks on food security in Asia. Wildlife Research 37: 355-359.

https://doi.org/10.1071/WR10084

\section{1}

Aplin, K. P., and E. Kale. 2011. Non-volant mammals of the Muller Range, Papua New Guinean. In Rapid Biological Assessments of the Nakanai Mountains and the Upper Strickland Basin: Surveying the Biodiversity of Papua New Guinea's Sublime Karst Environments, ed. S. J. Richards and B. G. Gamui, RAP Bulletin of Biological Assessment 60, pp. 211-221. Arlington: Conservation International.

Aplin, K. P., and M. Opiang. 2011. Mammals of the Nakanai Mountains, East New Britain Province, Papua New Guinea. In Rapid Biological Assessments of the Nakanai Mountains and the Upper Strickland Basin: Surveying the Biodiversity of Papua New Guinea's Sublime Karst Environments, ed. S. J. Richards and B. G. Gamui, RAP Bulletin of Biological Assessment 60, pp. 85-103. Arlington: Conservation International.

Aplin K. P., H. Suzuki, A. A. Chinen, R. T. Chesser, J. ten Have, S. C. Donnellan, J. Austin, A. Frost, J.-P. Gonzalez, V. Herbreteau, F. Catzeflis, J. Soubrier, Y.-P. Fang, J. Robins, E. Matisoo-Smith, A. D. S. Bastos, I. Maryanto, M. H. Sinaga, C. Denys, R. A. Van Den Bussche, C. Conroy, K. Rowe, and A. Cooper. 2011. Multiple geographic origins of commensalism and complex dispersal history of Black Rats. PLoS ONE 6: e26357. https://doi.org/10.1371/journal.pone.0026357

Armstrong, K. N., and K. P. Aplin. 2011. Bats of the Muller Range, Papua New Guinea. In Rapid Biological Assessments of the Nakanai Mountains and the Upper Strickland Basin: Surveying the Biodiversity of Papua New Guinea's Sublime Karst Environments, ed. S. J. Richards and B. G. Gamui, RAP Bulletin of Biological Assessment 60, pp. 222-234. Arlington: Conservation International.

Breed, W. G., S. Tan, C. M. Leigh, K. P. Aplin, K. DvorakovaHortova, and H. D. Moore. 2011. The morphology of the squirrel spermatozoon: a highly complex male gamete with a massive acrosome. Journal of Morphology 272: 883-889. https://doi.org/10.1002/jmor.10955

Byrne, M., D. A. Steane, L. Joseph, D. K. Yeates, G. J. Jordan, D. Crayn, K. Aplin, D. J. Cantrill, L. G. Cook, M. D. Crisp, J. S. Keogh, J. Melville, C. Moritz, N. Porch, J. M. K. Sniderman, P. Sunnucks, and P. H. Weston. 2011. Decline of a biome: evolution, contraction, fragmentation, extinction and invasion of the Australian mesic zone biota. Journal of Biogeography 38(9): 1635-1656.

https://doi.org/10.1111/j.1365-2699.2011.02535.x

David, B., J.-M. Geneste, R. L. Whear, J.-J. Delannoy, M. Katherine, R. G. Gunn, C. Clarkson, H. Plisson, P. Lee, F. Petchey, C. Rowe, B. Barker, L. Lamb, W. Miller, S. Hoerlé, D. James, É. Boche, K. Aplin, I. J. McNiven, T. Richards, A. Fairbairn, and J. Matthews. 2011. Nawarla Gabarnmang, a $45,180 \pm 910$ cal BP site in Jawoyn country, southwest Arnhem Land plateau. Australian Archaeology 73: 73-77. https://doi.org/10.1080/03122417.2011.11961928

Kambe, Y., T. Tanikawa, Y. Matsumoto, M. Tomozawa, K. P. Aplin, and H. Suzuki. 2011. Origin of agouti-melanistic polymorphism in wild Black Rats (Rattus rattus) inferred from $M c l r$ gene sequences. Zoological Science 28: 560-567. https://doi.org/10.2108/zsj.28.560

McNiven, I. J., B. David, T. Richards, K. Aplin, B. Asmussen, J. Mialanes, M. Leavesley, P. Faulkner, and S. Ulm. 2011. New direction in human colonisation of the Pacific: Lapita settlement of south coast New Guinea. Australian Archaeology 72: 1-6. https://doi.org/10.1080/03122417.2011.11690525

O’Connor, S., A. Barham, K. Aplin, K. Dobney, A. Fairbairn, and M. Richards. 2011. The power of paradigms: examining the evidential basis for early to mid-Holocene pigs and pottery in Melanesia. Journal of Pacific Archaeology 2: 1-25. 
Rowe K. C., K. P. Aplin, P. R. Baverstock, and C. Moritz. 2011. Recent and rapid speciation with limited morphological disparity in the genus Rattus. Systematic Biology 60: 188-203.

https://doi.org/10.1093/sysbio/syq092

\section{2}

McNiven, I. J., B. David, K. Aplin, J. Mialanes, B. Asmussen, S. Ulm, P. Faulkner, C. Rowe, and T. Richards. 2012. Terrestrial engagements by terminal Lapita maritime specialists on the southern Papuan coast. In Peopled Landscapes: Archaeological and Biogeographic Approaches to Landscapes, ed. S. Haberle and B. David. Terra Australiss 34: 121-156. https://doi.org/10.22459/TA34.01.2012.05

McNiven, I. J., B. David, T. Richards, C. Rowe, M. Leavesley, J. Mialanes, S. P. Connaughton, B. Barker, K. Aplin, B. Asmussen, P. Faulkner, and S. Ulm. 2012. Response: Lapita on the south coast of Papua New Guinea: challenging new horizons in Pacific Archaeology. Australian Archaeology 75: 16-22.

Suzuki, H., and K. P. Aplin. 2012. Phylogeny and biogeography of the genus Mus in Eurasia. In Evolution of the House Mouse, ed. M. Macholán, S. J. E. Baird, P. Munclinger, and J. Piálek, pp. 35-64. Cambridge: Cambridge University Press. https://doi.org/10.1017/CBO9781139044547.004

Westerman M., B. P. Kear, K. P. Aplin, R. W. Meredith, C. Emerling, and M. S. Springer. 2012. Phylogenetic relationships of living and recently extinct bandicoots based on nuclear and mitochondrial DNA sequences. Molecular Phylogenetics and Evolution 62: 97-108.

https://doi.org/10.1016/j.ympev.2011.09.009

\section{3}

Aplin, K., and F. Ford. 2013. Murine rodents: late but highly successful invaders. In Invasion Biology and Ecological Theory: Insights from a Continent in Transformation, ed. H. H. Prins and I. J. Gordon, pp. 196-240. Cambridge: Cambridge University Press. https://doi.org/10.1017/CBO9781139565424.012

Conroy, C. J., K. C. Rowe, K. M. Rowe, P. L. Kamath, K. P. Aplin, L. Hui, D. K. James, C. Moritz, and J. L. Patton. 2013. Cryptic genetic diversity in Rattus of the San Francisco Bay region, California. Biological Invasions 15(4): 741-758. https://doi.org/10.1007/s10530-012-0323-9

Marin, J., S. C. Donnellan, S. B. Hedges, N. Puillandre, K. P. Aplin, P. Doughty, M. N. Hutchinson, A. Couloux, and N. Vidal. 2013. Hidden species diversity of Australian burrowing snakes (Ramphotyphlops). Biological Journal of the Linnean Society 110(2): 427-441. https://doi.org/10.1111/bij.12132

Petchey, F., S. Ulm, B. David, I. J. McNiven, B. Asmussen, H. Tomkins, N. Dolby, K. Aplin, T. Richards, C. Rowe, M. Leavesley, and H. Mandui. 2013. High-resolution radiocarbon dating of marine materials in archaeological contexts: radiocarbon marine reservoir variability between Anadara, Gafrarium, Batissa, Polymesoda spp. and Echinoidea at Caution Bay, Southern Coastal Papua New Guinea. Archaeological and Anthropological Sciences 5(1): 69-80. https://doi.org/10.1007/s12520-012-0108-1

Shine, D., D. Wright, T. Denham, K. Aplin, P. Hiscock, K. Parker, and R. Walton. 2013. Birriwilk rockshelter: a mid- to late Holocene site in Manilikarr Country, southwest Arnhem Land, Northern Territory. Australian Archaeology 76: 69-78. https://doi.org/10.1080/03122417.2013.11681967
Suzuki, H., M. Nunome, G. Kinoshita, K. P. Aplin, P. Vogel, A. P. Kryukov, M. L. Jin, S. H. Han, I. Maryanto, K. Tsuchiya, H. Ikeda, T. Shiroishi, H. Yonekawa, and K. Moriwaki. 2013. Evolutionary and dispersal history of Eurasian house mice Mus musculus clarified by more extensive geographic sampling of mitochondrial DNA. Heredity 111(5): 375-390.

https://doi.org/10.1038/hdy.2013.60

Wright, D., P. Hiscock, and K. Aplin. 2013. Re-excavation of Dabangay, a mid-Holocene settlement site on Mabuyag in western Torres Strait. Queensland Archaeological Research 16: $15-32$.

https://doi.org/10.25120/qar.16.2013.221

\section{4}

Beck, R. M., K. J. Travouillon, K. P. Aplin, H. Godthelp, and M. Archer. 2014. The osteology and systematics of the enigmatic Australian Oligo-Miocene metatherian Yalkaparidon (Yalkaparidontidae; Yalkaparidontia; ?Australidelphia; Marsupialia). Journal of Mammalian Evolution 21: 127-172. https://doi.org/10.1007/s10914-013-9236-3

Breed, W. G., C. M. Leigh, K. P. Aplin, A. A. Shahin, and N. L. Avenant. 2014, Morphological diversity and evolution of the spermatozoon in the mouse-related clade of rodents. Journal of Morphology 275: 540-547.

https://doi.org/10.1002/jmor.20236

O'Connor, S., G. Robertson, and K. P. Aplin. 2014. Are osseous artefacts a window to perishable material culture? Implications of an unusually complex bone tool from the Late Pleistocene of East Timor. Journal of Human Evolution 67: 108-119. https://doi.org/10.1016/j.jhevol.2013.12.002

Robins, J. H., V. Tintinger, K. P. Aplin, M. Hingston, E. MatisooSmith, D. Penny, and S. D. Lavery. 2014. Phylogenetic species identification in Rattus highlights rapid radiation and morphological similarity of New Guinean species. PLoS ONE 9(5): e98002. https://doi.org/10.1371/journal.pone.0098002

Thomson, V., K. P. Aplin, A. Cooper, S. Hisheh, H. Suzuki, I. Maryanto, G. Yap, and S. C. Donnellan. 2014. Molecular genetic evidence for the place of origin of the Pacific Rat, Rattus exulans. PLoS ONE 9(3): e91356.

https://doi.org/10.1371/journal.pone.0091356

\section{5}

Aplin, K. P. 2015. Family Notoryctidae (marsupial moles). In Handbook of the Mammals of the World. Vol 5. Marsupials and Monotremes, ed. D. E. Wilson and R. A. Mittermeier, pp. 210-219. Barcelona: Lynx Edicions.

Aplin, K. P. 2015. Family Acrobatidae (feather-tailed gliders and feather-tailed possum). In Handbook of the Mammals of the World. Vol 5. Marsupials and Monotremes, ed. D. E. Wilson and R. A. Mittermeier, pp. 574-591. Barcelona: Lynx Edicions.

Aplin, K., K. N. Armstrong, and J. Novera. 2015. Mammals of Manus and Mussau Islands. In A Rapid Biodiversity Survey of Papua New Guinea's Manus and Mussau Islands, ed. N. Whitmore, pp. 50-68. Goroka, Papua New Guinea: Wildlife Conservation Society Papua New Guinea Program.

Aplin, K. P., and J. S. Lamaris. 2015. Non-flying mammals. In A Rapid Biodiversity Assessment of Papua New Guinea's Hindenburg Wall Region, ed. S. J. Richards and N. Whitmore, pp. 131-165. Goroka, Papua New Guinea: Wildlife Conservation Society Papua New Guinea Program.

Aplin, K. P., S. G. Rhind, J. ten Have, and R. T. Chesser. 2015. Taxonomic revision of Phascogale tapoatafa (Meyer, 1793) (Dasyuridae; Marsupialia), including descriptions of two new subspecies and confirmation of $P$. pirata Thomas, 1904 as a 'Top End' endemic. Zootaxa 4055(1): 1-73. https://doi.org/10.11646/zootaxa.4055.1.1 
Armstrong, K. N., K. P. Aplin, and J. S. Lamaris. 2015. Bats. In A Rapid Biodiversity Assessment of Papua New Guinea's Hindenburg Wall Region, ed. S. J. Richards and N. Whitmore, pp. 166-181. Goroka, Papua New Guinea: Wildlife Conservation Society Papua New Guinea Program.

Armstrong, K. N., J. Novera, and K. Aplin. 2015. Acoustic survey of the echolocating bats of Manus and Mussau Islands. In $A$ Rapid Biodiversity Survey of Papua New Guinea's Manus and Mussau Islands, ed. N. Whitmore, pp. 69-85. Goroka, Papua New Guinea: Wildlife Conservation Society Papua New Guinea Program.

David, B., K. Aplin, F. Petchey, R. Skelly, J. Mialanes, H. JonesAmin, J. Stanisic, B. Barker, and L. Lamb. 2015. Kumukumu 1, a hilltop site in the Aird Hills: implications for occupational trends and dynamics in the Kikori River delta, south coast of Papua New Guinea. Quaternary International 385: 7-26. https://doi.org/10.1016/j.quaint.2014.06.058

David, B., J. Mialanes, F. Petchey, K. Aplin, J. M. Geneste, R. Skelly, and C. Rowe. 2015. Archaeological investigations at Waredaru and the origins of the Keipte Kuyumen clan estate, upper Kikori River, Papua New Guinea. PALEO. Revue d'Archéologie Préhistorique 26: 33-57. https://doi.org/10.4000/paleo.2890

Gagan, M. K., L. K. Ayliffe, G. K. Smith, J. C. Hellstrom, H. Scott-Gagan, R. N. Drysdale, N. Anderson, B. W. Suwargadi, K. P., Aplin, J.-x. Zhao, C. W. Groves, W. S. Hantoro, and T. Djubiantono. 2015. Geoarchaeological finds below Liang Bua (Flores, Indonesia): a split-level cave system for Homo floresiensis?. Palaeogeography, Palaeoclimatology, Palaeoecology 440: 533-550. https://doi.org/10.1016/j.palaeo.2015.09.021

Kagl, J. P., N. Whitmore, and K. P. Aplin. 2015. Traditional and local ecological knowledge. In A Rapid Biodiversity Assessment of Papua New Guinea's Hindenburg Wall Region, ed. S. J. Richards and N. Whitmore, pp. 3-13. Goroka, Papua New Guinea: Wildlife Conservation Society Papua New Guinea Program.

Maryan, B., M. Adams, and K. P. Aplin. 2015. Taxonomic resolution of the Aprasia repens species-group (Squamata: Pygopodidae) from the Geraldton Sandplains: a description of a new species and additional mainland records of $A$. clairae. Records of the Western Australian Museum 30(1): 12-32.

https://doi.org/10.18195/issn.0312-3162.30(1).2015.012-032

Maryan, B., I. Brennan, M. Adams, and K. P. Aplin. 2015. Molecular and morphological assessment of Delma australis Kluge (Squamata: Pygopodidae), with a description of a new species from the biodiversity 'hotspot' of southwestern Western Australia. Zootaxa 3946: 301-330.

https://doi.org/10.11646/zootaxa.3946.3.1

McDowell, M. C., D. Haouchar, K. P. Aplin, M. Bunce, A. Baynes, and G. Prideaux. 2015. Morphological and molecular evidence supports specific recognition of the recently extinct Bettongia anhydra (Marsupialia: Macropodidae). Journal of Mammalogy 96: 287-296.

https://doi.org/10.1093/jmammal/gyv006

Motokawa, M., S. Shimoinaba, S. Kawada, and K. Aplin. 2015. Rediscovery of the holotype of Mus bowersii var. okinavensis Namiye, 1909 (Mammalia: Rodentia: Muridae). Bulletin of the National Museum of Nature and Science Series A (Zoology) 41: 131-136.

Richards, S. J., and K. Aplin. 2015. Herpetofauna of Manus and Mussau Islands. In A Rapid Biodiversity Survey of Papua New Guinea's Manus and Mussau Islands, ed. N. Whitmore, pp. 31-37. Goroka, Papua New Guinea: Wildlife Conservation Society Papua New Guinea Program.

Woxvold, I., B. Ken, and K. P. Aplin. 2015. Birds. In A Rapid Biodiversity Assessment of Papua New Guinea's Hindenburg Wall Region, ed. S. J. Richards and N. Whitmore, pp. 103-130. Goroka, Papua New Guinea: Wildlife Conservation Society Papua New Guinea Program.

\section{6}

Alfano, N., J. Michaux, S. Morand, K. Aplin, K. Tsangaras, U. Löber, P. H. Fabre, Y. Fitriana, G. Semiadi, Y. Ishida, K. M. Helgen, A. L. Roca, M. V. Eiden, and A. D. Greenwood. 2016. Endogenous gibbon ape leukemia virus identified in a rodent (Melomys burtoni subsp.) from Wallacea (Indonesia). Journal of Virology 90(18): 8169-8180. https://doi.org/10.1128/JVI.00723-16

Aplin, K., T. Manne, and V. Attenbrow. 2016. Using a 3-stage burning categorization to assess post-depositional degradation of archaeofaunal assemblages: some observations based on multiple prehistoric sites in Australasia. Journal of Archaeological Science: Reports 7: 700-714. https://doi.org/10.1016/j.jasrep.2015.11.029

Aplin, K., C. Rowe, H. Peck, B. Asmussen, S. Ulm, P. Faulkner, and T. Richards. 2016. The natural setting of Caution Bay: climate, landforms, biota, and environmental zones. In Archaeological Research at Caution Bay, Papua New Guinea: Cultural, Linguistic and Environmental Setting, ed. T. Richards, B. David, K. Aplin, and I. J. McNiven, pp. 75-111. Caution Bay Studies in Archaeology, 1. Oxford: Archaeopress.

Beck, R. M. D., N. M. Warburton, M. Archer, S. J. Hand, and K. P. Aplin. 2016. Going underground: postcranial morphology of the early Miocene marsupial mole Naraboryctes philcreaseri and the evolution of fossoriality in notoryctemorphians. Memoirs of Museum Victoria 74: 151-171. https://doi.org/10.24199/j.mmv.2016.74.14

David, B., H. Jones-Amin, T. Richards, J. Mialanes, B. Asmussen, F. Petchey, K. Aplin, M. Leavesley, I. J. McNiven, C. Zetzmann, and C. Rowe. 2016. Ruisasi 1 and the earliest evidence of massproduced ceramics in Caution Bay (Port Moresby Region), Papua New Guinea. Journal of Pacific Archaeology 7: 41-60.

Kear, B. P., K. P. Aplin, and M. Westerman. 2016. Bandicoot fossils and DNA elucidate lineage antiquity amongst xeric-adapted Australasian marsupials. Scientific Reports 6: 37537. https://doi.org/10.1038/srep37537

Langley, M. C., S. O'Connor, and K. Aplin. 2016. A >46,000year-old kangaroo bone implement from Carpenter's Gap 1 (Kimberley, northwest Australia). Quaternary Science Reviews 154: 199-213. https://doi.org/10.1016/i.quascirev.2016.11.006

Richards, T., B. David, K. Aplin, and I. J. McNiven. 2016. Archaeological Research at Caution Bay, Papua New Guinea: Cultural, Linguistic and Environmental Setting. Caution Bay Studies in Archaeology 1. Oxford: Archaeopress.

Richards, T. H., B. David, K. P. Aplin, and I. J. McNiven. 2016. The Caution Bay Project field and laboratory methods. In Archaeological Research at Caution Bay, Papua New Guinea: Cultural, Linguistic and Environmental Setting ed. T. Richards, B. David, K. Aplin, and I. J. McNiven, pp. 145-175. Caution Bay Studies in Archaeology, 1. Oxford: Archaeopress.

Richards, T., B. David, K. Aplin, I. J. McNiven, and M. Leavesley. 2016. Introduction to the Caution Bay Archaeology Project. In Archaeological Research at Caution Bay, Papua New Guinea: Cultural, Linguistic and Environmental Setting ed. T. Richards, B. David, K. Aplin, and I. J. McNiven, pp. 1-7. Caution Bay Studies in Archaeology, 1. Oxford: Archaeopress.

Timm, R. M., V. Weijola, K. P. Aplin, S. C. Donnellan, T. F. Flannery, V. Thomson, and R. H. Pine. 2016. A new species of Rattus (Rodentia: Muridae) from Manus Island, Papua New Guinea. Journal of Mammalogy 97: 1-18. https://doi.org/10.1093/jmammal/gyw034 


\section{7}

Aplin, K., S. O’Connor, D. Bulbeck, P. J. Piper, B. Marwick, E. St Pierre, and F. Aziz. 2017. The Walandawe Tradition from Southeast Sulawesi and osseous artifact traditions in Island Southeast Asia. In Osseous Projectile Weaponry: Towards an Understanding of Pleistocene Cultural Variability, ed. M. C. Langley, pp. 189-208. Dordrecht: Springer.

https://doi.org/10.1007/978-94-024-0899-7_13

Aplin, K. P., and M. Opiang. 2017. Non-volant mammals (rodents and marsupials). In Biodiversity Assessment of the PNG LNG Upstream Project Area, Southern Highlands and Hela Provinces, Papua New Guinea, ed. S. J. Richards, pp. 141-208. Port Moresby: ExxonMobil PNG Limited.

Armstrong, K., and K. P. Aplin. 2017. Enhancing biological monitoring with genetic information. In Biodiversity Assessment of the PNG LNG Upstream Project Area, Southern Highlands and Hela Provinces, Papua New Guinea, ed. S. J. Richards, pp. 255-269. Port Moresby: ExxonMobil PNG Limited.

Barker, B., L. Lamb, J. J. Delannoy, B. David, R. Gunn, E. Chalmin, G. Castets, K. Aplin, B. Sadier, I. Moffat, and J. Mialanes. 2017. Archaeology of JSARN-124 site 3, central-western Arnhem Land: determining the age of the so-called 'Genyornis' painting. In The Archaeology of Rock Art in Western Arnhem Land, Australia, ed. B. David, P. S. C. Taçon, J.-J. Delannoy, and J.-M. Geneste, pp. 423-496. Canberra: The Australian National University Press. https://doi.org/10.22459/TA47.11.2017.15

David, B., J. J. Delannoy, R. Gunn, L. M. Brady, F. Petchey, J. Mialanes, E. Chalmin, J. M. Geneste, I. Moffat, K. Aplin, and M. Katherine. 2017. Determining the age of paintings at JSARN-113/23, Jawoyn Country, central-western Arnhem Land plateau. In The Archaeology of Rock Art in Western Arnhem Land, Australia, ed. B. David, P. S. C. Taçon, J.-J. Delannoy, and J.-M. Geneste, pp. 371-422. Canberra: The Australian National University Press. https://doi.org/10.22459/TA47.11.2017.14

David, B., J. J. Delannoy, R. Gunn, E. Chalmin, G. Castets, F. Petchey, K. Aplin, M. O'Farrell, I. Moffat, J. Mialanes, and J. M. Geneste. 2017. Dating painted Panel E1 at Nawarla Gabarnmang, central-western Arnhem Land plateau. In The Archaeology of Rock Art in Western Arnhem Land, Australia, ed. B. David, P. S. C. Taçon, J.-J. Delannoy, and J.-M. Geneste, pp. 245-302. Canberra: The Australian National University Press. https://doi.org/10.22459/TA47.11.2017.11

Denys, C., P. J. Taylor, and K. P. Aplin. 2017. Family Muridae (true mice and rats, gerbils and relatives). In Handbook of the Mammals of the World. Vol. 7 Rodents II, ed. D. E. Wilson, T. E. Lacher Jr, and R. A. Mittermeier, pp. 536-886. Barcelona: Lynx Edicions.

Fabre, P.-H., A. H. Reeve, Y. Fitriana, K. P. Aplin, and K. M. Helgen. 2017. A new species of Halmaheramys (Rodentia: Muridae) from Bisa and Obi Islands (North Maluku Province, Indonesia). Journal of Mammalogy 99: 187-208. https://doi.org/10.1093/jmammal/gyx160

Hawkins, S., S. O'Connor, T. Maloney, M. Litster, S. Kealy, J. Fenner, K. Aplin, C. Boulanger, S. Brockwell, R. Willan, E. Piotto, and J. Louys. 2017. Oldest human occupation of Wallacea at Laili Cave, Timor-Leste, shows broad-spectrum foraging responses to late Pleistocene environments. Quaternary Science Reviews 171: 58-72. https://doi.org/10.1016/j.quascirev.2017.07.008

Jackson, S. M., C. P. Groves, P. J. S. Fleming, K. P. Aplin, M. D. B. Eldridge, A. Gonzalez, and K. M. Helgen. 2017. The wayward dog: is the Australian native dog or Dingo a distinct species? Zootaxa: 4317(2): 201-224.

https://doi.org/10.11646/zootaxa.4317.2.1
Louys, J., S. Kealy, S. O’Connor, G. J. Price, S. Hawkins, K. Aplin, Y. Rizal, J. Zaim, Mahirta, D. A. Tanudirjo, W. D. Santoso, A. R. Hidayah, A. Trihascaryo, R. Wood, J. Bevitt, and T. Clark. 2017. Differential preservation of vertebrates in Southeast Asian caves. International Journal of Speleology 46: 379-408. https://doi.org/10.5038/1827-806X.46.3.2131

O’Connor, S., A. Barham, K. Aplin, and T. Maloney. 2017. Cave stratigraphies and cave breccias: implications for sediment accumulation and removal models and interpreting the record of human occupation. Journal of Archaeological Science 77: $143-159$.

https://doi.org/10.1016/j.jas.2016.05.002

Woxvold, I., and K. P. Aplin. 2017. Camera trap monitoring of terrestrial birds and mammals: a pilot study. In Biodiversity Assessment of the PNG LNG Upstream Project Area, Southern Highlands and Hela Provinces, Papua New Guinea, ed. S. J. Richards, pp. 121-140. Port Moresby: ExxonMobil PNG Limited.

\section{8}

Aplin, K., K. N. Armstrong, and I. Woxvold. 2018. Non-volant mammals. In Identification Guide to Flora and Fauna of the Hides Range and the Agogo Range (Moro), Papua New Guinea, ed. S. J. Richards, pp. 117-144. Port Moresby: ExxonMobil PNG Limited.

Beaumont, P., S. O'Connor, M. Leclerc, and K. Aplin. 2018. Diversity in early New Guinea pottery traditions; north coast ceramics from Lachitu, Taora, Watinglo and Paleflatu. Journal of Pacific Archaeology 10(1): 15-32.

Chakma, N., N. J. Sarker, S. Belmain, S. U. Sarker, K. Aplin, and S. K. Sarker. 2018. New records of rodent species in Bangladesh: taxonomic studies from rodent outbreak areas in the Chittagong Hill Tracts. Bangladesh Journal of Zoology 46(2): 217-230. https://doi.org/10.3329/bjz.v46i2.39055

Eldridge, M. D., S. Potter, K. M. Helgen, M. H. Sinaga, K. P. Aplin, T. F. Flannery, and R. N. Johnson. 2018. Phylogenetic analysis of the tree-kangaroos (Dendrolagus) reveals multiple divergent lineages within New Guinea. Molecular Phylogenetics and Evolution 127: 589-599. https://doi.org/10.1016/j.ympev.2018.05.030

Fabre, P. H., Y. S. Fitriana, G. Semiadi, M. Pagès, K. Aplin, N. Supriatna, and K. M. Helgen. 2018. New record of Melomys burtoni (Mammalia, Rodentia, Murinae) from Halmahera (North Moluccas, Indonesia): a review of Moluccan Melomys. Mammalia 82(3): 218-247. https://doi.org/10.1515/mammalia-2016-0137

Hawkins, S., S. C. Samper Carro, J. Louys, K. Aplin, S. O’Connor, and Mahirta. 2018. Human palaeoecological interactions and owl roosting at Tron Bon Lei, Alor Island, eastern Indonesia. Journal of Coastal and Island Archaeology 13: 371-387 https://doi.org/10.1080/15564894.2017.1285834

Louys, J., M. Herrera, S. Hawkins, K. Aplin, C. Reepmeyer, F. Hopf, S. C. Donnellan, S. O'Connor, and D. A. Tanudirjo. 2018. Neolithic dispersal implications of murids from late Holocene archaeological and modern natural deposits in the Talaud Islands, northern Sulawesi. In The Archaeology of Sulawesi: Current Research on the Pleistocene to the Historic Period, ed. S. O'Connor, D. Bulbeck, and J. Meyer, pp. 223-242. Terra Australis 48. Canberra: ANU E Press. https://doi.org/10.22459/TA48.11.2018.14

Maloney, T., S. O'Connor, R. Wood, K. Aplin, and J. Balme. 2018. Carpenters Gap 1: a 47,000 year old record of indigenous adaption and innovation. Quaternary Science Reviews 191: 204-228.

https://doi.org/10.1016/j.quascirev.2018.05.016 
O'Connor, S., D. Bulbeck, P. J. Piper, F. Aziz, B. Marwick, F. Campos, J. Fenner, K. Aplin, F. Suryatman, T. Maloney, B. Hakim, and R. Wood. 2018. The human occupation record of Gua Mo'o hono shelter, Towuti-Routa region of Southeastern Sulawesi. In The Archaeology of Sulawesi: Current Research on the Pleistocene to the Historic Period, ed. S. O'Connor, D. Bulbeck, and J. Meyer, pp. 117-152. Terra Australis 48. Canberra: ANU E Press. https://doi.org/10.22459/TA48.11.2018.09

Pahl, T., H. J. McLennan, Y. Wang, A. S. Achmadi, K. C. Rowe, K. Aplin, and W. G. Breed. 2018. Sperm morphology of the Rattini-are the interspecific differences due to variation in intensity of intermale sperm competition? Reproduction, Fertility and Development 30(11): 1434-1442. https://doi.org/10.1071/RD17431

Theden-Ringl, F., K. P. Hislop, K. Aplin, R. Grün, and M. R. Schurr. 2018. The chronology and environmental context of a cave deposit and associated faunal assemblage including megafauna teeth near Wee Jasper, southeastern Australia. The Holocene 28(9): 1467-1482.

https://doi.org/10.1177/0959683618777073

Thomson, V., A. Wiewel, A. Chinen, I. Maryanto, M. H. Sinaga, R. How, K. Aplin, and H. Suzuki. 2018. A perspective for resolving the systematics of Rattus, the vertebrates with the most influence on human welfare. Zootaxa 4459(3): 431-452. https://doi.org/10.11646/zootaxa.4459.3.2

Zeng, L., C. Ming, Y. Li, L. Y. Su, Y. H. Su, N. O. Otecko, A. Dalecky, S. Donnellan, K. Aplin, X. H. Liu, Y. Song, Z.-B. Zhang, A. Esmailizadeh, S. S. Sohrabi, H. A. Nanaei, H.-Q. Liu, M.-S. Wang, S. A. Atteynine, G. Rocamora, F. Brescia, S. Morand, D. M. Irwin, M.-S. Peng, Y.-G. Yao, H.-P. Li, D.-D. Wu, Y.-P. Zhang. 2018. Out of Southern East Asia of the brown rat revealed by large-scale genome sequencing. Molecular Biology and Evolution 35(1): 149-158.

https://doi.org/10.1093/molbev/msx276

\section{9}

Balme, J., S. O'Connor, T. Maloney, D. Vannieuwenhuyse, K. Aplin, and I. E. Dilkes-Hall. 2019. Long-term occupation on the edge of the desert: Riwi Cave in the southern Kimberley, Western Australia. Archaeology in Oceania 54(1): 35-52. https://doi.org/10.1002/arco.5166

David, B., K. Aplin, H. Peck, R. Skelly, M. Leavesley, J. Mialanes, K. Szabó, B. Koppel, F. Petchey, T. Richards, and S. Ulm. 2019. Moiapu 3: settlement on Moiapu Hill at the very end of Lapita, Caution Bay hinterland. In Debating Lapita: Distribution, Chronology, Society and Subsistence, ed. S. Bedford and M. Spriggs, pp. 61-88. Terra Australis 52. Canberra: ANU Press. https://doi.org/10.22459/TA52.2019.03

\section{0}

Armstrong, K. N., K. P. Aplin, and M. Motokawa. 2020. A new species of extinct False Vampire Bat (Megadermatidae: Macroderma) from the Kimberley Region of Western Australia.
In Papers in Honour of Ken Aplin, ed. Julien Louys, Sue O'Connor, and Kristofer M. Helgen. Records of the Australian Museum 72(5): 161-174.

https://doi.org/10.3853/j.2201-4349.72.2020.1732

Brockwell, S., and K. P. Aplin. 2020. Fauna on the floodplains: late Holocene culture and landscape on the sub-coastal plains of northern Australia. In Papers in Honour of Ken Aplin, ed. Julien Louys, Sue O'Connor, and Kristofer M. Helgen. Records of the Australian Museum 72(5): 225-236.

https://doi.org/10.3853/j.2201-4349.72.2020.1728

Kealy, S., S. C. Donnellan, K. J. Mitchell, M. Herrera, K. Aplin, S. O'Connor, and J. Louys. 2020. Phylogenetic relationships of the cuscuses (Diprotodontia: Phalangeridae) of Island Southeast Asia and Melanesia based on the mitochondrial ND2 gene. Australian Mammalogy 42(3): 266-276. https://doi.org/10.1071/AM18050

Louys, J., M. B. Herrera, V. A. Thomson, A. S. Wiewel, S. C. Donnellan, S. O'Connor, and K. P. Aplin. 2020. Expanding population edge craniometrics and genetics provide insights into dispersal of commensal rats through Nusa Tenggara, Indonesia. In Papers in Honour of Ken Aplin, ed. Julien Louys, Sue O'Connor, and Kristofer M. Helgen. Records of the Australian Museum 72(5): 287-302. https://doi.org/10.3853/j.2201-4349.72.2020.1730

Miszkiewicz, J. J., J. Louys, R. M. D. Beck, P. Mahoney, K. Aplin, and S. O'Connor. 2020. Island rule and bone metabolism in fossil murines from Timor. Biological Journal of the Linnean Society 129(3): 570-586. https://doi.org/10.1093/biolinnean/blz197

Roberts, P., J. Louys, J. Zech, C. Shipton, S. Kealy, S. Samper Carro, S. Hawkins, C. Boulanger, S. Marzo, B. Fiedler, N. Boivin, Mahirta, K. Aplin, and S. O'Connor. 2020. Isotopic evidence for initial coastal colonization and subsequent diversification in the human occupation of Wallacea. Nature Communications 11(1): 1-11. https://doi.org/10.1038/s41467-020-15969-4

ACKNOWLEDGEMENTS. This introduction and remembrance of Ken Aplin is based on the eulogy given by Kris Helgen on 21 January 2019, at Ken's funeral at Pappinbarra, New South Wales.

We thank Ken's family, including his father, Kenneth Sr, his sisters Sue, Jenny, and Val, and his older children Nick, Lucy, Felix, and Charlotte, for their kindness and fellowship. We especially thank Ken's wife and partner, Dr Angela Frost, and their daughter Sophie, for sharing Ken with us, and for so many other things.

As editors, we thank the authors who have contributed these papers to this volume in celebration of Ken, and the many reviewers who assessed and improved our contributions. We also thank Rebecca Johnson, Kim McKay, Cameron Slatyer, Sandy Ingleby, Anja Divljan, Harry Parnaby, and Lauren Helgen for support.

We are deeply grateful to Dr Shane McEvey, editor of the Records of the Australian Museum, for the opportunity to edit this volume, and for his remarkable support in producing it on our behalf. 


\title{
A New Species of Extinct False Vampire Bat (Megadermatidae: Macroderma) from the Kimberley Region of Western Australia
}

\author{
Kyle N. Armstrong ${ }^{1,2,3}$ (D, Ken Aplin ${ }^{1,4} \uparrow \mathbb{D}$, and Masaharu Motokawa ${ }^{1}$ \\ ${ }^{1}$ The Kyoto University Museum, Yoshida Honmachi, Sakyo-ku, Kyoto, 606-8501, Japan \\ ${ }^{2}$ School of Biological Sciences, The University of Adelaide SA 5005, Australia \\ ${ }^{3}$ South Australian Museum, North Terrace, Adelaide SA 5000, Australia \\ ${ }^{4}$ Australian Museum Research Associate, 1 William Street, Sydney NSW 2010, Australia
}

\begin{abstract}
A new species of False Vampire Bat (Megadermatidae), Macroderma handae sp. nov., is described from dental, dentary and maxillary fragments recovered from limestone deposits at Dingo Gap, Oscar Range, in the Kimberley region of Western Australia. This material is likely to be of Pliocene age, or early Pleistocene, based on biocorrelation within the same sample. The absence of the $\mathrm{P}^{2}$ indicates that it is more derived than Miocene taxa including M. malugara and M. godthelpi, but its phylogenetic position relative to $M$. koppa could not be determined. It appears to be slightly smaller than M. gigas and M. koppa based on the size of $\mathrm{M}^{1}$ and $\mathrm{M}_{2}$. It can be distinguished from M. gigas by the lesser degree of fenestration in the maxilla; and from all other species of Macroderma by the shape of the protofossa of the $\mathrm{M}^{1}$, plus the $\mathrm{M}_{2}$ protoconid relatively high and of proportionally greater area within the trigonid. Other material collected, but not identified completely or described, includes several lower canines from a species of emballonurid, and a dentary with $\mathrm{M}_{1-3}$ representing a vespertilionid bat. Given the wear striations observed on the $\mathrm{M}_{3}$ of the newly-described Macroderma species, we suggest that it was a predator of small vertebrates, including possibly the chiropteran co-inhabitants of the cave. This new species of Macroderma is the sixth species recognized in the genus so far, and the second from the Pliocene.
\end{abstract}

\section{Introduction}

The family Megadermatidae (False Vampire Bats) has a long history that began in the mid-Eocene with its divergence from the Craseonycteridae c. 44-43 Ma, based on molecular dating methods $(95 \%$ credibility interval 47-39 Ma; Teeling et al., 2005; Foley et al., 2015). Until recently, the oldest known megadermatid fossil was considered to be Necromantis adichaster Weithofer, 1887, represented in the Quercy Phosphorites Formation, France, but this genus is now accepted to be part of a distinct family (Necromantidae; Sigé, 2011; Ravel et al., 2016;
Hand \& Sigé, 2018). Early megadermatid lineages are represented by modern extant taxa in the genera Lavia and Cardioderma, based on their inferred phylogenetic position (Hand, 1985; but see Kaňuch et al., 2015). The oldest megadermatid fossils, however, are: Saharaderma pseudovampyrus Gunnell et al., 2008 from early Oligocene deposits in Egypt (33.9-28.4 Ma), which shows similarities to Cardioderma and Lavia, and with which it may form a distinct African clade (Gunnell et al., 2008); and Megaderma lopezae Sevilla, 1990 from early Oligocene deposits in Spain. The remaining eight described Afro-European species of extinct Megaderma are represented in deposits that range

Keywords: Macroderma; Megaderma; Ghost Bat; False Vampire Bat; new species; Pliocene

Taxonomic registration: urn:Isid:zoobank.org:pub:D252FDFE-7C93-4E13-8DC7-FFB585ACC16F

Corresponding author: Kyle N. Armstrong kyle.armstrong@adelaide.edu.au

Received: 3 February 2020 Accepted: 20 August 2020 Published: 25 November 2020 (in print and online simultaneously)

Publisher: The Australian Museum, Sydney, Australia (a statutory authority of, and principally funded by, the NSW State Government)

Citation: Armstrong, Kyle N., Ken Aplin, and Masaharu Motokawa. 2020. A new species of extinct False Vampire Bat (Megadermatidae: Macroderma) from the Kimberley Region of Western Australia. In Papers in Honour of Ken Aplin, ed. Julien Louys, Sue O'Connor, and Kristofer M. Helgen. Records of the Australian Museum 72(5): 161-174. https://doi.org/10.3853/j.2201-4349.72.2020.1732 


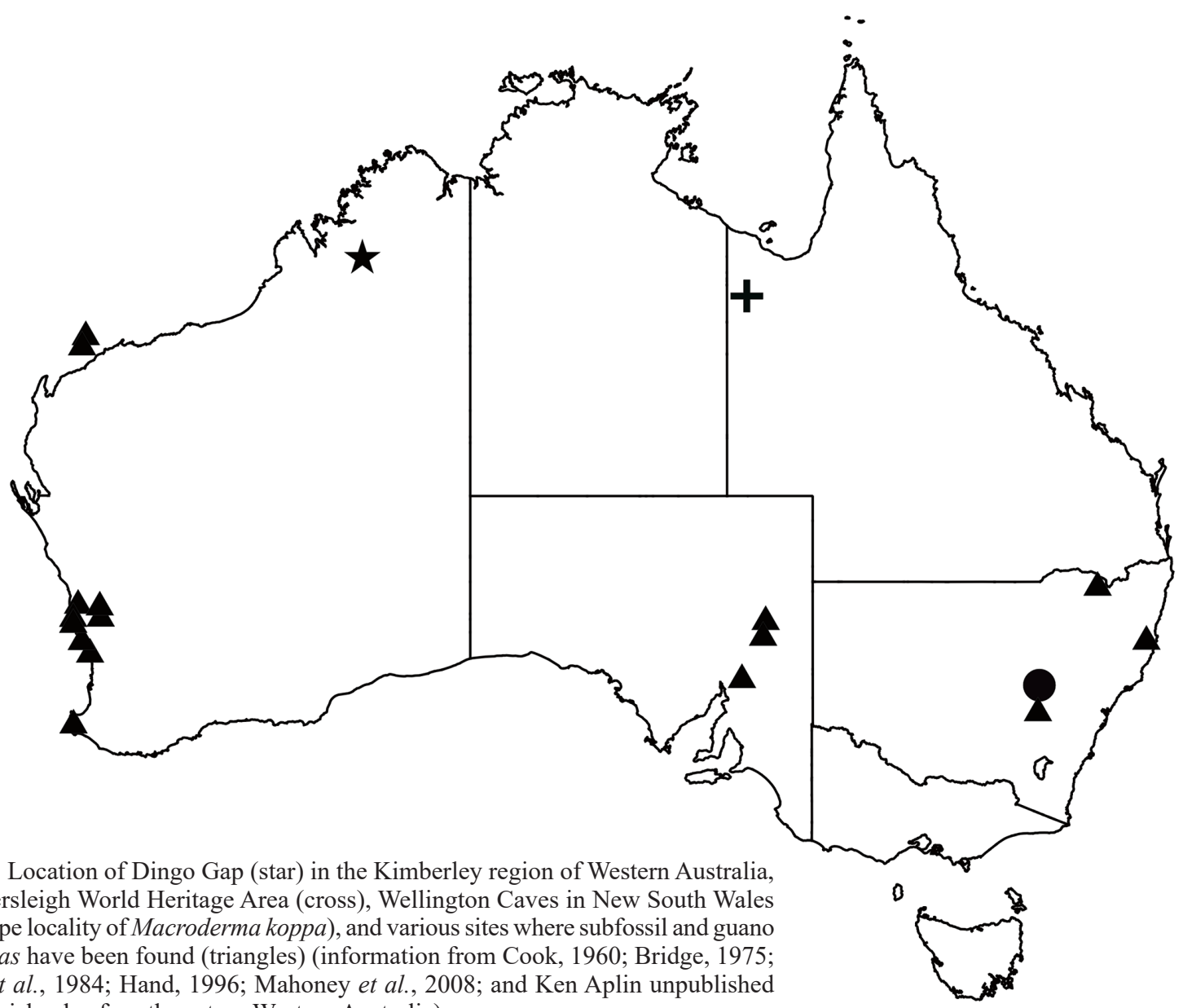

Figure 1. Location of Dingo Gap (star) in the Kimberley region of Western Australia, plus Riversleigh World Heritage Area (cross), Wellington Caves in New South Wales (circle; type locality of Macroderma koppa), and various sites where subfossil and guano of M. gigas have been found (triangles) (information from Cook, 1960; Bridge, 1975; Molnar et al., 1984; Hand, 1996; Mahoney et al., 2008; and Ken Aplin unpublished data from islands of northwestern Western Australia).

in age from the early Miocene (e.g., Megaderma brailloni Sigé, 1968 from the Aquitanian) to the Pleistocene (e.g., Megaderma watwat Bate, 1937) (reviewed in Sigé, 1976; Sevilla, 1990; Ziegler, 1993).

Australia has excellent representation of megadermatid fossil taxa, beginning from the mid-Cenozoic and extending to subfossil recent material (Molnar et al., 1984; Hand, 1996). Most have been discovered in the freshwater limestone deposits of Riversleigh World Heritage Area, northwestern Queensland, which has a rich diversity of bat species from the families Mystacinidae (Hand et al., 1998), Emballonuridae (Archer et al., 2006; King, 2013), Rhinonycteridae (Sigé et al., 1982; Hand, 1997a; Hand \& Archer, 2005), Hipposideridae (Hand, 1997b; Hand, 1998a, 1998b), Molossidae (Hand, 1990; Hand et al., 1997), and Vespertilionidae (Menu et al., 2002).

The genus Megaderma is thought to have entered Australia after the middle Miocene, and the small-sized Megaderma richardsi from the early Pleistocene Rackham's Roost Site at Riversleigh is its only known representative in Australia (Hand, 1995; Woodhead et al., 2016). Four extinct Australian megadermatid taxa have been referred to the endemic genus Macroderma-M. godthelpi Hand, 1985 from the early Miocene Microsite and middle Miocene Gag Site, Riversleigh; M. malugara Hand, 1996 from the middle Miocene Gotham City Site, Riversleigh; an unnamed species of Macroderma from the middle Miocene Henk's Hollow Site, Riversleigh (Hand, 1996); and M. koppa Hand, Dawson \& Augee, 1988 from the Pliocene deposits of Big Sink, Wellington Caves, New South Wales (Hand et al., 1988). The remaining two extinct megadermatid taxa from Australia have not been given a formal binomial name - Dwornamor Variant from the middle Miocene Gag Site, Riversleigh (Hand, 1985); and Megadermatidae indet. from the middle Miocene Henk's Hollow Site, Riversleigh (Hand, 1996).

The extant Macroderma gigas (Dobson, 1880) is currently distributed across northern Australia, from the Pilbara and Kimberley regions of Western Australia, through the Top End of the Northern Territory and part of the Gulf Coastal and Mt Isa Inlier bioregions of the Northern Territory and northwestern Queensland, to Cape York, Queensland (Worthington Wilmer et al., 1999; Churchill, 2008). It contracted from areas further south in the Holocene (Molnar et al., 1984), and has declined further since the arrival of Europeans (Churchill \& Helman, 1990; Churchill, 2008; Woinarski et al., 2014; Augusteyn et al., 2018; Armstrong et al., 2019). This taxon is also represented in the early Pleistocene deposit of Rackham's Roost, Riversleigh (Hand, 1996; Woodhead et al., 2016), as well as many sites of Pleistocene and Holocene age around Australia (Molnar et al., 1984). In Western Australia, fossil and subfossil bat material has been discovered in very few localities, though $M$. gigas is a conspicuous presence in numerous limestone caves in the south-west corner (reviews in Cook, 1960; Bridge, 1975; Baynes et al., 1975; Molnar et al., 1984; Armstrong \& Anstee, 2000), and few of these caves are now used by bats of any species (Armstrong et al., 2005). Megadermatid fossils have also been discovered further north on Barrow Island and the Monte Bello Islands off the Pilbara coast (Ken Aplin, unpublished observations). 
More recently, a limestone deposit from Dingo Gap in the Kimberley region, north-west of Fitzroy Crossing (Fig. 1), has produced material from a range of fossil mammals, which includes at least three species of bat. One of these is clearly a megadermatid, which is described here as a new species. The other bat species are not sufficiently well represented for identification or formal description, but they do provide context for the occurrence of the megadermatid bones and teeth.

\section{Methods}

Scanning electron micrographs were taken with a Jeol JSM6060B microscope. Holotype and paratype material was examined and illustrated in comparison with a specimen of M. gigas from the CSIRO Australian National Wildlife Collection (ANWC), Canberra (CM568, male, collected from Mt Etna, Queensland), as well as material in the Western Australian Museum (WAM; three dentaries from M. gigas specimens M3415, M18284 and M18575; all from the Pilbara region of Western Australia). Descriptions are made in comparison with information in Hand (1985, 1995, 1996) and Hand et al. (1988). Measurements were made from SEM images using the software ImageJ (Rasband, 1997-2005; Abramoff et al., 2004). Measurements of the newly described species made for direct comparison with M. gigas correspond to a subset of those in Hand (1985) and are numbered accordingly (Fig. 2). Additional measurements made for descriptive purposes are indicated by letters (Table 1). Higher level systematics follow Simmons \& Cirranello (2020). Anatomical terminology follows Hand (1985), Hand et al. (1988), and Hand (1996).

\section{Systematics}

Chiroptera Blumenbach, 1779

Yinpterochiroptera Springer, Teeling, Madsen, Stanhope \& de Jong, 2001

Rhinolophoidea Gray, 1825

Megadermatidae H. Allen, 1864

Macroderma Miller, 1906

\section{Macroderma handae sp. nov. Aplin and Armstrong}

urn:Isid:zoobank.org:act:018A744D-3AE6-44C0-988E-018C963EEE8E

\section{Figs $3-8$}

Holotype. Fragment of left dentary containing a mostly intact $M_{2}$, broken $P_{4}, M_{1}$ and $M_{3}$, and alveoli of single-rooted $P_{2}$ and $\mathrm{C}_{1}$ (WAM 2020.4.1; Figs 3A,B and 4A,C,E,G). Paratypes. A second fragment of left dentary with alveoli of incisors, $\mathrm{C}_{1}$, $\mathrm{P}_{2}$ and $\mathrm{P}_{4}$, and first two molars (WAM 2020.4.2; Fig. 3D,E); a third fragment of left dentary containing a worn $\mathrm{M}_{1}$ and one alveolus of $\mathrm{M}_{2}$ (WAM 2020.4.3; Fig. 3C); palatal fragment of left maxilla with lingual alveoli of $\mathrm{P}^{4}$ and $\mathrm{M}^{1}$ (WAM 2020.4.4; Fig. 5B,C); fragment of right maxilla with alveoli of $\mathrm{C}^{1}$ and $\mathrm{P}^{4}$ (WAM 2020.4.5; Fig. 5A); right $\mathrm{M}^{1}$ (WAM
2020.4.6; Fig. 6A,C); right $\mathrm{M}^{2}$ fragment (WAM 2020.4.10; Fig. 6E); anterior portion of right $\mathrm{C}^{1}$ (WAM 2020.4.7; Fig. 7A); right $\mathrm{C}^{1}$ with broken paracone (principal cusp, sensu Hand, 1985; WAM 2020.4.9; Fig. 7C,D); left $\mathrm{P}_{2}$ (WAM 2020.4.8; Fig. 8A,B,D); left $\mathrm{M}_{3}$ in poor condition (WAM 2020.4.11; Fig. 4I); left $\mathrm{P}^{4}$ with damaged paracone (principal cusp; WAM 2020.4.12; Fig. 8E-H). All type material is lodged in the Western Australian Museum.

Type locality, lithology, and age. Material was collected from a cemented accumulation of bone material that formed on the floor of a cave in a carbonate-rich stratigraphic sequence at Dingo Gap, Oscar Range, Kimberley region, Western Australia (17 $40^{\prime} \mathrm{S} 125^{\circ} 13^{\prime} \mathrm{E}$, Fig. 1). The location is part of the marginal reef slope and basinal facies of the northern face of the Oscar Range (Stephens \& Sumner, 2003). This range forms the northern edge of the Canning Basin, and is the remnant of an Upper Devonian marine reef complex.

The bone accumulation was in a hard limestone matrix and consisted of teeth and small bone fragments of mammals, particularly rodents (Muridae: Hydromyini (sensu Smissen \& Rowe, 2018); Rattus was absent). Further details of the fauna in this collection are not yet available. It is more likely to be an accumulation from a cave floor beneath a megadermatid bat roost site rather than a pellet accumulation from an owl given that larger jaw fragments were absent. Dental material from other bats was also present, including an unknown species of bat (Fig. 9A-D), canines from an emballonurid (probably Taphozous sp.; Fig. 9E-L), and a lower row of molars from an unidentified vespertilionid (Fig. 9M,N). Given the absence of Rattus, which is thought to have reached Australia by at least the mid-Pleistocene (Rowe et al., 2019), the material is aged tentatively as Pliocene or early Pleistocene.

Diagnosis. Referred to the genus Macroderma Miller, 1906 on the basis of the large size of the $\mathrm{M}^{1-2}$ (within the lower part of the size range of $M$. gigas and $M$. koppa; Table 1; cf. Hand, 1995: 52), the $\mathrm{M}^{1}$ with elongated heel, and markedly lingually displaced mesostyle (cf. Megaderma richardsi; Hand, 1995: 66); $\mathrm{M}_{1-3}$ paracristid (sensu Hand, 1995, 1996; = protocristid sensu Hand, 1985, who used both terms) longer than metacristid; $\mathrm{M}_{1-3}$ reduced metaconid contribution to the cristid obliqua; $\mathrm{M}_{1-3}$ robust and continuous anterior, labial (= buccal) and posterior cingula (see Hand, 1996: 373).

Compared with Macroderma gigas -Maxilla fenestrated (Fig. 5B,C), but not to the degree seen in M. gigas (cf. Hand, 1985: 31); anterior part of dentary thickened, though relatively gracile compared with that of $M$. gigas (dentary depth below $\mathrm{M}_{2}$ protoconid less in $M$. handae; Table 1; Fig. $3 \mathrm{~A}, \mathrm{~F})$; most molar measurements smaller than the average for $M$. gigas, or within the lower part of the size range (Table 1); the shape of the $\mathrm{M}^{1}$ protofossa (whose edges are defined by the preprotocrista and postprotocrista) is rounded rather than triangular (Fig. $6 \mathrm{~A}-\mathrm{D}) ; \mathrm{M}_{2}$ paraconid lower, and protruding less anteriorly past the protoconid (trigonid less expanded anteriorly than in $M$. gigas); $\mathrm{M}_{2}$ protoconid relatively high and of proportionally greater area within the trigonid (more than half in occlusal view (Fig. 4A,B); and $\mathrm{M}_{2}$ talonid proportionally larger with respect to the trigonid (Fig. 4A,B). No protostyle cusp on $\mathrm{P}^{4}$, which is obvious in M. gigas (Fig. 8E,F).

Compared with M. koppa (see Hand et al., 1988: 344-346) - Anterior upper tooth row relatively shorter in $M$. handae, alveoli of $\mathrm{C}^{1}$ and $\mathrm{P}^{4}$ indicating overlap of crowns 
Table 1. Measurements (mm; Fig. 2) of the holotype dentary and $\mathrm{M}_{2}$ (WAM 2020.4.1), and the paratypes $\mathrm{M}^{1}$ (WAM 2020.4.6) and $\mathrm{C}^{1}$ (WAM 2020.4.7) of Macroderma handae sp. nov., in comparison with M. gigas and M. koppa (values and character numbers are from Hand, 1985: 23,25; Hand et al., 1988: 349; mean and range in parentheses; RR indicates measurements from M. gigas in Rackham's Roost, see Hand, 1996: 370; letters in the first column represent measurements made in the present study only; * measurement from paratype WAM 2020.4.2).

\begin{tabular}{|c|c|c|c|c|}
\hline & holotype dentary and $\mathrm{M}_{2}$ & M. handae & M. gigas & M. корра \\
\hline 3 & Dentary depth below $\mathrm{M}_{2}$ protoconid & $3.5,3.42 *$ & $3.92(3.40-4.90)$ RR: 3.45 & $4.2(4.4-4.5)$ \\
\hline 10 & $\mathrm{M}_{2}$ length (sum measurements $14+15$ ) & 3.21 & 3.78 (3.41-4.17) RR: 3.27 & $4.2(3.9-4.1)$ \\
\hline 14 & $\mathrm{M}_{2}$ trigonid length & 1.73 & $2.41(1.91-2.79)$ RR: 2.10 & $2.5(2.3-2.5)$ \\
\hline 15 & $\mathrm{M}_{2}^{2}$ talonid length & 1.48 & $1.41(1.00-1.88)$ RR: 1.19 & $1.6(1.3-1.6)$ \\
\hline 21 & $\mathrm{M}_{2}$ trigonid width & 2.36 & $2.38(2.05-2.68)$ & $2.8(2.4-2.6)$ \\
\hline 22 & $\mathrm{M}_{2}^{2}$ talonid width & 2.16 & $2.31(1.86-2.85)$ & $2.6(2.2-2.5)$ \\
\hline 27 & $\mathrm{M}_{2}$ paracristid length & 1.44 & $1.72(1.38-1.92)$ & - \\
\hline 28 & $\mathrm{M}_{2}$ metacristid length & 1.04 & $1.25(0.98-1.65)$ & - \\
\hline A & $\mathrm{M}_{2}^{2}$ protoconid height (not illustrated) & 3.19 & - & - \\
\hline \multirow[t]{2}{*}{ B } & Mental foramen width (not illustrated) & $0.53,0.55$ & - & - \\
\hline & paratypes $\mathrm{M}^{1}$ and $\mathrm{C}^{1}$ & M. handae & M. gigas & M. koppa \\
\hline 14 & $\mathrm{M}^{1}$ labial (buccal) length & 3.53 & $3.93(3.36-4.40)$ RR: $3.36,3.52$ & $4.1(4.0-4.2)$ \\
\hline 18 & $\mathrm{M}^{1}$ lingual length & 3.13 & $4.24(3.60-4.76)$ RR: $3.59,3.85$ & 4.0 \\
\hline 21 & $\mathrm{M}^{1}$ width & 3.95 & $4.15(3.65-4.63)$ RR: $3.43,3.94$ & $4.4(4.1-4.3)$ \\
\hline 25 & $\mathrm{M}^{1}$ metacone apex to metastyle & 2.15 & $2.73(2.36-2.88)$ & - \\
\hline 28 & $\mathrm{M}^{1}$ paracone to heel & 2.43 & $3.20(2.29-3.66)$ & - \\
\hline 30 & $\mathrm{M}^{1}$ heel inflexions & 1.49 & $2.34(1.84-3.54)$ & - \\
\hline 32 & $\mathrm{M}^{1}$ length through protocone & 1.70 & $2.44(2.08-2.90)$ & - \\
\hline $\mathrm{C}$ & $\mathrm{M}^{1}$ protofossa width & 1.20 & - & - \\
\hline $\mathrm{D}$ & $\mathrm{M}^{1}$ heel width & 1.37 & - & - \\
\hline $\mathrm{E}$ & $\mathrm{C}^{1}$ height (not illustrated) & 4.29 & - & - \\
\hline
\end{tabular}

\section{Left $\mathrm{M}_{2}$}

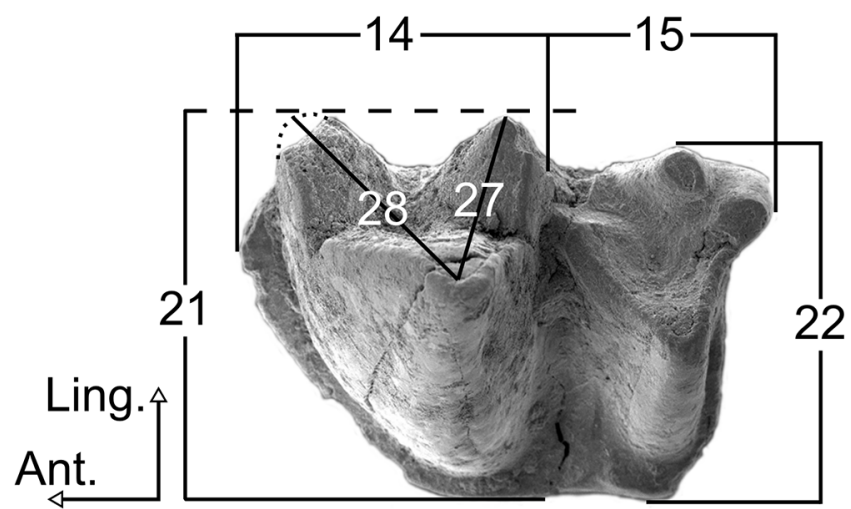

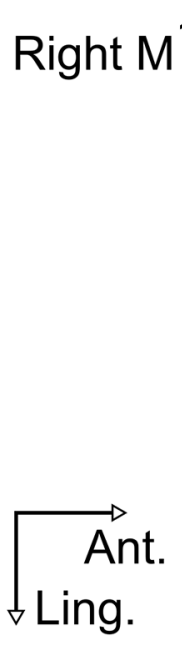

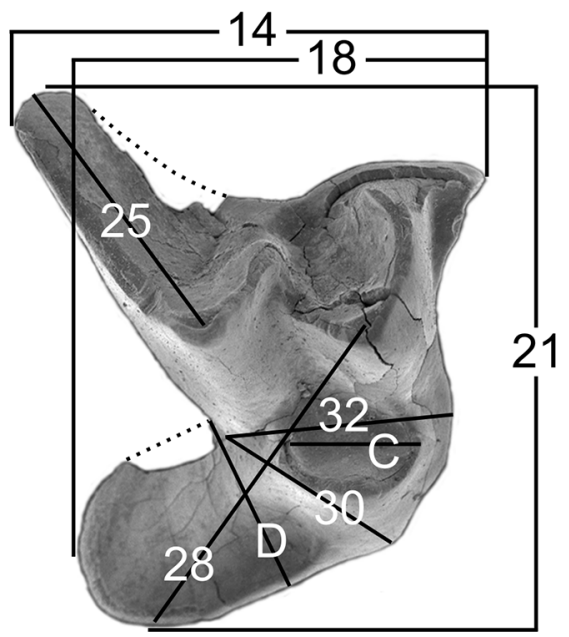

Figure 2. Dental measurements taken from the left $\mathrm{M}_{2}$ and the right $\mathrm{M}^{1}$, based on Hand (1985).

(Fig. 5A; cf. Hand et al., 1988: 345, fig. 2b,c); the shape of the $\mathrm{M}^{1}$ protofossa (with edges defined by the preprotocrista and postprotocrista) is rounded rather than triangular; molar measurements smaller than the values for M. koppa (Table 1; cf. Hand et al., 1988: 349); anterior part of dentary relatively gracile compared with that of $M$. koppa (dentary depth below $\mathrm{M}_{2}$ protoconid less in $M$. handae; Table 1); $\mathrm{M}_{2}$ paraconid relatively low, and protruding less anteriorly past the protoconid due to anterior compression of the trigonid (Fig. 4C,E; cf. Hand et al., 1988: 345, fig. 2a); $\mathrm{M}_{2}$ protoconid relatively high and of proportionally greater area within the trigonid (more than half in occlusal view; Fig. 4A); entoconid smaller than hypoconulid (Fig. 4E,G; cf. Hand et al., 1988: 345 , fig. 2a); the $\mathrm{P}_{2}$ is of a similar shape in both species (Fig. 8A,B,D; cf. Hand et al., 1988: 345, fig. 2a).

Compared with $M$. malugara Hand, 1996- $\mathrm{P}^{2}$ absent in $M$. handae; slightly smaller size of $\mathrm{M}^{1}$ and $\mathrm{M}_{2}$ (Table 1 ; cf. Hand, 1996: 368); the shape of the $\mathrm{M}^{1}$ protofossa (whose edges are defined by the preprotocrista and postprotocrista) is rounded rather than triangular; $\mathrm{M}_{2}$ paraconid relatively low, and protruding less anteriorly past the protoconid due to anterior compression of the trigonid (Fig. 4A,C,E; cf. Hand, 1996: 366-367, pl. 48k-m); $\mathrm{M}_{2}$ protoconid relatively high and of proportionally greater area of the trigonid (more than 

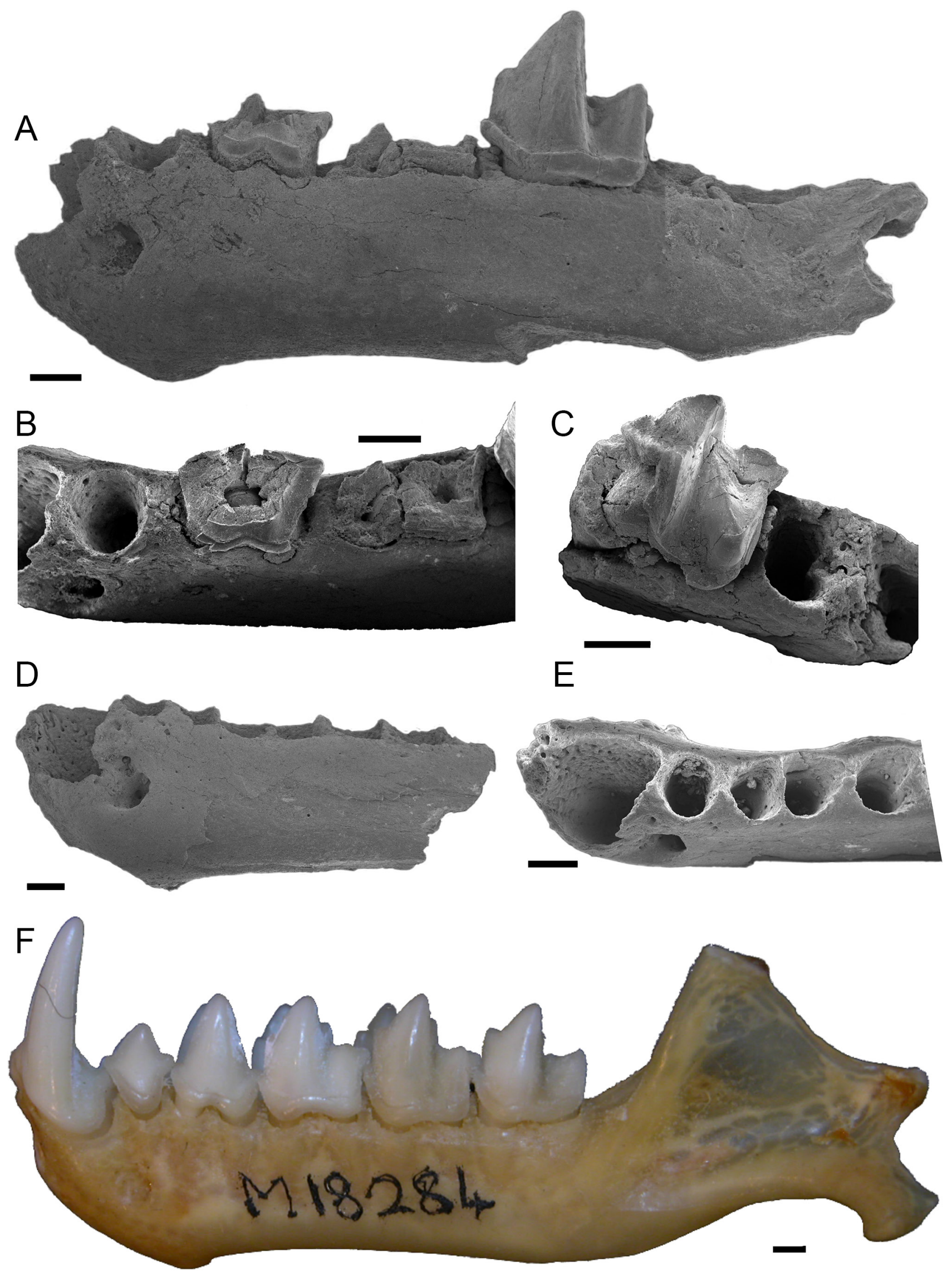

Figure 3. Scanning electron micrographs of holotype and paratype material of Macroderma handae sp. nov. $(A)$ lateral view of the left dentary of holotype WAM 2020.4.1 with mostly intact $\mathrm{M}_{2}$, broken $\mathrm{P}_{4}, \mathrm{M}_{1}$ and $\mathrm{M}_{3}$, and alveoli of single-rooted $\mathrm{P}_{2}$ and $\mathrm{C}_{1} ;(B)$ occlusal view of the holotype WAM 2020.4.1 anterior to the $\mathrm{M}_{2} ;(C)$ occlusal view of a fragment of left dentary, paratype WAM 2020.4.3; $(D, E)$ lateral and occlusal view of a fragment of left dentary, paratype WAM 2020.4.2; $(F)$ digital photograph of the left dentary of $M$. gigas WAM M18284. Scale bars $1 \mathrm{~mm}$. 

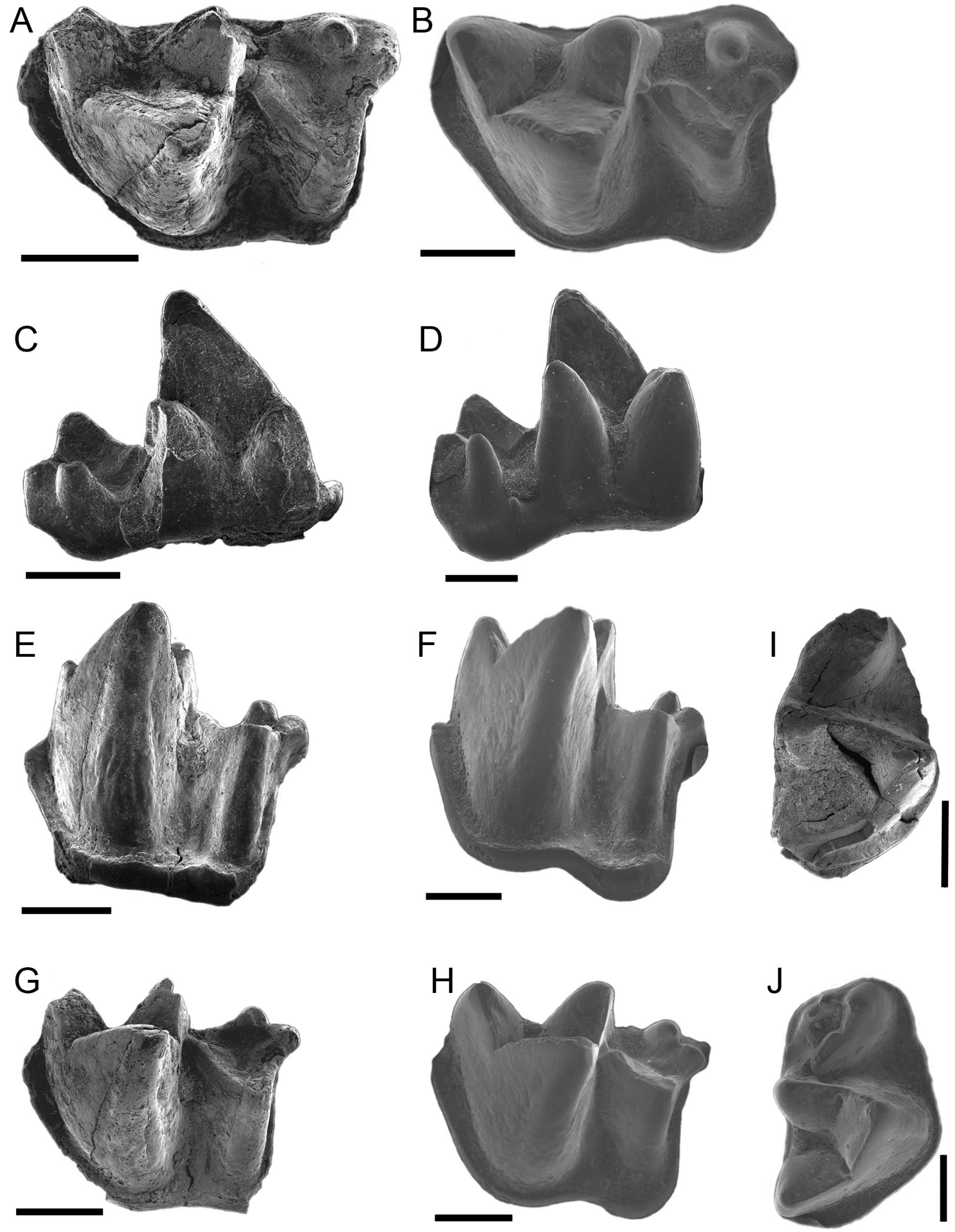

Figure 4. Scanning electron micrographs of holotype and paratype material of Macroderma handae sp. nov. $(A, C, E, G)$ occlusal, lingual, labial, and labial-oblique views of the left $\mathrm{M}_{2}$ from the holotype WAM 2020.4.1; $(B, D, F, H)$ corresponding views of the left $\mathrm{M}_{2}$ of $M$. gigas ANWC CM568; $(I)$ occlusal view of left $\mathrm{M}_{3}$, paratype WAM 2020.4.11; $(J)$ left $\mathrm{M}_{3}$ of $M$. gigas ANWC CM568. Scale bars 1 mm. 

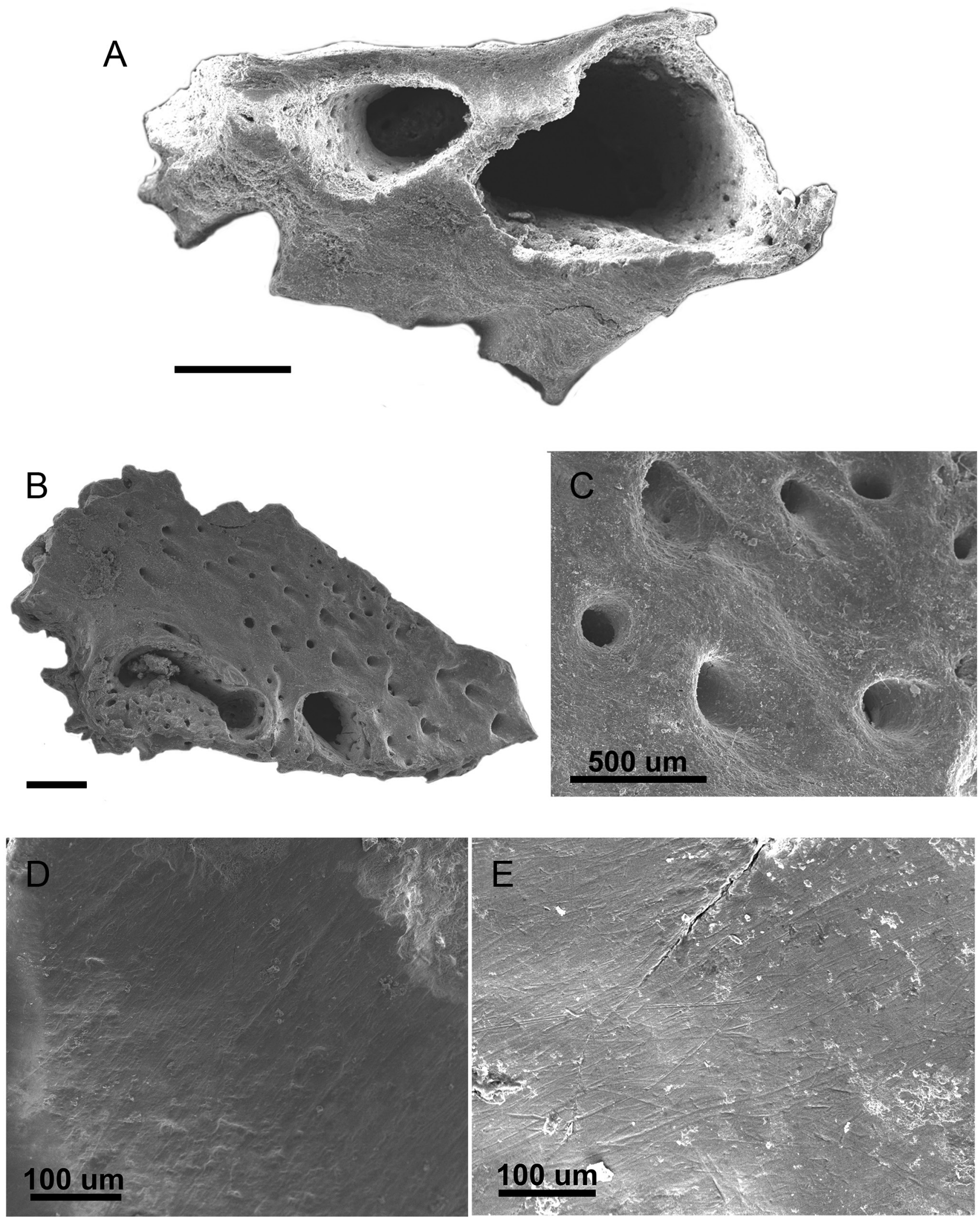

Figure 5. Scanning electron micrographs of paratype material of Macroderma handae sp. nov. (A) fragment of the right maxilla with alveoli of the $\mathrm{C}^{1}$ and $\mathrm{P}^{4}$, paratype WAM 2020.4.5; $(B)$ palatal fragment of left maxilla with lingual alveoli of $\mathrm{P}^{4}$ and $\mathrm{M}^{1}$, paratype WAM 2020.4.4; (C) detail of the blood vessel fenestrations in paratype WAM 2020.4.4; $(D)$ probable wear striations on the $\mathrm{M}_{3}$, paratype WAM 2020.4.11; (E) wear striations from M. gigas ANWC CM568. Scale bars $1 \mathrm{~mm}$, except where indicated otherwise. 
A

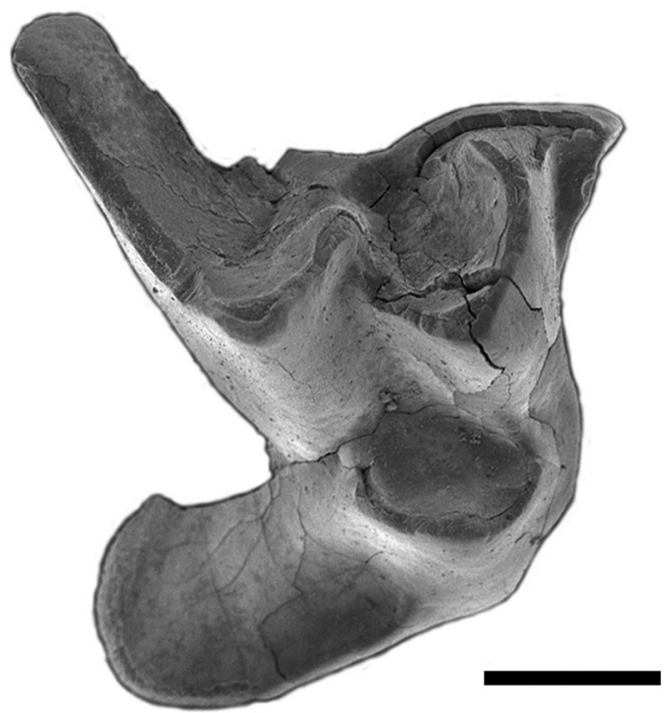

C
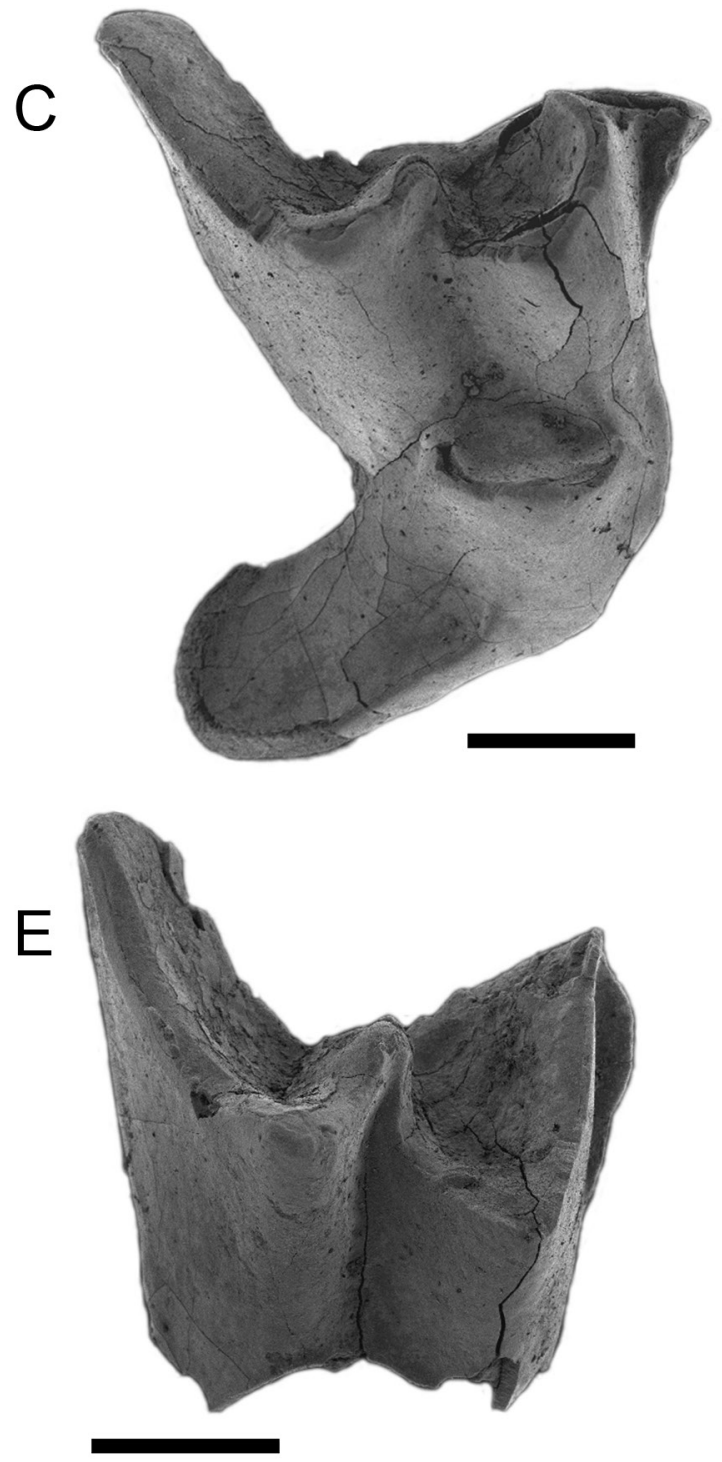

\section{$\mathrm{B}$}

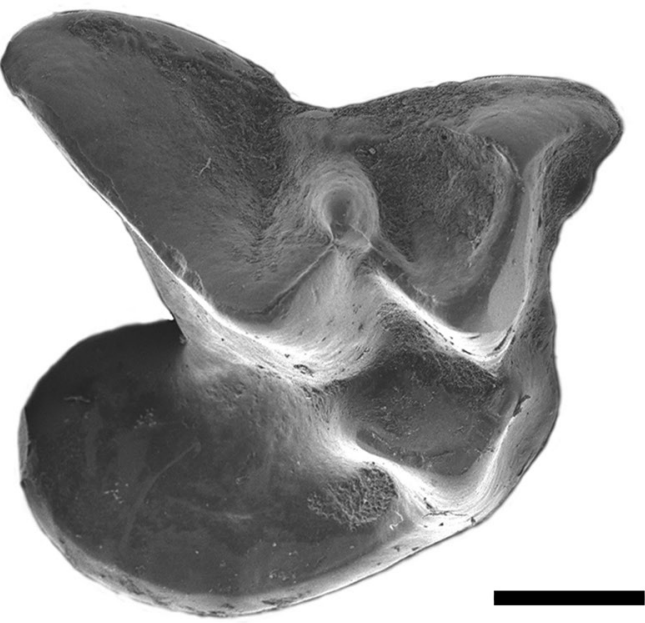

$\mathrm{D}$
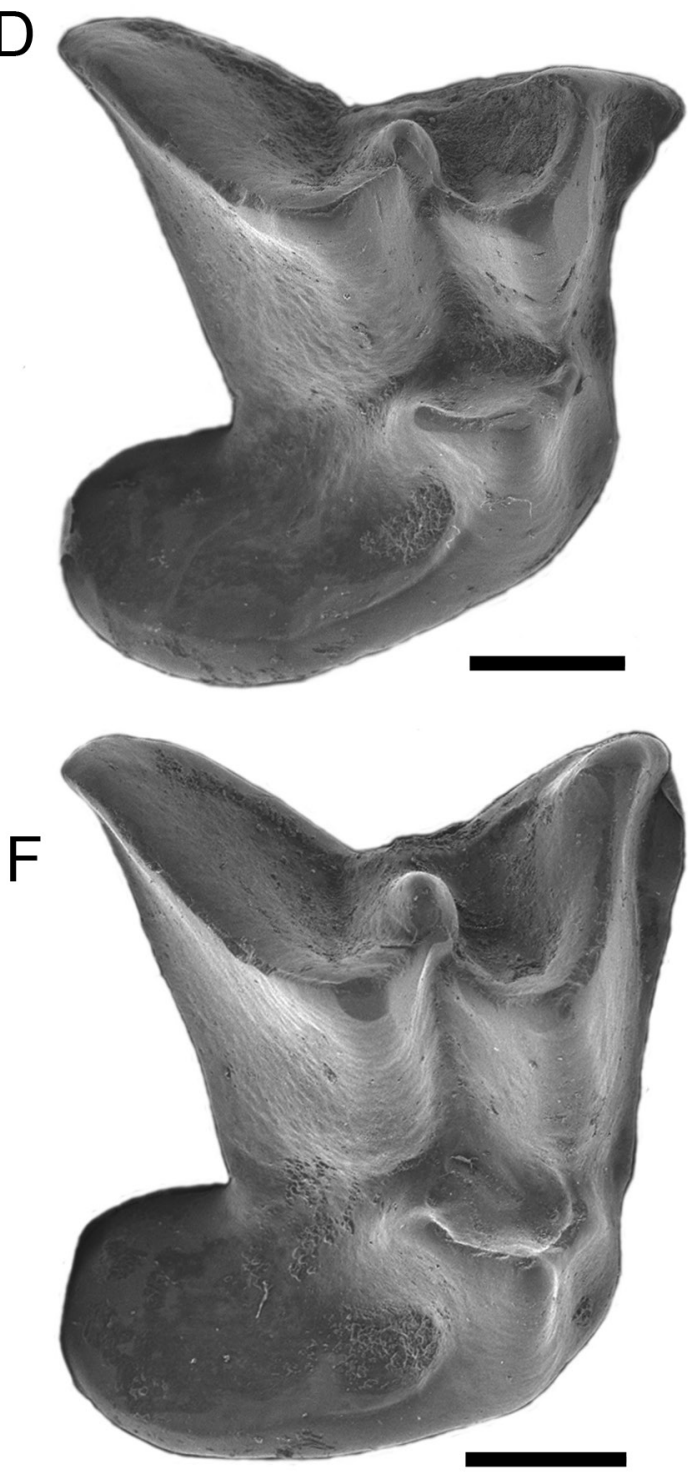

Figure 6. Scanning electron micrographs of paratype material of Macroderma handae sp. nov. ( $A$, $C$ ) occlusal-oblique views of a right $\mathrm{M}^{1}$, paratype WAM 2020.4.6; $(B, D)$ corresponding views of the right $\mathrm{M}^{1}$ of $M$. gigas ANWC CM568; $(E)$ occlusal view of a fragment of a right $\mathrm{M}^{2}$, paratype WAM 2020.4.10; $(F)$ corresponding view of the right $\mathrm{M}^{2}$ of $M$. gigas ANWC CM568. Scale bars $1 \mathrm{~mm}$. 

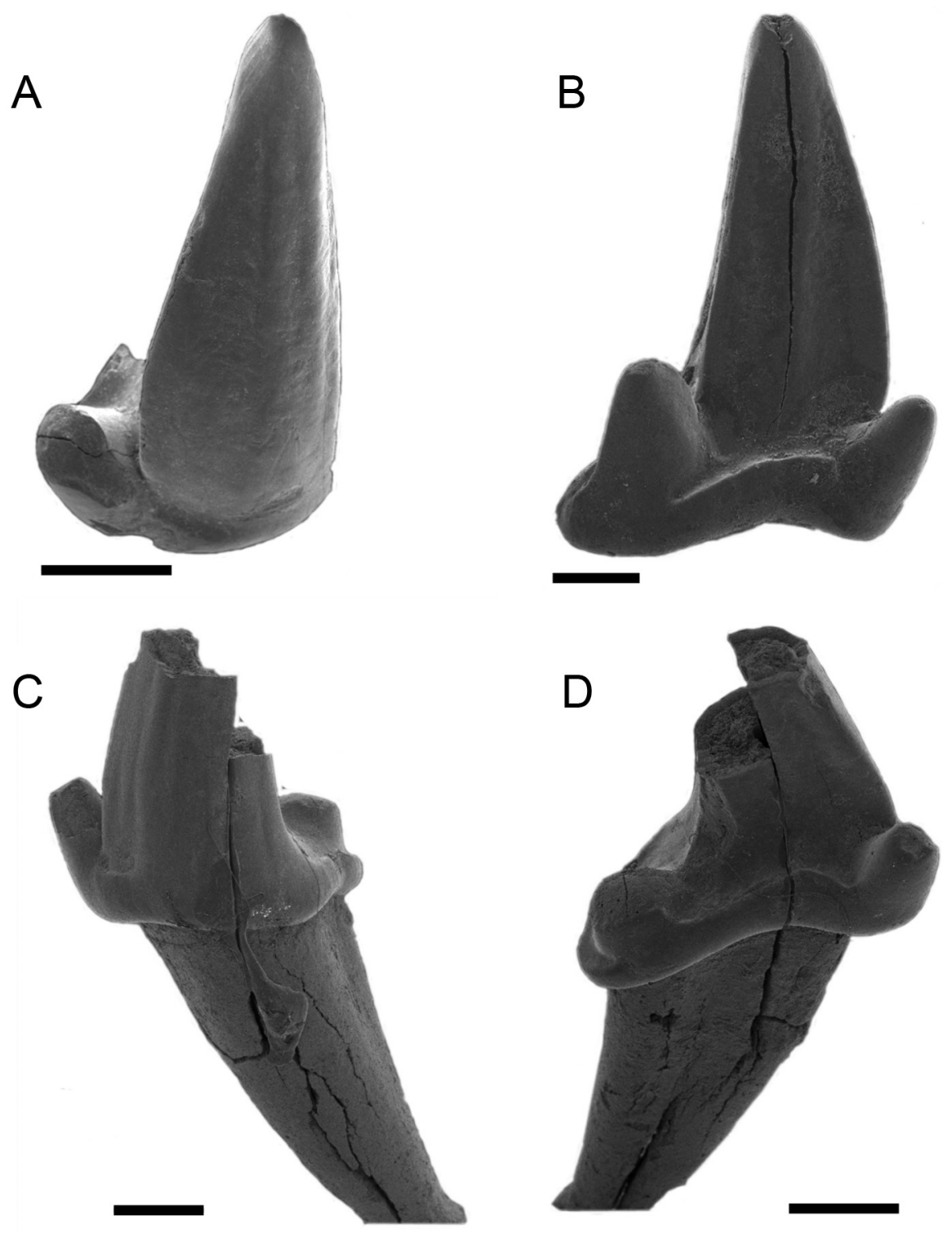

Figure 7. Scanning electron micrographs of paratype material of Macroderma handae sp. nov. $(A)$ anterior half of a right $\mathrm{C}^{1}$, paratype WAM 2020.4.7; $(B)$ lingual view of a right $\mathrm{C}^{1}$ of $M$. gigas ANWC CM568; $(C, D)$ labial and lingual views of a right $C^{1}$ with a damaged paracone, paratype WAM 2020.4.9. Scale bars $1 \mathrm{~mm}$.

half in occlusal view; Fig. 4A; cf. Hand, 1996: 366-367, pl. $48 \mathrm{~m}$ ); greater development of $\mathrm{M}_{2}$ hypoconulid (Fig. 4A; cf. Hand, 1996: 366-367, pl. 48m).

Compared with $M$. godthelpi Hand, $1985-\mathrm{C}^{1}$ and $\mathrm{M}^{1}$ and $\mathrm{M}_{2}$ slightly larger in size in $M$. handae, and $\mathrm{M}_{2}$ with greater protoconid height (Table 1; cf. measurements in Hand, 1985: 8-9; see also Sigé et al., 1982 for measurement key); taller and more robust $\mathrm{C}^{1}$ (Table $1 E$; Fig. 7A,C,D; cf. Hand, 1985: 9,12, fig. 5a,b); loss of $\mathrm{P}^{2}$; proportionally greater contribution of the cingulum to the height of the $\mathrm{P}_{2}$ (cf. Hand, 1985: 13, fig. 6c); $\mathrm{M}_{2}$ paraconid relatively low, and protruding less anteriorly past the protoconid due to anterior compression of the trigonid (Fig. 4A,C,E; cf. Hand, 1985: 11, fig. 4a,b,c); $\mathrm{M}_{2}$ protoconid relatively high and of proportionally greater area of the trigonid (more than half in occlusal view; Fig. 4A; cf. Hand, 1985: 11, fig. 4c).

Description. The anterior part of the dentary is thickened, though relatively gracile and shallower in depth compared to M. koppa and M. gigas, with likely two lower incisors per side (paratype WAM 2020.4.2; anterior detail not shown in Fig. 3A,B,D,E). Two premolars are present $-\mathrm{P}_{2}$ and $\mathrm{P}_{4}$, in addition to the $\mathrm{M}_{1-2}$ (Fig. 3A,B), and the $\mathrm{M}_{3}$ (Fig. 4I).

There is marked extension posterolingually of the $\mathrm{C}_{1}$, similar to $M$. gigas (Fig. 7A-D). The $\mathrm{P}_{2}$ has a proportionally large cingulum, as can be seen in occlusal view, which gives the tooth the appearance of a "witches hat" when viewed from either the labial or lingual side (Fig. 8A,B,D).

The $M_{1}$ is shorter than, or equal in length to, the tallcrowned $\mathrm{M}_{2}$ (Fig. 3A). The paracristid of the $\mathrm{M}_{2}$ is longer than the metacristid (Fig. 4A). There is relatively little contribution of the $\mathrm{M}_{2}$ metaconid to the cristid obliqua (Fig. 4A). The $\mathrm{M}_{2}$ hypoconulid is situated posteriorly (Fig. 4A). The anterior, labial, and posterior cingula are robust and continuous (Fig. 4A,E,G). There is no development of the entostylid (Fig. 4A).

The maxilla is rugose and fenestrated, with grooves of blood vessels along the surface (Fig. 5B,C). The condition of the infraorbital foramen (a key feature separating $M$. 

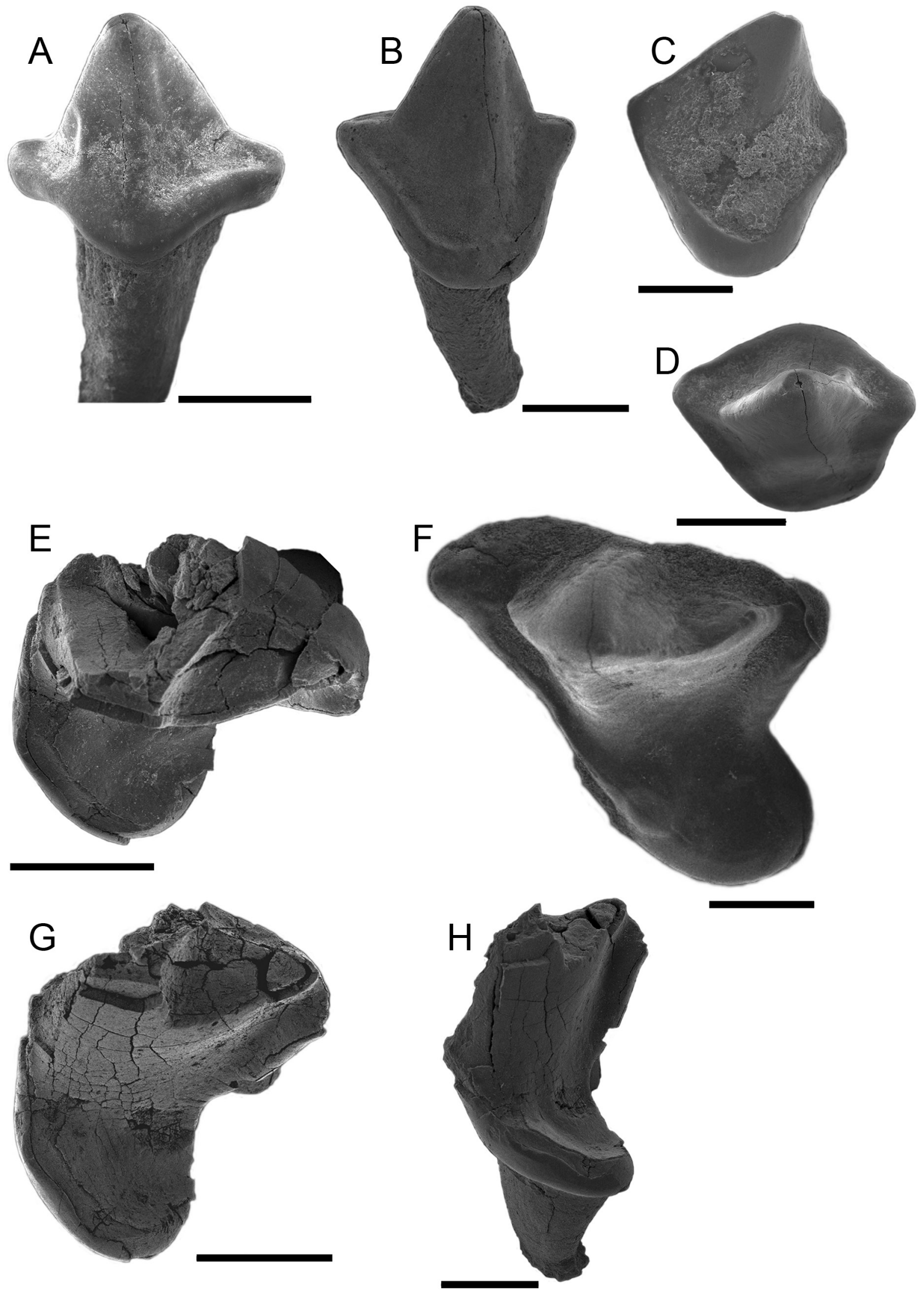

Figure 8. Scanning electron micrographs of paratype material of Macroderma handae sp. nov. $(A, B, D)$ lingual, labial and occlusal views of a left $\mathrm{P}_{2}$, paratype WAM 2020.4.8; (C) labial view of the left $\mathrm{P}_{2}$ of $M$. gigas ANWC CM568; $(E, G, H)$ occlusal, lingual-oblique, and posterior views of a damaged left $\mathrm{P}^{4}$, paratype WAM 2020.4.12; $(F)$ occlusal view of a left $\mathrm{P}^{4}$ of $M$. gigas ANWC CM568. Scale bars 1 mm. 

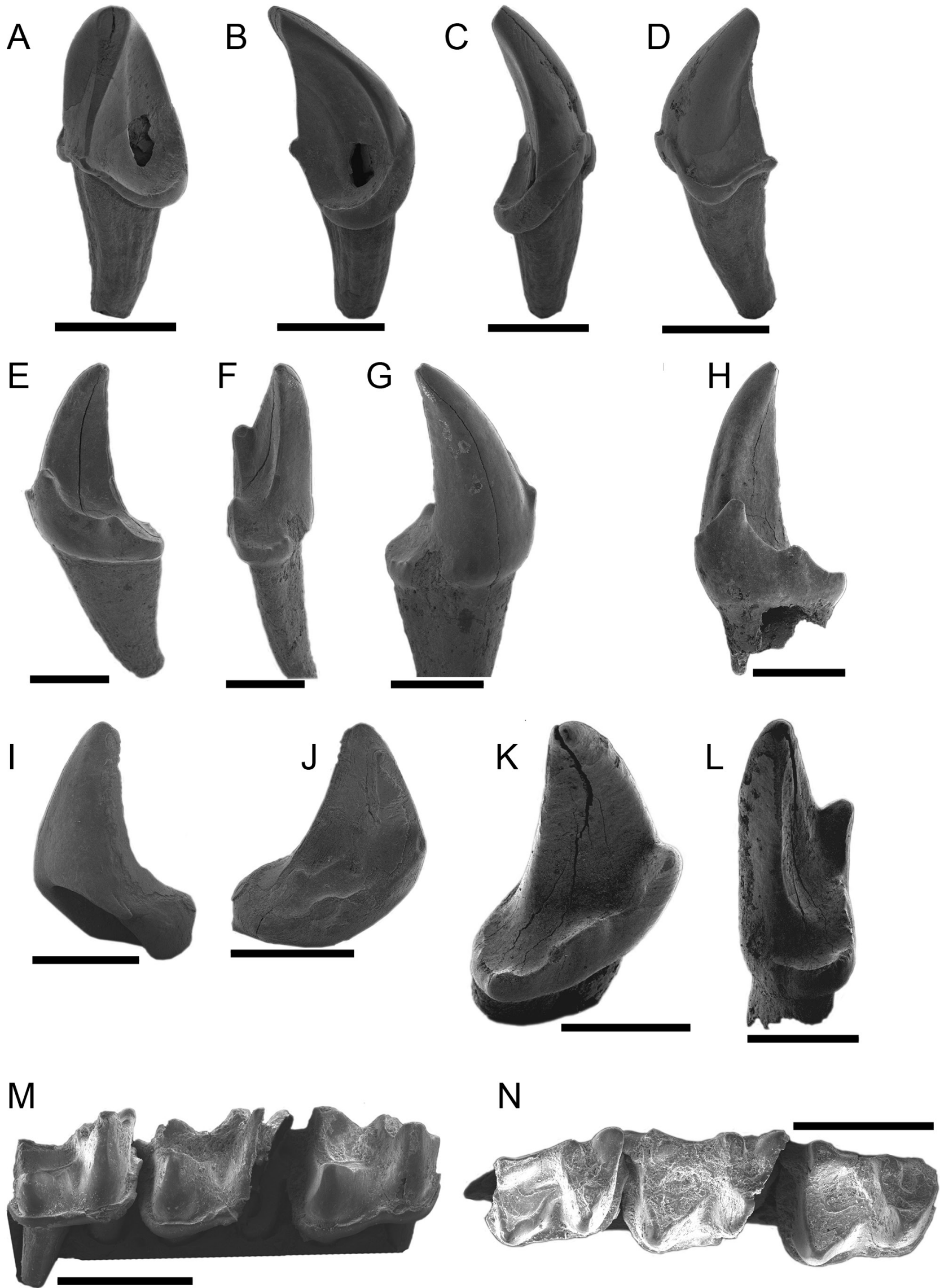

Figure 9. Scanning electron micrographs of other unidentified and undescribed bat material recovered from the same deposit at Dingo Gap. $(A-D)$ WAM 2020.4.13; $(E-G)$ right $\mathrm{C}_{1}$ of an emballonurid, WAM 2020.4.14; $(H)$ right $\mathrm{C}_{1}$ of an emballonurid, WAM 2020.4.15; $(I, J)$ left $\mathrm{C}_{1}$ of an emballonurid, WAM 2020.4.16; $(K, L)$ left $\mathrm{C}_{1}$ of an emballonurid, WAM 2020.4.17; $(M, N)$ lingual and occlusal views of a fragment of dentary of a vespertilionid containing $\mathrm{M}_{1}-\mathrm{M}_{3}\left(\mathrm{M}_{1}\right.$ is on the right in both views), WAM 2020.4.18. Scale bars 1 mm. 


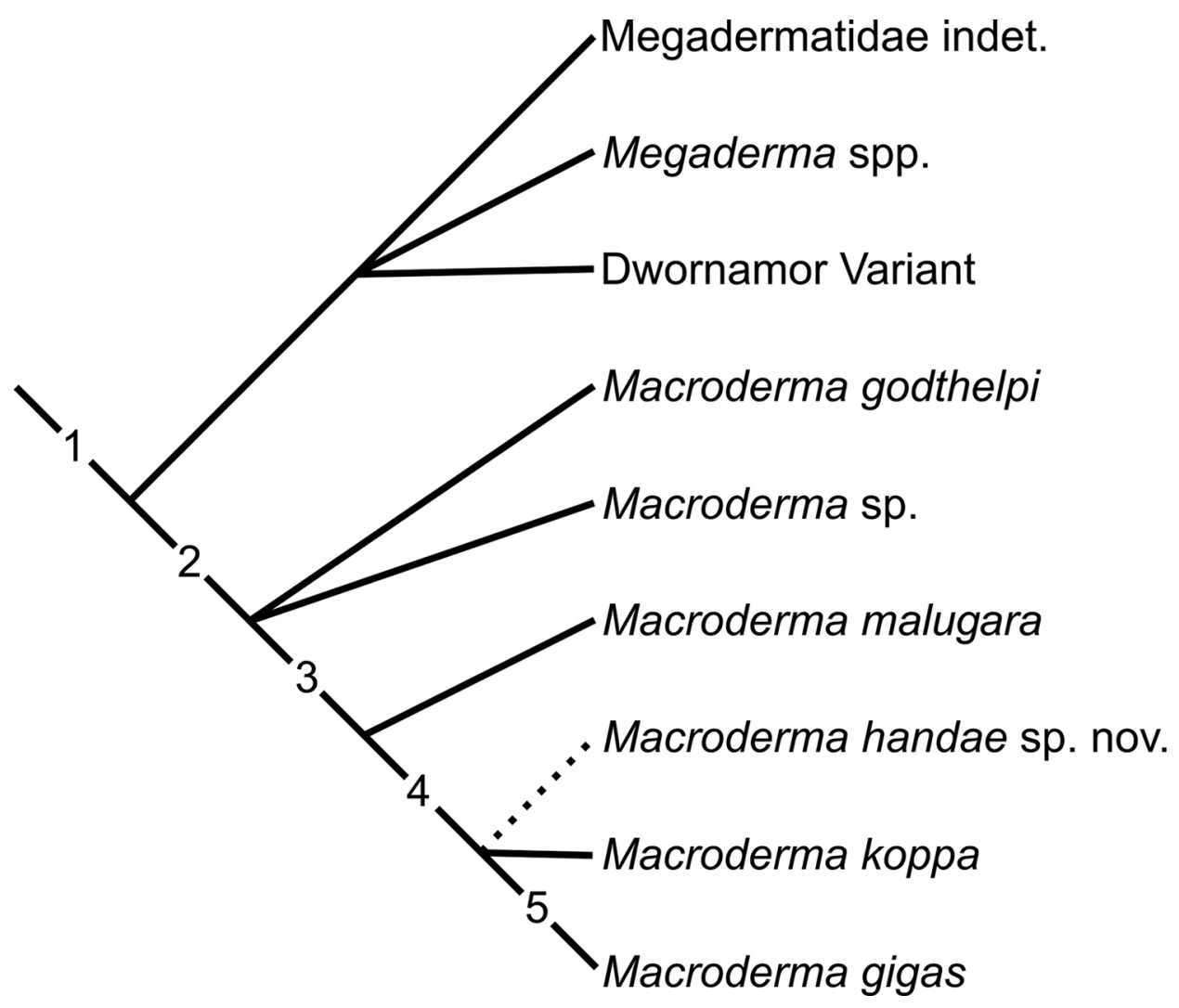

Figure 10. Inferred relative phylogenetic position of Macroderma handae sp. nov. based on observable synapomorphic features (modified after Hand, 1996; numbers indicate the development of potential apomorphic character states, as detailed in that reference).

koppa [two foramina] and M. gigas [one foramen]; Fig. 5A) cannot be observed.

The $\mathrm{P}^{2}$ is absent, as indicated by the absence of an alveolus between those of the canine and $\mathrm{P}^{4}$ (paratype WAM 2020.4.5; Fig. 5A). The alveolus of $\mathrm{C}^{1}$ and anterobuccal/ anterolabial alveolus of $\mathrm{P}^{4}$ indicate that the crowns of these teeth overlapped in the tooth row (Fig. 5A). The heel of the $\mathrm{P}^{4}$ is broad, and the posterior edge is at right angles to the paracone (it is angled close to $45^{\circ}$ lingually in M. gigas; Fig. $8 \mathrm{E}-\mathrm{H})$. There is no protostyle cusp, which is obvious in $M$. gigas (Fig. 8E,F).

The $\mathrm{M}^{1}$ has a broad labial (buccal, sensu Hand, 1996) shelf, though narrower than that of M. gigas (Fig. 6A,B), and a markedly lingually displaced mesostyle (cf. Megaderma richardsi; Hand, 1995). The preprotocrista and postprotocrista are curved, giving the protofossa a rounded shape, which contrasts with the more triangular form of other Macroderma species (Hand et al., 1988: 345, fig. 2c; Hand, 1985: 10, fig. 3c, 1996: 366-367, pl. 48d), and also Megaderma richardsi (Hand, 1995: pl. 1b,c). Both the $\mathrm{M}^{1}$ and $\mathrm{M}^{2}$ have tall crowns, and appear to be slightly compressed anteroposteriorly relative to Macroderma gigas (Fig. 6A-F).

Unidirectional wear striations are observable on the left $\mathrm{M}_{3}$, which resemble those found on the teeth of the predatory M. gigas that crush the bones of prey (Fig. 5D,E).

Etymology. Named in honour of Professor Suzanne ("Sue") J. Hand of the University of New South Wales, in recognition of her previous extensive work on fossils of this family, and her extraordinary, sustained, and ongoing work on fossils that has helped piece together the rich history of the Australasian mammal fauna.

\section{Discussion}

\section{Phylogenetic relationships}

The phylogenetic position of Macroderma handae relative to most megadermatids can be estimated based on the presence of various synapomorphies that characterize subclades within the family (character sets 1-5 listed in Hand, 1996: 373) (Fig. 10). It displays the following apomorphic conditions: (a) Characterizing it as part of the MegadermaMacroderma clade: $\mathrm{M}_{1}$ shorter than or equal in length to $\mathrm{M}_{2}$. (b) Distinguishing it from the Megaderma clade: $\mathbf{M}^{1}$ with elongated heel, and markedly lingually displaced mesostyle (cf. Megaderma richardsi; Hand, 1995); in the $\mathrm{M}_{2}$ : the paracristid longer than metacristid, reduced metaconid contribution to the cristid obliqua; robust, continuous anterior, labial and posterior cingula. (c) Distinguishing it from Macroderma godthelpi: large-sized, tall-crowned teeth; $\mathrm{M}_{2}$ with robust and broad anterior cingulum. $(d)$ Distinguishing it from M. malugara: $\mathrm{P}^{2}$ absent; $\mathrm{C}_{1}$ markedly posterolingually-extended; $\mathrm{M}_{1-2}$ larger and more posteriorlysituated hypoconulid; and preentocristid further reduced. The phylogenetic position of $M$. handae relative to M. koppa and $M$. gigas could not, however, be determined unambiguously based on the material from Dingo Gap because the condition of the infraorbital foramen (one or two foramina) and some other diagnostic features could not be observed.

\section{Australian Pliocene megadermatid diversity}

The new species $M$. handae represents the second Pliocene species of Macroderma discovered to date, together with 
M. koppa. The age of the Big Sink Site of Wellington Caves in New South Wales has also been estimated as Pliocene, though it has not been dated other than on the basis of biocorrelation with better-dated faunas (reviews in Hand, 1996; Dawson et al., 1999), and the inferred plesiomorphic condition of M. koppa (Dawson et al., 1999: 284). Both sites lack Rattus material, though they have representatives of the Old Endemic murid radiation (Hydromyini, sensu Smissen \& Rowe, 2018), so their likely age is at least somewhere between the first Australian murid radiations and the invasion of Rattus (Aplin, 2006; Rowe et al., 2019). The species $M$. handae and M. koppa might have been contemporaneous, or alternatively they could have arisen at slightly different ages sometime from the late Miocene to early Pliocene. While $M$. handae appears slightly smaller on the basis of a few molar measurements, it is not markedly so. Thus, it might have been an earlier or allopatric taxon. A proposed common name for M. handae is the Kimberley False Vampire Bat.

\section{Chiropteran assemblage}

Several other bat species were recovered from the same assemblage that contained M. handae (Fig. 9). The lack of molars, or those in an unbroken condition, precluded identification to species, or species description. But on the basis of canine morphology (the position of cingular cusps), an emballonurid species, most likely representing the genus Taphozous, is present. A small vespertilionid species was also present. Based on the wear striations on the $\mathrm{M}_{3}$ of $M$. handae (Fig. 5D), probably derived from crushing the bones of vertebrates, these smaller bat species might well have been prey, as well as co-inhabitants of the roost. Body parts of the species Taphozous georgianus, Rhinonicteris aurantia and Vespadelus finlaysoni have all been observed in the prey accumulations of modern M. gigas in the Pilbara region of Western Australia and Northern Territory (Churchill, 2008; K. N. Armstrong personal observations).

ACKNOwLEDGements. The authors are grateful to the Kyoto University Museum for support and use of facilities; to Hidetoshi Nagamasu for help with the SEM; the Western Australian Museum and the Australian National Wildlife Collection for the loan of material; Alexander Baynes of the Western Australian Museum for information on the collection and careful editing of the manuscript; and to Robin Beck, Gilbert Price, and Sue Hand, for helpful review comments that resulted in a much-improved text. KPA acknowledges the support of the Kyoto University Museum, which hosted him as a visiting professor; and KNA gratefully acknowledges the support of a JSPS Postdoctoral Fellowship for Foreign Researchers while at the Kyoto University Museum. Ken Aplin is a posthumous author on this publication. He collected and discovered the material described herein, designed the study, took the images together with KNA, and made numerous contributions and comments as the earlier versions of the manuscript were drafted. Some details about Ken's Dingo Gap collection are unfortunately not available.

\section{References}

Abramoff, M. D., P. J. Magelhaes, and S. J. Ram. 2004. Image processing with ImageJ. Biophotonics International 11: 36-42.

Aplin, K. P. 2006. Ten million years of rodent evolution in Australasia: phylogenetic evidence and a speculative historical biogeography. In Evolution and Biogeography of Australasian Vertebrates, ed. J. R. Merrick, M. Archer, G. M. Hickey, and M. S. Y. Lee, pp. 707-744. Oatlands, Sydney: Auscipub.

Archer, M., D. A. Arena, M. Bassarova, R. M. Beck, K. Black, W. E. Boles, P. Brewer, B. N. Cooke, K. Crosby, A. Gillespie, H. Godthelp, S. J. Hand, B. P. Kear, J. Louys, A. Morrell, J. Muirhead, K. K. Roberts, J. D. Scanlon, K. J. Travouillon, and S. Wroe. 2006. Current status of species-level representation in faunas from selected fossil localities in the Riversleigh World Heritage Area, northwestern Queensland. Alcheringa 30: 1-17. https://doi.org/10.1080/03115510608619570

Armstrong, K. N., R. Brown, and P. Armstrong. 2005. The status of bat roosts in caves in the south west of Western Australia, with a focus on Quininup Lake Cave. The Western Australian Naturalist 25: 41-56.

Armstrong, K. N., and S. D. Anstee. 2000. The ghost bat in the Pilbara: 100 years on. Australian Mammalogy 22: 93-101. https://doi.org/10.1071/AM00093

Armstrong, K. N., J. C. Z. Woinarski, N. M. Hanrahan, and A. A. Burbidge. 2019. Macroderma gigas. The IUCN Red List of Threatened Species 2019: e.T12590A22027714. https://doi.org/10.2305/IUCN.UK.2019-3.RLTS.T12590A22027714.en

Augusteyn, J., J. Hughes, G. Armstrong, K. Real, and C. Pacioni. 2018. Tracking and tracing central Queensland's Macrodermadetermining the size of the Mount Etna ghost bat population and potential threats. Australian Mammalogy 40: 243-253. https://doi.org/10.1071/AM16010

Bate, D. M. A. 1937. New Pleistocene mammals from Palestine. Annals and Magazine of Natural History (10)20: 397-400. https://doi.org/10.1080/00222933708655355

Baynes, A., D. Merrilees, and J. K. Porter. 1976. Mammal remains from the upper levels of a late Pleistocene deposit in Devil's Lair, Western Australia. Journal of the Royal Society of Western Australia 58: 97-126.

Bridge, P. 1975. Paleo-distribution of Macroderma gigas in the southwest of Western Australia. Helictite 13: 34-36.

Churchill, S. K. 2008. Australian Bats, 2nd edition. Crows Nest, N.S.W.: Allen and Unwin.

Churchill, S. K., and P. M. Helman. 1990. Distribution of the ghost bat, Macroderma gigas, (Chiroptera: Megadermatidae) in central and South Australia. Australian Mammalogy 13: 149-56.

Cook, D. L. 1960. Some mammal remains found in caves near Margaret River. The Western Australian Naturalist 7: 107-108.

Dawson, L., J. Muirhead, and S. Wroe. 1999. The Big Sink Local Fauna: a lower Pliocene mammalian fauna from the Wellington Caves complex, Wellington, New South Wales. Records of the Western Australian Museum supplement no. 57: 265-290.

Foley N. M., V. D. Thong, P. Soisook, S. M. Goodman, K. N. Armstrong, D. Jacobs, S. J. Peuchmaille, and E. C. Teeling. 2015. How and why overcome the impediments to resolution: lessons from rhinolophid and hipposiderid bats. Molecular Biology and Evolution 32: 313-333.

https://doi.org/10.1093/molbev/msu329

Gunnell G. F., E. L. Simons, and E. R. Seiffert. 2008. New bats (Mammalia: Chiroptera) from the late Eocene and early Oligocene, Fayum Depression, Egypt. Journal of Vertebrate Paleontology 28: 1-11. https://doi.org/10.1671/0272-4634(2008)28[1:NBMCFT]2.0.Co;2

Hand, S. J. 1985. New Miocene megadermatids (Chiroptera: Megadermatidae) from Australia, with comments on megadermatid phylogenetics. Australian Mammalogy 8: 5-43. 
Hand, S. J. 1990. First Tertiary molossid (Microchiroptera: Molossidae) from Australia: its phylogenetic and biogeographic implications. Memoirs of the Queensland Museum 28: 175-192.

Hand, S. J. 1995. First record of the genus Megaderma Geoffroy, 1810 (Microchiroptera: Megadermatidae) from Australia. Palaeovertebrata 24: 47-66.

Hand, S. J. 1996. New Miocene and Pliocene megadermatids (Mammalia, Microchiroptera) from Australia, with comments on broader aspects of megadermatid evolution. Geobios 29: $365-377$. https://doi.org/10.1016/S0016-6995(96)80038-6

Hand, S. J. 1997a. New Miocene leaf-nosed bats (Microchiroptera: Hipposideridae) from Riversleigh, northwestern Queensland. Memoirs of the Queensland Museum 41: 335-349.

Hand, S. J. 1997b. Miophyllorhina riversleighensis gen. et sp. nov., a Miocene leaf-nosed bat (Microchiroptera: Hipposideridae) from Riversleigh, Queensland. Memoirs of the Queensland Museum 41: 351-354.

Hand, S. 1998a. Riversleigha williamsi gen. et sp. nov., a large Miocene hipposiderid (Microchiroptera) from Riversleigh, Queensland. Alcheringa 22: 259-276. https://doi.org/10.1080/03115519808619204

Hand, S. 1998b. Xenorhinos, a new genus of old world leaf-nosed bats (Microchiroptera: Hipposideridae) from the Australian Miocene. Journal of Vertebrate Paleontology 18: 430-439. https://doi.org/10.1080/02724634.1998.10011070

Hand, S. J., and M. Archer. 2005. A new hipposiderid genus (Microchiroptera) from an early Miocene bat community in Australia. Palaeontology 48: 1-13. https://doi.org/10.1111/j.1475-4983.2005.00444.x

Hand, S., M. Archer, and H. Godthelp. 1997. First record of Hydromops (Microchiroptera: Molossidae) from Australia: its biocorrelative significance. Mémoires et Travaux de l'Institut de Montpellier de l'Ecole Pratique des Hautes Etudes 21: 153-162.

Hand, S., L. Dawson, and M. Augee. 1988. Macroderma koppa, a new Tertiary species of false vampire bat (Microchiroptera: Megadermatidae) from Wellington Caves, New South Wales. Records of the Australian Museum 40(6): 343-351. https://doi.org/10.3853/j.0067-1975.40.1988.160

Hand, S. J., P. Murray, D. Megirian, M. Archer, and H. Godthelp. 1998. Mystacinid bats (Microchiroptera) from the Australian Tertiary. Journal of Paleontology 72: 538-545. https://doi.org/10.1017/S0022336000024318

Hand, S. J., and B. Sigé. 2018. A new archaic bat (Chiroptera: Archaeonycteridae) from an Early Eocene forest in the Paris Basin. Historical Biology 30: 227-236. https://doi.org/10.1080/08912963.2017.1297435

Kaňuch, P., T. Aghová, Y. Meheretu, R. Šumbera, and J. Bryja. 2015. New discoveries on the ecology and echolocation of the heart-nosed bat Cardioderma cor with a contribution to the phylogeny of Megadermatidae. African Zoology 50: 53-57. https://doi.org/10.1080/15627020.2015.1021711

King, T. 2013. First Australian Pliocene Sheathtail Bats (Chiroptera: Emballonuridae) with a Review of Emballonurid Palaeoecology and Distribution. Unpublished B.Sc. (Hons) thesis. University of New South Wales, Sydney.

Mahoney J. A., M. J. Smith, and G. C. Medlin. 2008. A new species of hopping-mouse, Notomys robustus sp. nov. (Rodentia: Muridae), from cave deposits in the Flinders and Davenport Ranges, South Australia. Australian Mammalogy 29: 117-135. https://doi.org/10.1071/AM07017

Menu, H., S. Hand, and B. Sigé. 2002. Oldest Australian vespertilionid (Microchiroptera) from the early Miocene of Riversleigh, Queensland. Alcheringa 26: 319-331. https://doi.org/10.1080/03115510208619260

Molnar, R. E., L. S. Hall, and J. A. Mahoney. 1984. New fossil localities for Macroderma Miller, 1906 (Chiroptera: Megadermatidae) in New South Wales and its past and present distribution in Australia. Australian Mammalogy 7: 63-73.
Rasband, W. S. 1997-2005. ImageJ, U.S. National Institutes of Health, Bethesda, Maryland, USA. [Accessed 15 January 2020] http://rsb.info.nih.gov/ij/

Ravel, A., M. Adaci, M. Bensalah, A.-L. Charruault, E. M. Essid, H. K. Ammar, W. Marzougui, M. Mahboubi, F. Mebrouk, G. Merzeraud, M. Vianey-Liaud, R. Tabuce, and L. Marivaux. 2016. Origine et radiation initiale des chauves-souris modernes: Nouvelles découvertes dans l'Éocène d'Afrique du Nord. Geodiversitas 38: 355-434. https://doi.org/10.5252/g2016n3a3

Rowe, K. C., A. S. Achmadi, P.-H. Fabre, J. J. Schenk, S. J. Steppan, and J. A. Esselstyn. 2019. Oceanic islands of Wallacea as a source for dispersal and diversification of murine rodents. Journal of Biogeography 46: 2752-2768. https://doi.org/10.1111/jbi.13720

Sevilla, P. 1990. Rhinolophoidea (Chiroptera, Mammalia) from the upper Oligocene of Carrascosa del Campo (Central Spain). Geobios 23: 173-188. https://doi.org/10.1016/S0016-6995(06)80050-1

Sigé, B. 1968. Les Chiropteres du Miocene inférieur de Bouzigues. 1. Etude systématique. Palaeovertebrata 1: 65-133. https://doi.org/10.18563/pv.1.3.65-133

Sigé B. 1976. Les Megadermatidae (Chiroptera, Mammalia) miocènes de Béni Mellal, Maroc. In: Géologie Méditerranéenne 3: 71-85. https://doi.org/10.3406/geolm.1976.963

Sigé B. 2011. Cryptobune nov. gen., chiroptère carnivore des phosphorites du Quercy, SW France. Bulletin de la Société d'histoire naturelle de Toulouse 147: 47-54.

Sigé, B., S. Hand, and M. Archer. 1982. An Australian Miocene Brachipposideros (Mammalia, Chiropetra) related to Miocene representatives from France. Palaeovertebrata 12: 149-172.

Simmons, N. B., and A. L. Cirranello. 2020. Bat Species of the World: A Taxonomic and Geographic Database. [Accessed on 15 January 2020].

https://batnames.org/home.html

Smissen, P. J., and K. C. Rowe. 2018. Repeated biome transitions in the evolution of Australian rodents. Molecular Phylogenetics and Evolution 128: 182-191.

https://doi.org/10.1016/j.ympev.2018.07.015

Stephens, N. P., and D. Y. Sumner. 2003. Late Devonian carbon isotope stratigraphy and sea level fluctuations, Canning Basin, Western Australia. Palaeogeography, Palaeoclimatology, Palaeoecology 191: 203-219. https://doi.org/10.1016/S0031-0182(02)00714-9

Teeling, E. C., M. S. Springer, O. Madsen, P. Bates, S. J. O’Brien, and W. J. Murphy. 2005. A molecular phylogeny for bats illuminates biogeography and the fossil record. Science 307: $580-584$.

https://doi.org/10.1126/science.1105113

Woinarski, J. C. Z., A. A. Burbidge, and P. L. Harrison. 2014. The Action Plan for Australian Mammals 2012. Collingwood: CSIRO Publishing. https://doi.org/10.1071/9780643108745

Woodhead, J., S. J. Hand, M. Archer, I. Graham, K. Sniderman, D. A. Arena, K. H. Black, H. Godthelp, P. Creaser, and E. Price. 2016. Developing a radiometrically-dated chronologic sequence for Neogene biotic change in Australia, from the Riversleigh World Heritage Area of Queensland. Gondwana Research 29: 153-167. https://doi.org/10.1016/.gr.2014.10.004

Worthington Wilmer, J., L. Hall, E. Barratt, and C. Moritz. 1999. Genetic structure and male-mediated gene flow in the Ghost Bat (Macroderma gigas). Evolution 53: 1582-1591. https://doi.org/10.1111/j.1558-5646.1999.tb05421.x

Ziegler, R. 1993. Die Chiroptera (Mammalia) aus dem Untermiozän von Wintershof-West bei Eichstätt (Bayern). Mitteilungen der Bayerischen Staatssammlung für Paläontologie und historische Geologie 33: 119-154. 


\title{
Fossil Uromys (Rodentia: Murinae) from Central Queensland, with a Description of a New Middle Pleistocene Species
}

\author{
Jonathan Cramb ${ }^{1,2} \mathbb{D}$, Scott A. Hocknull ${ }^{1,3} \mathbb{D}$, and Gilbert J. Price ${ }^{2}$ (D) \\ ${ }^{1}$ Geosciences, Queensland Museum, 122 Gerler Road, Hendra QLD 4011, Australia \\ ${ }^{2}$ School of Earth and Environmental Sciences, The University of Queensland, Brisbane QLD 4072, Australia \\ ${ }^{3}$ School of BioSciences, Faculty of Science, University of Melbourne, Melbourne VIC 3010, Australia
}

\begin{abstract}
The first fossil species of Uromys (Giant Naked-tailed Rats) is described, as well as the southernmost records of the genus based on palaeontological data. Uromys aplini sp. nov. lived during the Middle Pleistocene in the area around Mount Etna, eastern central Queensland, but was probably driven extinct by climate-mediated habitat loss sometime after $205 \mathrm{ka}$ but before c. $90 \mathrm{ka}$. A second species, the extant U. caudimaculatus, occurred in the area during the Late Pleistocene, but became locally extinct prior to the Last Glacial Maximum. These fossils indicate an unexpectedly high diversity of species of Uromys in Australia, suggesting a long occupation of the continent. Phylogenetic analysis places $U$. aplini together with other species of Uromys endemic to Australia, at the base of the radiation of the genus. This may indicate that the initial diversification of Uromys occurred in Australia rather than New Guinea, as has previously been thought. These new Quaternary records of Uromys occur approximately $550 \mathrm{~km}$ south of the southern-most modern record for the genus, indicating that Uromys was able to cross the southern St Lawrence biogeographic barrier, possibly twice during the Pleistocene.
\end{abstract}

\section{Introduction}

Uromys (commonly called "Giant Rats" or "Giant Nakedtailed Rats") is a genus of generally very large murine rodents whose species are found on mainland and continental islands of northern Sahul (Australia and New Guinea), and the Melanesian island archipelago (Fig. 1). They belong to the tribe Hydromyini, in a subclade called the Uromys division (colloquially known as the "Mosaic-tailed Rats"), that also includes four related genera: Melomys, Paramelomys, Protochromys, and Solomys (Musser \& Carleton, 2005; Lecompte et al., 2008; Aplin \& Helgen, 2010). The ecology and conservation status of extant species of Uromys was summarized by Flannery (1995a, 1995b), Breed \& Ford (2007), Moore (2008), and Moore \& Winter (2008). These authors noted that many species are presently endangered, critically endangered or presumed extinct.
Currently, 11 species of Uromys are recognized. Two widely distributed and morphologically variable species occur on mainland New Guinea (U. anak and $U$. caudimactulatus, the latter also occurring on several nearby islands), with a further four near threatened to critically endangered species that are endemic to the nearby islands of Biak (U. boeadii), Awai (U. emmae), New Britain ( $U$. neobrittanicus) and Kai Besar (U. siebersi) (Flannery, 1995a, 1995b; Musser \& Carleton, 2005). Four species are recorded from the Solomon Islands, namely $U$. imperator, $U$. porculus, U. rex, and $U$. vika, all of which are either endangered, critically endangered or presumed recently extinct (Flannery, 1995b; Lavery \& Judge, 2017; taxonomic authorities listed below).

In Australia, two species of Uromys are currently recognized (Breed \& Ford, 2007). Uromys caudimaculatus has a distribution stretching from Cape York to the most

Keywords: Hydromyini; Muridae; rainforest; extinction

Taxonomic registration: urn:Isid:zoobank.org:pub:BEE60C62-CA61-48C2-B8EB-E7DAC94FEA09

Corresponding author: Jonathan Cramb j2.cramb@connect.qut.edu.au

Received: 3 February 2020 Accepted: 20 August 2020 Published: 25 November 2020 (in print and online simultaneously)

Publisher: The Australian Museum, Sydney, Australia (a statutory authority of, and principally funded by, the NSW State Government)

Citation: Cramb, Jonathan, Scott A. Hocknull, and Gilbert J. Price. 2020. Fossil Uromys (Rodentia: Murinae) from central Queensland, with a description of a new Middle Pleistocene species. In Papers in Honour of Ken Aplin, ed. Julien Louys, Sue O'Connor, and Kristofer M. Helgen. Records of the Australian Museum 72(5): 175-191. https://doi.org/10.3853/j.2201-4349.72.2020.1731 


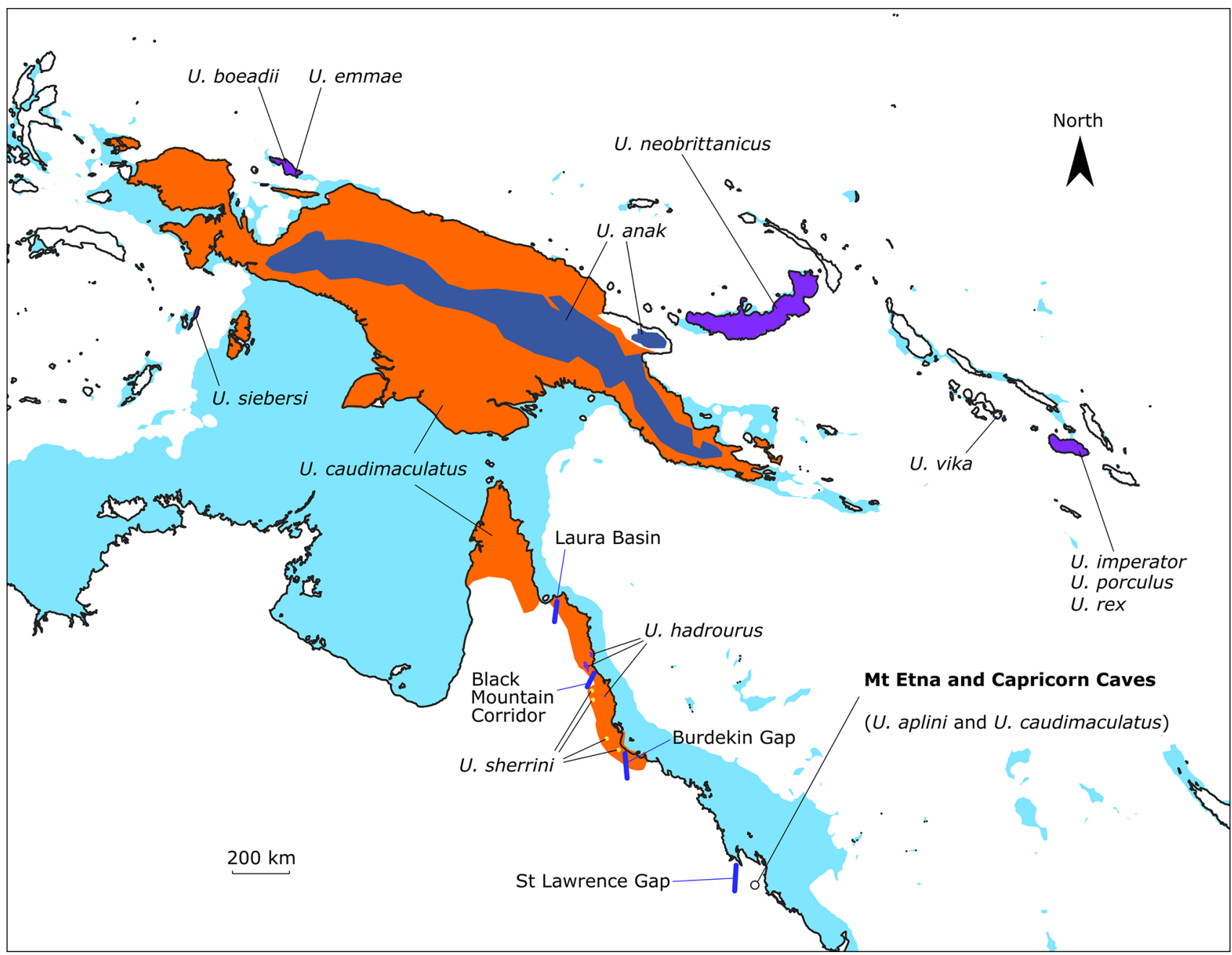

Figure 1. Map of north-east Sahul and Melanesia showing the location of study sites, the modern distributions of species of Uromys, and barriers to dispersal of mesic taxa in eastern Queensland (after Bryant \& Krosch, 2016). Bathymetric depth to $200 \mathrm{~m}$ marked in light blue. Distribution data is from Aplin \& Flannery (2017), Aplin et al. (2017), Groves \& Flannery (1994), Kennerley (2016), Lavery (2019), and Woinarski \& Burbidge (2016). Spot distribution of $U$. sherrini is based on known specimens in the collections of the Queensland Museum, CSIRO National Wildlife Collection, and Natural History Museum (London).

southerly modern occurrence of the genus, just south of Townsville in the Bowling Green National Park (Moore, 2008); QMJM1248 from Atlas of Living Australia website at https://www.ala.org.au/ (accessed 10 January 2020). The taxonomic history of Australian populations of $U$. caudimaculatus, and extralimital taxa synonymized with it, was summarized by Jackson \& Groves (2015). The second, smaller Australian species, U. hadrourus, is restricted to the upland regions of north-east Queensland (Atherton Tableland, Mount Carbine, Thornton Peak, and Mount Bartle Frere). A third taxon, U. sherrini, described originally by Thomas (1923a), is currently considered to be a junior synonym of U. caudimaculatus (Tate, 1951), but Kristofer Helgen and Ken Aplin (pers. comm. November 2009) considered $U$. sherrini to be distinct from $U$. caudimaculatus on the basis of unpublished morphological and molecular comparisons. We therefore treat it as a separate species in this study.

The evolutionary history of Australian rodents has been investigated in recent decades using several lines of morphological (e.g., craniodental, phallic, and spermatozoan morphology) and molecular evidence to assess phylogeny (e.g., Lidicker \& Brylski, 1987; Groves \& Flannery, 1994; Breed \& Aplin, 1995; Rowe et al., 2008; Robins et al., 2010; Steppan \& Schenk, 2017). Molecular sampling of hydromyin taxa is incomplete, and meta-analyses that include broad taxonomic sampling have recovered specific or generic level relationships that are questionable. For example, Upham et al. (2019), in their meta-analysis of mammalian phylogenies recovered Pithecheir as the sister taxon of Uromys, despite the placement of these genera in different divisions by other authors (Musser \& Carleton, 2005). Bryant et al. (2011) and Lavery \& Judge (2017) both conducted molecular analyses of Uromys division taxa, but unfortunately did not include the majority of species of Uromys. Bryant et al. (2011) did, however, recover Paramelomys as the sister taxon to a clade containing Melomys, Solomys, and Uromys, providing a potentially useful outgroup for any morphological assessment of phylogeny. Morphological phylogenetic methods are obviously of vital importance to palaeontological studies, but we are aware of only one published example that included Australian species of Uromys: Groves \& Flannery (1994) in their revision of the genus. 

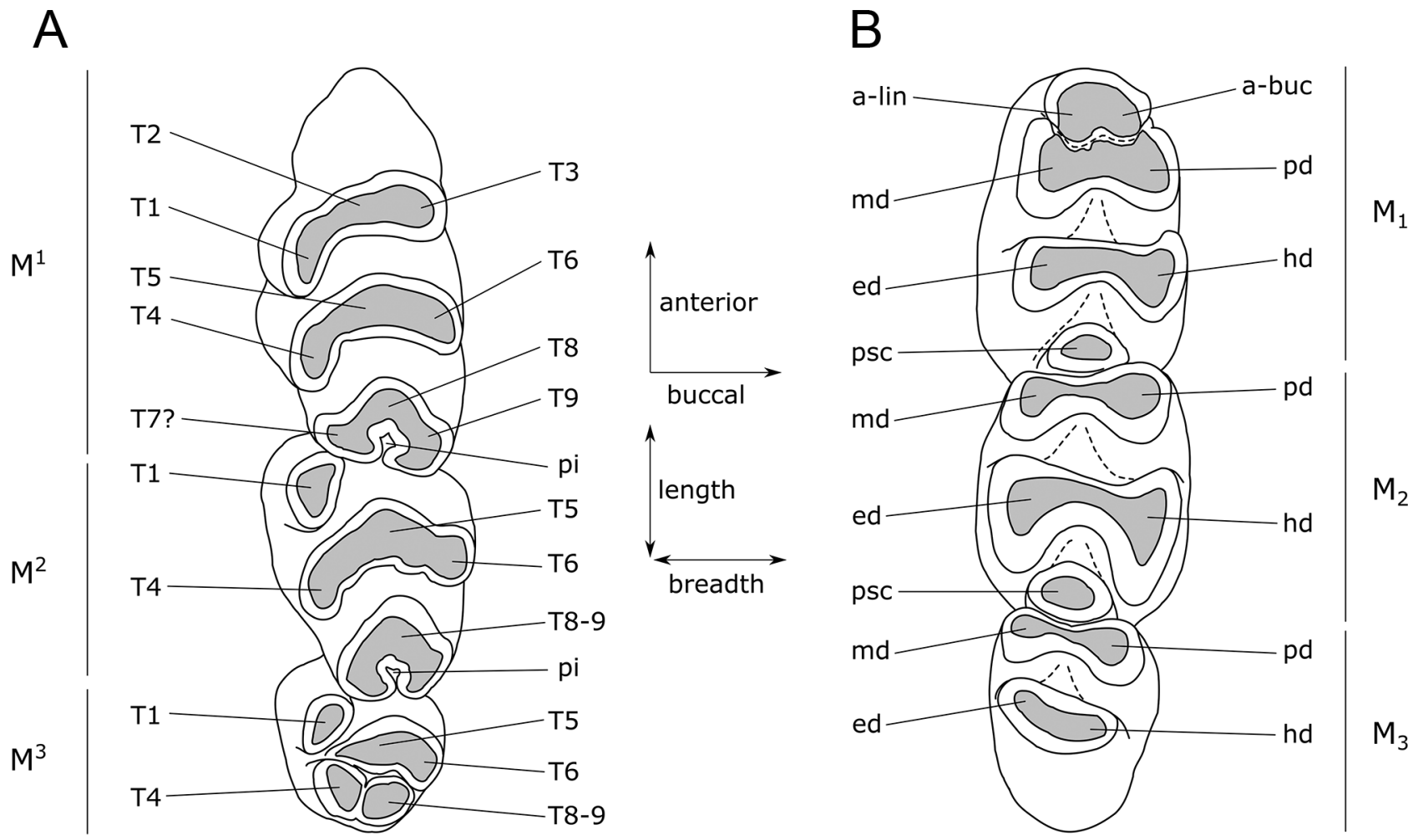

Figure 2. Molar cusp terminology. In Uromys and closely related genera the cusps in each molar loph are fused, so individual cusps may be difficult to distinguish in worn specimens. Molar terminology follows Musser (1981), Aplin \& Helgen (2010), and Lazzari et al. (2010). (A) upper molars, left side in occlusal outline; $(B)$ lower molars, right side, in occlusal outline. Abbreviations: $a$-buc, antero-buccal cuspid; $a$-lin, antero-lingual cuspid; $e d$, entoconid; $h d$, hypoconid; $m d$, metaconid; $p d$, protoconid; pi, posterior indent; $p s c$, posteroconid.

With the majority of species of Uromys found in New Guinea and Melanesia, it has long been assumed that Uromys had its phylogenetic origin in these regions; Watts \& Aslin (1981) posited that Uromys was a relatively recent arrival in Australia, having crossed the Torres Strait during the Last Glacial Maximum. This view was not held by all researchers with Tate (1951) suggesting that Uromys arrived in Australia during the Middle Pleistocene, and Hand (1984) stating that the timing of arrival was unclear. The recognition that $U$. hadrourus was a species of Uromys rather than a species of Melomys (see Jackson \& Groves, 2015) hinted that Uromys had been present in Australia for some substantial time, with Aplin (2006) citing Watts and Baverstock's (1994) molecular data to suggest the possibility that the genus was present before $2.5 \mathrm{Ma}$. Such a possibility would be supported if fossils of the right age were available. Despite the presence of murines in Sahul since at least 4.18 Ma (Piper et al., 2006), published reports of fossil Uromys are almost all restricted to the Late Pleistocene and Holocene (e.g., O'Connor et al., 2002; Aplin et al., 1999). The exception is Hocknull (2005), who reported a large Mosaic-tailed Rat from the Mount Etna caves, which was later found to be of Middle Pleistocene age (Hocknull et al., 2007). This taxon is here described as Uromys aplini sp. nov., and is the geologically oldest species of the genus yet recorded.

\section{Materials and methods}

All fossil specimens included in this study were excavated as part of ongoing research into the fossils of the caves in the Mount Etna and Capricorn Caves region, eastern central Queensland (Fig. 1). Fossils were compared with specimens of all available species of Uromys in the collections of the Queensland Museum, Australian Museum, and the Australian National Wildlife Collection (Appendix 1). Where specimens of some species were not available in Australian collections, comparisons with published descriptions and images were made. Fossil specimens were measured with digital callipers, and imaged with a Visionary Digital "passport storm" camera system, an Olympus Stylus TG-4 compact digital camera, a Hitachi TM-1000 environmental scanning electron microscope at the Queensland Museum, and a Leica DFC450 C digital microscope camera at the School of Earth and Environmental Sciences, The University of Queensland. All fossils described in this paper are catalogued in the collections of the Queensland Museum, in Brisbane, Australia. Molar cusp terminology is presented in Fig. 2.

\section{Study sites background}

Fossil remains described here were collected from cavernous limestone located at the Mount Etna and Limestone Ridge Caves National Park and the Capricorn Caves Tourist Park (Hocknull, 2005, 2009; Price et al., 2015). The bulk of fossils 
Table 1. Character matrix used in phylogenetic analysis. Modified from Groves \& Flannery (1994). Note that the original numbering of characters is retained from Groves \& Flannery (1994), although external characters are removed. Additional characters: (50) $\mathrm{M}^{1-3}$ length: $0 \leq 7 \mathrm{~mm}, 1=7-8 \mathrm{~mm}, 2=8-9 \mathrm{~mm}, 3=9-10 \mathrm{~mm}, 4=10-11 \mathrm{~mm}, 5=11-12 \mathrm{~mm}, 6=12-13$ $\mathrm{mm}, 7=13-14 \mathrm{~mm} ;(51) \mathrm{M}^{1-3}$ length $/ \mathrm{M}^{1}$ width: $0=3-3.2,1=3.2-3.4,2=3.4-3.6,3=3.6-3.8,4=3.8-4.0$.

\section{$\begin{array}{lllllllllllllllllllllllllllllll}1 & 1 & 1 & 1 & 1 & 1 & 1 & 1 & 1 & 1 & 2 & 2 & 2 & 2 & 2 & 2 & 2 & 2 & 3 & 3 & 3 & 4 & 4 & 4 & 4 & 4 & 4 & 4 & 4 & 5 & \end{array}$ \\ $\begin{array}{lllllllllllllllllllllllllllllllllllllllll}1 & 2 & 3 & 4 & 5 & 6 & 7 & 8 & 9 & 0 & 1 & 2 & 3 & 4 & 5 & 6 & 7 & 8 & 9 & 0 & 1 & 2 & 3 & 4 & 5 & 6 & 7 & 6 & 7 & 9 & 0 & 1 & 2 & 4 & 6 & 7 & 8 & 9 & 0 & & 1\end{array}$}

\begin{tabular}{|c|c|c|c|c|c|c|c|c|c|c|c|c|c|c|c|c|c|c|c|c|c|c|c|c|c|c|c|c|c|c|c|c|c|c|c|c|c|}
\hline Paramelomys rubex & 1 & & ? & & & & & & & & & & & & & & & & 0 & & & & & & & & & & & & & & & & & & 1 \\
\hline Uromys anak & 0 & & 0 & 1 & & & 1 & 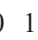 & 0 & 1 & 0 & 1 & 0 & 0 & 0 & 1 & $\begin{array}{ll}0 & 1\end{array}$ & 1 & 0 & 1 & 0 & 0 & 0 & 0 & 0 & 0 & 0 & 1 & & & & & & 0 & 0 & $\{67\}$ & $\left\{\begin{array}{lll}1 & 2 & 3\end{array}\right\}$ \\
\hline U. aplini sp. nov. & 1 & $?$ & $?$ & ? & & 0 & 0 & ? & 1 & 1 & 0 & 1 & 0 & 0 & ? & ? & 1 ? & ? & 0 & ? & ? & 0 & 0 & 0 & 0 & 1 ? & ? & 1 & & & & & & ? & 0 & $\{34\}$ & 2 \\
\hline U. boeadii & 0 & & 0 & 1 & & 0 & 0 & 0 & 0 & 0 & 0 & 0 & 0 & 0 & 0 & 0 & $\begin{array}{ll}0 & 1\end{array}$ & 0 & 0 & 1 & 0 & 0 & 0 & 0 & 0 & 00 & 0 & 1 & 1 & 1 & & & 0 & 0 & 0 & 5 & 2 \\
\hline U. caudimaculatus & 1 & & 1 & 1 & 1 & 0 & 1 & 1 & 1 & 0 & 0 & 1 & 0 & 0 & 1 & 1 & 11 & 1 & 0 & 0 & 0 & 0 & 0 & 0 & 0 & 1 & 1 & 1 & 1 & 1 & 0 & & & 0 & 0 & $\left\{\begin{array}{ll}5 & 6\end{array}\right\}$ & $\left\{\begin{array}{llll}1 & 2 & 3 & 4\end{array}\right\}$ \\
\hline U. emmae & 1 & 1 & 1 & 1 & & 0 & 1 & 1 & 1 & 0 & 0 & 1 & 0 & 0 & 1 & 0 & $\begin{array}{ll}0 & 1\end{array}$ & 1 & 0 & 0 & 0 & 0 & 0 & 0 & 0 & $0 \quad 1$ & 0 & 1 & 1 & 1 & 0 & 1 & & 0 & 1 & 5 & 2 \\
\hline U. hadrourus & 1 & 1 & 1 & 1 & 1 & 0 & p & ) & 1 & 1 & 0 & 1 & 0 & 1 & 1 & 0 & 11 & 1 & 0 & 0 & 0 & 0 & 0 & 0 & 0 & 11 & 1 & 1 & 1 & 1 & 0 & 1 & & 1 & 0 & $\{12\}$ & $\left\{\begin{array}{llll}0 & 1 & 2 & 3\end{array}\right\}$ \\
\hline U. imperator & 1 & 0 & 1 & 0 & & 1 & 0 & 0 & 1 & 0 & 0 & 1 & 1 & 0 & 0 & 0 & $\begin{array}{ll}0 & 0\end{array}$ & 0 & 1 & 0 & 1 & 0 & 0 & 1 & 1 & 0 & 1 & 0 & 0 & 0 & 1 & 0 & & 0 & 0 & 6 & 1 \\
\hline U. neobrittanicus & 0 & & 0 & 1 & & 0 & 1 & 1 & 0 & 1 & 0 & 1 & 0 & 0 & 0 & 0 & $\begin{array}{ll}0 & 1\end{array}$ & 1 & 0 & 1 & 0 & 0 & 0 & 0 & 0 & 0 & 0 & 1 & 1 & 1 & 0 & 1 & & 0 & 0 & $\{67\}$ & $\{23\}$ \\
\hline U. porculus & 0 & 0 & 0 & 0 & & 1 & 0 & & 0 & 0 & 0 & 1 & 1 & 0 & 0 & 0 & $\begin{array}{ll}0 & 0\end{array}$ & 0 & 1 & 0 & 1 & 0 & 0 & 1 & 1 & 0 & 1 & 0 & 0 & 0 & ) & ) & & 0 & 0 & 0 & 2 \\
\hline U. rex & 0 & 0 & 1 & 0 & 0 & 1 & 0 & 0 & 1 & 1 & 1 & 1 & 1 & 0 & 0 & 0 & $\begin{array}{ll}0 & 0\end{array}$ & 0 & 1 & 1 & 1 & 1 & 1 & 1 & 1 & 0 & 1 & 0 & 0 & 0 & 0 & 0 & & 0 & 0 & $\{45\}$ & $\{12\}$ \\
\hline U. sherrini & 1 & & $?$ & $?$ & & 0 & 0 & & 1 & 1 & 0 & & 0 & 0 & 0 & & & $?$ & 0 & $?$ & 0 & 0 & 0 & 0 & & 1 & 1 & 1 & 1 & 1 & 0 & 1 & & 0 & 0 & $\begin{cases}56 & 6\end{cases}$ & $\begin{cases}1 & 2\}\end{cases}$ \\
\hline U. vika & 0 & & $?$ & $?$ & 0 & 1 & 0 & $?$ & 1 & 1 & $?$ & 1 & 0 & 0 & 0 & $?$ & $\begin{array}{ll}0 & 1\end{array}$ & $?$ & 0 & $?$ & 1 & 0 & 0 & 1 & $?$ & 10 & 1 & 0 & 1 & 0 & & 0 & & 0 & 02 & 2 & 1 \\
\hline
\end{tabular}

from the deposits are most likely derived from the feeding activities of owls. Fossil deposits from Mount Etna were described initially by Hocknull (2005) with biocorrelation of these faunas suggesting a Pliocene age. Subsequent radiometric dating of flowstones associated with the fauna demonstrated, however, that these deposits were in fact Pleistocene in age and restricted to the Middle Pleistocene (Hocknull et al., 2007). Additional sites, descriptions, and dating assessments were also undertaken and available in Hocknull (2009). At Capricorn Caves Tourist Park, Queensland Museum Locality (QML) 1456 is located within the Olsen's Cave system. Faunal remains recovered from this site were described and chronometrically dated using a combination of radiocarbon and uranium-series techniques, resulting in a Late Pleistocene age (Price et al., 2015).

At Mount Etna, Middle Pleistocene faunal assemblages dated to $>500 \mathrm{ka}$ to $\geq 280 \mathrm{ka}$ are interpreted as having occupied closed rainforest palaeoenvironments (QML1311H, QML1313) including taxa or lineages now only found in rainforests of northern Queensland and New Guinea (Hocknull, 2005; Hocknull et al., 2007; Price \& Hocknull, 2011; Cramb \& Hocknull, 2010). A younger Middle Pleistocene fauna (QML1312) dated to $205-170 \mathrm{ka}$ is interpreted as having occupied a xeric environment and includes species or lineages found in arid habitats today. The Late Pleistocene fauna (QML1456) from Capricorn Caves is interpreted to be more mesic in comparison to the xeric Middle Pleistocene fauna, but still drier-adapted than the older Middle Pleistocene rainforest fauna. Together, these three periods show major faunal transitions typified by local extinction and replacement of species with new more dryadapted forms (Hocknull et al., 2007; Price, 2012).

\section{Phylogenetic analysis}

A preliminary attempt was made to ascertain the phylogenetic position of the new fossil species of Uromys by scoring craniodental characters using a character state matrix first developed by Groves \& Flannery (1994).
We restricted our assessment to the craniodental characters used by Groves \& Flannery (1994) with the addition of one measurement character (Character 50: $\mathrm{M}^{1-3}$ length) and one measurement ratio (Character 51: $\mathrm{M}^{1-3}$ length $/ \mathrm{M}^{1}$ width). These continuous data were binned and scored as multi-states for variable taxa. The length measurement was ordered in the analysis. All other characters were unordered. Three additional species, including the fossil taxon U. aplini sp. nov., U. vika (based on the description published by Lavery \& Judge, 2017) and specimens considered to represent $U$. sherrini were used to augment the phylogenetic analysis (see Appendix 1). Only $U$. siebersi was not able to be scored, due to the rarity of specimens. Some character states were not able to be scored due to either their lacking in preservation in the fossils and extant craniodental remains, or obscurity in determining the state. Character states for $2-4,8-9,17,20,22,44$ could not be ascertained from comparison of specimens with character descriptions provided by Groves \& Flannery (1994), so were given a "?" and considered uncertain. We have amended the character state of character 11 for $U$. hadrourus because it was incorrectly scored in Groves \& Flannery (1994). All characters were weighted equally.

Molecular analysis by Bryant et al. (2011) found that Melomys is the sister taxon to Uromys, while Paramelomys is the sister clade to both genera. For this reason, we included Paramelomys rubex as the outgroup for the analysis to polarize the character states within Uromys. The modified matrix is shown in Table 1. The analysis was conducted using Mesquite version 3.61 (Maddison \& Maddison, 2019) and PAUP 4.0 (Swofford, 2001).

Our phylogenetic assessment is only considered to be preliminary using standard parsimony, where the characters are polarized by an outgroup (Paramelomys rubex). Multistate characters are considered to be polymorphic, whilst those characters with "?"s are considered to be uncertain. The tree-searching algorithm used was tree-bisection and reconnection (TBR) from 100 random additions. Bootstrap values were calculated using 1000 replicates, with the resulting nodes with values greater than $50 \%$ retained. 


\section{Abbreviations}

QMF-Queensland Museum fossil specimen; QMLQueensland Museum fossil locality; QMJ, QMJMQueensland Museum modern mammal specimen; CMCSIRO Australian National Wildlife Collection mammal specimen; AM M.-Australian Museum mammal specimen; NMVC-Museum Victoria mammal specimen; ka (kilo annum) - thousands of years ago; Ma (mega annum) millions of years ago.

\section{Results}

Two species of Uromys were identified from fossils in the study region, the extant $U$. caudimaculatus and the extinct $U$. aplini sp. nov. Uromys caudimaculatus was recovered from Capricorn Caves (QML1456) in excavation spits 142-147 $\mathrm{cm}, 152-157 \mathrm{~cm}$, and $177-182 \mathrm{~cm}$ (inferred as dating to the Late Pleistocene), and $U$. aplini sp. nov. was recovered from multiple Middle Pleistocene deposits at Mount Etna.

\section{Systematic palaeontology}

Class Mammalia Linnaeus, 1758

Subclass Theria Parker \& Haswell, 1897

Supercohort Placentalia Bonaparte, 1838

Order Rodentia Bowdich, 1821

Family Muridae Illiger, 1811

Subfamily Murinae Illiger, 1811

Tribe Hydromyini Alston, 1876 sensu Lecompte et al., 2008

\section{Uromys Peters, 1867}

Synonyms: Gymnomys Gray, 1867; Cyromys Thomas, 1910; Melanomys Winter, 1983 (but see Jackson \& Groves, 2015, for explanation).

Included species:

Uromys caudimaculatus (Krefft, 1867)

Uromys imperator (Thomas, 1888)

Uromys rex (Thomas, 1888)

Uromys porculus (Thomas, 1904)

Uromys anak Thomas, 1907

Uromys sherrini Thomas, 1923a

Uromys siebersi Thomas, 1923b

Uromys neobrittanicus Tate \& Archbold, 1935

Uromys hadrourus (Winter, 1984)

Uromys boeadii Groves \& Flannery, 1994

Uromys emmae Groves \& Flannery, 1994

Uromys vika Lavery \& Judge, 2017

Generic diagnosis: Groves \& Flannery (1994) considered three cranial characters (with the addition of one soft-tissue character) to be diagnostic of species of Uromys: a hard palate that extends posterior of the posterior margin of $\mathrm{M}^{3}$, $\mathrm{I}_{1}$ is much deeper than it is wide, and a greatly expanded anterolateral spine on the auditory bulla.

\section{Uromys caudimaculatus (Krefft, 1867)}

Fig. 3A, 3B

Material examined. QML1456: spit $142-147 \mathrm{~cm}$ : QMF60126 right $\mathrm{M}^{1}$, QMF60127 left $\mathrm{M}^{1}$, QMF60128 right $\mathrm{M}^{1}$, QMF60129 left M², QMF60130 left $\mathrm{M}_{1}$, QMF60131 right $\mathrm{M}_{2}$. Additional specimens were also recovered from spits $152-157 \mathrm{~cm}$, and $177-182 \mathrm{~cm}$.
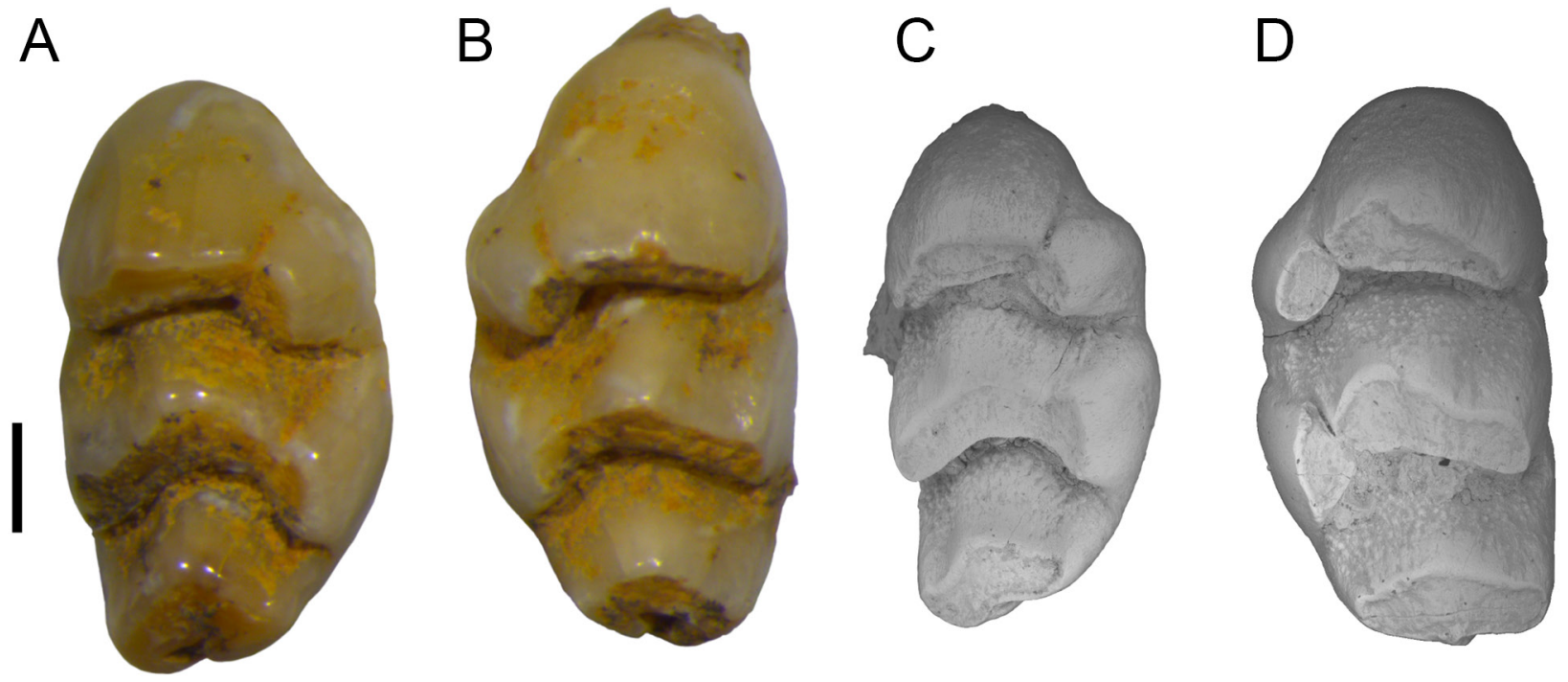

Figure 3. Succession of Uromys spp. in the Mt Etna area. (A-B) Uromys caudimaculatus, (A) QMF60126 right $\mathrm{M}^{1}$, QML1456 spit 142-147, c. $50 \mathrm{ka}$; (B) QMF60127 left $\mathrm{M}^{1}$, deposit and age as for A. (C-D) Uromys aplini, (C) QMF55340 left M ${ }^{1}$, QML1312, 205-170 ka; $(D)$ QMF60125 right $\mathrm{M}^{1}$, QML1311 H, > $450 \mathrm{ka}$. Scale bar $=1 \mathrm{~mm}$. 

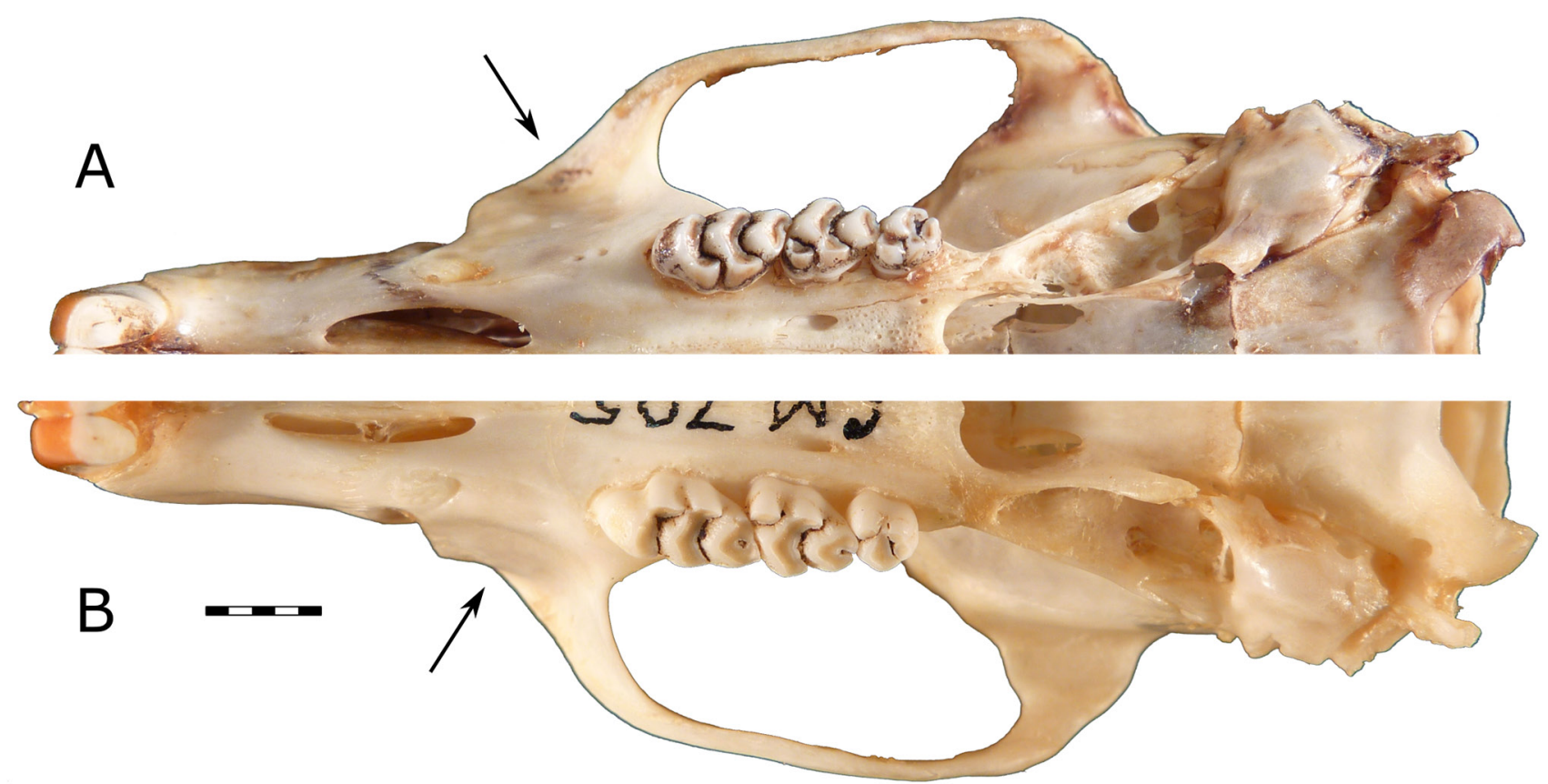

Figure 4. Comparison of skulls of Uromys sherrini and U. caudimaculatus in ventral outline. (A) U. sherrini (CM10822); (B) U. caudimaculatus (CM705). The larger degree of deflection in the zygomatic plate, seen in U. caudimaculatus, is indicated with an arrow. Scale bar $=5 \mathrm{~mm}$.

Remarks. Isolated molars of this species are distinguished by a combination of characters including very large size; crescentic lophs on $\mathrm{M}^{1-2}$; deep posterior indent present on $\mathrm{M}^{1-2}$; long, variably bifurcated lingual root on $\mathrm{M}^{1-2}$; crescentic lophids on $\mathrm{M}_{1-2}$; lingual root present on $\mathrm{M}_{1}$; large posteroconid on $\mathrm{M}_{1-2}$; and a relatively shallow cleft between the antero-buccal cuspid and protoconid on $\mathrm{M}_{1}$.

Uromys caudimaculatus was previously considered to include $U$. sherrini, so it is pertinent to include a list of characters that distinguish these species. These are: the margins of the interorbital area above the orbits, which are almost parallel in $U$. sherrini but divergent in $U$. caudimaculatus (Thomas, 1923a); the anterior palatal foramina are commonly broader in $U$. sherrini; the $\mathrm{M}^{1-2}$ of $U$. sherrini have shallower posterior indents on the T8-9 complex; the posterior loph on $\mathrm{M}^{3} / 3$ is commonly narrower; the nasals are shorter, not projecting anterior of the premaxillae as in U. caudimaculatus; the anterior edge of the zygomatic plate is directed antero-lingually in dorsal or ventral outline, while that of $U$. caudimaculatus is deflected, making it parallel with the rostrum (Fig. 4).

Specimens of $U$. caudimaculatus from QML1456 have only slightly worn tooth crowns, indicating that the owls thought to be the accumulating agents of the deposit were preying on young individuals. The excavation spit that yielded the stratigraphically youngest $U$. caudimaculatus specimens (i.e., $142-147 \mathrm{~cm}$ ) is probably slightly younger than $50 \mathrm{kyr}$ (see Price et al., 2015 for a full discussion of the age of the deposit). The older spits (i.e., $152-157 \mathrm{~cm}$ and $177-182 \mathrm{~cm}$ ) are undated, but are likely to be Late Pleistocene (c. 80-60 ka) based on the age model presented in Price et al. (2015). Deposition in QML1456 is thought to have been continuous during the late Quaternary, with no evidence of depositional hiatuses.

\section{Uromys aplini sp. nov.}

\section{urn:Isid:zoobank.org:act:C52317A8-D118-4E10-AA9C-21DF62C8EECA}

Figs 3C, 3D, 5-7

Holotype. QMF52014 (Queensland Museum fossil specimen) partial skull, QML1313 (Queensland Museum fossil locality) Speaking Tube Cave, Mount Etna, eastern central Queensland. Deposit has a minimum age of c. 280 ka (Hocknull et al., 2007). Paratypes. QMF55753 partial skull; QMF55542 right mandible with $\mathrm{M}_{1}$; both specimens have same locality as holotype, QML1313.

Material examined. QML1311H: QMF55547 right $\mathrm{M}^{1}$, QMF55548 right $\mathrm{M}^{2}$, QMF55549 right $\mathrm{M}^{3}$, QMF55550 left $\mathrm{M}_{1}$, QMF55551 right $\mathrm{M}_{1}$, QMF55552 left $\mathrm{M}_{3}$, QMF60125 right $\mathrm{M}^{1}$; QML1313: QMF52014 partial skull, QMF55522 left $\mathrm{M}^{1}$, QMF55523 left $\mathrm{M}^{1}$, QMF55524 right $\mathrm{M}^{1}$, QMF55525 left $\mathrm{M}^{2}$, QMF55526 right $\mathrm{M}^{2}$, QMF55527 right $\mathrm{M}^{2}$, QMF55528 right $\mathrm{M}^{3}$, QMF55529 left $\mathrm{M}^{3}$, QMF55530 left M ${ }^{3}$, QMF55531 left $\mathrm{M}_{1}$, QMF55532 left M, QMF55533 left $\mathrm{M}_{1}$, QMF55534 right $\mathrm{M}_{2}$, QMF55535 left $\mathrm{M}_{2}$, QMF55536 left $\mathrm{M}_{2}$, QMF55537 right $\mathrm{M}_{3}$, QMF55538 left $\mathrm{M}_{3}$, QMF55539 left $\mathrm{M}_{3}$, QMF55540 left I ${ }^{1}$, QMF55541 left maxilla fragment, QMF55543 right mandible with $\mathrm{M}_{1}$ and $\mathrm{M}_{3}$, QMF55544 right $\mathrm{M}^{3}$; QML1313A: QMF55545 left $\mathrm{M}^{1}$, QMF55546 right M1; QML1312: QMF55340 left $\mathrm{M}^{1}$. Additional specimens were also recovered from QML1284, QML1284A, QML1311C/D, QML1311J, QML1383, QML1384LU, and QML1385.

Age Range. Chibanian (Middle Pleistocene), chronometrically dated to $>500$ ka to c. $205 \mathrm{ka}$.

Diagnosis. Large Uromys, but smaller than most species of Uromys (Uromys) with the exception of $U$. hadrourus (Fig. 
Table 2. Craniodental measurements of Uromys aplini sp. nov. All measurements in millimetres. SD = standard deviation; $\mathrm{CV}=$ coefficient of variation; $\mathrm{APF}=$ anterior palatal foramen; QML = Queensland Museum Locality.

\begin{tabular}{|c|c|c|c|c|c|c|c|c|c|c|c|c|}
\hline & QML & $n$ & mean & SD & range & $\mathrm{CV}$ & & $n$ & mean & SD & range & $\mathrm{CV}$ \\
\hline$I^{1}$ depth & 1313 & 3 & 3.05 & 0.07 & $2.98-3.11$ & - & $\mathrm{I}^{1}$ width & 3 & 1.64 & 0.05 & $1.58-1.68$ & - \\
\hline interorbital width & 1313 & 2 & 8.58 & 0.33 & $8.34-8.81$ & - & zygomatic plate length & 2 & 7.40 & 0.79 & $6.84-7.96$ & - \\
\hline APF length & 1313 & 2 & 6.29 & 0.41 & $6.00-6.58$ & - & diastema length & 2 & 14.55 & 0.07 & $14.50-14.60$ & - \\
\hline hard palate length & 1313 & 2 & 25.97 & 0.79 & $25.40-26.53$ & - & hard palate width & 2 & 10.03 & 0.07 & $9.98-10.08$ & - \\
\hline $\mathrm{I}_{1}$ depth & 1313 & 1 & 1.98 & na & na & na & $\mathrm{I}_{1}$ width & 2 & 1.38 & 0.35 & $1.13-1.63$ & - \\
\hline \multirow[t]{5}{*}{$\mathrm{M}^{1}$ length } & $1311 \mathrm{H}$ & 1 & 4.82 & na & na & na & \multirow[t]{5}{*}{$\mathrm{M}^{1}$ width } & 1 & 2.57 & na & na & na \\
\hline & 1313 & 3 & 5.09 & 0.20 & $4.86-5.42$ & - & & 4 & 2.84 & 0.22 & $2.53-3.02$ & - \\
\hline & $1313 \mathrm{~A}$ & - & - & - & 一 & - & & 2 & 2.82 & 0.12 & $2.73-2.90$ & - \\
\hline & 1312 & 1 & 5.27 & na & na & na & & 1 & 2.85 & na & na & na \\
\hline & all & 5 & 5.08 & 0.26 & $4.82-5.42$ & - & & 8 & 2.80 & 0.18 & $2.53-3.02$ & - \\
\hline \multirow[t]{4}{*}{$\mathrm{M}^{2}$ length } & $1311 \mathrm{H}$ & 1 & 3.33 & na & na & na & \multirow[t]{4}{*}{$\mathrm{M}^{2}$ width } & 1 & 2.78 & na & na & na \\
\hline & 1313 & 6 & 3.71 & 0.21 & $3.46-4.00$ & - & & 7 & 2.83 & 0.12 & $2.71-3.04$ & - \\
\hline & $1313 \mathrm{~A}$ & - & - & - & 一 & - & & 1 & 2.72 & na & na & na \\
\hline & all & 7 & 3.66 & 0.24 & $3.33-4.00$ & - & & 9 & 2.81 & 0.11 & $2.71-3.04$ & - \\
\hline \multirow[t]{3}{*}{$\mathrm{M}^{3}$ length } & $1311 \mathrm{H}$ & 2 & 2.38 & 0.07 & $2.33-2.43$ & - & \multirow[t]{3}{*}{$\mathrm{M}^{3}$ width } & 2 & 2.13 & 0 & $2.13-2.13$ & - \\
\hline & 1313 & 6 & 2.26 & 0.15 & $2.08-2.52$ & - & & 6 & 2.08 & 0.12 & $1.92-2.21$ & - \\
\hline & all & 8 & 2.29 & 0.14 & $2.08-2.52$ & - & & 8 & 2.09 & 0.10 & $1.92-2.21$ & - \\
\hline $\mathrm{M}^{1-3}$ length & 1313 & 2 & 10.17 & 0.29 & $9.96-10.37$ & - & $\mathrm{M}_{1-3}$ length & 3 & 10.74 & 0.24 & $10.48-10.95$ & - \\
\hline \multirow[t]{4}{*}{$\mathrm{M}_{1}$ length } & $1311 \mathrm{H}$ & 4 & 4.15 & 0.17 & $3.96-4.33$ & - & \multirow[t]{4}{*}{$\mathrm{M}_{1}$ width } & 4 & 2.62 & 0.08 & $2.55-2.73$ & - \\
\hline & 1313 & 6 & 4.43 & 0.13 & $4.19-4.54$ & - & & 6 & 2.67 & 0.18 & $2.37-2.93$ & - \\
\hline & $1313 \mathrm{~A}$ & 2 & 4.17 & 0.09 & $4.10-4.23$ & - & & 2 & 2.55 & 0.12 & $2.46-2.63$ & - \\
\hline & all & 12 & 4.29 & 0.19 & $3.96-4.54$ & 4.46 & & 12 & 2.63 & 0.14 & $2.37-2.93$ & 5.50 \\
\hline \multirow[t]{4}{*}{$\mathrm{M}_{2}$ length } & $1311 \mathrm{H}$ & 4 & 3.51 & 0.14 & $3.42-3.72$ & 一 & \multirow[t]{4}{*}{$\mathrm{M}_{2}$ width } & 5 & 2.85 & 0.11 & $2.69-2.97$ & - \\
\hline & 1313 & 3 & 3.45 & 0.28 & $3.19-3.74$ & - & & 3 & 2.81 & 0.09 & $2.70-2.89$ & - \\
\hline & $1313 \mathrm{~A}$ & 3 & 3.31 & 0.14 & $3.23-3.47$ & - & & 3 & 2.68 & 0.08 & $2.61-2.77$ & - \\
\hline & all & 10 & 3.43 & 0.19 & $3.19-3.74$ & 5.51 & & 11 & 2.79 & 0.12 & $2.61-2.97$ & 4.14 \\
\hline \multirow[t]{3}{*}{$\mathrm{M}_{3}$ length } & $1311 \mathrm{H}$ & 2 & 3.01 & 0.26 & $2.82-3.19$ & - & \multirow[t]{3}{*}{$\mathrm{M}_{3}$ width } & 2 & 2.48 & 0.01 & $2.47-2.48$ & - \\
\hline & 1313 & 4 & 2.65 & 0.16 & $2.45-2.78$ & - & & 4 & 2.29 & 0.12 & $2.18-2.43$ & - \\
\hline & all & 6 & 2.77 & 0.25 & $2.45-3.19$ & - & & 6 & 2.35 & 0.13 & $2.18-2.48$ & - \\
\hline
\end{tabular}

8; Table 2); it is distinguished on the following combination of characters: posterior indent on $\mathrm{T} 8-9$ of $\mathrm{M}^{1-2}$ poorly developed; molar enamel ornament moderately developed; anterior palatal foramina short, shared equally between premaxilla and maxilla; rostrum proportionally short and robust; supraorbital ridges and postorbital processes absent. Features that further distinguish $U$. aplini from all other species of Uromys are listed in the Remarks section.

Groves \& Flannery (1994) divided Uromys into two subgenera: U. (Uromys) and U. (Cyromys). Uromys aplini is placed in $U$. (Uromys) on the basis of the following diagnostic characters identified by Groves \& Flannery (1994): short, slit-like anterior palatal foramina; simplified, elongate molars; reduced $\mathrm{M}^{3} / 3$; posteriorly lengthened bony palate; reduced anterior lophid on $\mathrm{M}_{1}$, which fuses to middle lophid after moderate wear; zygomatic arches swing posteriorly and ventrally to level of molar alveoli; and orthodont incisors.
Etymology: Named for Kenneth Peter Aplin (1958-2019), for his contribution to Australian palaeontology and the taxonomy and systematics of Australasian murids.

\section{Description}

Skull. Two partial skulls are known (QMF52014 and 55753, Fig. 5A,B). The lacrimals, jugals, and much of the posterior of the skull and basicranium are missing from both specimens.

The nasals appear to be consistent in width along preserved length, tapering sharply at posterior contact with frontals.

Premaxilla short and robust. Anterior palatal foramen short, narrow, tapering abruptly at extremities, occupying similar area of premaxilla and maxilla. Anterior palatal foramen roughly half of length anterior of $\mathrm{M}^{1}$. Narrow crest on ventral surface of maxilla between junction with premaxilla and anterior margin of $\mathrm{M}^{1}$ variably 

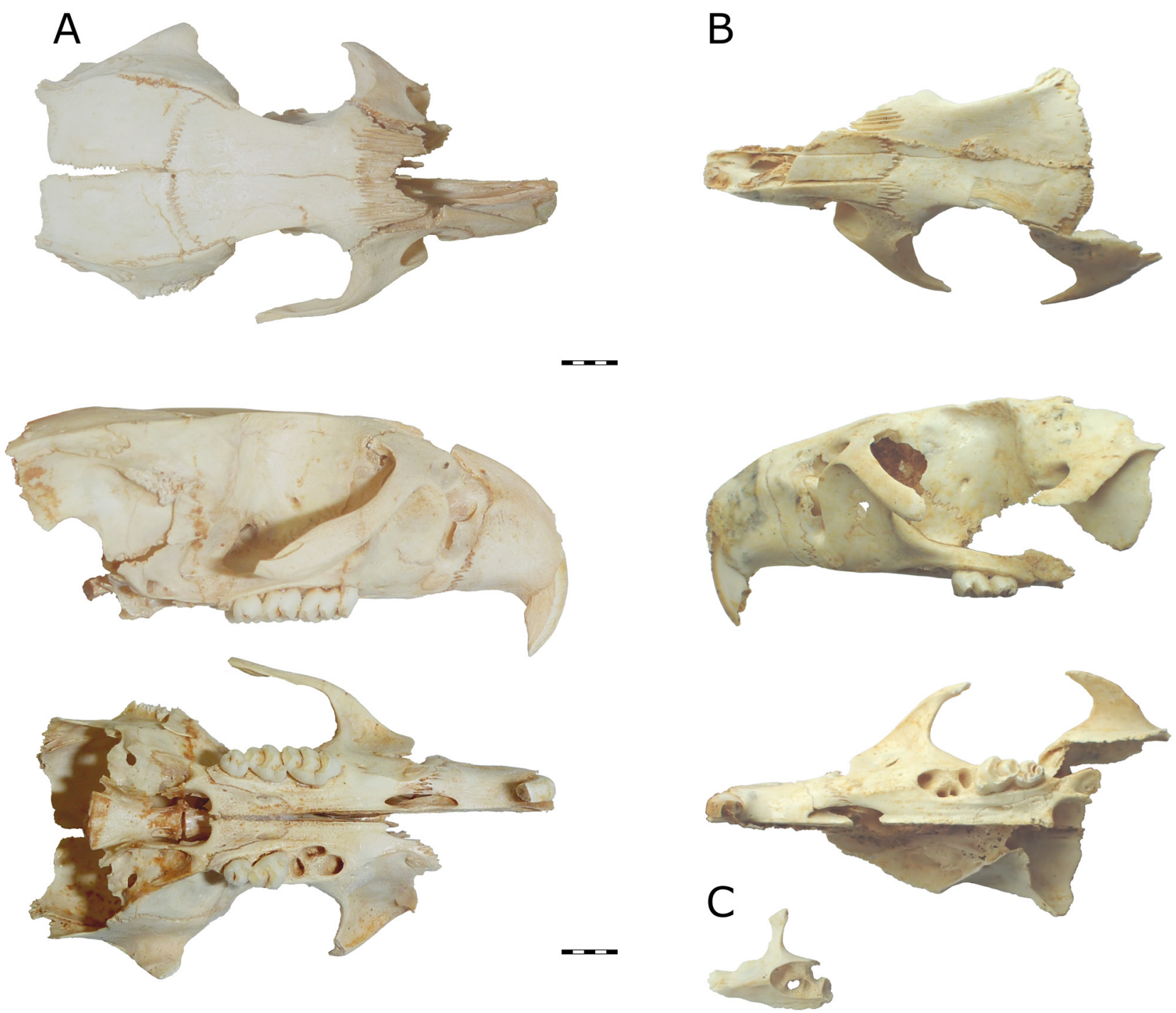

Figure 5. Cranial elements of Uromys aplini sp. nov. (A) QMF52014 partial skull in (top to bottom) dorsal, right lateral, and ventral view; $(B)$ QMF55753 partial skull in dorsal, left lateral, and ventral view; $(C)$ QMF55541 left maxilla fragment, showing a narrow crest on the diastema. Scale bar $=5 \mathrm{~mm}$.

developed, likely associated with age (some specimens, e.g., QMF55541, have it developed to an extreme degree, forming a blade. Fig. 5C). Zygomatic plate long, anterior edge straight, evenly curving posteriorly at dorsal end into zygomatic arch. Maxillary portion of zygomatic arch slopes posteroventrally at approximately $45^{\circ}$ angle, almost reaching level of molar alveoli.

Palatine contacts maxilla level with posterior margin of $\mathrm{M}^{1}$. Posterior palatal foramen level with $\mathrm{M}^{2}$. Palate terminates in small, blunt postpalatal spine, approximately level with most posterior point of maxilla.

Frontals with sharp corner between temporal and orbital faces. Very small postorbital processes on squamosals, not associated with sutures. Supraorbital ridges not evident on frontals; parietal crests weakly developed on dorsal margin of squamosals and parietals. Braincase not greatly inflated, relatively flat dorsally, width exaggerated on QMF52014 by parting of parietals at midline.

I $^{1}$. Proportionally deep $\left(\mathrm{I}^{1}\right.$ depth/width of QMF52014 =
2.98/1.66 mm), orthodont. One paratype (QMF55753, Fig. 5B) appears to retain orange pigment in enamel, although this may instead be diagenetic iron staining.

$\mathbf{M}^{1}$. Crown elongate, rounded anterior margin and angular posterior margin. Lophs sloped posteriorly. Accessory cusp and anterior cingulum absent. Lingual cusps bulge lingually at bases, giving lingual margin of crown an irregular appearance. Buccal cusps do not bulge at bases. T1 oval-shaped in occlusal outline, oriented antero-buccally postero-lingually. T1 postero-lingual of T2. T1 separated from T2 by shallow cleft; T1 and T2 join after moderate wear. T2 broad and robust. T3 directly buccal of T2, posterior margins of T2-3 form straight line. T3 small, fused to T2. T3 discernible from T2 by shallow, poorly defined groove on anterior face of T2-3 complex. T4 subcircular in occlusal outline when unworn, becomes subtriangular after wear. In occlusal outline, T4 projects to a point anterior of the junction with T5; tapers posteriorly. T4 tapers towards T5, separated by a shallow cleft, joined after moderate wear. T5 

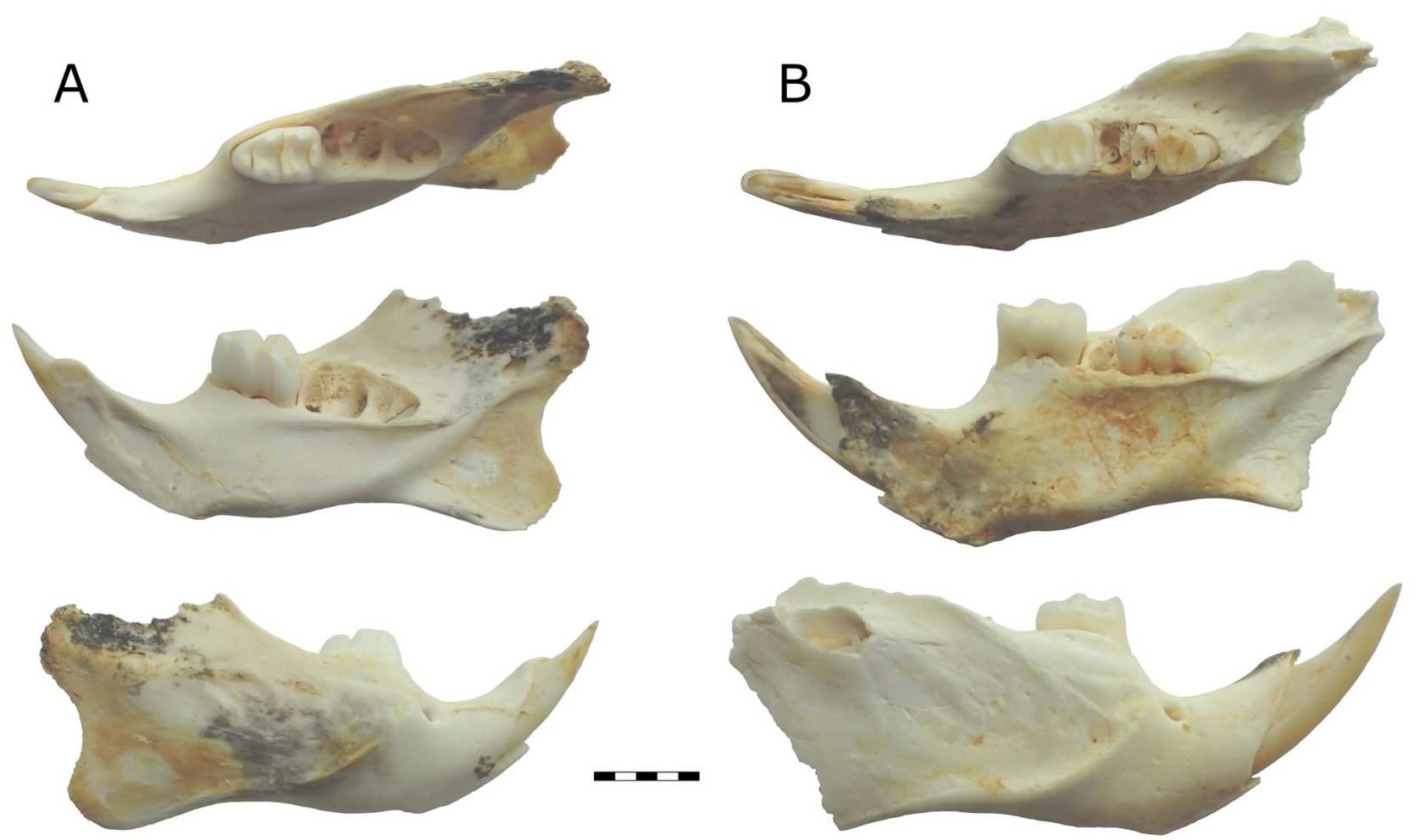

Figure 6. Mandibles of Uromys aplini sp. nov. (A) QMF55542 right mandible with $\mathrm{M}_{1}$; (B) QMF55543 right mandible with $\mathrm{M}_{1}$, partial $\mathrm{M}_{2}$, and $\mathrm{M}_{3}$. Scale bar $=5 \mathrm{~mm}$.

broad, boomerang-shaped in occlusal outline, with bulk of T5 antero-buccal of T4 and antero-lingual of T6. T6 poorly defined, variably separated from T5 by shallow groove on anterior face of T5-6 complex. T6 broad, oriented anterolingually postero-buccally, continuous with buccal half of T5. T5-6 complex roughly parallel with T8-9 complex. T7 appears absent, although one specimen (QMF55522, Fig. 7C) has a bulge in the posterior loph that could be interpreted as a T7 fused to T8. T8-9 complex broad, based between buccal margin of crown and posterior point of T4. T9 fused to $\mathrm{T} 8$, poorly defined by change in angle of anterior margin of occlusal surface of T8-9 complex. Very small posterior indent associated with posteroloph, commonly not visible in occlusal view.

Fine enamel ornament present on anterior faces of all lophs. $\mathrm{M}^{1}$ has four roots: anterior, two lingual (commonly fused close to crown), and postero-buccal. Molar roots commonly split into multiple rootlets at tips. Alveoli of lingual roots variably fused, creating appearance of a single elongate lingual root.

$\mathbf{M}^{2}$. Elongate, tapering posteriorly. Lingual cusps bulge lingually at bases, buccal cusps do not. T1 forms anterolingual corner of crown. T1 subcircular in occlusal outline when slightly worn, becomes subtriangular (tapering buccally and posteriorly) after wear. T2-3 absent. Position of T3 variably marked by shallow depression on anterior face of T5-6 complex. T4 directly posterior of T1. T4-6 loph essentially identical to that on $\mathrm{M}^{1}$. T8-9 complex based between buccal margin of T6 and posterior point of T4. T8-9 tapers slightly but does not form a point. T8 and T9 not differentiated.
A ridge on the lingual side of T8 may represent a T7. Very small posterior indent associated with posteroloph, commonly not visible in occlusal view. Fine enamel ornament on anterior faces of both lophs, possibly less developed than that on $\mathrm{M}^{1}$. $\mathrm{M}^{2}$ has four main roots: anterobuccal, postero-buccal, postero-lingual, and antero-lingual. The antero-lingual and postero-lingual roots are variably joined. The antero-buccal root is variably bifurcated at the tip into two small rootlets.

$\mathbf{M}^{3}$. Compact and simplified, moderately reduced. Some specimens (e.g., QMF55528, Fig. 7H) subcircular in occlusal outline. T1 well defined, rounded, oval-shaped in occlusal outline. T2-3 absent. Individual cusps of T4-6 loph not discernible. T4-6 loph gently curved, most anterior point at presumed location of T5. T4-6 loph sloped posteriorly. Posterior cusp broad, slightly narrower than T4-6 loph. Posterior cusp upright, very close to T4-6 loph. Some specimens (e.g., QMF55530, Fig. 7G) have posterior cusp very close to "T4" but larger gap separating posterior cusp from "T6". Posterior cusp oval-shaped in occlusal outline. One specimen (QMF55544) has a small posterior cingulum cusp. $\mathrm{M}^{3}$ has four roots: antero-buccal, posterior, and joined antero-lingual and lingual.

Mandible. No specimens are completely intact, with all displaying degrees of damage to the posterior processes and incisor alveolus. Mandible deep and robust, with deepest point ventral of $M_{1} \cdot M_{1}$ longer than $M_{2}$, but similar width. $M_{3}$ smaller than $\mathrm{M}_{2}$, but not heavily reduced. Coronoid process damaged or missing on all specimens, but appears to be taller than articular process. Articular process projects slightly posterior of angular process. Angular process damaged on 
A

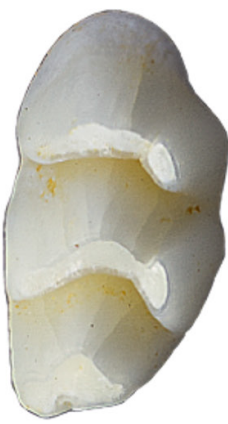

D

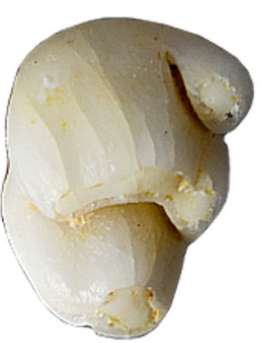

G

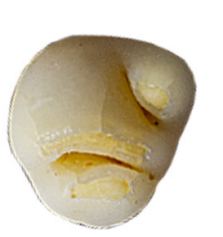

J

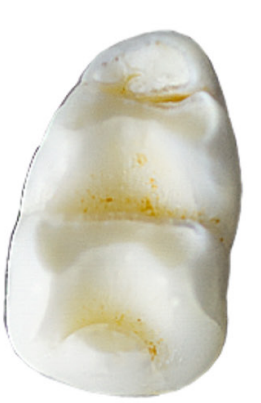

M

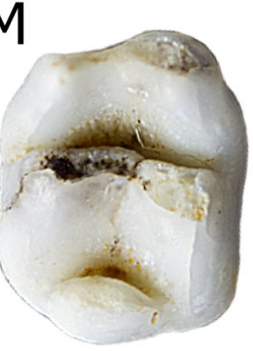

P

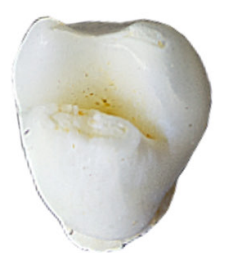

B

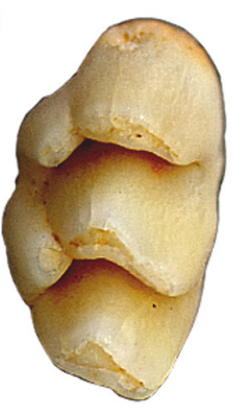

E

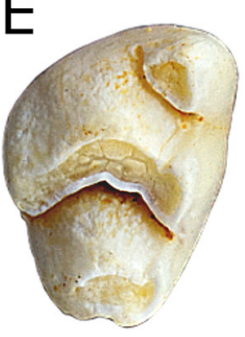

$\mathrm{H}$

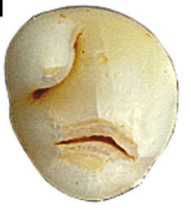

K

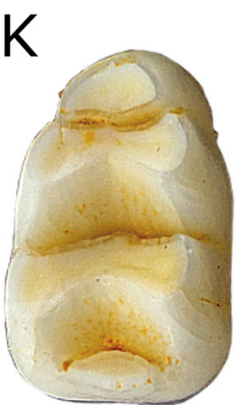

N

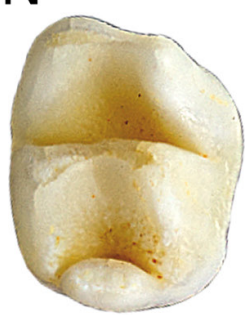

Q

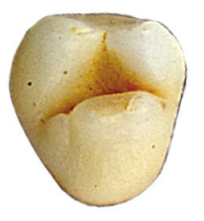

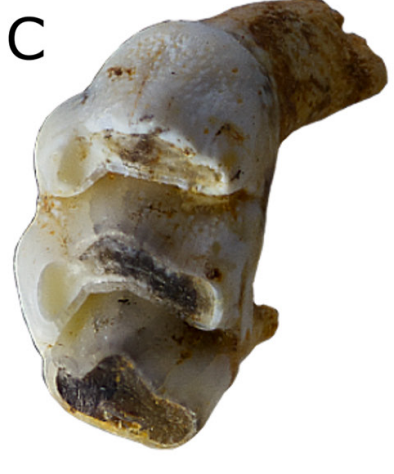

F

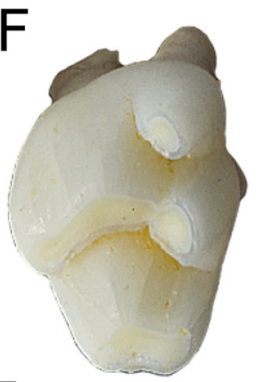

I

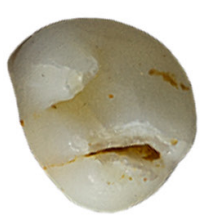

L

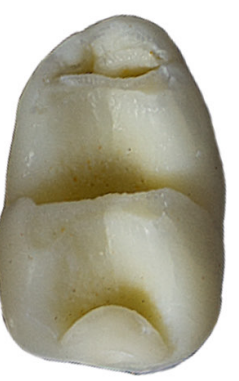

0

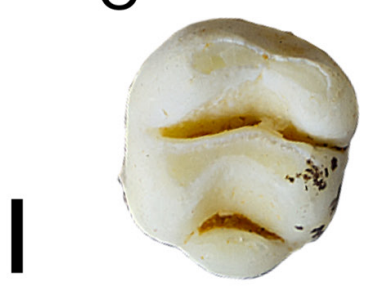

R

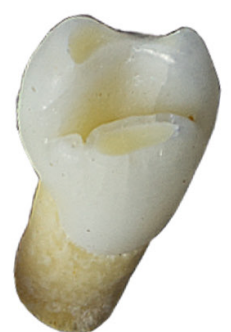

Figure 7. Isolated molars of Uromys aplini sp. nov. (A) QMF55524 right $\mathrm{M}^{1} ;(B) \mathrm{QMF}^{2} 5523$ left $\mathrm{M}^{1} ;(C) \mathrm{QMF}^{1} 5522$ left $\mathrm{M}^{1} ;(D) \mathrm{QMF}^{2} 5527$ right $\mathrm{M}^{2} ;(E)$ QMF55525 right $\mathrm{M}^{2} ;(F)$ QMF55526 right $\mathrm{M}^{2} ;(G)$ QMF55530 right $\mathrm{M}^{3} ;(H)$ QMF55528 left $\mathrm{M}^{3} ;(I) \mathrm{QMF}^{2}$ ( 5529 left $\mathrm{M}^{3} ;(J)$ QMF55531 left $\mathrm{M}_{1} ;(K)$ QMF55533 left $\mathrm{M}_{1} ;(L)$ QMF55532 left $\mathrm{M}_{1} ;(M)$ QMF55534 right $\mathrm{M}_{2} ;(N)$ QMF55536 left $\mathrm{M}_{2} ;(O)$ QMF55535 left $\mathrm{M}_{2} ;(P)$ QMF55537 right $\mathrm{M}_{3} ;(Q)$ QMF55539 left $\mathrm{M}_{3} ;(R)$ QMF55538 left $\mathrm{M}_{3}$. Scale bar $=1 \mathrm{~mm}$. 
all specimens, but appears to be rounded. Mental foramen ventral of dorsal inflection of diastema. Superior masseteric crest very poorly defined below molars; inferior masseteric crest well developed, terminates anteriorly posterior of mental foramen. Mandibular symphysis marked by dorsal crest in anterior part of diastema; symphysis ends ventrally of anterior root of $\mathrm{M}_{1}$. Incisor alveolus forms prominent tubercle on buccal surface of ascending ramus, although this is damaged in all specimens. Postalveolar ridge sharply defined below and posterior of $\mathrm{M}_{3}$, less defined posterior of retromandibular fossa. Retromandibular fossa small in young adult individuals, greatly expanded in mature individuals (assessed on the basis of molar wear).

$\mathbf{I}_{1}$. Proportionally deep $\left(\mathrm{I}_{1}\right.$ depth/width of QMF55542 [subadult] $=1.98 / 1.13$, adults proportionally deeper). One specimen (QMF55543, Fig. 6B) may retain orange pigment in enamel, but lost in majority of specimens.

$\mathbf{M}_{1}$. Rounded anteriorly, subrectangular posteriorly. Anterior and middle lophids crowded together. Anterior lophid upright, middle, and posterior lophids sloped anteriorly. Anterior lophid narrower than middle lophid. Middle and posterior lophids of similar width. Anterobuccal cuspid small, subcircular in occlusal outline, fused to antero-lingual cuspid. Antero-buccal and antero-lingual cuspids only distinguishable when unworn, form single anterior lophid after moderate wear. Antero-lingual cuspid much larger than antero-buccal cuspid, forms much of the anterior lophid. Unworn specimens show anterolingual cuspid with two buccal extensions: one joining the antero-buccal cuspid, the other directly posterior and postero-lingual of the antero-buccal cuspid between the main body of the anterior lophid and the middle lophid. Antero-buccal cuspid separated from protoconid by shallow cleft, eliminated by wear on some specimens; antero-lingual cuspid separated from metaconid by relatively deeper cleft, more resistant to wear.

Protoconid subtriangular in occlusal outline, tapering lingually to join metaconid and posteriorly along buccal margin of crown. Metaconid subequal in size to protoconid. Metaconid subtriangular in occlusal outline, tapering buccally to join protoconid, tapering slightly posteriorly and anteriorly. Anterior margin of middle lophid buccally perpendicular to long axis of crown, curves antero-lingually to most anterior point of metaconid. Posterior face of middle lophid curved, bowing anteriorly between most posterior points of protoconid and metaconid.

Entoconid directly posterior of metaconid. Entoconid subtriangular in occlusal outline, tapering buccally to join hypoconid and posteriorly to a lesser degree. Hypoconid directly posterior of protoconid, buccal and slightly posterior of entoconid. Hypoconid subtriangular in occlusal outline, tapering lingually to join entoconid, and posteriorly to a lesser degree. Hypoconid and entoconid variably have small anterior extensions. Hypoconid projects slightly further posteriorly than entoconid. Anterior edge of occlusal surface of posterior lophid commonly straight, but some specimens (e.g., QMF55533, Fig. 7K) have a slight bulge, at approximately the midline of the crown. Posterior margin of occlusal surface curved, bowed anteriorly with most anterior point directly posterior of midline junction between hypoconid and entoconid. Posteroconid tolerably well developed, lenticular in occlusal outline, bound by bases of hypoconid and entoconid. Posteroconid does not project beyond posterior margin of crown. Fine enamel ornament on posterior faces of middle and posterior lophids, not visible on anterior lophid due to close proximity of middle lophid. $\mathrm{M}_{1}$ has three roots: anterior, a broad posterior, and a small lingual root.

$\mathbf{M}_{2}$. Crown roughly square in occlusal outline, with rounded corners. Both lophids sloped anteriorly. Protoconid larger than metaconid, both at apex and base. Protoconid tear-shaped in occlusal outline, tapering lingually to join metaconid at midline of crown. Metaconid directly lingual of protoconid, tear-shaped in occlusal outline, tapering buccally. Unworn specimens (e.g., QMF55536, Fig. $7 \mathrm{~N}$ ) have no cleft separating protoconid and metaconid. Hypoconid directly posterior of protoconid. Hypoconid tear-shaped when unworn, becomes subtriangular after light wear. Hypoconid tapers antero-lingually to join entoconid at midline of crown. Hypoconid tapers posteriorly further than entoconid. Entoconid slightly less robust than hypoconid. Entoconid tear-shaped in occlusal outline, tapering directly buccally, meeting hypoconid at an angle. No separation between hypoconid and entoconid.

Posteroconid well developed, lenticular in occlusal outline. Posteroconid commonly centred on midline of crown, although one specimen (QMF55535, Fig. 7 O) has it centred slightly buccal of the midline. Posteroconid projects slightly beyond posterior margin of crown. Fine enamel ornament on posterior faces of lophids. $\mathrm{M}_{2}$ has two broad roots: anterior and posterior.

$\mathbf{M}_{3}$. Almost triangular in occlusal outline, with heavily rounded corners. Protoconid slightly larger than metaconid. Protoconid tear-shaped in occlusal outline, tapering lingually to join metaconid. Metaconid tear-shaped in occlusal outline, tapering buccally to join protoconid. Protoconid and metaconid joined by narrow ridge. Posterior lophid broad, commonly supplemented by small cuspid on buccal side. Posterior lophid shaped like an elongate oval in occlusal outline, supplementary cuspid subcircular. Supplementary buccal cuspid variably separated from posterior lophid by shallow cleft or fused. $\mathrm{M}_{3}$ has three roots: posterior, and fused antero-buccal and antero-lingual.

\section{Remarks}

Uromys aplini can be distinguished from other members of Uromys (Uromys) as follows: Uromys aplini differs from $U$. caudimaculatus by being smaller; having a less elongate rostrum; having a smaller posterior indent in T8-9 on $\mathrm{M}^{1-2}$; and having shorter anterior palatal foramina. Uromys aplini differs from $U$. sherrini by being smaller; having a less elongate rostrum; and having a more reduced $\mathrm{M}^{3} / 3$. Uromys aplini differs from $U$. hadrourus by being larger; having proportionally shorter anterior palatal foramina; having a proportionally shorter rostrum; by commonly possessing a crest on the maxilla between the maxilla/premaxilla contact and $\mathrm{M}^{1}$; and having a zygomatic arch that plunges further ventrally, reaching the level of the molar alveoli. The molars of Uromys aplini could not be effectively compared to those of $U$. hadrourus, as all examined specimens of the latter were heavily worn. Uromys aplini differs from 


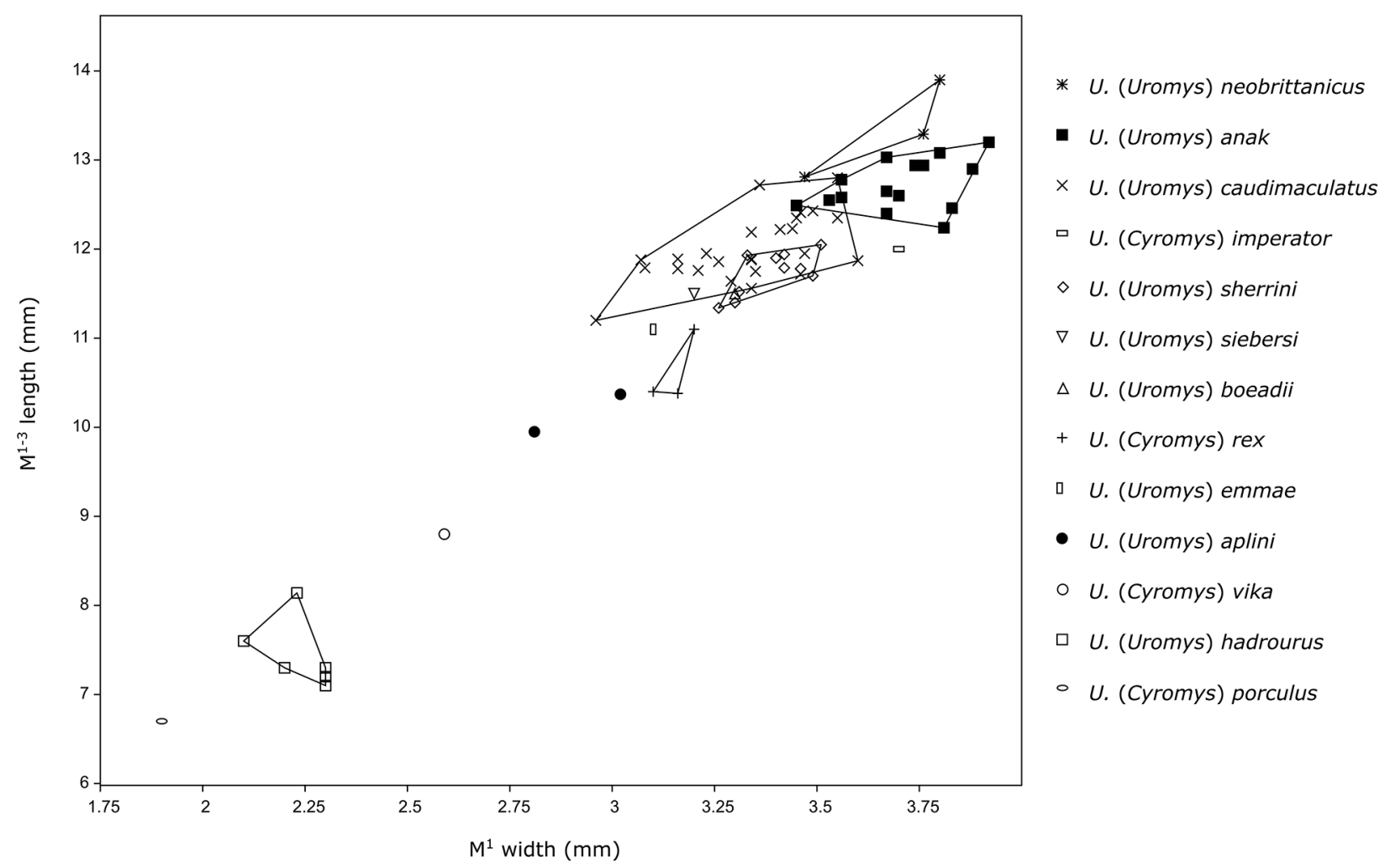

Figure 8. Bivariate plot of molar proportions ( $\mathrm{M}^{1}$ width vs $\mathrm{M}^{1-3}$ length, in $\mathrm{mm}$ ) of species of Uromys. Additional data provided by Tate (1951), Winter (1984), Groves \& Flannery (1994) and Lavery \& Judge (2017). Plot generated in PAST 2.12 (Hammer et al., 2001).

U. anak by being smaller; having a less elongate rostrum; lacking postorbital processes; having a smaller posterior indent in $\mathrm{T} 8-9$ on $\mathrm{M}^{1-2}$; and having the anterior palatal foramina shared equally between the premaxilla and maxilla. Uromys aplini differs from U. neobrittanicus by being smaller; lacking large postorbital processes; having the skull relatively flat dorsally; and having parietals that are roughly rectangular in dorsal outline. Uromys aplini differs from $U$. emmae by being smaller; having a deeper zygomatic arch; having the zygomatic plate not projecting as far anterior of the zygomatic arch; and having the anterior palatal foramina shared equally between the premaxilla and maxilla. Uromys aplini differs from $U$. boeadii by being smaller; having smaller postorbital processes; and lacking supraorbital ridges.

Only one skull of $U$. siebersi is known, and this specimen was not available for the current study. But a measurement of the molar row $(13.3 \mathrm{~mm})$ provided by Groves \& Flannery (1994) shows that $U$. siebersi is larger than U. aplini in this aspect (Table 2). Thomas (1923b) also provided measurements, though these are less precise than currently obtainable with modern precision measuring tools. The interorbital width and length of the "palatal foramina" (presumably the anterior palatal foramina) are both larger $(10.3 \mathrm{~mm}$ and $7 \mathrm{~mm}$, respectively, versus $8.34 \mathrm{~mm}$ and 6.00 $\mathrm{mm}$ for $U$. aplini).

Uromys aplini is hitherto known mostly from deposits at Mount Etna that are dominated by taxa that had ecological affinities to rainforest environments. The oldest deposits that yield the species are $>500 \mathrm{ka}$, whilst the youngest is 205-170 ka.

\section{Phylogenetic analysis}

Our phylogenetic analysis returned topological features similar to that recovered by Groves \& Flannery (1994). We used Paramelomys rubex as the most appropriate outgroup taxon to polarize the character-states within Uromys. Thirtythree characters were parsimony informative with seven uninformative and considered to be autapomorphies of these taxa. The derived character states for characters 12 , 24 and 25 are considered to be autapomorphies of U. rex, so are uninformative in relation to $U$. aplini. The derived character states for characters 34 and 38 are considered to be autapomorphies of $U$. imperator and U. emmae respectively, also uninformative for the fossil taxon. Finally, uninformative characters 15 and 37 are restricted to $U$. hadrourus, with the derived state of character 15 an autapomorphy and 37 ambiguous due to the missing states in the fossil taxon $(U$. aplini) and in U. sherrini.

The parsimony analysis returned two most parsimonious trees (MPT) of 93 steps (Fig. 9). Both MPTs consistently returned a basal split with one clade solely composed of species within the subgenus Cyromys and found today in the Solomon Islands group (U. imperator, U. rex, U. porculus, and $U$. vika). The Cyromys clade is strongly supported by bootstrap value of $91 \%$. The other clade is composed solely of species within the subgenus Uromys and includes our fossil taxon, U. aplini. Although this clade is poorly supported, it is likely that the large amount of missing data and morphological variability of $U$. caudimaculatus have created internal instability within this clade. Further characterization of $U$. caudimaculatus subspecies and better 

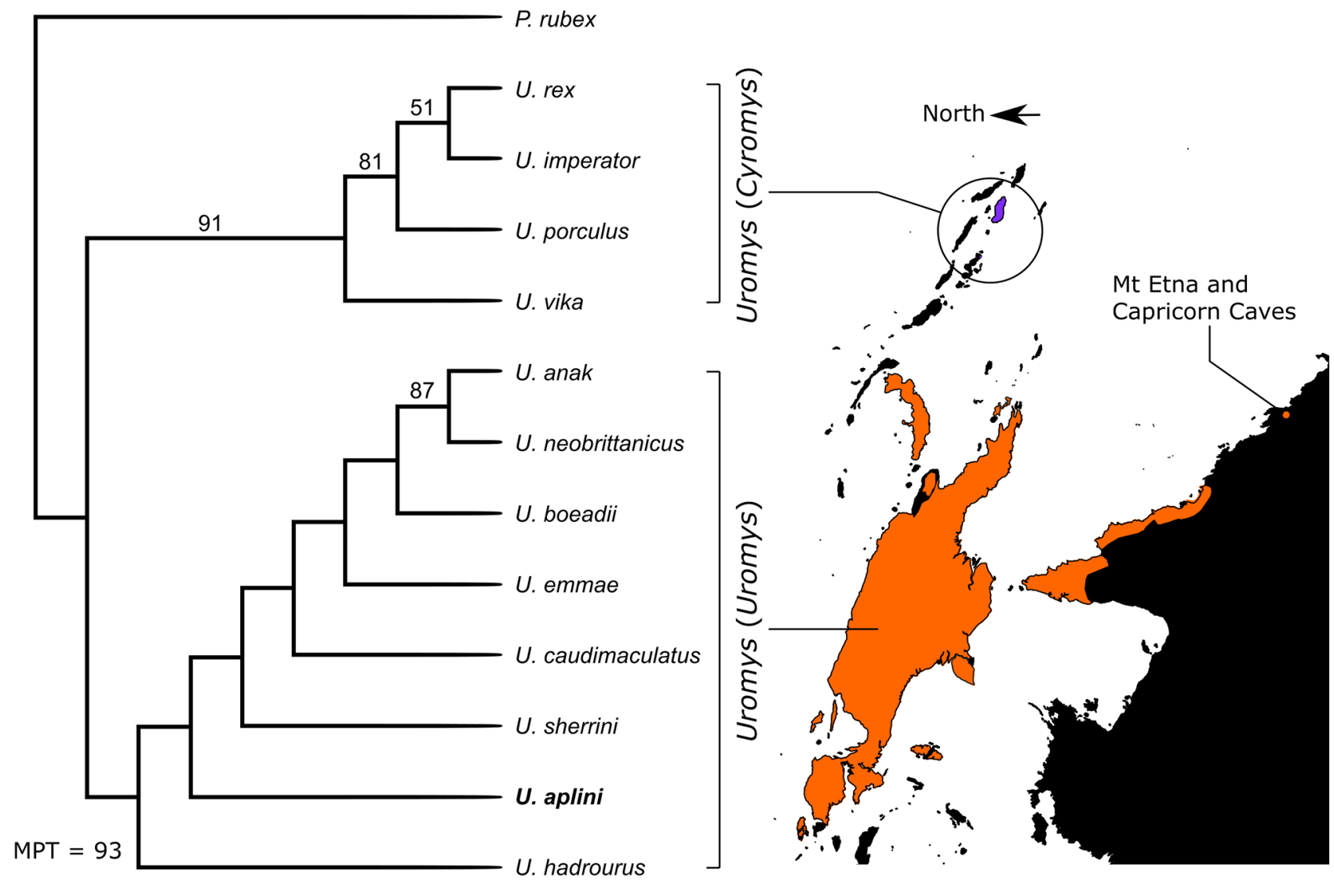

Figure 9. Results of preliminary phylogenetic analysis using parsimony. Bootstrap values $>50 \%$ provided showing monophyly of the Solomon Islands Uromys (Cyromys) and Australopapuan clade as sister taxon with Australian species basal to New Guinean species.

resolution of missing data may increase the support for the monophyly of Uromys (Uromys) and Uromys (Cyromys).

Resolution within the Uromys (Uromys) clade is poor, although the New Guinean $U$. anak and New Britain $U$. neobrittanicus are strongly supported (87\%) as sister taxa. The positions of the remaining taxa are poorly supported by bootstrap values, but both MPTs return identical positions of all species, suggesting that the overall topology is valid. At the base of the clade lie the Australian Uromys hadrourus, the fossil taxon U. aplini, and U. sherrini. In a more derived position, sister to these Australian endemic species, is $U$. caudimaculatus, which is then sister taxon to a clade containing the northern New Guinean island endemics $(U$. emmae and $U$. boeadii), the mainland New Guinea U. anak, and $U$. neobrittanicus from New Britain.

The two basal clades, comprising Uromys (Cyromys) and Uromys (Uromys), were supported by Groves \& Flannery (1994), so this result is not surprising. But our analysis, using Paramelomys as the outgroup, suggests that the Australian Uromys are basal to the Uromys (Uromys) clade.

The Middle Pleistocene age of our phylogenetically basal extinct taxon (U. aplini) is younger than the divergence time estimates (e.g., Early Pleistocene) for the more derived extant species within the clade (Watts \& Baverstock, 1994; Bryant et al., 2011). This would probably preclude $U$. aplini from being a chronospecies of the extant Australian species of Uromys (Uromys).

\section{Discussion}

\section{Phylogeny and biogeography of Uromys}

Our phylogenetic analysis supports three extant species of Uromys in northern Queensland, including two that are geographically restricted ( $U$. hadrourus and $U$. sherrini) and one that is more broadly distributed across the northern region of Cape York (U. caudimaculatus). Fossils described here demonstrate that species of Uromys were previously more widespread in northeastern Australia than would be expected on the basis of their present distribution. Importantly, they show that Uromys occurred in regions during the Pleistocene that are today south of major modern biogeographic barriers for mesic taxa (e.g., the Burdekin and St Lawrence Gaps, see Bryant \& Krosch, 2016).

The Middle Pleistocene extinct species U. aplini is phylogenetically positioned near the base of the Uromys (Uromys) clade between the geographically and ecologically restricted $U$. hadrourus and U. sherinni (Fig. 9). All taxa are found in northern Queensland, along the eastern seaboard. These taxa do not, however, form a resolved clade to the exclusion of species from New Guinea and its surrounding islands; therefore, it is hard to determine whether the Australian species are a monophyletic clade suggesting a single arrival and diversification. A reading of the current preliminary phylogenetic hypothesis would have the ancestor of Uromys dispersing from the Indo-New Guinea region 
and founding two, possibly parallel radiations that derive Uromys (Uromys) and Uromys (Cyromys). One lineage either diversified from isolation within, or has become restricted to, the Solomon Islands group, producing all of the members of Uromys (Cyromys) and their current biogeographic distribution. The other, arriving on mainland Australia, diversified first and then dispersed to the islands and mainland New Guinea with the most derived taxon reaching New Britain.

The Pleistocene record of $U$. aplini demonstrates that Uromys was present in Australia over 500,000 years ago, and occurred well south of the current biogeographical range of the genus, reaching at least the Mount Etna region by the Middle Pleistocene. Molecular-based data estimate that a $U$. hadrourus/U. caudimaculatus lineage extends back at least 1 million years, and possibly 2.5 million years ago to the Early Pleistocene (Watts \& Baverstock, 1994; Bryant et al., 2011). Currently no Early Pleistocene fossil sites are known from north-east Queensland, while in north-west Queensland, the Early Pleistocene Rackham's Roost fauna from Riversleigh, though rich in xeric-adapted rodents, understandably lacks Uromys (Godthelp, 1999). Therefore, the mesic-adapted habitats were probably already restricted to the wetter eastern seaboard by the Early Pleistocene. Thus, arrival, speciation, isolation, and extinction of species of Uromys in eastern Queensland potentially occurred all within the last two million years.

Based on current palaeoclimatic and palaeoenvironmental proxies across continental Australia (Christensen et al., 2017) and more local Neogene records (Henderson \& Nind, 2014), it is likely that corridors of mesic habitat were restricted to the eastern seaboard of Australia, including central-eastern and north-eastern Queensland, during the Quaternary. Therefore, connectivity of these mesic habitats would have been needed for ancestral Uromys to disperse southwards along the eastern seaboard to at least the Mount Etna region, subsequently producing $U$. aplini.

Local extinction of $U$. aplini occurred at Mount Etna sometime after 205-170 ka as the environment transitioned from closed wet rainforest to dry-adapted habitats (Hocknull et al., 2007). Sometime after this, U. caudimaculatus arrived in the region for the first time, likely dispersing southward along a route similar to that taken by the ancestor of $U$. aplini. The age of the $U$. caudimaculatus lineage is considered to be $>1 \mathrm{Ma}$ (Bryant et al., 2011) but the species has not been detected in the $>500-280 \mathrm{ka}$ deposits at Mount Etna. This dispersal may have occurred sometime after the extinction of $U$. aplini (c. 205-170 ka), during a period of mesic return. Therefore, corridors of habitat must have existed to allow the dispersal of this taxon south to the Mount Etna region. Until its local extinction, Uromys caudimaculatus existed in this region after $50 \mathrm{ka}$ but prior to the onset of the Last Glacial Maximum. The exact timing of the local extinction of $U$. caudimaculatus remains unresolved. Additional dating of layers containing this taxon could potentially refine this local extinction timeline.

Together, these two records of Uromys demonstrate multiple southern dispersals and subsequent local extinctions during the Pleistocene, with the likelihood that these dispersals required the crossing of several biogeographical barriers identified (Bryant \& Krosch, 2016) along the eastern seaboard in north-east and central-eastern Queensland (Fig. 1).
Combining the spatio-temporal record of Uromys along with our preliminary phylogenetic hypothesis suggests that the mesic regions of the Australian mainland supported the initial radiation of Uromys (Uromys), with a separate earlier lineage diversifying into the taxa contained within Uromys (Cyromys) that possibly occupied the emergent Solomon Islands. Subsequent dispersal of the Australian clade throughout New Guinea is contrary to what would be expected on the basis of the species richness of Uromys currently found today throughout the New Guinea to Solomon Islands region, compared to that of mainland Australia. It is, however, recognized that throughout much of the Cenozoic, bias of mesic faunal extinction resulted in an overall shift of mainland Australian biomes toward more xeric-adaptation, thus mesic biomes are now significantly under-represented (Byrne et al., 2011). The timing of these extinctions, and the effect of these on our understanding of present-day biogeography and phylogeography remains poor, without further study of the fossil record. Establishing the fossil record of these mesic biome lineages is crucial to understanding the timing and tempo of these biogeographical changes. Uromys represents just one group that can provide data on the evolution of this significant biome.

\section{Palaeoecology of Uromys}

Living species of Uromys are semiarboreal omnivores (Breed \& Ford, 2007). The ability to access food resources in the canopy (e.g., fruits, before they fall to the forest floor) has been suggested as a competitive advantage for species of Uromys (Rader \& Krockenberger, 2006); this probably played a role in resource partitioning in the species-rich Mount Etna Middle Pleistocene rainforest. The larger size of most species ( $U$. hadrourus and $U$. porculus being exceptions) allows them to utilize food resources that are inaccessible to smaller rodents. For example, large species of Uromys in north Queensland are known to gnaw through the hard, thick shells of coconuts (Watts \& Aslin, 1981) and are also infamous for opening metal traps (Elliot traps) to steal bait or prey upon smaller mammals (Laurance et al., 1993; Eric Vanderduys, pers. comm. January 2020). Furthermore, there is evidence that smaller murines actively avoid large species of Uromys (Leung, 2008) suggesting that an "ecology of fear" (Brown et al., 1999) may have a role in structuring small mammal assemblages, at least on a local scale. Uromys aplini is the largest murine in the Mount Etna deposits, and may have behaved much like its extant relatives, robbing large seeds, consuming fruits and insects, and generally terrorizing the smaller vertebrates.

\section{Extinction of Uromys in central Queensland}

The majority of rainforest-inhabiting species at Mount Etna became extinct after $280 \mathrm{ka}$ (minimum age of site QML1313). But a small number of rainforest-adapted species, e.g., Dendrolagus sp. (Hocknull et al., 2007) and Antechinus yuna (Cramb \& Hocknull, 2010) persisted for some tens of thousands of years, and appear in low numbers in QML1312, dated to 205-170 ka (Hocknull et al., 2007). Uromys aplini is one of these, and is represented by a single specimen in QML1312. The possibility of this specimen being derived from faunal mixing (e.g., a time-averaged or reworked deposit) can be discounted as the assemblage of surviving rainforest taxa shows clear selection of certain 
species. For example, multiple specimens of Antechinus yuna are present, yet Antechinus yammal is absent, despite these two species being ubiquitous in older rainforest assemblages (Cramb \& Hocknull, 2010).

The late survival of $U$. aplini implies some degree of ecological flexibility, a reasonable proposition in light of the apparent ability of extant $U$. caudimaculatus to make use of a variety of habitats in north Queensland (Moore, 2008). Despite this adaptability, U. aplini disappeared from the local record prior to deposition of site QML1456 $(<80$ ka, Price et al., 2015). Uromys caudimaculatus appears intermittently in the lower, older spits of QML1456, before apparently becoming locally extinct soon after $50 \mathrm{ka}$. The loss of both species may be explicable by an increasingly dry regional climate during the latter part of the Pleistocene and associated replacement of closed-canopy forests by open habitats. Despite a return to more mesic conditions during the Holocene, and deposits representing Holocene-aged accumulations, there is no evidence of Uromys returning to the Mount Etna area.

ACKNOwLEDGEMENTS. The authors wish to thank Kristen Spring and QM geosciences staff for curation of specimens, Heather Janetzki, Sandy Ingleby, Karen Roberts, Ken Aplin, and Fred Ford for access to comparative material, the Willi Hennig Society for providing phylogenetic software, Tyrone Lavery for providing an additional datum, Noel and Jeanette Sands and family for assistance in the field, all staff at Capricorn Caves including the Augusteyn family, for their support of palaeontological research, all researchers, honoraries, and volunteers involved in the Mount Etna project, and Liz Cramb for supporting her husband's palaeontology habit. Collection of material for this project was supported by the Ian Potter Foundation and ARC Linkage Grant (LP0453664).

\section{References}

Alston, E. R. 1876. On the classification of the Order Glires. Proceedings of the Zoological Society of London 1876: 61-98. https://doi.org/10.1111/j.1096-3642.1876.tb02543.x

Aplin, K. P. 2006. Ten million years of rodent evolution in Australasia: phylogenetic evidence and a speculative historical biogeography. In Evolution and Biogeography of Australasian Vertebrates, ed. J. R. Merrick, M. Archer, G. M. Hickey, and M. S. Y. Lee, pp. 707-744. Oatlands, Sydney: Auscipub.

Aplin, K. P., and T. F. Flannery. 2017. Uromys anak. The IUCN Red List of Threatened Species 2017: e.T22800A22447286. https://doi.org/10.2305/IUCN.UK.2017-2.RLTS.T22800A22447286.en

Aplin, K. P., and K. M. Helgen. 2010. Quaternary murid rodents of Timor part I: new material of Coryphomys buehleri Schaub, 1937, and description of a second species of the genus. Bulletin of the American Museum of Natural History 341: 1-80. https://doi.org/10.1206/692.1

Aplin, K. P., K. M. Helgen, and J. W. Winter. 2017. Uromys caudimaculatus. The IUCN Red List of Threatened Species 2017: e.T22801A22446882.

https://doi.org/10.2305/IUCN.UK.2017-2.RLTS.T22801A22446882.en

Aplin, K. P., J. M. Pasveer, and W. E. Boles. 1999. Late Quaternary vertebrates from the Bird's Head Peninsula, Irian Jaya, Indonesia, including descriptions of two previously unknown marsupial species. Records of the Western Australian Museum, Supplement no. 57: 351-387.
Breed, W. G., and K. P. Aplin. 1995. Sperm morphology of murid rodents from New Guinea and the Solomon Islandsphylogenetic implications. Australian Journal of Zoology 43: 17-30.

https://doi.org/10.1071/ZO9950017

Breed, W. G., and F. Ford. 2007. Native Mice and Rats. Collingwood: CSIRO Publishing, 185 pp. https://doi.org/10.1071/9780643095595

Brown, J. S., J. W. Laundré, and M. Gurung. 1999. The ecology of fear: optimal foraging, game theory, and trophic interactions. Journal of Mammalogy 80: 385-399. https://doi.org/10.2307/1383287

Bryant, L. M., S. C. Donnellan, D. A. Hurwood, and S. J. Fuller. 2011. Phylogenetic relationships and divergence date estimates among Australo-Papuan mosaic-tailed rats from the Uromys division (Rodentia: Muridae). Zoologica Scripta 40: 433-447. https://doi.org/10.1111/j.1463-6409.2011.00482.x

Bryant, L. M., and M. N. Krosch. 2016. Lines in the land: a review of evidence for eastern Australia's major biogeographical barriers to closed forest taxa. Biological Journal of the Linnean Society 119: 238-264. https://doi.org/10.1111/bij.12821

Byrne, M., D. A. Steane, L. Joseph, D. K. Yeates, G. J. Jordan, D. Crayn, K. Aplin, D. J. Cantrill, L. G. Cook, M. D. Crisp, J. S. Keogh, J. Melville, C. Moritz, N. Porch, J. M. K. Sniderman, P. Sunnucks, and P. H. Weston. 2011. Decline of a biome: evolution, contraction, fragmentation, extinction and invasion of the Australian mesic zone biota. Journal of Biogeography 38: $1635-1656$.

https://doi.org/10.1111/j.1365-2699.2011.02535.x

Christensen, B.A., W. Renema, J. Henderiks, D. De Vleeschouwer, J. Groeneveld, I. S. Castañeda, L. Reuning, K. Bogus, G. Auer, T. Ishiwa, and C. M. McHugh. 2017. Indonesian throughflow drove Australian climate from humid Pliocene to arid Pleistocene. Geophysical Research Letters 44: 6914-6925. https://doi.org/10.1002/2017GL072977

Cramb, J., S. Hocknull, and G. E. Webb. 2009. High diversity Pleistocene rainforest dasyurid assemblages with implications for the radiation of the Dasyuridae. Austral Ecology 34: 663-669. https://doi.org/10.1111/j.1442-9993.2009.01972.x

Cramb, J., and S. Hocknull. 2010. Two new species of Antechinus Macleay (Dasyuridae: Marsupialia) from mid-Pleistocene cave deposits in eastern central Queensland. Australian Mammalogy 32: $127-144$.

https://doi.org/10.1071/AM09025

Flannery, T. F. 1995a. Mammals of New Guinea. Chatswood: Reed Books, 568 pp.

Flannery, T. F. 1995b. Mammals of the South-west Pacific and Moluccan Islands. Chatswood: Reed Books, 464 pp.

Godthelp, H. 1999. The Australian rodent fauna, flotilla's, flotsam or just fleet footed? In Where Worlds Collide: Faunal and Floral Migrations and Evolution in SE Asia-Australasia, ed. I. Metcalfe, J. M. B. Smith, M. Morwood, and I. Davidson, pp. 319-321. Armidale: University of New England.

Gray, J. E. 1867. Notes on the variegated or yellow-tailed rats of Australasia. Proceedings of the Zoological Society of London 1867: 597-600.

Groves, C. P., and T. F. Flannery. 1994. A revision of the genus Uromys Peters, 1867 (Muridae: Mammalia) with descriptions of two new species. Records of the Australian Museum 46(2): $145-169$.

https://doi.org/10.3853/j.0067-1975.46.1994.12

Hammer, Ø., D. A. T. Harper, and P. D. Ryan. 2001. PAST: paleontological statistics software package for education and data analysis. Palaeontologia Electronica 4(1), 9 pp.

Hand, S. J. 1984. Australia's oldest rodents: master mariners from Malaysia. In Vertebrate Zoogeography and Evolution in Australia, ed. M. Archer and G. Clayton, pp. 905-912. Carlisle: Hesperian Press. 
Henderson, R. A., and M. A. P. Nind. 2014. Pliocene aridity and Neogene landscape evolution recorded by a fluvial sediment system (Campaspe Formation) in northeast Queensland. Australian Journal of Earth Sciences 61: 1041-1059. https://doi.org/10.1080/08120099.2014.965745

Hocknull, S. A. 2005. Ecological succession during the late Cainozoic of central eastern Queensland: extinction of a diverse rainforest community. Memoirs of the Queensland Museum 51(1): 39-122.

Hocknull, S. 2009. Late Cainozoic Rainforest Vertebrates from Australopapua: Evolution, Biogeography and Extinction. Unpublished Ph.D. thesis. University of New South Wales, Sydney, $627 \mathrm{pp}$.

Hocknull, S. A., J.-x. Zhao, Y.-x. Feng, and G. E. Webb. 2007. Responses of Quaternary rainforest vertebrates to climate change in Australia. Earth and Planetary Science Letters 264: 317-331. https://doi.org/10.1016/j.epsl.2007.10.004

Illiger, C. 1811. Prodromus systematis mammalium et avium additis terminis zoographicis utriusque classis, eorumque versione germanica. Berlin: C. Salfeld, 330 pp. https://doi.org/10.5962/bhl.title.106965

Jackson, S., and C. Groves. 2015. Taxonomy of Australian Mammals. Clayton South: CSIRO Publishing, 536 pp. https://doi.org/10.1071/9781486300136

Kennerley, R. 2016. Uromys siebersi (errata version published in 2017). The IUCN Red List of Threatened Species 2016: e.T136493A115209020. https://doi.org/10.2305/IUCN.UK.2016-3.RLTS.T136493A22446733.en

Krefft, G. 1867. Notes on the mammals and birds of Cape York: with description of two new rodents of the genus Hapalotis. Proceedings of the Zoological Society of London 1867: 316-319

Laurance, W. F., J. Garesche, and C. W. Payne. 1993. Avian nest predation in modified and natural habitats in tropical Queensland: an experimental study. Wildlife Research 20: 711-723. https://doi.org/10.1071/WR9930711

Lavery, T. H. 2019. Uromys vika. The IUCN Red List of Threatened Species 2019: e.T120569706A120569709. https://doi.org/10.2305/IUCN.UK.2019-1.RLTS.T120569706A120569709.en

Lavery, T. H., and H. Judge. 2017. A new species of giant rat (Muridae, Uromys) from Vangunu, Solomon Islands. Journal of Mammalogy 98: 1518-1530. https://doi.org/10.1093/jmammal/gyx116

Lazzari, V., J.-P. Aguilar, and J. Michaux. 2010. Intraspecific variation and micro-macroevolution connection: illustration with the late Miocene genus Progonomys (Rodentia, Muridae). Paleobiology 36: 641-657.

https://doi.org/10.1666/09046.1

Lecompte, E., K. Aplin, C. Denys, F. Catzeflis, M. Chades, and P. Chevret. 2008. Phylogeny and biogeography of African Murinae based on mitochondrial and nuclear gene sequences, with a new tribal classification of the subfamily. BMC Evolutionary Biology 8: 199. https://doi.org/10.1186/1471-2148-8-199

Leung, L. K. P. 2008. Cape York Melomys Melomys capensis Tate, 1951. In Mammals of Australia, 3rd edition, ed. S. M. Van Dyck and R. Strahan, pp. 669-671. Sydney: Reed New Holland.

Lidicker Jr, W. Z., and P. V. Brylski. 1987. The conilurine rodent radiation of Australia, analyzed on the basis of phallic morphology. Journal of Mammalogy 68: 617-641. https://doi.org/10.2307/1381596

Maddison, W. P., and D. R. Maddison. 2019. Mesquite: a modular system for evolutionary analysis. Version 3.61 http://www.mesquiteproject.org/

Moore, L. A. 2008. Giant White-tailed Rat Uromys caudimaculatus (Krefft, 1867). In Mammals of Australia, 3rd edition, ed. S. M. Van Dyck and R. Strahan, pp. 675-677. Sydney: Reed New Holland.
Moore, L. A., and J. W. Winter. 2008. Pygmy White-tailed Rat Uromys hadrourus (Winter, 1984). In Mammals of Australia, 3rd edition, ed. S. M. Van Dyck and R. Strahan, pp. 677-679. Sydney: Reed New Holland.

Musser, G. G. 1981. The giant rat of Flores and its relatives east of Borneo and Bali. Bulletin of the American Museum of Natural History 169: 67-175.

Musser, G. G., and M. D. Carleton. 2005. Superfamily Muroidea. In Mammal Species of the World: A Taxonomic and Geographic Reference volume 2, 3rd edition, ed. D. E. Wilson and D. M. Reeder, pp. 894-1531. Baltimore: The Johns Hopkins University Press.

O'Connor, S., K. P. Aplin, M. Spriggs, P. Veth, and L. K. Ayliffe. 2002. From savannah to rainforest: changing environments and human occupation at Liang Lembudu, Aru Islands, Maluku (Indonesia). In Bridging Wallace's Line: The Environmental and Cultural History and Dynamics of the Southeast AsianAustralian Region, ed. P. Kershaw, B. David, N. Tapper, D. Penny, and J. Brown, pp. 279-306, Advances in Geoecology Series, no. 34. Reiskirchen: Catena Verlag.

Peters, W. 1867. Über eine neue Gattung von Nagern, Uromys, aus Nordaustralien. Monatsberichte der Königlich Preussischen Akademie des Wissenschaften zu Berlin 1867: 343-345.

Piper, K. J., E. M. G. Fitzgerald, and T. H. Rich. 2006. Mesozoic to early Quaternary mammal faunas of Victoria, south-east Australia. Palaeontology 49: 1237-1262. https://doi.org/10.1111/j.1475-4983.2006.00595.x

Price, G. J. 2012. Plio-Pleistocene climate and faunal change in central eastern Australia. Episodes 35: 160-165. https://doi.org/10.18814/epiiugs/2012/v35i1/015

Price, G. J., and S. A. Hocknull. 2011. Invictokoala monticola gen. et sp. nov. (Phascolarctidae, Marsupialia), a Pleistocene plesiomorphic koala holdover from Oligocene ancestors. Journal of Systematic Palaeontology 9(2): 327-335. https://doi.org/10.1080/14772019.2010.504079

Price, G. J., J. Louys, J. Cramb, Y.-x. Feng, J.-x. Zhao, S. A. Hocknull, G. E. Webb, A. D. Nguyen, and R. Joannes-Boyau. 2015. Temporal overlap of humans and giant lizards (Varanidae; Squamata) in Pleistocene Australia. Quaternary Science Reviews 125: 98-105. https://doi.org/10.1016/j.quascirev.2015.08.013

Rader, R., and A. Krockenberger. 2006. Does resource availability govern vertical stratification of small mammals in an Australian lowland tropical rainforest? Wildlife Research 33: 571-576. https://doi.org/10.1071/WR04108

Robins, J. H., P. A. McLenachan, M. J. Phillips, B. J. McComish, E. Matisoo-Smith, and H. A. Ross. 2010. Evolutionary relationships and divergence times among the native rats of Australia. BMC Evolutionary Biology 10: 375. https://doi.org/10.1186/1471-2148-10-375

Rowe, K. C., M. L. Reno, D. M. Richmond, R. M. Adkins, and S. J. Steppan. 2008. Pliocene colonization and adaptive radiations in Australia and New Guinea (Sahul): multilocus systematics of the old endemic rodents (Muroidea: Murinae). Molecular Phylogenetics and Evolution 47: 84-101. https://doi.org/10.1016/j.ympev.2008.01.001

Steppan, S. J., and J. J. Schenk. 2017. Muroid rodent phylogenetics: 900-species tree reveals increasing diversification rates. PLoS ONE 12(8): e0183070. https://doi.org/10.1371/journal. pone. 0183070

Swofford, D. L. 2001. Paup*: phylogenetic analysis using parsimony (and other methods) 4.0. B5.

Tate, G. H. H. 1951. Results of the Archbold Expeditions. No. 65. The rodents of Australia and New Guinea. Bulletin of the American Museum of Natural History 97: 189-423.

Tate, G. H. H., and R. Archbold. 1935. Results of the Archbold Expeditions. No. 3. Twelve apparently new forms of Muridae (other than Rattus) from the Indo-Australian region. American Museum Novitates 803(9): 1-9. 
Thomas, O. 1888. Diagnoses of six new mammals from the Solomon Islands. Annals and Magazine of Natural History (6)1: 155-158.

https://doi.org/10.1080/00222938809460693

Thomas, O. 1904. On some mammals from British New Guinea presented to the National Museum by Mr. C. A. W. Monckton, with descriptions of other species from the same region. Annals and Magazine of Natural History (7)14: 397-403.

https://doi.org/10.1080/03745480409443026

Thomas, O. 1907. On three new mammals from British New Guinea. Annals and Magazine of Natural History (7)20: 70-74. https://doi.org/10.1080/00222930709487303

Thomas, O. 1910. New genera of Australasian Muridæ. Annals and Magazine of Natural History (8)6: 506-508. https://doi.org/10.1080/00222931008692883

Thomas, O. 1923a. The Godman Exploration Fund: list of mammals from North Queensland collected by Mr. T. V. Sherrin. Annals and Magazine of Natural History (9)11: 170-178. https://doi.org/10.1080/00222932308632835

Thomas, O. 1923b. A new Uromys from the Kei Islands. Treubia 3: 422.

Upham, N. S., J. A. Esselstyn, and W. Jetz. 2019. Inferring the mammal tree: species-level sets of phylogenies for questions in ecology, evolution, and conservation. PLOS Biology 17(12): e3000494.

https://doi.org/10.1371/journal.pbio.3000494

Watts, C. H. S., and H. J. Aslin. 1981. The Rodents of Australia. Sydney: Angus \& Robertson.

Watts, C. H. S., and P. R. Baverstock. 1994. Evolution in New Guinean Muridae (Rodentia) assessed by microcomplement fixation of albumin. Australian Journal of Zoology 42: 295-306. https://doi.org/10.1071/Z09940295

Winter, J. W. 1983. Thornton Peak Melomys. In The Complete Book of Australian Mammals, ed. R. Strahan, p. 379. Sydney: Angus \& Robertson.

Winter, J. W. 1984. The Thornton Peak Melomys, Melomys hadrourus (Rodentia: Muridae): a new rainforest species from northeastern Queensland, Australia. Memoirs of the Queensland Museum 21: 519-539.

Woinarski, J., and A. A. Burbidge. 2016. Uromys hadrourus. The IUCN Red List of Threatened Species 2016: e.T22802A22446971. https://doi.org/10.2305/IUCN.UK.2016-1.RLTS.T22802A22446971.en
Appendix 1. List of modern specimens examined.

Uromys anak: AM M.15633, AM M.15634, AM M.15645, AM M.15646, AM M.15647, AM M.15753, AM M.15754, AM M.15854, AM M.16695, AM M.32337, AM M.38676, AM M.38702, AM M.38864, QMJM3838.

Uromys caudimaculatus: CM705, QMJ2344, QMJ5907, QMJ5908, QMJ6349, QMJ9304, QMJ9386, QMJ9387, QMJ9388, QMJ9389, QMJ9390, QMJ9454, QMJ9455, QMJ10131, QMJ10133, QMJ10134, QMJ11512, QMJ16181, QMJ16187, QMJ16450, QMJ16725, QMJ16768, QMJ16772, QMJM17309, QMJ17609, QMJ17610, QMJ17611, QMJ20347, QMJ22127, QMJ22538, QMJ22540, QMJ22606, QMJ22607, QMJ23023, QMJM1001, QMJM8738, QMJM10038, QMJM18470, QMJM21138.

Uromys hadrourus: QMJM504, QMJM2173, QMJM8146. Uromys neobrittanicus: AM M.20689, NMVC6890.

Uromys rex: AM M.13594.

Uromys sherrini: CM10822, QMJ5907, QMJ5908, QMJ8000, QMJ16725, QMJ17612, QMJ17613, QMJ17614, QMJ21272, QMJ22539, QMJ22606. 



\title{
Late Quaternary Fossil Vertebrates of the Broken River Karst Area, Northern Queensland, Australia
}

\author{
Gilbert J. Price ${ }^{1} \mathbb{D}$, Jonathan Cramb $^{1} \mathbb{D}$, Julien Louys $^{2} \mathbb{D}$, Kenny J. Travouillon ${ }^{3} \mathbb{D}$, \\ Eleanor M. A. Pease $^{1} \mathbb{D}$, Yue-Xing Feng ${ }^{1} \mathbb{D}$, Jian-Xin ZhaO ${ }^{1} \mathbb{D}$, and Douglas Irvin ${ }^{4}$ \\ ${ }^{1}$ School of Earth and Environmental Science, The University of Queensland, Brisbane Qld 4072, Australia \\ ${ }^{2}$ Australian Research Centre for Human Evolution, Griffith University, Brisbane Qld 4111, Australia \\ ${ }^{3}$ Western Australian Museum, Locked Bag 49, Welshpool DC WA 6986, Australia \\ ${ }^{4}$ Hills Speleology Club Limited, Sydney, Australia
}

\begin{abstract}
Two new fossil deposits from caves of the Broken River area, northeast Queensland, provide the first regional records of vertebrate species turnover and extinction through the late Quaternary. Fossil assemblages from Big Ho and Beehive Caves are dominated by small-bodied vertebrates, especially mammals. They represent owl roost deposits, although limited presence of larger-bodied taxa such as macropodids may be the result of occasional pitfall trapping. U-series dating demonstrates that Big Ho dates to the penultimate glacial cycle (c. $165 \mathrm{ka}$ ) and Beehive to the early Holocene (c. $8.5 \mathrm{ka}$ ). A total of 34 mammalian taxa were identified; within the two deposits, seven taxa are unique to Big Ho and another seven are found only in Beehive. The deposits also preserve five extinct fossil taxa (bandicoots and rodents) that add to a growing list of small-bodied species known to have suffered extinction in the late Quaternary. The deposits further yield the remains of four species of bandicoots and rodents (Chaeropus yirratji, Notomys longicaudatus, Conilurus albipes, and Pseudomys gouldii) that suffered extinction postEuropean colonization. These new fossil records represent significant increases in the known geographic and temporal range of several species and begin to fill an important gap in our understanding of the faunal history of tropical northeast Australia.
\end{abstract}

\section{Introduction}

Modern Australian ecosystems emerged during the Quaternary under a backdrop of major fluctuations in atmospheric carbon dioxide concentration, sea levels, and temperature, with a long-term trend towards progressively drier climates (Martin, 2006; Kershaw et al., 2003; Price, 2013). The period was marked not only by significant evolutionary events, but also major extinctions and geographic range shifts of many flora and fauna (e.g., Kershaw, 1994; Jordan et al., 1995; Reed \& Bourne, 2000,
2009; Hocknull et al., 2007; Prideaux et al., 2007; Price, 2012; Price et al., 2005; Black et al., 2014). Today, at a time of widespread awareness over detrimental anthropogenic and climatic impacts on Australian ecosystems, it has become critical to understand the history of ecosystem origins and responses to similar past events. The Quaternary fossil record has a significant role to play in yielding that crucial information (Reisinger et al., 2014).

While many vertebrate fossil deposits of Quaternary age have been recognized in Australia, the record is patchy and geographic coverage is strongly biased towards southern 


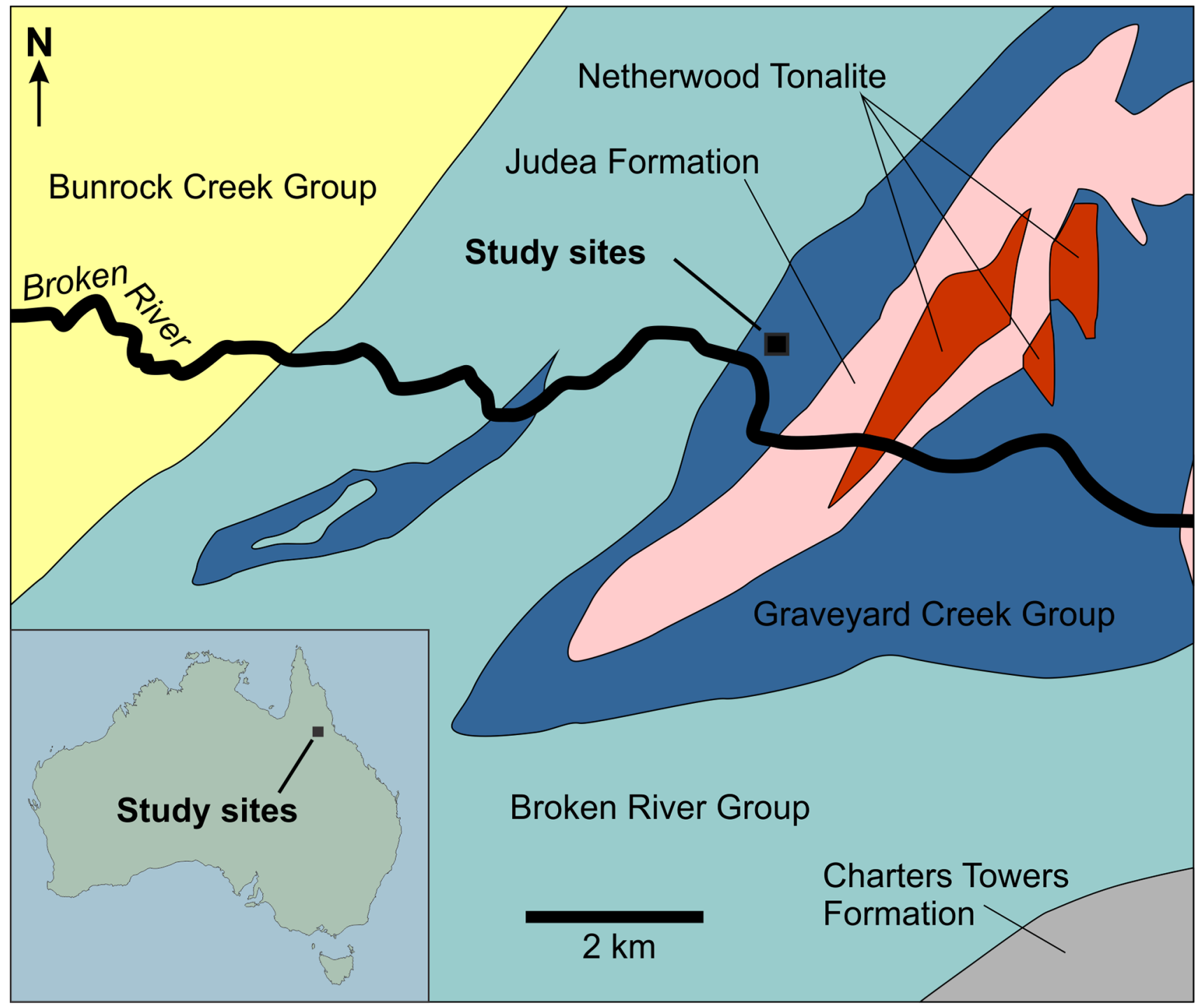

Figure 1. Map showing study sites and regional geological provinces of the Broken River karst area.

Australia. Very little is known about the Quaternary history of ecosystems in northern Australia (Price et al., 2017; Hocknull et al., 2020). This situation is not necessarily due to a paucity of fossil sites in the region, but more likely results from a dearth of field investigations; when these have been conducted, they have yielded records comparable to the south. Areas such as the Darling Downs (southeast Queensland) and Mt Etna (central eastern Queensland), for example, have produced some of the most extensive records of Quaternary vertebrates north of the QueenslandNew South Wales border. There, records show waves of extinction of both megafauna and micro-fauna (e.g., rodents, bandicoots) alongside progressive decreases in precipitation and expansion of more open habitats through the late Quaternary (Hocknull, 2005a; Hocknull et al., 2007; Cramb \& Hocknull, 2010a; Price \& Hocknull, 2011; Price et al., 2009; Price \& Sobbe, 2005; Price \& Webb, 2006; Price et al., 2015). While some Quaternary vertebrate fossils have been recovered from northern Australia (e.g., Archer et al., 1978; Molnar, 1981; Klinkhammer \& Godthelp, 2015; Cramb et al., 2018), the records remain patchy, are mostly undated, and are usually one-off collections or reports of single species.

Here we describe new Quaternary fossil faunas from two limestone caves in the Broken River area, Greenvale, northeast Queensland (Fig. 1). Although Palaeozoic marine fossils have long been known in the area (see Henderson \& Withnall, 2013 and references therein), Quaternary vertebrate fossils within the cavernous limestones were only reported in the 1980s and remained unstudied until the 2000s. Since then, individual reports of bilbies, bandicoots, rodents, and megafaunal taxa such as Diprotodon and Thylacoleo have been produced (Hocknull, 2005b; Cramb \& Hocknull, 2010b; Price et al., 2017; Travouillon et al., 2019). Full mammalian palaeocommunities from the region have yet to be documented. The aim of the present paper is to report on the first two (of several) fossil assemblages excavated from caves of the region. 

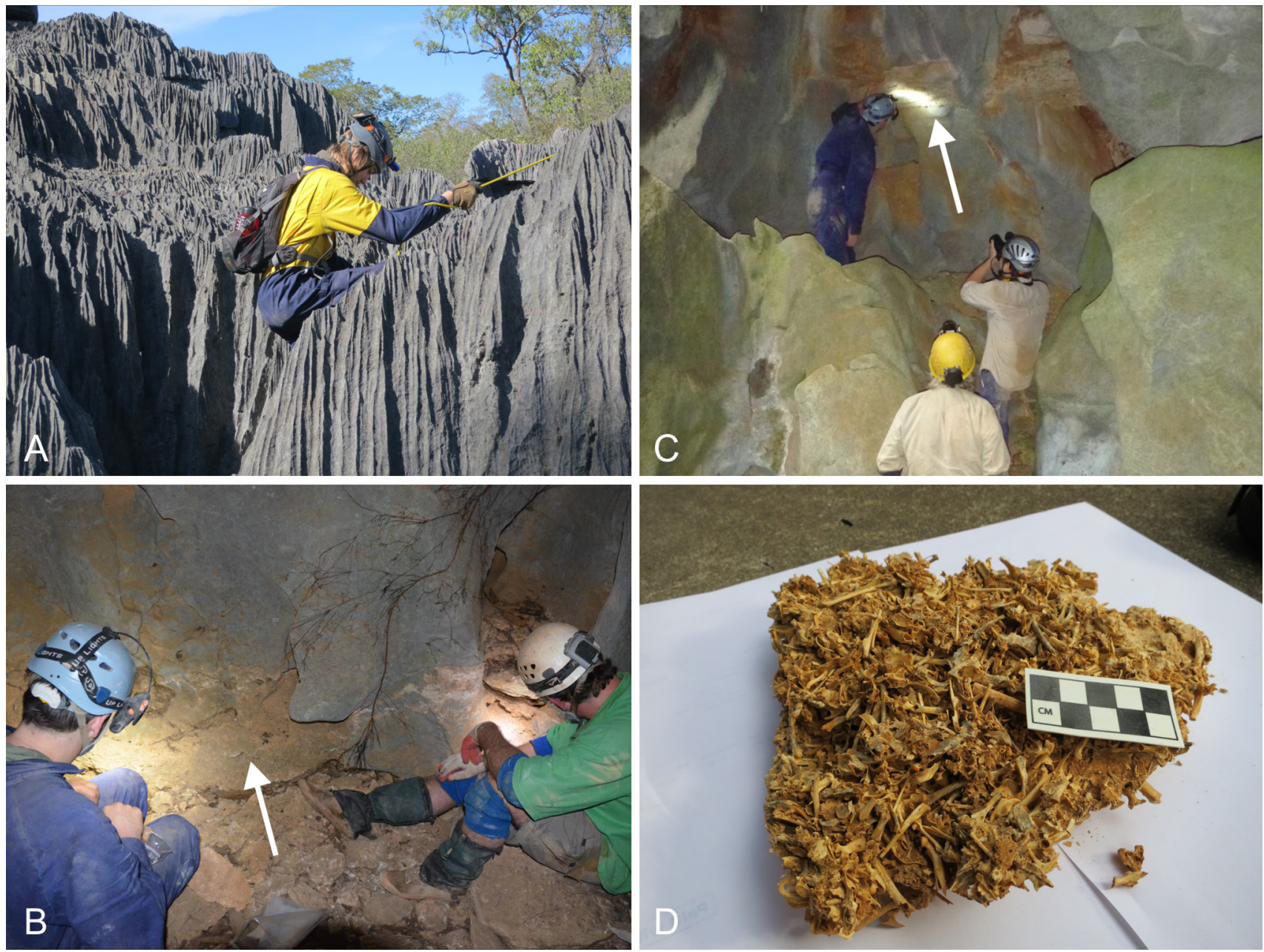

Figure 2. Images of the karst, study caves, and fossils of the Broken River karst area. $(A)$ rillenkarren typical of the Broken River limestone karst; $(B)$ Beehive fossil deposit (arrow indicating fossil-bearing breccia); $(C)$ Big Ho fossil deposit (arrow indicating fossil-bearing breccia exposed as a false floor); $(D)$ partially acid-digested breccia from Beehive showing high concentration of vertebrate fossils.

\section{Geographic and geological settings}

The Broken River area has been the subject of explorations by the Chillagoe Caving Club who are working on mapping many of the region's caves. The two deposits reported here are from Big Ho and Beehive, caves that formed in the main outcrop of limestone in the southern part of the Jack Formation, Graveyard Creek Group, part of the larger Broken River Province (Fig. 1). As this part of the outcrop is located on private property, specific locality details remain confidential but are available to bona fide researchers upon request to the Chillagoe Caving Club, Chillagoe, Queensland.

The Graveyard Creek Group is $150 \mathrm{~m}$ to $>5000 \mathrm{~m}$ thick and contains folded Silurian-Mississippian siliciclastic and carbonate sedimentary rocks, with the contained Jack Formation being around $580 \mathrm{~m}$ thick (Henderson \& Withnall, 2012). The Jack Formation is dominated by limestone and mudstone rich in autochthonous fossils that include corals, molluscs, brachiopods, conodonts, and fish remains, among other taxa (Henderson \& Withnall, 2012). The Jack Formation outcrop is heavily karstified and contains extensive and well-developed rillenkarren (Fig. 2A) making access to the caves particularly challenging. The formation is tilted to c. $90^{\circ}$ and the caves are largely joint controlled, thus, contain many narrow but tall passages and caverns, including Big Ho and Beehive.

\section{Materials and methods}

\section{Collection and curation}

Fossil breccias were collected during a short fieldtrip in conjunction with the Chillagoe Caving Club in May 2012. The aim of the trip was to conduct a general survey of selected caves to assess their palaeontological significance. Both of the caves visited contain heavily lithified, fossil-rich breccias. Due to the high degree of lithification, the breccias could only be removed by breaking them into smaller blocks for transport out of the cave; more traditional excavation techniques (e.g., top-down excavations with small hand tools such as trowels) were not possible. The stratigraphic depths of the collected breccias varied from $50-70 \mathrm{~mm}$ for both deposits, with the breccia blocks weighing a total of approximately $12 \mathrm{~kg}$. Stratification within both deposits was not evident, thus for the purpose of this study, are considered as two single, discrete accumulation phases. It is likely that the two assemblages are only minimally time-averaged and do not represent a large amount of time in terms of their depositional accumulation, respectively.

Breccia blocks from the two deposits were taken to The University of Queensland for digestion using weak (2-3\%) acetic acid. The acid dissolved the carbonate cements and caused the blocks to break down, allowing the vertebrate 
fossils to be recovered. Higher concentrations of acid were initially trialled (5-10\%) for small, single blocks, but caused too much damage to the contained fossils. Even at the lowest concentrations of acid, gastropods within the breccias were dissolved and thus could not be reported in this study. Following digestion, the loose sediments were wet sieved with $1 \mathrm{~mm}$ mesh and fossilized skeletal remains then sorted under microscopes and magnifier lamps. Two c. $500 \mathrm{~g}$ breccia blocks, one from each site, remain unprocessed and are retained in the collection as representative material of the original deposits.

Fossils were identified using typical comparative morphological techniques; minor but pertinent remarks concerning the taxonomic identifications are given in the results. We concentrate largely on the identification of mammals due to their abundance, degree of preservation, and ease of identification, although other vertebrates including frogs, squamates, and birds are represented in the deposits. These will be detailed in future reports.

We calculated the number of identified specimens present (NISP) and minimum number of individuals (MNI) for each taxon identified at the lowest taxonomic level possible. The skeletal element used for such calculations varied for each taxon. For frogs, we used pelves; monitor lizards used osteoderms; snakes used vertebrae; birds used humeri; dragon lizards, skinks, and mammals used teeth/maxillae/mandibular elements).

Fossils figured in this study are accessioned in the collections of the Palaeontology Laboratory at The University of Queensland, Brisbane, Australia (accession abbreviation: UQPL, University of Queensland Palaeontology Laboratory). Additional fossil specimen accession abbreviation: QMF (Queensland Museum Fossil; Queensland Museum, Brisbane, Australia).

\section{Dating}

Analytical dating of the fossil-rich breccias is difficult as they are heavily lithified and thus not suited to common Quaternary methods such as luminescence dating. They also lack dateable charcoals that might be amenable for radiocarbon dating. The deposits also lack interbedded and capping flowstones and cannot be dated using U-series stratigraphic bracketing approaches. Thus, the only viable option was direct dating of in situ fossils using U-series.

Fresh skeletal tissues typically lack U. However, postburial diagenesis means that $\mathrm{U}$ is commonly taken up from burial sediments by apatite that scavenges $U$ but excludes Thorium. Subsequent radioactive decay of the original U via alpha and beta emissions eventually leads to stable lead isotopes. However, the early part of the decay sequence to form ${ }^{230} \mathrm{Th}$ (i.e., ${ }^{238} \mathrm{U}--^{234} \mathrm{U}-{ }^{230} \mathrm{Th}$ ) has a half-life of $500-600$ $\mathrm{ka}$, thus, making U-series a viable option for dating late Quaternary vertebrate fossils. The U-series age is calculated by determining the amount of daughter ${ }^{230} \mathrm{Th}$ to parent ${ }^{238} \mathrm{U}$. In ideal situations, $\mathrm{U}$ is taken up rapidly from the sedimentary environment post-burial, and assuming that $U$ has not subsequently leached from the bone, the resulting $\mathrm{U}-\mathrm{Th}$ age will represent a minimum age for the fossil, but one that is close to the true age. Loss of $U$ from the system post-uptake can lead to age overestimation making the fossil tissues unsuitable for dating. The mode of $U$ uptake and potential of loss from the fossils can easily be determined by constructing ${ }^{230} \mathrm{Th}$ and $\mathrm{U}$-concentration profiles through the dated tissues.
Most of the fossils are from small-bodied vertebrate species (e.g., rodents) that required extraction from the breccias using dilute acetic acid. It was determined that such tissues may not be suitable for dating for two reasons: (a) it is difficult to construct U-profiles and thus test the reliability of the ages using such small specimens; and $(b)$ there is a risk that acetic acid might strip the fossils of $U$ rendering the specimens unsuitable for dating. Consequently, dating focused on broken cross-sections of bones from in situ larger-bodied species (macropodids) within the breccias that were not processed in acid baths. Multiple dating samples (powders) were drilled from one bone each in both deposits using a $1 \mathrm{~mm}$ diameter bit following procedures described in Price et al. (2013). The sampled bones are from approximately the middle of each of the sampled portion of the deposits. These samples were then prepared for U-series dating following techniques described in Zhao et al. (2009) and measured using a Nu Plasma multi-collector inductively coupled plasma mass spectrometer at the Radiogenic Isotope Facility, The University of Queensland, following the analytical procedures of Clark et al. (2012).

\section{Results and interpretation}

\section{Geology}

The fossils were preserved in haematite-rich clay matrixsupported breccias. Both Big Ho and Beehive are particularly fossiliferous with clasts dominated by fragmentary smallbodied vertebrate remains. Larger clasts were rarely observed. The breccias are massive with no obvious sedimentary structures, including evidence of stratification, in hand samples collected.

The deposit in Beehive is from a small chamber known to cavers as the "Greenroom". The deposit is at floor level, adjacent to a limestone wall and lacks associated speleothems (Fig. 2B). It is predominately preserved in phreatic niches along the cave wall. Only the top c. $70 \mathrm{~mm}$ of the deposit was collected considering the degree of exposure, lithification, and difficulty in excavating with only hand tools. The outcrop runs around $3 \mathrm{~m}$ horizontally and no more than c. $30 \mathrm{~cm}$ wide when measured from the wall. The total depth of the deposit is unknown.

The Big Ho breccia is located approximately $4 \mathrm{~m}$ above ground level in a large open chamber (Fig. 2C). Enough sunlight enters the chamber to allow an extensive groundcover of maidenhair ferns and mosses to grow. Like Beehive, deposits were concentrated in phreatic niches along the cave wall. Breccia scars at the same level on either side of the chamber indicates that the original deposit was extensive and likely formed the entire floor of the chamber. Remains of the in situ breccia now consist only of a false floor that juts out of the limestone wall by no more than $30 \mathrm{~cm}$, and extends horizontally along the wall for approximately $1 \mathrm{~m}$. The most likely mode of deposit formation is as follows: (a) sediment and bone entered the chamber and began to create the deposit; $(b)$ the deposit then lithified into a breccia; and $(c)$ subsequent erosion of the breccia from above and especially underneath created the false floor. The Big Ho breccia was more heavily cemented than the Beehive breccia, less extensively preserved, and topographically higher relative to current floor levels. Thus, on geological evidence and field observations we considered the Big Ho breccia to be substantially older than the Beehive breccia. 
Table 1. Taxonomic list for vertebrates of the fossil deposits of the Broken River karst area.

\begin{tabular}{|c|c|c|c|c|c|}
\hline \multirow[b]{2}{*}{ taxon } & \multirow[b]{2}{*}{ common name } & \multicolumn{2}{|c|}{ Beehive } & \multicolumn{2}{|c|}{ Big Ho } \\
\hline & & NISP & MNI & NISP & MNI \\
\hline anuran gen. et sp. indet. 1 & Frog & 3 & 1 & 1 & 1 \\
\hline anuran gen. et sp. indet. 2 & Frog & - & - & 1 & 1 \\
\hline scincid gen. et sp. indet. & Skink & 5 & 1 & 3 & 1 \\
\hline agamid gen. et sp. indet. & Dragon Lizard & 10 & 1 & - & - \\
\hline Varanus sp. indet. & Monitor Lizard & 6 & 1 & 2 & 1 \\
\hline pythonid gen. et sp. indet. & Python & - & - & 2 & 1 \\
\hline elapid gen. et sp. indet. & Venomous snake & 3 & 1 & 2 & 1 \\
\hline Aves gen. et sp. indet. & Bird & 6 & 1 & - & - \\
\hline Dasyurus sp. & Quoll & - & - & 7 & 1 \\
\hline Antechinus sp. & Antechinus & 6 & 2 & 5 & 1 \\
\hline Phascogale tapoatafa & Brush-tailed Phascogale & 5 & 1 & 5 & 1 \\
\hline Planigale sp. cf. ingrami/tenuirostris & Planigale & 2 & 1 & 5 & 2 \\
\hline Sminthopsis macroura & Striped-faced Dunnart & 11 & 3 & 14 & 5 \\
\hline Sminthopsis sp. cf. murina & Slender-tailed Dunnart & 2 & 1 & 3 & 1 \\
\hline Chaeropus yirratji & Northern pig-footed Bandicoot & 2 & 2 & 1 & 1 \\
\hline Isoodon peninsulae & Cape York Brown Bandicoot & 1 & 1 & 2 & 2 \\
\hline Isoodon sp. 2 & Short-nosed Bandicoot & 1 & 1 & 2 & 2 \\
\hline Perameles sp. & Long-nosed Bandicoot & - & - & 2 & 1 \\
\hline Petaurus norfolcensis & Squirrel Glider & 5 & 2 & 1 & 1 \\
\hline Trichosurus sp. & Brushtail Possum & 1 & 1 & 1 & 1 \\
\hline ?hypsiprymnodontid & Rat Kangaroo & - & - & 1 & 1 \\
\hline macropodid indet. & Macropod & - & - & 1 & 1 \\
\hline macropodid "small" & Macropod & 1 & 1 & - & - \\
\hline Conilurus albipes & White-footed Rabbit Rat & 8 & 1 & 3 & 1 \\
\hline Conilurus capricornensis & Capricorn Rabbit Rat & - & - & 3 & 1 \\
\hline Leggadina forrest $i$ & Forrest's Mouse & 17 & 7 & 38 & 24 \\
\hline Notomys longicaudatus & Long-tailed Hopping Mouse & 34 & 14 & 48 & 26 \\
\hline Notomys sp. 2 & Hopping Mouse & 9 & 1 & - & - \\
\hline Pseudomys australis & Plains Mouse & 87 & 47 & 107 & 55 \\
\hline Pseudomys sp. cf. P. delicatulus & Delicate Mouse & 3 & 3 & 7 & 4 \\
\hline Pseudomys desertor & Desert Mouse & 1 & 1 & - & - \\
\hline Pseudomys gouldii & Gould's Mouse & 13 & 8 & 10 & 7 \\
\hline Pseudomys gracilicaudatus & Eastern Chestnut Mouse & 15 & 10 & 22 & 12 \\
\hline Zyzomys sp. 1 & Rock Rat & 2 & 1 & 1 & 1 \\
\hline Hydromys chrysogaster & Water Rat & - & - & 1 & 1 \\
\hline Melomys cervinipes & Fawn-footed Melomys & 2 & 1 & - & - \\
\hline Rattus spp. & Native Rat & 72 & 36 & 81 & 40 \\
\hline Rattus lutreolus & Swamp Rat & 1 & 1 & - & - \\
\hline "Microchiroptera" sp. indet. & Microbat & 1 & 1 & 1 & 1 \\
\hline Miniopterus orianae & Bent-wing Bat & - & - & 1 & 1 \\
\hline
\end{tabular}

\section{Taphonomy}

Both deposits preserve very similar taphonomic signatures in that the breccias are heavily lithified, lack obvious stratification, and are dominated by the remains of smallbodied vertebrates. Prior to acid digestion (or at least in the early stage of acid digestion), bones within the breccias were mostly complete in situ (Fig. 2D). Where fragmentation was observed on skeletal elements, the broken ends lacked evidence of abrasion suggestive of re-working (e.g., Fig. 2D). Subsequent acid processing of the breccias led to higher fragmentation of the bones.

The breccias have a high concentration of skeletal remains (e.g., Fig. 2D). The majority of the fauna are nocturnal, non-cavernous species. The fossils lack tooth markings suggestive of predation from carnivorous mammals. They bear the appearance of typical owl deposits like those of modern roosts observed elsewhere (e.g., Walton, 1990). Thus, the most parsimonious interpretation is that these assemblages were produced predominately by owls. Owls typically hunt at night either consuming their prey in the surrounding region or back in the caves. They will tear the prey apart to consume before regurgitating pellets that contain difficult to digest elements such as bones and teeth, fur and feathers. More robust elements (i.e., bone and teeth) are more resilient to post-burial diagenesis and readily make their way into the fossil record (Walton, 1990). Skeletal remains of larger-bodied taxa preserved within the breccias are unlikely to have been brought into the caves by owls, but rather, are likely victims of the caves acting as pitfall traps. Today, it is not unusual to see the remains of modern skeletons of macropodids (especially rock wallabies and 
wallaroos) lying on the floors of other caves in the area.

Forty taxa were identified from the two deposits, with 26 identified to species level (Table 1). Mammals (32 taxa) are the most abundant in terms of taxonomically identifiable remains. Most mammalian taxa occur in both deposits, although five are unique to Beehive and another seven are found only in Big Ho. Species richness is similar across deposits: Big Ho contains 27 species of mammal versus 25 for Beehive. To test for potential bias introduced by sampling intensity, we conducted a rarefaction analysis (Fig. 3) using PAST 4.0 (Hammer et al., 2001). For mammals, although Big Ho has more specimens identified to lowest taxonomic level possible than Beehive (372 vs 302), rarefaction diversity curves for both deposits tend towards an asymptote. When compared at a common number of specimens, i.e., 302, both curves predict that 25 species would be present. This further highlights the taphonomic similarities between both deposits. It is likely that more collecting from both sites, especially Beehive, would yield a greater diversity of mammalian species. Pertinent taxonomic remarks for the Broken River taxa are given below.

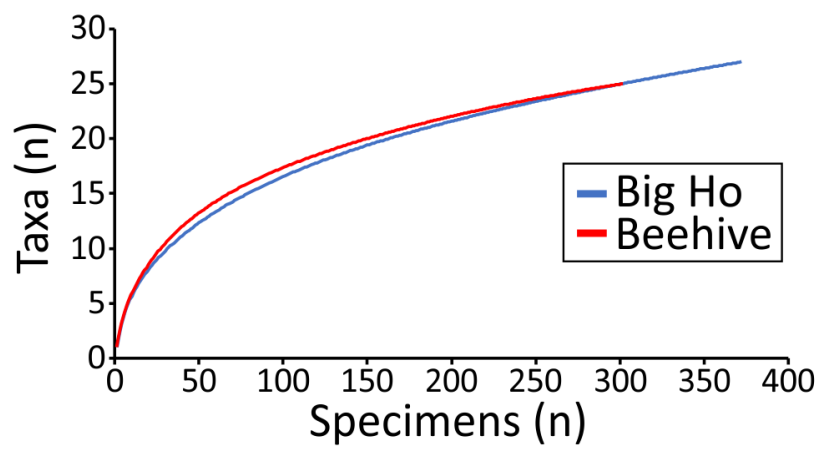

Figure 3. Rarefaction curves comparing Big Ho and Beehive mammalian diversity within respective fossil breccias.

\section{Fauna}

\section{Anura}

Frogs (Fig. 4A,B) were identified on the basis of postcranial remains. Ilial morphologies indicate that at least two taxa are present.

\section{Sauropsida}

Squamates (Fig. 4C-G) were identified to family predominantly on the basis of vertebrae, maxillae, and mandible fragments, revealing the presence of varanid, agamid, and scincid lizards, as well as elapid and pythonid snakes. Osteoderms and jaws were less commonly recovered.

\section{Aves}

Birds (Fig. 4H,I) are abundant in both study sites, with a variety of sizes and morphologies hinting at a sizeable diversity of taxa. These specimens await future study.

\section{Mammalia \\ Marsupialia}

\section{Dasyuridae}

Dasyurus sp. indet. (Fig. 5A). A medium-sized quoll is represented by isolated molars. Dimensions of the molars indicate that it is within the size range of $D$. viverrinus and D. geoffroii, but the available material is insufficient to separate these species.

Antechinus sp. indet. (Fig. 5B). The identification of fossil Antechinus is discussed in Cramb \& Hocknull (2010a). Antechinus is a rare taxon at Broken River, represented by mandibular fragments and isolated teeth. Most species of Antechinus have posterior cingula on $\mathrm{M}^{1-3}$, and this is the distinguishing feature of the Broken River specimens. The exact identity of the Broken River specimens cannot be established on the basis of available material.

Phascogale tapoatafa (Fig. 5C). The Brush-tailed Phascogale is a medium-sized dasyurid with a reduced $\mathrm{P}_{3}$, posterior cingula on the upper molars, commonly buccal cingula on $\mathrm{M}^{1}$, and relatively strong buccal cingulids on the lower molars. It is distinguished from other species ( $P$. pirata, $P$. calura, and an undescribed species from Mount Etna) by being larger and having stronger buccal cingula on the upper molars.

Planigale sp. cf. P. ingrami / tenuirostris (Fig. 5D). Archer's (1976) revision of Planigale found that the most reliable dental features separating species were size and presence/ absence of a $\mathrm{P}^{3} /{ }_{3}$. One specimen from Big Ho has a lower molar row measuring 4.05, within the ranges of $P$. ingrami and $P$. tenuirostris, and equidistant between the means for both species as given by Archer (1976).

Sminthopsis macroura (Fig. 5E). The Stripe-faced Dunnart is medium-size (for a species of Sminthopsis), and possesses large entoconids on $\mathrm{M}_{1-3}$ that do not contact the hypocristids (Archer, 1981).

Sminthopsis sp. cf. S. murina (Fig. 5F). The majority of Sminthopsis specimens in the study sites lack entoconids on $\mathrm{M}_{1-3}$. They are assigned to $S$. murina here, although distinguishing that species from other "entoconid-less" species of Sminthopsis is difficult (Cramb et al., 2009).

\section{Chaeropodidae}

Chaeropus yirratji (Fig. 5G). Three specimens from Big Ho and four from Beehive represent the Northern Pig-footed Bandicoot and were included in the description of the species in Travouillon et al. (2019). Characters on the $\mathrm{M}^{1}$ and $\mathrm{M}_{1}$ are diagnostic and help separate it from Chaeropus ecaudatus. These include the paracone connecting to StB (stylar cusp B) only on $\mathrm{M}^{1}$ (not StA, in unworn teeth); the metaconule on $\mathrm{M}^{1-3}$ is well-developed, making molars more rectangular in shape; StD present on $\mathrm{M}^{1}$ and the paracristid on $\mathrm{M}_{1}$ does not connect to the protoconid (in unworn teeth).

\section{Peramelidae}

Isoodon sp. (Fig. 5H). This taxon is recorded only in Big Ho and is represented only by isolated lower molars $\left(\mathrm{M}_{1}\right.$ and $\mathrm{M}_{2}$ ). All measurements are within the modern range for I. macrourus torosus, but at the smaller end of the range. There are very few diagnostic characters on lower molars of 


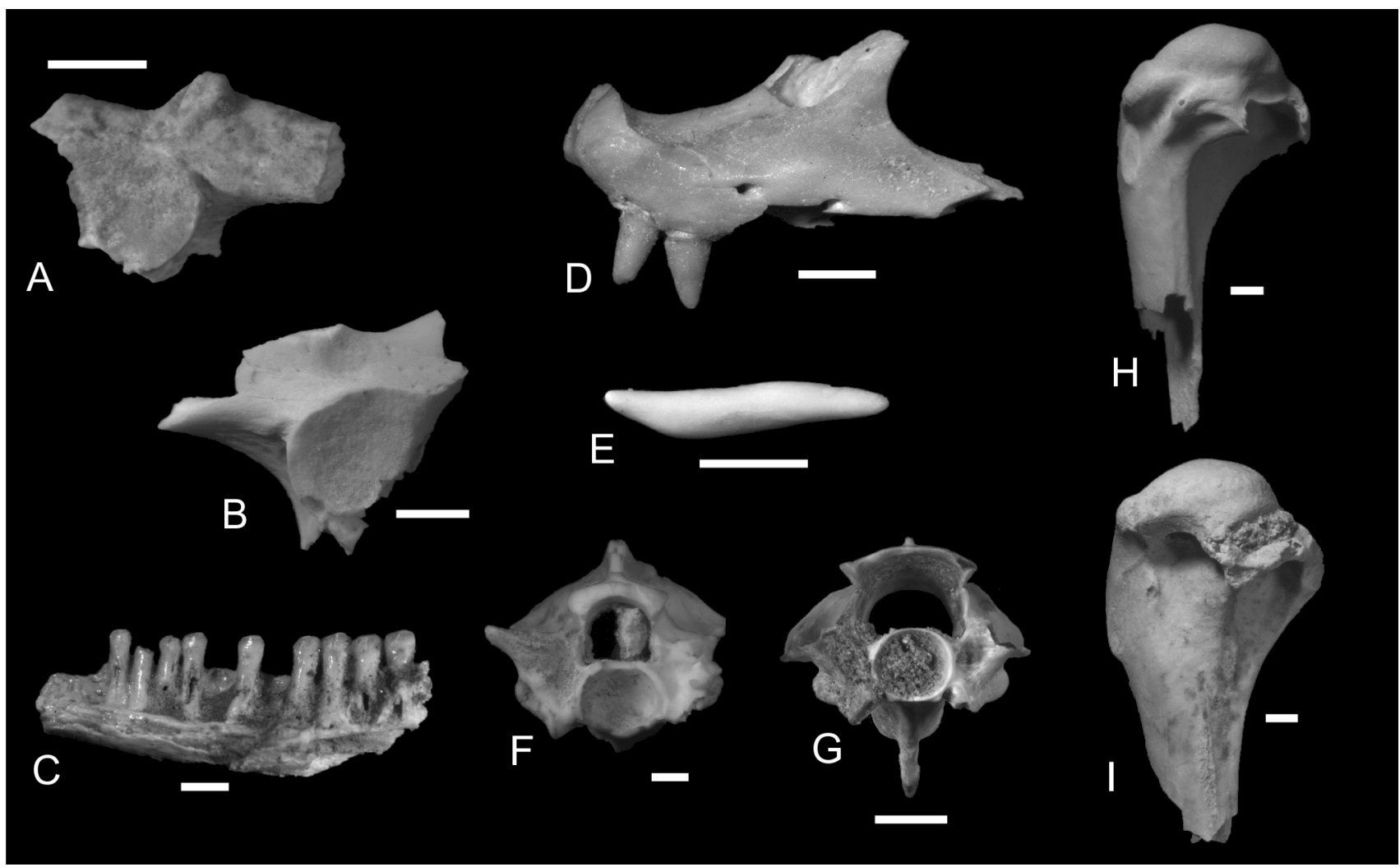

Figure 4. Non-mammal vertebrates of the Broken River karst area. $(A-B)$ anuran pelves (UQPL1-2); $(C)$ scincid dentary (UQPL3); $(D)$ agamid upper jaw (UQPL4); $(E)$ varanid osteoderm (UQPL5); $(F)$ pythonid vertebra (UQL6; $(G)$ elapid vertebra (UQPL7); $(H-I)$ avian humeri (UQPL8-9). Scale bars $=1 \mathrm{~mm}$.

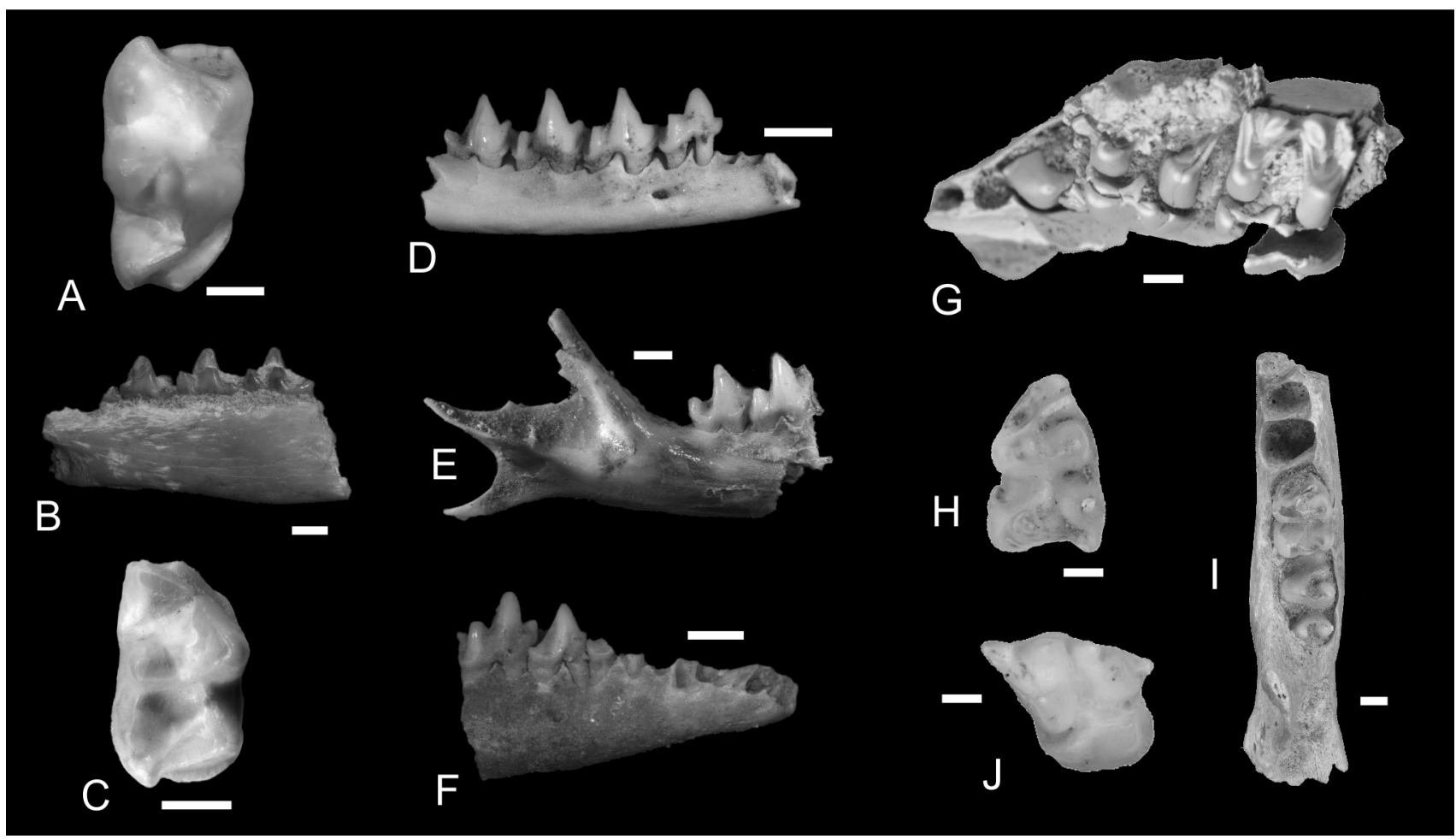

Figure 5. Dasyurids and bandicoots of the Broken River karst area. (A) Dasyurus lower molar (UQPL10); (B) Antechinus sp. dentary (UQPL11); (C) Phascogale tapoatafa lower molar (UQPL12); (D) Planigale sp. cf. P. ingrami/tenuirostris dentary (UQPL13); (E) Sminthopsis macroura dentary (UQPL14); (F) Sminthopsis sp. cf. S. murina dentary (UQPL15); $(G)$ Chaeropus yirratji maxilla (QMF58987); (H) Isoodon sp. lower molar (UQPL17); (I) Isoodon peninsulae mandible (UQPL16); $(J)$ Perameles sp. upper molar (UQPL18). Scale bars $=1 \mathrm{~mm}$. 
Isoodon. Despite being clearly a specimen of Isoodon, and being too large to be any other species than I. macrourus, there are a number of differences compared to the modern taxon. The paraconid on $\mathrm{M}_{1}$ is large and in line with the metaconid (the paraconid is commonly reduced and more buccally positioned in all described species of Isoodon). The posthypocristid is not perpendicular to the toothrow on either the $\mathrm{M}_{1}$ or $\mathrm{M}_{2}$, which is a feature typically seen in Isoodon auratus, I. fusciventer, and I. peninsulae but not in I. macrourus. It is an undescribed species of Isoodon. We do not erect a new species here, but rather wait on the discovery of additional, more comprehensively diagnosable material.

Isoodon peninsulae (Fig. 5I). The Cape York Brown Bandicoot is the most common species of bandicoot present in both Big Ho and Beehive. The dental measurements are slightly larger than the modern range for this taxon, but still below that of I. macrourus. The overall morphology matches that of I. peninsulae. It differs from I. auratus, I. fusciventer, and I. macrourus in having a preparacrista of $\mathrm{M}^{1}$ buccally orientated then posterobuccally orientated. It differs from $I$. fusciventer and I. macrourus in having a stylar crest present on $\mathrm{M}^{1}$ and no $\mathrm{StC} / \mathrm{D}$ on $\mathrm{M}^{4}$. It differs from I. fusciventer, I. macrourus, and I. obesulus in having a small anterior cingulum on $\mathrm{M}^{1}$ not connected to the talon, and a large anterior cingulum of $\mathrm{M}^{2}$ not connected to talon. It differs from I. macrourus and I. obesulus in having the posthypocristid of $\mathrm{M}_{1}$ and $\mathrm{M}_{2}$ oblique to the tooth row.

Perameles sp. (Fig. 5J). This taxon is only represented by two isolated molars, a left $\mathrm{M}^{1}$ and a left $\mathrm{M}_{2}$, both from Big Ho. The $\mathrm{M}^{1}$ length is within the range of modern Perameles pallescens, but the tooth is wider than in the modern species. The $\mathrm{M}_{2}$ width is also within the modern range, but the length is longer. The $\mathrm{M}_{2}$ typically has no reliable characters to identify specimens to known species (see Travouillon, 2016). The $\mathrm{M}^{1}$ has several characters which are diagnostic: it differs from Perameles bougainville, P. fasciata, P. myosuros, $P$. notina, and $P$. gunnii in having a short stylar crest not connected to StD. It differs from Perameles eremiana, $P$. fasciata, $P$. myosuros, $P$. notina, and $P$. papillon in that the preparacrista not reconnecting to the postparacrista posteriorly. It differs from Perameles bougainville, $P$. eremiana, P. fasciata, P. myosuros, and P. papillon in having $\mathrm{StB}$ and $\mathrm{StC}$ distinguishable with $\mathrm{StC}$ larger than $\mathrm{StB}$. It differs from all Perameles except $P$. eremiana and $P$. nasuta in having a very small StA. It differs from $P$. nasuta and $P$. pallescens in having a postprotocrista that ends posteriorly to metacone. It differs from $P$. fasciata in having no anterior cingulum. While there are enough characters to separate it from all modern taxa, it is not described as a separate species here, as it cannot be compared to the extinct fossil species Perameles sobbei, from which no $\mathrm{M}^{1}$ has been recovered to date. The $\mathrm{M}_{2}$ matches the morphology of P. sobbei (e.g., Price, 2002), but it also matches that of other Perameles, such as $P$. pallescens. As a result, we consider this taxon as Perameles sp. until further material is recovered, but it is undoubtedly an extinct species.

\section{Petauridae}

Petaurus norfolcensis (Fig. 6A). The Squirrel glider is a medium-sized Petaurus distinguished by having molar rows longer than those of $P$. breviceps and P. biacensis but shorter than P. australis, P. gracilis, and P. abidi.

\section{Phalangeridae}

Trichosurus sp. indet. (Fig. 6B). Phalangerids are easily distinguished from similarly-sized pseudocheirids by their bunodont molars.

Few morphological characters separate the species of Trichosurus, but T. vulpecula is extant in the Broken River area and is thus considered to be the most likely identity of the fossil specimens. One specimen from Big Ho is an unerupted molar, indicating that the individual was a juvenile.

\section{Hypsiprymnodontidae}

cf. Hypsiprymnodontidae gen. et sp. indet. (Fig. 6C). An isolated premolar fragment has the distinctive "buzzsaw" shape and ridges seen in hypsiprymnodontids, some burramyids, and propleopines. The size of the specimen is similar to Hypsiprymnodon, but its generic and specific identity is unknown.

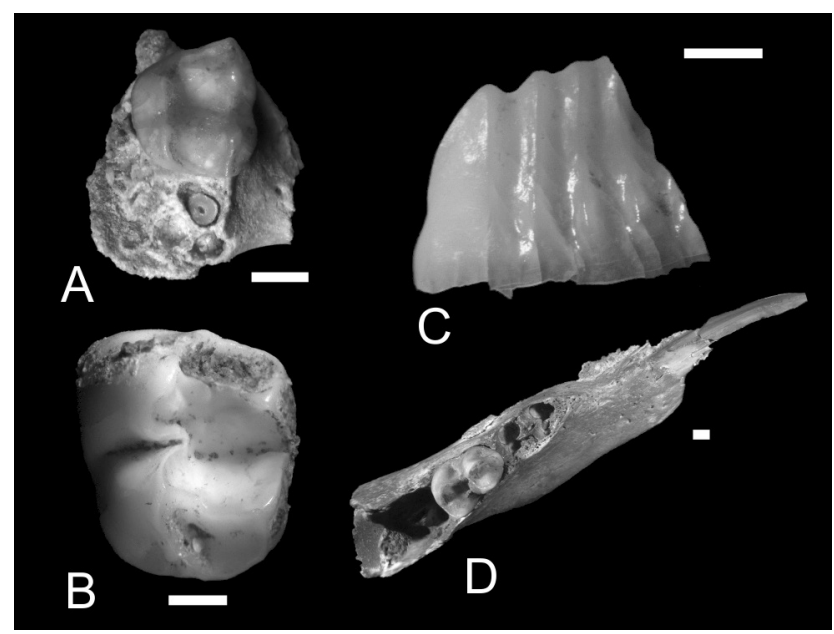

Figure 6. Diprotodonts from the Broken River karst area. $(A)$ Petaurus norfolcensis upper molar (UQPL19); (B) Trichosurus sp. upper molar (UQPL20); (C) ?hypsiprymnodontid premolar (UQPL21); (D) juvenile macropodid mandible (UQPL22). Scale bars $=1 \mathrm{~mm}$.

\section{Macropodidae}

Macropodidae indet. (Fig. 6D). Macropodid remains are uncommon, fragmentary, and appear to be from immature individuals. A partial mandible from Beehive represents a very young individual, most likely from a rock wallaby (Petrogale sp.) although additional material is required to confirm the identification.

\section{Placentalia}

\section{Muridae}

Rats and mice are most readily identified to species by their upper molars and maxillae, which form the majority of referred specimens here.

Conilurus albipes (Fig. 7A). Distinguishing features of the species are listed by Cramb \& Hocknull (2010b). The Broken River sites are the northern-most records of this species. 


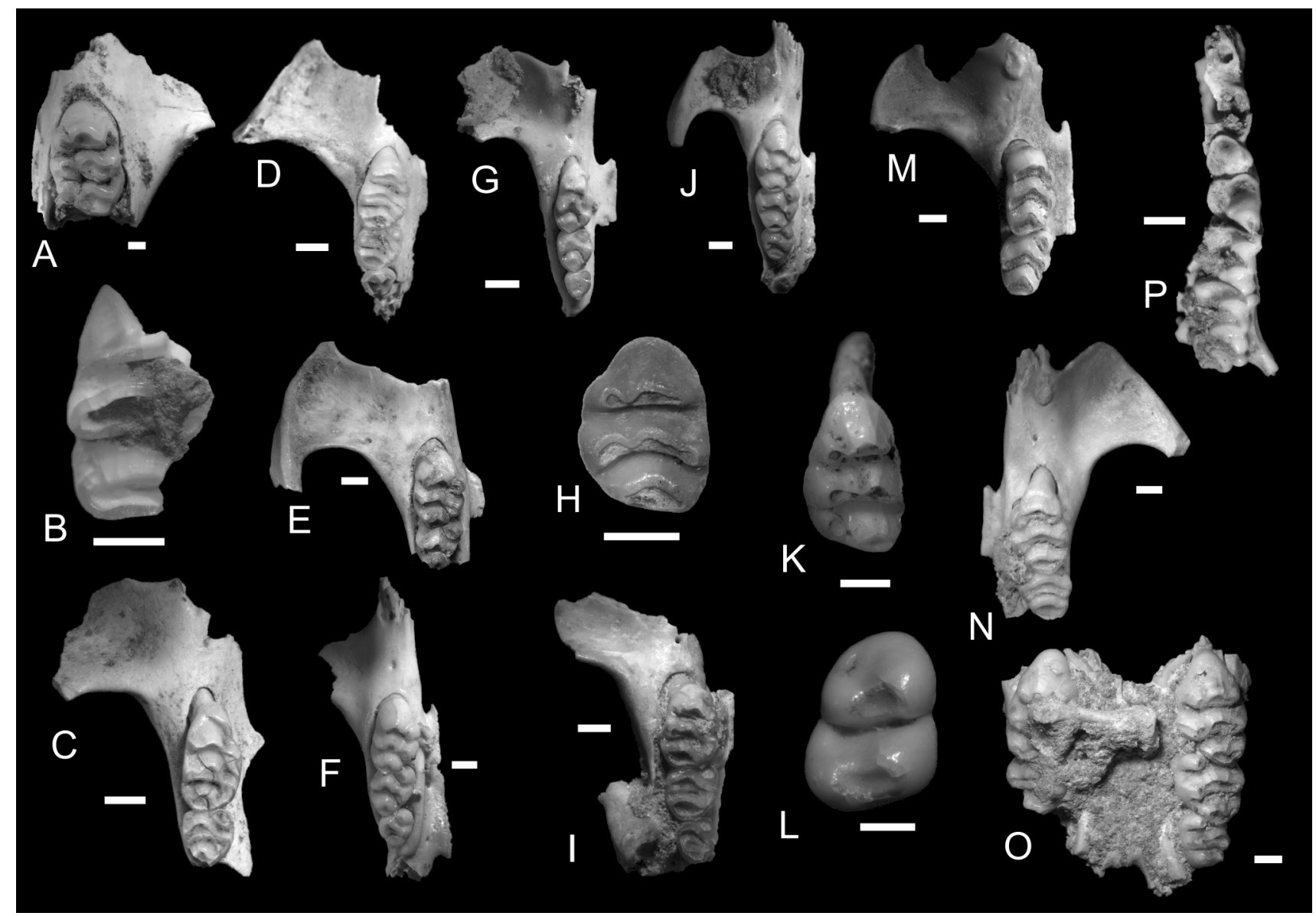

Figure 7. Placentals from the Broken River karst area. (A) Conilurus albipes maxilla (UQPL23); (B) Conilurus capricornensis molar fragment (UQPL24); (C) Leggadina forresti maxilla (UQPL25); (D) Notomys longicaudatus maxilla (UQPL26); (E) Notomys sp. 2 maxilla (UQPL27); (F) Pseudomys australis maxilla (UQPL28); (G) Pseudomys sp. cf. P. delicatulus maxilla (UQPL29); (H) Pseudomys desertor molar (UQPL30); (I) Pseudomys gouldii maxilla (UQPL31); (J) Pseudomys gracilicaudatus maxilla (UQPL32); (K) Zyzomys sp. molar (UQPL33); (L) Hydromys chrysogaster molar (UQPL34); (M) Melomys cervinipes maxilla (UQPL35); ( $N$ ) Rattus sp. maxilla (UQPL36); $(O)$ Rattus lutreolus maxilla (UQPL37); (P) Miniopterus orianae maxilla (UQPL38). Scale bars $=1 \mathrm{~mm}$.

Conilurus capricornensis (Fig. 7B). Isolated molar fragments from Big Ho are referred to a large species of Conilurus that has proportionally shorter, broader cusps than $C$. albipes. Of the three species, C. capricornensis is the best fit for these specimens. The type locality for the species is also in the Broken River area (Cramb \& Hocknull, 2010b).

Leggadina forresti (Fig. 7C). Distinguishing features for species of Leggadina are listed by Cramb et al. (2017).

Field guides (e.g., Menkhorst \& Knight, 2010; Van Dyck et al., 2013) show the distributions of $L$. forresti and $L$. lakedownensis as non-overlapping, with the latter present in northeast Queensland. However, L. forresti is recorded as extant in the area so its palaeo-occurrence in the study sites is perhaps not surprising.

Notomys longicaudatus (Fig. 7D). The Long-tailed Hopping-mouse is identified by its large, Pseudomys-like molars; broad T8-9 complex on $\mathrm{M}^{1}$; proportionally short molar row; concave anterior margin of zygomatic plate with associated spine; and deep zygomatic bar.

Notomys sp. 2 (Fig. 7E). This species was originally identified by Ken Aplin based on specimens from Christmas Creek (an unpublished collection from west of the study sites). It has since been found in other deposits in the Broken River area. It is a moderately large species that cannot be placed in any described species with confidence (Ken Aplin pers. comm., November 2009).

Pseudomys australis (Fig. 7F). The Plains Mouse is distinguished by having molars that are proportionally narrow, each tapering posteriorly; cusps taller than those of $P$. gracilicaudatus, but not as tall as $P$. oralis; a T3 on $\mathrm{M}^{1}$ that is heavily reduced or absent; accessory cusp absent; and a proportionally long $\mathrm{M}^{3}$. The anterior palatal foramen is posteriorly narrow. Specimens from the study sites are among the northern-most records of this species.

Pseudomys sp. cf. P. delicatulus (Fig. 7G). Small species of Pseudomys are difficult to distinguish. Two species are known to occur in eastern tropical Queensland today: $P$. delicatulus and $P$. patrius. A maxilla from Big Ho preserves the posterior end of the anterior palatal foramen, which extends past the anterior margin of $\mathrm{M}^{1}$. This suggests that it is probably $P$. delicatulus, although the presence of $P$. patrius, or other small species of Pseudomys, cannot be excluded.

Pseudomys desertor (Fig. $7 \mathrm{H}$ ). An isolated $\mathrm{M}^{1}$ is assigned to $P$. desertor due to its broad T4 and T8-9 complex, and straight posterior margin on the anterior loph. 
Pseudomys gouldii (Fig. 7I). Gould's Mouse is a mediumsized Pseudomys characterized by the following features of $\mathrm{M}^{1}$ : crown not as broad as $P$. gracilicaudatus, variably developed accessory cusp, commonly with a link between the bases of $\mathrm{T} 1$ and $\mathrm{T} 2$; reduced or absent $\mathrm{T} 3$; cusps of middle loph all well-defined; T4 noticeably larger than T1; and T8-9 tapering posteriorly. Several of these features are diagnostic of $P$. australis, but the fossils appear to be closer to $P$. gouldii in that they commonly have an accessory cusp; a less elongate $\mathrm{M}^{3}$; and a posteriorly broader anterior palatal foramen.

Pseudomys gracilicaudatus (Fig. 7J). The Eastern Chestnut Mouse is a medium-sized mouse that has broad molars and commonly has a well-developed accessory cusp on $\mathrm{M}^{1}$. It is very similar to P. nanus, leading Watts \& Aslin (1981) to suggest that these two species are best separated by geographic distribution (a dubious proposition when applied to fossils). Known distributions of $P$. gracilicaudatus and $P$. nanus suggest that $P$. gracilicaudatus is the most likely species in the study sites.

Zyzomys sp. (Fig. 7K). A large species of rock rat is found in several cave sites in eastern Queensland. Godthelp (1997) stated that both $Z$. argurus and $Z$. woodwardi were present in the Chillagoe area until recently. However, examination of more complete specimens from Mount Etna has indicated that the larger species of Zyzomys found in eastern tropical Queensland sites is an undescribed species. It is identified in the study sites by the dimensions of $\mathrm{M}^{1}$, which is larger than that of $Z$. argurus.

Hydromys chrysogaster (Fig. 7L). A single right $\mathrm{M}_{2}$ is the only evidence of this species in the study sites. Isolated molars are easily recognized by their bulbous molar lophs with indistinguishable cusps. The single specimen here is unworn, indicating that it was a young individual.

Melomys cervinipes (Fig. 7M). Melomys and Uromys molars are distinguished by having well-developed lingual cusps on $\mathrm{M}^{1-2}$ but lacking a $\mathrm{T} 7$; having more than three roots on $\mathrm{M}^{1}$; molar cusps that seem to wear rapidly, so that most specimens exhibit joining of the cusps to form flat-topped lophs; and fine ornament on the molar enamel. Melomys cervinipes is distinguished from $M$. burtoni by being larger and having four roots on $\mathrm{M}^{1}$. Melomys capensis also has four roots on $\mathrm{M}^{1}$, and it is probably not possible to distinguish $M$. capensis and M. cervinipes on the basis of isolated molars. The specimens in Beehive are close to the mean $\mathrm{M}^{1}$ width of $M$. cervinipes, and are also considered more likely to be this species on the basis of extant distributions.

Rattus sordidus/tunneyi/villosissimus/colletti group (Fig. $7 \mathrm{~N}$ ). Four of the seven indigenous species of Rattus form an obvious group based on morphology and molecular phylogenetics: $R$. sordidus, $R$. tunneyi, $R$. villosissimus, and R. colletti (Aplin, 2006). Molar measurements of species within this complex are similar, making identification of fossil specimens difficult.

Rattus lutreolus (Fig. 7O). Isolated molars of the Swamp Rat can be distinguished from other Australian species of Rattus by their larger size. One specimen from Beehive is a partial palate, with associated maxillae and palatines.

\section{Miniopteridae}

Miniopterus orianae (Fig. 7P). Diagnostic craniodental characters for Australian microbats are given by Martinez (2010). Multiple species of microbats are present in the study sites based on different sized limb elements, but only M. orianae is represented by generic and specific diagnostic craniodental material: a left maxilla with $\mathrm{P}^{1-2}$ and $\mathrm{M}^{1-3}$. Miniopterus orianae (M. schreibersii in Martinez, 2010) is distinguished from M. australis by the larger dimensions of the $\mathrm{M}^{1}$, particularly width.

\section{Geochronology}

We produced $10 \mathrm{U}$-Th dates (Table 2) for two fossil bones (Fig. 8), one each from Big Ho (broken cross-section of a femur) and Beehive (broken cross-section of a tibia). Uranium concentration is relatively consistent in both specimens (c. $7 \mathrm{ppm}$ for Big Ho and $3.5 \mathrm{ppm}$ for Beehive) regardless of proximity to the outer natural surface of the bones. Similarly, ${ }^{230} \mathrm{Th}$ ages are relatively consistent through both respective cross-sections. This suggests that both bones rapidly took up $\mathrm{U}$ following burial and both have acted as closed systems after recrystallization of the calcium phosphate; there is no evidence of U leaching. Thus, the dates for Big Ho (c. 165 ka) and Beehive (c. $8.5 \mathrm{ka}$ ) are reliable minimum ages and are most likely close to the burial ages of the collected portions of the respective deposits. Considering the shallow stratigraphic depth of the sampled portion of both deposits (i.e., 50-70 $\mathrm{mm}$ depth), lack of stratification, and no geological evidence of sedimentological hiatuses, it is unlikely that the breccias accumulated over long periods of time. Thus, we consider the ages as reliable approximations for the contained fossil assemblages from both respective breccias.

The hypothesized relative ages of the breccias as estimated by geological inferences is supported by direct U-series dating (i.e., that Big Ho is older). Both deposits are clearly late Quaternary, with Big Ho dating to the penultimate glacial cycle between Marine Isotope Stage (MIS) 7A and 6, while Beehive dates to the early Holocene (MIS 1).

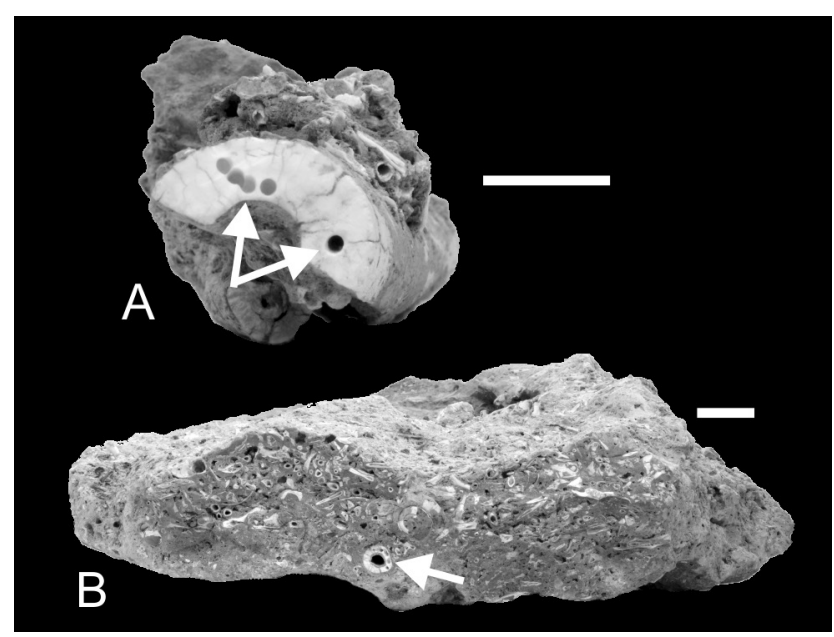

Figure 8. U-series dated fossil samples from the Broken River karst area. $(A)$ breccia karst from Beehive; $(B)$ breccia clast from Big Ho. Arrows indicate dated specimens. Scale bars $=10 \mathrm{~mm}$. 
Table 2. U-series isotopic data for the two dated bones from Big Ho (BH) and Beehive (BeH) caves of the Broken River karst area.

\begin{tabular}{lrrrrrrrr}
\hline \multicolumn{1}{l}{ sample name } & $\mathrm{U}(\mathrm{ppm})$ & ${ }^{232} \mathrm{Th}(\mathrm{ppb})$ & ${ }^{230} \mathrm{Th} /{ }^{232} \mathrm{Th}$ & ${ }^{230} \mathrm{Th} /{ }^{238} \mathrm{U}$ & ${ }^{234} \mathrm{U} /{ }^{238} \mathrm{U}$ & $\begin{array}{c}\text { uncorr. } \\
\text { age }(\mathrm{ka})\end{array}$ & $\begin{array}{c}\text { corrected } \\
\text { age }(\mathrm{ka})\end{array}$ & $\begin{array}{c}\text { corrected } \\
\text { initial }\end{array}$ \\
\hline $\mathrm{BeH}-1 \mathrm{~A}$ & $3.031 \pm 0.002$ & $124.19 \pm 0.21$ & $8.9 \pm 0.1$ & $0.120 \pm 0.001$ & $1.411 \pm 0.002$ & $9.6 \pm 0.1$ & $8.8 \pm 0.4$ & $1.426 \pm 0.003$ \\
$\mathrm{BeH}-1 \mathrm{~B}$ & $3.996 \pm 0.003$ & $4.43 \pm 0.01$ & $288.9 \pm 1.8$ & $0.106 \pm 0.001$ & $1.402 \pm 0.001$ & $8.5 \pm 0.1$ & $8.5 \pm 0.1$ & $1.412 \pm 0.001$ \\
$\mathrm{BeH}-1 \mathrm{C}$ & $4.268 \pm 0.002$ & $9.68 \pm 0.01$ & $145.9 \pm 0.8$ & $0.109 \pm 0.001$ & $1.395 \pm 0.001$ & $8.9 \pm 0.1$ & $8.8 \pm 0.1$ & $1.406 \pm 0.001$ \\
$\mathrm{BeH}-1 \mathrm{D}$ & $3.452 \pm 0.002$ & $7.96 \pm 0.02$ & $136.1 \pm 1.2$ & $0.103 \pm 0.001$ & $1.401 \pm 0.001$ & $8.3 \pm 0.1$ & $8.3 \pm 0.1$ & $1.410 \pm 0.001$ \\
$\mathrm{BeH}-1 \mathrm{E}$ & $3.491 \pm 0.002$ & $5.49 \pm 0.01$ & $185.2 \pm 1.7$ & $0.096 \pm 0.001$ & $1.405 \pm 0.001$ & $7.7 \pm 0.1$ & $7.7 \pm 0.1$ & $1.414 \pm 0.001$ \\
$\mathrm{BH}-\mathrm{A}$ & $6.492 \pm 0.005$ & $95.82 \pm 0.24$ & $176.6 \pm 0.9$ & $0.859 \pm 0.004$ & $1.094 \pm 0.003$ & $161.6 \pm 1.9$ & $161.2 \pm 1.9$ & $1.148 \pm 0.004$ \\
$\mathrm{BH}-\mathrm{B}$ & $8.113 \pm 0.006$ & $5.96 \pm 0.04$ & $3622.5 \pm 28.6$ & $0.876 \pm 0.003$ & $1.095 \pm 0.002$ & $168.7 \pm 1.7$ & $168.7 \pm 1.7$ & $1.152 \pm 0.003$ \\
$\mathrm{BH}-\mathrm{C}$ & $7.041 \pm 0.006$ & $13.35 \pm 0.06$ & $1398.8 \pm 8.1$ & $0.874 \pm 0.003$ & $1.093 \pm 0.003$ & $168.2 \pm 2.0$ & $168.1 \pm 2.0$ & $1.150 \pm 0.004$ \\
$\mathrm{BH}-\mathrm{D}$ & $5.465 \pm 0.006$ & $48.94 \pm 0.20$ & $292.4 \pm 1.8$ & $0.863 \pm 0.004$ & $1.091 \pm 0.003$ & $164.2 \pm 2.2$ & $164.0 \pm 2.2$ & $1.145 \pm 0.005$ \\
$\mathrm{BH}-\mathrm{E}$ & $7.035 \pm 0.007$ & $31.22 \pm 0.10$ & $597.7 \pm 3.3$ & $0.874 \pm 0.004$ & $1.096 \pm 0.002$ & $167.2 \pm 2.0$ & $167.1 \pm 2.0$ & $1.154 \pm 0.003$ \\
\hline
\end{tabular}

Note: Ratios in parentheses are activity ratios calculated from the atomic ratios, but normalized to measured values of secular-equilibrium HU-1 (Pike et al., 2002). All errors are given at the $2 \sigma$ level. ${ }^{230} \mathrm{Th}$ ages are calculated using Isoplot EX 3.0 (Ludwig, 2003) with decay constants $\lambda_{238}=1.551 \times 10^{-10} \mathrm{yr}^{-1}$ (for ${ }^{238} \mathrm{U}$ ), $\lambda_{234}=2.826 \times 10^{-6} \mathrm{yr}^{-1}$ (for ${ }^{234} \mathrm{U}$ ) and $\lambda_{230}=$ $9.158 \times 10^{-6} \mathrm{yr}^{-1}$ (for ${ }^{230} \mathrm{Th}$ ), respectively (Cheng et al. 2000). $2 \sigma$ errors in the uncorrected (uncorr.) ages were propagated directly from the uncertainties in the $\left({ }^{230} \mathrm{Th} /{ }^{238} \mathrm{U}\right)$ and $\left({ }^{234} \mathrm{U} /{ }^{238} \mathrm{U}\right)$. The corrected (corr.) ${ }^{230} \mathrm{Th}$ age was calculated using the assumed bulk earth or upper crust value equivalent to the detrital ${ }^{230} \mathrm{Th} /{ }^{232} \mathrm{Th}$ activity ratio of 0.83 .

\section{Discussion}

\section{Palaeoenvironment}

The palaeohabitat signatures from the two deposits are very similar to each other. Both contain several taxa that indicate a mosaic of open grassland (e.g., Pseudomys spp., Leggadina forresti, Sminthopsis spp.) and woodland habitats (e.g., Phascogale tapoatafa, Antechinus sp., Trichosurus sp.). Local permanent waterbodies are inferred by the presence of Hydromys chrysogaster (Big Ho) and Rattus lutreolus (Beehive).

Open-habitat adapted taxa such as Chaeropus yirratji, Pseudomys australis, Leggadina forresti, and Notomys longicaudatus are by far the most abundant species in both deposits. However, it is uncertain if open habitats were more common around the caves than wooded areas, or if their abundance simply reflects a feeding bias whereas the owls preferred to hunt, or were more successful hunters, in open environments rather than woodlands. In any case, most owl species hunt within a $3 \mathrm{~km}$ radius of their roost sites (Walton, 1990), indicating that the inferred palaeohabitats existed proximal to the caves.

Several arid-adapted species are present in the fossil assemblages that are now locally extinct, such as Pseudomys australis and $P$. gouldii. Their presence at Broken River during both the penultimate glacial cycle and early Holocene hints at an expanded arid zone during those times. Indeed, similar expansions of the arid zone towards the coastline have been inferred based on vertebrate-rich deposits from elsewhere such as Mt Etna (Hocknull et al., 2007), although the climate event recorded in those deposits occurred before $170 \mathrm{ka}$.

\section{Diversity}

The Broken River fossil record preserves a record of both continuity and change in terms of species persistence through time. Numerous species have been recorded in both deposits in relatively similar proportions (e.g., species of Pseudomys,
Notomys longicaudatus, Leggadina forresti). For taxa that appear in only one of the deposits, they are typically uncommon and generally represented by relatively low numbers of specimens (e.g., ?hypsiprymnodontid, Dasyurus sp., Rattus lutreolus, Pseudomys desertor), hence we err on the side of caution in reading too much into those scant records. Strikingly, however, five species (16\%) of mammals in the Broken River deposits reported here represent globally extinct taxa. Of those five, only one, Conilurus capricornensis, has been formally described (Cramb \& Hocknull, 2010b). The Big Ho specimens represent the oldest record of that species. The timing of its extinction is unclear but is probably late Holocene.

The other extinct but hitherto undescribed fossil taxa include one species in each of Zyzomys, Notomys, Isoodon, and Perameles. The species of Perameles is so far known only from Big Ho and the Notomys species only from Beehive. Species of Isoodon and Zyzomys probably have a long history in the region as they are recorded from both deposits. Overall, these taxa add to the growing bestiary of Australian small-bodied species that went globally extinct during the Late Pleistocene (e.g., Cramb et al., 2018; Klinkhammer \& Godthelp, 2015), highlighting that vertebrate extinctions during this period did not just occur among large-bodied "megafauna" (cf. Flannery, 1990).

Several species are recorded in the Broken River records that suffered extinction since European colonization of the continent. These include Chaeropus yirratji, Notomys longicaudatus, Conilurus albipes, and Pseudomys gouldii. In each case, the fossil records are far outside of the known historic geographic range of each species. It is unknown if those species occurred locally at Broken River at the time of European colonization or were extirpated from the region prior to their arrival. It is possible that they were present but were decimated rapidly and never recorded in modern ecological surveys of the area. Similar extirpation records for small-bodied mammal species have been noted elsewhere in Australia (e.g., Fusco et al., 2016; Price et al., 2019). 
Meaningful comparisons of the Broken River fossil species with modern regional records is hampered by a paucity of geographic distributional data, especially for non-volant mammals. We obtained a species list for the area based on records within the Queensland Government's Wildnet database (accessed 26 January 2020). For the area within a $5 \mathrm{~km}$ radius of Broken River (thus encompassing a typical owl's hunting range), only four non-volant native mammal species are recorded: three species of macropodoid (Aepyprymnus rufescens, Osphranter robustus and Petrogale assimilis) and the brushtail possum, Trichosurus vulpecula. Extending the search area to a $50 \mathrm{~km}$ radius recovered 27 non-volant mammals. Of these, nine are historically introduced species (e.g., pigs, cattle), ten are relatively large-bodied native species (mostly macropodoid), and the remainder are in a similar weight range to those of the Broken River fossil assemblages. For rodents, modern surveys record only four native species, compared to 13 species in our early Holocene record (i.e., the Beehive assemblage). This could indicate a major decline in diversity of rodents between the early Holocene and today, or simply a lack of modern ecological surveys for small-bodied mammals. We strongly suspect a combination of both. This hypothesis is testable if younger pre-European colonization fossils deposits can be found, in combination with a dedicated small-mammal trapping survey of the region.

\section{Final remarks}

Big Ho and Beehive represent the first report of complete fossil mammal assemblages from the Quaternary of northern Australia. While preliminary, they are part of a larger project to record the palaeontological history of the Broken River region. As part of this effort, many other caves have been explored and fossil deposits excavated, with laboratory processing of breccias (e.g., acid digestion, sorting of bones, taxonomic identification) and dating (mostly U-series) ongoing. Most caves we visited yielded fossil deposits, but like Big Ho and Beehive, the deposits are heavily lithified and difficult to extract. Speleothems are rarely associated with the breccias, making dating with methods such as U-series and optically stimulated luminescence challenging. Considering the paucity of information about Australia's Quaternary history of the region, and the promising results generated in this study, future research will no doubt provide further evidence of biotic change in tropical northeast Australia. Such records are critical for testing the timing and potential causes of the extinctions documented. We note also that these investigations would not be possible without the support of private landowners and "citizen scientists" within the speleological community who have been willing to introduce us to the caves of the area. At a time of limited funding for research in general, and a time of great concern over the future of Australian ecosystems, such partnerships are becoming increasingly vital and will likely lead to new insights and discoveries about our unique continent, the results of which will benefit us all.
Acknowledgements. We are indebted to Paul Osborne and the Chillagoe Caving Club for introducing us, and for coordinating access to, the Broken River karst area. For additional field support, we acknowledge Mary Ann Irvin, Paco Murray, Alan Pryke, and other members of the club for assistance in the field areas. We thank local landowners and numerous volunteers of the Palaeo Lab of The University of Queensland who have assisted on the broader project, and two anonymous referees whose comments greatly improved this paper. The Australian Research Council supported the research under grants DE120101533 and DP120101752.

\section{References}

Aplin, K. P. 2006. Ten million years of rodent evolution in Australasia: phylogenetic evidence and a speculative historical biogeography. In Evolution and Biogeography of Australasian Vertebrates, ed. J. R. Merrick, M. Archer, G. M. Hickey, and M. S. Y. Lee, pp. 707-744. Oatlands, Sydney: Auscipub.

Archer, M. 1976. Revision of the marsupial genus Planigale Troughton (Dasyuridae). Memoirs of the Queensland Museum 17(3): 341-365.

Archer, M. 1981. Results of the Archbold Expeditions. No. 104. Systematic revision of the marsupial dasyurid genus Sminthopsis Thomas. Bulletin of the American Museum of Natural History 168(2): 63-223.

Archer, M., A. Bartholomai, and L. G. Marshall. 1978. Propleopus chillagoensis, a new north Queensland species of extinct giant rat-kangaroo (Macropodidae: Potoroinae). Memoirs of the National Museum of Victoria 39: 55-60. https://doi.org/10.24199/j.mmv.1978.39.04

Black, K. H., G. J. Price, M. Archer, and S. J. Hand. 2014. Bearing up well? Understanding the past, present and future of Australia's koalas. Gondwana Research 25(3): 1186-1201. https://doi.org/10.1016/j.gr.2013.12.008

Cheng, H., R. L. Edwards, J. Hoff, C. D. Gallup, D. A. Richards, and Y. Asmerom. 2000. The half-lives of uranium-234 and thorium-230. Chemical Geology 169(1-2): 17-33.

https://doi.org/10.1016/S0009-2541(99)00157-6

Clark, T. R., J.-x. Zhao, Y.-x. Feng, T. J. Done, S. Jupiter, J. Lough, and J. M. Pandolfi. 2012. Spatial variability of initial ${ }^{230} \mathrm{Th} /{ }^{232} \mathrm{Th}$ in modern Porites from the inshore region of the Great Barrier Reef. Geochimica et Cosmochimica Acta 78: 99-118. https://doi.org/10.1016/j.gca.2011.11.032

Cramb, J., and S. A. Hocknull. 2010a. Two new species of Antechinus Macleay (Dasyuridae: Marsupialia) from midPleistocene cave deposits in eastern central Queensland. Australian Mammalogy 32(2): 127-144. https://doi.org/10.1071/AM09025

Cramb, J., and S. A. Hocknull. 2010b. New Quaternary records of Conilurus (Rodentia: Muridae) from eastern and northern Australia with the description of a new species. Zootaxa 2615: $47-65$.

https://doi.org/10.11646/zootaxa.2634.1.3

Cramb, J., S. Hocknull, and G. E. Webb. 2009. High diversity Pleistocene rainforest dasyurid assemblages with implications for the radiation of the Dasyuridae. Austral Ecology 34(6): 663-669.

https://doi.org/10.1111/j.1442-9993.2009.01972.x

Cramb, J., G. J. Price, and S. A. Hocknull. 2018. Short-tailed mice with a long fossil record: the genus Leggadina (Rodentia: Muridae) from the Quaternary of Queensland, Australia. PeerJ 6: e5639.

https://doi.org/10.7717/peerj.5639

Flannery, T. F. 1990. Pleistocene faunal loss: implications of the aftershock for Australia's past and future. Archaeology in Oceania 25: 45-55.

https://doi.org/10.1002/j.1834-4453.1990.tb00232.x 
Fusco, D. A., M. C. McDowell, and G. J. Prideaux. 2015. LateHolocene mammal fauna from southern Australia reveals rapid species declines post-European settlement: implications for conservation biology. The Holocene 26(5): 699-708.

https://doi.org/10.1177/0959683615618261

Godthelp, H. 1997. Zyzomys rackhami sp. nov. (Rodentia, Muridae) a rockrat from Rackham's Roost Site, Riversleigh, northwestern Queensland. Memoirs of the Queensland Museum 41: 329-334.

Hammer, Ø., D. A. T. Harper, and P. D. Ryan. 2001. PAST: paleontological statistics software package for education and data analysis. Palaeontologia Electronica 4(1), 9 pp.

Henderson, R. A., and I. W. Withnall. 2013. Broken River Province. In Geology of Queensland, ed. P. A. Jell, pp. 250-279. Brisbane, Australia: Geological Survey of Queensland.

Hocknull, S. A. 2005a. Ecological succession during the late Cainozoic of central eastern Queensland: extinction of a diverse rainforest community. Memoirs of the Queensland Museum 51(1): 39-122.

Hocknull, S. A. 2005b. Late Pleistocene-Holocene occurrence of Chaeropus (Peramelidae) and Macrotis (Thylacomyidae) from Queensland. Memoirs of the Queensland Museum 51(1): 38.

Hocknull, S. A., R. Lewis, L. J. Arnold, T. Pietsch, R. JoannesBoyau, G. J. Price, P. Moss, R. Wood, A. Dosseto, J. Louys, J. Olley, and R. A. Lawrence. 2020. Extinction of eastern Sahul megafauna coincides with sustained environmental deterioration. Nature Communications 11: 2250.

https://doi.org/10.1038/s41467-020-15785-w

Hocknull, S. A., J.-x. Zhao, Y.-x. Feng, and G. E. Webb. 2007. Responses of Quaternary rainforest vertebrates to climate change in Australia. Earth and Planetary Science Letters 264(1-2): 317-331.

https://doi.org/10.1016/j.epsl.2007.10.004

Jordan, G., M. MacPhail, R. Barnes, and R. Hill. 1995. An Early to Middle Pleistocene flora of subalpine affinities in lowland western Tasmania. Australian Journal of Botany 43(2): 231-242. https://doi.org/10.1071/BT9950231

Kershaw, A. P. 1994. Pleistocene vegetation of the humid tropics of northeastern Queensland, Australia. Palaeogeography, Palaeoclimatology, Palaeoecology 109(1-4): 399-412. https://doi.org/10.1016/0031-0182(94)90188-0

Kershaw, A. P., S. van der Kaars, and P. T. Moss. 2003. Late Quaternary Milankovitch-scale climatic change and variability and its impact on monsoonal Australasia. Marine Geology 201(1-3): 81-95. https://doi.org/10.1016/S0025-3227(03)00210-X

Klinkhamer, A. J., and H. Godthelp. 2015. Two new species of fossil Leggadina (Rodentia: Muridae) from Northwestern Queensland. PeerJ 3: e1088. https://doi.org/10.7717/peerj. 1088

Ludwig, K. R. 2003. Users Manual for Isoplot/Ex version 3.0: A Geochronological Toolkit for Microsoft Excel. Berkeley: Berkeley Geochronology Centre.

Martin, H. A. 2006. Cenozoic climatic change and the development of the arid vegetation in Australia. Journal of Arid Environments 66(3): 533-563.

https://doi.org/10.1016/j.jaridenv.2006.01.009

Martinez, S. 2010. Palaeoecology of the Mount Etna Bat Fauna, Coastal Eastern Queensland. Unpublished Ph.D. thesis. Queensland University of Technology, Brisbane.

Menkhorst, P., and F. Knight. 2010. A Field Guide to the Mammals of Australia, 3rd edition. South Melbourne, Australia: Oxford University Press.

Molnar, R. E. 1977. Crocodile with laterally compressed snout: first find in Australia. Science 197: 62-64.

https://doi.org/10.1126/science.197.4298.62
Pike, A. W. G., R. E. M. Hedges, and P. Van Calsteren. 2002. U-series dating of bone using the diffusion-adsorption model. Geochimica et Cosmochimica Acta 66(24): 4273-4286. https://doi.org/10.1016/S0016-7037(02)00997-3

Price, G. J. 2002. Perameles sobbei sp. nov. (Marsupialia, Peramelidae), a Pleistocene bandicoot from the Darling Downs, south-eastern Queensland. Memoirs of the Queensland Museum 48(1): 193-197.

Price, G. J. 2012. Plio-Pleistocene climate and faunal change in central eastern Australia. Episodes 35(1): 160-165. https://doi.org/10.18814/epiiugs/2012/v35i1/015

Price, G. J., J. Cramb, J. Louys, and Y.-x. Feng. 2017. Palaeontology of northeastern Australian caves. In Proceedings of the 17th International Congress of Speleology, July 22-28, Sydney, NSW Australia, ed. K. Moore and S. White, vol. 1, pp. 25-28. Sydney: Australian Speleological Federation Incorporated.

Price, G. J., Y.-x. Feng, J.-x. Zhao, and G. E. Webb. 2013. Direct $\mathrm{U}-\mathrm{Th}$ dating of vertebrate fossils with minimum sampling destruction and application to museum specimens. Quaternary Geochronology 18: 1-8. https://doi.org/10.1016/j.quageo.2013.07.003

Price, G. J., and S. A. Hocknull. 2011. Invictokoala monticola gen. et sp. nov. (Phascolarctidae, Marsupialia), a Pleistocene plesiomorphic koala holdover from Oligocene ancestors. Journal of Systematic Palaeontology 9(2): 327-335. https://doi.org/10.1080/14772019.2010.504079

Price, G. J., J. Louys, J. Cramb, Y.-x. Feng, J.-x. Zhao, S. A. Hocknull, G. E. Webb, A. D. Nguyen, and R. Joannes-Boyau. 2015. Temporal overlap of humans and giant lizards (Varanidae; Squamata) in Pleistocene Australia. Quaternary Science Reviews 125: 98-105. https://doi.org/10.1016/j.quascirev.2015.08.013

Price, G. J., J. Louys, G. K. Smith, and J. Cramb. 2019. Shifting faunal baselines through the Quaternary revealed by cave fossils of eastern Australia. PeerJ 6: e6099. https://doi.org/10.7717/peerj.6099

Price, G. J., and I. H. Sobbe. 2005. Pleistocene palaeoecology and environmental change on the Darling Downs, southeastern Queensland, Australia. Memoirs of the Queensland Museum 51(1): 171-201.

Price, G. J., M. J. Tyler, and B. N. Cooke. 2005. Pleistocene frogs from the Darling Downs, south-eastern Queensland, and their palaeoenvironmental significance. Alcheringa 29: 171-182. https://doi.org/10.1080/03115510508619566

Price, G. J., and G. E. Webb. 2006. Late Pleistocene sedimentology, taphonomy and megafauna extinction on the Darling Downs, southeastern Queensland. Australian Journal of Earth Sciences 53: 947-970.

https://doi.org/10.1080/08120090600880842

Price, G. J., J.-x. Zhao, Y.-x. Feng, and S. A. Hocknull. 2009. New records of Plio-Pleistocene koalas from Australia: palaeoecological and taxonomic implications. Records of the Australian Museum 61(1): 39-48. https://doi.org/10.3853/j.0067-1975.61.2009.1518

Prideaux, G. J., J. A. Long, L. K. Ayliffe, J. C. Hellstrom, B. Pillans, W. E. Boles, M. N. Hutchinson, R. G. Roberts, M. L. Cupper, L. J. Arnold, P. D. Devine, and N. M. Warburton. 2007. An aridadapted Middle Pleistocene vertebrate fauna from south-central Australia. Nature 445: 422-425.

https://doi.org/10.1038/nature05471

Reed, E. H., and S. J. Bourne. 2000. Pleistocene fossil vertebrate sites of the south-east region of South Australia. Transactions of the Royal Society of South Australia 124(2): 61-90.

Reed, E. H., and S. J. Bourne. 2009. Pleistocene fossil vertebrate sites of the South East region of South Australia II. Transactions of the Royal Society of South Australia 133(1): 30-40.

https://doi.org/10.1080/03721426.2009.10887108 
Reisinger, A., R. L. Kitching, F. Chiew, L. Hughes, P. C. D. Newton, S. S. Schuster, A. Tait, and P. Whetton. 2014. Australasia. In Climate Change 2014: Impacts, Adaptation, and Vulnerability. Part B: Regional Aspects. Contribution of Working Group II to the Fifth Assessment Report of the Intergovernmental Panel on Climate Change, ed. V. R. Barros, C. B. Field, D. J. Dokken, M. D. Mastrandrea, K. J. Mach, T. E. Bilir, M. Chatterjee, K. L. Ebi, Y. O. Estrada, R. C. Genova, B. Girma, E. S. Kissel, A. N. Levy, S. MacCracken, P. R. Mastrandrea \& L. L. White, pp. 1371-1438. Cambridge, United Kingdom, and New York, United States of America: Cambridge University Press.

Travouillon, K. J. 2016. Investigating dental variation in Perameles nasuta Geoffroy, 1804, with morphological evidence to raise P. nasuta pallescens Thomas, 1923 to species rank. Zootaxa 4114(4): 351-392.

https://doi.org/10.11646/zootaxa.4114.4.1
Travouillon, K. J., B. F. Simões, R. Portela Miguez, S. Brace, P. Brewer, D. Stemmer, G. J. Price, J. Cramb, and J. Louys. 2019. Hidden in plain sight: reassessment of the Pig-footed Bandicoot, Chaeropus ecaudatus (Peramelemorphia, Chaeropodidae), with a description of a new species from central Australia, and use of the fossil record to trace its past distribution. Zootaxa 4566(1): 1-69. https://doi.org/10.11646/zootaxa.4566.1.1

Walton, A. H. 1990. Owl pellets and the fossil record. In Evolutionary Paleobiology of Behavior and Coevolution, ed. A. J. Boucot, pp. 233-241. New York: Elsevier.

Watts, C. H. S., and H. J. Aslin. 1981. The Rodents of Australia. Sydney: Angus and Robertson.

Zhao, J.-X., K.-f. Yu, and Y.-x. Feng. 2009. High-precision ${ }^{238} \mathrm{U}-{ }^{234} \mathrm{U}-{ }^{230} \mathrm{Th}$ disequilibrium dating of the recent past: a review. Quaternary Geochronology 4(5): 423-433.

https://doi.org/10.1016/j.quageo.2009.01.012 


\title{
Characterizing Environmental Change and Species' Histories from Stratified Faunal Records in Southeastern Australia: A Regional Review and a Case Study for the Early to Middle Holocene
}

\author{
Fenja Theden-Ringl ${ }^{1,2}$, Geoffrey S. Hope ${ }^{1}$ iD, \\ Kathleen P. Hislop ${ }^{3} \mathbb{D}$, and Benedict J. Keaney ${ }^{1}$ \\ ${ }^{1}$ Archaeology and Natural History, College of Asia \& the Pacific, \\ The Australian National University, Canberra ACT 0200, Australia \\ ${ }^{2}$ Australian Research Council Centre of Excellence for Australian Biodiversity and Heritage, \\ The Australian National University, Canberra ACT 0200, Australia \\ ${ }^{3}$ School of Archaeology and Anthropology, College of Arts \& Social Sciences, \\ The Australian National University, Canberra ACT 0200, Australia
}

\begin{abstract}
We explore the potential contribution of faunal assemblages from the Australian Alps and surrounding regions towards the characterization of climate and landscape change, and for geochronological species distribution mapping. The limitations of existing faunal sites and collections- their rarity, their stratigraphic integrity and resolution, and accurate dating of their histories - are discussed in a regional review of known and potential assemblages and locations. We also revisit a faunal sequence from a stratified cave deposit at Wee Jasper, focusing on a Holocene "climatic optimum" phase. A suite of species fluctuations between 8000 and $6000 \mathrm{cal}$. BP suggests responses to local changes such as a warmer and possibly moister environment, with probable associated vegetation shifts. For example, eucalypt forests had replaced more open communities across the region by $8600 \mathrm{cal}$. BP, and were generally dominant until after $6000 \mathrm{cal}$. BP. Several faunal species are examined in a regional context using available chronologically defined species histories. Emerging robust multi-proxy investigations demonstrate the potential of faunal assemblages for the development of geographically detailed histories of species that can provide indications of palaeoenvironments. This approach can be strengthened by increasing resolution and developing improved age models in presently known fauna-bearing sites.
\end{abstract}

\section{Introduction}

Many natural archives in south-eastern (SE) Australia, including fluvial, alluvial, peat, and lake records, have for decades contributed stratified layers with inclusions such as dust, charcoal, pollen, and other environmental components to act as proxy records for the reconstruction of palaeoenvironmental conditions since the Last Glacial Maximum (LGM) (e.g., Costin, 1972; Dodson et al., 1994; Erikkson et al., 2006; Kemp \& Hope, 2014; Marx et al., 2009, 2011; Stanley \& DeDeckker, 2002). In contrast, the contribution of faunal assemblages to inform our 
understanding of the environmental history of this region has typically been minor. In fact, faunal assemblages have usually been placed into a known environmental context based on other proxies, rather than informing environmental change in their own right. There are several reasons for this.

First, relatively old and well-preserved faunal deposits are rare in the Australian montane country and surrounds, and still absent from the subalpine and alpine areas above $1100 \mathrm{~m}$ altitude. This is despite the promising existence of numerous limestone karst areas, which are known to preserve organic materials including bone, and the unique "rain shadow" feature of much of the high Monaro plain to the east of the main ranges, which has resulted in several fauna-rich alluvial basalt-derived terraces. Second, known faunal deposits are very rarely continuous, often preserving only "snapshots" for certain periods of time, disrupted by erosion events, absence of deposition, breccia formation, etc. And third, even where relative chronological continuity may have existed in an in-situ deposit, the long history of faunal investigation in SE Australia since the 1830s, with a strong resurgence during the 1960s and 1970s, has resulted in the majority of assemblages being associated with little accurate chronological information due to the unavailability (and/or expense) of accurate dating techniques at the time. This problem is compounded by the fact that pre-treatment chemistry associated with radiocarbon and other dating techniques prior to the 1990s was inadequate, significantly failing to account for contaminants in ancient deposits. Undated, poorly dated, dated at coarse resolution, or with chronologies inferred through comparison to other sequences, these assemblages simply lack the fine-scale resolution required for use as environmental proxies.

The purpose of this paper is to explore the current and emerging potential of faunal assemblages as proxies for environmental change from the Late Pleistocene and through the Holocene. We summarize and assess some of the known faunal assemblages and their contexts from the Australian Alps region, with selected geographical extensions northwards to the Southern Tablelands and southern Blue Mountains, eastwards along the steep coastal ranges of the New South Wales South Coast, and southwards into the lower Gippsland region of Victoria. Our focus here is on faunal assemblages known or thought to date from after the height of Last Glacial Maximum (LGM) to the present; we ignore the deeper time question of environmental change coinciding with Late Pleistocene megafauna extinctions.

In a case study towards examining faunal shifts for a phase of environmental fluctuation - an early to middle Holocene "Climatic Optimum"-we discuss the faunal assemblage from a deep, stratified cave deposit near Wee Jasper, site Wee Jasper 99 (hereafter "WJ99"). The faunal assemblage from WJ99 was analysed by one of the authors (KPH) under the careful supervision of Ken Aplin in 2016 (see ThedenRingl et al., 2018), and it is in Ken's honour that we re-visit the collection here. The faunal changes associated with the Holocene Climatic Optimum at this site are compared to other regional faunal assemblages coinciding with this time period, and also to other proxies for environmental change, in order to assess (and attempt to define) the capacity and limitations of faunal assemblages, as well as several individual species, as environmental proxies.

\section{Regional context and review}

The Australian Alps have a complex geological history, consisting of a series of undulating plateaux and ridges, surrounded and dissected by steep slopes, gorges, river valleys, and escarpments. They are formed from a large range of rock types including sedimentary sandstone and mudstone, volcanic basalts, metamorphic slate, schist, and gneiss. The Monaro Plain (Fig. 1), for example, is a large area of Cenozoic basalt lava flows. Large bodies of Palaeozoic granite, resistant to erosion, form many of the distinct plateaux and ridges visible throughout the Alps landscape today. Former coral reefs formed pockets of limestone, which over time dissolved to form caves and gorges in the limestone karst areas.

The underlying conditions lending themselves to the preservation of faunal materials are relatively sparse in the Australian Alps and wider region, where many of the surface sediments are derived from the regions' granodiorite geology. Archaeological excavations of granitic rock shelter sites in the Namadgi Ranges in the northern Alps region, for example, have in many cases yielded only highly fragmented and heavily calcined bone material, typically only from late Holocene units $(<2000$ years cal. BP $)$, and in most cases unsuited to species-level identification (e.g., at Birrigai, Flood et al., 1987; at Nursery Swamp 2, Rosenfeld et al. 1983; and at Middle Creek and surrounding sites, Flood, 1980 and Theden-Ringl, 2016). Similar issues with older bone preservation were encountered by Josephine Flood (1973) and Phil Boot (2002) in rock shelter excavations within sandstone and granite areas along the NSW South Coast escarpment. Boot ascribed the poor preservation conditions to geology, drainage patterns and soil acidity.

Sites with well-preserved faunal remains are thus typically limited to certain geologic regions. One such area is found on the high Monaro Plain, where alluvial terraces form favourable preservation conditions for fossil beds due to a combination of arid conditions (a rain shadow in the lee of the Alps affects the Monaro) and of weathering and calcium richness from the Monaro's basalt geology (Ride \& Davis, 1997). Of the Monaro fossil beds, several have faunal assemblages dating to the Late Pleistocene and Holocene. The gully walls of Pilot Creek, for example, revealed stratigraphically distinct faunas dated by radiocarbon analysis (Davis, 1996; Ride et al., 1989). The oldest unit dates to 30,800-27,900 cal. BP (SUA-2088 and Beta-18297). ${ }^{1}$

Holocene units (unit PCB and PCLB), dated to 7660-6720 cal. BP (SUA-2087) and 5580-4870 cal. BP (Beta-18300) respectively, are interpreted by the authors to have been

1 To allow for consistent comparison of regional dated sites, most radiocarbon ages noted here have been calibrated by the authors against SHCal13 (Hogg et al., 2013) using Oxcal v4.2 at 95.4\% probability (Bronk Ramsay, 2009). Calibrated age ranges are expressed as years "cal. BP". Where calibration by the authors was not possible (due to insufficient data, or because published age ranges were inferred from age-depth models), uncalibrated dates and age ranges are specifically expressed as years "BP (uncal.)" or "ka (uncal.)" depending on the authors' original terminology. In several instances, published age ranges are based on calibrated age-depth models. Here, we defer to the already published age ranges (years "cal. BP"). 


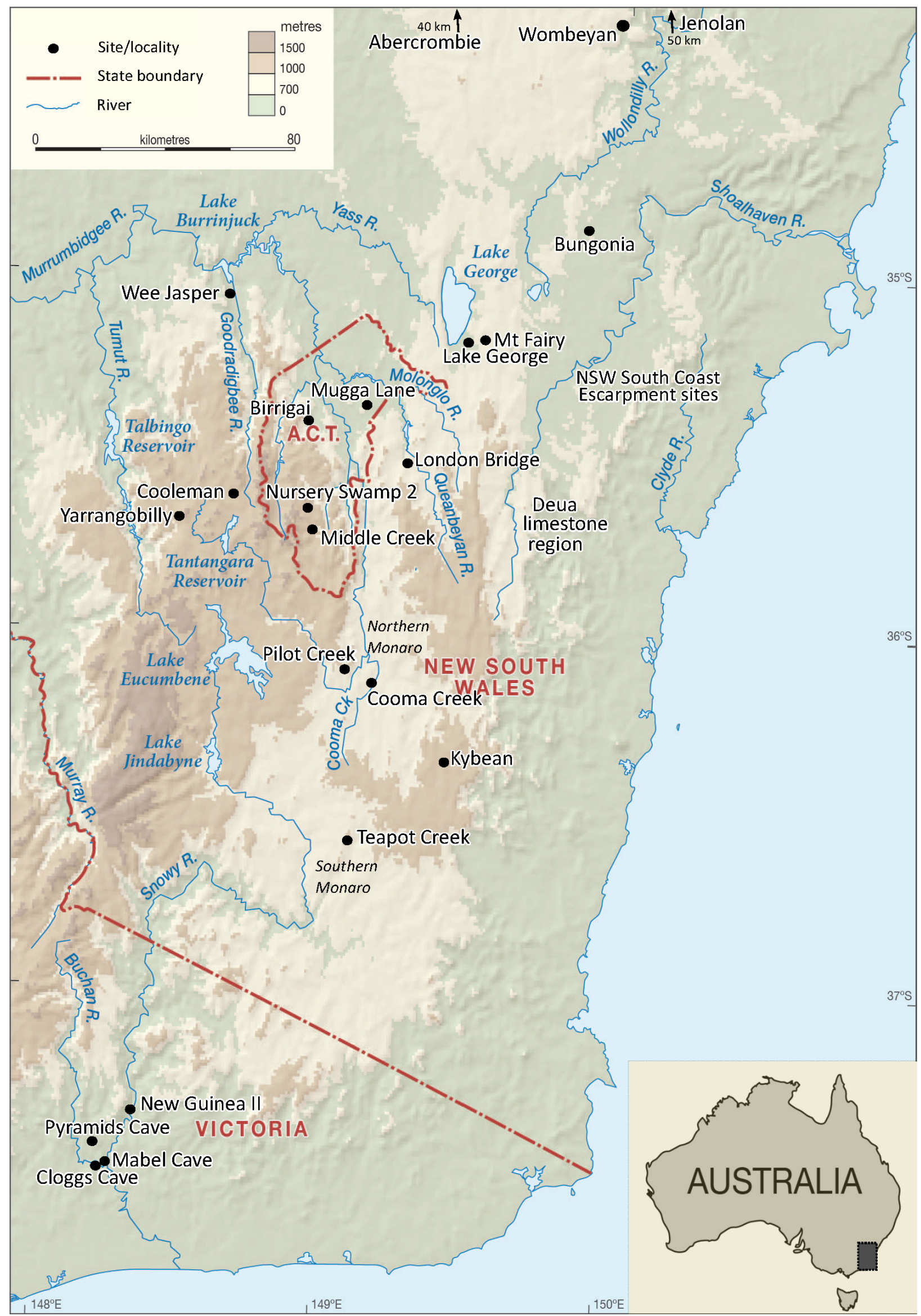

Figure 1. Map of SE Australian Alps and region, indicating locations of sites with faunal material mentioned in text. 
deposited during a dry interval dated between 6 and $2 \mathrm{ka}$ (uncal.) (Ride et al., 1989: 95). The base of a nearby road cutting also containing mammal fossils, Cooma Creek, was radiocarbon dated to 27,200-25,300 cal. BP (Beta-18298). At both sites, the older Pleistocene units include megafauna species and the sites are interpreted by the authors as having been deposited during a phase of widespread erosional instability of slopes, and active alluviation of valley floors (Ride et al., 1989). The differences in species representation between the older and younger faunal assemblages are significant. In all samples, however, the number of species represented is relatively small. Teapot Creek, on the Monaro Plain, also contains a younger terrace dated by two radiocarbon dates to around 6280-5320 cal. BP (Beta-50156 and Beta-50157), and an older, undated, terrace (Armand et al., 2000; Dansie, 1992). Armand et al. (2000: 113) speculated that the Holocene terrace was formed during a wet period between 8 and $5 \mathrm{ka}$ (uncal.) that saw increased transport capacity of the creek and consequent erosion of the plains. The fact that only three bone fragments were found in the Holocene deposit limits the site's interpretive potential for this period of time.

These examples of open sites come with their own significant sets of interpretative issues. They include not only selective preservation of faunal materials due to their exposed and reworked contexts, episodic clay expansion and contraction, and calcrete impregnation, but also the limitation of coarse stratigraphic and rudimentary chronological frameworks. Accurate dating, particularly of older deposits, has also presented issues at the open sites in the region, with problematic materials such as soils and organic rich silts frequently used for radiocarbon dating. This was demonstrated, for example, at the Mugga Lane site in South Canberra, where a radiocarbon date of c. 19,700 years (uncal.) from organic-rich silty clays, on which the dating of nearly fossil kangaroo bone layers was interpreted, was later demonstrated to post-date those bone layers (Macphail \& Hope, 2002, revised 2012). Thus, the region's open sites generally are able to characterize subsets of species for broad windows in time, and to infer prevailing environmental conditions and environmental changes that occurred between units. But they lack the fine chronological resolution and fauna preservation capacities necessary for bone assemblages to inform on environmental change for any contiguous sequence of time.

Pockets of limestone karst occur scattered throughout the SE Australian mountain regions; it is these geological formations that have proven the most promising for the stratified deposition and accumulation of sediments and for the preservation of organic materials. The regions' limestone karst areas are well documented (e.g., Lishmund et al., 1986; Matthews, 1985; Nicoll \& Brush, 1976; Spate, 2018). Faunal studies of limestone cave deposits have a long history in SE Australia, dating back to the 1830s when one of the earliest studies of Australian palaeontology was carried out in the Wellington Caves complex near Dubbo, to the north of the immediate region investigated here (Dawson \& Augee, 1997; Ride \& Davis, 1997). Another fossil site that received early palaeontological attention occurs as part of the Wombeyan Caves complex in the Blue Mountains (Broom, 1896). Faunal investigations pre-dating the onset of scientific dating techniques typically focused on anatomical descriptions and taxonomic classifications of new species, including Australia's unique megafauna, rather than on the ages of the assemblages. In the case of the Broom Breccia from Wombeyan, this led to the first descriptions of several small marsupials, notably the previously unknown Burramys parvus, the mountain pygmy possum. Over half a century later, W. D. L. Ride's re-investigation of the Broom breccia from Wombeyan added to the list of newly described species (Ride, 1960). At the same time, B. parvus was also discovered within the faunal remains found in Pyramids Cave in the Buchan limestone region of Victoria by Norman Wakefield (Wakefield, 1960a, 1960b).

Wakefield's work at Pyramids Cave led to one of the first regional attempts to place a faunal assemblage into a chronological context from which to assess palaeoecological interpretations (Wakefield, 1972a, 1972b). Initially basing his age classification of the (apparently mechanically mixed) faunal remains on a two-fraction analysis relying primarily on colour and texture, Wakefield's interpretation of two discrete assemblages (Holocene and Pleistocene) separated in time by a discontinuity in accumulation, was called into question by a series of six radiocarbon dates on the bone material. Including six Pleistocene dates ranging from $>33,000$ to 15,450 years BP (uncal.), and two late Holocene dates (calibrated here to 3850-1890 cal. BP and 2740-2360 cal. BP [GaK-1103]), the dates did not correlate with the estimated ages based on colour. Given our modern understanding of difficulties in directly radiocarbon dating bone and tooth material (e.g., issues of diagenesis, contamination, and "legacy data" from pre-standardized laboratory practices prior to the 1990s), the chronological interpretations from Pyramids Cave based on both physical appearance and on radiocarbon dates of bulk bone material must be viewed cautiously. The additional issues of coarsegrained excavation, and consequent dismissal of stratigraphy as an analytical factor (Wakefield, 1972b: 7), further highlight significant problems for chronostratigraphic interpretations.

Nevertheless, at the time, Wakefield's colour fractionation and radiocarbon dates formed an important chronological context upon which Flood and Jeannette Hope based their comparative faunal analyses from the newly excavated site of Cloggs Cave only several kilometres from Pyramids Cave (Flood, 1973, 1974). With several Late Pleistocene and one early Holocene radiocarbon dates from the main cave excavation, Flood and Hope found "an excellent fit" (Flood, 1973: 260) between the faunal assemblages of the two sites. Other cave studies in the Buchan region (Mabel Cave, M27 and M28, in Wakefield, 1972b) remain undated.

Similarly forced to rely on the few available dates known for regional faunal sequences, Hope (1982) based her chronological interpretations of species fluctuations from the Wombeyan Broom breccia and the later salvaged Wombeyan Quarry assemblage on the inferred chronological sequence of the Cloggs Cave faunal assemblage. In a study that will undoubtedly have far-reaching consequences, partnership research currently being undertaken at Cloggs Cave by researchers from Monash University and the region's Gunaikurnai Traditional Owners through the Gunaikurnai Land and Waters Aboriginal Corporation (GLaWAC), indicates that the original dates obtained by Flood for the main sequence of human occupation (post-dating the lower, Pleistocene, megafauna-associated layers) are inaccurate (R. Mullett, B. David, and J. Freslov, pers. comm.). Rather than primarily representing a sequence transitioning from 
the terminal Pleistocene to the early Holocene, all material associated with Aboriginal use of the eastern, excavated parts of the main excavation pit can now be shown to have been deposited during the Holocene (e.g., David et al., in press). The new chronology from Cloggs Cave will have implications not only for the cultural and faunal assemblages from this particular site, but also for many studies that have relied on the Cloggs Cave sequence to extrapolate patterns of timing and events for other undated site sequences.

Surprisingly, despite the introduction of radiocarbon dating and other dating techniques decades ago, very few robust faunal sequences of relative temporal continuity and depth are known from in and around the Australian Alps, even within limestone contexts. To the west of the Blue Mountains, a number of radiocarbon dates from the Late Pleistocene to the late Holocene were obtained from several caves at Abercrombie during the 1980s, although their stratigraphic associations and relationships are unclear (Willis, 1993). An earlier archaeological excavation at Abercrombie Arch Shelter by Johnson (1977) recovered some faunal material, analysed and reported to family level by Ken Aplin. But deposit concretion, lack of dating, and unclear stratigraphic relationships due to heavy roof fall means the site was unable to be used in the reconstruction of archaeological or environmental histories through time.

During the 1990s, several further studies attempted to define the chronologies of cave deposits and the associated faunal (and cultural in some cases) assemblages. One date of $8.2 \mathrm{ka}$ (uncal.) was obtained from Coronation Cave in the Wombeyan complex (Ride \& Davis, 1997: 212), but the authors, without explanation, considered the date to be unreliable for the associated fauna. At Nettle Cave in the nearby Jenolan karst area, where faunal remains are typically uncommon, Deborah Morris and colleagues (Morris et al., 1997) obtained two conventional radiocarbon dates from dark charcoal lenses in a $68 \mathrm{~cm}$ deep deposit which consisted primarily of owl pellet remains. The upper deposit (overlying the lower radiocarbon date) was excavated in four arbitrary spits. Thus, as calibrations of the two dates give ages of 8450-7435 cal. BP (ANU-7897, at 28/29 cm depth) and 10,490-9030 cal. BP (ANU-7898, at 35/36 cm depth), the entire Holocene sequence above these dates, even if dated retrospectively, would be at a very coarse resolution. Interestingly, however, a cemented, calcareous layer between the two dates suggests an external change, which Morris and colleagues attributed to an early to middle Holocene humid period. Below $35 \mathrm{~cm}$, excavation proceeded in spits of 2 to $5 \mathrm{~cm}$ depth. All inferences made from the faunal assemblages assumed constant rates of accumulation, despite the observation of several changes in deposition and an unconformity. Nevertheless, Nettle Cave remains a site with significant potential for further detailed study: the cave retains deposits with good chronostratigraphic resolution, appears well stratified, and a wide range of species are represented. Improvements in radiocarbon and other dating methods increase the likelihood of being able to date the deposit at fine resolution.

Other cave studies conducted in the 1980s and 1990s ran into excavation and stratigraphic issues: the archaeological excavations at New Guinea II in Gippsland (Ossa et al., 1995) and at Douglas Cave near London Bridge in the Canberra region (Boot \& Cooke, 1990; earlier excavation work undertaken by J. Hope) both contained deep deposits rich with cultural and faunal remains. Radiocarbon dates from both sites included Holocene and Late Pleistocene ages: ten radiocarbon dates from charcoal ranging (nonsequentially) from $21,000+900 /-800$ to $1080 \pm 70 \mathrm{BP}$ (uncal.) at New Guinea II, and three Pleistocene/Holocene transition dates from bulk bone material in Douglas Cave (16,120-14,350 cal. BP [ANU-7464], 13,170-11,810 cal. BP [ANU-7463], and 12,000-10,410 cal. BP [ANU-7462]). But stratigraphic and excavation inconsistencies exacerbated by masses of rock fall, and possible deposit reworking through burrowing, respectively, impacted on the reliability and the resolution of the chronologies from both sites (for example, evidence of Sarcophilus harrisii and Oryctolagus cuniculus in the same excavation unit at New Guinea II). No detailed quantification is available for the thousands of fragmented vertebrate remains from New Guinea II, although a general species list including several Pseudomys species, B. parvus and Mastacomys fuscus, is provided (Ossa et al., 1995). Of the Douglas Cave material, faunal material of only five spits was analysed (with the authors also noting difficulties in identifying small mammals species such as Pseudomys), an estimated additional metre of deposit remains underneath the $1.57 \mathrm{~m}$ excavation depth, several other complementary analyses were undertaken on the sediments themselves, and the question of whether or not the deposit almost wholly represents a very brief accumulation period at the Pleistocene/Holocene transition was not resolved. The Douglas Cave material is a potential resource for further investigation, particularly if undertaken with dating work to resolve and clarify the site's chronology.

A more recent excavation by Aplin and colleagues (Aplin et al., 2010) of the deposit from cave Y259 in the Yarrangobilly karst region (cave previously investigated by Drummond, 1963) was archaeologically most notable for its discovery of the earliest dated layers containing cultural stone artefacts from the high-altitude region of the Australian Alps (>1000 m). Despite sparse but reliable AMS radiocarbon dating of the cultural unit (indicating at least two visits by people dated to $9695-9525$ cal. BP [Wk18839] and 9440-9135 cal. BP [Wk-18838]) and good site integrity, the shallow (around $30 \mathrm{~cm}$ deep) and discontinuous nature of the deposit, including two flowstone horizons, means that while the study represents a valuable record of several environmental and human "snapshots" in time, it is unable to contribute a contiguous, high-resolution sequence through time.

There are other known localities for bone assemblages where the data they contain are yet to be explored and/ or analysed. The Cooleman karst region, for example, has received some archaeological attention including a late Holocene radiocarbon date (1350-990 cal. BP, ANU-6191) on collagen from an Aboriginal skull found on the surface of rock shelter CP75, and several faunal species identified in associated sediments by J. Calaby and J. Wombey (Cooke, 1988). But no below-surface investigation has been undertaken at Cooleman.

Fossil faunas of Quaternary age are known from cave fills and bone breccia in the Wee Jasper karst area, notably in Punchbowl and Dip Caves (Dunkley et al., 2010; Rich et al., 1993), from a now-submerged floor deposit at Cave Flat (now Cave Island) excavated in 1881 by Charles Jenkins (Hope ms) and from surface collection by Hope 
at Narrangullen (Hope, ms). Willis (1993: 107) cited a personal comment by Gillieson and Spate providing a radiocarbon date from cave earth at Cave Island $(21,840$ 17,970 cal. BP).

A faunal assemblage from the Mt Fairy limestone caves near Weereewaa (Lake George) was recently excavated as part of an ARC Linkage project, but the excavation and analysis are yet to be reported. Previously, megafauna remains were found at a disused dolomite quarry near Mt Fairy (Flannery \& Hope, 1983). Other sites for faunal remains, of unknown chronological potential, include Nargun Cave, Marble Arch, and Wyanbene in the Deua limestone region (Calaby \& Wimbush, 1964; Hall, 1975), Jerrara Cave and others near Bungonia (Osborne, 1993; Willis, 1993), Kybean Caves southeast of Cooma (Willis, 1993), the Lake George region (Sanson et al., 1980), and various caves near Jenolan (Hope, ms; Willis, 1993).

Combined, the known faunal sites of the Australian Alps and surrounding regions are generally plagued by issues that limit and compromise their value for reconstructing and understanding environmental sequences from the Late Pleistocene to the present. Despite their limitations, both the undated and the poorly dated collections of the region may still be useful for broad geographical mapping of preEuropean versus modern species distributions, but they do lack demonstrated chronological depth. An early attempt at forming a geographical transect through SE Australia, for example, was made by Aplin in the 1970s (unpublished) in collaboration with Hope. Nonetheless, the largest past and ongoing barrier to the understanding of faunal assemblages in SE Australia (and elsewhere) is the ability to chronologically characterize the observed changes in species. Even today, Ride \& Davis' (1997: 206) comment that "dating (together with a lack of stratigraphic understanding) remains the single most pressing impediment to the interpretation of the cave faunas", remains apt.

\section{Case study: WJ99 and the Holocene Climatic Optimum}

The cave WJ99 lies in the northern foothills of the northern Australian Alps region (Fig. 1). As part of the Taemas Limestone formation of the Wee Jasper valley, the site (entrance at $400 \mathrm{~m}$ above sea level) overlooks the Goodradigbee River to the east. The valley sits at the interface between the mountainous high country of New South Wales and the milder tablelands to the north, providing a geographically and ecologically sensitive location likely to have been locally influenced by climatic shifts through time. In addition to archaeological evidence for Aboriginal use of the cave since at least $14,260-13,860$ cal. BP shortly after sediment began accumulating, a $2 \mathrm{~m} \times 1 \mathrm{~m}$ exploratory test pit excavated to $3.6 \mathrm{~m}$ in $10 \mathrm{~cm}$ vertical units in 2013 revealed a well-stratified and superbly preserved faunal record (accumulated predominantly from the pellets of roosting owls and from prey remains of smaller predators) that dates from the terminal Pleistocene to just after 1990-1750 cal. BP (Fig. 2). The upper sediment (below a layer of modern dung) was dry sieved through $3 \mathrm{~mm}$ mesh; due to increasing moisture, sediment below c. $70 \mathrm{~cm}$ was wet sieved through a $1.5 \mathrm{~mm}$ mesh. The deposit contains no discernible evidence of significant sedimentation breaks or gaps. The chronological, sedimentary, archaeological, and faunal contexts have been published separately (ThedenRingl \& Gadd, 2017; Theden-Ringl \& Langley, 2018; Theden-Ringl et al., 2018) and a taphonomic assessment is also available (Hislop, 2017).

With the exception of material from one anomalous stratigraphic unit interpreted as a filled-in burrow, SU7, faunal analysis included all recovered faunal material from Square 10B. All tooth-bearing elements and isolated teeth were collected, as were cranial and selected postcranial elements (further details in Theden-Ringl et al., 2018). Number of Individual Specimens (NISP) are presented in Table 1 and show a wide variety of taxa present in the pre-European landscape. Two specimens of Rabbit (Oryctolagus cuniculus) are preserved in the upper analysed excavation unit; the remainder of the assemblage comprises native fauna.

The chronology of WJ99 is based primarily on ten AMS radiocarbon dates on sedimentary charcoal from throughout the deposit (Fig. 2). The value of this site is in its relatively stable and rapid sedimentation record, allowing for a contiguous account of faunal species fluctuations, almost to century-scale for some units, which can improve and more narrowly define the chronological histories for many species. For example, the Pleistocene-Holocene transition around 11,700 cal. BP corresponds closely to a series of species fluctuations at this time. They include the significant reduction of Mastacomys fuscus, Pseudomys fumeus, Pseudomys higginsi, Isoodon obesulus, Cercartetus lepidus, and Perameles nasuta, and corresponding increases in numbers of Rattus spp. and Conilurus albipes. The faunal patterns suggest a developing local landscape including establishing forest and wetland habitats, and a reduction of heath, scrubland, and grassland at this time.

Of particular interest to this case study are the changes to the faunal assemblage, and their implications, for the early to middle Holocene. The Holocene Climatic Optimum is identified in most parts of the world as a complex and prolonged period of warm conditions occurring sometime between 10,000 and 4000 years ago (e.g., Marcott et al., 2013; Zhou et al., 2004), exhibiting significant temporal and spatial variation globally. Its local timing and landscape effects for the SE Australian mountain ranges are still being refined. Figure 3 summarizes some of the environmental shifts and their timing identified from various proxy records, including dust, pollen, elements, etc., for the SE Australian high country during the early to middle Holocene. The figure highlights the significant challenge of determining the timing - the commencement, height, and conclusion - of this phase. When viewed together, information from even just the handful of regional studies summarized here demonstrates that the timing is broad and that changes may have occurred gradually and cumulatively. The commencement of wetter and warmer conditions is dated to anywhere from shortly after 10,000 to 7000 years ago, while the end of the phase, generally thought to have been triggered by the onset of ENSO conditions, is dated to sometime after 6000 years ago.

In part, the broad chronological resolution for the Holocene Climatic Optimum may be due to dating resolution affecting studies. Another problem is that many early to middle Holocene records - particularly fluvial, peat, and 


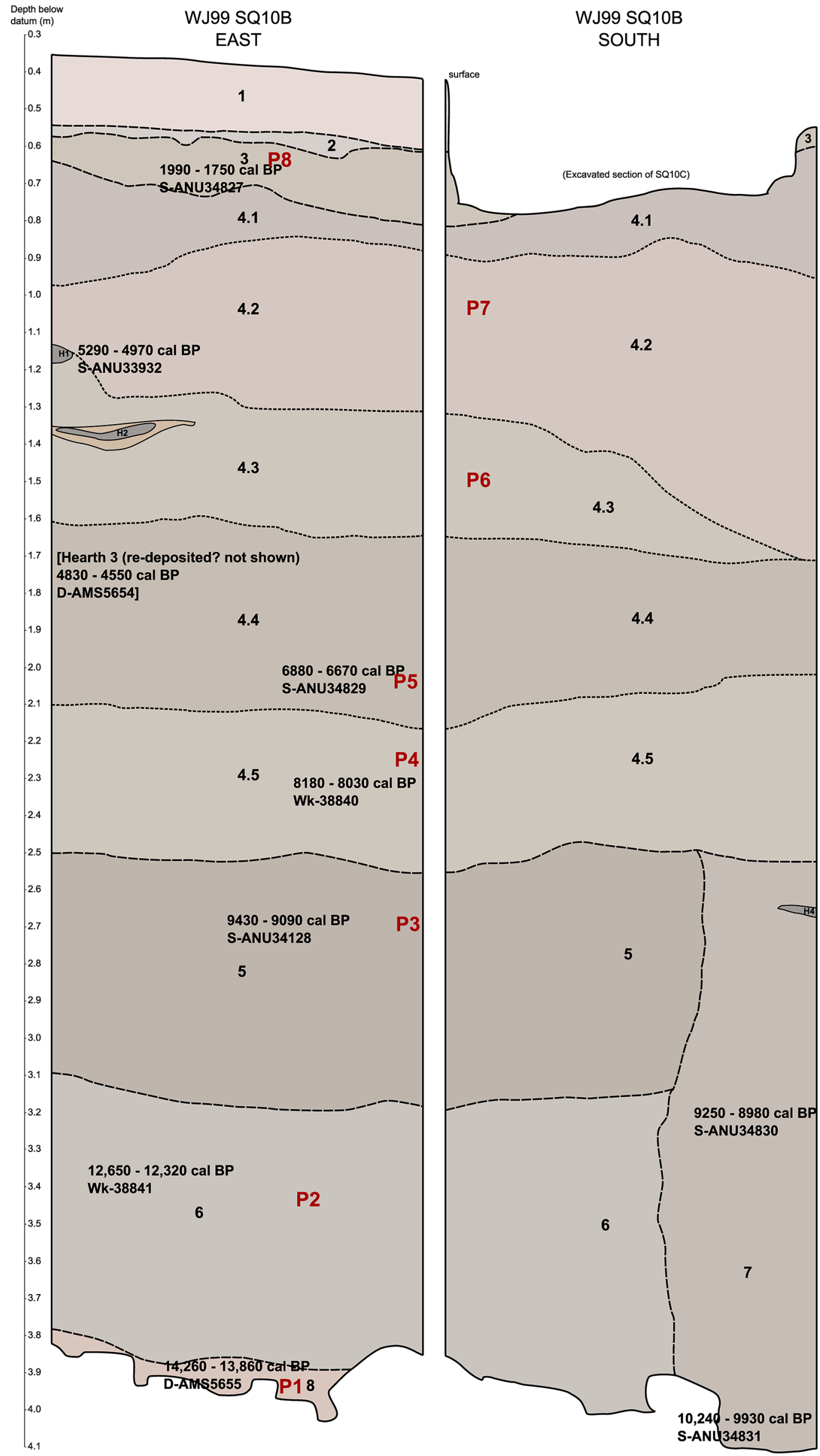

Figure 2. Representative (east and south) sections of WJ99 Square 10B, showing locations of AMS radiocarbon dates and of sediment samples (Px) from which pollen was extracted. 
Table 1. Taxonomic composition of the WJ99 vertebrate fauna recovered from all excavation units (XU36-XU2) in Square 10B, excluding SU7, as identified from crania and mandibles. Taxa listed as "indet." are identified only to the indicated taxonomic level. $[\mathrm{EX}]=$ extinct; $[\mathrm{ex}]=$ extinct in SE Australia. The two megafauna species were demonstrated to be chronologically anomalous to the faunal assemblage (Theden-Ringl et al., 2018).

\begin{tabular}{|c|c|c|c|}
\hline taxon & common name & NISP & $\%$ \\
\hline Rattus fuscipes / tunneyi & Bush Rat/Pale Field Rat & 604 & \\
\hline Rattus lutreolus & Australian Swamp Rat & 192 & \\
\hline Rattus sp. indet. & & 1 & \\
\hline Conilurus albipes & White-footed Rabbit Rat [EX] & 172 & \\
\hline Hydromys chrysogaster & Rakali/Water Rat & 1 & \\
\hline Mastacomys fuscus & Broad-toothed Rat & 248 & \\
\hline Pseudomys australis & Plains Mouse [ex] & 17 & \\
\hline Pseudomys fumeus & Smoky Mouse & 650 & \\
\hline Pseudomys gracilicaudatus & Eastern Chestnut Mouse & 133 & \\
\hline Pseudomys higginsi & Long-tailed Mouse [ex] & 409 & \\
\hline Pseudomys novaehollandiae & New Holland Mouse & 388 & \\
\hline Pseudomys oralis & Hastings River Mouse & 240 & \\
\hline total murids & & 3055 & 51.8 \\
\hline Acrobates spp. & Feathertail Gliders & 48 & \\
\hline Burramys parvus & Mountain Pygmy Possum & 1 & \\
\hline Cercartetus lepidus & Tasmanian Pygmy Possum & 36 & \\
\hline Cercartetus nanus & Eastern Pygmy Possum & 160 & \\
\hline Petaurus breviceps & Sugar Glider & 19 & \\
\hline total small possums & & 264 & 4.5 \\
\hline Petaurus norfolcensis & Squirrel Glider & 6 & \\
\hline Pseudocheirus peregrinus & Common Ringtail Possum & 40 & \\
\hline Trichosurus vulpecula & Common Brushtail Possum & 31 & \\
\hline total medium to large possums & & 77 & 1.3 \\
\hline Phascolarctos cinereus & Koala & 7 & \\
\hline Vombatus ursinus & Common Wombat & 21 & \\
\hline total koalas and wombats & & 28 & 0.5 \\
\hline Aepyprymnus rufescens & Rufous Bettong & 23 & \\
\hline Bettongia lesueur & Boodie/Burrowing Bettong [ex] & 2 & \\
\hline Bettongia penicillata & Woylie/Brush-tailed Bettong [ex] & 2 & \\
\hline Bettongia spp. & & 24 & \\
\hline Potorous tridactylus & Long-nosed Potoroo & 9 & \\
\hline Potorous / Bettongia sp. indet. & & 117 & \\
\hline total potoroids & & 177 & 3.0 \\
\hline Petrogale penicillata & Brush-tailed Rock Wallaby & 229 & \\
\hline Wallabia bicolor & Swamp Wallaby & 6 & \\
\hline Notamacropus rufogriseus & Red-necked Wallaby & 6 & \\
\hline Macropus giganteus & Eastern Grey Kangaroo & 2 & \\
\hline Osphranter robustus & Common Wallaroo & 17 & \\
\hline M. giganteus/O. robustus & & 7 & \\
\hline Lagorchestes leporides & Eastern Hare-wallaby [EX] & 4 & \\
\hline Lagostrophus fasciatus? & Banded Hare-wallaby [ex] & 1 & \\
\hline Procoptodon gilli & Short-faced Kangaroo [EX] & 2 & \\
\hline Procoptodon browneorum & Short-faced Kangaroo [EX] & 1 & \\
\hline total macropodids & & 275 & 4.7 \\
\hline Isoodon obesulus & Southern Brown Bandicoot & 189 & \\
\hline Perameles nasuta & Long-nosed Bandicoot & 126 & \\
\hline Perameles sp. 2 & & 1 & \\
\hline bandicoot gen. et sp. indet. & & 2 & \\
\hline total peramelids & & 318 & 5.4 \\
\hline
\end{tabular}


Table 1 (continued).

\begin{tabular}{llrr}
\hline taxon & common name & NISP & $\%$ \\
\hline Thylacinus cynocephalus & Thylacine/Tasmanian Tiger [EX] & 3 & \\
Sarcophilus harrisii & Tasmanian Devil [ex] & 8 & \\
Dasyurus viverrinus & Eastern Quoll [ex] & 29 & \\
Phascogale tapoatafa & Brush-tailed Phascogale & 975 & $\mathbf{1 7 . 3}$ \\
Dasyuridae sp. indet. (small) & & $\mathbf{1 0 2 2}$ & \\
total dasyurids \& thylacinids & & 61 & $\mathbf{1 0}$ \\
Microchiroptera spp. & Insectivorous bats & $\mathbf{6 1}$ & $\mathbf{1 . 0}$ \\
total microchiropterans & & 180 & \\
Aves (small) & Small birds & 57 & $\mathbf{4 . 0}$ \\
Aves (large) & Large birds & $\mathbf{2 3 7}$ & \\
total birds & & 35 & \\
Egernia spp. & Large skinks & 253 & \\
Scincidae small spp. & Small skinks & 80 & \\
Tiliqua spp. & Blue-tongued Skinks & $\mathbf{3 6 9}$ & $\mathbf{6 . 3}$ \\
Agamidae spp. & Lizards & 9 & 0.15 \\
total reptiles & & 1 & 0.02 \\
Anura & Frogs & 2 & 0.03 \\
Anguilliformes & Eel & $\mathbf{5 8 9 5}$ & $\mathbf{1 0 0}$ \\
Oryctolagus cuniculus & European Rabbit & & \\
total all vertebrates & & & \\
\hline
\end{tabular}

alluvial - are frequently "missing" due to what is thought to be a combination of increased rainfall and river flows resulting in enhanced flushing of sediments, and less supply available for sediment re-accumulation due to well-vegetated catchments (Cohen \& Nanson, 2007; Eriksson et al., 2006; Johnston \& Brierly, 2006; Kershaw \& Strickland, 1989).

In contrast, the sedimentation rates at WJ99 appears to have increased just prior to $8000 \mathrm{cal}$. BP, resulting in enhanced vertical resolution available to map faunal changes from this time (estimated to between 400 years to less than 200 years per $10 \mathrm{~cm}$ excavation unit). The phase begins with a distinct sedimentary transition from compact and dry sandy clayey silt, to weak and moist silt (transition between SU5 and SU4.5). The transition marks not only the onset of more rapid sediment deposition (the cave floor of WJ99 acts as a sediment trap), but also the beginning of significant changes in local species composition that would last until around $6000 \mathrm{cal}$. BP. Given that many species, particularly Australian native murids, have highly specialized features suited to clearly defined habitat preferences and do not adapt well to habitat disturbance (Breed \& Ford, 2007), changes in their histories at WJ99 can indicate local environmental fluctuations.

Figure 4 shows representations of selected species from WJ99 through time. A summary of taxon change from 10,000 to 4000 cal. BP is also included in Fig. 3. Three particular trends are noted. First, the peak of the Holocene Climatic Optimum, placed here from $8000 \mathrm{cal}$. BP to just before 6000 cal. BP, was different enough to earlier and later conditions to have affected the ability of species to reside locally. Very little significant taxon fluctuation is seen in the two millennia preceding $8000 \mathrm{cal}$. BP, or in the three millennia after 6000 cal. BP (Theden-Ringl et al., 2018). Broadly, the timing corresponds to the peak of Holocene
Climatic Optimum conditions indicated by other proxies for the high country, and the date of 8000 cal. BP gives a definitive "tipping point" for the start of local species shifts.

A second observation is that the final disappearance of "cold-adapted" species (whose populations had declined from the Pleistocene/Holocene transition, but which had locally remained nonetheless) was not simultaneous, but possibly spaced over a period of 1500 years. An isolated final occurrence of the pygmy possum, Cercartetus lepidus, is recorded at $8000 \mathrm{cal}$. BP, the Broad-toothed Rat Mastacomys fuscus is last recorded around $7250 \mathrm{cal}$. BP, and the Long-tailed Mouse Pseudomys higginsi persisted until 6500 cal. BP. Both M. fuscus and P. higginsi persisted in SE Australia at relatively low elevations until a few hundred years ago (Aplin et al., 2010) so the timing of their decline at WJ99 is useful to contribute to a more precise timing of distributional changes of the species. As in many other SE Australian records, the Hastings River Mouse, Pseudomys oralis, appears to have "replaced" other murid species, with numbers at WJ99 increased substantially from 8000 cal. BP. The spaced disappearance and appearance of species within the 8000 to $6000 \mathrm{cal}$. BP window of time may indicate two factors: $(a)$ that each species had different tolerances/ tipping-points to environmental change; and/or (b) that ecosystem changes occurred gradually over centuries rather than as abrupt shifts.

Third, and related to the previous point, the relatively large number of species experiencing distinct fluctuations during the period from 8000 to $6000 \mathrm{cal}$. BP allows for a more holistic approach to interpreting landscape change, extending not only to temperatures, but also to moisture, vegetation, and other habitat shifts. The decline of C. lepidus, for example, may signal a further decrease in shrub availability around 


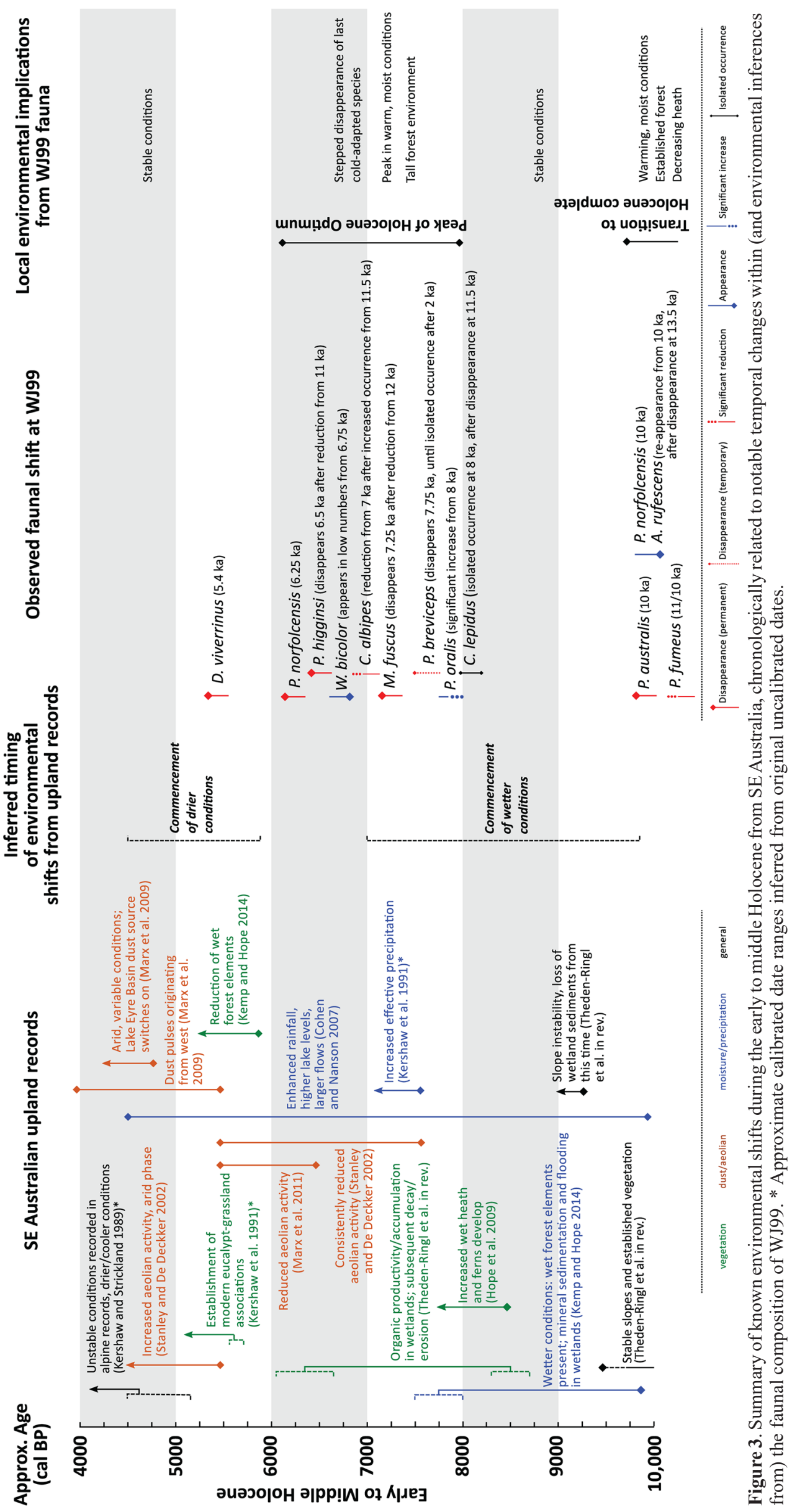




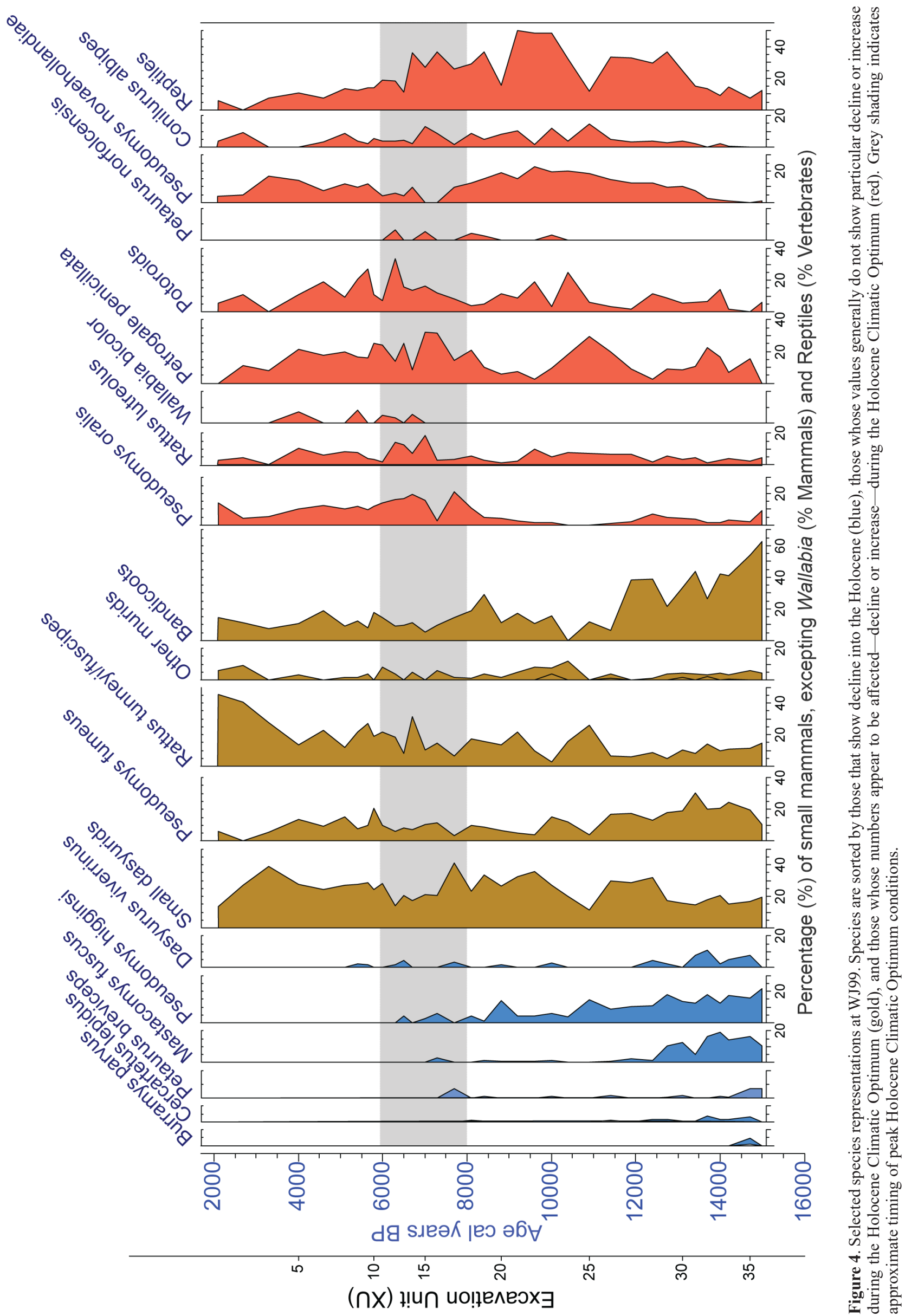


8000 cal. BP (already reduced from the early Holocene) as more open forest displaced heath. The simultaneous specimen increase in P. oralis, an open forest dweller (Breed $\&$ Ford, 2007), substantiates the suggestion. The swamp wallaby, Wallabia bicolor, appears in low numbers from 6750 cal. BP, and together with a small increase in the swamp rat, Rattus lutreolus, at 7000 cal. BP, may suggest increased moisture in the landscape.

Contradicting the suggestion of open forest replacing shrub is the slight reduction of the White-footed Rabbit Rat, Conilurus albipes, from 7000 cal. BP. This rat was widespread prior to European colonization and preferred tall open eucalypt forest, relying on tree hollows and logs for shelter (Dyck et al., 2013: 162). At WJ99, a specimen increase occurs around 10,000 cal. BP as forest appears to have established locally, but favoured conditions were apparently not maintained.

The sugar glider, Petaurus breviceps, disappears by 7750 cal. BP (it reappears in isolated cases after $2000 \mathrm{cal}$. BP), as does the squirrel glider Petaurus norfolcensis by 6250 cal. $\mathrm{BP}$, but the overall low numbers of both species means any interpretations must be made with caution.

The WJ99 faunal trends noted here for the Holocene Climatic Optimum - and their inferences - are preliminary only, intended to demonstrate the potential for more detailed patterns that can emerge from increased chronological resolution of stratified deposits. There are, of course, more complex considerations that may require assessment for individual sites and species. For example, the estimation of potential time lags between environmental change and species extinction/appearance/fluctuation requires knowledge of species-specific behaviours, habitat constraints and tipping-points, and the potential for short-term population fluctuations and/or responses to extreme events such as fires or drought.

Another site-specific consideration is the accumulation agent(s) for faunal remains at that locality. Arboreal predators such as owls, non-arboreal small to large predators, the activities of people, natural death components, faunal traps, or combinations of these agents, would result in different species representations between sites and possibly also within single deposits, with indirect relationships to local environmental changes. At WJ99, for example, owls were considered the primary accumulation agent, with carnivorous marsupials a secondary agent (Theden-Ringl et al., 2018). People, Thylacinus, and Sarcophilus were also present during phases including the early to middle Holocene. So although no direct evidence of predation or butchery was identified from the bone material, the presence of burnt bone and a shift towards larger prey species corresponding to units with increased evidence for human activity and with units corresponding to evidence of large predators, suggests a portion of the assemblage may well derive from such agents.

Preliminary pollen, diatom, and microcharcoal analysis of eight selected sediment samples from WJ99, largely coinciding with dated sections (Fig. 2), offers local vegetation proxies with which to compare and validate the inferences made from the faunal shifts. Fine fractions $(<125 \mu \mathrm{m})$ of the samples were processed with heavy liquid to collect the organic fraction; percentages (or presence) for pollen and spores, and for diatoms, are shown in Fig. 5.

Pollen was only abundant within the upper $120 \mathrm{~cm}$ of the deposit, where a eucalypt woodland with abundant ferns is indicated. Below this only scattered pollen from resistant pollen types such as Asteraceae occurs showing that most pollen has decayed. It is not possible to reconstruct the source vegetation in these lower levels although it is clear that grass (indicated by phytoliths) is abundant around 14,000 cal. BP and again around 7000 cal. BP, when there is also an indicator of daisy yam (Asteraceae-Liguliflorae) being a component in the ground cover. Diatoms are present in very low frequencies and may indicate moist surfaces and drips. Microcharcoal is present from the deepest levels of the deposit but reaches its highest concentrations in the early to middle Holocene. It probably reflects hearth debris but possibly also particulates from fires outside the cave that arrived with the sediment.

Interpreting the likely vegetation setting of WJ99 can be assisted by a pollen record from a montane fen $28 \mathrm{~km}$ to the south of WJ99. Micalong Swamp, at $980 \mathrm{~m}$ altitude, provides a 16,000-year record of transition from the Late Pleistocene (Kemp \& Hope, 2014). Open grasslands were replaced by subalpine woodland by 16,000 to $15,000 \mathrm{cal}$. BP. Well-developed eucalypt forest was present after 10,000 cal. $\mathrm{BP}$ and indicators of wet forest, such as tree ferns, persisted until around $6000 \mathrm{cal}$. BP. This record supports the view that WJ99 was surrounded by open forest or woodland and that conditions may have been wetter during the early Holocene. The local information suggests that the woodland was grassy at that time.

Despite the limited information to be obtained from the pollen and microcharcoal samples from this particular site, the tests do contribute to the multi-proxy nature of the site's analyses and interpretations. In combination with archaeological and faunal investigations, dating at regular intervals, and information from sedimentary analyses including geochemical and particle tests, a comprehensive site history can be compiled.

\section{Regional comparisons and discussion}

The stratified deposit from WJ99 is not unique in providing a record for the early to middle Holocene: a small number of other sequences from the SE Australian mountain ranges also represent this period. Interestingly, the open fossil terraces of the Monaro appear to contradict the trend of eroded and/or scoured deposits characterizing landscapes of the Holocene Climatic Optimum. But although sites such as Teapot Creek and Pilot Creek contain early to middle Holocene deposits, their scarcity of faunal remains, selective preservation and coarse chronological resolution means the open Monaro sites' value lies in assessing faunal and environmental change over vast periods of time rather than along continuous timelines. More detailed chronological resolution and higher future research potential lies with the region's cave deposits. Several murid species from these sites are compared and discussed here, revealing their potential for addressing questions of species and landscape change.

At Y259 on the Yarrangobilly Plateau, Aplin et al. (2010) suggested that the bulk of the taxa represented the relatively warm and moist conditions of the Holocene Climatic Optimum. The two early Holocene dates were derived from the lowest unit, III; in terms of improving Holocene resolution, a date from Unit II (distinctly underlain and 


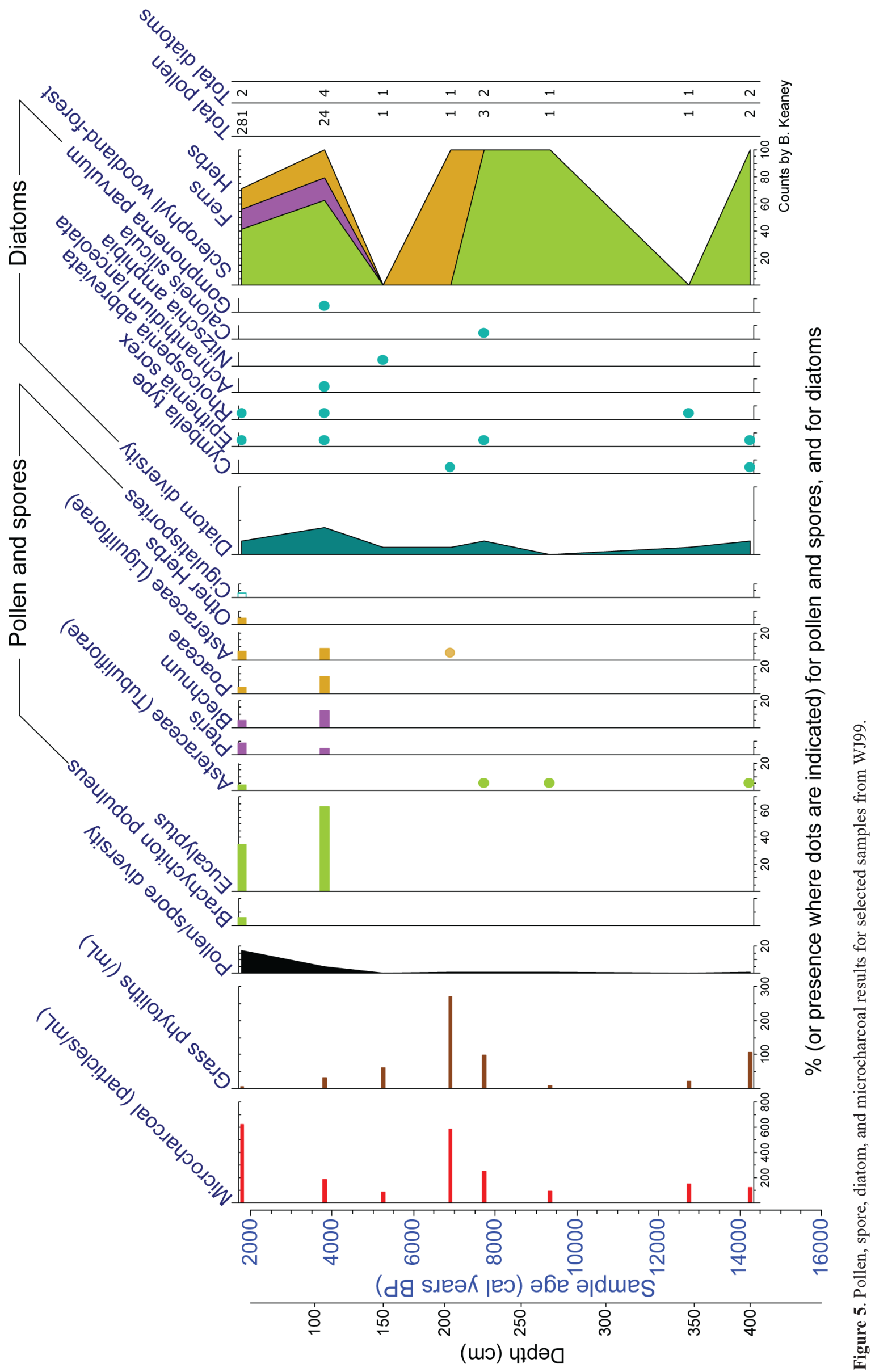


overlain by flowstones) would be ideal to distinguish its antiquity from that of the uppermost Unit I. Two murids from Y259, Pseudomys higginsi and Mastacomys fuscus, are worth noting here for the purpose of geographical mapping of species through time, particularly for altitudinal comparison: Y259 representing a high elevation site (1100 $\mathrm{m})$, and WJ99 representing a lower elevation site $(400 \mathrm{~m})$ $70 \mathrm{~km}$ to the north. Unlike at WJ99, Pseudomys higginsi is represented in all units at Y259, indicating its persistence in the SE high country until recent times. Direct AMS dating of $P$. higginsi bones to less than 500 years old at other Yarrangobilly sites confirms its late local presence (Breed \& Ford, 2007); Aplin et al. (2010) noted the mainland populations's history of post-glacial range reduction and apparent retreat to higher elevation regions. The contrast to WJ99 at a lower altitude, where P. higginsi is the last of the murids to disappear during the later Holocene Climatic Optimum phase (around $6500 \mathrm{cal}$. BP), provides the beginnings for mapping the species' chronological and geographical retreat to relatively cooler habitats.

Given the present work being undertaken at Cloggs Cave (including recovery and analysis of new faunal material), only a brief mention is made here of the original faunal analysis. Flood (1973) placed the extinction of P. higginsi, abundant in the lower levels but disappearing by level 12, at around 14,000 BP (uncal.). She also observed the appearance of Pseudomys oralis in level 20 (inferred to date to the Late Pleistocene), with early low numbers increasing towards the deposit surface. Ignoring the precise chronology of the Cloggs Cave sequence for the moment, the two general patterns are reflected in the WJ99 sequence. At WJ99, the disappearance of $P$. higginsi is timed at around $6500 \mathrm{cal}$. BP, and although $P$. oralis is present in low numbers from the earliest units, the species experiences a significant population increase around $8000 \mathrm{cal}$. BP. The apparent "replacement" of several Pseudomys species by P. oralis is noted from sequences across SE Australia (Breed \& Ford, 2007) so a better understanding of the nature and timing of this transition may be widely applicable. It is yet to be seen whether new data from Cloggs Cave, including in a part of the cave where a Holocene sequence was previously interpreted as a Late Pleistocene to early Holocene sequence, correlates with the chronologies for these two species at WJ99.

The presence/absence of Mastacomys fuscus presents a similar case study to $P$. higginsi, again highlighting how little is known about a species' past geographical and chronological distributions. At Y259, M. fuscus is present throughout all units. Today, the species persists in the higher altitudes of the Australian Alps, with a broader and lower altitude range in Victoria (Wallis, 1992). It is thought to have disappeared from lower altitude sites throughout the Southern Tablelands only in the past 200 years (Ford et al., unpublished, cited in Aplin et al., 2010). A study of the morphologies and $\delta^{13} \mathrm{C}$ isotopes of modern and ancient specimens found that increased aridity is unlikely to have reduced the range of M. fuscus (May, 1990). Rather, May concludes that higher temperatures which favoured forest environments and increased diversity at the expense of grassland availability, sometime between 10,000 and $5000 \mathrm{BP}$ (uncal.), may have led to the establishment of the species' modern range at that time. It is worth noting that $M$. fuscus was recorded in high numbers in the uppermost levels at Cloggs Cave (Flood, 1973), indicating that even with the anticipated revision of the chronology of this site's deposit, M. fuscus persisted well into the middle to late Holocene in the low-lying East Gippsland region of Victoria. Its remains were also recovered from London Bridge, both within the upper layers of the Douglas Cave excavation (of unknown antiquity, probably Holocene) and from an associated open site excavation (Burra Shelter) dated to within the past 1000 years (Boot \& Cooke, 1990). In Nettle Cave at Jenolan, $M$. fuscus is also recorded throughout the deposit including the upper units (Morris et al., 1997). Relative abundance trends, however, indicate it decreasing through the Nettle Cave sequence, with a corresponding increase of Pseudomys oralis. As noted above, P. oralis increased at WJ99 and at Cloggs Cave during the early to middle Holocene, mirroring that species' trend from Nettle Cave. For M. fuscus, however, its complete disappearance from the Wee Jasper valley after $7250 \mathrm{cal}$. BP, following a reduction in numbers from 12,000 cal. BP, is perhaps then an anomaly. A suite of questions, including whether the absence of $M$. fuscus from the middle Holocene in WJ99 is a local or a broader trend for the lower elevations surrounding the northern Australian Alps, requires more chronologically robust stratified faunal sequences, of both known sites that have potential for finer chronological assessments, and of new sites.

The species comparisons highlighted above, and the questions and themes they raise, are not new. Attempts to trace and map species' geochronological distributions relative to changing environments, for both the understanding of pre-European climates and landscapes and of post-European losses, have been made for many decades. But until now, the few known stratified sites, combined with poor dating resolution for most of these sites, has rendered most observed patterns both chronologically vague and thematically distanced from the landscapes and climates in which the records were formed. Shifts towards both fine-resolution recovery techniques and the increased use of multi-proxy analyses have the potential to fundamentally change the way in which faunal information can be interpreted and incorporated into wider palaeoecological themes. For example, emerging analytical techniques include the use of X-ray fluorescence for high-resolution geochemical characterization of stratified sediments through the use of portable hand-held units and laboratory-based scanners. The combination of several dating methods on various materials to strengthen and validate the chronological sequence of a site is also now commonplace. As briefly touched upon in this study, the analysis of micro fossils such as diatoms and pollen, or of macro fossils such as charcoal and seeds, can add further dimensions to the environmental and cultural histories of sites. Fine-resolution, multi-proxy studies are the ideal platform from which to start developing, through cross-referencing with other proxies, solid reference material to reconstruct species histories within their environmental contexts. 


\section{Conclusion}

Faunal fluctuation patterns have typically been used to strengthen and validate signals of local environmental change as determined from other proxies, rather than viewed as primary environmental proxies in their own right. In the past, the main reason for this has been the inability to obtain site chronologies at anywhere near the resolution necessary for such analyses. Even today, the known number of stratified faunal-bearing sites with reasonable chronological resolution and integrity remains small for the Australian Alps and surrounds, insufficient to chronologically cross-reference stratigraphic sequences and associated faunal patterns with any certainty.

Yet as this review and study demonstrates, the information that can be extracted from stratified faunal assemblagesgiven a solid chronological and environmental frameworkis significant. Robust multi-proxy approaches can provide the beginnings from which detailed species' histories linked to local environmental shifts can be mapped. Combined and interpreted regionally, such studies have significant potential to characterize how certain faunal species reacted to environmental shifts, to map their geographic distributions through time, and ultimately, to be able to utilize this information to confidently infer environmental change from faunal assemblages in their own right.

ACKNOWLedgements. We thank Andy Spate for first recommending cave WJ99 as a site with high stratigraphic and preservation potential, landowners Ian and Helen Cathles for supporting our excavation teams, and Ken Aplin for attentive tutoring and supervision of the faunal analysis. We also thank the Namadgi region's traditional owners for permission and encouragement to work at WJ99. For discussion on available records of faunal sites, we thank Jeannette Hope.

FunDING. The compilation of this manuscript was supported by the ARC Centre of Excellence for Australian Biodiversity and Heritage (CABAH) (CE170100015). Pollen analysis was funded by G. Hope. The work at WJ99 was supported by an Australian Postgraduate Award, The Australian National University, and the Australian Institute of Nuclear Science and Engineering.

\section{References}

Aplin, K., undated. Recent Mammalian Sub-fossils of Southeastern Australia: A Geographical Transect. Unpublished manuscript.

Aplin, K., F. Ford, and P. Hiscock. 2010. Early Holocene human occupation and environment of the southeast Australian Alps: new evidence from the Yarrangobilly Plateau, New South Wales. In Altered Ecologies: Fire, Climate and Human Influence on Terrestrial Landscapes, ed. S. Haberle, J. Stevenson, and M. Prebble, pp. 187-212. Terra Australis 32. Canberra: ANU E-Press.

https://doi.org/10.22459/TA32.11.2010.11

Armand, L., W. D. L. Ride, and G. Taylor. 2000. The Stratigraphy and Palaeontology of Teapot Creek, MacLaughlin River, NSW. Proceedings of the Linnean Society of New South Wales 122: 101-121.
Boot, P. 2002. Didthul, Bhundoo, Gulaga and Wadbilliga: an Archaeological Study of the Aboriginals of the New South Wales South Coast Hinterland. Unpublished Ph.D. thesis. The Australian National University, Canberra.

Boot, P., and H. Cooke. 1990. Conservation and Management Plan for London Bridge Karst Area, Googong Foreshores Reserve. Unpublished report to the ACT Heritage Unit, Dept. of Environment, Land and Planning, ACT Government Service, Canberra.

Breed, W., and F. Ford. 2007. Native Mice and Rats. Collingwood: CSIRO Publishing.

https://doi.org/10.1071/9780643095595

Bronk Ramsey, C. 2009. Bayesian analysis of radiocarbon dates. Radiocarbon 51(1): 337-360.

https://doi.org/10.1017/S0033822200033865

Broom, R. 1896. Report on a bone breccia deposit near the Wombeyan Caves, N.S.W.: with descriptions of some new species of marsupials. Proceedings of the Linnean Society of New South Wales 11: 48-61.

https://doi.org/10.5962/bhl.part.8460

Calaby, J. H., and D. J. Wimbush. 1964. Observations on the broad-toothed rat, Mastacomys fuscus Thomas. CSIRO Wildlife Research 9(2): 123-133. https://doi.org/10.1071/CWR9640123

Cohen, T. J., and G. C. Nanson. 2007. Mind the gap: an absence of valley-fill deposits identifying the Holocene hypsithermal period of enhanced flow regime in southeastern Australia. The Holocene 17: 411-419. https://doi.org/10.1177/0959683607076475

Cooke, H. 1988. An Investigation into the Prehistory of Blue Water Holes and Cooleman Plains, NSW. Unpublished B.A. (Hons) thesis. The Australian National University, Canberra.

Costin, A. B. 1972. Carbon 14 dates from the Snowy Mountains area, southeastern Australia and their interpretation. Quaternary Research 2: 579-590. https://doi.org/10.1016/0033-5894(72)90092-0

Dansie, L. K. 1992. Stratigraphy and Palaeontology of Teapot Creek, Sherwood and Boco Stations, near Nimmitabel, N.S.W. Unpublished B.Sc. (Hons) thesis. Department of Geology, The Australian National University, Canberra.

Dawson, L. 1985. Marsupial fossils from Wellington Caves, New South Wales; the historic and scientific significance of the collections in the Australian Museum, Sydney. Records of the Australian Museum 37(2): 55-69. https://doi.org/10.3853/j.0067-1975.37.1985.335

Dawson, L., and M. L. Augee. 1997. The Late Quaternary sediments and fossil vertebrate fauna from Cathedral Cave, Wellington Caves, New South Wales. Proceedings of the Linnean Society of New South Wales 117: 51-78.

David, B., J. Fresløv, R. Mullett, J.-J. Delannoy, F. Petchey, Gunaikurnai Land and Waters Aboriginal Corporation, J. Mialanes, L. Russell, R. Wood, L. Arnold, M. McDowell, J. Berthet, R. Fullagar, V. N. L. Wong, H. Green, C. Urwin, L. Metz, J. Crouch, and J. Ash. 2021, in press. Paradigm shifts and ontological turns at Cloggs Cave, Gunaikurnai Country, Australia. In Ontologies of Rock Art: Images, Relational Approaches and Indigenous Knowledge, ed. O. Moro Abadía, and M. Porr. London: Routledge.

Davis, A. C. 1996. Quaternary Mammal Faunas and their Stratigraphy in the Northern Monaro Region, Southeastern Australia. Unpublished Ph.D. thesis. The Australian National University, Canberra.

Dodson, J. R., V. M. McRae, K. Molloy, F. Roberts, and J. D. Smith. 1993. Late Holocene human impact on two coastal environments in New South Wales, Australia: a comparison of Aboriginal and European impacts. Vegetation History and Archaeobotany 2: 89-100.

https://doi.org/10.1007/BF00202186 
Drummond, D. C. 1963. Bone deposits in caves. Journal of the Sydney University Speleological Society 6: 29-42.

Dunkley, J., A. Spate, and B. Welch. 2010. Wee Jasper Caves. Broadway, NSW: Australian Speleological Federation Inc.

Eriksson, M. G., J. M. Olley, D. R. Kilham, T. Pietsch, and R. J. Wasson. 2006. Aggradation and incision since the very Late Pleistocene in the Naas River, south-eastern Australia. Geomorphology 81: 66-88.

https://doi.org/10.1016/j.geomorph.2006.04.001

Flannery, T. F., and J. Hope. 1983. Occurrences of the extinct macropodid marsupial Simosthenurus maddocki in New South Wales. Australian Mammalogy 6: 37-39.

Flood, J. 1973. The Moth Hunters-Investigations Towards a Prehistory of the South-Eastern Highlands of Australia. Unpublished Ph.D. thesis (two volumes). The Australian National University, Canberra.

Flood, J. 1974. Pleistocene Man at Cloggs Cave: his tool kit and environment. Mankind 9(3): 175-188. https://doi.org/10.1111/j.1835-9310.1974.tb01389.x

Flood, J. 1980. The Moth Hunters: Aboriginal Prehistory of the Australian Alps. Canberra: Australian Institute of Aboriginal Studies.

Flood, J., B. David, J. Magee, and B. English. 1987. Birrigai: a Pleistocene site in the south-eastern highlands. Archaeology in Oceania 22: 9-26. https://doi.org/10.1002/j.1834-4453.1987.tb00159.x

Hall, L. S. 1975. A recent bone deposit at Marble Arch, N.S.W. Australian Speleological Federation (Proceedings 10th Biennial Conference) 3: 35-46.

Harris, J. M., and R. L Goldingay. 2005. The distribution of fossil and sub-fossil records of the eastern pygmy-possum in Victoria. Victorian Naturalist 122(4): 160-170.

Hislop, K. P. 2017. A Taphonomic Assessment of Faunal Remains from the Cave Site WJ99 at Wee Jasper, New South Wales. Unpublished M. Arch. Science thesis. The Australian National University, Canberra.

Hogg, Alan G., Quan Hua, Paul G. Blackwell, Mu Niu, Caitlin E. Buck, Thomas P. Guilderson, Timothy J. Heaton, Jonathan G. Palmer, Paula J. Reimer, Ron W. Reimer, Christian S. M. Turney, and Susan R. H. Zimmerman. 2016. SHCal13 Southern Hemisphere Calibration, 0-50,000 years cal BP. Radiocarbon 55(4): 1889-1903.

https://doi.org/10.2458/azu_s__rc.55.16783

Hope, G. S., R. Nanson, and I. Flett. 2009. The Peat-forming Mires of the Australian Capital Territory. Technical Report 19. Territory and Municipal Services, Canberra.

Hope, Jeannette. Undated, c. 1970s. Quaternary Fossil Mammal Localities in Southeastern New South Wales and Eastern Victoria. Unpublished typewritten document.

Hope, J. 1982. Fossil Vertebrates from Wombeyan Caves. In Wombeyan Caves, ed. H. J. Dyson, R. Ellis, and J. M. James, pp. 155-164. Sydney Speleological Society Occasional Paper No. 8.

Johnson, I. 1977. Abercrombie arch shelter: an excavation near Bathurst, N.S.W. Australian Archaeology 6: 28-40. https://doi.org/10.1080/03122417.1977.12093316

Johnston, P., and G. Brierley. 2006. Late Quaternary river evolution of floodplain pockets along Mulloon Creek, New South Wales, Australia. The Holocene 16: 661-674. https://doi.org/10.1191/0959683606hl962rp

Kemp, J., and G. S. Hope. 2014. Vegetation and environments since the Last Glacial Maximum in the Southern Tablelands, New South Wales. Journal of Quaternary Science 29(8): 778-788. https://doi.org/10.1002/jgs.2749

Kershaw, A. P., D. M. D’Costa, J. McEwen, J. R. C. Mason, and B. E. Wagstaff. 1991. Palynological evidence for Quaternary vegetation and environments of mainland southeastern Australia. Quaternary Science Reviews 10: 391-404. https://doi.org/10.1016/0277-3791(91)90003-D
Kershaw, A. P., and K. M. Strickland. 1989. The development of alpine vegetation on the Australian mainland. In The Scientific Significance of the Australian Alps, ed. R. Good, pp. 113-126. Canberra: The Australian Alps National Parks Liaison Committee.

Lishmund, S. R., A. D. Dawood, and W. V. Langley. 1986. The Limestone Deposits of New South Wales, Geological Survey of New South Wales. Mineral Resources 25, 2nd edition. Sydney: Department of Mineral Resources.

Macphail, M. K., and G. S. Hope. 2002. Kangaroos in an Ice Age Landscape: Fossil Pollen Evidence for Conditions on the Canberra Plain 20,000 Years Ago. Unpublished Report. Archaeology and Natural History, The Australian National University, Canberra (with note added 1 June 2012).

Marcott, S. A., J. D. Shakun, P. U. Clark, and A. C. Mix. 2013. A reconstruction of regional and global temperature for the past 11,300 years. Science 339: 1198-1201.

https://doi.org/10.1126/science.1228026

Marx, S. K., H. A. McGowan, and B. S. Kamber. 2009. Long-range dust transport from eastern Australia: a proxy for Holocene aridity and ENSO-type climate variability. Earth and Planetary Science Letters 292: 167-177. https://doi.org/10.1016/j.epsl.2009.03.013

Marx, S. K., B. S. Kamber, H. A. McGowan, and J. Denholm. 2011. Holocene dust deposition rates in Australia's Murray-Darling Basin record the interplay between aridity and the position of the mid-latitude westerlies. Quaternary Science Reviews 30: 3290-3305.

https://doi.org/10.1016/j.quascirev.2011.07.015

Matthews, P. G., ed. 1985. Australian Karst Index. Broadway, New South Wales: Australian Speleological Federation Inc.

May, S. A. 1990. Mastacomys fuscus (the Broad-toothed Rat) a Palaeoenvironmental Indicator? Unpublished B.Sc. (Hons) thesis. Department of Geography, The Australian National University, Canberra.

Morris, D. A., M. L. Augee, D. Gillieson, and J. Head. 1997. Analysis of a late Quaternary deposit and small mammal fauna from Nettle Cave, Jenolan, New South Wales. Proceedings of the Linnean Society of New South Wales 117: 135-162.

Nicoll, R. S., and J. B. Brush. 1976. Guidebook to the Caves of South Eastern New South Wales and Eastern Victoria. Sydney: Australian Speleological Federation Guide-book 1.

Osborne, R. A. L. 1993. A new history of cave development at Bungonia, New South Wales. Australian Geographer 24: 62-74. https://doi.org/10.1080/00049189308703078

Ossa, P., B. Marshall, and C. Webb. 1995. New Guinea II Cave: a Pleistocene site on the Snowy River, Victoria. Archaeology in Oceania 30: 22-35. https://doi.org/10.1002/j.1834-4453.1995.tb00325.x

Rich, P. V., G. F. van Tets, and F. Knight. 1993. Kadimakara: Extinct Vertebrates of Australia, 2nd edition. New Jersey: Princeton University Press.

Ride, W. D. L. 1960. The fossil mammalian fauna of the Burramys parvus breccia from the Wombeyan Caves, New South Wales. Journal of the Royal Society of Western Australia 43: 74-80.

Ride, W. D. L., G. Taylor, P. H. Walker, and A. C. Davis. 1989. Zoological history of the Australian Alps - the mammal fossilbearing deposits of the Monaro. In The Scientific Significance of the Australian Alps, ed. R. Good, pp. 79-110. Canberra: The Australian Alps National Parks Liaison Committee.

Ride, W. D. L., and A. C. Davis. 1997. Origins and setting: mammal Quaternary palaeontology in the eastern highlands of New South Wales. Proceedings of the Linnean Society of New South Wales 117: 197-221.

Rosenfeld, A., J. Winston-Gregson, and K. Maskell. 1983. Excavations at Nursery Swamp 2, Gudgenby Nature Reserve, Australian Capital Territory. Australian Archaeology 17: 48-58. https://doi.org/10.1080/03122417.1983.12092909 
Sanson, G. D., S. J. Riley, and M. A. J. Williams. 1980. A Late Quaternary Procoptodon fossil from Lake George, New South Wales. Search 11: 39-40.

Schram, F. R., and W. D. Turnbull. 1970. Structural composition and dental variation in the murids of the Broom Cave fauna, Late Pleistocene, Wombeyan Caves Area, N.S.W., Australia. Records of the Australian Museum 28(1): 1-24.

https://doi.org/10.3853/j.0067-1975.28.1970.420

Spate, A., and A. Baker. 2018. Karst values of Kosciuszko National Park: a review of values and of recent research. Proceedings of the Linnean Society of New South Wales 140: 253-264.

Stanley, S., and P. De Deckker. 2002. A Holocene record of allochthonous, aeolian mineral grains in an Australian alpine lake: implications for the history of climate change in southeastern Australia. Journal of Paleolimnology 27: 207-219. https://doi.org/10.1023/A:1014249404845

Theden-Ringl, F. 2016. Aboriginal presence in the high country: new dates from the Namadgi Ranges in the Australian Capital Territory. Australian Archaeology 82: 25-42. https://doi.org/10.1080/03122417.2016.1163955

Theden-Ringl, F., and P. Gadd. 2017. The application of X-ray fluorescence core scanning in multi-element analyses of a stratified archaeological cave deposit at Wee Jasper, Australia. Journal of Archaeological Science: Reports 14: 241-251. https://doi.org/10.1016/j.jasrep.2017.05.038

Theden-Ringl, F., and M. Langley. 2018. At the margins of the high country: a terminal Pleistocene to late Holocene occupation record from Wee Jasper, southeastern Australia. Australian Archaeology 84: 145-163.

https://doi.org/10.1080/03122417.2018.1510626

Theden-Ringl, F., K. P. Hislop, K. Aplin, R. Grün, and M. R. Schurr. 2018. The chronology and environmental context of a cave deposit and associated faunal assemblage including megafauna teeth near Wee Jasper, southeastern Australia. The Holocene 28(9): 1467-1482.

https://doi.org/10.1177/0959683618777073
Turnbull, W. D., and F. R. Schram. 1973. Broom Cave Cercartetus: with observations on pygmy possum dental morphology, variation, and taxonomy. Records of the Australian Museum 28(19): 437-464. https://doi.org/10.3853/j.0067-1975.28.1973.404

Van Dyck, S., I. Gynther, and A. Baker. 2013. Field Companion to the Mammals of Australia. Sydney: New Holland Publishers.

Wakefield, N. A. 1960a. Recent mammal bones in the Buchan district-1. Victorian Naturalist 77: 164-178.

Wakefield, N. A. 1960b. Recent mammal bones in the Buchan district-2. Victorian Naturalist 77: 277-240.

Wakefield, N. A. 1967. Mammal bones in the Buchan district. Victorian Naturalist 84: 211-214.

Wakefield, N. A. 1972a. Studies in Australian Muridae: review of Mastacomys fuscus, and description of a new subspecies of Pseudomys higginsi. Memoirs of the National Museum of Victoria 33: 15-31.

https://doi.org/10.24199/j.mmv.1972.33.02

Wakefield, N. A. 1972b. Palaeoecology of fossil mammal assemblages from some Australian caves. Proceedings of the Royal Society of Victoria 85: 1-26.

Willis, P. M. A. 1993. Vertebrate (Tetrapod) Palaeontological Sites in New South Wales. Report to National Parks Association of NSW.

Zhou, Weijian, Xuefeng Yu, A. J. Timothy Jull, G. Burr, J. Y. Xiao, Xuefeng Lu, and Feng Xian. 2004. High-resolution evidence from southern China of an early Holocene optimum and a midHolocene dry event during the past 18,000 Years. Quaternary Research 62(1): 39-48.

https://doi.org/10.1016/j.yqres.2004.05.004 



\title{
Fauna on the Floodplains: Late Holocene Culture and Landscape on the Sub-coastal Plains of Northern Australia
}

\author{
SAlly BrockWEll ${ }^{1,2}$ (DAND Ken APLiN ${ }^{3} \dagger$ (D) \\ ${ }^{1}$ Faculty of Arts and Design, University of Canberra, 11 Kirinari St, Bruce ACT 2617, Australia \\ ${ }^{2}$ Archaeology and Natural History, School of Culture, History and Language, College of Asia and the Pacific, \\ The Australian National University, Acton ACT 2601, Australia \\ ${ }^{3}$ Australian Museum Research Associate, 1 William Street, Sydney NSW 2010, Australia
}

\begin{abstract}
This paper describes the faunal record from a late Holocene archaeological site located on the freshwater wetlands of the South Alligator River and compares it with that from the Adelaide River, in the Northern Territory. The information characterizes freshwater wetland resources and their use by Aboriginal people, providing a snapshot of life on the floodplains immediately prior to European contact. Although the two wetland systems appear similar, and extractive technology in the form of bone points is also similar, the faunal assemblages show that Aboriginal hunting strategies differed between the two areas. These differences can be explained by variations in regional topography and seasonality of site use.
\end{abstract}

\section{Introduction}

This paper compares two late Holocene faunal assemblages from different regions of the sub-coastal floodplains located in the Top End of the Northern Territory (Fig. 1). The information characterizes freshwater wetland resources and their use by Aboriginal people, providing a snapshot of life on the floodplains immediately prior to European contact. The paper presents new information about faunal remains and bone points recovered from the earth mound site of Kina on the South Alligator River, originally excavated in 1981 as part of the Kakadu Archaeological Project (Jones, 1985). The faunal assemblage was not analyzed in detail at the time; however, this has since been undertaken by Ken Aplin (2016). Aplin's results are compared with those of Brockwell (2009) from earth mounds on the Adelaide River. Although these two tropical freshwater wetland systems appear similar, their faunal assemblages show that Aboriginal hunting strategies differed between regions, although extractive technology in the form of bone points is similar. Aplin's results demonstrate a dominance of fish in the Kina sequence, while Brockwell's study shows the upper levels of the Adelaide River sites are dominated by freshwater turtle. This paper seeks explanations for these differences and similarities.

\section{Climate}

The climate of northern Australia consists of a long dry season from about April to November and a shorter but intense wet season from about December to March. This regime affects the seasonal availability of both flora and fauna.

\section{Geomorphology}

The evolutionary history of the floodplains of the major river systems of the Top End of the Northern Territory is well understood from various geomorphic studies and is broadly similar between river systems (e.g., Clark \& Guppy, 1988; Hope et al., 1985; Woodroffe \& Mulrennan, 1983; Woodroffe et al., 1985, 1993). The floodplains were initiated 


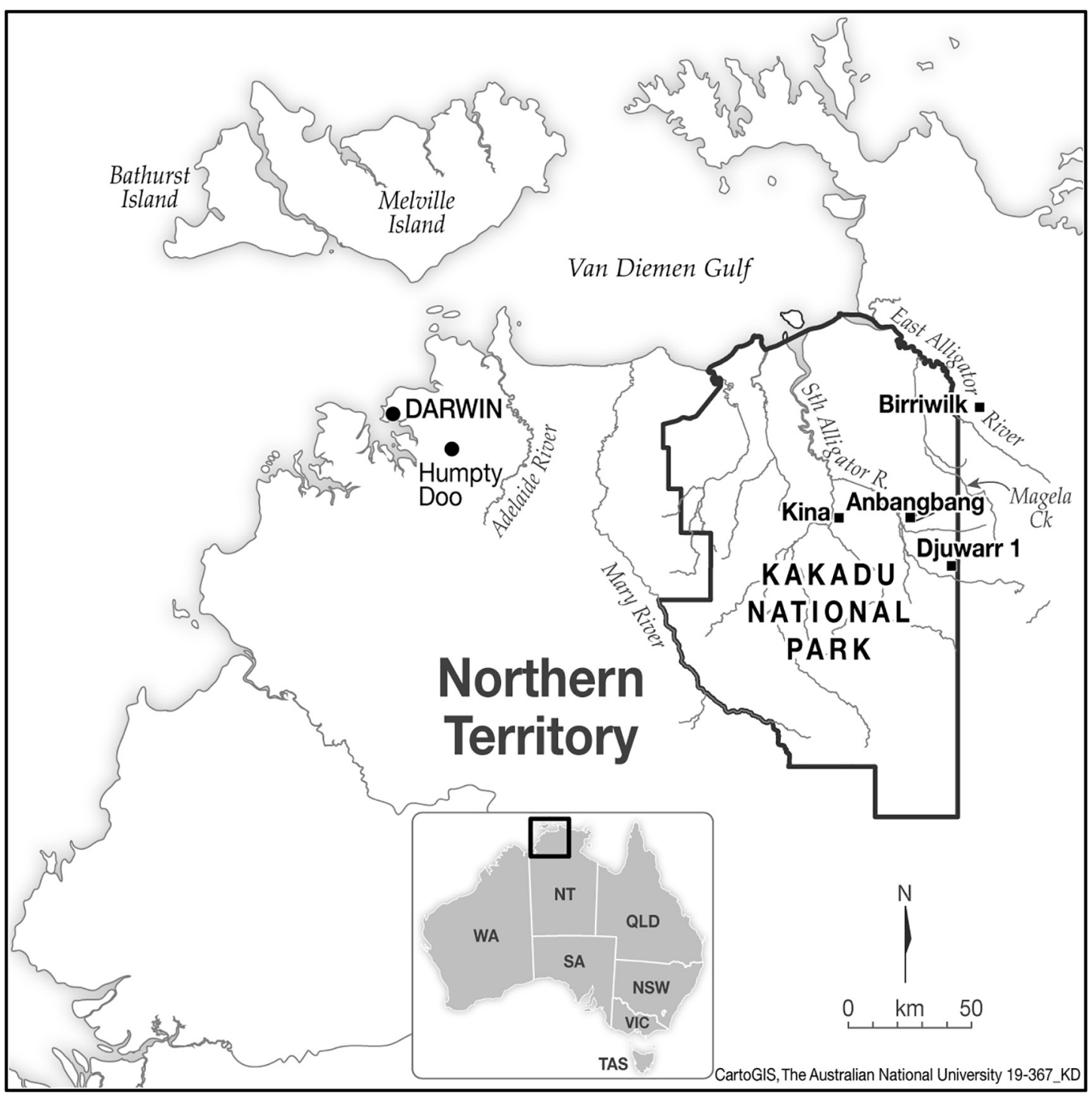

Figure 1. South Alligator River (Kina) and Adelaide River: location map (ANU Carto-GIS).

by post-Pleistocene sea level rise that flooded down-cut river valleys in the region. Subsequent processes of siltation led to the Big Swamp Phase when mangroves colonized the floodplains c. 8000-6000 years BP (Woodroffe et al., 1985). Further siltation and coastal progradation cut off the tidal influence, mangroves retreated to river channels and the coast, and a period of transition initiated a mosaic of estuarine and freshwater environments that existed on the floodplains between about 5000-2000 years BP. This has been referred to as the Transition Phase on both the Adelaide River (Woodroffe et al., 1993: 264) and in Kakadu (Clark \& Guppy, 1988: 682). With the ponding of freshwater from the annual monsoon against cheniers, freshwater wetlands with their exceedingly rich floral and faunal resources became widely established on the floodplains from c. 2000 years $\mathrm{BP}$, which is known as the Freshwater Phase.

\section{Archaeology}

Archaeologists have demonstrated the key importance of these floodplains to the pre-contact Aboriginal economy throughout the mid to late Holocene (cf. Allen, 1996; Baker,
1981; Brockwell, 1996, 2001, 2006, 2009; Brockwell \& Akerman, 2007; Brockwell et al., 2001; Guse, 1992; Hiscock, 1996, 1999; Hiscock et al., 1992; Meehan et al., 1985; Schrire, 1982). With the arrival of the Big Swamp Phase c. 7000 years BP, settlement in the Alligator Rivers Region was concentrated in rock shelters close to the northern floodplains around the East Alligator River and Magela Creek, exploiting the rich estuarine resources of the mangroves. Occupation continued there until the Transition Phase when the rockshelters were abandoned c. 3000 years $\mathrm{BP}$, then reoccupied in the Freshwater Phase with the establishment of freshwater wetlands c. 1500 years BP. At the same time, open sites were established on the floodplain margins in the north and south of the region to take advantage of the exceedingly rich freshwater flora and fauna (Meehan et al., 1985).

On the Adelaide River, which lacks the rockshelter formations of the Arnhem Land escarpment and its outliers, settlement was focused mainly on the floodplain margins from at least 4000 years BP, exploiting estuarine resources towards the end of the Big Swamp Phase (Brockwell, 2009). During the Transition Phase, the archaeology demonstrates 
Table 1. Kina: cultural remains from excavation, as reported by Meehan et al. (1985: 149, table 7.5). The material from the two squares (SE and NE) is pooled for this summary.

\begin{tabular}{cccccc}
\hline $\begin{array}{c}\text { excavation } \\
\text { unit }\end{array}$ & $\begin{array}{c}\text { depth below } \\
\text { surface }(\mathrm{cm})\end{array}$ & $\begin{array}{c}\text { sediment } \\
\text { weight }(\mathrm{kg})\end{array}$ & $\begin{array}{c}\text { stone } \\
\text { artefacts (no.) }\end{array}$ & $\begin{array}{c}\text { haematite } \\
\text { (no.) }\end{array}$ & $\begin{array}{c}\text { freshwater mussels } \\
\text { weight }(\mathrm{g})\end{array}$ \\
\hline 1 & 12 & 74 & 84 & 1 & 545 \\
2 & 28 & 77 & 123 & - & 720 \\
3 & 45 & 77 & 229 & 1 & 301 \\
4 & 63 & 80 & 79 & - & 35 \\
5 & 78 & 80 & 99 & - & 26 \\
\hline
\end{tabular}

exploitation of both estuarine and freshwater zones until the establishment Freshwater Phase c. 2000 years BP, at which time exploitation became focused on freshwater species (Brockwell, 2009; Brockwell \& Akerman, 2007).

\section{The Kina archaeological site}

Kina is located beside a freshwater billabong on the eastern side of the South Alligator River and lies within Kakadu National Park, 200 km east of Darwin (Fig. 1). The site consists of extensive surface concentrations of archaeological material covering some 30,000 square metres, and several small discrete earth mounds containing stone artefacts, freshwater mussel shell and other cultural remains in a dark clay matrix (Meehan et al., 1985: 117-119). Surface collection and excavation were undertaken and described in detail by Meehan et al. (1985: 148-152). This information is summarized below.

Three transects were set up across the site. The northsouth traverse measured $210 \mathrm{~m}$, while the two east-west traverses were $110 \mathrm{~m}$ and $100 \mathrm{~m}$ respectively. Systematic surface collections of $1 \times 1 \mathrm{~m}$ were made every $10 \mathrm{~m}$ along transects by the project team members. A $5 \times 5 \mathrm{~m}$ square was laid out over one earth mound and the material contained in each $1 \times 1 \mathrm{~m}$ square was collected and bagged separately (Meehan et al., 1985: 117). A test pit $(1 \mathrm{~m} \times 50 \mathrm{~cm})$ was excavated into one of the mounds, in five excavation units measuring between $12-18 \mathrm{~cm}$, and the deposit was sieved through $12 \mathrm{~mm}$ and $3 \mathrm{~mm}$ mesh (Meehan et al., 1985: 149; Johnson \& Jones, 1985: 33). Bedrock, on the laterite surface of the plain, was reached at $78 \mathrm{~cm}$ (Table 1). The mound had been disturbed by goanna burrows, and it is likely that the soil and archaeological remains throughout the pit were reworked. There was no marked stratigraphy, although the deposit changed from hard and compact in the uppermost level to soft, dark grey silt or clay containing freshwater mussel shell, and numerous charcoal particles. Along with the shell (Velesunio sp. and Alathyia sp.), stone artefacts were recovered, as well as two examples of mangrove shell (reported as Geloina sp.) in the lowermost cultural units. Some bone was recovered from the upper levels $(0-36 \mathrm{~cm}$ below surface), including the carapace and other remains of long necked turtle, fish vertebrae and otoliths. A broken bone point was found in unit 1. A summary of the cultural remains from excavation of the Kina site is shown in Table 1 (based on Meehan et al., 1985: 152, table 7.5). The Kina assemblage is lodged with the Museum and Art Gallery of the Northern Territory (MAGNT).

\section{The Adelaide River archaeological sites}

The Adelaide River earth mounds are located beside ephemeral lagoons on the western side of the floodplains of the lower Adelaide River, $60 \mathrm{~km}$ southeast of Darwin and 30 $\mathrm{km}$ northeast of the township of Humpty Doo, adjacent to the floodplains in an area of pandanus fringe (Fig. 1). Thirty-one earth mounds were recorded in this area (Brockwell, 2009: 33). Of these, two (HD1 and HD2) were located in 1968 by Carmel Schrire, and HD1 was subsequently excavated. Additional earth mounds were located in surveys in 1993 (MP1-MP6, NP1-NP20) (Brockwell, 2005). Five sites were excavated by SB in 1995 (MP2, MP5, MP6, NP19, NP20) and the deposit was sieved through $6 \mathrm{~mm}$ and $3 \mathrm{~mm}$ sieves. The excavations, discussed in detail in Brockwell (2009), yielded numerous stone artefacts, and two sites (MP2 and HD1) contained large quantities of well-preserved faunal remains from both the floodplains (fish and turtle) and open savanna species (goannas, wallabies, possums, and bandicoots). The Adelaide River collections are lodged with MAGNT.

\section{Chronology}

Adelaide River. The cultural assemblages on the Adelaide River date back to c. 4000 years BP and relate to the environmental phases of the evolution of the floodplains covering the Big Swamp, Transition, Freshwater, and Contact Phases (Table 2) (Brockwell, 2009: 36-38; Brockwell et al., 2009). The dates from the Freshwater Phase fell into two clusters and were divided for analysis into the Early Freshwater Phase from c. 2000, and the Late Freshwater Phase from c. 750 years BP (Brockwell \& Akerman, 2007: 114). For the purposes of this paper, we will be examining the faunal assemblage from the Late Freshwater Phase only, making it comparable with that of Kina.

Kina. A charcoal sample dated by Meehan et al. (1985) from unit $4(45-63 \mathrm{~cm})$ produced a date of $425-153 \mathrm{cal}$. BP (ANU 3212) (Brockwell et al., 2009: 71; Jones \& Johnson, 1985: 41). Meehan et al. (1985) postulated an earlier basal age, perhaps around 500-1000 BP, based on the occurrence of mangrove shell at the bottom of the pit, although Hope et al. (1985: 233-236) posited an earlier transition (c. 1400 BP) to freshwater conditions from their geomorphic studies of the neighbouring floodplain. A more recent dating of another charcoal sample, also from unit 4 , places the Kina assemblage at 268-14 cal. BP (Wk 38070). A sample of estuarine shell (Geloina sp.) from the basal unit 5 $(63-78 \mathrm{~cm})$ produced a date of $330 \pm 27 \mathrm{BP}$ (uncalibrated, Wk 38068). These dates fall within the Late Freshwater Phase described for the Adelaide River (Brockwell, 2009: 36-38; Brockwell \& Akerman, 2007: 114) (Table 2). 
Table 2. Chronological phases and radiocarbon dates of earth mound sites (after Brockwell, 2009: 36-38; Brockwell \& Akerman, 2007: 114; Brockwell et al., 2009). AR = Adelaide River, SAR = South Alligator River (Bronk Ramsey, 2013; Reimer et al., 2013; Stuiver \& Polach, 1977; Stuiver et al., 2005).

\begin{tabular}{|c|c|c|c|c|c|c|c|c|}
\hline phase & area & $\begin{array}{c}\text { site \& } \\
\text { spit no. }\end{array}$ & lab. no. & material & $\begin{array}{l}\text { depth below } \\
\text { surface }(\mathrm{cm})\end{array}$ & $\mathrm{C}-14$ & $\begin{array}{c}\text { cal. BP } 68.2 \% \\
\text { confidence }\end{array}$ & $\begin{array}{c}\text { cal. BP } 95.4 \% \\
\text { confidence }\end{array}$ \\
\hline Contact & AR & NP19 & Wk 5580 & Geloina sp. & $5-7$ & Modern & - & - \\
\hline \multirow[t]{7}{*}{ Late Freshwater } & SAR & Kina & ANU 3212 & Charcoal & $45-63$ & $280 \pm 40$ & - & $425-153$ \\
\hline & SAR & Kina & Wk 38068 & Geloina sp. & $63-78$ & $330 \pm 27$ & - & - \\
\hline & SAR & Kina & Wk 38070 & Charcoal & $45-63$ & $206 \pm 20$ & $300-14$ & $293-9$ \\
\hline & $\mathrm{AR}$ & MP2/5 & Wk 5581 & Charcoal & $22-26$ & $350 \pm 70$ & $460-310$ & $510-150$ \\
\hline & $\mathrm{AR}$ & MP6/5 & Wk 6668 & Bone & $10-15$ & $434 \pm 56$ & $510-340$ & $530-310$ \\
\hline & AR & MP5/11 & Wk 7400 & Charcoal & $36-41$ & $630 \pm 60$ & $639-537$ & $659-517$ \\
\hline & & $\mathrm{MP} 2 / 7$ & Wk 8452 & Charcoal & $31-35$ & $460 \pm 130$ & $600-460$ & $750-150$ \\
\hline \multirow[t]{3}{*}{ Early Freshwater } & AR & $\mathrm{MP} 2 / 10$ & Wk 6374 & Turtle carapace & $42-47$ & $2040 \pm 260$ & $2350-1650$ & $2750-1350$ \\
\hline & $\mathrm{AR}$ & $\mathrm{MP} 2 / 13$ & Wk 5582 & Charcoal & $53-59$ & $1880 \pm 210$ & $2050-1550$ & $2350-1350$ \\
\hline & $\mathrm{AR}$ & HD1/3 & Wk 6373 & Turtle carapace & $10-19$ & $2027 \pm 77$ & $2070-1870$ & $2180-1750$ \\
\hline \multirow[t]{2}{*}{ Transition/Big Swamp } & $A R$ & HD1/9 & Wk 5957 & Geloina sp. & $49-56$ & $3880 \pm 60$ & $3950-3740$ & $4050-3660$ \\
\hline & $\mathrm{AR}$ & HD1/11 & Wk 5796 & Geloina sp. & $62-69$ & $4060 \pm 60$ & $4200-3990$ & $4300-3890$ \\
\hline
\end{tabular}

\section{Materials, methods, and identifications}

Five major groups of vertebrates might be represented in an assemblage from the Top End-fish, frogs, reptiles, birds, and mammals. Each of these vertebrate groups has a distinctive skeletal anatomy and, with undamaged bones, virtually any bone can be allocated to one of the five groups. Fragmentation of bone results in a loss of diagnostic morphological features. However, for some classes of remains textural features allow even very small fragments to be allocated to a higher taxonomic category. For example, fish bone typically has a ropey or flaky texture that derives from a contrasting mode of bone formation to other vertebrates, and fragments of turtle carapace and plastron show a distinctive surface texture coupled with a spongy internal structure that remain visible down to quite small fragments. By contrast, for other groups of vertebrate fauna, the ability to identify fragmented remains depends on how much morphology is preserved. Fragments that retain some part of an articular surface are usually identifiable at least to higher taxon and often to lower level (genus or species), whereas small fragments derived from long bone shafts are rarely identifiable below family level.

\section{Kina faunal assemblage}

The Kina surface and excavated faunal assemblage was analysed by KA. Each fragment was examined microscopically for surface modifications caused by human intervention including manufacturing marks and use-related wear or damage, cut and tooth marks, and percussion marks, as well as signs of post-depositional degradation including corrosion associated with root contact, and pitting caused by microbial activity (Aplin, 2016).

Quantification of taxonomic and burning categories was performed by count (number of individual specimensNISP) and weight (to the nearest $0.01 \mathrm{~g}$ ). NISP values are used in preference to a Minimum Number of Individuals (MNI - the smallest number of original animals needed to account for all of the recovered remains) because the small samples available from the majority of the analysed sites dictate that the likelihood of recovering multiple fragments of any one individual is extremely low.

The distinctive lenticular otoliths of ariid catfish feature prominently in the assemblage. To determine whether otoliths were from the same fish, up to three measurements were taken from each otolith, depending on the degree of completeness; otolith symmetry was also recorded but no two otoliths seem close enough in size and shape to be derived from the same individual.

Macropodidae. Three molar fragments from the surface collection are confidently allocated to the agile wallaby (Notamacropus agilis), which is the only intermediate sized macropodid in tropical Australia (Aplin et al., 2016; Goodfellow, 1993). None of the excavated bone fragments tentatively identified as coming from mammals are large enough to be from agile wallabies.

Pteropodidae. Two species of flying foxes are found in western Arnhem Land today, the black flying fox (Pteropus alecto) and the little red flying fox (Pteropus scapulatus). Foley (1985) reported remains of both species in the Angbangbang 1 surface sample. Two fragmentary limb bones are present in the Kina excavated collection. Both appear too small to be black flying fox and they are tentatively referred to P. scapulatus. Both species are known to congregate in multiple dry-season camps within Kakadu National Park (Tidemann et al., 1999). Camps of $P$. scapulatus within Kakadu are most often located in patches of monsoon forest (Friend \& Braithwaite, 1985).

Muridae. At least two species are represented. One is a small rat, represented by an upper incisor and a fragmentary femur; these are the size of the Western Chestnut Mouse (Pseudomys nanus) but they might also be referred to various other similar sized species. The second taxon is a larger animal, represented by a distal tibia; this is comparable in size to the Dusky Rat (Rattus colletti), found only on 
the monsoonal subcoastal plains of the Northern Territory, and eaten by Aboriginal people (Goodfellow, 1993). It probably represents this species or the Brush-tailed Rabbit Rat (Conilurus penicillatus), an arboreal rat of the northern savanna landscape (Burbidge \& Woinarski, 2016).

Varanidae. A moderately large species of Varanus is represented by a vertebra and one limb element in Square SE. These might be referable to any of the three large monitors that occur in the western Arnhem Land region Gould's monitor (Varanus gouldii), Merten's water monitor (Varanus mertensi), or the yellow-spotted monitor (Varanus panoptes). As all Varanus species are very similar in their skeletal morphology, there is currently no set of criteria on which to base species identifications.

Meehan et al. (1985: 147) reported the presence of goanna burrows in the Kina mound deposit and noted the possibility that people may have dug into the mound in the past to locate animals undergoing seasonal aestivation.

Pythonidae. Two conjoined vertebrae from Square NE/3 are from a moderately large python. Candidate species include the black-headed python (Aspidites melanocephalus), the water python (Liasis fuscus) and the olive python (Liasis olivaceus). The vertebrae are complete enough for identification but this not been attempted due to lack of access to sufficient reference material.

Chelidae. The small fragments of carapace and plastron, and fragmentary bony elements do not permit lower level determination. Several species of Chelidae are known to occur in the freshwater lagoons and streams of northern Australia. The most commonly observed is the long-necked turtle (Chelodina rugosa), but short-necked turtles are also present-northern snapping turtle (Elseya dentata), pig-nosed or Fly River turtle (Carettochelys insculpta) and yellow-faced turtle (Emydura tanybaraga) (Cogger, 2018).

Teleost fishes. A total of 58 species of fishes have been recorded in the rivers of the Alligator River systems, the largest tally for any single river system in tropical Australia (Pusey et al., 2017). Of these, 15 or more can attain adult lengths of $30 \mathrm{~cm}$ or more, making them likely targets for Aboriginal subsistence strategies.

The fork-tailed catfishes (family Ariidae) are readily recognizable archaeologically from their robust, lenticular otoliths (Acero \& Bentacur, 2007), the highly distinctive nodular surface texture to the dorsal cranial bones, and their robust and distinctive dentigerous bones. Three species of ariid catfish are recorded in the regional river systems, with the most common taxon being the salmon catfish, Sciades leptaspis. This species can reach $100 \mathrm{~cm}$ in length but individuals around $30-50 \mathrm{~cm}$ are more commonplace. It is found in the estuarine, lowland, and floodplain environments. Like most ariid catfish, S. leptaspis has high salt tolerance and it can move freely between the marine and freshwater environments.

No other fish taxa were recognizable among the fragmentary remains but further study with access to more complete reference collections might allow additional remains to be determined.

\section{Adelaide River faunal assemblages}

The Adelaide River faunal assemblages were analysed by SB. Preliminary identifications were based on broad categories such as mammal, bird, reptile, fish, etc. Categories such as large and small mammals, most likely macropods, possums and rodents, and birds were identified by long bones. Species identifications of mammals, birds, and reptiles were made mainly on teeth, jaws, and vertebrae. Those identified to species level include Agile Wallaby (Notamacropus agilis), Northern Brushtail Possum (Trichosurus vulpecula arnhemensis), Northern Brown Bandicoot (Isoodon macrourus), Dusky Rat (Rattus colletti), and Northern Blue-tongue Lizard (Tiliqua scincoides). Other identifications were to family only.

Fish species were identified on skeletal elements, such as vomer, dentary, premaxilla, articular, maxilla, quadrate, hyomandibular, opercular, preopercular, urohyal, cleithrum, post-temporal, pterygiophores, supra-cleithrum, spines, and vertebrae (Barnett, 1978: 37; Colley, 1990: 213).

Most of the faunal remains from the Adelaide River sites were very fragmented and came from the $3 \mathrm{~mm}$ fraction, rather than the $6 \mathrm{~mm}$ sieve. For example, MP2 yielded an estimated $12.4 \mathrm{~kg}$ of faunal remains from the $3 \mathrm{~mm}$ sieve, most of it unidentifiable. Consequently MNI analysis was not used because the skeletal elements available did not allow a calculation of minimum numbers. There were, for example, no fish otoliths present. NISP analysis also seemed inappropriate because of the fragmented nature of the remains. Given this situation, it was decided the best method available was to calculate the weight of each taxon. This was compared directly to weight of taxonomic classes from Kina. The disadvantage of this method is that larger animals may be over-represented in the relative abundance of fauna (Peres, 2010: 27). However, as the fauna from the sites was mainly from small taxa, this possibility was reduced.

\section{Results}

\section{Kina: general results}

At Kina, the faunal remains come from a surface collection and from a test pit excavation into the mound. Preservation of the remains is reasonable, and this is probably due to the relatively high concentration of molluscan shell in the deposit, thereby buffering any natural acidity. The surface and excavated assemblages are dominated by the remains of fish, among which fork-tailed catfish (family Ariidae) are prominent. Other taxa that are represented in smaller quantities include freshwater turtle, agile wallaby, flying foxes, monitor lizards, a python, and several kinds of rodents. A small number of worked and utilized bone implements are described.

\section{Kina: surface collection}

Bone and/or shell were recovered from 17 of the surface collection sampling units described above (see Table 2). The surface bone assemblage consists of 35 individual pieces weighing a total of $45.9 \mathrm{~g}$. Eighteen of the 35 pieces are either complete or fragmentary fish otoliths, three are fragments of mammal teeth, and the remainder are fragments of fish or mammal bone.

Physical state of remains. The bone fragments and otoliths show signs of physical degradation including surface root 
Table 3. Kina: taxonomic composition of the faunal remains recovered from the surface collection. Data are summarized by NISP and weight $(\mathrm{g})$.

\begin{tabular}{|c|c|c|c|c|c|c|c|c|c|c|c|c|}
\hline \multirow[b]{2}{*}{ sample ID } & \multicolumn{6}{|c|}{ NISP } & \multicolumn{6}{|c|}{ weight (g) } \\
\hline & Hyriidae & Ariidae & $\begin{array}{c}\text { Teleost } \\
\text { indet. }\end{array}$ & Chelidae & $\begin{array}{c}\text { Agile } \\
\text { Wallaby }\end{array}$ & $\begin{array}{c}\text { mammal } \\
\text { indet. }\end{array}$ & Hyriidae & Ariidae & $\begin{array}{l}\text { Teleost } \\
\text { indet. }\end{array}$ & Chelidae & $\begin{array}{c}\text { Agile } \\
\text { Wallaby }\end{array}$ & $\begin{array}{c}\text { mammal } \\
\text { indet. }\end{array}$ \\
\hline SC G1A & - & 2 & - & - & - & - & - & 0.37 & - & - & - & - \\
\hline SC G1E & - & 2 & 1 & - & - & - & - & 0.07 & 0.04 & - & - & - \\
\hline SC G1L & - & 1 & - & - & - & - & - & 0.31 & - & - & - & - \\
\hline SC G2D & - & 1 & - & - & - & - & - & 2.40 & - & - & - & - \\
\hline SC G2E & 1 & - & - & 1 & - & - & 10.36 & - & - & 0.05 & - & - \\
\hline SC G2L & - & 3 & - & - & - & - & - & 1.82 & - & - & - & - \\
\hline SC G3A & - & 2 & - & - & 1 & - & - & 1.52 & - & - & 0.01 & - \\
\hline SC G3B & - & 1 & 2 & - & 一 & - & - & 0.68 & 0.14 & - & - & - \\
\hline $\mathrm{SC}$ G3C & - & 2 & 1 & - & 1 & - & - & 1.19 & 0.06 & - & 0.10 & - \\
\hline SC G3E & 1 & 1 & 1 & - & - & - & 23.44 & 0.52 & 0.18 & - & - & - \\
\hline SC G4B & - & 1 & - & - & 1 & - & - & 0.29 & - & - & 0.07 & - \\
\hline SC G4C & - & 1 & 2 & - & - & - & - & 0.09 & 0.10 & - & - & - \\
\hline SC G4E & - & 1 & 1 & - & - & - & - & 0.88 & 0.14 & - & - & - \\
\hline SC G4L & - & 2 & - & - & - & - & - & 0.32 & - & - & - & - \\
\hline SC G5A & - & 1 & - & - & - & - & - & 0.03 & - & - & - & - \\
\hline SC G5D & - & 1 & - & - & - & - & - & 0.37 & - & - & - & - \\
\hline SC G5E & - & - & - & - & - & 1 & - & - & - & - & - & 0.14 \\
\hline total & 2 & 22 & 8 & 1 & 3 & 1 & 33.8 & 10.86 & 0.66 & 0.05 & 0.18 & 0.14 \\
\hline
\end{tabular}

channeling and exfoliation. Calcined fragments are less damaged. Two fragments of freshwater mussel (Velesunio sp.) weigh $10.4 \mathrm{~g}$ and $23.4 \mathrm{~g}$. The larger fragment from SC G3E shows evidence of utilization along one margin.

Taxonomic composition. The surface collection assemblage is dominated by fish remains ( $83 \%$ of total by NISP and $97 \%$ by weight; Table 3 ) with the most common items being the distinctive lenticular otoliths (18 examples) of Ariidae (forktail or hardhead catfish). Other remains include one fragment of freshwater turtle (family Chelidae) carapace or plastron, three fragments of molars of agile wallaby, and one small fragment of a mammal long-bone shaft. Metrics showing size and shape attributes of the sample of ariid catfish otoliths in the Kina surface collection sample are shown in Table 4.

\section{Kina: excavated assemblages}

Small quantities of faunal remains are available from five excavated units in Square NE (labelled NE1-5) and four excavated units in adjacent Square SE (labelled SE1-SE5). Only vertebrate remains have been analysed.

Table 4. Kina: metric attributes ( $\mathrm{mm}$ ) of ariid catfish otoliths in surface collection.

\begin{tabular}{lrrc}
\hline & length & depth & thickness \\
\hline $\mathrm{n}$ & \multicolumn{1}{c}{10} & 12 & 15 \\
average & 10.75 & 9.83 & 5.88 \\
minimum & 8.00 & 7.00 & 3.10 \\
maximum & 15.95 & 13.55 & 10.50 \\
stand. dev. & 2.12 & 1.73 & 1.95 \\
\hline
\end{tabular}

There is no obvious pattern in the vertical distribution of remains with the largest quantity found in Level 4 of Square $\mathrm{NE}$ and Level 1 of Square SE. When the samples are pooled by unit across the two squares the quantity of vertebrate remains varies from 6.4 to $12.9 \mathrm{~g}$ per unit, with the greatest quantities in each of Unit 1 and 4.

Physical state of remains. The physical state of the remains is broadly consistent with the surface collection sample and there is no obvious sign of progressive degradation with depth. The relatively good preservation state of the vertebrate remains is probably due in large part to the presence in Units 1-3 of abundant mollusc remains that may have buffered the natural acidity of the soil (Table 2).

Taxonomic composition. Fish are dominant at all levels in both squares by both NISP and weight (Tables 5 and 6). Ariid catfish are represented in almost all levels, identified either from their otoliths, tooth bearing elements, or distinctive cranial plates that bear a linear, nodular ornamentation. No other fish taxon could be identified with certainty from the fragmentary remains.

Turtle remains are present in small quantities in four out of five levels in Square NE but are absent from Square SE. Other groups of vertebrates are represented by occasional fragments, including moderately large individuals of python and goanna, a medium-sized mammal (possum-sized), flying foxes (Pteropus spp.), and small to medium-sized rodents.

None of excavated bone fragments tentatively identified as coming from mammals are large enough to be from agile wallabies. Ariid catfish are proportionally less abundant in the excavated samples than in the surface collection, presumably because of the high visibility and robusticity of these distinctive objects. A total of 10 ariid otoliths are present in the excavated samples; these are consistent in size with those collected on the surface of the deposit (Table 7). 
Table 5. Kina: taxonomic composition of the excavated faunal remains recovered from Squares NE and SE. Data are summarized by NISP.

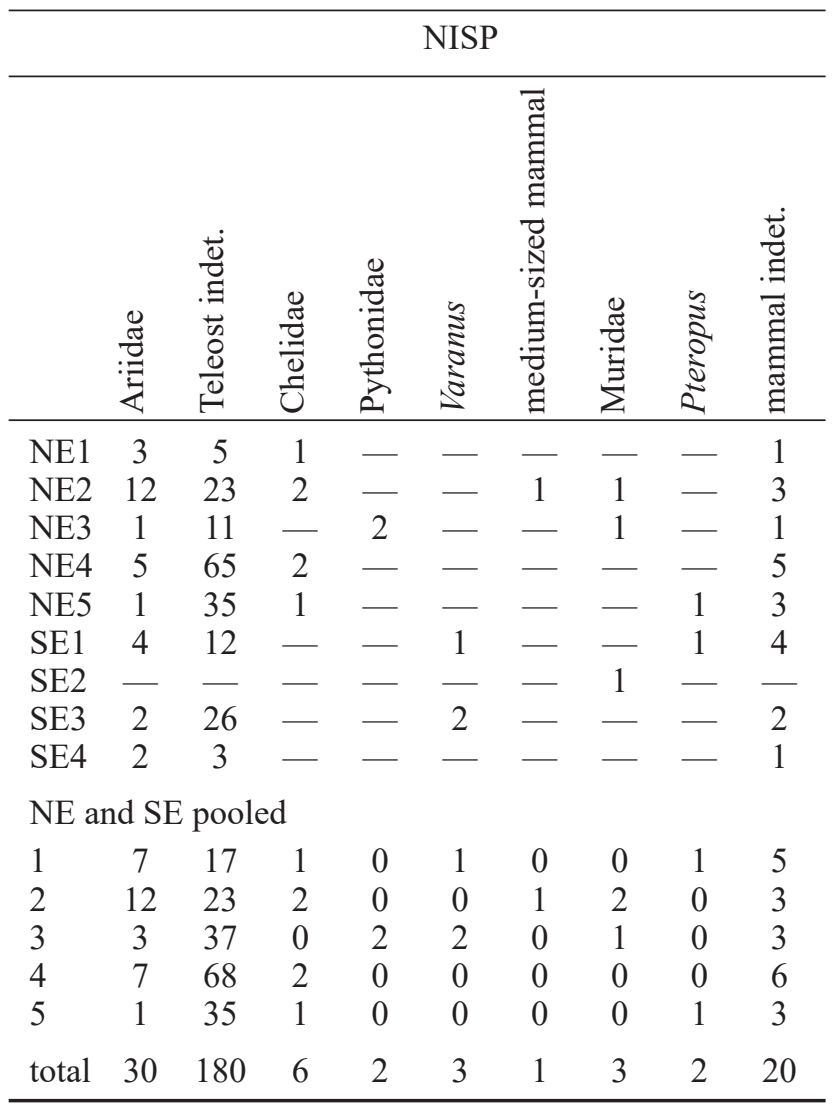

Bone artefacts. Two definite and one probable bone artefacts are identified within the submitted samples. Two came from Square NE Unit 1; one from Square NE Unit 4. Meehan et al. (1985: 150) mentioned a "broken bone point" from Unit 1 , no doubt the same specimen.

The example from Square NE/1 is a fragment of a bone point that has been produced by scraping. The fragment weighs $0.02 \mathrm{gm}$ and is formed on unburnt bone. The raw material appears to be a sliver of cortical bone of a mammal or reptile. The fragment is $16.1 \mathrm{~mm}$ long and is ovate in crosssection at the base, measuring $4.45 \mathrm{~mm}$ in width and 3.25 $\mathrm{mm}$ in perpendicular thickness. The tip shows no obvious use-related wear or damage.

The specimen from Square NE/4 is a fragment of bone point; the surface of the bone fragment is partially obscured

Table 7. Kina: metric attributes $(\mathrm{mm})$ of ariid catfish otoliths in the excavated samples.

\begin{tabular}{lcrc}
\hline & length & depth & thickness \\
\hline $\mathrm{n}$ & 8 & 9 & 10 \\
average & 12.08 & 10.24 & 5.60 \\
minimum & 9.50 & 8.30 & 3.50 \\
maximum & 14.35 & 12.60 & 7.20 \\
stand. dev. & 1.77 & 1.56 & 1.14 \\
\hline
\end{tabular}

Table 6. Kina: taxonomic composition of the excavated faunal remains recovered from Squares NE and SE. Data are summarized by weight $(\mathrm{g})$.

\begin{tabular}{|c|c|c|c|c|c|c|c|c|c|}
\hline \multicolumn{10}{|c|}{ weight (g) } \\
\hline & : & 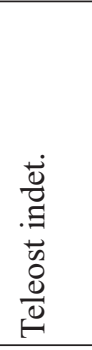 & $\begin{array}{l}\frac{\pi}{0} \\
: \frac{\pi}{0} \\
\text { ల }\end{array}$ & 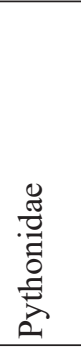 & 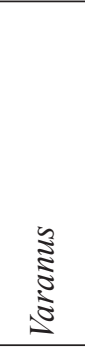 & 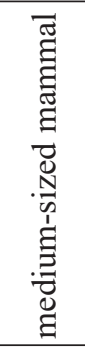 & $\frac{\mathbb{\pi}}{\stackrel{\Xi}{\Xi}}$ & $\frac{3}{2} \frac{2}{2}$ & 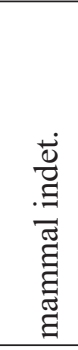 \\
\hline NE1 & 1.8 & 0.59 & 0.48 & - & - & - & - & - & 0.02 \\
\hline & & & 0.49 & - & - & 0.30 & 0.01 & - & .20 \\
\hline NE3 & 0.0 & 1.34 & - & 0.29 & - & - & 0.22 & - & 0.01 \\
\hline & & & 1.54 & - & - & - & - & - & 0.33 \\
\hline $\mathrm{NH}$ & 1.3 & 4.12 & 0.44 & - & - & - & - & 0.07 & 1.10 \\
\hline SE1 & 2.50 & 3.92 & - & - & 0.54 & - & 0.33 & - & 0.34 \\
\hline 2 & - & - & - & - & - & - & 0.12 & - & - \\
\hline 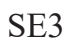 & 0.15 & & - & - & 0.94 & - & - & - & 0.27 \\
\hline SE4 & 0.10 & 0.49 & - & - & - & - & - & - & 0.10 \\
\hline \multicolumn{10}{|c|}{ NE and SE pooled } \\
\hline & & & 0.48 & 0 & 0.54 & 0 & 0.33 & 0 & 0.36 \\
\hline & & & 0.49 & 0 & 0 & 0.30 & & 0 & \\
\hline & & & 0 & 0.29 & 0.94 & 0 & 0.22 & 0 & 0.28 \\
\hline & 1.6 & 9. & 1.54 & 0 & 0 & 0 & 0 & 0 & 0.43 \\
\hline 5 & 1.39 & 4.12 & 0.44 & 0 & 0 & 0 & 0 & 0.07 & 1.10 \\
\hline tota & 11.71 & 24.35 & 2.95 & 0.29 & 1.48 & 0.30 & 0.68 & 0.07 & 2.37 \\
\hline
\end{tabular}

by a thin encrustation thus creating some uncertainty about the extent of modification and/or usage. It weighs $1.2 \mathrm{~g}$ and has a maximum length of $16.0 \mathrm{~mm}$ but the presumed functional tip is broken off. The maximum width of $4.5 \mathrm{~mm}$ is observed at the base where the cross-section is ovate, with a perpendicular thickness of $2.8 \mathrm{~mm}$. It is manufactured from an unburnt sliver of a long-bone shaft, most likely of a medium-sized mammal, possibly a brushtail possum.

The probable specimen from Square NE/1 is a burnt but otherwise unmodified teleost bone. The fragment weighs $0.05 \mathrm{~g}$ and has a maximum length of $11.6 \mathrm{~mm}$, maximum width of $4.7 \mathrm{~mm}$. All ridges and edges are covered with a network of fine scratches and polish, indicating heavy utilization.

\section{Adelaide River: excavated assemblages}

There is marked variation in species between the top and bottom of the Adelaide River deposits reflecting changing conditions on the floodplains during the Big Swamp Phase, through the Transition and Freshwater Phases, until contact. Estuarine shell is located at the base, which was replaced by increasing quantities of fish bone. The upper layers are dominated by large quantities of turtle remains, with glass and metal objects on the surface (Brockwell, 2009). However, for the purposes of this analysis, we present results from the Late Freshwater Phase only to make the Adelaide River assemblages comparable with the Kina assemblage dated to the same chronological period (Table 2). 


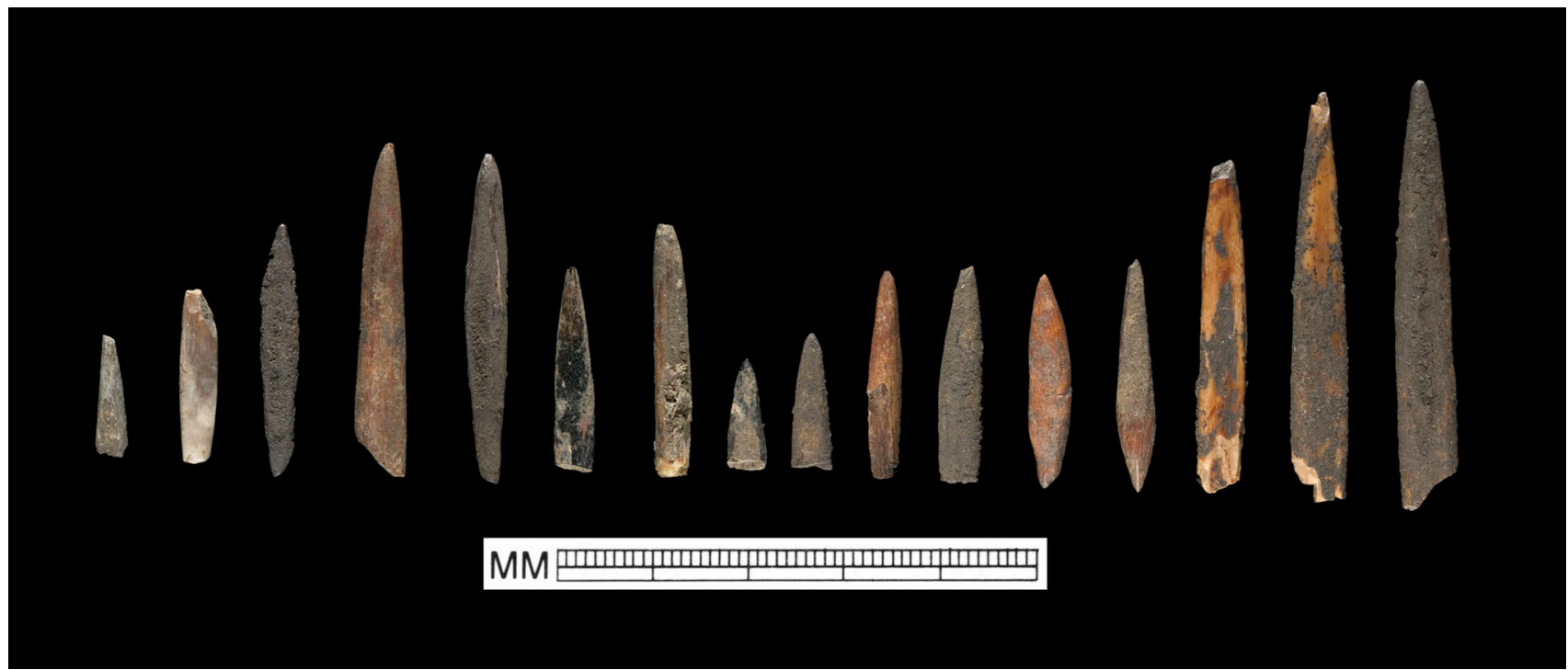

Figure 2. Adelaide River bone points (Adelaide River collection, MAGNT; photograph by Darren Boyd).

Physical state of the remains. The fragmented nature of the fauna means that much of it remains unidentified. As the analysis examines the distribution of fauna by weight through the deposits, it must be borne in mind that the results can be regarded only as gross indicators of foraging strategies. The fragmented state of the faunal remains and the amount that could not be identified, as well as the taphonomic factors (extremes of wet and dry seasons, exposure on open sites, trampling by feral buffalo) in operation at the sites, mean that delicate species are probably under-represented or entirely undetected.

Taxonomic composition. The following information is summarized from Brockwell (2009: 91-108). A sample of $5961.0 \mathrm{~g}$ of faunal remains was examined from MP2, of which $1448.5 \mathrm{~g}$ was identifiable in the Late Freshwater Phase (Tables 2 and 8). The range of fauna includes the remains of both floodplains and woodland taxa. Freshwater turtle is the dominant taxon represented in the Late Freshwater Phase, mainly carapace fragments that have been identified as longnecked turtle (Chelodina rugosa). This freshwater species typically inhabits swamps, billabongs, and waterholes across northern Australia today (Cogger, 2018). Other taxa include large and small mammals, including macropodids, possums, and rodents, as well as birds, snakes, goannas, and fish. Fauna identified to species level include the remains of the Northern Brushtail Possum (Trichosurus vulpecula arnhemensis), Dusky Rat (Rattus colletti), Barramundi (Lates calcarifer), Forktail Catfish (Ariidae), and Threadfin Salmon (family Polynemidae).

There were only $8.9 \mathrm{~g}$ of faunal remains in MP5, $2.0 \mathrm{~g}$ of which could be identified in the Late Freshwater Phase. A limited number of taxa were represented at this site, including goanna, turtle, fish, and forktail catfish (Table 8).

The total weight of faunal remains in MP6 is $1839.1 \mathrm{~g}$, of which $45.4 \mathrm{~g}$ was identifiable in the Late Freshwater Phase. A similar range of fauna was present as at MP2, consisting of macropodid, rodent, bird, reptile, snake, goanna, freshwater turtle and fish. The only fauna identified to species level were barramundi (Lates calcarifer), and forktail catfish (Table 8).
Bone artefacts. Twenty-seven bone points were recovered from the Adelaide River excavations, however only two were from the Late Freshwater Phase, one from MP2 (spit 6) and one from MP6 (spit 3). These bone points are described in detail in Brockwell \& Akerman (2007) (Fig. 2).

\section{Discussion}

Wetland systems situated on the coastal plains of northern Australia are of recent origin, dating from the stabilization of post-Pleistocene sea level rise c. 6000 years BP. The floodplains associated with major rivers have evolved through a sequence of mangrove forests and saline mudflats to freshwater wetlands from c. 2000 years BP. As freshwater wetlands are highly productive ecosystems home to a diverse variety of fauna and flora, they were a focus of food and material culture extraction for Aboriginal populations in the late Holocene (Brockwell, 1983). Faunal species available from the wetlands differ according to location, though generally they include mammals, waterbirds and their eggs, reptiles and their eggs, fish, and shellfish, which can be classified as seasonal staples.

Analysis of the of Adelaide River sites (Brockwell, 2009; Brockwell \& Akerman, 2007) suggests that, in the Late Freshwater Phase, the sites of MP2, MP5 and MP6 continued to be occupied from the Early Freshwater Phase when they were first established (Table 2). An increase in the discard rate of stone artefacts in the same phase indicates lower residential mobility perhaps reflecting the increased productivity of the floodplains. Faunal assemblages are dominated by the remains of turtles $(>80 \%)$ with lesser quantities of fish (Table 8). The proportion of woodland fauna is low, and estuarine shellfish and marine species are absent (Brockwell, 2009: 104, 107). The small quantities of fish in Late Freshwater Phase assemblages represent the end point of a decline that follows a peak representation of fish remains (at around 60\%) during the Transition Phase c. $4000 \mathrm{BP}$ to $2000 \mathrm{BP}$, when the floodplains were a mosaic of estuarine, freshwater, and hypersaline flats (Brockwell \& Akerman, 2007). 
Table 8. Adelaide River and Kina: proportions of vertebrate fauna for the Late Freshwater Phase by weight (after Aplin, 2016; Brockwell, 2009).

\begin{tabular}{lccccrr}
\hline site & mammal & bird & reptile & turtle & fish & wt (g) \\
\hline Adelaide R/MP2 & $3 \%$ & $1 \%$ & $1 \%$ & $85 \%$ & $10 \%$ & 1448.5 \\
MP5 & $0 \%$ & $0 \%$ & $6 \%$ & $77 \%$ & $17 \%$ & 2.0 \\
MP6 & $1 \%$ & $1 \%$ & $1 \%$ & $82 \%$ & $15 \%$ & 45.4 \\
Adelaide R total & $3 \%$ & $1 \%$ & $1 \%$ & $85 \%$ & $10 \%$ & 1495.9 \\
& & & & & & 45.7 \\
Kina surface & $2 \%$ & $0 \%$ & $0 \%$ & $1 \%$ & $97 \%$ & 44.2 \\
excavation & $7 \%$ & $0 \%$ & $4 \%$ & $7 \%$ & $82 \%$ & 89.9 \\
Kina total & $7 \%$ & $0 \%$ & $3 \%$ & $5 \%$ & $85 \%$ & \\
\hline
\end{tabular}

The composition of the Kina faunal assemblage does not conform with this regional model. In particular, the quantity of fish bone in the site greatly exceeds that of all other vertebrate groups and, while turtle is present in several levels, it does not comprise the dominant class of faunal remains at any point within the sequence (Table 8; Aplin, 2016). This makes the Kina faunal assemblage more like the Adelaide River assemblages dated to the Transition Phase, which were also dominated by fish. The substantial quantities of freshwater shellfish in the Kina deposit reported by Meehan et al. (1985) also seem at odds with the general model.

A broadly contemporaneous faunal assemblage was reported by Shine et al. (2013) from the upper levels of the Birriwilk site on the East Alligator River. Although this is a rockshelter rather than a mound site, it is positioned adjacent to Birriwilk Lagoon. Excavation units 8-12 of the Birriwilk site date to c. 300-150 years BP. The faunal assemblage from these levels consists of $36 \%$ fish bone (with Ariidae well-represented), $16 \%$ turtle and $48 \%$ unidentified, with the latter category probably made up of fragmentary turtle bone, as well as smaller quantities of mammal remains and other reptile bone. Only small quantities of shellfish were found in this deposit, which clearly presents an aggressive chemical environment for preservation. This assemblage differs from the Kina assemblage mainly in the higher representation of turtle remains and, in this respect, it conforms more closely to Brockwell and Akerman's (2007) expectation for a Late Freshwater Phase assemblage.

Foley (1985) reported the taxonomic composition of two collections made from loose surface contexts in two rockshelter sites in Kakadu National Park-Anbangbang I and Djuwarr I. Both assemblages were dated no older than 1200 years BP (Jones \& Johnson, 1985) and presumably dated from the Contact and/or the Late Freshwater Phases, as defined by Brockwell (2009; Brockwell \& Akerman, 2007). Both contained small quantities of turtle and fish bone, the latter dominated by the remains of ariid catfish. However, these exceptionally well-preserved assemblages differ from each of the Kina and Birriwilk assemblages in the much greater abundance of flying foxes, bandicoots, and terrestrial reptiles (especially Agamidae and Varanidae), as well as the presence of a wide variety of other mammals and birds. The majority of these taxa are usually still recognizable in highly degraded assemblages, typically from fragmentary teeth and foot bones in the case of bandicoots, fragments of dentaries and teeth in the case of flying foxes, and fragmentary dentaries and vertebrae in the case of the reptiles (Foley, 1985). The contrast between the two sets of assemblages is thus unlikely to be due entirely to differential preservation, and more likely reflects a greater emphasis on the faunal resources of the wetland system adjacent to each of the Kina and Birriwilk sites.

In the same way, the occupants of Kina and Adelaide River sites are clearly foraging the same set of vertebrate fauna from the freshwater wetlands and surrounds, just in different proportions. Therefore, the differences between these assemblages probably relate to differential availability of wetlands resources due to environmental differences between regions and/or seasonality.

We suggest here that both explanations are probable. The topography of the two floodplains where the sites are located differs. Kina is located next to a perennial backwater swamp whereas the Adelaide River mounds are located next to a discrete seasonal water body (Brockwell, 2001). Both turtles and fish are foraged from the northern wetlands in the early, mid and late dry season (Brockwell, 1989: 249, table 7.1). Fish are particularly easy to catch in the late dry season when they become stranded in pools of water and billabongs on the floodplains. Kina is located below the wet season flood level, and so would have been occupied only during the mid to late dry season when flood waters had retreated (Meehan et al., 1985). Whereas the Adelaide River sites were probably only occupied in the early dry season as the adjacent lagoon dries out by the middle of the year (Brockwell, 2006).

The ethnographic evidence confirms that traditional owners of the South Alligator River occupied floodplains sites in the mid to late dry season, where they exploited a variety of aquatic resources, obtaining different items from different sites, according to season and resource availability (Meehan et al., 1985). Waterlilies, spike rush, freshwater turtles, file snakes, and various fish species (barramundi, catfish, and mud cod) were exploited at Kina. In the wet season, they foraged the open woodlands on the higher ground behind the floodplains, hunting possums and wallabies and gathering yams and wet season fruits. During the late wet season, they returned to the floodplains and harvested geese, cormorants, and goose eggs (Meehan et al., 1985).

The absence of larger wallaby remains in the Kina assemblage is puzzling, especially as Meehan et al. (1985: 147-148) interpret the construction of the mound as being largely a product of accumulation of termite mound material imported specifically to roast wallaby-sized game in earth 
ovens. Presumably the same method was used to roast catfish and other smaller game items but the quantities of oven materials required may be considerably smaller; if so, the estimates of rate of accumulation of the mound through this mechanism may require revision.

The otoliths from the Kina excavation are consistent in size with those from the surface collection (Table 7). This fact suggests that similar size fish were being targeted over time, perhaps using a consistent method of capture. Interestingly, and unlike Kina, otoliths are missing entirely from the Adelaide River assemblages (Brockwell, 2009: 94), although they are a common feature of the faunal collections from excavated shell middens in the Darwin Harbour region (Bourke, 2000). It seems that because they are made of aragonite, a crystalline form of calcium carbonate, they are prone to decay in acidic conditions even though the cranial bones surrounding them may survive (Colley, 1990: 214). Like the Darwin Harbour shell mounds, the presence of otoliths in the Kina excavation is likely due to favourable alkaline preservation conditions created by the presence of shell (Meehan et al., 1985: 150).

\section{Comparison of bone artefacts}

Small bipoints made of bone are present throughout the archaeological record of the Adelaide River sites (Brockwell $\&$ Akerman, 2007). Their use continued into recent times as components of single and multi-pronged spears used to hunt aquatic resources, such as fish, tortoises, and water snakes (Spencer, 1914: 357). They have also been recorded as being used as sorcery items and worn in nasal septa (Akerman, 1995). Most of the bone points from the Adelaide River sites are from the Transition Phase (c. 4000-2000 years BP) when highest proportion of fish remains were recorded. Thus, these bone points have been attributed as barbs on fishing spears (Brockwell \& Akerman, 2007).

Within Kakadu National Park, the site of Anbangbang 1 produced numerous small bipoints in loose surface deposits that date to within the last 1200 years (Jones \& Johnson, 1985: 60-61). Schrire (1982) also reported numerous bone bipoints, unipoints, and spatulate points from her excavations in rockshelters north of Kakadu.

Two of the modified bones from Kina are comparable to this regional sample of bipoints, although neither of them is sufficiently complete to be certain of its original form. In particular, the maximum widths of around 3-5 $\mathrm{mm}$ for the Kina points are consistent with the Adelaide River samples (Fig. 2; Brockwell \& Akerman, 2007; Langley, 2018). Similarly, they were most likely used as components of fishing spears, given the high proportion of fish remains at the Kina site.

The third example from Kina is a utilized but otherwise unmodified fish bone. It presumably represents an example of expedient use of a natural element of suitable shape. This clearly represents a different class of implement to the bipoints and, to our knowledge, there are no comparable specimens from other regional sites. However, careful examination of other assemblages is likely to reveal other examples of expedient use of fish bone for penetrative functions.

\section{Conclusion}

This paper has described a faunal assemblage from the earth mound site of Kina located on the edge of the South Alligator River floodplains and compared it with those from the Adelaide River floodplains. These assemblages attest to Aboriginal foraging from freshwater wetlands in the late Holocene, immediately prior to contact. While the sites contain the same range of fauna, and similar extractive technology in the form of bone points, they demonstrate a different emphasis on subsistence strategies; Kina (South Alligator River) has a higher proportion of fish remains, while the Adelaide River sites contains a higher proportion of turtle remains.

These differences appear not to be due to preservational factors but rather the result of differences in topography and seasonality of occupation between the two river systems. Fish and turtle are traditionally caught from the wetlands in the dry season. The billabong next to the Adelaide River sites is ephemeral and dries out by mid dry season. Kina lies next to a perennial water body, which can be used late into the dry season when fish are easily caught in shallow pools of water. The comparison of these faunal assemblages emphasises the point made previously by Brockwell (2001: 336-337) that post 2000 years BP, although the freshwater floodplain systems of the Top End appear superficially similar, there are differences that have led to distinct archaeological land use patterns. Future investigations should take this into account.

Acknowledgements. This research was supported by an Australian Research Council Discovery Project (DP120100512). We acknowledge the assistance of Museum and Art Gallery of the Northern Territory in curating the materials from Kina and the Adelaide River and for providing access to the collections. We thank the Traditional Owners of Kakadu National Park and the Wairuk Aboriginal Corporation, who granted permission for the original fieldwork in Kakadu (1981) and Adelaide River (1993 and 1995). For the Adelaide River faunal assemblages, Dr Ian Walters and Dr Scott Mitchell (formerly of Northern Territory University, now Charles Darwin University) assisted with initial identifications; Dr Helen Larson (former Curator of Fishes at MAGNT) made expert identifications on fish; Dr Paul Horner (former Curator of Vertebrates, MAGNT) and Dr Dirk Megirian (Museum of Central Australia) assisted with the identification of mammals, birds, and reptiles; and Kim Akerman (University of Western Australia) analysed the bone points. We thank Kay Dancey and ANU Carto-GIS for the production of Fig. 1. We also thank Professor Jane Balme (University of Western Australia) and another anonymous reviewer for their helpful suggestions.

\section{References}

Acero, A. P., and R. Betancur. 2007. Monophyly, affinities and subfamilial clades of sea catfishes (Siluriformes: Ariidae). Ichthyological Exploration of Freshwaters 18: 133-143.

Akerman, K. 1995. The use of bone, shell and teeth by Aboriginal Australians. In Ancient Peoples and Landscapes, ed. E. Johnson, pp. 173-183. Lubbock: Museum of Texas.

Allen, H. 1996. The time of the mangroves: changes in midHolocene estuarine environments and subsistence in Australia and Southeast Asia. Bulletin of the Indo-Pacific Prehistory Association 15: 193-205.

https://doi.org/10.7152/bippa.v15i0.11548 
Aplin, K. 2016. Vertebrate fauna from the Kina Site, South Alligator River, Northern Territory. Canberra: Report to Department of Archaeology and Natural History, College of Asia and the Pacific, The Australian National University.

Aplin, K., C. Dickman, L. Salas, J. Woinarski, and J. Winter. 2016. Macropus agilis. The IUCN Red List of Threatened Species. IUCN. e.T40560A21954106.

https://doi.org/10.2305/IUCN.UK.2016-2.RLTS.T40560A21954106.en

Baker, R. 1981. The Aboriginal Environmental History of the Chambers Bay Coastal Plains. Unpublished B.A. (Hons) thesis. Department of Prehistory and Anthropology, The Australian National University, Canberra.

Barnett, G. 1978. A Manual for the Identification of Fish Bones. Technical Bulletin No.1. Canberra: Department of Prehistory, Research School of Pacific Studies, The Australian National University.

Bourke, P. 2000. Late Holocene Indigenous Economies of the Tropical Australian Coast: An Archaeological Study of the Darwin Region. Unpublished Ph.D. thesis. Northern Territory University, Darwin.

Brockwell, S. 1983. Wetlands in Focus. Unpublished M.A. (Qual.) thesis. Department of Prehistory and Anthropology, The Australian National University, Canberra.

Brockwell, S. 1996. Open sites of the South Alligator River wetland, Kakadu. In Archaeology of Northern Australia, ed. P. Veth and P. Hiscock, pp. 90-105. Tempus No. 4. St Lucia: Anthropology Museum, University of Queensland.

Brockwell, S. 2001. Wetlands archaeology in the Top End: models, mounds and mobility. In Histories of Old Ages: Essays in Honour of Rhys Jones, ed. A. Anderson, I. Lilley, and S. O'Connor, pp. 327-340. Canberra: Pandanus Books, Research School of Pacific and Asian Studies, The Australian National University.

Brockwell, S. 2005. Settlement patterns on the lower Adelaide River in the mid to late Holocene. In Darwin Archaeology: Aboriginal, Asian and European Heritage of Australia's Top End, ed. P. Bourke, S. Brockwell, and C. Fredericksen, pp. 9-18. Darwin: Charles Darwin University Press.

Brockwell, S. 2006. Earth mounds in northern Australia: a review. Australian Archaeology 63: 47-56. https://doi.org/10.1080/03122417.2006.11681837

Brockwell, S. 2009. Archaeological Settlement Patterns and Mobility Strategies: Lower Adelaide River, Northern Australia. Oxford: British Archaeological Reports (BAR), International Series S1987. https://doi.org/10.30861/9781407304618

Brockwell, S., and K. Akerman. 2007. Bone points from the Adelaide River, Northern Territory. Australian Aboriginal Studies 1: 83-97.

Brockwell, S., A. Clarke, and R. Levitus. 2001. Seasonal movement in the prehistoric ecology of the Alligator Rivers region, north Australia. In Histories of Old Ages: Essays in Honour of Rhys Jones, ed. A. Anderson, I. Lilley, and S. O'Connor, pp. 361-380. Canberra: Pandanus Books, Research School of Pacific and Asian Studies, The Australian National University.

Brockwell, S., P. Faulkner, P. Bourke, A. Clarke, C. Crassweller, D. Guse, B. Meehan, and R. Sim. 2009. Radiocarbon dates from the Top End: a cultural chronology for the Northern Territory coastal plains. Australian Aboriginal Studies 1: 54-76.

Bronk Ramsey, C. 2013. OxCal v4 2.3. [Accessed 20 April 2020] https://c14.arch.ox.ac.uk/explanation.php

Burbidge, A. A., and J. Woinarski. 2016. Conilurus penicillatus. The IUCN Red List of Threatened Species. IUCN. e.T5224A22450418. https://doi.org/10.2305/IUCN.UK.2016-1.RLTS.T5224A22450418.en

Clark, R. L., and J. C. Guppy. 1988. A transition from mangrove forest to freshwater wetland in the monsoon tropics of Australia. Journal of Biogeography 15: 665-684.

https://doi.org/10.2307/2845444
Cogger, H. 2018. Reptiles and Amphibians of Australia. Melbourne: CSIRO. https://doi.org/10.1071/9781486309702

Colley, S. M. 1990. The analysis and interpretation of archaeological fish remains. In Archaeological Method and Theory, ed. M. B. Schiffer, pp. 207-253. Volume 2. Tucson: University of Arizona Press.

Foley, D. 1985. Faunal analysis of Anbangbang 1 and Djuwarr 1. In Archaeological Research in Kakadu National Park, ed. R. Jones, pp. 97-102. Special Publication 13. Canberra: Australian National Parks and Wildlife Service.

Friend, G. R., and R. W. Braithwaite. 1985. The bat fauna of Kakadu National Park, Northern Territory. Australian Mammalogy 9: 43-52.

Goodfellow, D. 1993. Fauna of Kakadu and the Top End. Winnellie: Wakefield Press.

Guse, D. 1992. Predictive Models of Prehistoric Settlement and Subsistence Patterns for the South Alligator and Mary River Wetlands. Unpublished B.A. (Hons) thesis. Northern Territory University, Darwin.

Hiscock, P. 1996. Mobility and technology in the Kakadu coastal wetlands. Bulletin of the Indo-Pacific Prehistory Association 15: $151-157$.

https://doi.org/10.7152/bippa.v15i0.11544

Hiscock, P. 1999. Holocene coastal occupation of western Arnhem Land. In Australian Coastal Archaeology, ed. J. Hall and I. J. McNiven, pp. 91-103. Research Papers in Archaeology and Natural History No. 31. Canberra: ANH Publications, Department of Archaeology and Natural History, Research School of Pacific and Asian Studies, The Australian National University.

Hiscock, P., D. Guse, and F. Mowat. 1992. Settlement patterns in the Kakadu wetlands: initial data on size and shape. Australian Aboriginal Studies 2: 84-89.

Hope, G., P. Hughes, and J. Russell-Smith. 1985. Geomorphological fieldwork and the evolution of the landscape of Kakadu National Park. In Archaeological Research in Kakadu National Park, ed. R. Jones, pp. 229-240. Special Publication 13. Canberra: Australian National Parks and Wildlife Service.

Johnson, I., and R. Jones. 1985. Fieldwork methods. In Archaeological Research in Kakadu National Park, ed. R. Jones, pp. 31-37. Special Publication 13. Canberra: Australian National Parks and Wildlife Service.

Jones, R., ed. 1985. Archaeological Research in Kakadu National Park. Special Publication 13. Canberra: Australian National Parks and Wildlife Service.

Jones, R., and I. Johnson. 1985. Rockshelter excavations: Nourlangie and Mt Brockman. In: Archaeological Research in Kakadu National Park, ed. R. Jones, pp. 39-76. Special Publication 13. Canberra: Australian National Parks and Wildlife Service.

Langley, M. 2018. Establishing a typology for Australian pointed bone implements. Australian Archaeology 84(2): 164-180. https://doi.org/10.1080/03122417.2018.1509541

Meehan, B., S. Brockwell, J. Allen, and R. Jones. 1985. The wetland sites. In Archaeological Research in Kakadu National Park, ed. R. Jones, pp. 103-153. Special Publication 13. Canberra: Australian National Parks and Wildlife Service.

Peres, T. M. 2010. Methodological issues in zooarchaeology. In Integrating Zooarchaeology and Paleoethnobotany: A Consideration of Issues, Methods, and Cases, ed. A. M. VanDerwarker and T. M. Peres, pp. 15-35. New York: Springer-Verlag. https://doi.org/10.1007/978-1-4419-0935-0_2

Pusey, B. J., D. W. Burrows, M. J. Kennard, C. N. Perna, P. J. Unmack, Q. Allsop, and M. P. Hammer. 2017. Freshwater fishes of northern Australia. Zootaxa 4253(1): 1-104. https://doi.org/10.11646/zootaxa.4253.1.1 
Reimer, P. J., E. Bard, A. Bayliss, J. W. Beck, P. G. Blackwell, C. Bronk Ramsey, P. M. Grootes, T. P. Guilderson, H. Haflidason, I. Hajdas, C. Hatt, T. J. Heaton, D. L. Hoffmann, A. G. Hogg, K. A. Hughen, K. F. Kaiser, B. Kromer, S. W. Manning, M. Niu, R. W. Reimer, D. A. Richards, E. M. Scott, J. R. Southon, R. A. Staff, C. S. M. Turney, and J. van der Plicht. 2013. IntCal13 and Marine 13 radiocarbon age calibration curves $0-50,000$ years cal BP. Radiocarbon 55: 1869-1887.

https://doi.org/10.2458/azu_js_rc.55.16947

Schrire, C. 1982. Alligator Rivers Prehistory: Prehistory and Ecology in Western Arnhem Land. Terra Australis 7. Canberra: Department of Prehistory, Research School of Pacific Studies, The Australian National University.

Shine, D., D. Wright, T. Denham, K. Aplin, P. Hiscock, K. Parker, and R. Walton. 2013. Birriwilk rockshelter: a mid to late Holocene site in Manilikarr Country, southwest Arnhem Land, Northern Territory. Australian Archaeology 76: 12-21. https://doi.org/10.1080/03122417.2013.11681967

Spencer, B. 1914. Native Tribes of the Northern Territory of Australia. London: Macmillan. London.

Stuiver, M., and H. A. Polach. 1977. Reporting of 14C data. Radiocarbon 19: 355-363.

https://doi.org/10.1017/S0033822200003672
Stuiver, M., P. J. Reimer, and R. Reimer. 2005. Calib 5.0.1. Calib Radiocarbon Calibration Program. Queens University, Belfast.

Tidemann, C. R., M. J. Vardon, R. A. Loughland, and P. J. Brocklehurst. 1999. Dry season camps of flying-foxes (Pteropus spp.) in Kakadu World Heritage Area, north Australia. Journal of Zoology (London) 247: 155-163. https://doi.org/10.1111/j.1469-7998.1999.tb00979.x

Woodroffe, C. D., and M. E. Mulrennan. 1993. Geomorphology of the Lower Mary River Plains, Northern Territory. Darwin: North Australia Research Unit, The Australian National University, Darwin.

Woodroffe, C. D., B. G. Thom, and J. Chappell. 1985. Development of widespread mangrove swamps in mid-Holocene times in northern Australia. Nature 317: 711-713.

https://doi.org/10.1038/317711a0

Woodroffe, C. D., M. E. Mulrennan, and J. Chappell. 1993. Estuarine infill and coastal progradation, southern van Diemen Gulf, northern Australia. Sedimentary Geology 83: 257-285. https://doi.org/10.1016/0037-0738(93)90016-X 


\title{
Metal-Age Maritime Culture at Jareng Bori Rockshelter, Pantar Island, Eastern Indonesia
}

\author{
Stuart Hawkins $^{1,2}$ (D), Fayeza Shasliz Arumdhati ${ }^{3} \mathbb{D}$, Mirani Litster $^{1,4} \mathbb{D}$, Tse Siang Lim $^{5}$ (D),

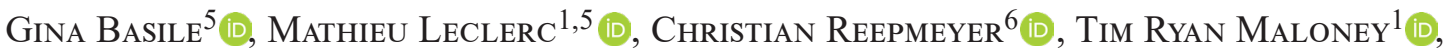

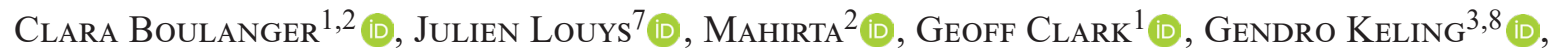 \\ Richard C. Willan ${ }^{9}$, Pratiwi Yuwono ${ }^{10}\left(\mathbb{D}\right.$, and Sue O’Connor ${ }^{1,2}$
}

\author{
${ }^{1}$ Archaeology and Natural History, School of Culture, History and Language, \\ ANU College of Asia and the Pacific, The Australian National University, Acton ACT 2601, Australia \\ ${ }^{2}$ ARC Centre of Excellence for Australian Biodiversity and Heritage, ANU College of Asia and the Pacific, \\ The Australian National University, Acton ACT 2601, Australia \\ 3 Jurusan Arkeologi, Fakultas Ilmu Budaya, Universitas Gadjah Mada, Yogyakarta, Indonesia \\ ${ }^{4}$ Faculty of Arts and Design, University of Canberra, Bruce ACT 2617, Australia \\ ${ }^{5}$ School of Archaeology and Anthropology, ANU College of Art and Social Sciences, \\ The Australian National University, Acton ACT 2601, Australia \\ ${ }^{6}$ ARC Centre of Excellence for Australian Biodiversity and Heritage, \\ College of Arts, Society, and Education, James Cook University, Cairns QLD 4870, Australia \\ ${ }^{7}$ Australian Research Centre for Human Evolution, Griffith University, Brisbane QLD 4110, Australia \\ ${ }^{8}$ Ministry of Education and Culture of the Republic of Indonesia, Denpasar, Bali, Indonesia \\ ${ }^{9}$ Museum and Art Gallery of the Northern Territory, GPO Box 4646, Darwin NT 0801, Australia \\ ${ }^{10}$ New York University, Department of Anthropology, NYC, 10003, United States of America
}

\begin{abstract}
The archaeological record of Wallacea remains exceptionally fragmentary. This is especially the case for late Holocene human occupation of the region when lifestyle and culture in marginal island environments is relatively unknown. Here we report on the archaeology of Jareng Bori rockshelter, a Metal-Age site spanning c. $1800 \mathrm{cal}$. BP up to the late historic period and situated on the eastern coast of Pantar Island in the Lesser Sunda Islands of eastern Indonesia. We use osteoarchaeological (human and vertebrate remains), invertebrate zooarchaeological (crustacean and molluscan remains), technological (lithics, shell, and pottery) and chemical sourcing (obsidian and metal) datasets to discuss networking, migration, and human subsistence strategies during this recent period of history. While some communities were no doubt living in open village settlements where they were producing pottery, the data indicate that aspects of maritime life-ways continued much as in earlier Pleistocene settlements, with people using rockshelters like Jareng Bori to pursue a range of subsistence activities focused on the shoreline. Shellfishing of rocky and reef intertidal species and fishing for mostly small herbivorous and omnivorous fishes was practised, while domestic animals only appear in the late historic period. Wider regional cultural interactions and networking are epitomized by obsidian exchange, dental modification practices, and pottery decorations, while lithic analyses indicates continuity of stone tool technology up until recent times.
\end{abstract}




\section{Introduction}

Maritime culture was present in the tropical island region of Wallacea over several millennia and provides the earliest evidence of open sea crossing capability for our species (Anderson, 2017; Balme, 2013). The region also contains some of the earliest direct evidence of marine resource exploitation in the world (O'Connor et al., 2011, 2017a; Ono et al., 2010; Roberts et al., 2020; Szabó \& Amesbury, 2011), and this maritime emphasis continued into the Metal-Age and historic periods (Ono et al., 2018a). By the terminal Pleistocene it appears that this insular region had developed inter-connectedness, as evidenced by analyses of obsidian artefacts recovered from sites on Alor and Timor ( $\mathrm{O}^{\prime}$ Connor et al., 2018; Reepmeyer et al., 2011, 2016, 2019), however, the extent of these networks is not well known. The migration of Austronesian cultures beginning c. $3500 \mathrm{BP}$, followed by a more widespread Indonesian Metal-Age from c. 2500 BP (Bellwood et al. 1993, 1998), saw the establishment of complex agricultural societies in the Asia-Pacific (Denham, 2013; Piper et al., 2014; Silva et al., 2015). This, combined with the mobility afforded by more sophisticated water-craft, and possibly spurred by heightening sea levels, resulted in large scale maritime networks and the rapid dispersal of Neolithic, and then Metal-Age cultures throughout the Wallacean region (Bellwood, 1998, 2017; O'Connor, 2015). These dispersals linked material culture, burial practices, and more complex socio-political economic systems (Glover, 1986; Koesbardiati et al., 2015; O’Connor, 2015; O'Connor et al., 2017b; Ono et al., 2018b; Shaffer, 1996).
Into the historic period the Wallacean region continued to see dynamic movements of peoples and cultures, and eastern Indonesia became part of a globalized trade network, particularly the Moluccas where spices were traded as far as India, China, and the Mediterranean after 2000 BP (Miller, 1969). During this pre-Islamic period, kingdoms were established in Wallacea, such as the Bugis on Sulawesi (Hakim et al., 2018). During the 14th century, after a period of trade and conflict between Java and East Nusa Tenggara, a dependency of the Majapahit empire named Galiyao in the Nagarakretagama was established. Barnes (1982) and Rodemeier (1995) identified this dependency with Pantar, or a kingdom that included both Pantar and eastern Alor. Later, Islamic and then Portuguese, British, and Dutch controlled states were established in the region.

Metal-Age sites with published data covering the period of these maritime interactions are widespread, from the Philippines (Bellwood \& Dizon, 2013), stretching to the Talaud islands north of Sulawesi (Ono et al., 2018a), Sulawesi (Bulbeck, 2010; Bulbeck et al., 2016), northern Maluku islands (Bellwood et al., 1993; Bellwood, 1998, 2017; Ono et al., 2018b), Timor (Glover, 1986), Bali (Calo et al., 2020a, 2020b), and into east Sumba (Heekeren, 1956), where metal items, glass beads, distinctive Metal-Age earthenware, in some cases Chinese tradeware, and jar burials have been dated from the 5th century B.C. On Bali, archaeological investigations indicated that the Lesser Sunda Islands were part of a wider Trans-Asiatic trade network since the 2nd century B.C. (Calo et al., 2020a, 2020b). At Sembiran harbour, Chinese tradeware was

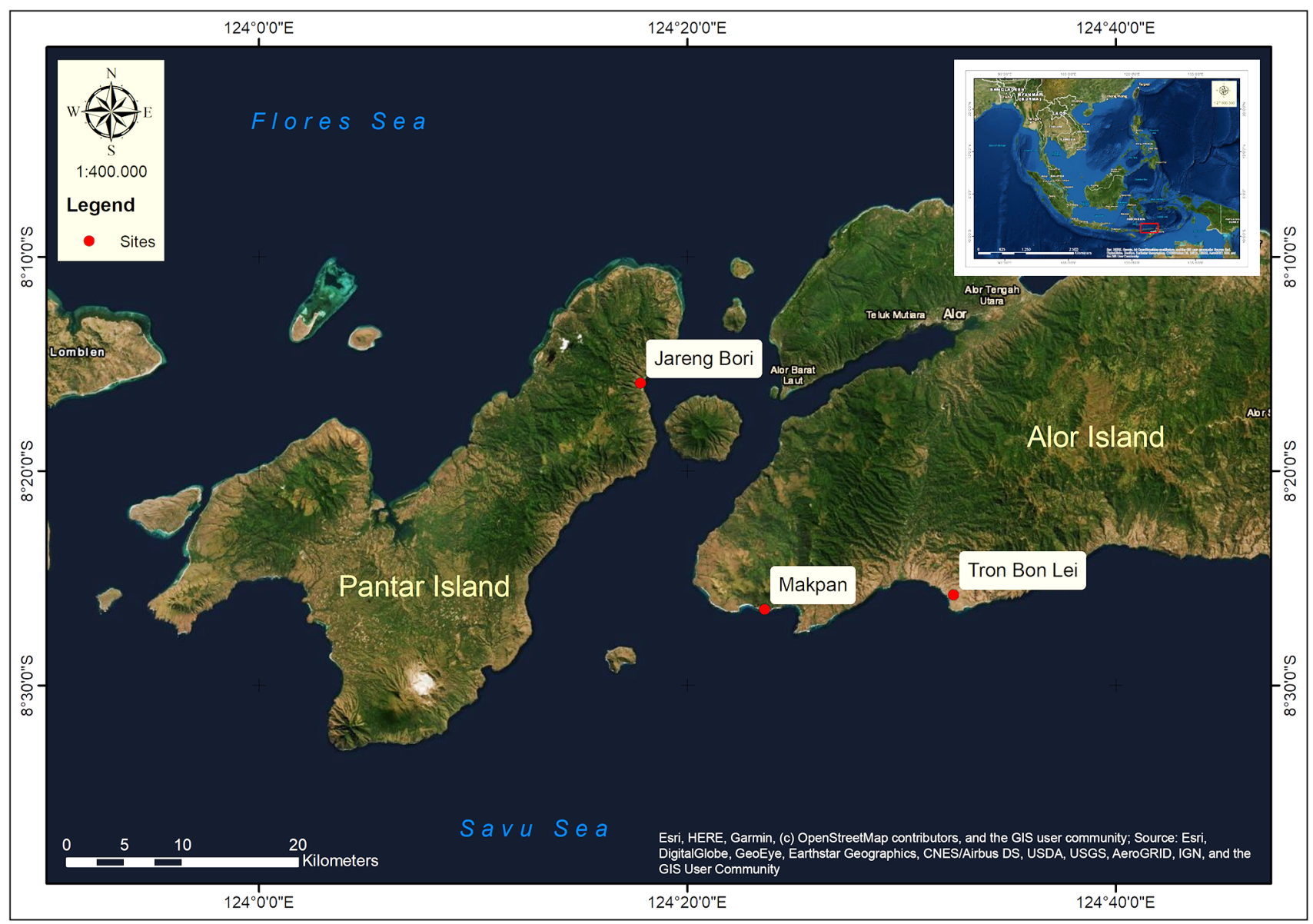

Figure 1. Location of Jareng Bori rockshelter, Pantar Island, eastern Indonesia in relation to recent sites excavated on nearby Alor. 
prominent by the 8 th and 12 th centuries A.D., indicating a growth in Chinese trade during this period (Calo et al., 2020a). At Pangkung Paruk, Roman gold beads were found indicating a southern maritime trade route connecting Bali to the wider Indo-Pacific region since the 1st to 4th centuries A.D. (Calo et al., 2020b). Such networks also likely facilitated the dispersal of commensal rodent species, which began to make an appearance from the Neolithic onwards (Aplin et al., 2003, 2011).

Here we discuss archaeological excavations of the Metal-Age rockshelter, Jareng Bori, on the island of Pantar, East Nusa Tenggara, in the eastern Indonesian region of Wallacea (Fig. 1). We discuss our findings at Jareng Bori rockshelter within a context of Wallacean maritime culture. We use multidisciplinary archaeological data, including zooarchaeological analyses of vertebrate and invertebrate remains, artefact analyses (ceramics, lithics, metal, shell) and geochemical analysis of obsidian flakes from a well dated chronostratigraphic context to add knowledge on maritime trade networks, cultural practices, and socioeconomic systems during this historic period of human settlement. This study represents the first archaeological excavation on the island, and its proximity to recent significant discoveries on Alor (Hawkins et al., 2018; O'Connor et al., 2017b; Samper Carro et al., 2016) made the island an attractive target for investigation. Moreover, the archaeological survey that led to this study was informed by a desire for increased knowledge of the faunal history of the region, and in large part spurred by the need, identified by Ken Aplin, for increased sampling of natural and archaeological records, especially of rodents, on Pantar. Ken Aplin had a deep and enduring interest in archaeology and throughout his career made major contributions to our understanding of human subsistence practices, hunting technology, and faunal succession resulting from environmental change in the Wallacean islands (e.g., Aplin \& Helgen, 2010; O’Connor \& Aplin, 2007; O'Connor et al., 2013). This site report honours Ken Aplin's contribution to the archaeology of this region.

\section{Physical setting}

Pantar Island has a land area of $728 \mathrm{~km}^{2}$ and is the second largest island in the Alor Archipelago. Jareng Bori, located by Pantar Timur school ( $\left.8^{\circ} 15^{\prime} 51.7^{\prime \prime} \mathrm{S} 124^{\circ} 17^{\prime} 55.4^{\prime \prime} \mathrm{E}\right)$, is a small rockshelter formed in a large boulder fallen from the ridgeline above. It is situated on the coastal beach flat at the base of a cliff, $40 \mathrm{~m}$ north of the school and $120 \mathrm{~m}$ from the current shoreline to the east (Fig. 2). The rockshelter has a restricted living floor area of only $40 \mathrm{~m}^{2}$.

\section{Methods and materials}

An intensive survey of Pantar Island was conducted by our joint ANU/Universitas Gadjah Mada team guided by local informants in 2015, focusing on uplifted limestone outcrops along the shoreline, as well as rocky ridges. Prospective rockshelters and caves that had potential or observable archaeological and palaeontological deposits, and modern faunal remains were recorded using GPS and camera, while local names for each site were noted for easy relocation (see Louys et al., 2017 for more detail). Isolated human skeletal
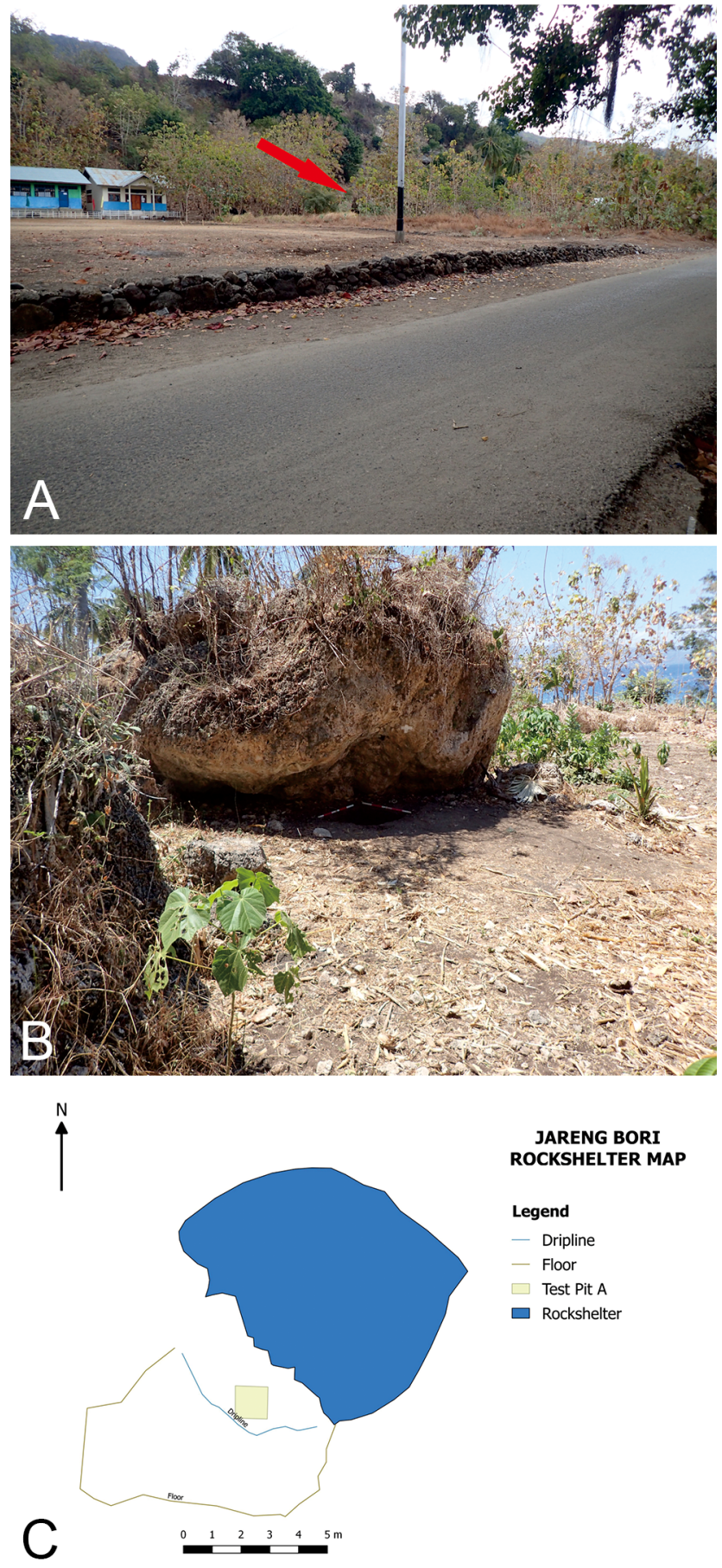

Figure 2. Jareng Bori rockshelter, A: view from the beach facing west, B: the rockshelter facing east towards the beach, C: excavation site plan.

material was also found in a niche on the west coast and dated to c. 2200 cal. BP (Louys et al., 2017). However, and despite two weeks of survey, very few sites with potential deposits were identified, of which only two on Pantar Timur (east Pantar), Jareng Bori, and Sindawapa, showed any promise for archaeological deposits.

Excavations were conducted first at Sindawapa Cave situated at Tuabang village. However, the deposit consisted of recent cave infill comprising rubble, goat bones, and goat dung. It was excavated to a depth of $1.5 \mathrm{~m}$ before it became 
unsafe and excavation was discontinued. The decision was then made to relocate to Jareng Bori rockshelter, $2 \mathrm{~km}$ south. This rockshelter appeared promising as notched rim pottery was discovered on the surface near the lip of the platform beneath the dripline. Pottery was also observed inland of the beach between the road to the base of the cliff where the shelter is located. Today, this area is used for gardening and grazing goats, which probably accounts for the exposure of much of the pottery.

\section{Excavations}

A $1 \mathrm{~m}^{2}$ test excavation was conducted in the shelter in 5 $\mathrm{cm}$ spits within sedimentary stratigraphic layers - test pit A (JAR-A). Features once identified in plan were excavated as discrete provenance units. The 3D position of features, finds and charcoal samples discovered in situ were recorded using a Leica 800 series total station. All excavated sediment was first dry sieved near the rockshelter and then wet sieved at the adjacent beach using $1.5 \mathrm{~mm}$ sieves. Materials were sorted by local field crew under the supervision of students from Universitas Gadjah Mada into general classes (e.g., bone, crustacean, mollusc, sea urchin, charcoal, ceramic, metal, glass bead, and stone artefact). They were later washed in fresh water, re-sorted and analysed in the Archaeology and Natural History (ANH) laboratory at The Australian National University (ANU). In situ charcoal samples were dated at the ANU Radiocarbon Dating Centre (Fallon et al., 2010). All dates were calibrated in OxCal 4.2, using Sh Cal 13 (Hogg et al., 2013) to $95.4 \%$.

\section{Vertebrate fauna}

Vertebrate fauna was analysed in the ANH osteology laboratory by morphological comparison with modern and archaeological reference specimens. All specimens were identified to the lowest taxonomic level possible, in many cases only class, order, family or genus was possible owing to the available reference material and high levels of fragmentation. Fish skeletal identifications followed protocols similar to other studies in the Asia-Pacific region (Dye \& Longenecker, 2004; Leach, 1997; Ono et al., 2012; Samper Carro et al., 2016) that focus on the fivepaired jaw-bones (premaxilla, maxilla, dentary, articular, quadrate) and various special bones including pharyngeal plates, dermal scutes, dermal spines, dorsal spines, and vertebrae. Typically, fish remains in the Pacific are identified only to the family level given the high number of species with morphological similarity. Most elements were highly fragmented or not morphologically distinctive, and these were identified as bony fish specimens (Actinopterygii). Fish feeding behaviour categorization into herbivorous, omnivorous, and carnivorous fish families follows Butler (1994).

Tetrapod remains were identified to various taxonomic levels depending on the presence of diagnostic cranial specimens (e.g., Aplin \& Helgen, 2010). The most fragmented bones, lacking diagnostic morphological features (usually long bone shaft fragments), were only identified to superclass (Tetrapoda) or class (Reptilia, Aves, Mammalia). Limited reference material for birds, lizards, snakes, and bats restricted identification of these taxa to higher categories (Passeriformes, Lacertilia, Serpentes, Chiroptera, respectively). However, fruit bat (Pteropodidae) bones are quite distinctive from insectivorous bats and these could often be distinguished based on articulating limb appendages and cranial material. Turtle bones were identified to the superfamily level (Chelonioidea) as extant species worldwide can only be distinguished by mandibles and crania (Wyneken \& Witherington, 2001), which were not present. Bones belonging to the Muridae were sorted by size (small or large). More specific identifications to species and genus were made on the maxillae and mandible teeth and tooth rows.

Vertebrates were quantified by the Number of Identified Specimens Present (NISP) and weight. These quantitative methods are independent of aggregated provenance units and avoid the overestimation of rare taxa (Lyman, 2008). Change in fish feeding behavior over time was statistically quantified using Cochrane's test of linear trends, which is a linear chi square test that takes sample size into account (Zar, 2010).

\section{Invertebrate fauna}

Jareng Bori molluses were identified using the ANH malacology collections at The Australian National University as well as those housed at the Museum and Art Gallery of the Northern Territory (MAGNT). Mollusc remains were quantified by recording the Number of Identifiable Specimens Present (NISP), Minimum Number of Individuals (MNI) and weight (g) of each taxon per spit. The MNI was calculated by selecting the most frequently occurring nonrepetitive element (NRE) for each identified taxon; this element was then recorded consistently throughout all spits (Claassen, 1998).

Jareng Bori crustaceans were identified using the ANH reference collection and the marine invertebrate collection at the Muséum national d'Histoire naturelle in Paris. Sea urchin and barnacle remains were quantified by weight (g) per spit at The Australian National University. Crab remains - exoskeleton, cheliped, and dactyl fragmentswere quantified by recording the Number of Identifiable Specimens (NISP) and weight of each taxon per spit.

\section{Bioarchaeology}

The human burial was excavated in the southern area of test pit A in accordance with standard field procedures (Bass, 1995; Willis \& Tayles, 2009) as a separate feature and was recorded digitally using a digital camera and total station 3-D plotting to determine the burial position and orientation to understand mortuary practices at Jareng Bori during late history. Much of the burial was disturbed by ant nests and tree roots, so the skeletal material was damaged and slightly disarticulated. The skull and most of the upper body and limbs were excavated; however, the rest of the skeleton which extends into the south wall of the pit remains unexcavated. The skeletal material from the burial was first carefully cleaned using ethanol in the Archaeology and Anthropology Quarantine laboratory at ANU to remove encrusted sediment to make observations possible (after Gilbert, 2015). 


\section{Pottery}

Data from both metric measurements and non-metric observations were recorded and taken from various attributes in the sherds and simultaneously used in their analysis. These attributes include their weight, sherd thickness, estimated rim diameter, rim form, vessel-forming techniques and associated surface treatment and decoration. All sherds bearing potentially diagnostic characteristics useful for typological identification-such as rim and base form, surface treatment and decoration-were photographed and described in greater detail.

Considering that the identification of attributes on sherds under $1 \mathrm{~g}$ is not as accurate as on large sherds, only the sherds $\geq 1$ g were comprehensively analysed in order to avoid biases caused by the highly fragmentary nature of majority of the assemblage. However, decorated and/or slipped and/or rim sherds under $1 \mathrm{~g}$ were included in the analysis because of their relative paucity.

All ceramic samples were gently cleaned with fresh water and soft bristle toothbrushes to remove residual sediment and thereafter, individually laid out to dry. The weight of each sherd was measured using a scale with the smallest increment limited to $1 \mathrm{~g}$. Sherd thickness and dimensions were measured using a pair of metal electronic digital callipers to the nearest $0.1 \mathrm{~mm}$. Measurements of rim, orifice and basal diameters were estimated using a rim diameter estimating chart.

\section{Lithics}

Stone artefacts were identified following Hiscock (2007), with flakes, flake fragments, cores, and flaked pieces counted. Heat shatter present on stone artefacts was recognized by crazing, potlids, and crenulated surfaces. No morphological analysis was conducted.

\section{Geochemical analysis of obsidian flakes}

The obsidian artefacts were geochemically fingerprinted by portable X-Ray Fluorescence analysis ( $\mathrm{pXRF}$ ) with a Bruker Tracer III-SD. Manufacturer recommended settings of 40 $\mathrm{keV}$ and $42 \mathrm{~mA}$ were employed using a $0.1524 \mathrm{~mm} \mathrm{Cu}$, $0.0254 \mathrm{~mm}$ Ti and $0.3048 \mathrm{~mm} \mathrm{Al}$ filter in the X-Ray path and a $60 \mathrm{~s}$ live-time count at 145 FWHM setting. The raw counts of the pXRF were calibrated using 40 international standards provided by MURR (Glascock \& Ferguson, 2012). Each artefact was analysed at two spots. Element concentrations of manganese $(\mathrm{Mn})$, iron $(\mathrm{Fe})$, zinc $(\mathrm{Zn})$, gallium $(\mathrm{Ga})$, thorium (Th), rubidium $(\mathrm{Rb})$, strontium $(\mathrm{Sr})$, yttrium $(\mathrm{Y})$, zirconium $(\mathrm{Zr})$, and niobium $(\mathrm{Nb})$ were calculated.

\section{Metal}

A section of the corroded ferrous metal fragment surface was cleaned and a pXRF (Bruker Tracer III-V+) used to examine the composition of the oxidized and parent material. Three analyses were made of the cleaned area and six analyses of the corrosion surface, with measurements for each area averaged. Instrument parameters were $40 \mathrm{keV}, 27 \mu \mathrm{A}$, using a filter ( 12 mil Aluminium +1 mil Titanium +6 mil Titanium $)$ in the X-ray path and a $180 \mathrm{~s}$ live-time count at $185 \mathrm{FWHM}$. Element fluorescence peaks (Calcium, Ca; Chromium, Cr; Manganese, Mn; Iron, Fe; Strontium, Sr; Molybdenum, Mo) were examined semi-quantitatively with ROI data in the S1PXRF program.

\section{Results}

\section{Excavations}

A total of 21 spits, ranging from $2-6 \mathrm{~cm}$ depending on the depth of stratigraphic layers, were excavated to a maximum depth of $120 \mathrm{~cm}$. Seven stratigraphic layers, and one burial feature in the south side of the excavation in plan and extending into the southern wall, were identified (Fig. 3), from which a number of cultural materials (pottery, lithics, animal bone, molluscs, shell artefacts) and charcoal for radiocarbon dating were recovered (Tables 1-2).

Layer 1 (spit 1) is a thin $(2-3 \mathrm{~cm})$ topsoil layer of loosely consolidated soft light brown (10 YR 3/4) silty sand and small amounts of limestone rubble inclusions, molluses, vertebrates, lithics, and an incised rim-sherd. Layer 2 (spit 2: 5-10 cm) occurs in the southern and western sections, with Layer 3 (spit 3: 5-15 cm) apparent in the north and east sections. Layer 2 is a light brown compact silty sand (10 YR $3 / 4$ ) and layer 3 is a mixed dark brown silty sand sediment less compact than layer 2 with more limestone rubble (10 YR 3/3), including the top of the burial grave feature which was cut through this layer. Both layers contained pottery, lithics, charcoal, bones, and molluscs with signs of insect bioturbation and tree root disturbances in the northwestern corner. Layer 2 was compact silt with a chert flake, human bone, pig bone, and pottery recovered during excavation. Layer 3 was less compact dark brown silty sand with limestone rubble, pottery, charcoal, shellfish, and fishbone.

Layer 4 (spits 4-6) is a light grey moderately compact silty sand layer with (10 YR 5/3) with an average thickness of $5-15 \mathrm{~cm}$. Ant nest disturbance and tree roots became apparent in this layer, which contained shellfish, limestone rubble, and fishbone. In spits $4-6$, the human grave cuts through layer 4 about $20 \mathrm{~cm}$ deep in the eastern half of the square. This side of the square continued to be excavated separately as a burial deposit once the outline of the burial could be determined. The skeleton's base was c. $40 \mathrm{~cm}$ deep, extending from spit 5 to spit 9 (through layers 4-5). The burial was of a small individual which appears in the foetal position lying on the right side with arms tucked in near the rib cage and knees tucked in facing south towards the school (Fig. 4). The lower leg was left unexcavated in the southern baulk. The cervical column was damaged by rockfall and the skull was disturbed by tree roots. The skeletal material was fragile and eroding within the sedimentary matrix of the burial fill. It is poorly preserved with tree roots crushing the skull and neck, and ant nests throughout the burial. The atlas was discovered quite far from the disturbed neck area. The bone was carefully excavated owing to the post-depositional weathering. The burial appears to be a shallow grave with fragmented pottery included in the fill, which as noted below is believed to be an incidental inclusion. There was no sign of grave goods aside from some poorly preserved fragments of Nautilus shell which may have been placed with the burial.

Layer 5 (spits 7-9) (10 cm thick) consists of a dark brown alluvial silt sand with increased small limestone rubble (10 YR 3/3). Layer 6 (spits 10-12) (15 cm thick) is a mixed anthropogenic alluvial sediment dark brown with less small limestone rubble (10 YR 3/3), but increasingly larger limestone boulders which covered most of the square. Layer 7 (spits 13-21) is dark brown silt sand sediment (10 YR 2/2) with larger limestone rubble in between bedrock (50 
$\mathrm{cm}$ thick in places). Sediment gradually declined in volume down to spit 21 , by which stage very little sediment was being retrieved and the base was reached. Oven stones were recorded in this layer and pottery was abundant.

\section{Radiocarbon dating}

Twenty in situ charcoal radiocarbon samples were recovered and dated (ANU 53113-53139) (Table 1), suggesting three occupation periods. The first covers most of the deposit with spits 1-12 (layers 1-6) and the human burial excavated from layer 3 into layer 4 . These contexts all appear modern with 15 dates clustered between $430-0$ cal. BP, although there is one inversion in spit $11 \mathrm{c}$. 1384-1524 cal. BP (ANU 53131). Four of the dates are associated with the burial, including one adjacent to the skull (ANU 53127) 0-304 cal. $\mathrm{BP}$ in spit 7, and another from the base of the skull (ANU 53130) 0-423 cal. BP in spit 8; (ANU 53129) 152-429 cal. $\mathrm{BP}$ from charcoal in sediment inside the mouth of the skull in spit 7; and (ANU136) 0-420 cal. BP from a charcoal sample under the right arm in spit A9. A middle occupation phase represented by one date gives an age of 1187-1305 cal. BP (ANU 53137) in the upper part of layer 7 in spit 14 , while the basal part of layer 7 deposit is dated between 1612-1807 cal. BP with two dates falling within the range (ANU 53138-53139) in spits 18-19.

\section{Fauna}

\section{Vertebrates}

In total 8958 vertebrate remains were recovered from Jareng Bori rockshelter (Table 3). Most of these were concentrated in the lower two layers, 6 (NISP $=1943$ ) and 7 (NISP = 4209) with 19.12 and 17.02 bones respectively per kilogram of sediment compared to 2.64 for layer 1, 2.85 for layers 2 and 3, 4.8 for layer 4, and 7.96 for layer 5 (Table 2). Most of the vertebrate remains were those of noticeably small fish $(\mathrm{NISP}=7771)$ based on the size of jaw bones and vertebrae, including sharks of the family Carcharhinidae and bony fishes (Actinopterygii) that made up $86.8 \%$ of the vertebrate assemblage. Mammals were represented in modest quantities including small rats, shrews, and bats. Reptiles included small amounts of small squamate lizards (Lacertilia) and snakes (Serpentes) with very small amounts of marine turtle (Chelonioidea). Bird bones were represented by a single large passerine element. A single amphibian bone was recovered from spit 15 in layer 7. A single shrew (Soricidae) was identified from layer 4 in the late historic period. Fruit bat (Pteropodidae) bones were present in very small numbers between spits 2 to 9 (layers 2-5). Domesticates including pig (Sus scrofa) bones were associated with late historic provenances between spits $1-5$ in the upper layers. A dog (Canis familiaris) canine tooth was recovered from the middle occupation period (1187-1365 cal. BP) in spit 14. Small rat bones were consistently recovered throughout the sequence, of which Rattus sp. and Melomys sp. were identified to genus.

Only $5 \%$ of the fish bones were identified to taxon, including 16 families, dominated by small herbivorous and omnivorous taxa: balistids (triggerfishes), ostraciids (boxfishes), acanthurids (surgeonfishes, tangs, and unicornfishes), diodontids (porcupinefishes), with smaller numbers of carnivorous fish taxa including serranids
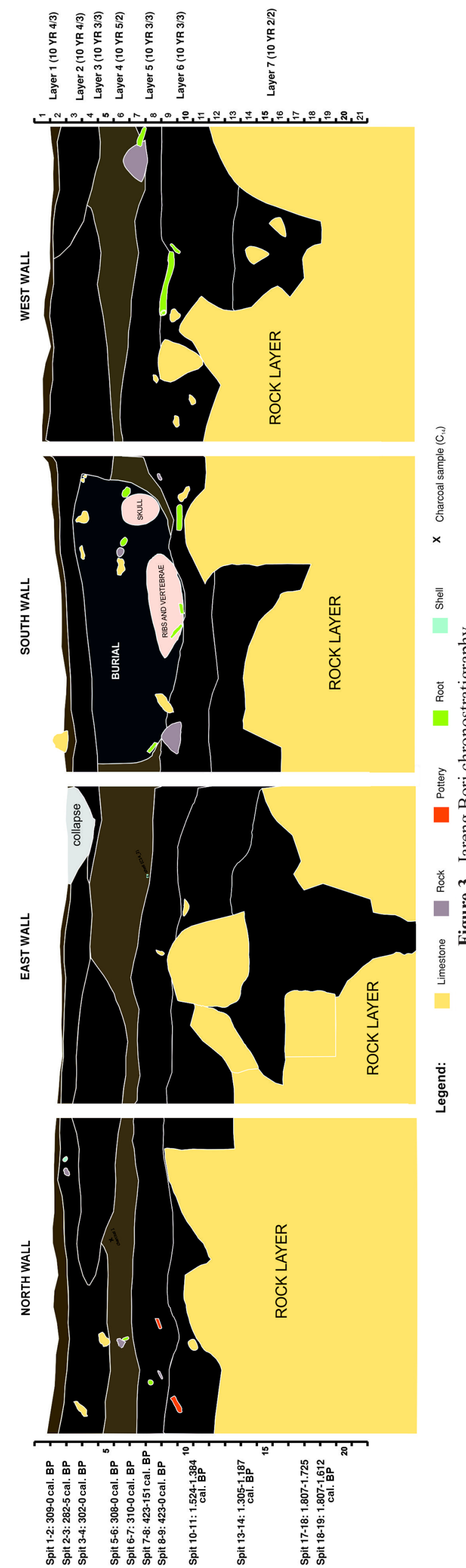
Table 1. Jareng Bori radiocarbon dates by provenance.

\begin{tabular}{lcccccccc}
\hline spit (depth) & $\begin{array}{c}\text { in situ sample } \\
\text { number }\end{array}$ & $\begin{array}{c}\text { stratigraphic } \\
\text { unit }\end{array}$ & $\begin{array}{c}\text { AMS } \\
\text { code }\end{array}$ & ID & material & $\begin{array}{c}\text { radiocarbon } \\
\text { age (years) }\end{array}$ & $\begin{array}{c}\text { age range } \\
\text { cal. BP (95.4\%) }\end{array}$ \\
\hline S16 JAR A2 & C14-1 & 1 & 53113 & 16877 & charcoal & 230 & 23 & $309-0$ \\
S18 JAR A2 & n/a & $2-3$ & 53114 & 16878 & charcoal & 144 & 24 & $282-5$ \\
S19 JAR A3 & C14-2 & $2-3$ & 53116 & 16879 & charcoal & 191 & 23 & $293-0$ \\
S20 JAR A3 & C14-3 & $2-3$ & 53117 & 16880 & charcoal & 175 & 24 & $289-0$ \\
S21 JAR A4 & C14-4 & 4 & 53118 & 16881 & charcoal & 205 & 23 & $302-0$ \\
S22 JAR A4 & C14-5 & 4 & 53121 & 16882 & charcoal & $>$ Modern & -12 \\
S23 JAR A6 & C14-7 & 4 & 53123 & 16883 & charcoal & $>$ Modern & - \\
S24 JAR A6 & C14-8 & 4 & 53124 & 16884 & charcoal & 225 & 23 & $308-0$ \\
S25 JAR A6 & C14-9 & 4 & 53125 & 16885 & charcoal & 232 & 23 & $310-0$ \\
S26 JAR A7 & C14-11 & 5 & 53126 & 16886 & charcoal & 250 & 23 & $423-151$ \\
S27 JAR A7 & C14-12 & 5 & 53127 & 16887 & charcoal & 215 & 23 & $304-0$ \\
S28 JAR A7 & C14-13 & 5 & 53129 & 16888 & charcoal & 265 & 25 & $429-152$ \\
S30 JAR A8 & C14-14 & 5 & 53130 & 16890 & charcoal & 248 & 24 & $423-0$ \\
S27 JAR A7 a & n/a & 5 & 53133 & 16902 & charcoal & 208 & 23 & $303-0$ \\
S34 JAR A9 & C14-15 & 5 & 53136 & 16894 & charcoal & 242 & 23 & $420-0$ \\
S31 JAR A11 & C14-16 & 6 & 53131 & 16891 & charcoal & 1548 & 24 & $1524-1384$ \\
S32 JAR A12 & C14-17 & 6 & 53132 & 16892 & charcoal & 236 & 23 & $310-0$ \\
S35 JAR A14 & C14-18 & 7 & 53137 & 16895 & charcoal & 1343 & 24 & $1305-1187$ \\
S36 JAR A18 & C14-20 & 7 & 53138 & 16896 & charcoal & 1863 & 24 & $1807-1725$ \\
S37 JAR A19 & C14-21 & 7 & 53139 & 16897 & charcoal & 1773 & 24 & $1807-1612$ \\
\hline
\end{tabular}

a duplicate

Table 2. Jareng Bori materials recovered (bone, marine shell, chert, obsidian, pottery, charcoal, seed, and wood), sediment volume (before sieving/bucket weight) and residue weight (discarded material in field after sieving and field sorting), by spit and layer.

\begin{tabular}{|c|c|c|c|c|c|c|c|c|c|c|c|}
\hline layer & spit & $\begin{array}{l}\text { bone } \\
\text { (NISP) }\end{array}$ & $\begin{array}{l}\text { marine shell } \\
\text { (NISP) }\end{array}$ & $\begin{array}{l}\text { chert } \\
\text { (n) }\end{array}$ & $\begin{array}{l}\text { obsidian } \\
\text { (n) }\end{array}$ & $\begin{array}{l}\text { pottery } \\
\text { (n) }\end{array}$ & $\begin{array}{l}\text { charcoal } \\
(\mathrm{g})\end{array}$ & $\begin{array}{l}\text { seed } \\
(\mathrm{g})\end{array}$ & $\begin{array}{l}\text { wood } \\
(\mathrm{g})\end{array}$ & $\begin{array}{l}\text { bucket } \\
\text { weight (g) }\end{array}$ & $\begin{array}{l}\text { residue } \\
(\mathrm{g})\end{array}$ \\
\hline surface & - & - & - & - & - & 5 & - & - & - & - & - \\
\hline 1 & A01 & 212 & 52 & 11 & 6 & 86 & 6.3 & 69.3 & 0.02 & 80.3 & 6.4 \\
\hline \multirow[t]{2}{*}{$2-3$} & A02 & 182 & 72 & 1 & 1 & 78 & 2.3 & 84.2 & 0.09 & 57.4 & 5.7 \\
\hline & A03 & 185 & 57 & 1 & 2 & 187 & 13.6 & 91.9 & - & 71.2 & 6.7 \\
\hline \multirow[t]{3}{*}{4} & A04 & 322 & 152 & - & - & - & 7.3 & 28.7 & - & 77.6 & 9.8 \\
\hline & A05 & 520 & 259 & 1 & - & 277 & - & 7.1 & - & 66.2 & 9.9 \\
\hline & A06 & 170 & 408 & - & - & 186 & 3.7 & - & - & 67.2 & 10.2 \\
\hline \multirow[t]{3}{*}{5} & A07 & 432 & 546 & - & - & 178 & 8.9 & - & - & 62.1 & 11.0 \\
\hline & A08 & 381 & 379 & 3 & 1 & 42 & 3.8 & 0.1 & - & 49.5 & 8.2 \\
\hline & A09 & 402 & 215 & - & - & 355 & 4.2 & - & - & 41.0 & 4.8 \\
\hline \multirow[t]{3}{*}{6} & A10 & 693 & 245 & - & - & 216 & 7.6 & 0.1 & - & 25.7 & 8.1 \\
\hline & A11 & 584 & 372 & - & - & 153 & 2.3 & - & - & 41.7 & 5.8 \\
\hline & A12 & 666 & 402 & 6 & 4 & 151 & 3.4 & - & - & 34.2 & 3.6 \\
\hline \multirow[t]{9}{*}{7} & A13 & 413 & 171 & - & - & 90 & - & - & - & 30.7 & 3.5 \\
\hline & A14 & 1393 & 676 & 3 & - & 412 & 29.6 & - & - & 60.5 & 9.2 \\
\hline & A 15 & 809 & 345 & 2 & 1 & 180 & 9.2 & - & - & 26.7 & 5.6 \\
\hline & A16 & 472 & 182 & 2 & - & 102 & 39.9 & - & - & 28.4 & 4.0 \\
\hline & A17 & 348 & 256 & 1 & - & 52 & 1.9 & - & - & 37.4 & 5.3 \\
\hline & A18 & 144 & 71 & - & - & 17 & 1.4 & - & - & 13.0 & 2.1 \\
\hline & A19 & 360 & 164 & - & 1 & 83 & 40.7 & $<0.1$ & - & 26.1 & 6.9 \\
\hline & A20 & 146 & 65 & - & - & 16 & 0.2 & - & - & 11.6 & 1.6 \\
\hline & A21 & 124 & 9 & - & - & 5 & - & - & - & 12.9 & 1.8 \\
\hline burial & - & - & 1 & - & - & - & - & - & - & - & - \\
\hline total & - & 8958 & 5099 & 31 & 16 & 2871 & 186.2 & 281.4 & 0.1 & 921.5 & 130.3 \\
\hline
\end{tabular}




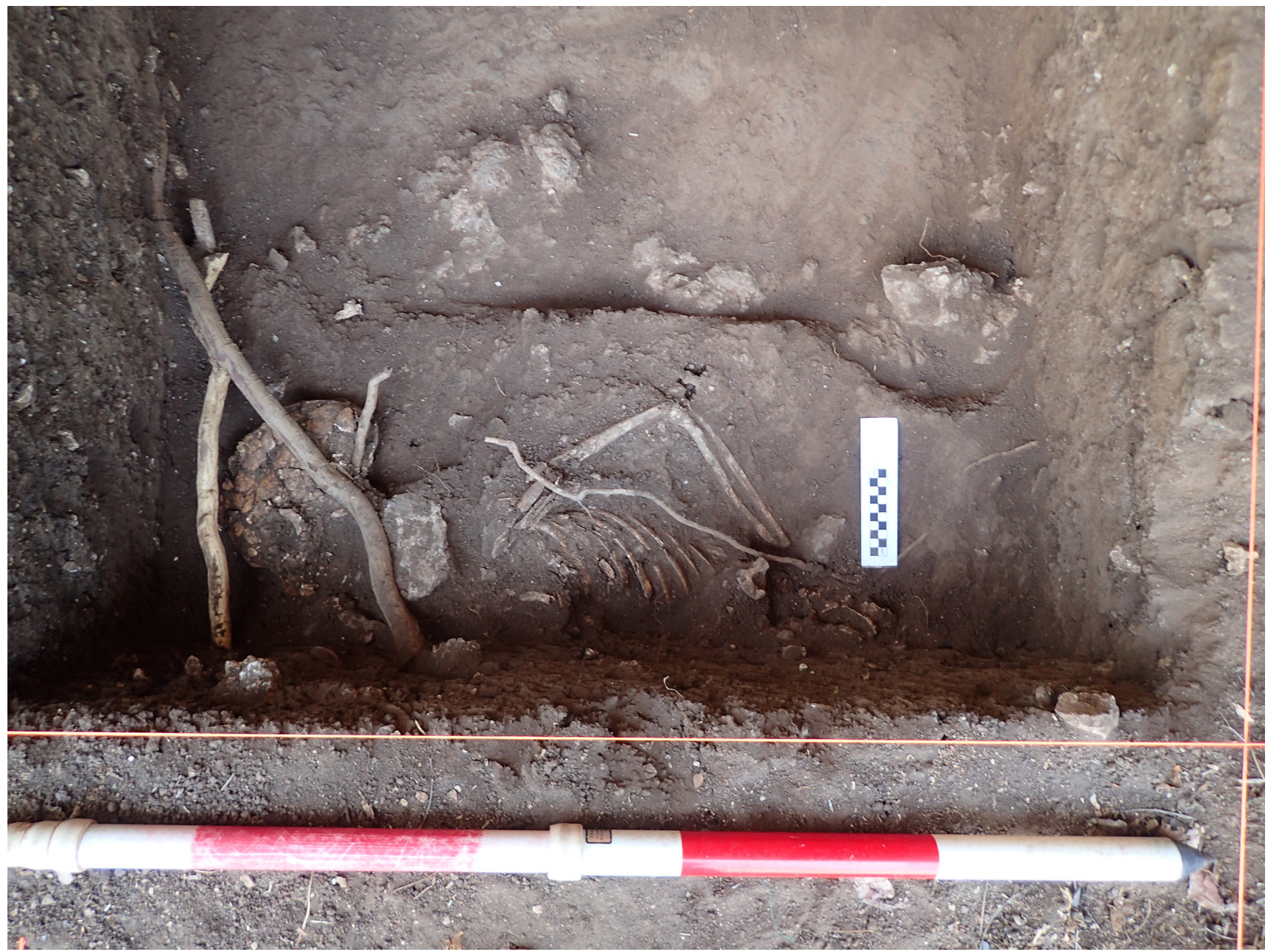

Figure 4. Jareng Bori late historic burial c. 0-429 cal. BP layers 4-5 (spits 6-9). Scale bar: 20 cm units.

(groupers), labrids (wrasses), holocentrids (squirrelfishes), and muraenids (moray eels). The proportions of herbivorous and omnivorous fishes versus carnivorous fishes are higher in the upper three layers, however, there are no statistically significant changes over the course of the entire sequence $\left(\chi_{\text {trend }}^{2}=2.443, \mathrm{p}=0.118 ; \chi^{2}\right.$ departure $\left.=5.202, \mathrm{p}=0.267\right)$.

\section{Invertebrates}

The major molluscan taxa are summarized in Fig. 5 and their habitats in Fig. 6. Table 4 summarizes all results by NISP (see also appendices for results by NISP [Appendix 1], MNI [Appendix 2] and weight [Appendix 3]). Marine shellfish occurred from the surface to the base in spit 21 (square A, total NISP = 5099; MNI = 1176; weight = 3595.1 g), with a peak in MNI, NISP and weight in spit 14, during the middle occupation period. Terrestrial gastropods were found in small quantities throughout, totalling $96.3 \mathrm{~g}$, also peaking in spit 14 (12.2 g). At least 79 species of marine molluscs were identified from a range of marine habitats including rocky and coral reef intertidal zones, deep water, sea grass flats near reefs and mangrove zones. Rocky and coral reef zones dominate throughout the sequence. The most abundant species, Nerita polita (NISP 2036, MNI 486, weight 362.1 $\mathrm{g})$, comprised almost half of the assemblage by NISP and MNI, of which many specimens were juvenile, indicating frequent harvesting of this species.
Crab occurs from the surface to spit 20 (NISP $=406$; weight $=14.0 \mathrm{~g})$. At least nine different taxa were identified from a range of terrestrial (Ocypodidae, Paguroidea), marine (Cirripedia, Etisus sp.), and mangrove environments (Portunidae: Scylla sp., Thalamita crenata). The dominant taxon is Paguroidea (hermit crab) (NISP $=207)$, representing more than the half of the assemblage. The intertidal dwelling barnacle Megabalanus sp. was identified in spits 5, 8 and 10 (total $=2.3 \mathrm{~g}$ ). Sea urchin was also recovered in small amounts (spits 5, 6, 7, 9, 10-15, 17, 19, 20, total =4.2 g).

\section{Late historic burial}

The burial (Fig. 4) was poorly preserved, and disturbed post-deposition by rockfall, tree roots, and ant nests. It was first encountered in layer 3 (between spits 6-9) and appears to have been dug as a shallow grave through layer 4 in the southern side of the square. The sediment around the burial was excavated separately within each spit as a burial unit although the burial fill could not be distinguished during excavation. The burial, which had filing of the front teeth (filed labial and occlusal surfaces of the upper first and second incisors) (Fig. 7), was in the flex position. More details of this burial with regards to the specifics of tooth ablation, dietary reconstruction, ancestry, stature, sex, and age will be presented in a subsequent paper. 
Table 3. Jareng Bori vertebrate fauna. Number of Identified Specimens (NISP) by spit.

\begin{tabular}{|c|c|c|c|c|c|c|c|c|c|c|c|c|c|c|c|c|c|c|c|c|c|c|}
\hline & spit & & & & & & & & & & & & & & & & & & & & & total \\
\hline taxon & A01 & A02 & A03 & A04 & A05 & A06 & A07 & A08 & A09 & A10 & A11 & A12 & A13 & A14 & A15 & A16 & A17 & A18 & A19 & A 20 & A21 & (NISP) \\
\hline \multicolumn{23}{|l|}{ Fish } \\
\hline Acanthuridae & 1 & - & - & 1 & 1 & - & 3 & - & 1 & 4 & 7 & 2 & 2 & 5 & 4 & 4 & 4 & - & 3 & - & - & 42 \\
\hline Balistidae & - & - & - & 2 & 4 & - & 10 & 5 & 1 & 4 & 8 & 13 & 6 & 19 & 7 & 1 & - & 2 & 4 & 5 & - & 91 \\
\hline Belonidae & - & - & - & - & - & 1 & - & - & 1 & 1 & - & 2 & 1 & - & 1 & - & - & - & - & - & - & 7 \\
\hline Carangidae & - & - & - & - & - & - & - & - & - & 3 & - & - & - & - & 1 & - & - & - & 1 & - & - & 5 \\
\hline Carcharhinidae & - & - & - & - & - & - & - & - & - & - & - & - & - & - & 1 & - & - & - & - & - & - & 1 \\
\hline Holocentridae & - & - & 1 & - & - & - & 4 & 1 & 2 & 3 & 2 & 2 & 1 & 2 & 2 & - & - & - & 4 & - & - & 24 \\
\hline Diodontid & 8 & - & 5 & 4 & 6 & - & 3 & 2 & 2 & 4 & 5 & - & - & 1 & 0 & - & - & - & 1 & - & - & 41 \\
\hline Labr & 1 & - & - & 1 & - & - & - & 1 & 2 & - & 2 & 7 & 1 & 7 & 2 & 1 & 3 & - & - & - & - & 28 \\
\hline Lethri & - & - & - & - & 1 & 1 & 3 & - & 2 & - & 1 & 2 & - & 1 & 0 & - & - & - & - & - & - & 11 \\
\hline Lutjanidae & - & - & - & - & - & - & 1 & - & - & 1 & 2 & - & - & - & 0 & 1 & - & - & - & - & - & 5 \\
\hline Muraenidae & - & - & - & - & - & - & 1 & 1 & - & 1 & 2 & 4 & 1 & - & 2 & - & 3 & - & 4 & 1 & - & 20 \\
\hline Mullic & - & - & - & - & - & - & - & - & - & - & 一 & 1 & - & 1 & 1 & - & - & - & - & - & - & 3 \\
\hline Ostr & - & - & - & 1 & 2 & 1 & - & 5 & 4 & 6 & 8 & 4 & 2 & 14 & 2 & - & 1 & 3 & 1 & - & - & 54 \\
\hline Scaridae & - & - & - & 2 & 1 & 1 & 1 & - & - & - & 2 & - & 1 & 6 & 1 & - & - & - & 1 & - & - & 16 \\
\hline Serranidae & 1 & - & 1 & 1 & 1 & - & 3 & 2 & 4 & 4 & 2 & 2 & 1 & 6 & 8 & 1 & 3 & - & - & - & - & 40 \\
\hline Sphy! & - & - & - & - & - & - & - & - & - & - & - & - & - & 1 & - & - & - & - & - & - & - & 1 \\
\hline \multirow{2}{*}{\multicolumn{23}{|c|}{ 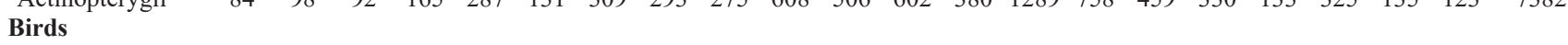 }} \\
\hline & & & & & & & & & & & & & & & & & & & & & & \\
\hline Passeriformes large & $e-$ & - & 1 & - & - & - & - & - & - & - & - & - & - & - & - & - & - & - & - & - & - & 1 \\
\hline Unidentified & 3 & 2 & 1 & 5 & 5 & 2 & 3 & 1 & 0 & 6 & - & - & - & - & - & - & - & - & 3 & - & - & 31 \\
\hline \multicolumn{23}{|l|}{ Amphibians } \\
\hline Anura & - & - & - & - & - & - & - & - & - & - & - & - & - & - & 1 & - & - & - & - & - & - & \\
\hline \multicolumn{23}{|l|}{ Reptiles } \\
\hline Lacertilia & 9 & 8 & 5 & 7 & 5 & - & 2 & 3 & 2 & - & 3 & 4 & 1 & 3 & 7 & 2 & 1 & 1 & 1 & - & - & 64 \\
\hline Chel & - & - & - & - & - & 1 & - & - & - & - & 1 & - & - & - & - & - & - & - & - & - & - & 2 \\
\hline \multirow{2}{*}{\multicolumn{23}{|c|}{ Mammals }} \\
\hline & & & & & & & & & & & & & & & & & & & & & & \\
\hline Chiroptera & - & - & - & - & - & - & - & - & 一 & - & - & - & - & - & 1 & - & - & - & - & - & - & 1 \\
\hline Pterop & - & 2 & - & - & - & - & - & 2 & 1 & - & - & 一 & - & - & - & - & - & - & - & - & - & 5 \\
\hline Sus st & 1 & 1 & - & 1 & 1 & - & - & - & - & - & - & - & - & - & - & - & - & - & - & - & - & 4 \\
\hline Canis familiaris & - & - & - & - & - & - & - & - & - & - & - & 1 & - & 1 & - & - & - & - & - & - & - & 2 \\
\hline Carnivol & - & - & - & - & - & - & - & - & - & - & - & - & 1 & - & - & - & - & - & - & - & - & 1 \\
\hline Homo & - & - & - & - & - & - & - & - & - & 2 & - & - & - & - & - & - & - & - & - & - & - & 2 \\
\hline & 6 & 6 & 11 & 16 & 10 & 1 & 4 & 5 & 7 & 8 & 7 & 4 & 1 & 7 & 4 & 1 & 3 & 2 & 8 & 5 & 1 & 117 \\
\hline Murid & - & - & - & - & - & - & - & - & - & - & - & - & - & 3 & - & - & - & - & - & - & - & 3 \\
\hline Melom & - & - & - & - & 1 & - & - & - & - & - & - & - & - & - & - & - & - & - & - & - & - & 1 \\
\hline Rattus & 5 & 7 & 3 & 4 & 5 & 1 & - & - & 1 & 1 & - & - & - & - & - & - & - & - & - & - & - & 27 \\
\hline Soricidae & - & - & - & 1 & - & - & - & - & - & - & - & - & - & - & - & - & - & - & - & - & - & 1 \\
\hline mammal & 2 & - & 7 & 10 & 26 & 5 & - & 14 & 6 & 12 & 3 & - & 13 & 18 & 1 & - & - & - & - & - & - & 117 \\
\hline & - & - & - & - & - & - & - & - & - & - & 21 & - & - & - & - & - & - & - & - & - & - & 21 \\
\hline Tetrapod & 82 & 52 & 44 & 95 & 155 & 25 & 84 & 43 & 89 & 24 & - & 16 & - & 9 & 4 & 2 & - & 3 & 1 & - & - & 728 \\
\hline total (NISP) & 212 & 182 & 185 & 322 & 520 & 170 & 432 & 381 & 402 & 693 & 584 & 666 & 413 & 1393 & 809 & 472 & 348 & 144 & 360 & 146 & 124 & 8958 \\
\hline
\end{tabular}

\section{Artefacts}

\section{Shell tools}

Shell scrapers were found from spits 5-16, manufactured on bivalves (Asaphis violascens and Pitar sp.) and univalves (Cellana testudinaria) (see Fig. 8). Two examples of Tridacna were also found, and may represent potential adzes, however, these specimens are too weathered to conclusively ascertain use-wear traces.

\section{Shell and glass bead ornaments}

Nautilus shell fragments were recovered from spits 4-17 and two Nautilus disc-beads, one single hole and one double hole (spit 10), were identified. A single oblate black glass bead was found in spit 4 .

\section{Ceramics}

Ceramics were recovered throughout the sequence with the highest concentration in spit 14 during the middle occupation period (Table 5-6). Of the total 2871 samples, 933 were analysed in detail; 836 sherds have weights above or equal to $1 \mathrm{~g}(29 \%$ of the collection), 81 (of which 46 are under $1 \mathrm{~g}$ ) sherds are decorated, 44 are slipped, 79 are black-burnished and 48 are fragments of vessel rims (Table 5).

Technology. The majority of the assemblage analysed (724 sherds; $82 \%$ ) is composed of medium-paste earthenware vessel fragments with a predominance of medium to fine sand mineral inclusions $(0.125-0.25 \mathrm{~mm})$ within their fabric. Occasionally, stray coarse sand $(0.5-1 \mathrm{~mm})$ to granule $(2-4 \mathrm{~mm})$ mineral inclusions are present, but they are usually low in frequency. This results in a relatively "rough" surface texture on both exterior and interior surfaces, but this "roughness" is often mitigated by smoothing or burnishing (surface treatment does not appear 
Table 4. Jareng Bori marine molluscs, number of identified specimens (NISP). See Appendices 2 and 3, for MNI and weight.

\begin{tabular}{|c|c|c|c|c|c|c|c|c|c|c|c|}
\hline taxon & A01 & A02 & $\mathrm{A} 03$ & A04 & A05 & A06 & $\begin{array}{l}\text { A06 } \\
\text { (B) }\end{array}$ & A07 & $\begin{array}{c}\mathrm{A} 07 \\
\text { (B) }\end{array}$ & A08 & $\begin{array}{l}\text { A08 } \\
\text { (B) }\end{array}$ \\
\hline Acanthopleura sp. & 3 & 5 & 2 & 10 & 26 & 53 & 4 & 52 & 18 & 23 & 10 \\
\hline Cryptoplax sp. 1 & - & - & - & - & 1 & 3 & - & - & - & 2 & - \\
\hline Cryptoplax sp. 2 & - & - & - & - & - & - & - & - & 1 & - & - \\
\hline Haliotis sp. & 1 & - & - & 1 & 3 & 2 & - & 3 & - & 2 & 1 \\
\hline Patella sp. & - & - & 2 & - & - & - & - & 1 & - & - & - \\
\hline Cellana testudinaria & - & - & - & - & 2 & 14 & - & - & - & 4 & - \\
\hline Trochus maculatus & 3 & - & - & 9 & - & - & 1 & - & 17 & 12 & - \\
\hline Trochus sp. & 1 & 7 & 4 & - & 17 & 34 & - & 11 & - & - & 4 \\
\hline Tectus fenestratus & - & - & - & 1 & - & - & - & - & - & - & - \\
\hline Tectus pyramis & 1 & - & - & - & - & - & - & - & - & - & - \\
\hline Rochia nilotica & - & - & 1 & 6 & 1 & 2 & - & - & - & 15 & - \\
\hline Monodonta canalifera & 2 & - & - & 3 & 1 & - & - & 2 & - & - & - \\
\hline Turbo chrysostomus & - & - & - & - & - & - & - & - & - & - & - \\
\hline Turbo setosus & - & - & - & - & - & - & - & - & - & - & - \\
\hline Turbo sp. & 3 & - & 1 & - & - & 6 & - & 3 & 1 & 9 & - \\
\hline Turbinidae operculum & 2 & 3 & 2 & 10 & 23 & 11 & 1 & 6 & 7 & 11 & 3 \\
\hline Lunella cinerea & - & 2 & 2 & - & - & 2 & - & - & 1 & - & - \\
\hline Angaria delphinus & - & - & 1 & 2 & 1 & - & - & - & - & 1 & 2 \\
\hline Liotinaria peronii & - & 1 & - & - & - & 1 & - & - & - & - & - \\
\hline Neritopsis radula & - & - & - & - & - & - & - & - & - & - & - \\
\hline Nerita albicilla & - & - & 2 & 2 & 4 & 2 & - & - & - & - & - \\
\hline Nerita balteata & 7 & 6 & 3 & 1 & 4 & 9 & 1 & 2 & 4 & 3 & - \\
\hline Nerita chamaeleon & - & - & 1 & - & 3 & 1 & 1 & 4 & - & 1 & - \\
\hline Nerita exuvia & 4 & 7 & 1 & 14 & 26 & 15 & - & 24 & 11 & 7 & 5 \\
\hline Nerita grossa & - & - & - & - & - & - & - & - & - & - & - \\
\hline Nerita plicata & - & 3 & 1 & 2 & 2 & 15 & 2 & 14 & 4 & 13 & 2 \\
\hline Nerita polita & 12 & 18 & 15 & 31 & 47 & 133 & 18 & 175 & 61 & 127 & 34 \\
\hline Nerita undata & - & - & 1 & 2 & - & 1 & - & - & - & - & 1 \\
\hline Neritidae operculum & - & - & - & - & - & 2 & 1 & 4 & - & - & - \\
\hline Indomodulus tectum & - & - & - & - & 1 & - & - & 1 & - & - & - \\
\hline Clypeomorus bifasciata & 2 & - & - & - & - & - & - & - & - & 2 & - \\
\hline Clypeomorus irrorata & - & - & - & - & - & 2 & 1 & - & - & - & - \\
\hline Clypeomorus subbrevicula & - & - & 1 & 4 & 2 & 3 & - & 3 & - & - & - \\
\hline Clypeomorus sp. & - & - & - & - & - & - & - & 2 & - & 3 & 1 \\
\hline Opalia sp. & - & - & - & - & - & - & - & - & - & 1 & - \\
\hline Cerithium nodulosum & - & - & - & - & - & - & - & - & - & - & - \\
\hline Cerithidea sp. & - & 1 & - & - & - & - & - & - & - & - & - \\
\hline Canarium labiatum & - & - & - & - & - & - & - & - & - & - & - \\
\hline Gibberulus gibberulus gibbosus & - & - & - & - & 2 & - & - & - & - & - & - \\
\hline Strombus sp. & - & - & - & - & - & - & - & - & - & - & - \\
\hline Lambis lambis & - & - & - & - & - & - & - & 1 & - & - & - \\
\hline Cypraeidae & - & - & 1 & 8 & - & 4 & 1 & 4 & - & 1 & - \\
\hline Turritriton labiosus & - & - & - & - & - & - & - & - & - & - & - \\
\hline Monoplex vespaceus & - & - & 1 & - & - & - & - & - & - & - & - \\
\hline Chicoreus sp. & - & - & - & - & - & - & - & 2 & - & 1 & - \\
\hline Indothais sp. & - & - & - & - & - & - & - & - & - & 5 & - \\
\hline Thais sp. & - & - & - & - & - & - & - & - & - & - & - \\
\hline Muricidae & - & 1 & - & - & - & - & - & - & - & - & - \\
\hline Orania nodosa & - & - & - & - & - & - & - & - & - & 3 & - \\
\hline Nassa serta & - & - & - & - & - & - & - & - & - & - & - \\
\hline Prodotia sp. & - & - & - & 2 & - & - & - & - & - & - & - \\
\hline Euplica turturina & - & - & - & - & 1 & - & - & - & - & - & - \\
\hline Nassarius albescens & 1 & - & - & 1 & 2 & 1 & - & 1 & - & - & - \\
\hline Nassarius globosus & - & - & - & - & 1 & - & - & - & - & - & - \\
\hline Nassarius leptospirus & - & - & 1 & - & - & - & - & 1 & - & - & - \\
\hline Nassarius shacklefordi & - & - & 1 & - & - & - & 2 & 2 & 3 & 2 & 1 \\
\hline Latirolagena smaragdulus & - & - & - & - & - & 1 & - & - & - & - & - \\
\hline Vasum turbinellus & - & - & 1 & - & - & 1 & - & - & - & - & - \\
\hline Oliva sp. & 2 & - & - & - & - & - & - & - & - & - & - \\
\hline Harpidae & - & - & - & - & - & - & - & - & - & - & - \\
\hline Cymbiola vespertilio & - & - & - & - & 1 & - & - & - & - & - & - \\
\hline Lophiotoma acuta & - & - & - & - & - & - & - & - & - & - & - \\
\hline Conus litteratus & - & - & - & - & 1 & - & - & - & - & - & - \\
\hline Conus marmoreus & - & 1 & - & - & 1 & - & - & - & - & - & 1 \\
\hline Conus textilis & - & - & - & - & 1 & - & - & 2 & - & - & - \\
\hline Conus sp. & 2 & 5 & 2 & 13 & 18 & 19 & - & 5 & 8 & 5 & - \\
\hline Siphonaria atra & - & - & - & 4 & 11 & 9 & - & 9 & 7 & 5 & 2 \\
\hline Barbatia sp. & - & - & 1 & 4 & 1 & 3 & - & - & 7 & - & - \\
\hline la corrugata & - & - & - & 1 & - & - & - & - & - & - & - \\
\hline Septifer bilocularis & - & - & - & 1 & - & 1 & - & - & - & - & - \\
\hline Pinna sp. & - & - & - & - & - & - & - & - & - & - & - \\
\hline Pinctada margaritifera & - & - & - & - & - & - & - & 1 & - & - & - \\
\hline Isognomon ephippium & - & - & - & - & - & - & - & - & - & - & - \\
\hline Codakia $\mathrm{sp}$ & 2 & - & - & - & - & - & - & - & - & - & - \\
\hline Vasticardium subrugosum & - & 1 & - & - & - & - & - & - & - & - & - \\
\hline Vasticardium sp. & - & - & 1 & 1 & 3 & - & - & 1 & - & 3 & 1 \\
\hline Tridacna $\mathrm{sp}$ & 1 & 7 & 5 & 13 & 31 & 16 & - & 10 & 8 & 27 & - \\
\hline Gari elongata & - & - & - & 2 & 3 & 2 & - & 17 & 16 & 12 & 2 \\
\hline Asaphis violascens & 3 & 2 & 1 & - & 7 & 2 & - & 2 & - & 1 & - \\
\hline Periglypta puerpera & - & 2 & 2 & 1 & 6 & 2 & - & 1 & 2 & 5 & 2 \\
\hline Periglypta sp. & - & - & - & 2 & - & - & - & - & 2 & - & - \\
\hline Pitar sp. & - & - & - & - & - & - & - & - & - & - & - \\
\hline Dosinia sp. & - & - & - & - & - & - & - & - & - & - & - \\
\hline Bivalvia sp. & - & - & - & - & 7 & - & 1 & 1 & - & - & - \\
\hline Nautilus sp. & - & - & - & 1 & - & - & - & 1 & - & - & 1 \\
\hline total (NISP) & 52 & 72 & 57 & 152 & 259 & 374 & 34 & 368 & 178 & 306 & 73 \\
\hline
\end{tabular}




\section{Jareng Bori, Pit A, Major Mollusc Taxa (NISP)}

600

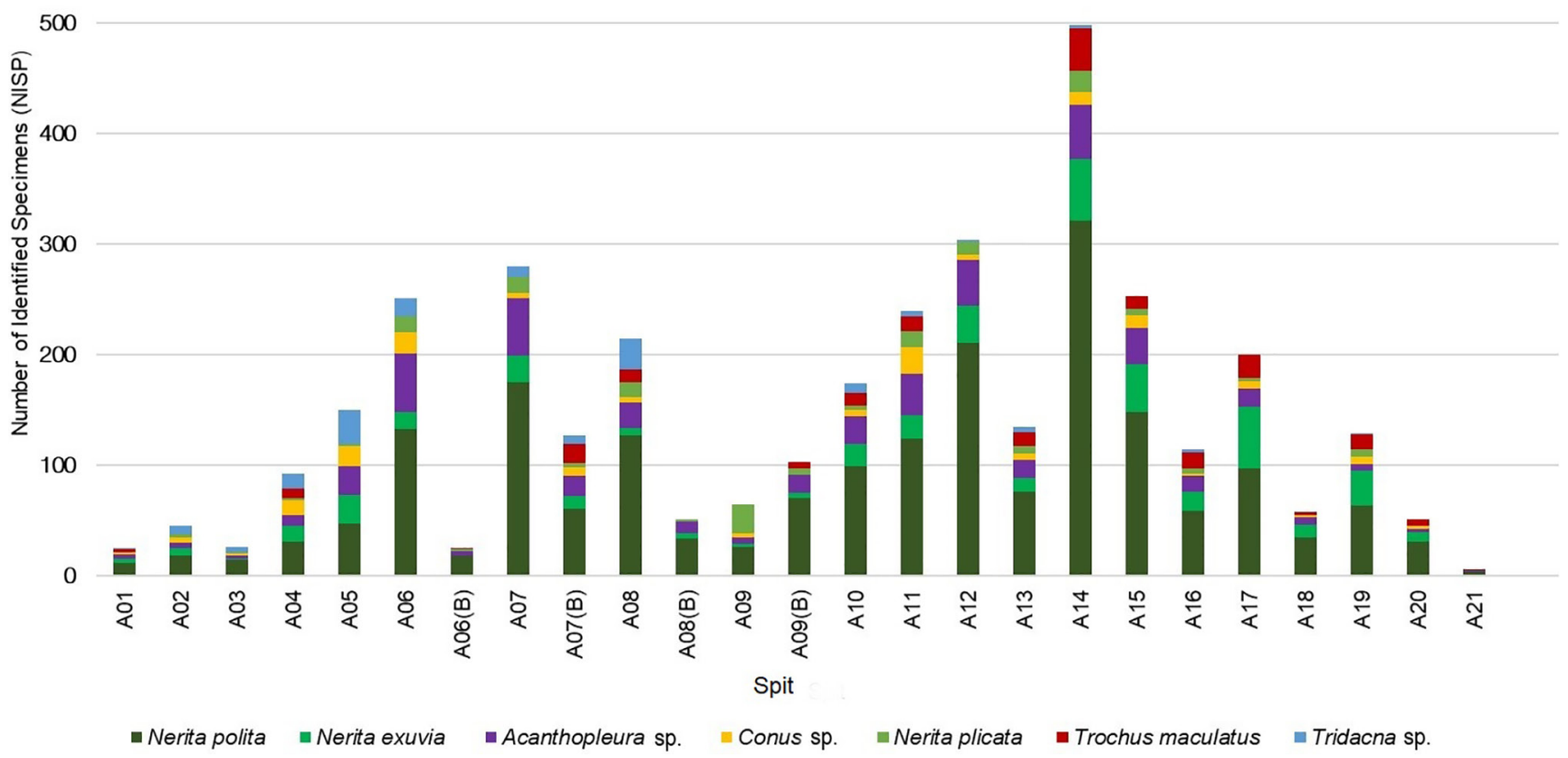

Figure 5. Major mollusc taxa (NISP) at Jareng Bori.

\section{Jareng Bori, Pit A, Mollusc Habitats (NISP)}

800

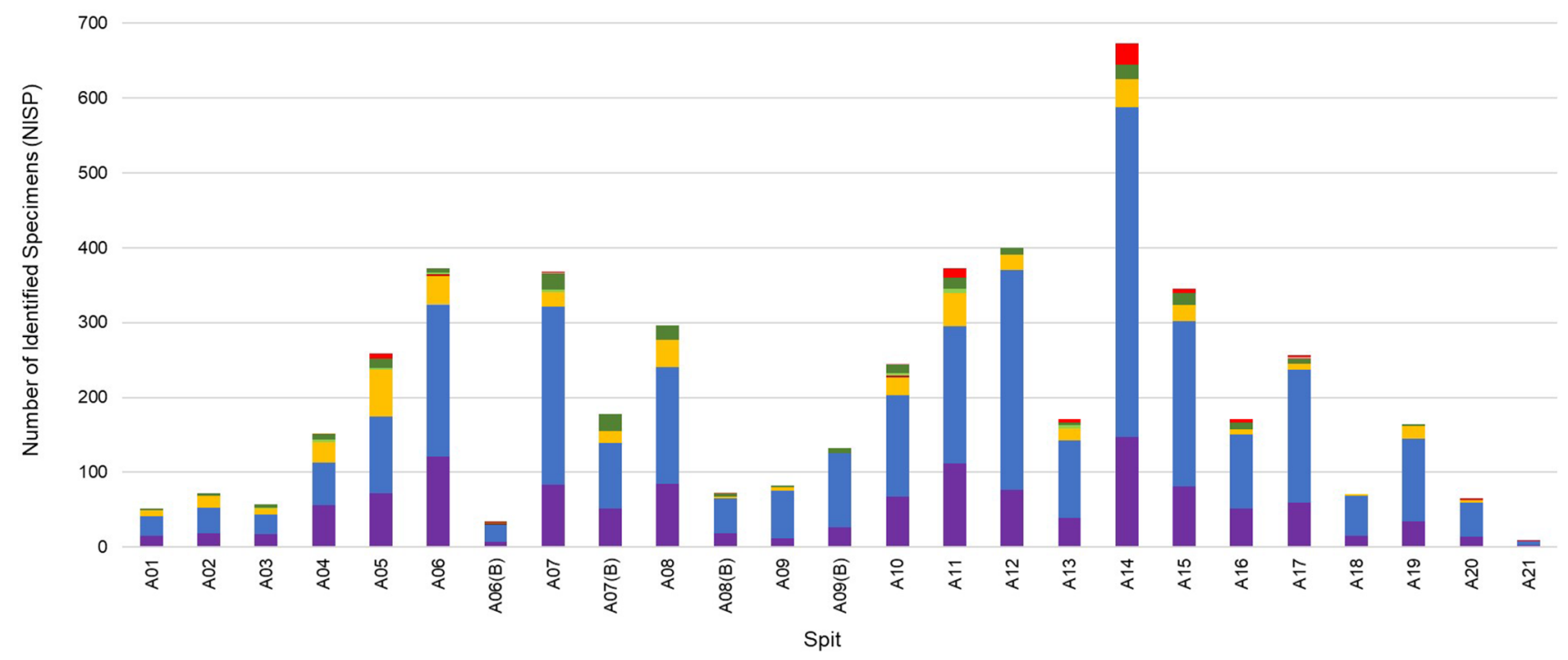

- Rocky and coral reefs, at low tide and subtidally

- Rocky and coral reefs, at low tide

mocky and coral reefs, at low tide and subtidally. High energy locations $=$ Coral reefs, at low tide and subtidally

- Cobbles and rocks mixed with coarse sand, at mid- to high tide

$\square$ Cobbles and rocks, at low tide. High energy locations

Seagrass flats near reefs, at low tide and subtidally

n Deepwater Pelagic

- Mangroves

- Varied

Figure 6. Mollusc habitats (NISP) at Jareng Bori. 


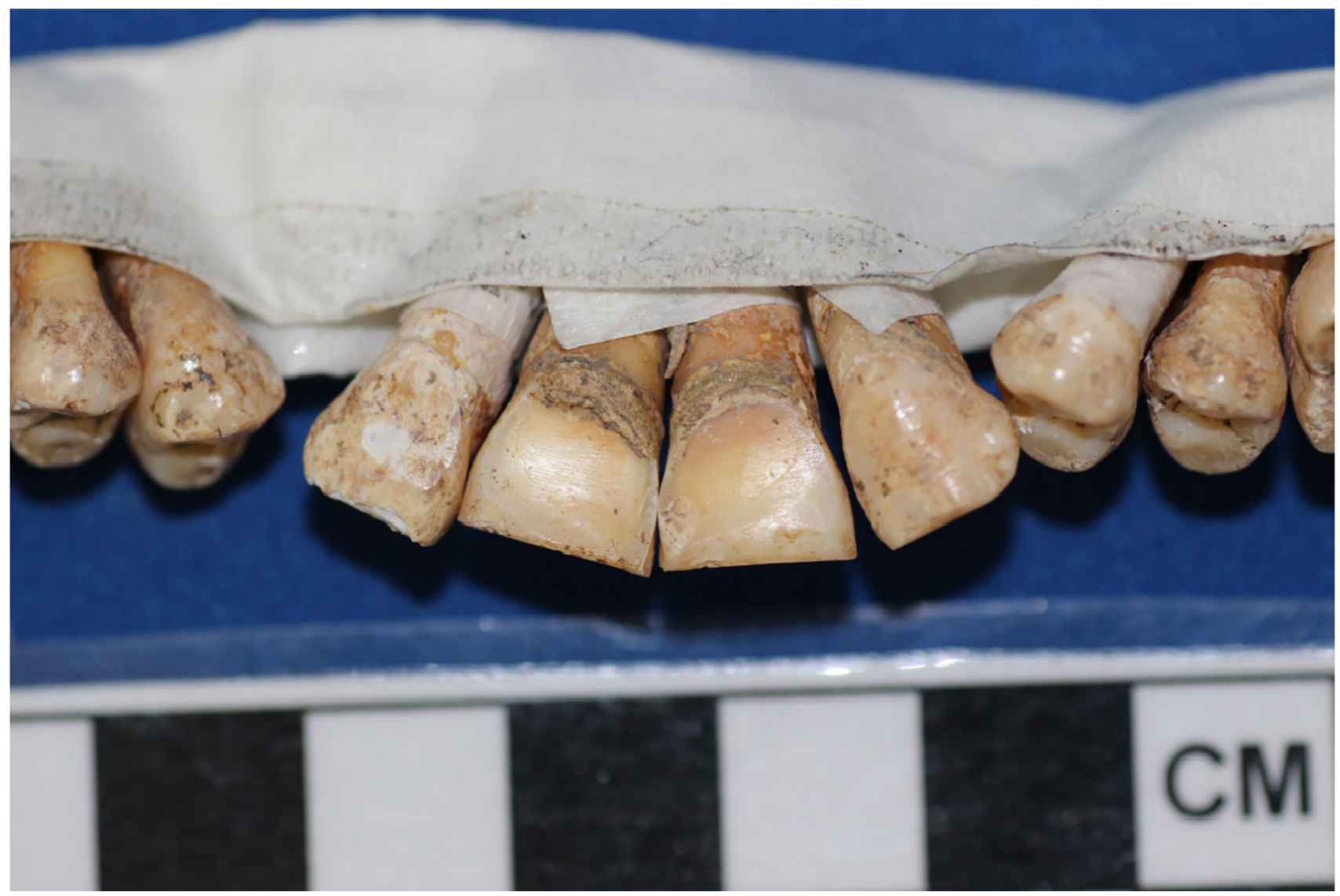

Figure 7. Cultural dental filing of the labial and occlusal surfaces of the upper first and second incisors recorded on the human burial at Jareng Bori (photo: Fayeza Shasliz Arumdhati).

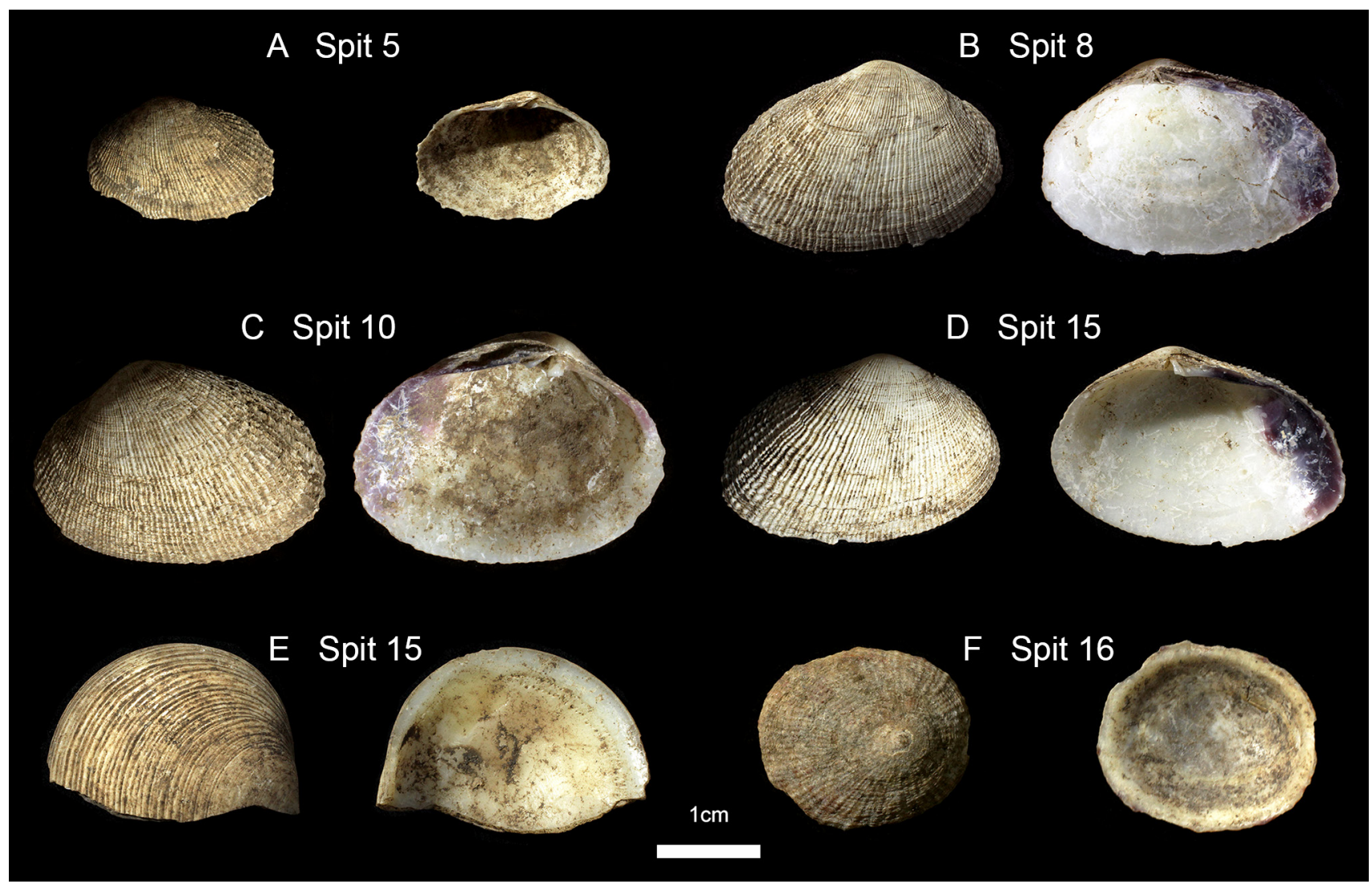

Figure 8. Shell scrapers manufactured from $(A-D)$ Asaphis violascens (spits 5, 8, 10 and 15); (E) Pitar sp. (spit 15); and (F) Cellana testudinaria (spit 16) from Jareng Bori. 
Table 5. Jareng Bori ceramics by layer and spit.

\begin{tabular}{|c|c|c|c|c|c|c|c|}
\hline \multirow[t]{2}{*}{${ }^{14} \mathrm{C}$ date } & \multirow[t]{2}{*}{ layers/context } & \multirow[t]{2}{*}{ spits } & \multicolumn{2}{|c|}{ sherds $>1 \mathrm{~g}$} & \multirow{2}{*}{$\begin{array}{c}\begin{array}{c}\text { decorated } \\
\text { sherds }\end{array} \\
\text { number }\end{array}$} & \multirow{2}{*}{$\begin{array}{c}\text { slipped sherds } \\
\text { number }\end{array}$} & \multirow{2}{*}{$\begin{array}{c}\text { rim sherds } \\
\text { number }\end{array}$} \\
\hline & & & number & weight & & & \\
\hline \multirow{14}{*}{ 430-0 cal. BP (Period 3) } & surface & surface & 5 & 160 & 4 & & 3 \\
\hline & 1 & $\mathrm{~A} 01$ & 24 & 51.6 & 3 & 2 & 3 \\
\hline & 2 & $\mathrm{~A} 02$ & 22 & 43.7 & 1 & & \\
\hline & 3 & $\mathrm{~A} 03$ & 55 & 95 & 6 & 2 & 4 \\
\hline & \multirow{3}{*}{4} & A04 & & & & & \\
\hline & & A05 & 76 & 153.5 & 3 & & 2 \\
\hline & & A06 & 67 & 182.9 & 5 & 1 & 4 \\
\hline & \multirow{3}{*}{5} & $\mathrm{~A} 07$ & 51 & 135.8 & 6 & 3 & 3 \\
\hline & & A08 & 12 & 62 & 4 & 1 & 1 \\
\hline & & A09 & 115 & 221.3 & 8 & 2 & 7 \\
\hline & burial & A07-A09 & 28 & 58 & 8 & & \\
\hline & \multirow{3}{*}{6} & $\mathrm{~A} 10$ & 54 & 87 & 9 & 2 & 3 \\
\hline & & A11 & 24 & 53 & 2 & 1 & 2 \\
\hline & & A12 & 38 & 89.9 & 3 & 1 & 1 \\
\hline- & \multirow{9}{*}{7} & A13 & 29 & 73.3 & 2 & 1 & \\
\hline 1365-1187 cal. BP (Period 2) & & A14 & 120 & 294.8 & 6 & 3 & 8 \\
\hline \multirow[t]{5}{*}{ ( } & & A15 & 45 & 101.4 & 5 & 4 & 3 \\
\hline & & A16 & 31 & 70.2 & 1 & 8 & 4 \\
\hline & & A17 & 15 & 35.3 & 2 & 1 & \\
\hline & & A18 & 3 & 9.8 & 1 & & \\
\hline & & A19 & 15 & 25.2 & 2 & 10 & \\
\hline \multirow{2}{*}{ 1807-1612 cal. BP (Period 1) } & & A20 & 6 & 9.7 & & 2 & \\
\hline & & A21 & 1 & 1.6 & & & \\
\hline \multicolumn{3}{|r|}{ total } & 836 & 2015 & $81^{\text {a }}$ & $44^{\mathrm{b}}$ & $48^{\circ}$ \\
\hline
\end{tabular}

a 31 sherds under $1 \mathrm{~g}$

20 sherds under $1 \mathrm{~g}$

c 11 sherds under $1 \mathrm{~g}$

Table 6. Jareng Bori ceramic decoration data by spit, number of ceramic sherds.

\begin{tabular}{|c|c|c|c|c|c|c|c|c|c|c|c|c|}
\hline $\overrightarrow{\vec{z}}$ & 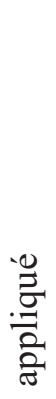 & 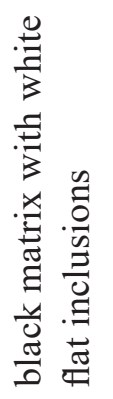 & . & 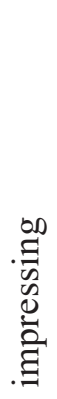 & 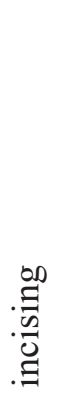 & $\frac{\stackrel{b}{\Xi}}{\frac{\Xi}{\Xi}}$ & 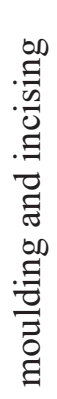 & 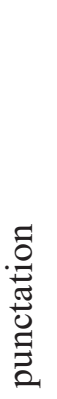 & 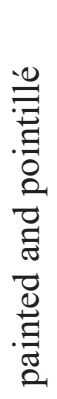 & 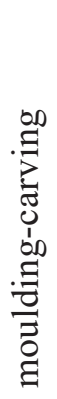 & 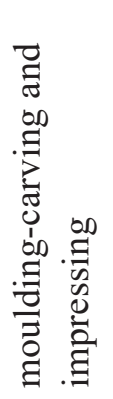 & 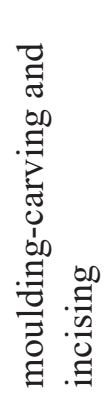 \\
\hline surface & - & - & - & - & - & - & - & - & - & 3 & - & 1 \\
\hline A01 & - & - & - & - & 2 & 1 & - & - & - & - & - & - \\
\hline A02 & - & 1 & - & - & - & - & - & - & - & - & - & - \\
\hline A03 & - & - & 2 & 1 & 1 & 1 & - & - & - & 1 & - & - \\
\hline A05 & - & 2 & - & - & 1 & - & - & - & - & - & - & - \\
\hline A06 & - & 1 & 1 & 1 & 1 & 1 & - & - & - & - & - & - \\
\hline A07 & - & - & 1 & - & 2 & - & - & 1 & - & 1 & 1 & - \\
\hline A08 & - & - & - & - & 3 & - & - & - & - & 1 & - & - \\
\hline A09 & - & 4 & - & 1 & - & 1 & - & 1 & - & 1 & - & - \\
\hline A10 & - & - & 1 & 2 & 1 & 2 & - & - & - & 3 & - & - \\
\hline A11 & 1 & - & - & - & 1 & - & - & - & - & - & - & - \\
\hline A12 & - & - & - & - & 1 & 1 & - & - & - & 1 & - & - \\
\hline A13 & - & - & - & - & 2 & - & - & - & - & - & - & - \\
\hline A14 & 1 & - & - & - & 2 & 1 & 1 & - & 1 & - & - & - \\
\hline A15 & - & - & - & - & 4 & - & 1 & - & - & - & - & - \\
\hline A16 & - & - & - & - & 1 & - & - & - & - & - & - & - \\
\hline A17 & - & - & - & 1 & 1 & - & - & - & - & - & - & - \\
\hline A18 & - & - & - & - & - & - & - & 1 & - & - & - & - \\
\hline A19 & - & - & - & - & 1 & 1 & - & - & - & - & - & - \\
\hline total & 2 & 8 & 5 & 6 & 24 & 9 & 2 & 3 & 1 & 11 & 1 & 1 \\
\hline
\end{tabular}




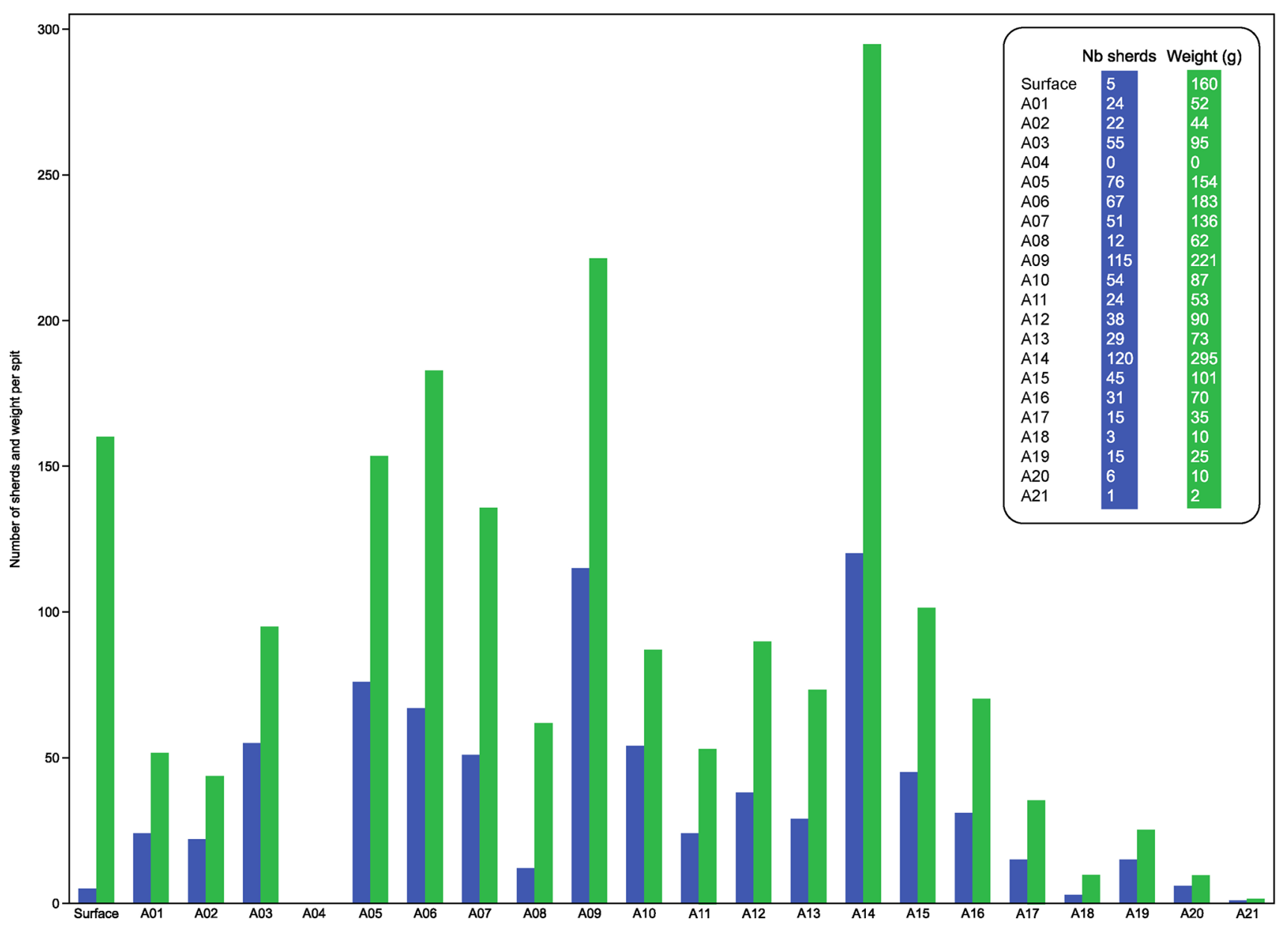

Figure 9. Vertical distribution of ceramics from Jareng Bori for sherds over $1 \mathrm{~g}$.

to display any similar diachronic distribution patterns). Most share broadly similar technological features and are designated as the "general" variety of medium-paste earthenware. They are highly variable in sherd thickness (from $0.8-17.9 \mathrm{~mm}$ ).

Seventy-nine medium-paste earthenware sherds appear to be fragments of "black-burnished" vessels with black exterior/interior surfaces and reduced cores. All but two of "black-burnished" sherds are body sherds with a relatively small range of sherd thicknesses varying from 1.4-6.2 mm. Only two black-burnished sherds are rim fragments and they have a comparably small range in thicknesses (from $2.8-6.2 \mathrm{~mm}$ ). The rim diameter of one sherd is around $20 \mathrm{~cm}$, whereas the other sherd was too small to derive a rim diameter estimate. Three "black-burnished" sherds display decorations, i.e., paint or punctation, the latter likely impressed through "rouletting" in one case.

Forty-four medium-paste earthenware sherds are slipped; 20 of them with black slips, 20 with red slips and four with light brown slips. Twelve samples have distinctively fine fabrics comprising of relatively small mineral inclusions (fine to very fine sand sizes $0.062-0.125 \mathrm{~mm}$ ).

Vertical distribution. Ceramic artefacts were recovered across all seven stratigraphic layers except for spit 4 (Fig. 9). Most of the pottery analysed (645 sherds, 69\%) was recovered from the latest occupation period (from the surface to spit 12). The vertical distribution of the pottery by weight and number of sherds per spit reveals the same pattern: a continuous occupation of the site from 1807-1612 cal. BP with two periods characterized by distinctively intensive pottery-related activity.

The initial occupation of the site is associated with very few pottery sherds (spits 20 to 21). The number of sherds per spit then gradually increases until it reaches its highest concentration in spit 14 , dated to $1305-1187$ cal. BP, which corresponds with the middle occupation period. There was then a sudden decline in ceramic frequency in spits 11-13, before a sharp increase in spits 9-10 that peaks with the most intensive phase of occupation during the late period dated to 430- 0 cal. BP (spits $11-13$ to 2 ). The low number of sherds recovered from spit 8 probably relates to the presence of the burial and therefore it is likely that the gap in frequency between both spits 12-9 and spits 7-3 does not represent two distinctive occupation episodes, as also suggested by the distribution of molluscan remains. Density of pottery remains is relatively stable throughout the late historic period, with a slight decreasing trend over time.

A wide range of decoration types can be found on the exterior surfaces of body sherds such as appliqué, burnishing, combing-incising, incising, impressing, moulding, moulding-carving, and painting (Table 6; Fig. 10). Regarding the distribution of decorative techniques across the stratigraphy, a few decorative types are associated with specific occupation periods (Table 6). Black-matrixwhite-inclusions, moulding-carving, and painting are 

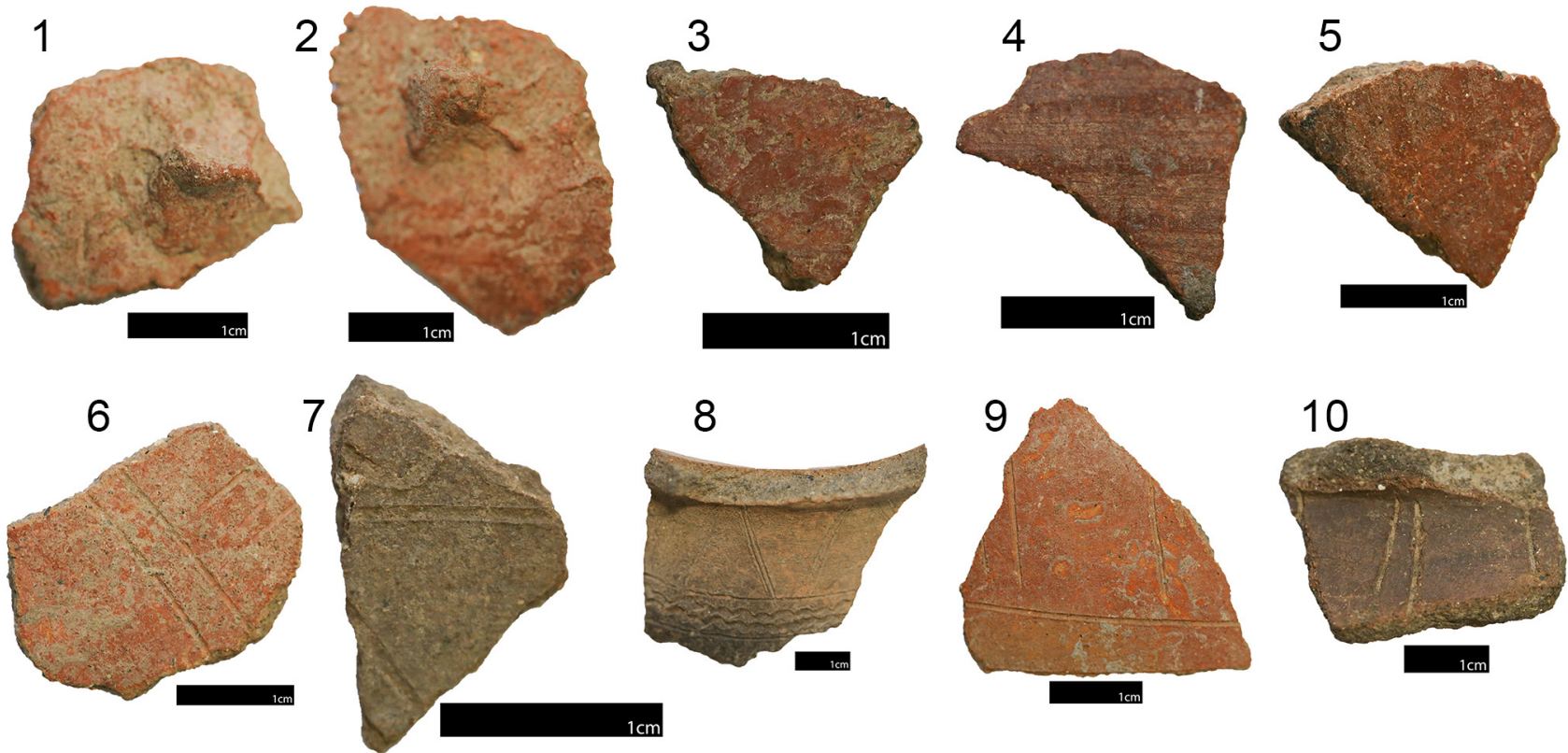

\section{0}
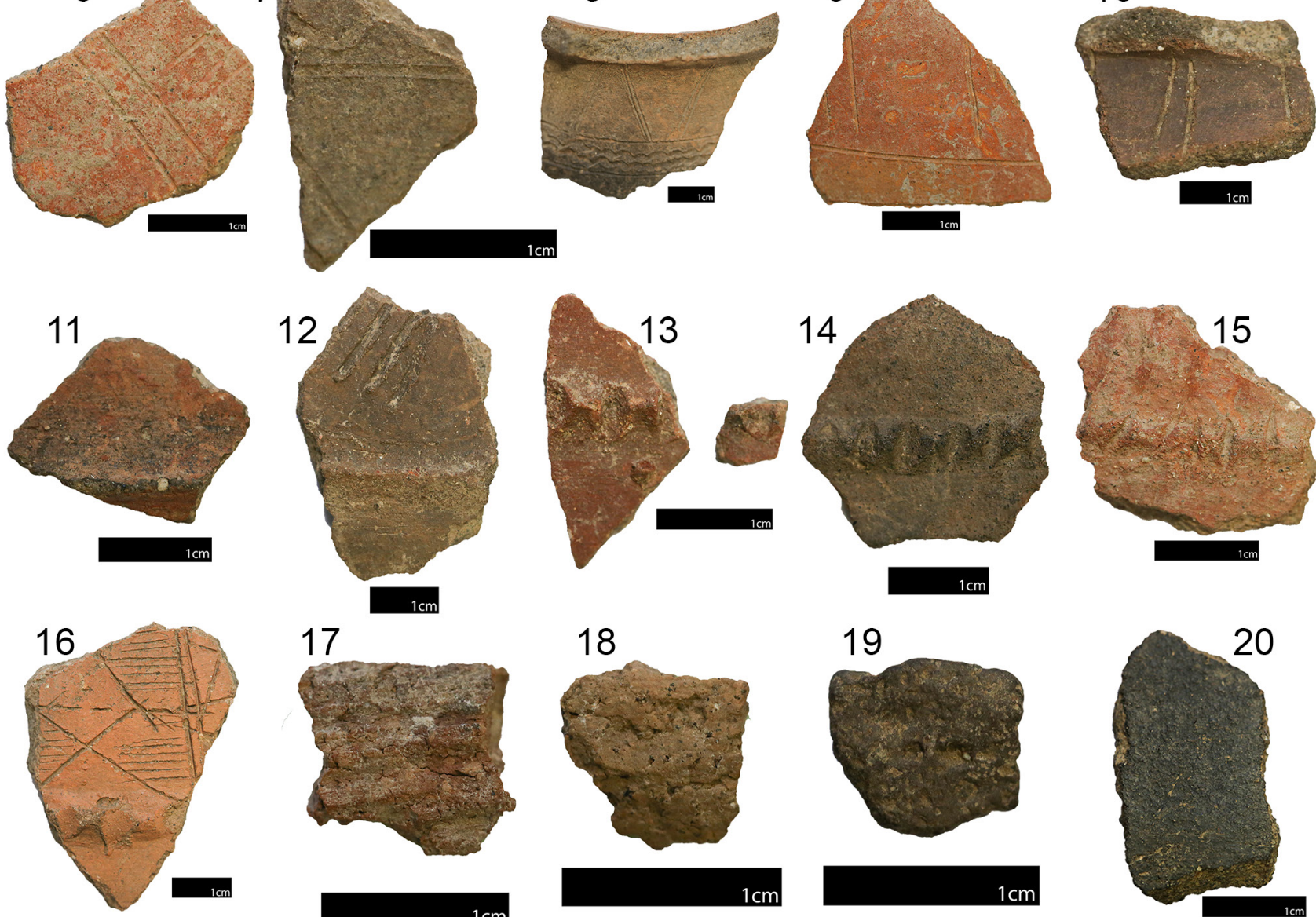

17
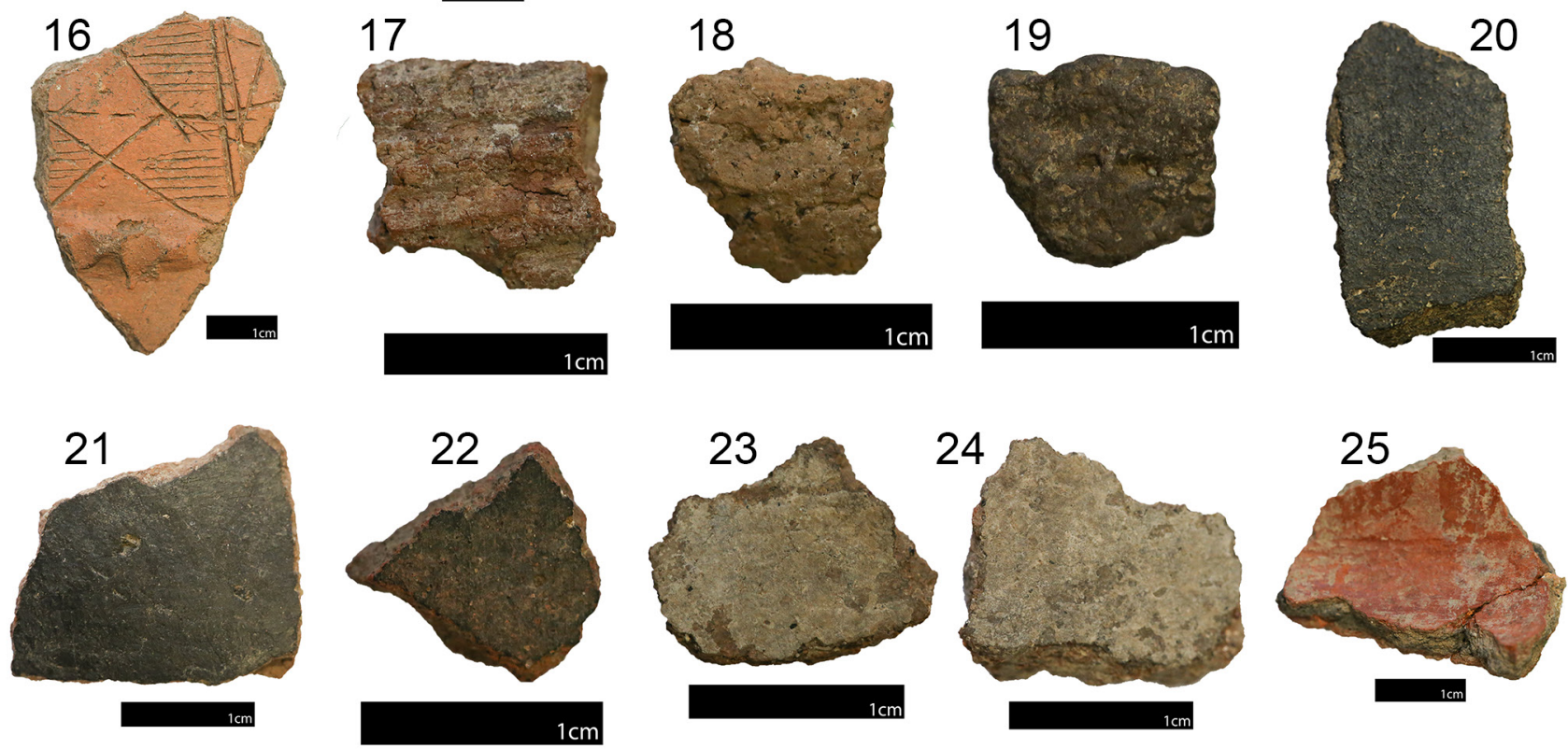

Figure 10. Representative sherds for the decorative styles on pottery from Jareng Bori: Appliqué (1-2); Burnishing (3-5); Incising (6-10); Moulding (11); Moulding \& Incising (12); Moulding-carving (13-15); Moulding-carving \& Incising (16); Impressing (17-18); Punctation (19); Black-burnished (19-20); Black slipped (21-22); Grey slipped (23-24); Red slipped (25).

found only in spits associated with the latest occupation period. On the other hand, the samples displaying appliqué and painted-pointillé are recorded only during period 2. No significant pattern can be identified from the other decorative techniques as they are found across the stratigraphy. Among other attributes noticeably changing through time, it is worth noting that there was a general trend for a slight increase in sherd thickness (Fig. 11) and more slipped samples, particularly with red slip, were recorded during occupation period 2 (Fig. 12). 


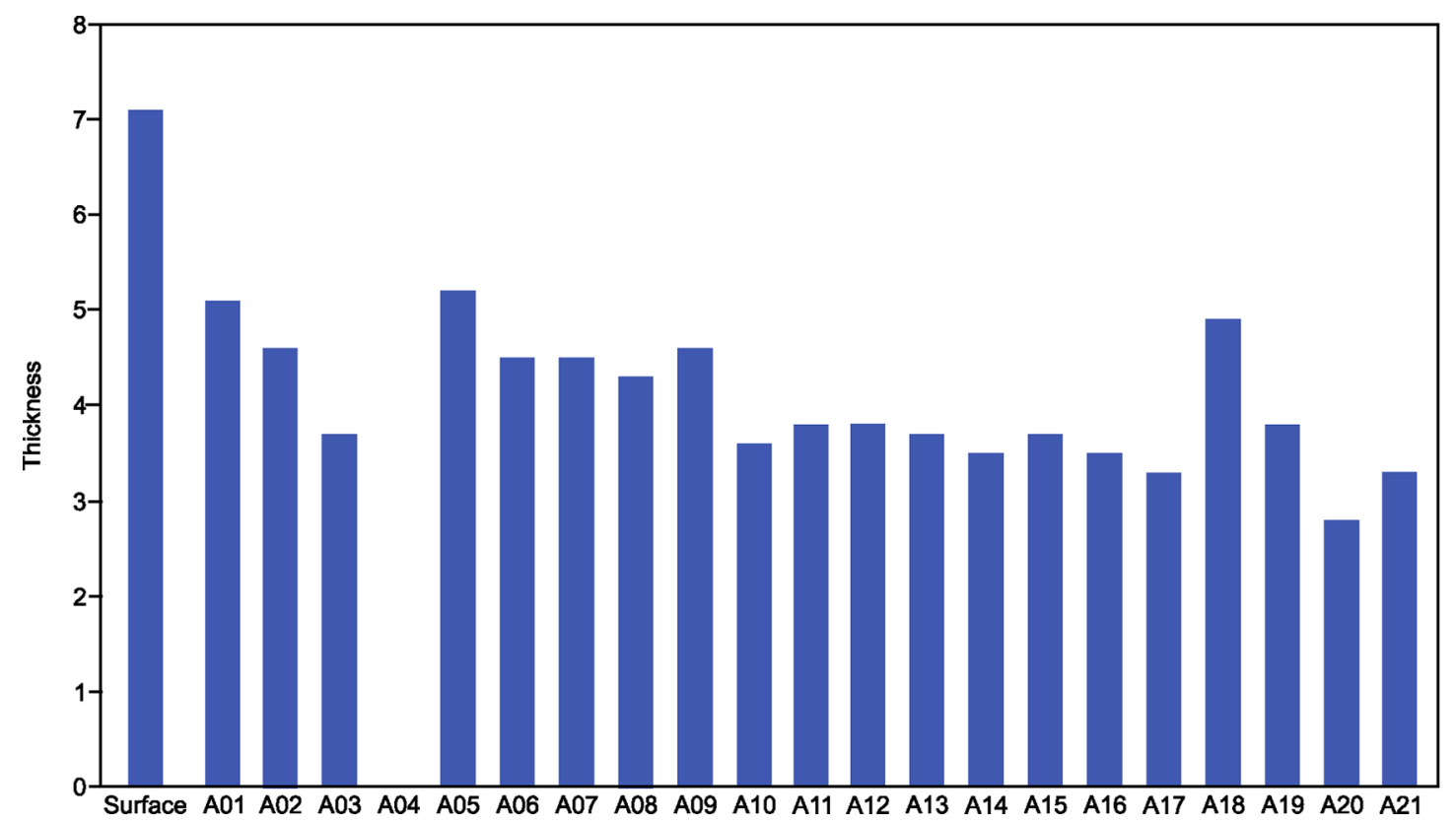

Figure 11. Average sherd thickness $(\mathrm{mm})$ by spit at Jareng Bori.

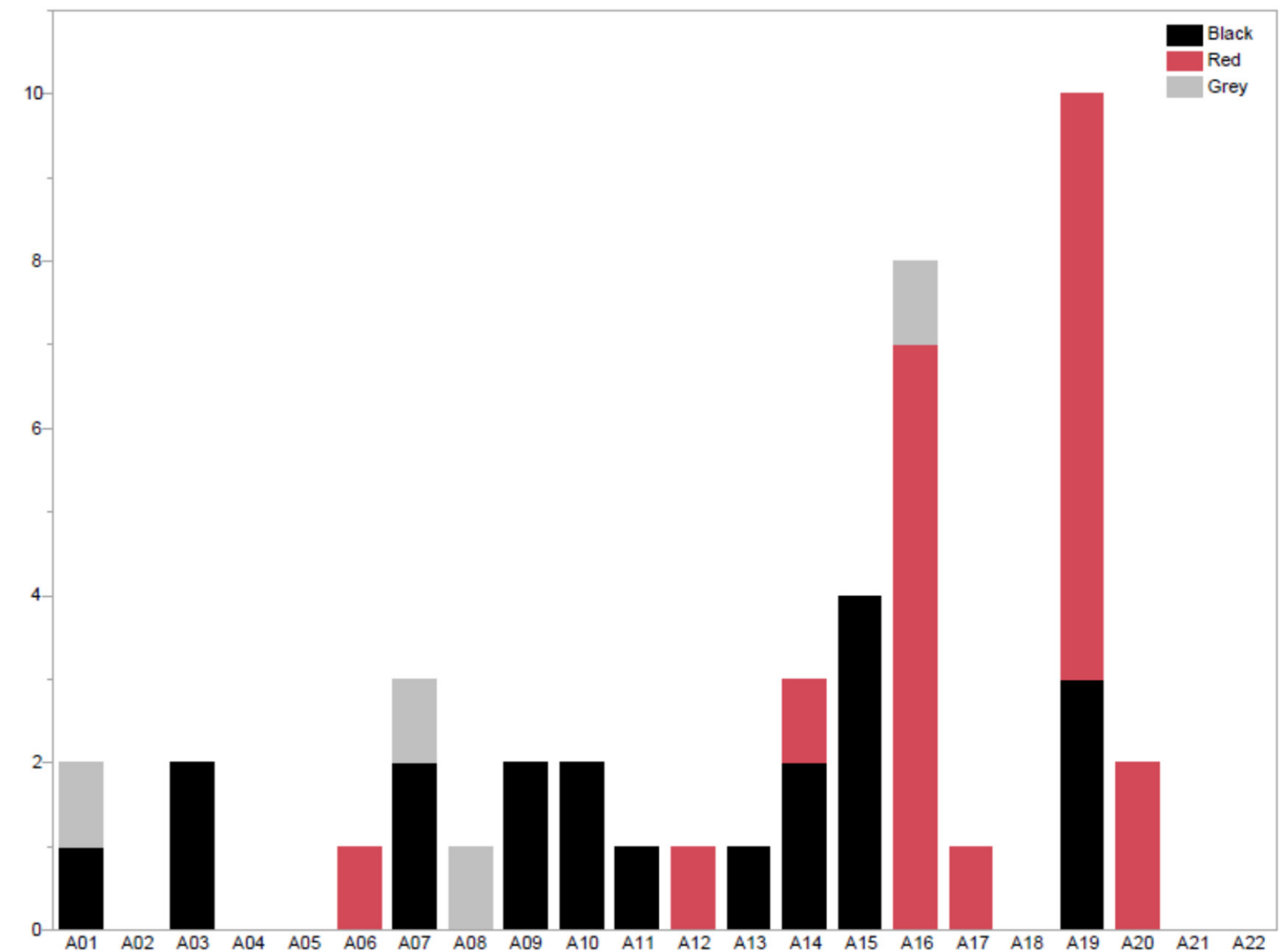

Figure 12. Slipped sherds by spit at Jareng Bori.

Vessel form. Only one base sherd has been preliminarily identified within the "general" medium-paste earthenware assemblage. Most of the estimated rim diameters appear to range from $13-20 \mathrm{~cm}$, while the remainder have either small diameters measuring $10 \mathrm{~cm}$ or large diameters ranging from $30-38 \mathrm{~cm}$. Even though few rim sherds are large enough to be informative of the vessel form, three main vessel forms are identified throughout the sequence
(Fig. 13). Vessels with incurving rims, amongst which is one bearing a notched "pie-crust" lip (830), are recorded exclusively from the latest occupation period, in spits 6 and 7. The two other main vessel forms are recorded in spits 14 and 16 and are characterized, respectively, by out-curving rims with wide flat lips $(836,824,2691)$ and inverted rims with a sharp angle on the exterior surface $(841,831,828)$. Another element worth highlighting is the concave break 

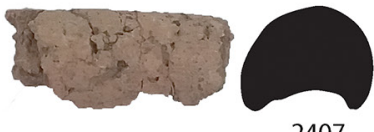

2407
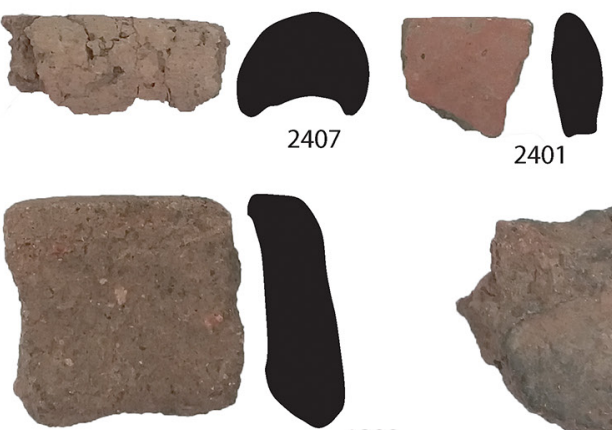

1288
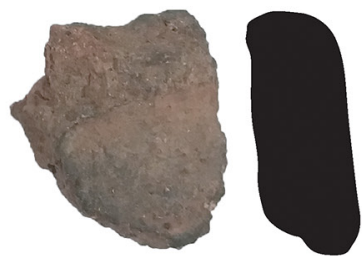

1290

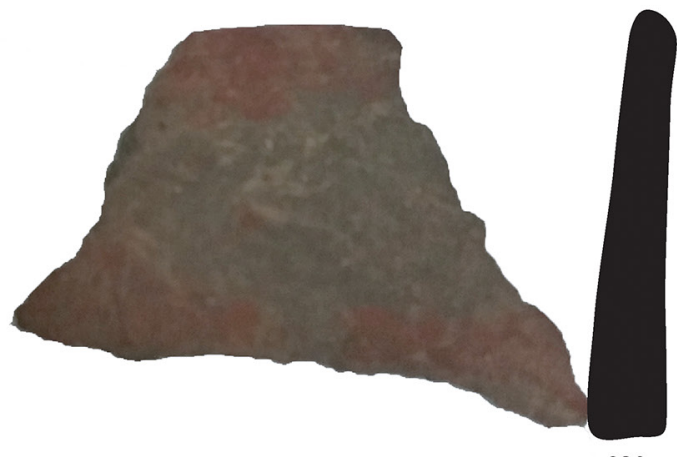

830

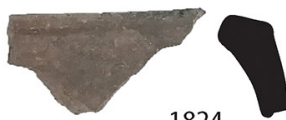

1824
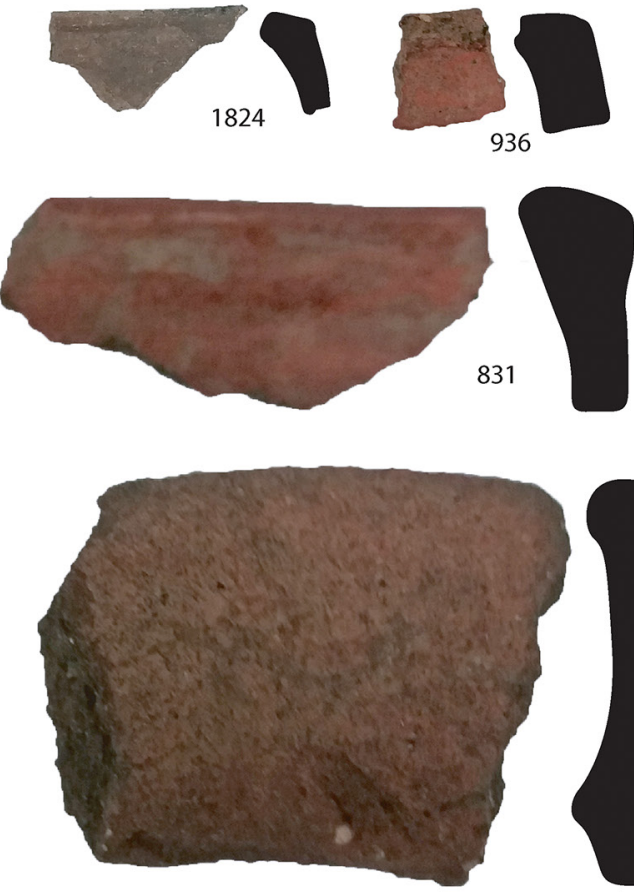

Surface

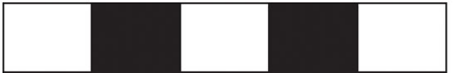

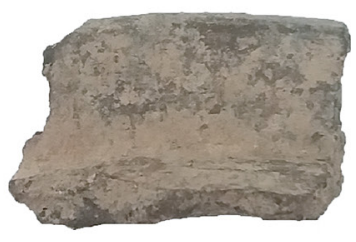
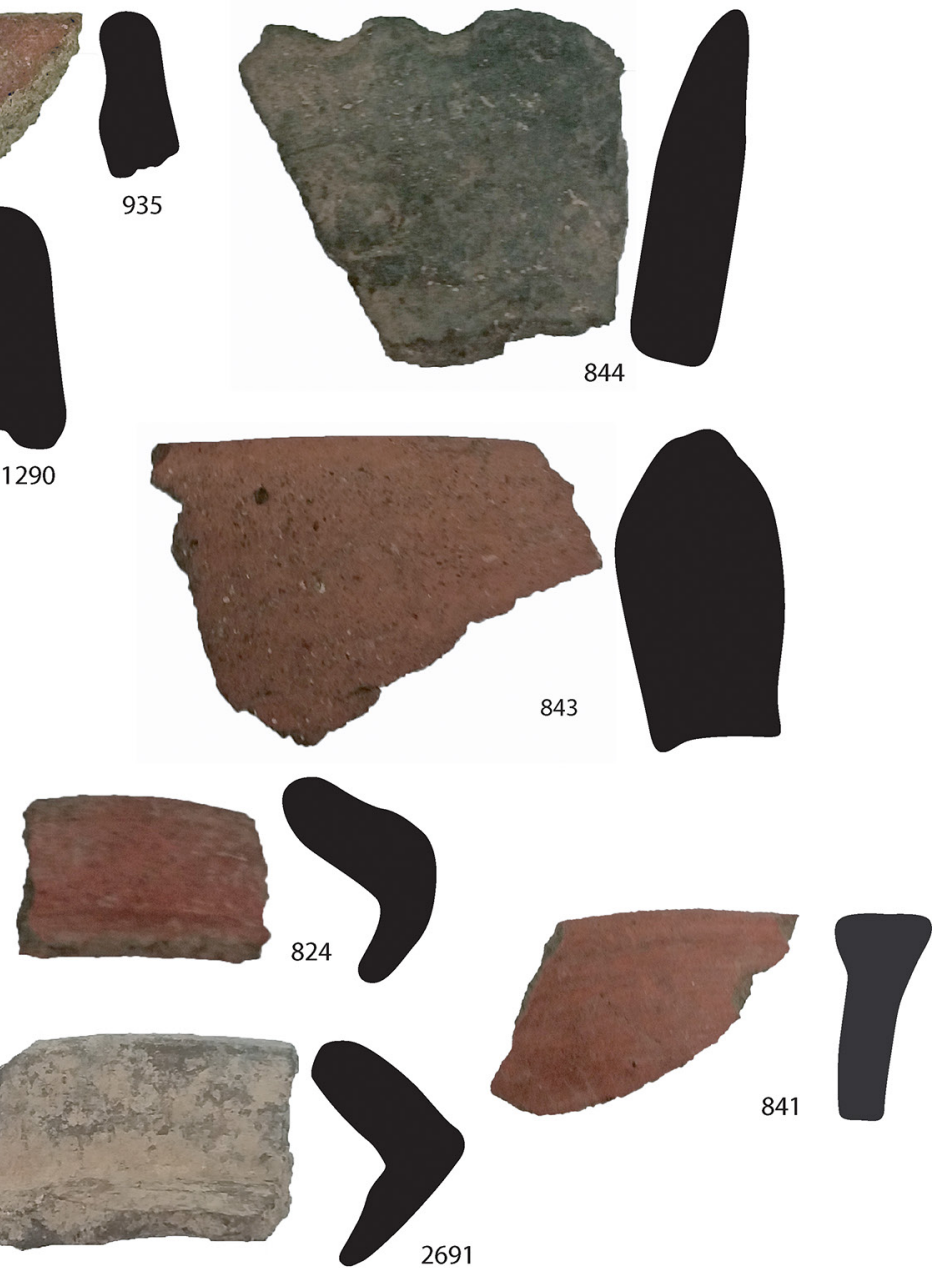

691
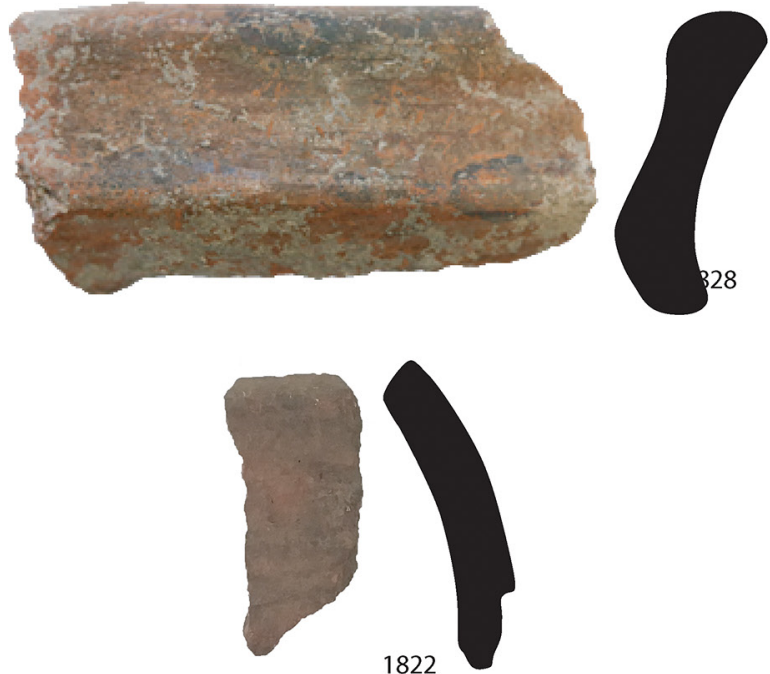

Figure 13. Rim sherds illustrating the range of straight, incurving, and out-curving rims at Jareng Bori. With the exception of the incurving notched pie-crust lip (844), out-curving rims (Surface) with wide flat lips $(824,2691)$ and inverted rims $(841,828)$, the fragmentary nature of the assemblage prevents further identification of vessel forms.

on the rim sherd 2407 that suggests that the lip was applied as a coil for some of the vessels.

A total of 28 earthenware sherds over $1 \mathrm{~g}$ were recovered from the burial context, however significant disturbance of the burial suggest that some are post-depositional intrusions.
None of the generally very small sherds appear to belong to the same vessel. Their fragmentary nature suggests that these sherds are probably waste ceramics that were mixed into the grave fill during the process of excavating and backfilling the grave. 


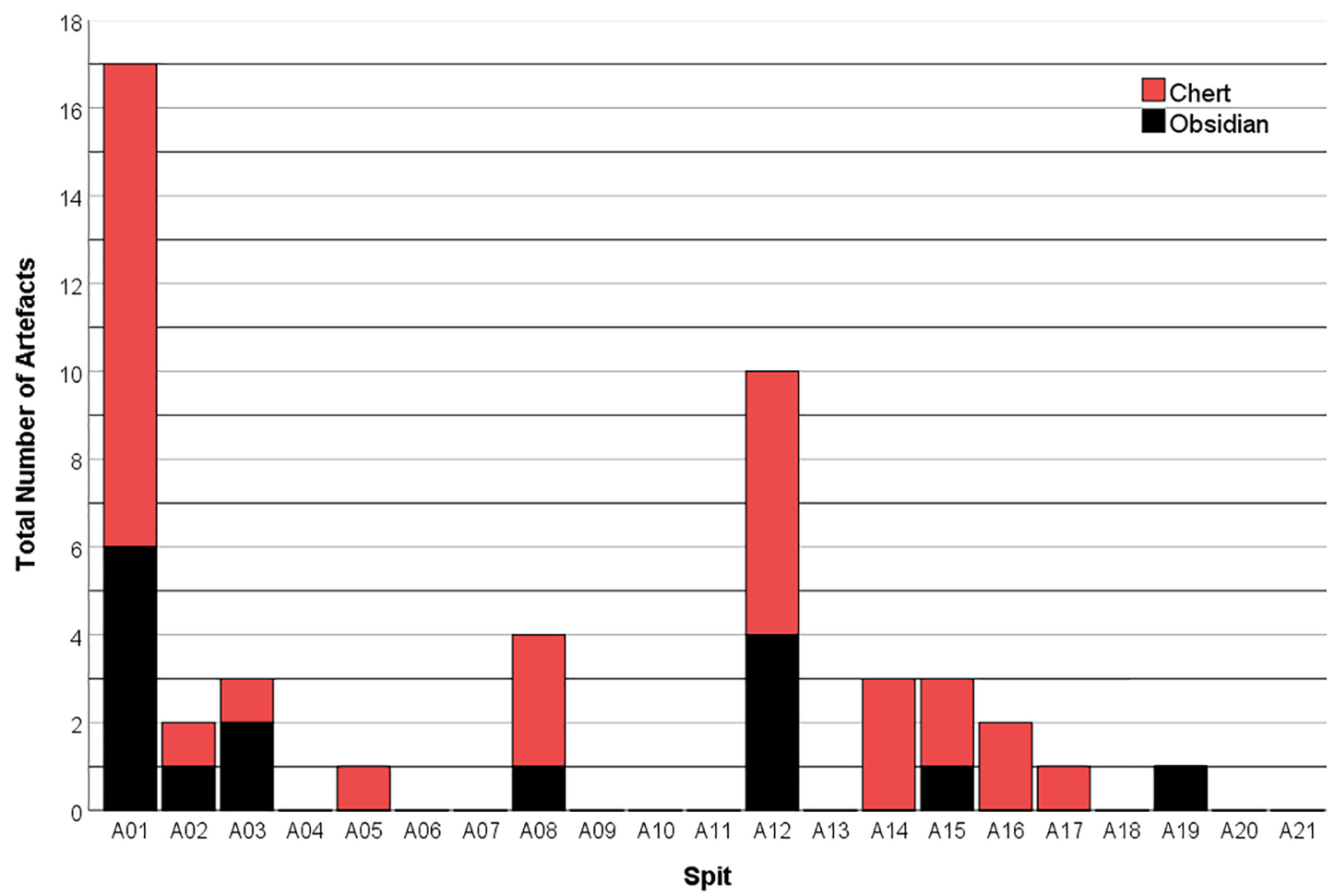

Figure 14. Total number of lithic (chert and obsidian) artefacts by excavation unit ( $5 \mathrm{~cm} \mathrm{spit)} \mathrm{at} \mathrm{Jareng} \mathrm{Bori.}$

\section{Lithics}

The lithic assemblage includes a stone pounder recovered from spit 10, and a concentration of three basalt stone pounders in spit 14 (complete with clear indentations). Small obsidian artefacts were found during the wet sieving and sorting from spit 1 onwards, as were chert artefacts between spits 1-17. A total of 47 flaked lithic artefacts were recovered from Jareng Bori rockshelter; composed of a very fine-grained black chert $(n=31)$ and obsidian $(n=16)$. Most of these artefacts were recovered either in the upper two spits, or below spit 12 (Fig. 14). The assemblage contains a single core and only eight complete flakes, one of which is bipolar. The assemblage is dominated by flake fragments $(20 \%)$, and flaked pieces $(49 \%)$, with four pieces of heatshattered chert. The size of obsidian artefacts is small, with a maximum length of $10.4 \mathrm{~mm}$. A single chert flake was recovered within the burial units of spit 8 .

\section{Geochemical analysis}

In total, 16 artefacts fulfilled size requirements for pXRF analysis. Geochemical data were compared with known source locations in Island Southeast Asia (ISEA). None of the known source locations matched the geochemistry present in the samples. The dataset (Table 7) was then enhanced with two unknown obsidian source locations from the nearby vicinity. These two source locations have so far only been reported in archaeological sites in the area, Group 1 and 2 obsidian sources (Maloney et al., 2018; Reepmeyer et al., 2016, 2019). Fourteen artefacts matched Group 2 obsidian, which is believed to be located on Alor Island. Two artefacts (\#28 and \#29) show very low counts of Rb and high counts of $\mathrm{Y}$ and remain unsourced.

\section{Metal}

A small iron fish-hook was recovered from spit 2, and a single rusty metal fragment was found in spit 12 at the protohistoric to late Metal-Age interface (Fig. 15). The fragment is $5.9 \times 2.4 \times 0.7 \mathrm{~cm}$ in size and weighs $7.3 \mathrm{~g}$ with a red, outer ferrous crust c. $0.7-1.1 \mathrm{~mm}$ thick. The fragment may be part of a metal blade as it has a straight margin (spine) tapering to a point. The exposed interior of the fragment has a flattened elliptical core surrounded by a second layer of metal bearing a heavily oxidized exterior. Cobalt (Co, $6.93 \mathrm{keV})$ is an important additive to steel that could not be accurately measured with pXRF due to spectral overlap with Fe (6.93 $\mathrm{keV})$ and $\mathrm{Ni}(7.48 \mathrm{keV})$.

\section{Discussion}

Our survey and excavation program for Pantar did not reveal Pleistocene human settlement of the island, as was reported from Alor where dates of c. 21 ka have been found (SamperCarro et al., 2016), or Timor-Leste, where radiocarbon ages greater than 40 kyr have been recovered from several caves (Hawkins et al., 2017a; O'Connor et al., 2010, 2011). This is likely an artefact of archaeological sampling strategies and taphonomic bias, as no large caves with probable cultural deposits were located during the Pantar survey. In ISEA, archaeological research often relies on caves and rockshelters as focal points for human settlement; however, on many Wallacean islands these are often young caves and rockshelters that rarely preserve archaeological remains (Louys et al., 2017). Our findings from Jareng Bori indicate a late Holocene occupation from the Metal-Age c. 1800 BP to the late historic period. The data indicate that the Jareng Bori rockshelter was occupied by small pottery-making communities that used marine resources, wild animals such 

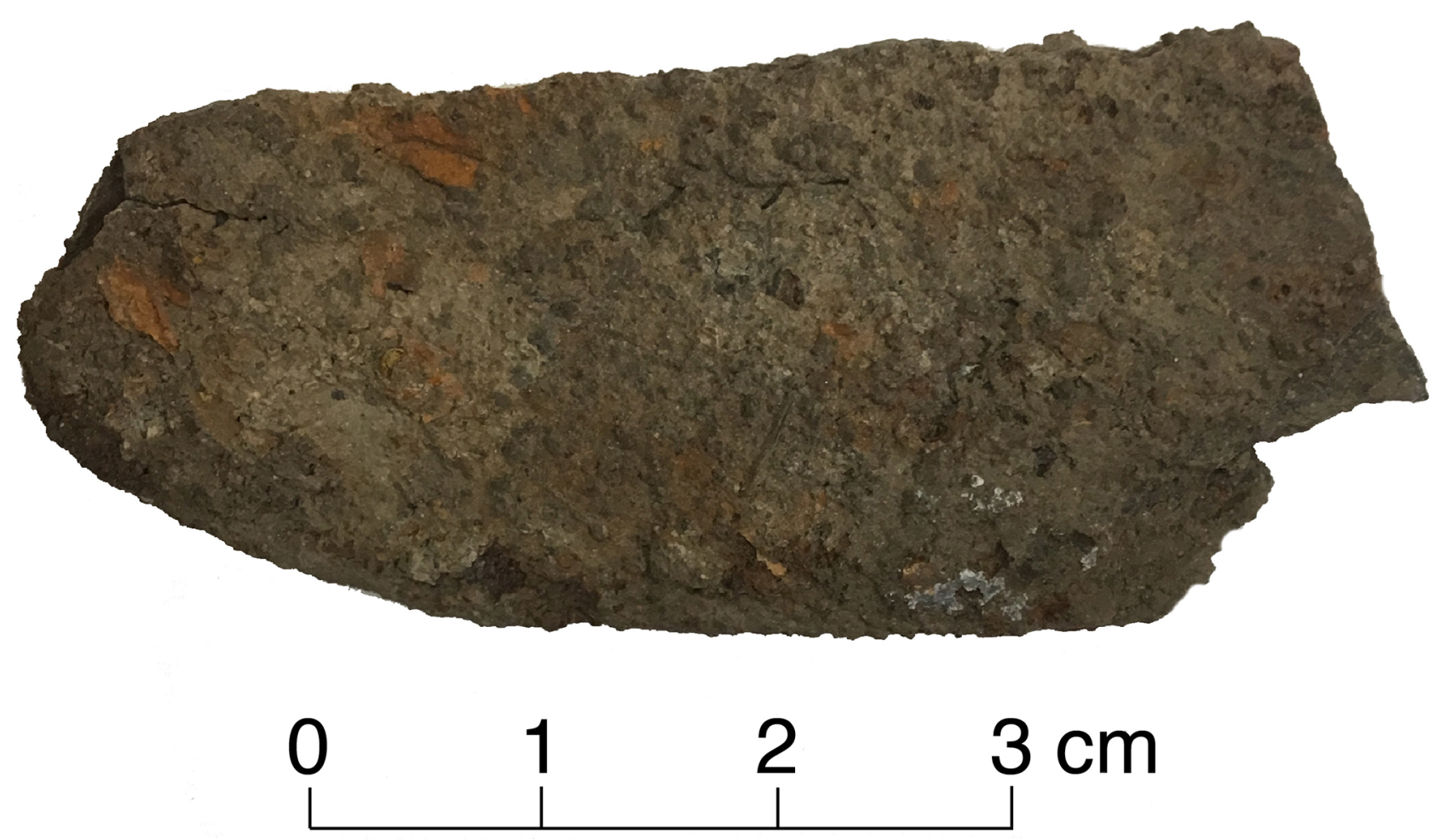

Figure 15. Ferrous metal artefact cf. knife from Jareng Bori.

Table 7. Summary data of obsidian pXRF analysis.

\begin{tabular}{lrrrrrrrrrr}
\hline & MnKa1 & FeKa1 & ZnKa1 & GaKa1 & ThLa1 & RbKa1 & SrKa1 & YKa1 & ZrKa1 & NbKa1 \\
\hline JAR Alg 1 & 834 & 9933 & 57 & 22 & 28 & 138 & 161 & 21 & 117 & 11 \\
JAR Alg 2 & 924 & 9266 & 80 & 21 & 30 & 137 & 160 & 20 & 116 & 11 \\
JAR A3 2 & 1172 & 12559 & 112 & 25 & 31 & 154 & 173 & 20 & 125 & 14 \\
JAR A1 \#1 & 836 & 11103 & 82 & 25 & 31 & 157 & 166 & 19 & 127 & 14 \\
JAR A1 \#2 & 835 & 9521 & 55 & 23 & 31 & 148 & 164 & 22 & 126 & 13 \\
JAR A3 \#9 & 974 & 10915 & 52 & 26 & 29 & 167 & 179 & 21 & 133 & 14 \\
JAR A1 \#13 & 810 & 9851 & 82 & 18 & 32 & 141 & 155 & 19 & 122 & 12 \\
JAR A1 \#14 & 1236 & 14947 & 136 & 27 & 43 & 166 & 183 & 19 & 121 & 13 \\
JAR A1 \#15 & 764 & 9218 & 116 & 17 & 23 & 112 & 138 & 13 & 101 & 9 \\
JAR A1 \#16 & 1030 & 10258 & 82 & 21 & 33 & 144 & 159 & 20 & 122 & 11 \\
JAR A8 \#25 & 1017 & 11459 & 70 & 25 & 32 & 161 & 186 & 25 & 132 & 14 \\
JAR A12 \#26 & 669 & 8139 & 32 & 15 & 24 & 125 & 139 & 20 & 116 & 11 \\
JAR A12 \#27 & 757 & 8163 & 60 & 18 & 23 & 132 & 151 & 20 & 116 & 10 \\
JAR A12 \#28 & 1207 & 19870 & 115 & 17 & 4 & 52 & 202 & 45 & 164 & 9 \\
JAR A12 \#29 & 1123 & 19507 & 129 & 20 & 3 & 50 & 182 & 44 & 161 & 7 \\
JAR A15 \#35 & 1041 & 12287 & 105 & 21 & 22 & 149 & 165 & 18 & 116 & 11 \\
\hline
\end{tabular}

as fruit bats, and domestic animals, with some subsistence change recorded over the occupation period.

The lack of botanical evidence precludes a discussion of plant resource utilization in the human diet at Jareng Bori, however, unidentified seeds were present in the site and agriculture is indicated by the presence of small numbers of stone pounders and domestic animal bones. The dog tooth in spit 14 (layer 7), associated with a date of c. 1305-1187 cal. BP is not unanticipated, considering dog remains have been recovered from Matja Kuru 2 in Timor-Leste at c. 3000 BP (Gonzalez et al., 2013). Domesticated pigs are thought to have entered ISEA between 4-3 ka (Dobney et al., 2008). The late appearance of pig bones at Jareng Bori (spits 1-5) indicates either that domestic animal production was not a major focus of Pantar communities during the early years of rockshelter use, or more likely, that the rockshelter assemblage reflects occasional casual shoreline foraging and fishing by people living mostly in open village settings, much as occurs today.

Fishing was concentrated on noticeably small inshore herbivorous fishes with secondary importance of small carnivores, indicating the use of mass harvesting techniques on the adjacent and extensive rocky reef. These methods and technologies were observable on the island during fieldwork and included traps, spearing, and nets, but poisons may also have been used (see Ono, 2010 for detailed discussion 
of ethnoarchaeology of fishing on Borneo that may be comparable). These fishing practices did not significantly change during the cultural sequence, and appear to be a continuation of similar fishing strategies that were occurring since the early to late Holocene elsewhere in Wallacea, e.g., at Here Sorot Entepa rockshelter on Kisar Island (O'Connor et al., 2018) and Tron Bon Lei rockshelter on Alor (Samper Carro et al., 2016). Metal-Age subsistence studies comparable to Jareng Bori are rare in Wallacea. At Leang Buida and Bukit Tiwing in the Talaud Islands, marine resources and domesticated animals were exploited since A.D. 1000 (Ono et al., 2018a), suggesting widespread mixed economic systems continued into the Metal-Age. However, there were significant changes in fishing intensity over time at Jareng Bori, as fish remains were far more abundant in the lower levels of layers 6 and 7 and declined over time, indicating that either occupation intensity declined, or site use changed.

Mollusc harvesting returned a diverse assemblage with over 79 marine species dominated by rocky reef species, with a large number of juvenile Nerita polita suggesting frequent harvesting. The broad spectrum of rocky reef taxa exploited could potentially reflect a division of labour that was able to target a variety of shellfish sources, thus boosting protein returns, provisioning offspring, and reducing risk while balancing energy return trade-offs (Codding et al., 2011). Crabs were present in low numbers indicating use of terrestrial, marine, and mangrove environments, but the assemblage was dominated by terrestrial hermit crabs which typically disturb archaeological sites post-deposition and are unlikely to reflect human subsistence (Walker, 1989).

The presence of fruit bats, often targeted for food in the Asia-Pacific region (Hawkins et al., 2016), suggests that these larger bats were consumed by the late historic occupants of the rockshelter. Our findings at Tron Bon Lei rockshelter on Alor and Laili Cave in Timor-Leste indicate that the very small quantities of small murids, lizard, bat, snake, and birds recovered from Jareng Bori were likely deposited by barn owls rather than people (Hawkins et al., 2017b, 2018).

The earthenware reveals two distinct intensive phases of occupation. The initial occupation of the site is associated with relatively few sherds associated with spits $21-16$ and refitting of sherds across these spits indicates a synchronous temporal unit. The middle and late periods of occupation saw not only significant increases in pottery abundance by weight and sherd number but also a slight increase in sherd thickness over time (Fig. 11). The surface treatments and decorations borne by the pottery assemblage at Jareng Bori appear to be relatively commensurate with those found on ceramic assemblages across many other sites in Indonesia. For instance, the application of burnishing, slipping, and painting as surface treatments and decoration were also adopted by both prehistoric and historic potters in Timor, Sulawesi, and other sites across Indonesia (Bulbeck \& Clune, 2003; Glover, 1986: 35-40; Latinis \& Stark, 2003; McKinnon, 2003; Mundardjito et al., 2003; Soegondho, 2003). All decoration types identified on the rim and body sherds, as well as carinations and flat bases, in the Jareng Bori ceramic assemblage are also commonly found on earthenware sherds across various Metal-Age sites in Indonesia (Bellwood, 1998; Bulbeck \& Clune, 2003; Glover, 1986: 210-212; Latinis \& Stark, 2003; McKinnon, 2003; Mundardjito et al., 2003; Ono et al., 2018b; Soegondho, 2003). As such, no specific type of surface treatment, decoration, and vessel-constituent (i.e. rim, body or base) morphology — as a variable on its own - appears to be specific to Jareng Bori. At the same time, the relatively low proportions of "black-burnished," "slipped", and "fine-paste" ceramics may be indicative of their relatively higher economic values compared with "general" medium-paste earthenware ceramics. Fine-paste earthenware ceramics, in particular, are thought to have a higher value than their medium paste counterparts (Ueda et al., 2017: 67) presumably because of the scarcity of fine-paste clay deposits in Southeast Asia as well as their exchange and circulation in the region through intra-regional maritime trade (Jutimoosik et al., 2017; Miksic \& Yap, 1988-1989; Ueda et al., 2017). Similarly, both "black-burnished" and "slipped" medium-paste vessels are likely to have higher values than their "general" cousins because of the additional production steps taken - in burnishing, slipping, and reduction-firing and higher energy expenditure in their respective chaînes opératoires.

There was a change in pottery style from more Appliqué and Painted Pointillé during the middle period 1305-1187 cal. BP to more frequent deposition of painted earthenware vessels with a mostly black matrix decorated by incising, impressing, moulding, and carving during the later $430-0$ cal. BP period. Ethnographic examples of traditional uses of earthenware ceramics in ISEA indicate several different uses by different cultural groups that were present in Nusa Tenggara. These include the storage of the placenta during birthing ceremonies, as ritual vessels during weddings, and as offerings or burial jars during funerals. Fine-paste earthenware vessels in the form of "kendis" (spouted vessels), in particular, are strongly associated with HinduBuddhist culture where they were used as ritual vessels for "sprinkling lustral water in Brahmanic or Buddhist ceremonies" (Groslier, 1981; Khoo, 1991).

The lithics included only small amounts of chert and obsidian flakes, the former often heat shattered. Geochemical analyses of the obsidian indicate some mobility in the region, probably between Alor and Pantar, that continues today. A new obsidian source not previously identified in previous regional studies (Reepmeyer et al., 2011, 2016, 2019) was observed in the Jareng Bori assemblage, and this may be a local Pantar source as volcanic activity is locally present at Sirung mountain.

Tools of note recovered during excavation at Jareng Bori include shell scrapers, a small iron fish-hook in spit 2, and a ferrous metal artefact in spit 12 at the interface between the late and middle periods. Metal appeared in eastern Indonesia sometime after $2500 \mathrm{BP}$ coinciding with the late Neolithic period (Bellwood, 1998), while shell tools have been used in the region since the late Pleistocene (Szabo et al., 2007). The Nautilus disc beads from Jareng Bori are similar to those found in the archaeological record in Timor-Leste and Kisar Island since the terminal Pleistocene (O'Connor, 2015; O'Connor et al., 2018) demonstrating a continuous cultural tradition within the region. These shell beads clearly continued to be used, alongside glass beads, into the late historic period of the last 400 years at Jareng Bori.

The incomplete burial in flex position dated to the last 400 years has tooth modifications similar to those found in burials from Java, Bali, Sumba, and Flores during the same time period, which has been interpreted as the unique cultural practice of the latest population arriving in the eastern Indonesian region (Kasnowihardjo et al., 2013; Koesbardiati 
et al., 2015; Suriyanto et al., 2012). This suggests a culture of shared ritualistic beliefs as well as indicators of social status (Domett et al., 2013). Burial goods were not noted in association with the burial, although several ceramics were mixed in the burial fill, probably post-deposition.

\section{Conclusions}

Our analyses of artefacts, mortuary practices, and fauna provide an extensive dataset that allows comparison with other sites in the wider Wallacea region, providing opportunities to investigate ecological adaptations and potential socio-cultural and economic relationships and interactions. Early occupation of Jareng Bori appears to reflect casual use of the shelter as a stopover for exploiting and eating resources obtained from the nearby shoreline. Jareng Bori preserves no evidence of the far reaching TransAsiatic trade network seen on Bali since the 1st century A.D., although Metal-Age pottery, metal, beads, shell artefacts, and introduced fauna indicates that Pantar was connected to regional networks within Wallacea during the last 2000 years. More specifically the obsidian sourcing and dental modification evidence indicates links between the inhabitants of Jareng Bori with Java and neighbouring islands in the Lesser Sunda Islands.

ACKNOWLEDGEMENTS. We thank the students of Universitas Gadjah Mada, Devi Mustika Sari, Yuni Suniarti, Alifah, and the villagers of Tuabang and Batu for their invaluable help in the field. Robinus James Laufa of the Department of Education and Culture Kalabahi was invaluable in helping negotiate with local villages for logistical support. Radiocarbon dating was conducted by Rachel Wood at The Australian National University Radiocarbon Dating Centre. The research was conducted as part of ARC Laureate Project FL120100156. SH was also supported by the Gerda Henkel Foundation AZ 35/F/18.

\section{References}

Anderson, A. 2017. Ecological contingency accounts for earliest seagoing in the western Pacific Ocean. The Journal of Island and Coastal Archaeology 13(2): 224-234.

https://doi.org/10.1080/15564894.2016.1277286

Aplin, K. P., T. Chesser, and J. ten Have. 2003. Evolutionary biology of the genus Rattus: profile of an archetypal rodent pest. In Rats, Mice and People: Rodent Biology and Management, ed. G. R. Singleton, L. A. Hinds, C. J. Krebs, and D. M. Spratt, pp. 487-498. ACIAR Monograph no. 96, 564 pp.

Aplin, K. P., and K. M. Helgen. 2010. Quaternary murid rodents of Timor part I: new material of Coryphomys buehleri Schaub, 1937, and description of a second species of the genus. Bulletin of the American Museum of Natural History 341: 1-80. https://doi.org/10.1206/692.1

Aplin, K., H. Suzuki, A. A. Chinen, R. T. Chesser, J. ten Have, S. C. Donnellan, J. Austin, A. Frost, J. P. Gonzalez, V. Herbreteau, F. Catzeflis, J. Soubrier, Y. P. Fang, J. Robins, E. Matisoo-Smith, A. D. Bastos, I. Maryanto, M. H. Sinaga, C. Denys, R. A. Van Den Bussche, C. Conroy, K. Rowe, and A. Cooper. 2011. Multiple geographic origins of commensalism and complex dispersal history of black rats. PLOS ONE 6: e26357. https://doi.org/10.1371/journal. pone.0026357

Balme, J. 2013. Of boats and string: the maritime colonisation of Australia. Quaternary International 285: 68-75.

https://doi.org/10.1016/j.quaint.2011.02.029
Barnes, R. H. 1982. The Majapahit dependency Galiyao. Bijdragen tot de Taal-, Land-en Volkenkunde 4: 407-412. https://doi.org/10.1163/22134379-90003461

Bass, W. M. 1995. Human Osteology: A Laboratory and Field Manual of the Human Skeleton. Columbia: Missouri Archaeological Society.

Bellwood, P. 1998. The archaeology of Papuan and Austronesian prehistory in the northern Moluccas, eastern Indonesia: expansion of East and Southeast Asian Neolithic. In Archaeology and Language II: Archaeological Data and Linguistic Hypotheses, ed. R. Blench and M. Spriggs, pp. 128-140. London: Routledge. https://doi.org/10.4324/9780203202913_chapter_5

Bellwood, P. 2017. First Islanders: Prehistory and Human Migration in Island Southeast Asia. Oxford: Wiley Blackwell. https://doi.org/10.1002/9781119251583

Bellwood, P., and E. Dizon, eds. 2013. 4000 Years of Migration and Cultural Exchange. Terra Australis 40. Canberra: ANU E-Press.

Bellwood, P., A. Waluyo, G. Nitihaminoto, and G. Irwin. 1993. Archaeological research in the northern Moluccas: interim results, 1991 field season. Bulletin of the Indo-Pacific Prehistory Association 13: 20-33. https://doi.org/10.7152/bippa.v13i0.12035

Bulbeck, D. 2010. Uneven development in southwest Sulawesi, Indonesia during the Early Metal Phase. In 50 Years of Archaeology in Southeast Asia: Essays in Honour of Ian Glover, ed. B. Bellina, E. A. Bacus, T. O. Pryce, and J. Wisseman Christie, pp. 152-169. Bangkok: River Books.

Bulbeck, D., F. Arifin Aziz, S. O’Connor, A. Calo, J. N. Fenner, B. Marwick, J. Feathers, R. Wood, and D. Prastiningtyas. 2016. Mortuary caves and the dammar trade in the Towuti-Routa region, Sulawesi, in an Island Southeast Asian context. Asian Perspectives 55(2): 148-183. https://doi.org/10.1353/asi.2016.0017

Bulbeck, D., and G. Clune. 2003. Macassar historical decorated earthenwares: preliminary chronology and Bajau connections. In Earthenware in Southeast Asia. Proceedings of the Singapore Symposium on Premodern Southeast Asian Earthenwares, ed. J. N. Miksic, pp. 80-102. Singapore: Singapore University Press.

Butler, V. L. 1994. Fish feeding behaviour and fish capture: the case for variation in Lapita fishing strategies. Archaeology in Oceania 29(2): 81-90. https://doi.org/10.1002/arco.1994.29.2.81

Calo, A., P. Bellwood, J. Lankton, A. Reinecke, R. Bawono, and B. Prasetyo. 2020a. Trans-Asiatic exchange of glass, gold and bronze: analysis of finds from the late prehistoric Pangkung Paruk site, Bali. Antiquity 94(373): 110-126. https://doi.org/10.15184/aqy.2019.199

Calo, A., I. Moffat, D. Bulbeck, M. F. Dupoizat, K. Simyrdanis, C. P. Walker, R. A. Bawono, and B. Prasetyo. 2020b. Reconstruction of the late first millennium AD harbor site of Sembiran and analysis of its tradeware. The Journal of Island and Coastal Archaeology. https://doi.org/10.1080/15564894.2020.1749194

Claassen, C. 1998. Shells. Cambridge: Cambridge University Press. Codding, B. F., R. B. Bird, and D. W. Bird. 2011. Provisioning offspring and others: risk-energy trade-offs and gender differences in hunter-gatherer foraging strategies. Proceedings of the Royal Society B: Biological Sciences 278: 2502-2509. https://doi.org/10.1098/rspb. 2010.2403

Denham, T. 2013. Early farming in Island Southeast Asia: an alternative hypothesis. Antiquity 87(335): 250-257. https://doi.org/10.1017/S0003598X00048766

Dobney, K., T. Cucchi, and G. Larson. 2008. The pigs of Island Southeast Asia and the Pacific: new evidence for taxonomic status and human-mediated dispersal. Asian Perspectives 47: 59-74. https://doi.org/10.1353/asi.2008.0009

Domett, K. M., J. Newton, D. O'Reilly, N. Tayles, L. Shewan, and N. Beavan. 2013. Cultural modification of the dentition in prehistoric Cambodia. International Journal of Osteoarchaeology 23(3): 274-286. https://doi.org/10.1002/oa.1245 
Dye, T. S., and K. Longenecker. 2004. Manual of Hawaiian Fish Remains: Identification Based on the Skeletal Reference Collection of Alan C. Ziegler and Including Otoliths. Honolulu: Society for Hawaiian Archaeology.

Fallon, S. J., L. K. Fifield, and J. M. Chappell. 2010. The next chapter in radiocarbon dating at The Australian National University. Status report on the single stage AMS. Nuclear Instruments and Methods in Physics Research Section B: Beam Interactions with Materials and Atoms 268: 898-901. https://doi.org/10.1016/j.nimb.2009.10.059

Gilbert, F. 2015. Human Skeletal Analysis Lab Book (Revised). Canberra: School of Archaeology and Anthropology, The Australian National University.

Glascock, M. D., and J. R. Ferguson. 2012. Report on the Analysis of Obsidian Source Samples by Multiple Analytical Methods. Available upon request from the Archaeometry Lab at the University of Missouri, Columbia

Glover, I. 1986. Archaeology in eastern Timor, 1966-67. Terra Australis 11. Canberra: Department of Prehistory, Research School of Pacific Studies, The Australian National University.

Gonzalez, A., G. Clark, S. O'Connor, and L. Matisoo-Smith. 2013. A 3000-year-old dog burial in Timor-Leste. Australian Archaeology 76: 13-20.

https://doi.org/10.1080/03122417.2013.11681961

Groslier, B. P. 1981. Introduction to the ceramic wares of Angkor. In Khmer Ceramics. 9th-14th Century, ed. D. Stock, pp. 9-39. Singapore: Southeast Asian Ceramic Society.

Hakim, B., S. Hawkins, D. Bulbeck, I. Caldwell, S. Druce, and C. Macknight. 2018. Material culture at Allangkanangnge ri Latanete in relation to the origins of Bugis kingdoms. In The Archaeology of Sulawesi: Current Research on the Pleistocene to the Historic Period, ed. S. O'Connor, D. Bulbeck, and J. Meyer, pp. 287-312. Canberra: ANU-E-Press. https://doi.org/10.22459/TA48.11.2018.17

Hawkins, S., S. O’Connor, and S. Kealy. 2016. Late Quaternary hominin-bat (Chiroptera) interactions in the Asia-Pacific. Archaeology in Oceania 51(1): 7-17.

https://doi.org/10.1002/arco.5084

Hawkins, S., S. O'Connor, T. Maloney, M. Litster, S. Kealy, J. Fenner, K. Aplin, C. Boulanger, S. Brockwell, R. Willan, E. Piotto, and J. Louys. 2017a. Oldest human occupation of Wallacea at Laili Cave, Timor-Leste, shows broad-spectrum foraging responses to late Pleistocene environments. Quaternary Science Reviews 171: 58-72.

https://doi.org/10.1016/j.quascirev.2017.07.008

Hawkins, S., S. O'Connor, and J. Louys. 2017b. Taphonomy of bird (Aves) remains at Laili Cave, Timor-Leste and implications for human-bird interactions during the Pleistocene. Journal of Archaeological and Anthropological Sciences 11(12): 6325-6337.

https://doi.org/10.1007/s12520-017-0568-4

Hawkins, S., S. Samper Carro, J. Louys, K. Aplin, S. O'Connor, and Mahirta. 2018. Human palaeoecological interactions and owl roosting at Tron Bon Lei, Alor Island, eastern Indonesia. Journal of Island and Coastal Archaeology 13(3): 371-387. https://doi.org/10.1080/15564894.2017.1285834

Heekeren, H. R. van. 1956. The Urn Cemetery at Melolo, East Sumba. Berita Dinas Purbakala 3. Jakarta: Dinas Purbakala.

Hiscock, P. 2007. Looking the other way: a materialist/technological approach to classifying tools and implements, cores and retouched flakes. In Tools or Cores? The Identification and Study of Alternative Care Technology in Lithic Assemblages, ed. S. McPherron and J. Lindley, pp. 198-222. Newcastle: Cambridge Scholars Publishing.

Hogg, A., Q. Hua, P. Blackwell, M. Niu, C. Buck, T. Guilderson, T. Heaton, J. Palmer, P. Reimer, R. Reimer, and C. Turney. 2013. SHCal13 Southern Hemisphere calibration, 0-50,000 years cal BP. Radiocarbon 55(4): 1889-1903.

https://doi.org/10.2458/azu_js_rc.55.16783
Jutimoosik, J., C. Sirisathitkul, W. Limmun, R. Yimnirun, and W. Noonsuk. 2017. Synchrotron XANES and ED-XRF analyses of fine-paste ware from 13th to 14th century maritime Southeast Asia. X-Ray Spectrometry 46(6): 492-496. https://doi.org/10.1002/xrs.2780

Kasnowihardjo, G., R. A. Suriyanto, T. Koesbardiati, and D. Murti. 2013. Human teeth modification in Binangun and Leran: new findings in the northern coast of Rembang district, central Java. Berkala Arckeologi 33(2): 169-184.

https://doi.org/10.30883/jba.v33i2.26

Khoo, J. E. 1991. Kendi: Pouring Vessels in the University of Malaya Collection. Singapore: Oxford University Press.

Koesbardiati, T., D. B. Murti, and R. A. Suriyanto. 2015. Cultural dental modification in prehistoric population in Indonesia. Bulletin of the International Association of Paleodontology 9(2): 52-60.

Latinis, D. K., and K. Stark. 2003. Roasted dirt: assessing earthenware assemblages from sites in Central Maluku, Indonesia. In Earthenware in Southeast Asia. Proceedings of the Singapore Symposium on Premodern Southeast Asian Earthenwares, ed. J. N. Miksic, pp. 81-103. Singapore: Singapore University Press.

Leach, B. F. 1997. A Guide to the Identification of Fish Remains from New Zealand Archaeological Sites. Wellington: Archaeozoology Laboratory, Museum of New Zealand Te Papa Tongarewa.

Louys, J., S. Kealy, S. O’Connor, G. J. Price, S. Hawkins, K. Aplin, Y. Rizal, J. Zaim, Mahirta, D. A. Tanudirjo, W. D. Santoso, A. R. Hidayah, A. Trihascaryo, R. Wood, J. Bevitt, and T. Clark. 2017. Differential preservation of vertebrates in Southeast Asian caves. International Journal of Speleology 46(3): 379-408. https://doi.org/10.5038/1827-806X.46.3.2131

Lyman, R. L. 2008. Quantitative Paleozoology. Cambridge: Cambridge University Press.

https://doi.org/10.1017/CBO9780511813863

Maloney, T. R., S. O'Connor, and C. Reepmeyer. 2018. Specialised lithic technology of terminal Pleistocene maritime peoples of Wallacea. Archaeological Research in Asia 16: 78-87. https://doi.org/10.1016/j.ara.2018.05.003

McKinnon, E. P. E. 2003. Historic period earthenware from the island of Sumatra. In Earthenware in Southeast Asia. Proceedings of the Singapore Symposium on Premodern Southeast Asian Earthenwares, ed. J. N. Miksic, pp. 162-172. Singapore: Singapore University Press.

Miksic, J. N., and C. T. Yap. 1988-1989. Fine-bodied white earthenwares of Southeast Asia: some x-ray fluorescence tests. Asian Perspectives 28(1): 45-60.

Miller, I. 1969. The Spice Trade of the Roman Empire: 29 B.C. to A.D. 641. Oxford: The Clarendon Press.

Mundardjito, I. H., E. Pojoh, and W. D. Ramelan. 2003. Forgotten small things: early historic earthenware of Java (7th to 10th Centuries). In Earthenware in Southeast Asia. Proceedings of the Singapore Symposium on Premodern Southeast Asian Earthenwares, ed. J. N. Miksic, pp. 136-145. Singapore: Singapore University Press.

O'Connor, S. 2015. Rethinking the Neolithic in Island Southeast Asia with particular reference to the archaeology of Timor-Leste and Sulawesi. Archipel 90: 15-47. https://doi.org/10.4000/archipel.362

O'Connor, S., and K. Aplin. 2007. A matter of balance: an overview of Pleistocene occupation history and the impact of the Last Glacial Phase in East Timor and the Aru Islands, eastern Indonesia. Archaeology in Oceania 42(3): 82-90. https://doi.org/10.1002/j.1834-4453.2007.tb00021.x

O'Connor, S., A. Barham, M. Spriggs, P. Veth, K. Aplin, and E. St Pierre. 2010. Cave archaeology and sampling issues in the tropics: a case study from Lene Hara Cave, a 42,000-year-old occupation site in East Timor, Island Southeast Asia. Australian Archaeology 71: 29-40.

https://doi.org/10.1080/03122417.2010.11689382 
O'Connor, S., Mahirta, S. Kealy, C. Boulanger, T. Maloney, S. Hawkins, M. C. Langley, H. Kaharudin, Y. Suniarti, H. Muhammad, M. Ririmasse, D. A. Tanudirjo, L. Wattimena, W. Handoko, Alifah, and J. Louys. 2018. Kisar and the archaeology of small islands in the Wallacean Archipelago. Journal of Island and Coastal Archaeology 14(2): 198-225. https://doi.org/10.1080/15564894.2018.1443171

O'Connor, S., R. Ono, and C. Clarkson. 2011. Pelagic fishing at 42,000 years before the present and the maritime skills of modern humans. Science 334: 1117-1121. https://doi.org/10.1126/science.1207703

O’Connor, S., G. Robertson, and K. P. Aplin. 2014. Are osseous artefacts a window to perishable material culture? Implications of an unusually complex bone tool from the Late Pleistocene of East Timor. Journal of Human Evolution 67: 108-119. https://doi.org/10.1016/j.jhevol.2013.12.002

O'Connor, S., S. Samper Carro, S. Hawkins, S. Kealy, J. Louys, and R. Wood. 2017a. Fishing in life and death: Pleistocene fishhooks from a burial context on Alor Island, Indonesia. Antiquity 91(360): 1451-1468. https://doi.org/10.15184/aqy.2017.186

O’Connor, S., D. Tanudirjo, M. Ririmasse, M. Husni, S. Kealy, and S. Hawkins. 2017b. Ideology, ritual performance and its manifestations in the rock art of Timor-Leste and Kisar Island, Island Southeast Asia. Cambridge Archaeological Journal 28(2): 225-241.

https://doi.org/10.1017/S0959774317000816

Ono, R. 2010. Ethno-archaeology and early Austronesian fishing strategies in near-shore environments. The Journal of the Polynesian Society 119: 269-314.

Ono, R., F. Aziz, A. A. Oktaviana, D. Prastiningtyas, M. Ririmasse, N. Iriyanto, and M. Yoneda. 2018b. Development of regional maritime networks during the Early Metal Age in Northern Maluku Islands: a view from excavated glass ornaments and pottery variation. The Journal of Island and Coastal Archaeology 13(1): 90-108.

https://doi.org/10.1080/15564894.2017.1395374

Ono, R., and G. Clark. 2012. A 2,500-year record of marine resource use of Ulong Island, Republic of Palau. International Journal of Osteoarchaeology 22: 637-654. https://doi.org/10.1002/oa.1226

Ono, R., Sriwigati, and J. Siswanto. 2018a. Development of marine and terrestrial resource use in the Talaud Islands AD 1000-1800, northern Sulawesi region. In The Archaeology of Sulawesi: Current Research on the Pleistocene to the Historic Period, ed. S. O'Connor, D. Bulbeck, and J. Meyer, pp. 243-246. Canberra: ANU-E-Press. https://doi.org/10.22459/TA48.11.2018.15

Piper, P. J., F. Campos, D. Ngoc Kinh, N. Amano, M. Oxenham, B. Chi Hoang, P. Bellwood, and A. Willis. 2014. Early evidence for pig and dog husbandry from the Neolithic site of An Son, Southern Vietnam. International Journal of Osteoarchaeology 24(1): 68-78. https://doi.org/10.1002/oa.2226

Reepmeyer, C., S. O’Connor, and S. Brockwell. 2011. Long-term obsidian use in East Timor: provenancing lithic artefacts from the Jerimalai cave. Archaeology in Oceania 46: 85-90. https://doi.org/10.1002/j.1834-4453.2011.tb00102.x

Reepmeyer, C., S. O’Connor, S. Kealy, and T. Maloney. 2019. Kisar: a small island participant in an extensive maritime obsidian network in the Wallacean Archipelago. Archaeological Research in Asia 19: 100139. https://doi.org/10.1016/.ara.2019.100139

Reepmeyer, C., S. O'Connor, Mahirta, T. Maloney, and S. Kealy. 2016. Late Pleistocene/early Holocene maritime interaction in Southeastern Indonesia-Timor Leste. Journal of Archaeological Science 76: 21-30.

https://doi.org/10.1016/j.jas.2016.10.007
Roberts, P., J. Louys, J. Zech, C. Shipton, S. Kealy, S. Samper Carro, S. Hawkins, C. Boulanger, S. Marzo, B. Fiedler, N. Boivin, Mahirta, K. Aplin, and S. O'Connor. 2020. Isotopic evidence for initial coastal colonization and subsequent diversification in the human occupation of Wallacea. Nature Communications 11(1): $1-11$.

https://doi.org/10.1038/s41467-020-15969-4

Rodemeier, S. 1995. Local tradition on Alor and Pantar: an attempt at localizing Galiyao. Bijdragen tot de Taal-, Land-en Volkenkunde 151(3): 438-442.

https://doi.org/10.1163/22134379-90003040

Samper Carro, S., S. O'Connor, J. Louys, S. Hawkins, and Mahirta. 2016. Human maritime subsistence strategies in the Lesser Sunda Islands during the terminal Pleistocene-early Holocene: new evidence from Alor, Indonesia. Quaternary International 416: 1-16.

https://doi.org/10.1016/j.quaint.2015.07.068

Shaffer, L. N. 1996. Maritime Southeast Asia, 300 BC to AD 1528. New York: Routledge.

Silva, F., C. J. Stevens, A. Weisskopf, C. Castillo, L. Qin, A. Bevan, and D. Fuller. 2015. Modelling the geographical origin of rice cultivation in Asia using the rice archaeological database. PLoS ONE 10(9): e0137024.

https://doi.org/10.1371/journal.pone. 0137024

Soegondho, S. 2003. Prehistoric earthenwares of Indonesia. In Earthenware in Southeast Asia. Proceedings of the Singapore Symposium on Premodern Southeast Asian Earthenwares, ed. J. N. Miksic, pp. 69-79. Singapore: Singapore University Press.

Suriyanto, R. A., T. Koesbardiati, and D. B. Murti. 2012. Mongoloidization Around the Neolithic until Present Indonesia: A Perspective of Dental Modification. Proceedings of the 2nd International Joint Symposium on Oral and Dental Sciences. Yogyakarta: FKG.

Szabó, K., and J. R. Amesbury. 2011. Molluscs in a world of islands: the use of shellfish as a food resource in the tropical island AsiaPacific region. Quaternary International 239(1): 8-18. https://doi.org/10.1016/j.quaint.2011.02.033

Szabó, K., A. Brumm, and P. Bellwood. 2007. Shell artefact production at 32,000-28,000 BP in Island Southeast Asia: thinking across media? Current Anthropology 48(5): 701-723. https://doi.org/10.1086/520131

Ueda, K., J. N. Miksic, S. C. Wibisono, N. Harkantiningsih, G. Y. Goh, E. Edwards McKinnon, and A. M. Z. Shah. 2017. Trade and consumption of fine paste ware in Southeast Asia: petrographic and portable X-ray fluorescence analyses of ninthto fourteenth-century earthenware. Archaeological Research in Asia 11: 58-68. https://doi.org/10.1016/j.ara.2017.05.004

Walker, S. E. 1989. Hermit crab as taphonomic agents. PALAIOS 4(5): 439-452. https://doi.org/10.2307/3514588

Willis, A., and N. Tayles. 2009. Field anthropology: application to burial contexts in Prehistoric Southeast Asia. Journal of Archaeological Science 36: 547-554.

https://doi.org/10.1016/j.jas.2008.10.010

Wyneken, J., and D. Witherington. 2001. The Anatomy of Sea Turtles. US Department of Commerce: Southeast Fisheries Science Center, National Marine Fisheries Service, National Oceanic and Atmospheric Administration.

Zar, J. H. 2010. Biostatistical Analysis. New Jersey: Pearson Prentice Hall. 
Appendix 1. Number of identified specimens present (NISP), Jareng Bori mollusc assemblage.

spit/context

\begin{tabular}{lllllllllllllllllllllllllllllllllllllllllll}
\hline taxon & 1 & 2 & 3 & 4 & 5 & 6 & 6 (B) & 7 & 7 (B) & 8 & 8 (B) & 9 & 9 (B) & 10 & 11 & 12 & 13 & 14 & 15 & 16 & 17 & 18 & 19 & 20 & 21 & burial & $(\mathrm{NIS})$
\end{tabular}

Acanthopleura sp.

Cryptoplax sp. 1

Cryptoplax sp.

Haliotis sp.
Patella $\mathrm{sp}$.

Patella sp.
Cellana testudinaria

Trochus maculatus

Trochus sp.

Tectus fenestratus

Tectus pyramis

Rochia nilotica
Monodonta canalifer

Turbo chrysostomu.

Turbo setosus

Turbo sp.

Turbinidae operculum

Lunella cinerea

Angaria delphinus

Liotinaria peronii

Neritopsis radula

Nerita albicilla

Nerita balteata

Nerita chamaeleon

Nerita exuvia

Nerita grossa

Nerita plicata

Nerita polita

Neritidae operculum

Indomodulus tectum

Clypeomorus bifasciata

Clypeomorus irrorata

Clypeomorus subbrevicula

Clypeomorus sp.

Opalia sp.

Cerithium nodulosum

Cerithidea sp.

Canarium labiatum

Gibberulus gibberulus gibbosus

Strombus sp.

Lambis lambis

Cypraeidae

Turritriton labiosus

Monoplex vespaceus

Chicoreus sp.

Indothais sp.

Thais sp.

Orania nodosa

Nassa serta

Prodotia sp.

Euplica turturina

Nassarius albescens

Nassarius globosus

Nassarius leptospirus

Nassarius shacklefordi

Latirolagena smaragd

Oliva sp.

Harpidae

Cymbiola vespertilio

Lophiotoma acuta

Conus litteratus

Conus marmoreu

Conus textilis

Conus sp.

Siphonaria atra

Barbatia sp.

Austriella corrugata

Septifer bilocularis

Pinna sp.

Pinctada margaritifera

Isognomon ephippium

Codakia sp.

Vasticardium subrugosum

Vasticardium $\mathrm{sp}$.

Tridacna sp.

Gari elongata

Asaphis violascens

Periglypta puerpera

Periglypta sp.

Pitar sp.

Dosinia sp.

Bivalvia sp.

Nautilus sp.

\begin{tabular}{|c|c|c|c|c|c|c|c|c|c|c|c|c|c|c|c|c|c|c|c|c|c|c|c|c|}
\hline 5 & 2 & 10 & 26 & 53 & 4 & 52 & 18 & 23 & 10 & 6 & 16 & 25 & 38 & 41 & 16 & 49 & 33 & 14 & 16 & 7 & 6 & 2 & 1 & - \\
\hline- & - & - & 1 & 3 & - & - & - & 2 & - & 1 & - & - & 3 & 1 & - & - & 1 & 1 & - & - & - & - & - & - \\
\hline- & - & - & - & - & - & - & 1 & - & - & - & - & - & - & - & - & - & - & - & - & - & - & - & - & - \\
\hline- & - & 1 & 3 & 2 & - & 3 & - & 2 & 1 & 2 & 1 & 3 & 4 & 3 & 3 & 5 & 1 & 4 & 8 & 2 & 3 & - & - & - \\
\hline- & 2 & - & - & - & - & 1 & - & - & - & - & - & - & - & - & - & - & - & - & - & - & - & - & - & - \\
\hline- & - & - & 2 & 14 & - & - & - & 4 & - & - & - & 1 & 1 & 2 & - & 4 & - & 1 & - & - & - & - & - & - \\
\hline- & - & 9 & - & - & 1 & - & 17 & 12 & - & - & 6 & 11 & 14 & - & 13 & 39 & 12 & 15 & 21 & 3 & 14 & 6 & 1 & - \\
\hline
\end{tabular}

476

total (NISP)

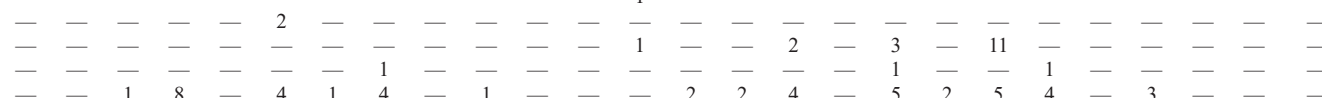


Appendix 2. Minimum number of individuals (MNI), Jareng Bori mollusc assemblage.

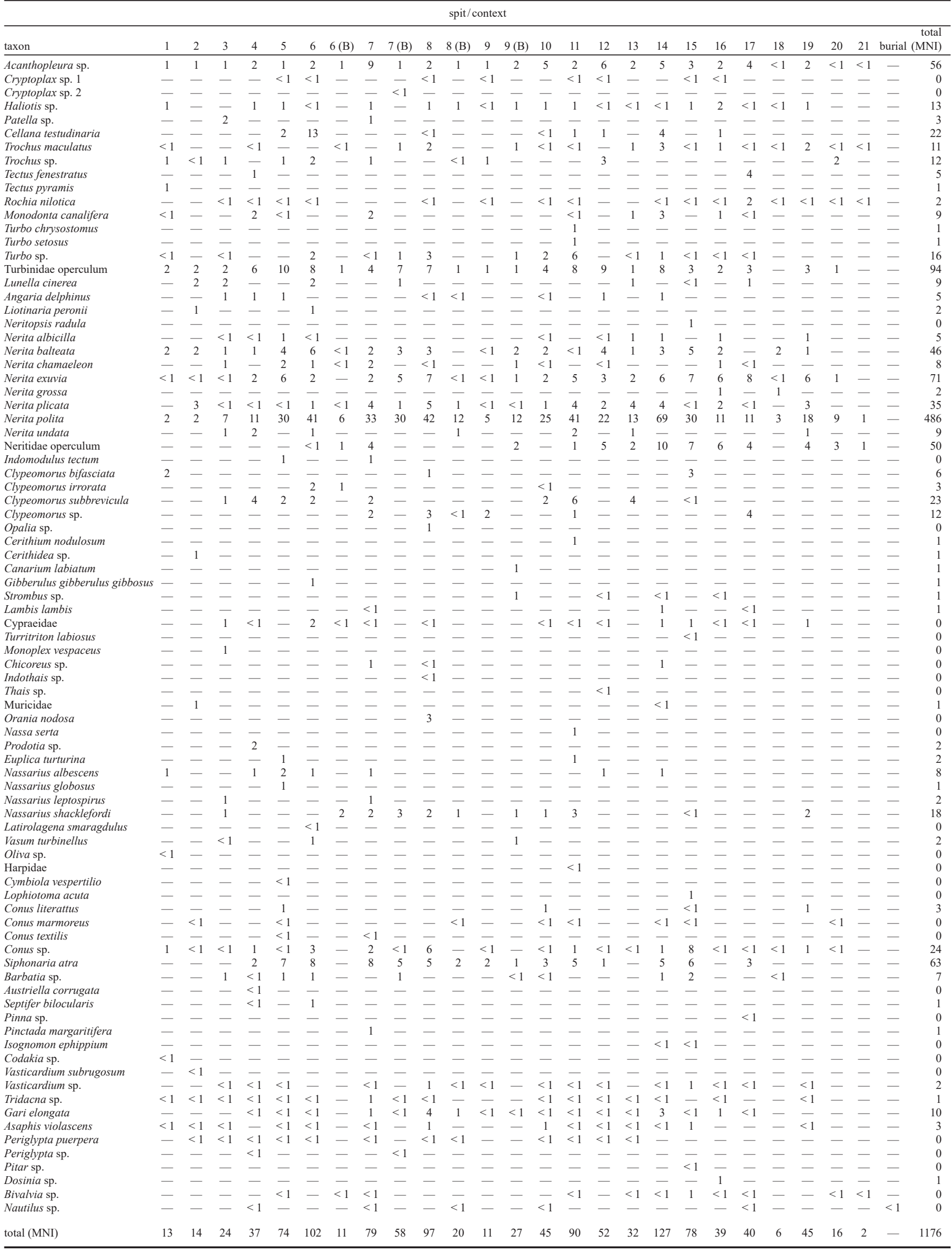


Appendix 3. The weight (g) of Jareng Bori mollusc assemblage.

\begin{tabular}{|c|c|c|c|c|c|c|c|c|}
\hline & & & & & & & & \\
\hline taxon & 1 & 2 & 3 & 4 & 5 & 6 & 6 (B) & 7 \\
\hline Acanthapleura sp. & 0.17 & 0.32 & 0.3 & 1.1 & 4.5 & 3.9 & 0.3 & 3.74 \\
\hline ryptoplax sp & 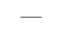 & - & - & - & 0.1 & 0.3 & - & - \\
\hline ryptoplax sp. 2 & - & - & - & - & - & & - & - \\
\hline & 0.16 & - & - & 0.9 & 1.1 & 0.5 & - & 0.84 \\
\hline ella sp. & - & - & 0.5 & - & - & - & - & 0.7 \\
\hline llana & - & - & - & - & 0.1 & 2.4 & - & - \\
\hline ochus ma & 1.72 & - & - & 3.8 & - & - & 0.7 & - \\
\hline ochus sp. & 0.42 & 1.86 & 2.1 & - & 10.7 & 28 & - & 4.87 \\
\hline Tectus fenestratus & - & - & - & 0.3 & - & - & - & - \\
\hline 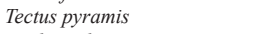 & 6.44 & - & - & & - & - & - & - \\
\hline & & - & 3.1 & & 0.5 & 0.5 & - & \\
\hline alifera & 0.28 & - & - & 0.5 & 1 & - & - & 0.23 \\
\hline rbo chrysost & - & - & - & - & - & - & - & - \\
\hline rbo setosus & - & - & - & - & - & - & - & - \\
\hline Irbo sp. & 1.65 & - & 0.5 & - & - & 4.1 & - & 1.4 \\
\hline urbin & 0.13 & 0.51 & 0.5 & 4.4 & 18.5 & 9.36 & 1 & 2.54 \\
\hline & - & 1.49 & & & & 0.8 & - & - \\
\hline & - & - & 0.4 & 2.1 & 2.7 & - & - & - \\
\hline tinaria peronii & - & 0.64 & - & - & - & 0.5 & - & - \\
\hline ritopsis radula & - & - & - & - & - & - & - & - \\
\hline rita a & - & - & 0.5 & 0.7 & 0.5 & 0.3 & - & - \\
\hline rita & 0.7 & 0.91 & 0.1 & 0.1 & 0.8 & 1.2 & $<0.1$ & 0.67 \\
\hline & & & 0. & & 0.5 & 0.4 & $<0.1$ & 1.99 \\
\hline & 0.95 & 0.92 & 0.3 & 2.7 & 3.1 & 5 & - & 3.12 \\
\hline rita grossa & - & - & - & - & - & - & - & - \\
\hline rita plicata & - & 0.86 & 0.5 & 0.8 & 0.2 & 6.3 & 0.6 & 2.37 \\
\hline rita & 1.66 & 3.1 & 4.7 & 5.8 & 11.4 & 26.3 & 3.5 & 25.68 \\
\hline$t a$ & - & - & 0.9 & 0.8 & - & 0.8 & - & - \\
\hline & - & - & - & & - & 0.2 & 0.1 & 0.28 \\
\hline & - & - & - & - & 0.4 & - & - & 0.44 \\
\hline & 1.56 & - & - & - & - & - & - & - \\
\hline Clypeon & - & - & - & - & - & 2.1 & 1.2 & - \\
\hline Typeor & - & - & 0.1 & 2.1 & 2.5 & 2.4 & - & 2.32 \\
\hline & - & - & - & - & - & - & - & 0.54 \\
\hline & - & - & - & - & - & - & - & - \\
\hline & - & - & - & - & - & - & - & - \\
\hline & - & 0.68 & - & - & - & - & - & - \\
\hline Canariu & - & - & - & - & - & - & - & - \\
\hline Fibber & - & - & - & - & - & 2.5 & - & - \\
\hline & - & - & - & - & - & - & - & - \\
\hline & - & - & - & - & - & - & - & 0.31 \\
\hline & - & - & 3.9 & 7 & - & 5.3 & 0.6 & 2.78 \\
\hline urre & - & - & - & - & - & - & - & - \\
\hline опо & - & - & 0.1 & - & - & - & - & - \\
\hline & - & - & - & - & - & - & - & 1.4 \\
\hline & - & - & - & - & - & - & - & - \\
\hline & - & - & - & - & - & - & - & - \\
\hline & - & 1.04 & - & - & - & - & & - \\
\hline & - & - & - & - & - & - & - & - \\
\hline & - & - & - & - & - & - & - & - \\
\hline & - & - & - & 0.1 & - & - & - & - \\
\hline surit & - & - & - & - & 2.4 & - & - & - \\
\hline & 0.08 & - & - & 0. & 1.2 & 0.5 & - & 0.18 \\
\hline & - & - & - & & 0.26 & - & - & \\
\hline & - & - & 0. & - & - & - & - & \\
\hline & - & - & 0.1 & - & - & - & 1.8 & 0.29 \\
\hline & - & - & & - & - & 2.1 & - & - \\
\hline & - & - & 0. & - & - & 0. & - & - \\
\hline & 0.21 & - & - & - & - & . & - & - \\
\hline & - & - & - & - & - & - & - & - \\
\hline & - & - & - & - & 1.1 & - & - & - \\
\hline & - & - & - & - & - & - & - & - \\
\hline & - & - & - & - & 0.8 & - & - & - \\
\hline & & 21 & - & - & & - & - & - \\
\hline & - & & - & - & 1 & - & - & 3.37 \\
\hline & 1.9 & 8.97 & 3.1 & & & 19.1 & - & \\
\hline & - & - & - & 0 & 2. & 2. & - & 1.73 \\
\hline & - & - & 0. & 1 & 2.2 & 1.5 & - & - \\
\hline & - & - & & 0. & - & - & - & - \\
\hline & - & & & & & 1. & & \\
\hline & - & - & - & & - & - & & - \\
\hline & - & - & - & - & - & - & - & 0.5 \\
\hline & - & - & - & - & - & - & - & - \\
\hline & 1.8 & - & - & - & - & - & - & - \\
\hline & & 0.58 & 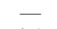 & 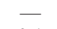 & 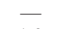 & - & - & - \\
\hline & & & & & & & & \\
\hline & & & & & & & & \\
\hline & & 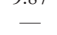 & . & 0.3 & 0.7 & 1.3 & - & 1.29 \\
\hline & 39 & 0.32 & 0 & $=$ & 5 & 1.3 & - & \\
\hline & & 2.66 & 0. & 0.5 & 4.5 & 0. & - & 0.84 \\
\hline & - & & & 1. & & - & - & - \\
\hline & - & - & - & & - & - & & - \\
\hline & - & - & & & - & - & - & \\
\hline & - & - & - & - & 2.5 & - & 1.3 & 0.8 \\
\hline Nautilus sp. & - & - & - & 0.2 & - & - & - & 0.1 \\
\hline unidentified marine shell & 36.01 & 57.23 & 93.5 & 58.7 & 10.3 & 123.5 & 8.2 & 106.05 \\
\hline nacre & 1.4 & 0.56 & - & 0.6 & 1.1 & 5.2 & - & 1.42 \\
\hline total $(\mathrm{g}$ & 54 & 92.4 & 122 & 116.8 & 138.7 & 285.1 & 19 & 2033 \\
\hline
\end{tabular}




\title{
Genetic Relationships of Long-nosed Potoroos Potorous tridactylus (Kerr, 1792) from the Bass Strait Islands, with Notes on the Subspecies Potorous tridactylus benormi Courtney, 1963
}

\author{
Greta J. Frankham ${ }^{1}$ (D) Linda E. Neaves $^{2}$ (D), and Mark D. B. Eldididge $^{3}$ (D) \\ ${ }^{1}$ Australian Centre for Wildlife Genomics, Australian Museum Research Institute, \\ Australian Museum, 1 William Street, Sydney NSW 2010, Australia
}

2 The Fenner School of Environment and Society, The Australian National University, Canberra ACT 2601; and Australian Museum Research Associate, 1 William Street, Sydney NSW 2010, Australia

${ }^{3}$ Terrestrial Vertebrates, Australian Museum Research Institute, Australian Museum, 1 William Street, Sydney NSW 2010, Australia

\begin{abstract}
Bass Strait is an important biogeographic barrier for Australian mammals, often resulting in significant genetic differentiation between populations on the mainland and Tasmania for species with a trans-Bassian distribution. King and Flinders Islands, in Bass Strait, are the largest remnants of the land bridge that once linked Tasmania with mainland Australia. Due to their remote locality and habitat loss on the islands since European settlement, little is known about the evolutionary movements of species across the former land bridge. Here we present genetic data, generated from museum skins, on the King and Flinders Island populations of Long-nosed Potoroo, Potorous tridactylus (Kerr, 1792) to investigate their affinities with other populations of this species. We also assessed the validity of the subspecies Potorous tridactylus benormi Courtney, 1963 described from King Island. Analysis of two partial mitochondrial DNA genes $(C O 1, N D 2)$ indicate that potoroos on King and Flinders Islands are more closely related to Tasmanian rather than mainland potoroo populations. Molecular and morphological data from the holotype and paratype of Potorous tridactylus benormi does not support separate taxonomic status and places it within the Tasmanian subspecies Potorous tridactylus apicalis (Gould, 1851).
\end{abstract}

\section{Introduction}

Bass Strait is a $240 \mathrm{~km}$ expanse of ocean that separates Victoria on mainland Australia and the island of Tasmania. It is relatively shallow, mostly less than $100 \mathrm{~m}$ deep, and during glacial cycles, sea level drops have resulted in the exposure of a land bridge - "the Bassian Plain"-facilitating the dispersal of species between mainland Australia and Tasmania. This land bridge was most recently exposed from around 43,000 years ago until around 14,000 years ago, including the period of the Last Glacial Maxima (Lambeck \& Chappell, 2001) and since its most recent breakdown, has formed a biogeographic barrier for many species with a trans-Bassian distribution (Firestone, 1998; Symula et al., 2008; Schultz et al., 2007; Toon et al., 2010).

Today, all that remains of this land bridge are over 50 islands in Bass Strait (Fig. 1). Along the western edge of the former Bassian Plain lies King Island (c. $1100 \mathrm{sq} \mathrm{km}$ ) located 


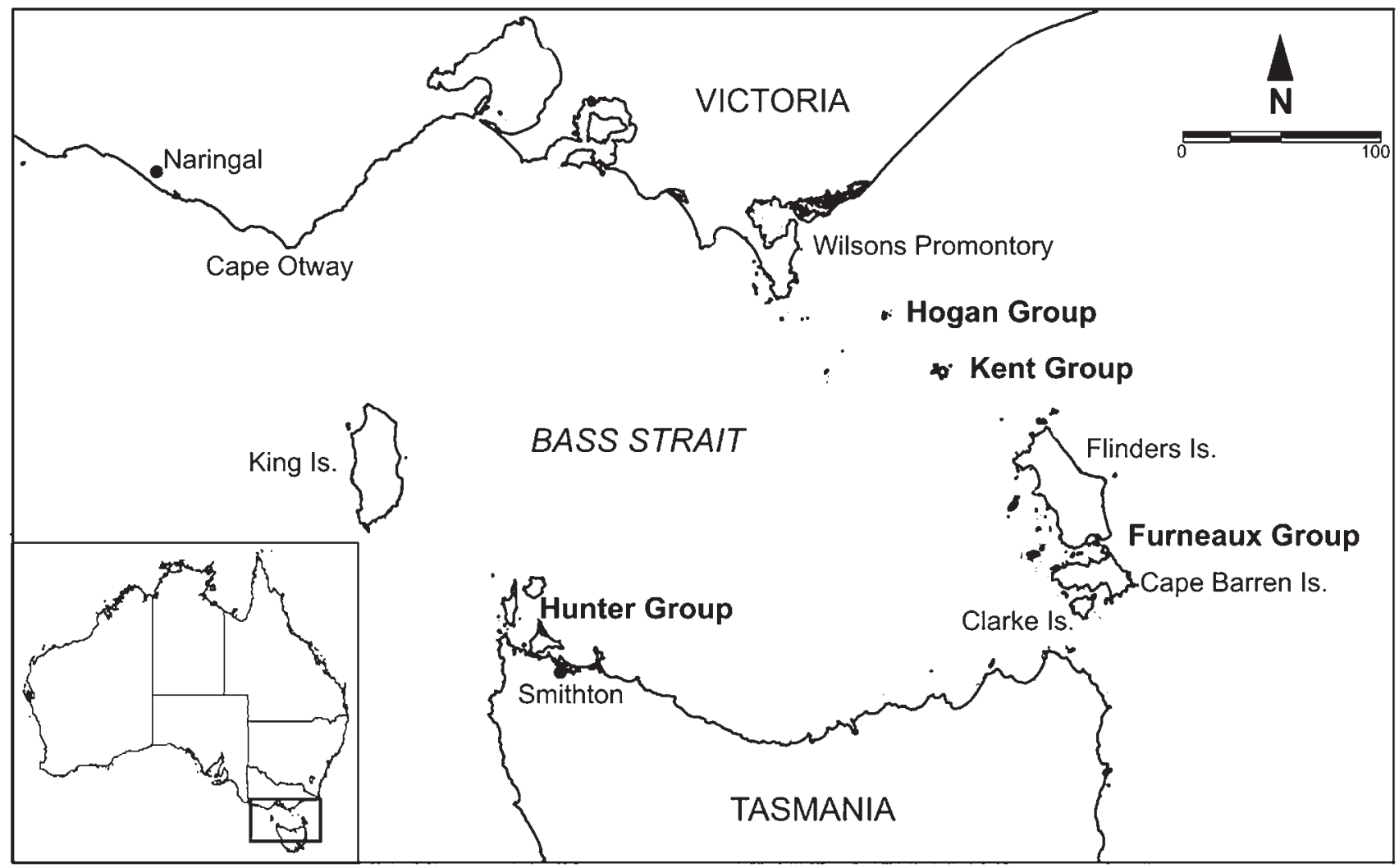

Figure 1. A map of Bass Strait and the Bass Strait Islands.

halfway between Cape Otway, Victoria and north-western Tasmania, as well as the Hunter Group, extending from the north-west tip of Tasmania. Along the eastern edge of the former Bassian Plain is a string of island groups running between Wilsons Promontory in Victoria and north-eastern Tasmania, including the Hogan, the Kent, and the Furneaux Groups (Fig. 1). Flinders Island (c. $1367 \mathrm{sq} \mathrm{km}$ ) is the largest of the Bass Strait Islands and is part of the Furneaux Group (Abbott \& Burbidge, 1995).

Due to the presence of seal colonies, settlement of the Bass Strait Islands by Europeans began as early as the late 18th century, thus these islands have a long history of settlement and habitat disturbance (Hope, 1973). Many of the islands have experienced extensive habitat loss and modification primarily from agricultural land practices (Courtney, 1963; Green \& McGarvie, 1971; Hope, 1973), as well as the introduction of exotic and/or invasive species (Abbott \& Burbidge, 1995). These changes have resulted in declines in native faunal assemblages, as well as the extinction of populations of several species, including Southern Elephant Seal (Mirounga leonina), Common Wombat (Vombatus ursinus), Spotted-tail Quoll (Dasyurus maculatus), and King Island Emu (Dromaius novaehollandiae minor) (Hope, 1973).

The loss of species from the Bass Strait Islands, coupled with the logistical difficulty of surveying the islands, means that specimens, and in particular tissue samples, from these islands are rare or absent from natural history collections, and therefore not available for inclusion in studies looking at the biogeography of the Australian mainland and Tasmania (Frankham et al., 2016). Analyses of these populations would provide important insights into the evolutionary history of the Bassian Plain land bridge.
The Long-nosed Potoroo (Potorous tridactylus) (Kerr 1792) has a trans-Bassian distribution and has been recorded on many of the larger Bass Strait islands, including King Island, the Furneaux Group Islands (Flinders Island, Clarke Island, Cape Barren Island), the Kent Group Islands (Deal Island), as well as several in the Hunter Group (Robbins, Walker, and Three Hummock Islands) (Hope, 1963; Abbott \& Burbidge, 1995). While considered reasonably common prior to the 1940s on King Island (Courtney, 1963), it has since declined, likely due to its sensitivity to habitat loss and disturbance (Frankham et al., 2011; Holland \& Bennett, 2009; Andren et al., 2018). The last confirmed record of a Long-nosed Potoroo on the Bass Strait Islands was an individual trapped on Flinders Island in 1970 (Johnston, 1973). Johnston (1973) commented at the time, that the species was considered very rare on King Island, Flinders Island, and Clarke Island. Since the 1970s there has only been a handful of sightings (ALA, 2020) and these populations may be very rare or have gone extinct (Eldridge \& Frankham, 2015).

Courtney (1963) assessed the size and pelage colouration of the Long-nosed Potoroos on King Island and designated this population a separate subspecies, Potorous tridactylus benormi Courtney, 1963, with the holotype lodged with the Australian Museum (AM M.8319) (Fig. 2), along with a paratype (AM M.8373). Subsequent authors have not considered the proposed King Island subspecies as valid or taxonomically distinct (Calaby \& Richardson, 1988; Johnston, 2008; Jackson \& Groves, 2015; Eldridge \& Frankham, 2015). However, this proposed taxon has never been tested with molecular data, making this population of particular interest. 


\section{Potorous tridactylus benormi}

\section{AM M.8319 holotype}
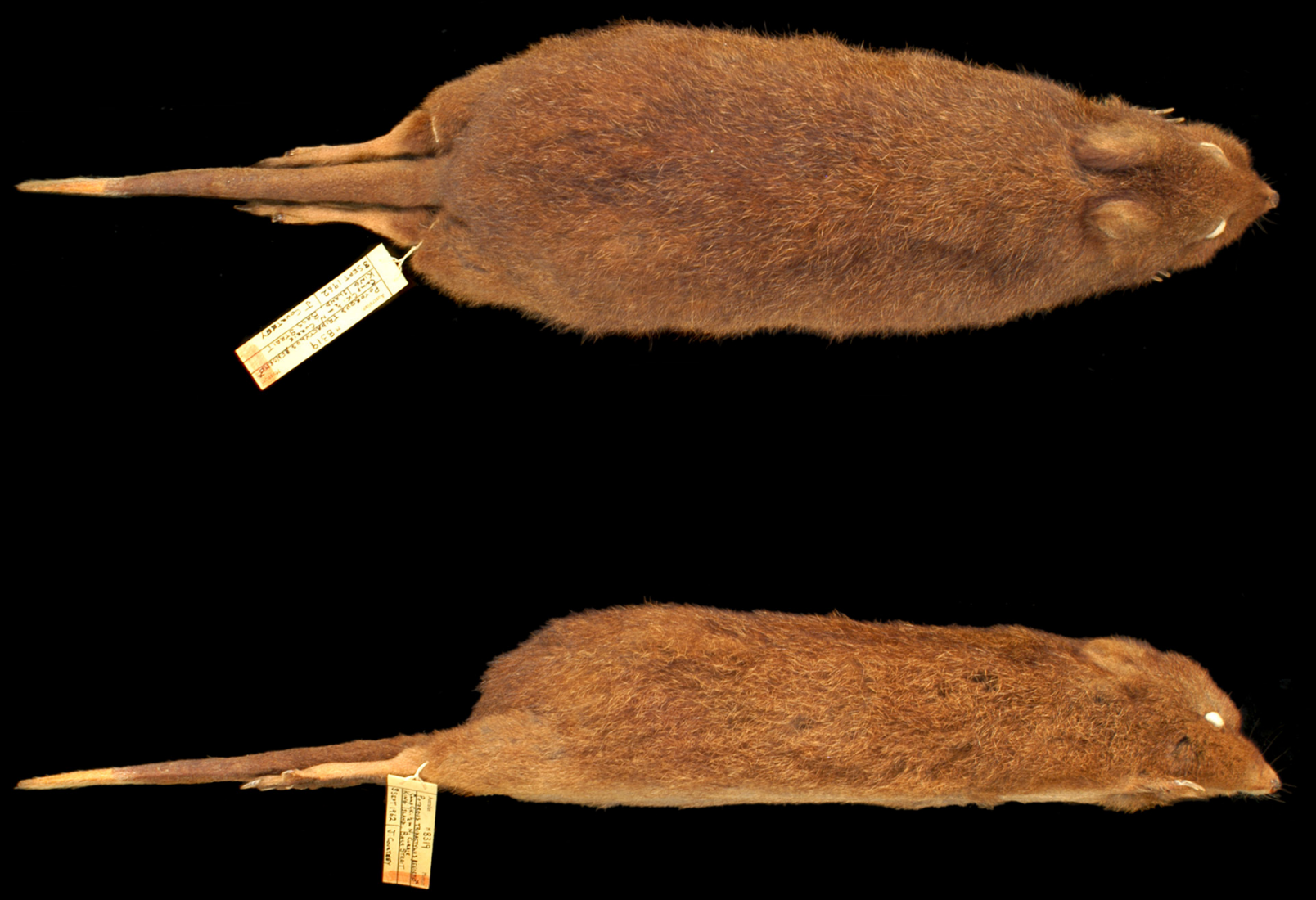

$200 \mathrm{~mm}$

Figure 2. Holotype of Potorous tridactylus benormi AM M.8319 dorsal view (top) and lateral view (bottom). Photography by Sally Cowan.

Recent genetic studies by Frankham et al., (2012; 2016) examined the phylogeography of the Long-nosed Potoroo across its range. These studies identified Bass Strait as a major biogeographic barrier within the species, suggesting that gene flow between mainland Australia and Tasmanian populations last occurred around 2.45 million years ago. Given the last confirmed trapping of a potoroo on a Bass Strait Island was in 1970 (Johnston, 1973), no tissue samples were available for inclusion in these studies, thus data from the Bass Strait island populations were not assessed.

In this study, we aimed to fill this gap to understand the evolutionary history of the species across the Bassian Plain by using genetic data generated from dried museum specimens. We aimed to examine the relationship of Longnosed Potoroos from King Island and Flinders Island to determine if these shared a closer relationship with either the mainland or Tasmanian populations. We also sampled the holotype and paratype of Potorous tridactylus benormi in order to assess its validity as a subspecies.

\section{Methods}

Skin samples $(2 \times 2 \mathrm{~mm})$ were taken with separate sterile scalpels from Potorous tridactylus study skins in the Australian Museum (AM) and Museum Victoria (NMV), including AM M.8319 (holotype of benormi) AM M.8373 (paratype of benormi) from King Island; AM M.4398 and NMV C.8859 from Flinders Island; and AM M.9138 and AM M.10788 from Cobargo, NSW. DNA extraction was undertaken in a designated low-template laboratory (with positive air pressure and HEPA filtered air handling 
Table 1. Summary of primers designed to amplify Cytochrome c oxidase subunit 1 and NADH dehydrogenase subunit 2 for this study, those modified from or designed by previous studies are indicated.

\begin{tabular}{clll}
\hline forward & 5'-3' $^{\prime}$ & reverse & 5'-3' \\
\hline Cytochromec oxidase subunit 1 & & \\
Pot_CO1_F5 & CACGCAGGRGCYTCAGTAG & Pot_CO1_R6 & GATAGTAGVAGMAGRACTGCTGT \\
Pot_CO1_F6 & ACCACCCGCCCTRTCMCAATATC & Pot_CO1_R7 & CTTCTGGGTGRCCRAAGAATCA \\
Pot_CO1_F7 & ACYATRCTATTAACAGACCG & Pot_CO1_R8 & TTACCAGAGTAGTAGTYAC \\
Pot_CO1_Cox_F8 a & TGATTCTTYGGYCACCCAGAAG & Pot_CO1_R9 & TAGGCTCGGGTATCKACRTC \\
Pot_CO1_F9 & ACAGTTGGACTRGAYGTAG & Pot_CO1_R10 & ATRAATCCTAGGGCTCATAG \\
Pot_CO1_F10 & GTTTTCAGCTGRTTAGCAAC & Pot_CO1_R11 & CCTATWGATAGGACGTAGTGGAAGTG \\
NADH dehydrogenase subunit 2 & & \\
Pot_ND2_F2 & AAATCYTTAACCAACYTATG & Pot_ND2_R3 & GGGAATATRGTGAGAGTTGAG \\
Pot_ND2_F3 & GCWATCCTAATAGCYATATCA & mrND2cb & GATTTGCGTTCGAATGAGCAAG \\
\hline
\end{tabular}

a Primer modified from M320 Schneider et al., 1998.

b M636 from Osborne \& Christidis, 2001.

system) at the Australian Centre for Wildlife Genomics at the Australian Museum. Prior to extraction samples were rehydrated in sterile phosphate buffered saline (PBS) on a gentle shake (300 rpm) overnight at $37^{\circ} \mathrm{C}$. DNA was extracted using the QIAamp DNA Investigator Kit (QIAGEN) using the Isolation of Total DNA from Chewing Gum protocol following manufacturer's instructions, including the addition of Carrier RNA.

Primers were designed to amplify a series of overlapping short fragments (125-200 base pairs) for the partial regions of the mitochondrial DNA genes; cytochrome c oxidase subunit 1 (CO1, 6 overlapping fragments) and NADH dehydrogenase subunit 2 (ND2, 2 overlapping fragments) (Table 1). PCRs were carried out in $25 \mu \mathrm{l}$ reactions and comprised 100-400 ๆg genomic DNA, $1 \times$ PCR Buffer II (Applied Biosystems), $0.2 \mathrm{mM}$ each dNTP, $1.5-3.0 \mathrm{mM} \mathrm{MgCl}, 0.2 \mu \mathrm{mol}$ each primer (Table 1) and 1.0U AmpliTaq Gold ${ }^{\mathrm{TM}}$ polymerase (Applied Biosystems); negative controls were used for all PCR reactions. PCR reactions were conducted on an Eppendorf Thermocycler under the following conditions; $95^{\circ} \mathrm{C}$ for 9 minutes for one cycle, followed by 50 cycles of $94^{\circ} \mathrm{C}(60 \mathrm{~s})$ denaturation, $50^{\circ} \mathrm{C}(60 \mathrm{~s})$ annealing, and $60^{\circ} \mathrm{C}$ $(60 \mathrm{~s})$ extension, followed by a final cycle of extension at $60^{\circ} \mathrm{C}$ for 10 minutes. All PCR products were purified using Exo-SapIT (USB Corporation, Cleveland, Ohio, USA), and directly sequenced on an $\mathrm{AB} 3730 \mathrm{xl}$ Sequencer at the Australian Genome Research Facility, Sydney.

Sequences were visually checked with reference to chromatograms using SEQUENCHer version 5.2.4. Sequence alignments were carried out in MEgA version 6 with comparison to $\mathrm{CO} 1$ and $\mathrm{ND} 2$ fragments generated by Frankham et al. (2012) (GenBank Accession numbers CO1: JX111894-JX111903 and ND2 JX104566-JX104576), CO1 and $N D 2$ sequences from the common wallaroo, Osphranter robustus (GenBank accession number Y10524) were used as outgroups. Phylogenetic relationships were estimated using both Bayesian inference (BI) and maximum likelihood (ML). Mega version 6 (Nei \& Kumar, 2000; Tamura et al., 2013), was used to determine an appropriate model of evolution $(\mathrm{HKY}+\Gamma)$ based on the Bayesian Information Criterion (BIC scores) and Akaike information criterion, corrected (AICc scores). All phylogenetic analyses were carried out using this model. Bayesian Inference (BI) analysis was conducted in MrBAYES version 3.2 (Ronquist et al., 2012).
Metropolis-Coupled Markov Chain Monte Carlo sampling was used to calculate posterior probabilities. The analyses were run using default settings for priors. Chains were run for 1 million generations and sampled every 100 generations to obtain 10,000 sampled trees. Maximum Likelihood was estimated using Mega version 6 (Tamura et al., 2013) with 1000 bootstrap replicates. TRACER version 1.7.1 (Rambaut et al., 2018) was used to check for chain convergence and adequate effective sample size $(>200)$. Posterior probabilities (decimals) and bootstrap values (percentages) were used to assess the level of branch support.

\section{Results}

Partial $\mathrm{CO} 1$ and $N D 2$ fragments were recovered from specimens from both King and Flinders Islands with differing success. $695 \mathrm{bp}$ of $\mathrm{CO} 1$ sequence was obtained from both King Island samples (AM M.8373, AM M.8319), from one Flinders Island sample (NMV C8859), and both Cobargo (NSW) samples (AM M.9138, AM M.10788). One of the overlapping $\mathrm{CO} 1$ sections failed to amplify in the remaining Flinders Island sample (AM M.4398) and only $490 \mathrm{bp}$ of $\mathrm{CO} 1$ was recovered from this sample. A total of $344 \mathrm{bp}$ of partial ND2 were successfully amplified from one Flinders Island sample (AM M.4398) and one King Island sample (AM M.8373) and both Cobargo samples (AM M.9138, AM M.10788). Amplification failed in the remaining King (AM M.8319) and Flinders Island (NMV C8859) samples. Sequence data were deposited into GenBank (accession numbers, CO1: MT422368-MT422373; ND2: MT431409-MT431412).

Phylogenetic analyses were carried out on two datasets, one with $\mathrm{COl}$ only in order to maximize the data available from the Bass Strait Islands, including investigating the placement of the Potorous tridactylus benormi holotype and paratype (Fig. 3), and one with $C O 1$ and $N D 2$ concatenated in order to maximize the mtDNA data available for analyses (Fig. 4). The ML and BI trees for both data sets resolved trees of similar topology, with three well supported lineages concordant with currently recognized subspecies, the resolution however was superior in the concatenated dataset. The King and Flinders Island samples analysed in this study consistently grouped with samples of Potorous tridactylus apicalis, the Tasmanian subspecies, across all analyses. 


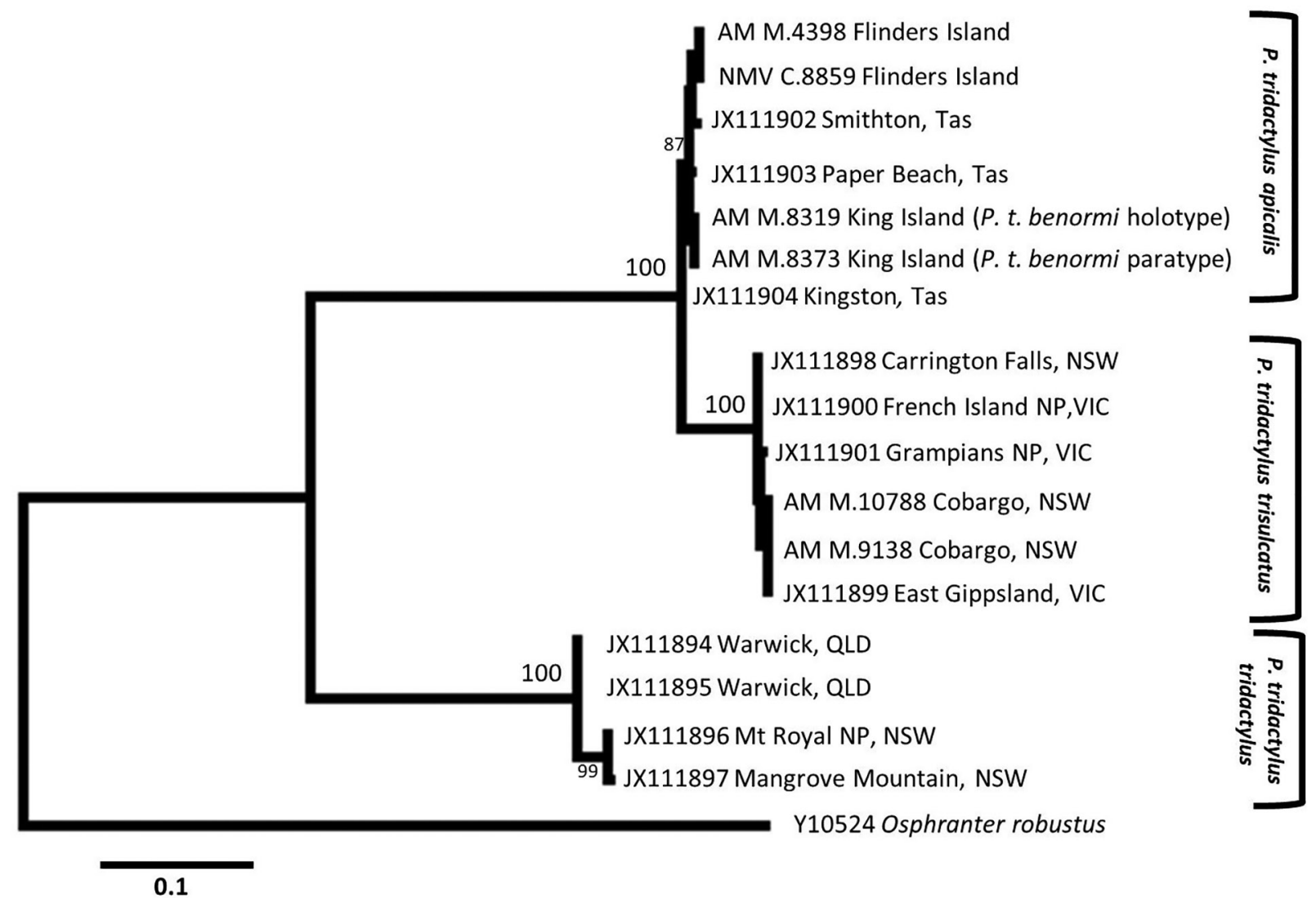

Figure 3. Maximum Likelihood phylogenetic tree inferred from $695 \mathrm{bp}$ of CO1 mtDNA sequence, including data from the Potorous tridactylus benormi Holotype (AM M.8319) and Paratype (AM M.8373). Bootstrap values for major lineages are shown. A similar tree topology was inferred from Bayesian inference.

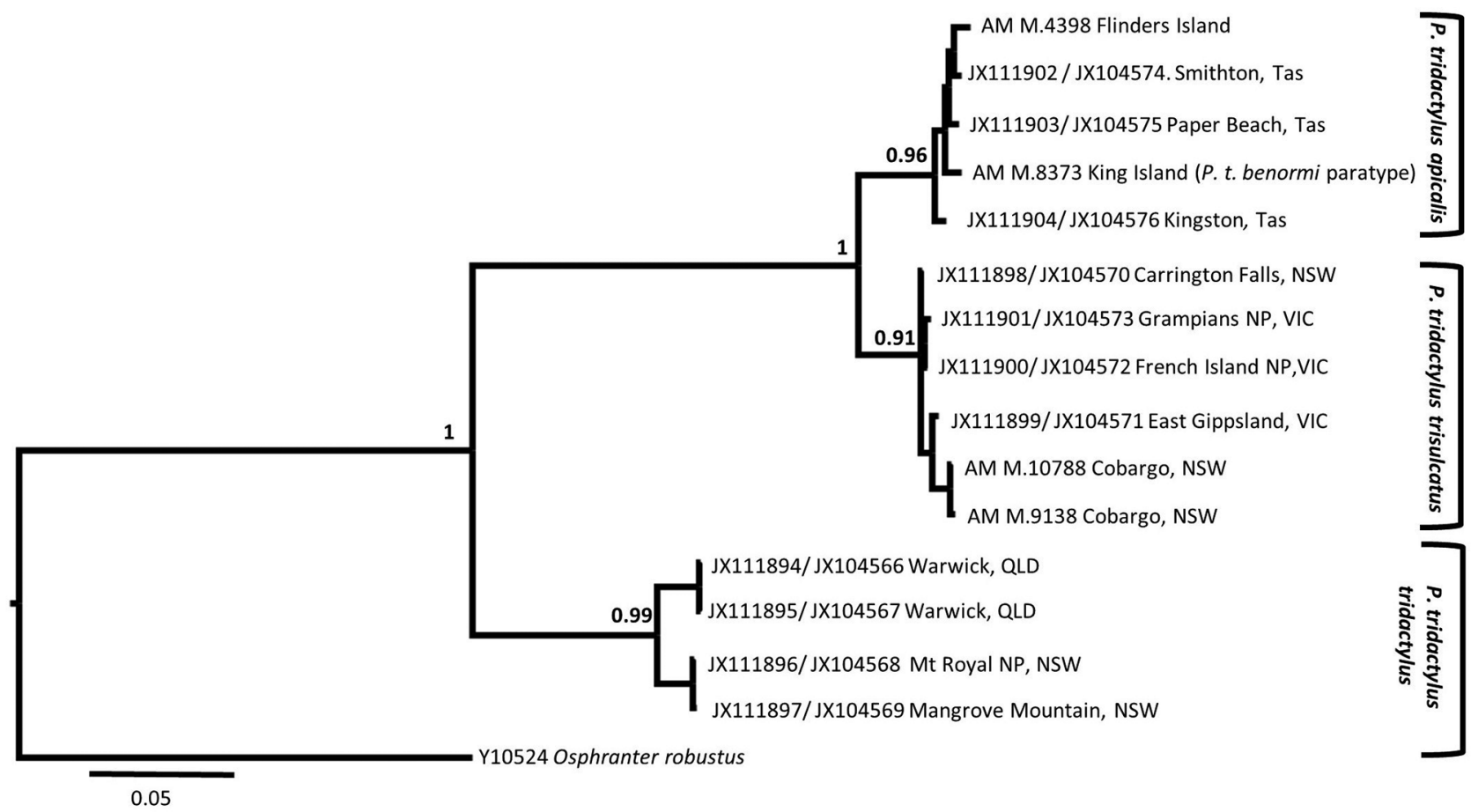

Figure 4. Bayesian Inference phylogenetic tree inferred from 1039 bp of concatenated CO1 and ND2 mitochondrial DNA sequence data. Posterior probabilities for major lineages are shown. A similar tree topology was also inferred from Maximum Likelihood. 


\section{Discussion}

Although only partial fragments ( $695 \mathrm{bp}$ of $\mathrm{COI}[\mathrm{n}=4]$ and $344 \mathrm{bp}$ of $N D 2[\mathrm{n}=2]$ ) were available for analysis, these data consistently placed the individuals from both King and Flinders Islands within the Tasmanian subspecies Potorous tridactylus apicalis. The topology of the phylogenetic trees generated in this study were concordant with those describing three divergent potoroo subspecies generated by Frankham et al. (2012) who examined a longer mtDNA fragment of $2103 \mathrm{bp}$ of $\mathrm{CO} 1$ and ND2 from 11 potoroo samples, as well as $1893 \mathrm{bp}$ of nuDNA. These subspecies were Potorous tridactylus tridactylus (distributed in New South Wales north of Sydney and in southeast Queensland), Potorous tridactylus trisulcatus (New South Wales south of Sydney, plus Victorian and South Australian populations) and Potorous tridactylus apicalis (Tasmanian populations). In addition, Frankham et al., (2016) examined c. $630 \mathrm{bp}$ of mtDNA control region from 347 individuals and resolved the same three lineages with the larger sample size from across the species distribution. The concordance of the current data with these previous studies lends confidence in the placement of the sequences obtained from the museum skins. The current study is limited to the examination of mtDNA (more reliably amplified from museum skins) and so does not allow for further investigation of nuDNA and the possibility of introgression between subspecies. However, Frankham et al. (2012) investigated both mtDNA and nuDNA and found no evidence of introgression and both nuDNA and mtDNA sequence data were able to distinguish between Tasmania and the mainland populations. Thus, we believe that mtDNA is a reliable indicator of subspecies boundaries in this species. This closer affinity with Tasmania is congruent with the few other molecular studies of small or specialist mammal species with a trans-Bassian distribution that have also included samples from the Bass Strait Islands, including, Southern Brown Bandicoots (Isoodon obesulus) (Flinders Island only) (Cooper et al., 2018) and Platypus (Ornithorhynchus anatinus) (King Island only) (Gongora et al., 2012). A mtDNA study by Le Page et al. (2000) on the larger red-neck wallaby (Notamacropus rufogriseus) included samples from both King and Flinders Islands, as well as samples from Tasmania and mainland Australia (Warwick, QLD). Results from this study suggested Flinders Island samples grouped more closely with mainland Australia while King Island animals showed a closer affinity to Tasmanian samples. Historical connectivity between Tasmania and mainland populations and a lack of significant differentiation across Bass Strait have been shown in mtDNA studies for other generalist or larger more vagile species including Eastern Grey Kangaroos (Macropus giganteus) (Zenger et al., 2003) and Emu (Dromaius novaehollandiae) (Thomson et al., 2018).

While King and Flinders Islands are geographically closer to Tasmania (and associated islands) at present, the formation sequence of the Bassian Plain also supports the closer relationship between Tasmanian and Bass Strait Island potoroo populations. As the sea level fell during the last glacial maximum, the Furneaux Island Group would have first enlarged, merged, and formed a connection with northeastern Tasmania, followed by a similar process exposing the land around King Island and forming a connection with north western Tasmania. These connections would have occurred prior to the connection with mainland Australia (Hope, 1963; Lambeck \& Chappell, 2001). This process, over thousands of years, would have allowed for the expansion northward of Tasmanian faunal populations, much earlier than mainland populations could move south. It was also suggested by Frankham et al., (2016) that much of the Bassian Plain likely contained unsuitable habitat for Long-nosed Potoroos, which resulted in an extended period of genetic isolation (estimated 2.45 million years) between the Australian mainland and Tasmanian populations despite the periodic presence of a land bridge. Although molecular dating was not carried out for this study, the inclusion of individuals from the Bass Strait Islands in the analysis did not significantly alter the tree topology for either $\mathrm{CO} 1$ or $\mathrm{ND} 2$ based on the data of Frankham et al. (2012). Therefore, it is likely that suitable habitat for dispersal was found along the northern coasts of Tasmania and into the Furneaux Island Group and King Island, but did not extend further north or into the central Bassian Plain, forming a barrier to dispersal and geneflow, and maintaining this deep divergence even during the last glacial maximum.

As part of this study we generated DNA sequence data from the holotype and paratype of Potorous tridactylus benormi Courtney, 1963, from King Island. This taxon was described on the basis of size and colour, being on average smaller and having a dark grey-brown belly compared to "the typical race" (Courtney, 1963). Sequences obtained from these specimens however, were similar to, and nested within the Tasmanian Potorous tridactylus apicalis lineage identified by Frankham et al. (2012). These genetic data indicate that subsequent authors were correct in not recognizing the proposed subspecies Potorous tridactylus benormi Courtney, 1963. The morphological measurements given for the male holotype of Potorous tridactylus benormi described by Courtney (1963, p. 19) as "rather old and very fat" with a mass of " $2 \mathrm{lb} 6 \mathrm{oz}$ " $(1.07 \mathrm{~kg})$, are not smaller than male potoroos measured in Smithton, north west Tasmania or Naringal in Victoria (Fig. 1). Smithton males have been recorded weighing c. $800 \mathrm{~g}$ to over $1 \mathrm{~kg}$ (Heinsohn, 1968; unpublished data) and several studies on Naringal populations have recorded males average c. $780 \mathrm{~g}$ (Bennett, 1987; Long, 2001; unpublished data). Surveys of Long-nosed Potoroos across their range, which encompasses a variety of different habitats, soil and geology types, have documented morphological variation in pelage colour and morphometric measurements that includes the variation seen in the King Island population (e.g., hindfoot measurements). These data suggest the King Island potoroos described by Courtney (1963) were not significantly smaller overall, but instead that at the time of publication the extent of the morphological variation in potoroo populations across their range was still largely undocumented (Heinsohn, 1968; Johnston \& Sharman, 1976; Bennett, 1987; Bryant, 1989; Mason, 1997; Long, 2001; Frankham et al., 2011; Norton et al., 2011).

Dried study skins from natural history collections are often the only representatives of rare or extinct populations, in this case, the last potoroo trapped on a Bass Strait Island was caught in 1970 (Johnston, 1973), predating the establishment of tissue collections in any Australian museum and routine tissue sampling as part of general survey methods. The availability of low template DNA extraction methods, meant that from these skins, ranging in age from 45 to 85 years old, we were able to amplify up to $1039 \mathrm{bp}$ of mitochondrial 
DNA allowing us to place with confidence Long-nosed Potoroos found on King and Flinders Island within the Tasmanian subspecies. These museum skins have provided valuable insights about Long-nosed Potoroo populations on the Bass Strait Islands and these data should guide any future conservation management decisions regarding these populations, e.g., any translocations or re-introductions should be sourced from Tasmanian populations. More broadly, the range of taxa represented in museum collections, coupled with continuingly-improving genomic techniques, means there is great museum-based potential for unlocking genetic information to continue to improve our knowledge of the evolutionary history of the Australian fauna (Eldridge et al., 2020).

ACKNOWLEDGEMENTS. The authors would like to thank the late Ken Aplin for many helpful and insightful discussions over the years regarding potoroos, subspecies, and island populations. We would also like to thank Sandy Ingleby, Anja Divljan, and Harry Parnaby for access to the Australian Museum specimens, in particular the Potorous tridactylus benormi holotype and paratype, as well as the Museum Victoria mammalogy staff for access to their specimens.

\section{References}

Abbott, I., and A. A. Burbidge. 1995. The occurrence of mammal species on the islands of Australia: a summary of existing knowledge. CALMScience 1: 259-324.

Andren, M., D. Milledge, D. Scotts, and J. Smith. 2018. The decline of the Northern Long-nosed Potoroo Potorous tridactylus tridactylus on the far north coast of New South Wales. Australian Zoologist 39(3): 414-423.

https://doi.org/10.7882/AZ.2018.010

Atlas of Living Australia. 2020. Long-nosed potoroo. [Accessed 14 January 2020].

https://www.ala.org.au

Bennett, A. F. 1987. Conservation of mammals within a fragmented forest environment: the contributions of insular biogeography and autecology. In Nature Conservation: The Role of Remnants of Native Vegetation, ed. D. A. Saunders, G. W. Arnold, A. A. Burbidge, and A. J. M. Hopkins, pp. 41-52. Sydney, Australia: Surrey Beatty.

Bryant, S. L. 1989. Growth, development, and breeding patterns of the long-nosed potoroo, Potorous tridactylus (Kerr, 1792). In Kangaroos, Wallabies and Rat-kangaroos, ed. G. Griggs, P. Jarman, and I. Hume, pp. 449-456. Sydney, Australia: Surrey Beatty.

Calaby, J. H., and B. J. Richardson. 1988. Potoroidae. In Zoological Catalogue of Australia. Vol. 5 Mammalia, ed. D. W. Walton, pp. 53-59. Canberra: Australian Government Publishing Service.

Cooper, S. J. B., K. Ottewell, A. J. MacDonald, M. Adams, M. Byrne, S. M. Carthew, M. D. B. Eldridge. Y. Li, L. C. Pope, K. M. Saint, and M. Westerman. 2018. Phylogeography of southern brown and golden bandicoots: implications for the taxonomy and distribution of endangered subspecies and species. Australian Journal of Zoology 66: 379-393. https://doi.org/10.1071/ZO19052

Courtney, J. 1963. King Island, Bass Strait the remarkable faunal unit. Australian Aviculture 17: 18-20.

Eldridge, M. D. B., J. E. Deakin, A. J. MacDonald, M. Byrne, A. Fitzgerald, R. N. Johnson, C. Moritz, S. Palmer, and A. Young. 2020. The Oz Mammals Genomics (OMG) initiative: developing genomic resources for mammal conservation at a continental scale. Australian Zoologist 40: 505-509.

https://doi.org/10.7882/AZ.2020.003
Eldridge, M. D. B., and G. J. Frankham. 2015. Family Potoroidae (Bettongs and Potoroos). In Handbook of the Mammals of the World Vol. 5. Monotremes and Marsupials, ed. D. E. Wilson and R. A. Mittermeier, pp. 600-628. Barcelona: Lynx Edicions.

Firestone, K. B., M. S. Elphinstone, W. B. Sherwin, and B. A. Houlden. 1999. Phylogeographical population structure of tiger quolls Dasyurus maculatus (Dasyuridae: Marsupialia), an endangered carnivorous marsupial. Molecular Ecology 8(10): 1613-1625.

https://doi.org/10.1046/j. 1365-294x.1999.00745.x

Frankham, G. J., R. L. Reed, T. P. Fletcher, and K. A. Handasyde. 2011. Population ecology of the long-nosed potoroo (Potorous tridactylus) on French Island, Victoria. Australian Mammalogy 33(1): 73-81.

https://doi.org/10.1071/AM10051

Frankham, G. J., K. A. Handasyde, and M. D. B. Eldridge. 2012. Novel insights into the phylogenetic relationships of the endangered marsupial genus Potorous. Molecular Phylogenetics and Evolution 64(3): 592-602.

https://doi.org/10.1016/j.ympev.2012.05.013

Frankham, G. J., K. A. Handasyde, M. Norton, A. Murray, and M. D. B. Eldridge. 2014. Molecular detection of intrapopulation structure in a threatened potoroid, Potorous tridactylus: conservation management and sampling implications. Conservation Genetics 15: 547-560. https://doi.org/10.1007/s10592-013-0560-1

Frankham, G. J., K. A. Handasyde, and M. D. B. Eldridge. 2016. Evolutionary and contemporary responses to habitat fragmentation detected in a mesic zone marsupial, the longnosed potoroo (Potorous tridactylus) in south-eastern Australia. Journal of Biogeography 43(4): 653-665. https://doi.org/10.111//jbi.12659

Gongora, J., A. B. Swan, A. Y. Chong, S. Y. W Ho, C. S. Damayanti, S. Kolomyjec, T. Grant, E. Miller, D. Blair, E. Furlan, and N. Gust. 2012. Genetic structure and phylogeography of platypuses revealed by mitochondrial DNA. Journal of Zoology 286(2): 110-119. https://doi.org/10.1111/j.1469-7998.2011.00854.x

Green, R. H., and A. M. McGarvie. 1971. The Birds of King Island. Launceston, Tasmania: Queen Victoria Museum.

Heinsohn, G. E. 1968. Habitat requirements and reproductive potential of the macropod marsupial Potorous tridactylus in Tasmania. Mammalia 32(1): 30-43.

https://doi.org/10.1515/mamm.1968.32.1.30

Holland, G., and A. Bennett. 2009. Differing responses to landscape change: implications for small mammal assemblages in forest fragments. Biodiversity and Conservation 18: 2997-3016. https://doi.org/10.1007/s10531-009-9621-7

Hope, J. H. 1974. The biogeography of the mammals of the islands of Bass Strait. In Biogeography and Ecology in Tasmania, ed. W. D. Williams, pp. 397-415. Netherlands: Springer. https://doi.org/10.1007/978-94-010-2337-5_15

Jackson, S., and C. Groves. 2015. Taxonomy of Australian Mammals. Clayton South, Melbourne: CSIRO Publishing. https://doi.org/10.1071/9781486300136

Johnston, P. G. 1973. Variation in Island and Mainland Populations of Potorous tridactylus and Macropus rufogriseus (Marsupialia). Doctoral dissertation, University of New South Wales.

Johnston, P. G., and G. B. Sharman. 1976. Studies on populations on Potorous Desmarest (Marsupialia). I. Morphological variation. Australian Journal of Zoology 24: 573-588. https://doi.org/10.1071/ZO9760573

Johnston, P. G. 2008. Long nosed Potoroo. In The Mammals of Australia, ed. S. Van Dyck and R. Strahan, pp. 302-304. Sydney: New Holland Publishers.

Lambeck, K., and J. Chappell. 2001. Sea level change through the last glacial cycle. Science 292(5517): 679-686.

https://doi.org/10.1126/science.1059549 
Le Page, S. L., R. A. Livermore, D. W. Cooper, and A. C. Taylor. 2000. Genetic analysis of a documented population bottleneck: introduced Bennett's wallabies (Macropus rufogriseus rufogriseus) in New Zealand. Molecular Ecology 9(6): 753-763. https://doi.org/10.1046/j.1365-294x.2000.00922.x

Long, K. I. 2001. Spatio-temporal interactions among male and female long-nosed potoroos, Potorous tridactylus (Marsupialia: Macropodoidea): mating system implications. Australian Journal of Zoology 49: 17-26. https://doi.org/10.1071/Z000077

Mason, R. J. 1997. Habitat use and population size of the longnosed potoroo, Potorous tridactylus (Marsupialia: Potoroidae) in a coastal reserve, north-eastern New South Wales. Australian Mammalogy 20: 35-42.

Nei, M., and S. Kumar. 2000. Molecular Evolution and Phylogenetics. New York: Oxford University Press.

Norton, M. A., A. W. Claridge, K. French, and A. Prentice. 2011. Population biology of the long-nosed potoroo (Potorous tridactylus) in the Southern Highlands of New South Wales. Australian Journal of Zoology 58(6): 362-368. https://doi.org/10.1071/Z010075

Osborne, M. J., and L. Christidis. 2001. Molecular phylogenetics of Australo-Papuan possums and gliders (family Petauridae). Molecular Phylogenetics and Evolution 20(2): 211-224. https://doi.org/10.1006/mpev.2001.0960

Rambaut A, A. J. Drummond, D. Xie, G. Baele, and M. A. Suchard. 2018. Posterior summarisation in Bayesian phylogenetics using Tracer 1.7. Systematic Biology 67(5): 901-904. https://doi.org/10.1093/sysbio/syy032

Ronquist, F., M. Teslenko, P. Van Der Mark, D. L. Ayres, A. Darling, S. Höhna, B. Larget, L. Liu, M. A. Suchard, and J. P. Huelsenbeck. 2012. MrBayes 3.2: efficient Bayesian phylogenetic inference and model choice across a large model space. Systematic Biology 61(3): 539-542.

https://doi.org/10.1093/sysbio/sys029
Schneider, C. J., M. Cunningham, and C. Moritz. 1998. Comparative phylogeography and the history of endemic vertebrates in the Wet Tropics rainforests of Australia. Molecular Ecology 7(4): 487-498. https://doi.org/10.1046/j. 1365-294x.1998.00334.x

Schultz, M. B., S. A. Smith, A. M. M Richardson, P. Horwitz, K. A. Crandall, and C. M. Austin. 2008. Cryptic diversity in Engaeus Erichson, Geocharax Clark and Gramastacus Riek (Decapoda: Parastacidae) revealed by mitochondrial $16 \mathrm{~S}$ rDNA sequences. Invertebrate Systematics 21(6): 569-587. https://doi.org/10.1071//S07019

Symula, R., J. S. Keogh, and D. C. Cannatella. 2008. Ancient phylogeographic divergence in southeastern Australia among populations of the widespread common froglet, Crinia signifera. Molecular Phylogenetics and Evolution 47(2): 569-580. https://doi.org/10.1016/j.ympev.2008.01.011

Tamura, K., G. Stecher, D. Peterson, A. Filipski, and S. Kumar. 2013. MEGA6: Molecular Evolutionary Genetics Analysis version 6.0. Molecular Biology and Evolution 30(12): 2725-2729. https://doi.org/10.1093/molbev/mst197

Thomson, V. A., K. J. Mitchell, R. Eberhard, J. Dortch, J. J. Austin, and A. Cooper. 2018. Genetic diversity and drivers of dwarfism in extinct island emu populations. Biology Letters 14(4): 20170617. https://doi.org/10.1098/rsbl.2017.0617

Toon, A. J., M. Hughes, and L. Joseph. 2010. Multilocus analysis of honeyeaters (Aves: Meliphagidae) highlights spatio-temporal heterogeneity in the influence of biogeographic barriers in the Australian monsoonal zone. Molecular Ecology 19(14): 2980-2994. https://doi.org/10.1111/j.1365-294X.2010.04730.x

Zenger, K. R., M. D. B. Eldridge, and D. W. Cooper. 2003. Intraspecific variation, sex-biased dispersal and phylogeography of the eastern grey kangaroo (Macropus giganteus). Heredity 91(2): 153.

https://doi.org/10.1038/sj.hdy.6800293 


\title{
Odorants Differentiate Australian Rattus with Increased Complexity in Sympatry
}

\author{
Kevin C. Rowe ${ }^{1,2} \mathbb{D}$, Helena A. Soini ${ }^{3,4} \mathbb{D}$, Karen M. C. Rowe ${ }^{1,2} \mathbb{D}$, \\ Mark Adams ${ }^{5,6}$ D, And Milos V. Novotny ${ }^{3,4}$ (D) \\ ${ }^{1}$ Sciences Department, Museums Victoria, GPO Box 666, Melbourne VIC 3001, Australia \\ ${ }^{2}$ School of BioSciences, The University of Melbourne, Parkville VIC 3010, Australia \\ ${ }^{3}$ Department of Chemistry, Indiana University, Bloomington, IN 47405-7102, United States of America \\ ${ }^{4}$ Institute for Pheromone Research, Indiana University, Bloomington, IN 47405-7102, United States of America \\ ${ }^{5}$ Institute for Applied Ecology, University of Canberra, Bruce ACT 2617, Australia \\ ${ }^{6}$ Department of Biological Sciences, University of Adelaide, Adelaide SA 5000, Australia
}

\begin{abstract}
Odorant cues play a critical role in premating isolation among many species. In mammals, they have been most well-studied in rodents, but only in a handful of species. The genus Rattus is one of the most species-rich genera of mammals, with a natural distribution from Asia to Australia and a nearly global distribution for a few species that spread through human commensalism. More than one-third of Rattus species are the result of a recent and rapid radiation on continental Australia (Sahul) centred on the island of New Guinea. The two most widespread species resulting from this radiation, Rattus fuscipes and Rattus leucopus, occur sympatrically in the Wet Tropics region of Queensland, Australia. Despite their recent divergence, morphological similarity, and ability to produce fertile offspring in captivity, hybrids of the two species have not been reported in the wild, suggesting that premating isolation mechanisms maintain the species' boundaries. Odorant cues are a plausible mechanism that these species could use to identify mates of the same species, but the chemical composition of their odours has not been characterized. With allozyme data from 166 specimens of the two species we confirmed the absence of gene flow between the species in sympatry. From chemical analysis of preputial glands of 32 males from sympatric and allopatric populations of the two species we identified 120 volatile organic compounds of which 80 were reliably quantitated for statistical analysis. Some of these chemicals have been indicated as signalling compounds in other species of mammals, including seven thiazolines. Among them two (2-sec-butylthiazoline and 2-isopropythiazoline) have been previously detected in a rodent, the House Mouse, Mus musculus, and are involved in social interactions including attracting females. We demonstrate that $R$. fuscipes and $R$. leucopus are quantitatively and qualitatively distinguishable by the chemical composition of their preputial gland secretions. In comparison to allopatric subspecies, sympatric species contained more unique chemical compounds and a higher abundance of compounds overall, suggesting that sympatric populations have more complex and concentrated odours. Together these results indicate that odorant chemistry has evolved rapidly in these two species, with substantial differences among species and subspecies, especially in sympatry. Ultimately, the rapid evolution of chemical signals involved in mate recognition may help to explain the exceptional diversity of species in the genus Rattus.
\end{abstract}




\section{Introduction}

A gifted mammalogist, like Dr Ken Aplin, can identify similar and closely related but reproductively isolated species using only morphology. Defining reproductively isolated species in this way involves arduous quantitative and qualitative examination of many specimens distributed across large geographic areas and collected over many years (e.g., Patton et al., 2008; Aplin et al., 2015). While mammalian taxonomy is increasingly integrative, incorporating morphology, genetics, acoustics, environment, and other variables (e.g., Dayrat, 2005; Padial et al., 2010; Schlick-Steiner et al., 2010; Phuong et al., 2014; Shekelle et al., 2017), the vast majority of species have been described with only morphological data (Wilson \& Reeder, 2005; Burgin et al., 2018). While mammalian species descriptions rely heavily on internal morphological characters, mammalian species themselves rely on other visible, auditory, or chemosensory characters to identify mates of the same species (Panhuis et al., 2001; Smadja \& Butlin, 2009).

Chemical communication is the oldest and most widespread form of communication in nature and plays a central role in social interactions such as mate choice, parental care, territoriality, sociality, and species recognition (Burger, 2005; Brennan \& Kendrick, 2006; Hull \& Domingues, 2007; Ferrero \& Liberles, 2009, Steiger et al., 2011). For invertebrate species, chemical cues are a primary mechanism for choosing mates of the same species and have been used to delimit species boundaries (Linn \& Roelofs, 1995; Blows \& Allan, 1998; Higgie et al., 2000; Lassance et al., 2019). Chemical cues, odorants, also play an essential role in mate choice in many mammalian species, but our knowledge of odorant variation is limited to very few mammalian species. In rodents they have been most completely characterized in the House Mouse, Mus musculus, where over 100 compounds have been identified that affect a host of reproductive behaviours and conditions including estrous induction, puberty onset, intermale aggression, and female attraction (Novotny et al., 1990, 2003; Zhang et al., 2007; Novotny \& Soini, 2013). Closely related rodent species often have distinct chemical signatures suggesting that these cues are useful in maintaining species boundaries and the rapid evolution of odorant signatures after speciation (Lane et al., 2004; Smadja \& Butlin, 2009). For example, closely related species of Mus (e.g., M. musculus and M. spicilegus; Soini et al., 2009), subspecies of M. musculus (M. m. musculus and M. m. domesticus; Smadja \& Ganem, 2002) and labderived strains of M. musculus (Zhang et al., 2007) are each distinguishable by chemical compounds in their urine. Between Mus musculus subspecies, these differences have been linked to premating isolation, especially in sympatry (Smadja \& Ganem, 2007; Bimova et al., 2009; Hurst et al., 2017). The role of chemical cues in differentiating closely related species and their involvement in premating isolation has been studied in a handful of genera from a few families of rodents including Cricetidae (Graomys, Theiler \& Blanco, 1996; Mesocricetus, Johnston \& Robinson, 1993; Microtus, Welsh et al., 1988; Peromyscus, Moore, 1965; and Phodopus, Soini et al., 2005); Spalacidae (Spalax, Nevo et al., 1976); and Muridae (Mus, Kotenkova \& Naidenko, 1999; Mastomys, Apps et al., 1990; Otomys, Pillay et al., 1995; Rattus, Kannan et al., 1998; and Rhabdomys, Pillay et al., 2006). However, chemical cues involved in species boundaries have not been examined in the vast majority of rodent species. Given that these cues are species-specific, our ability to extend these patterns across the diversity of rodents is limited by the paucity of species examined (Brennan \& Zufall, 2006).

The most significant sources of odorant cues in rodents are bladder urine and preputial glands. Preputial glands are specialized subdermal exocrine glands that empty directly into the urinary tract, providing many of the odorant signals found in urine (Brown \& Williams, 1972; Orsulak \& Gawienowski, 1972; Novotny, 2003). Secretions from preputial glands are composed of a large number of volatile compounds immersed in a complex of proteins, especially the major urinary proteins (Brown \& Williams, 1972; Novotny, 2003). The preputial glands of rodents have an independent origin from the preputial glands of other mammals, such as those of artiodactyls (Brown \& Williams, 1972). Preputial gland anatomy varies widely among rodent species, including absence in some species (Brown \& Williams, 1972; Breed et al., 2020). In the genus Rattus and its closest relatives, the preputial gland is large and prominent (Jackson, 1938; Mallick, 1991; Natynczuk et al., 1995). In many species of rodents, including Rattus, males have more developed preputial glands than females suggesting a role in sexual selection (Kannan et al., 1997). Studies of preputial gland secretions in rodent species show that they are involved in social signalling, including identifying conspecifics and maintaining species boundaries (Bronson \& Caroom, 1971; Brown \& Williams, 1972; Orsulak \& Gawienowski, 1972; Welsh et al., 1988; Novotny, 2003; Kamalakkannan et al., 2006; Zhang et al., 2008a).

With 68 recognized species, Rattus is the most speciesrich genus of rodent (Burgin et al., 2018; Mammal Diversity Database, 2019). The genus has diversified recently and rapidly since its origin in the Pliocene, with a high degree of morphological similarity retained among species (Rowe et al., 2011). More than one-third of Rattus species $(\mathrm{n}=25)$ are native to continental Australia (Sahul) and evolved from a single colonization of New Guinea circa 1 million years ago (Rowe et al., 2011). From an origin on the Asian continent, Rattus colonized Sahul via the island archipelago of Wallacea during the Pleistocene and the subsequent diversification of Rattus on Sahul is among the most rapid reported for mammals (Rowe et al., 2011, 2019). The two most widespread species of Australian Rattus, R. fuscipes and R. leucopus, are sympatric in mid-elevation rainforests of the Wet Tropics region of Queensland Australia between Cooktown and Townsville (Fig. 1), but allopatric throughout the remainder of their respective ranges. Rattus fuscipes is distributed from the Wet Tropics south along the eastern, southern, and southwestern coasts of Australia whereas R. leucopus is distributed from the Wet Tropics north into southern New Guinea. Where they are sympatric, they are recognized as the subspecies $R$. f. coracius $(R f c)$ and $R$. l. cooktownensis $(R l c)$, respectively. Both subspecies are separated from their geographically closest subspecies by a gap in their distribution; i.e. $R$. $f$. assimilis (Rfa) from south of MacKay, QLD and R. l. leucopus (Rll) from north of Coen, QLD (Fig. 1). In sympatry, the two species are notoriously difficult to distinguish based on external morphological characters (Taylor \& Calaby, 1988; Lidicker \& Laurance, 1991), and laboratory crosses between the species have produced fertile offspring in captivity (Baverstock et al., 1983). However, the species can be 


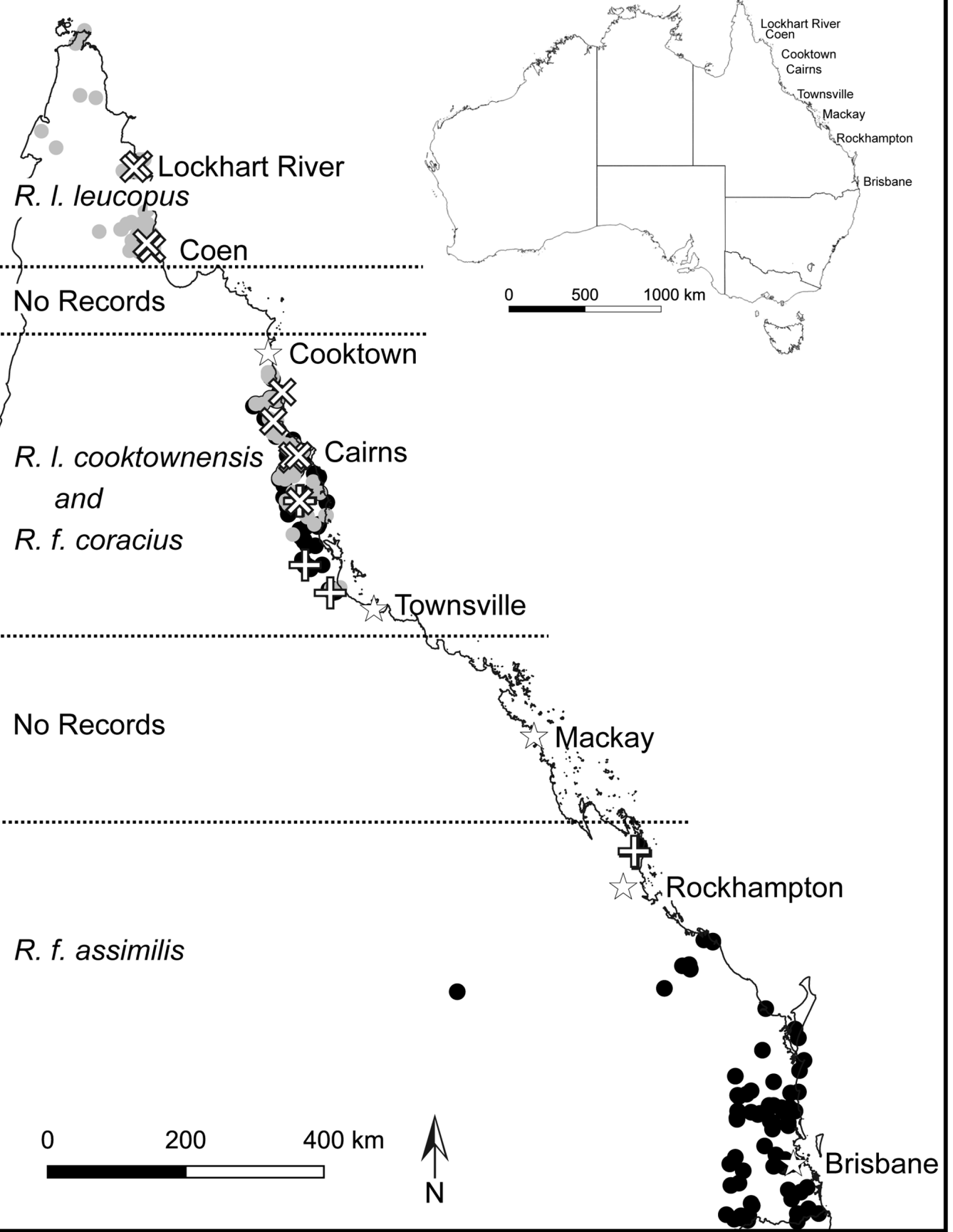

Figure 1. Map of sample localities across Queensland with select cities and towns indicated with stars. Preputial gland sample localities are indicated by open plus symbols (Rattus fuscipes) or open crosses (R. leucopus). Allozyme samples (not shown) were obtained from the same or nearby localities that are indistinguishable at this scale. Circles show the geographic distribution of all specimen records of $R$. fuscipes (black) and $R$. leucopus (grey) in Queensland (downloaded from the Atlas of Living Australia) demonstrating the gap in records between sympatric and allopatric populations of both species. Inset map shows area of sampling with respect to Australia.

distinguished by cranial characters, karyotypes, and genetic data (Watts \& Aslin, 1981; Baverstock et al., 1986; VasquezDominguez et al., 2001; Robins et al., 2007) indicating that they are genetically isolated biological species. Given that the species are genetically isolated but externally similar in phenotype, we anticipate that they are likely to use non-visual signals such as odorants in premating isolation (Panhuis et al., 2001; Zozaya et al., 2019).
In this study, we first used allozyme data to confirm the absence of gene flow between sympatric subspecies of Rattus fuscipes and Rattus leucopus. We then tested if the two species can be distinguished by the chemical composition of their preputial glands using extracts from wild-caught individuals. We compared compositional differences between species, between sympatric subspecies, and between allopatric conspecific subspecies to identify 
putative compounds associated with species' boundaries. We also tested if sympatric subspecies $(R f c$ and $R l c)$ differ in the complexity of the chemical composition of their preputial glands compared to allopatric subspecies ( $R f a$ and $R l l)$. We predicted that if preputial gland odorants help the species to differentiate each other, then we would observe more complex chemical signatures in sympatric species versus allopatric subspecies and populations.

\section{Methods}

\section{Specimens and tissue samples}

Specimens were collected from four subspecies representing sympatric and allopatric populations of $R$. fuscipes and $R$. leucopus. $R$. fuscipes coracius $(R f c)$ and $R$. leucopus cooktownensis $(R l c)$ have sympatric distributions in the Wet Tropics region between Cooktown and Townsville, Queensland, Australia whereas R. fuscipes assimilis $(R f a)$ and $R$. leucopus leucopus (Rll) are from allopatric populations to the south and north respectively (Fig. 1). All populations sampled were from wet sclerophyll rainforest. Samples of $R f c, R f a$, and $R l c$ were collected over two seasons, February-March and July-August 2007, whereas all Rll were collected in August 2007. Heart, kidney, muscle, spleen, and preputial glands were collected in the field and stored in liquid nitrogen immediately after euthanizing vouchered specimens. All tissues were stored at $-70^{\circ} \mathrm{C}$ until being shipped on dry ice to relevant labs for analyses. All samples were collected under permits from the Queensland Environmental Protection Agency (WITK04115806) following procedures authorized by the Southern Cross University Animal Care and Ethics Committee (permit 06/21). All tissues and voucher specimens were deposited in the Queensland Museum (Table S1, Rowe et al., 2020).

\section{Allozyme analyses}

Frozen subsamples of heart, kidney, muscle, and spleen from 166 specimens (13Rfa, $68 R f c, 64 R l c$, and $21 R l l)$ were sent to the South Australian Museum for allozyme analysis, completed in 2007 (Table S1, Rowe et al., 2020). Homogenates of each tissue were subjected to allozyme electrophoresis on cellulose acetate gels following procedures described previously (Richardson et al., 1986). We scored alleles for the following eighteen allozyme loci shown by Baverstock et al. (1986) to be informative in diagnosing the relevant species and subspecies: Alb, Dia, Got-1, Got-2, Gpi, Gus, Idh-2, Ldh-1, Me, Mpi, Np, Pep-C2, 6Pgd, Pgm-1, Pgm-2, Pk-3, Sod-1, and Sordh. Details of enzyme and locus abbreviations, enzyme commission numbers, electrophoretic conditions, and stain recipes are provided in Richardson et al. (1986). We used the allozyme results to test for gene flow among sympatric taxa using the program STRUCTURE v2.3.3. We set the number of populations to 4 to reflect the four subspecies in our study but did not assign individuals to subspecies. We included admixture in model runs and ran 1,000,000 MCMC cycles, with the first 10,000 cycles discarded as burn-in.

\section{Gas chromatography-mass spectrometry (GC-MS) Analysis of Preputial Glands}

We used 32 preputial glands for chemical analysis. Glands were collected from eight males from each of the subspecies $R f a, R f c, R l c$, and $R l l$. All but two samples ( $1 R l l$ and $1 R f c)$ were collected from scrotal (i.e. reproductive) males. Whole, frozen preputial glands were shipped to the Institute for Pheromone Research at Indiana University (Bloomington, Indiana, USA) in 2009 where they were processed immediately. Frozen preputial glands were weighed and homogenized with a mortar and pestle on liquid nitrogen. Volatile organic compounds (VOCs) were extracted from each of the resulting homogenates using the sorptive extraction method with a polydimethylsiloxane (PDMS) polymer coated magnetic stir bar as described previously (Pohorecky et al., 2008; Baltussen et al., 1999; Soini et al., 2005). Briefly, the homogenized tissue (about $100 \mathrm{mg}$ ) was rinsed into the $20 \mathrm{~mL}$ glass scintillation vial (a tin foil lined cap) with $2.0 \mathrm{~mL} \mathrm{OmniSolv}{ }^{\mathrm{TM}}$ water (EMD Chemicals Inc., Billerica, Massachusetts, USA) and $500 \mu \mathrm{L}$ of ethanol was added (100\%, Pharmco-Aaper, Brookfield, Connecticut, USA). As an internal standard, $80 \mathrm{ng}$ of 7-tridecanone (Sigma-Aldrich) in $10 \mu \mathrm{L}$ of methanol (Baker Analyzed, Mallinckrodt Baker Inc., Phillipsburg, New Jersey, USA) was added to the vial. VOCs were extracted with a Twister ${ }^{\mathrm{TM}}$ stir bar (Gerstel GmbH, Mülheim an der Ruhr, Germany, $10 \times 0.5 \mathrm{~mm}$ polydimethylsiloxane) by stirring at $800+\mathrm{rpm}$ for $60 \mathrm{~min}$ (15-place stir plate Variomag Multipoint HP15, $\mathrm{H}+\mathrm{P}$ Labortechnic, Oberschleissheim, Germany). The stir bar was then rinsed with OmniSolv ${ }^{\mathrm{TM}}$ water, dried gently with a lint-free paper tissue (Kimwipes, Kimberly-Clark, Roswell, Georgia, USA) and placed in a Thermal Desorption Autosampler and Cooled Injection System (TDSA-CIS 4 from Gerstel $\mathrm{GmbH}$ ) connected to an Agilent 6890N gas chromatograph-5973iMSD mass spectrometer (Agilent Technologies, Inc., Wilmington, Delaware, USA).

Splitless mode was used for thermal desorption with a temperature program of $20^{\circ} \mathrm{C}$ for $0.5 \mathrm{~min}$, then a $60^{\circ} \mathrm{C} /$ min increase up to $270^{\circ} \mathrm{C}$ for $8 \mathrm{~min}$. The transfer line temperature was set at $280^{\circ} \mathrm{C}$ and the CIS was cooled using liquid nitrogen to $-80^{\circ} \mathrm{C}$. For the sample introduction into the $\mathrm{GC}-\mathrm{MS}$, the $\mathrm{CIS}$ was heated at $12^{\circ} \mathrm{C} / \mathrm{s}$ to $280^{\circ} \mathrm{C}$ and held for $8 \mathrm{~min}$. Solvent vent mode was used for the CIS inlet with a vent pressure of $8.0 \mathrm{psi}$, a vent flow of $50 \mathrm{~mL} / \mathrm{min}$, and a purge flow of $50 \mathrm{~mL} / \mathrm{min}$. The gas chromatograph (GC) separation capillary was a DB-5MS $(30 \mathrm{~m} \times 0.25 \mathrm{~mm}$, i.d., $0.25 \mu \mathrm{m}$ film thickness) from Agilent, and the GC helium carrier gas head pressure was 8.0 psi at a constant $1.1 \mathrm{~mL} /$ min flow. The GC oven temperature program started at $40^{\circ} \mathrm{C}$ for $5 \mathrm{~min}$, then increased at $2^{\circ} \mathrm{C} / \mathrm{min}$ to $200^{\circ} \mathrm{C}$ and was held for $15 \mathrm{~min}$. For the mass spectrometer (MS), positive electron ionization (EI) mode at $70 \mathrm{eV}$ was used with a scanning rate of $2.47 \mathrm{scans} / \mathrm{s}$ and mass range of 41-350 amu. The mass spectrometric detector (MSD) transfer line temperature was $280^{\circ} \mathrm{C}$, the ion source was $230^{\circ} \mathrm{C}$, and quadrupole temperature was set at $150^{\circ} \mathrm{C}$.

Compounds were positively or tentatively identified by matching retention times and mass spectra with standard 
compounds when available from Sigma-Aldrich Chemical Co. and with spectra through NIST Mass Spectral Search Program for the NIST/EPA/NIH Mass Spectral Library (Version 2.0a, 2002). Presence of sulphur and nitrogen in the identified compounds was verified by using the elementspecific Agilent 6890 gas-chromatography-G2350A atomic emission detector (GC-AED) system (Agilent Technologies, Inc., Wilmington, Delaware, USA) under the conditions described previously (Novotny et al., 2007).

\section{Statistical analyses of preputial gland chemical composition}

We first used the chemical analysis to test if species and subspecies could be distinguished by the chemical composition of their preputial glands. For statistical analyses of preputial gland chemical composition, we included only identified and quantitated compounds. We conducted analyses on two sets of compounds. The first set included all identified compounds, hereafter referred to as "total". The second set, hereafter referred to as "subset", included compounds proposed to have roles in chemical communication based on studies of other mammalian species, i.e. thiazolines, carboxylic acids, and two geranylrelated compounds (Schwende et al., 1986; reviewed in Petrulis, 2013). To visualize the dissimilarity in preputial gland chemical composition among species, subspecies, and individuals we used a non-metric multidimensional scaling (MDS) approach described previously (Zimmerman et al., 2009; Weber et al., 2016). For each sample we calculated the relative abundance of each compound by dividing its absolute peak area by the sum of all peak areas for that sample. We transformed these percent values with a squareroot. For the subset analysis, we retained percent values calculated from the total pool of compounds. From these transformed values, representing relative abundance of each chemical compound in each individual, we calculated a BrayCurtis index of dissimilarity among pairs of individuals. The Bray-Curtis index considers only compounds shared between each pair of individuals. We used MDS in the R (v. 3.6.1, R Core Team 2019) package "vegan" (v. 2.5-6, Oksanen et al. 2019) to reduce the dimensionality of this matrix of Bray-Curtis distances. We used 1000 iterations with the "metaMDS" function to identify the scores with the minimum stress values. To visualize the dissimilarity among individuals we plotted the first two dimensions of the resulting MDS. We used an analysis of similarity (ANOSIM) using the "anosim" function in "vegan" to test if MDSordinated chemical composition is significantly different among species and subspecies relative to variation among individuals within groups. To determine which chemical compounds most-differentiate species and subspecies we performed a SIMPER (similarity percentage) analysis using the "simper" function in "vegan".

To examine if the complexity of preputial gland chemical composition varies among all subspecies and between sympatric and allopatric subspecies of $R$. fuscipes and $R$. leucopus we quantified two variables per individual, (1) the number of chemical compounds detected, and (2) the total abundance of chemical compounds. We defined the number of chemical compounds per individual as a count of detected compounds regardless of peak area. We defined the total abundance of chemical compounds per individual as the sum of the peak areas of all compounds. We tested for an overall significant difference among the four subspecies using a Kruskal-Wallis $\mathrm{H}$ test. We then tested for a significant increase in the count and abundance of chemical compounds in sympatric subspecies compared to allopatric subspecies with a one-way Mann-Whitney U test. Both tests were performed using the R Core "stats" package.

\section{Results}

\section{Allozyme analyses}

We recovered no shared polymorphism between $R$. fuscipes and $R$. leucopus for 10 out of the 18 allozyme loci screened (Table 1). Not surprisingly, STRUCTURE analyses found no evidence of gene flow among species in sympatry. With $\mathrm{K}=4$ populations, STRUCTURE clearly separated the two species and most individuals of the four subspecies (Fig. 2 ). All $R f a$ and $R f c$ individuals were correctly classified to their respective populations with high probability, whereas a few $R l c$ and one $R l l$ individuals were close to equivocal with regard to population assignment suggesting the retention of shared polymorphism between these two allopatric subspecies.

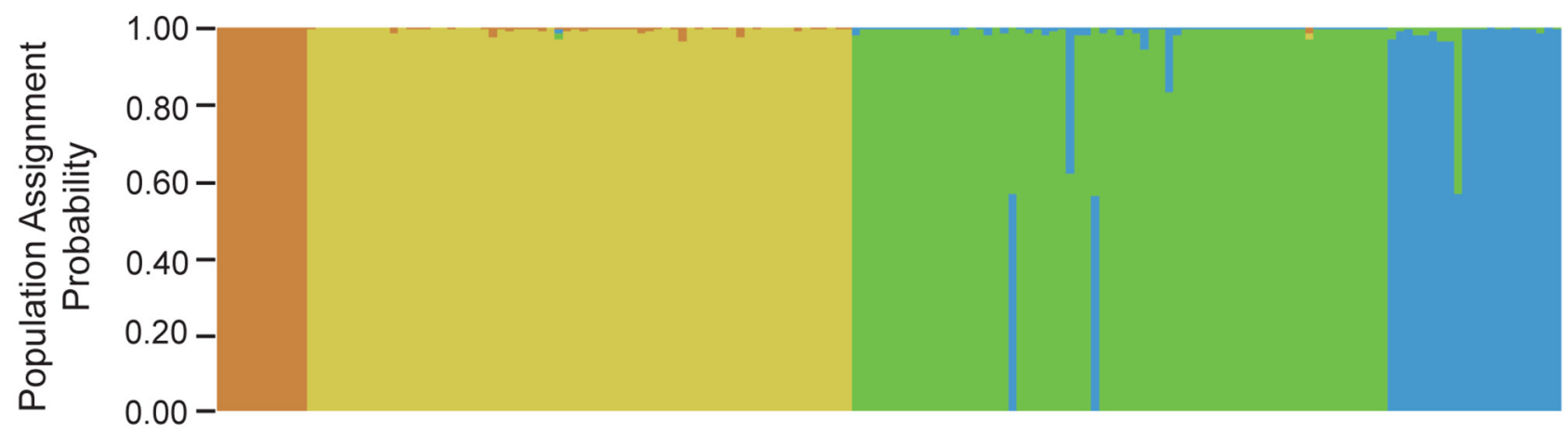

Figure 2. StRucture plot of allozyme variation among four subspecies of Australian Rattus. Each of the 166 samples analysed in this study (13Rfa, $67 R f c, 65 R l c, 21 R l l)$ is represented by a vertical bar shaded based on the likelihood of assignment to one of four populations. Individual samples are not distinguishable where they share a high likelihood of assignment to the same population (e.g., all $R f a$ samples). Plot demonstrates lack of gene flow between species in sympatry ( $R f c$ and $R l c$ ) with no mixed likelihood between species. Limited gene flow (or shared polymorphism) among subspecies, Rlc and Rll, are evident in bars with mixed shading. 
Table 1. Allozyme profiles at 18 loci for the four Rattus taxa surveyed. For polymorphic loci, allozyme frequencies for all but the rarest are expressed as percentages and shown as superscripts. Loci that display fixed differences between species, $R$. leucopus and $R$. fuscipes are highlighted with an asterisk. Sample sizes per taxon are shown in parentheses.

\begin{tabular}{|c|c|c|c|c|}
\hline locus & $\begin{array}{l}\text { R. } . \text {. } \\
\text { leucopus } \\
\text { (21) }\end{array}$ & $\begin{array}{c}R . l . \\
\text { cooktownensis } \\
(65)\end{array}$ & $\begin{array}{l}R . f . \\
\text { coracius } \\
(67)\end{array}$ & $\begin{array}{l}R . f . \\
\text { assimilis } \\
\text { (13) }\end{array}$ \\
\hline$A l b$ & $b^{52}, c$ & $b^{98}, c$ & $\mathrm{~b}^{99}, \mathrm{a}$ & $b^{92}, c$ \\
\hline Dia & $a^{64}, b$ & $\mathrm{a}$ & $a^{98}, \mathrm{~b}$ & $\mathrm{a}$ \\
\hline Got-1 & $\mathrm{c}$ & $\mathrm{c}$ & $c^{72}, a^{27}, b$ & $\mathrm{c}$ \\
\hline Got-2* & $\mathrm{a}$ & $\mathrm{a}$ & $\mathrm{b}$ & b \\
\hline$G p i^{*}$ & $a^{55}, c$ & $\mathrm{a}$ & $\mathrm{b}$ & $\mathrm{b}$ \\
\hline Gus & b & $\mathrm{b}^{99}, \mathrm{c}$ & $c^{93}, d^{6}, b$ & $\mathrm{c}^{73}, \mathrm{a}$ \\
\hline$I d h-2 *$ & $\mathrm{c}$ & c & $a^{60}, b$ & $\mathrm{a}$ \\
\hline$L d h-1 *$ & $\mathrm{~b}$ & $\mathrm{~b}$ & $\mathrm{a}$ & $\mathrm{a}$ \\
\hline$M e^{*}$ & $\mathrm{~b}^{90}, \mathrm{a}$ & $\mathrm{b}^{98}, \mathrm{c}$ & $\mathrm{d}$ & d \\
\hline$M p i *$ & $\mathrm{a}$ & $\mathrm{a}$ & $\mathrm{b}$ & $\mathrm{b}$ \\
\hline$N p^{*}$ & $\mathrm{c}^{98}, \mathrm{~d}$ & $c^{98}, \mathrm{~d}$ & $\mathrm{~b}^{69}, \mathrm{a}$ & a \\
\hline Рер-C2 & $\mathrm{a}$ & $b^{86}, \mathrm{a}$ & $\mathrm{a}$ & $\mathrm{a}$ \\
\hline $6 P g d$ & $b^{93}, d$ & $\mathrm{~b}$ & $b^{97}, \mathrm{c}$ & a \\
\hline Pgm-1 & $\mathrm{c}^{93}, \mathrm{~b}$ & $c^{99}, d$ & $b^{64}, c^{20}, a$ & $\mathrm{c}$ \\
\hline Pgm-2 & $\mathrm{b}^{90}, \mathrm{a}$ & $\mathrm{b}$ & $\mathrm{b}$ & $\mathrm{b}^{54}, \mathrm{c}$ \\
\hline$P k-3 *$ & $\mathrm{a}$ & $a^{98}, c$ & $\mathrm{~b}$ & $\mathrm{~b}$ \\
\hline Sod $-1 *$ & $\mathrm{~b}$ & $\mathrm{~b}$ & $\mathrm{a}$ & $\mathrm{a}$ \\
\hline Sordh* & $\mathrm{b}$ & $\mathrm{b}^{99}, \mathrm{c}$ & $\mathrm{a}$ & a \\
\hline
\end{tabular}

\section{Chemical composition of preputial glands}

Preputial gland volatile compound profiles from male $R$. fuscipes and $R$. leucopus determined by GC-MS recovered 278 volatile organic compounds (VOCs; data not shown). Among these 278 compounds, we positively or tentatively identified 120 compounds (43\%), including linear ketones, a series of ten methylketones from 2-heptanone to 2-heptadecanone, aldehydes, alcohols, aliphatic acids, esters, hydrocarbons, cholesterol, terpenes, terpene alcohols, seven thiazolines, and seven carboxylic acids. Out of these 120 compounds, we quantitated 80 consistently appearing compounds $(29 \%$ of all compounds) by measuring their peak areas and normalizing them by the peak area of the internal standard (Table S2, Rowe et al., 2020). We refer to these 80 quantitated compounds for subsequent analysis of differences between species and among subspecies. We identified the seven thiazoline compounds as 2-methylthiazoline, 2-ethylthiazoline, 2-isopropylthiazoline, 2-propylthiazoline, 2-sec-butylthiazoline, 2-isobutylthiazoline and 2-butylthiazoline (Table 2 and Table S2). The thiazoline chemical structures found in this study are presented in Fig. 3. We also identified the seven carboxylic acid compounds as dodecanoic acid, tetradecanoic acid, pentadecanoic acid, hexadecanoic acid, linoleic acid, oleic acid, octadecanoic acid. Finally, we partially identified, three geranyl-related sesquiterpenes at retention times of $40.83 \mathrm{~min}, 41.62 \mathrm{~min}$ and $42.27 \mathrm{~min}$ that are potentially important in chemical communication similar to farnesenes (Harvey et al., 1989; Novotny et al., 1980; Pohorecky et al., 2008).

Between species, we detected eight quantitated compounds exclusively in R. leucopus (Table 2; Table S2;

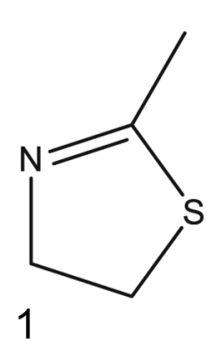

1

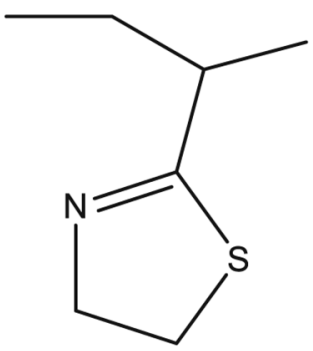

5

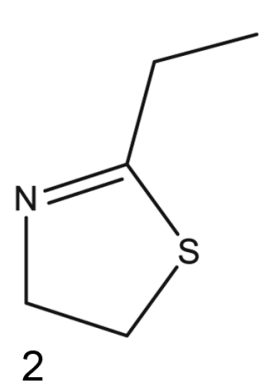

2
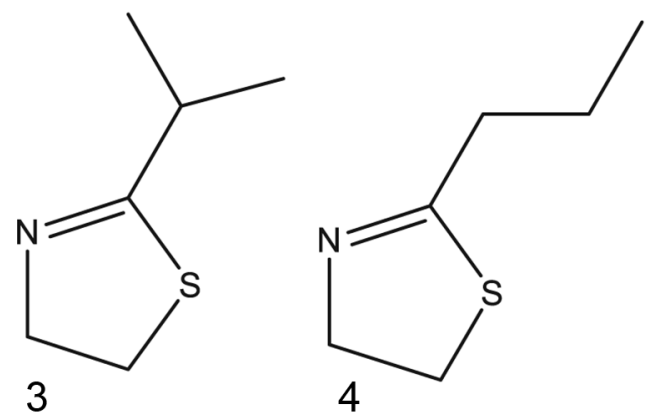

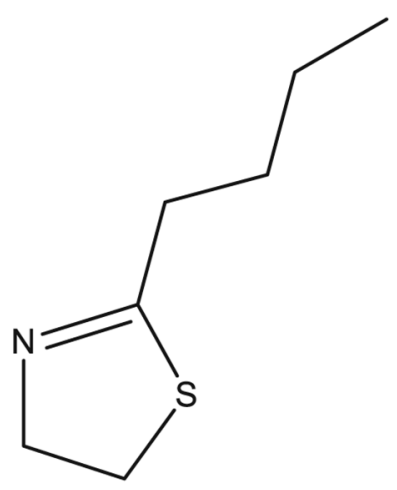

7

Figure 3. Chemical structures of seven thiazoline compounds identified from preputial glands of Rattus fuscipes and R. leucopus in this study. Numbers refer to (1) 2-methylthiazoline; (2) 2-ethylthiazoline; (3) 2-isopropylthiazoline; (4) 2-propylthiazoline; (5) 2-sec-butylthiazoline; (6) 2-isobutylthiazoline (detected only in R. l. leucopus); and (7) 2-butylthiazoline. 
Table 2. Means \pm standard deviations for relative proportion of each of the 80 quantitated chemical compounds from preputial gland extracts of $R$. fuscipes, $R$. leucopus, and subspecies. Molecular weight ( $M W$ ), quantification single ion (ion), and retention time (min) presented for each compound. For ion quantification, TIC indicates that peak areas were calculated from the total ion chromatogram, whereas numerical ion values are indicative of peak areas defined by post-run extracted single ion chromatograms (SIC). Compounds included in our subset analyses our indicated with an asterisk.

\begin{tabular}{|c|c|c|c|c|c|c|c|c|c|}
\hline \multirow[b]{2}{*}{ MW } & \multicolumn{3}{|c|}{ chemical compound } & \multicolumn{2}{|c|}{ species } & & subsp & secies & \\
\hline & ion & name & $\min$ & R. fuscipes & R. leucopus & R.f.assimilis & R.f.coracius & R.l.cooktownensis & R.l.leucopus \\
\hline 98 & TIC & Furfuryl alcohol & 9.48 & $0.183( \pm 0.10)$ & $0.066( \pm 0.03)$ & $0.220( \pm 0.13)$ & $0.146( \pm 0.04)$ & $0.053( \pm 0.01)$ & $0.079( \pm 0.04)$ \\
\hline 101 & 60 & 2-Methylthiazoline* & 10.56 & $0.049( \pm 0.02)$ & $0.024( \pm 0.01)$ & $0.063( \pm 0.01)$ & $0.035( \pm 0.01)$ & $0.021( \pm 0.01)$ & $0.027( \pm 0.01)$ \\
\hline 114 & 58 & 2-Heptanone & 11.31 & $0.014( \pm 0.01)$ & $0.026( \pm 0.01)$ & $0.012( \pm 0.01)$ & $0.015( \pm 0.01)$ & $0.020( \pm 0.00)$ & $0.033( \pm 0.02)$ \\
\hline 84 & TIC & Crotonolactone & 12.5 & $0.079( \pm 0.04)$ & $0.023( \pm 0.02)$ & $0.095( \pm 0.05)$ & $0.063( \pm 0.02)$ & $0.017( \pm 0.01)$ & $0.028( \pm 0.02)$ \\
\hline 115 & 60 & 2-Ethylthiazoline* & 16.2 & $0.044( \pm 0.01)$ & $0.031( \pm 0.01)$ & $0.048( \pm 0.01)$ & $0.041( \pm 0.01)$ & $0.024( \pm 0.00)$ & $0.039( \pm 0.01)$ \\
\hline 140 & 55 & 1-Decene & 18.03 & $0.052( \pm 0.02)$ & $0.024( \pm 0.01)$ & $0.069( \pm 0.01)$ & $0.036( \pm 0.01)$ & $0.015( \pm 0.00)$ & $0.034( \pm 0.01)$ \\
\hline 129 & 60 & 2-Isopropylthiazoline* & 19.59 & $0.069( \pm 0.04)$ & $0.101( \pm 0.05)$ & $0.039( \pm 0.01)$ & $0.099( \pm 0.04)$ & $0.052( \pm 0.02)$ & $0.151( \pm 0.02)$ \\
\hline 138 & TIC & 1-para-Menthene & 19.99 & $0.057( \pm 0.03)$ & $0.037( \pm 0.02)$ & $0.073( \pm 0.02)$ & $0.041( \pm 0.02)$ & $0.036( \pm 0.01)$ & $0.037( \pm 0.02)$ \\
\hline 136 & TIC & Limonene & 20.41 & $0.075( \pm 0.03)$ & $0.037( \pm 0.01)$ & $0.098( \pm 0.01)$ & $0.052( \pm 0.01)$ & $0.03( \pm 0.01)$ & $0.044( \pm 0.01)$ \\
\hline 129 & 60 & 2-Propylthiazoline* & 22.49 & $0.015( \pm 0.01)$ & $0.014( \pm 0.01)$ & $0.005( \pm 0.01)$ & $0.026( \pm 0.01)$ & $0.009( \pm 0.00)$ & $0.02( \pm 0.01)$ \\
\hline 142 & 58 & 4-Methyl-2,6-heptanedione? & 22.46 & $0.012( \pm 0.01)$ & $0.042( \pm 0.02)$ & 0 & $0.025( \pm 0.01)$ & $0.027( \pm 0.00)$ & $0.056( \pm 0.01)$ \\
\hline 126 & TIC & 2-Octenal & 22.7 & $0.123( \pm 0.07)$ & $0.041( \pm 0.02)$ & $0.164( \pm 0.08)$ & $0.083( \pm 0.04)$ & $0.025( \pm 0.01)$ & $0.057( \pm 0.02)$ \\
\hline 120 & TIC & Acetophenone & 22.93 & $0.104( \pm 0.05)$ & $0.047( \pm 0.02)$ & $0.144( \pm 0.05)$ & $0.064( \pm 0.02)$ & $0.032( \pm 0.01)$ & $0.062( \pm 0.01)$ \\
\hline 142 & TIC & 7-Methyl-2-octanone & 23.57 & 0 & $0.003( \pm 0.01)$ & 0 & 0 & $0.006( \pm 0.02)$ & 0 \\
\hline 142 & 58 & 2-Nonanone & 25.19 & $0.112( \pm 0.06)$ & $0.311( \pm 0.06)$ & $0.070( \pm 0.02)$ & $0.154( \pm 0.06)$ & $0.284( \pm 0.05)$ & $0.338( \pm 0.05)$ \\
\hline 143 & 60 & 2-sec-Butylthiazoline* & 25.89 & $0.180( \pm 0.06)$ & $0.078( \pm 0.03)$ & $0.173( \pm 0.05)$ & $0.187( \pm 0.07)$ & $0.056( \pm 0.01)$ & $0.100( \pm 0.02)$ \\
\hline 144 & TIC & 2-Nonanol & 26.01 & $0.050( \pm 0.06)$ & $0.021( \pm 0.02)$ & 0 & $0.099( \pm 0.05)$ & $0.030( \pm 0.02)$ & $0.013( \pm 0.03)$ \\
\hline 143 & 60 & 2-Isobutylthiazoline* & 26.1 & 0 & $0.024( \pm 0.03)$ & 0 & 0 & 0 & $0.047( \pm 0.01)$ \\
\hline 142 & TIC & Nonanal & 26.14 & $0.176( \pm 0.08)$ & $0.048( \pm 0.03)$ & $0.226( \pm 0.06)$ & $0.126( \pm 0.06)$ & $0.040( \pm 0.02)$ & $0.056( \pm 0.03)$ \\
\hline 156 & TIC & C9 2,x-Diketone A branched & 29.25 & $0.024( \pm 0.03)$ & $0.034( \pm 0.03)$ & 0 & $0.047( \pm 0.02)$ & $0.050( \pm 0.02)$ & $0.019( \pm 0.02)$ \\
\hline 156 & 58 & C9 2,x-Diketone B & 29.76 & $0.005( \pm 0.01)$ & $0.032( \pm 0.02)$ & 0 & $0.010( \pm 0.01)$ & $0.013( \pm 0.00)$ & $0.050( \pm 0.01)$ \\
\hline & TIC & C9 2,x-Diketone B & 29.76 & $0.015( \pm 0.03)$ & $0.066( \pm 0.04)$ & 0 & $0.030( \pm 0.03)$ & $0.030( \pm 0.00)$ & $0.102( \pm 0.03)$ \\
\hline 143 & 60 & 2-Butylthiazoline* & 29.85 & $0.011( \pm 0.01)$ & $0.007( \pm 0.00)$ & $0.005( \pm 0.01)$ & $0.016( \pm 0.00)$ & $0.005( \pm 0.00)$ & $0.009( \pm 0.00)$ \\
\hline 140 & TIC & 2-Nonenal & 30.01 & $0.077( \pm 0.05)$ & $0.040( \pm 0.03)$ & $0.087( \pm 0.07)$ & $0.068( \pm 0.03)$ & $0.023( \pm 0.01)$ & $0.057( \pm 0.03)$ \\
\hline 156 & 58 & C9 2,x-Diketone C & 30.13 & $0.025( \pm 0.02)$ & $0.033( \pm 0.01)$ & $0.011( \pm 0.00)$ & $0.038( \pm 0.01)$ & $0.032( \pm 0.01)$ & $0.034( \pm 0.01)$ \\
\hline 150 & TIC & Ethyl benzoate & 30.55 & $0.105( \pm 0.04)$ & $0.033( \pm 0.01)$ & $0.135( \pm 0.04)$ & $0.076( \pm 0.02)$ & $0.027( \pm 0.01)$ & $0.039( \pm 0.01)$ \\
\hline 156 & 58 & 2-Decanone & 32.37 & $0.062( \pm 0.06)$ & $0.145( \pm 0.03)$ & $0.020( \pm 0.03)$ & $0.104( \pm 0.04)$ & $0.140( \pm 0.02)$ & $0.151( \pm 0.03)$ \\
\hline 158 & TIC & 2-Decanol & 33.14 & $0.040( \pm 0.05)$ & $0.022( \pm 0.01)$ & 0 & $0.08( \pm 0.04)$ & $0.021( \pm 0.01)$ & $0.022( \pm 0.02)$ \\
\hline 156 & TIC & Decanal & 33.34 & $0.148( \pm 0.08)$ & $0.061( \pm 0.03)$ & $0.191( \pm 0.06)$ & $0.105( \pm 0.06)$ & $0.041( \pm 0.01)$ & $0.080( \pm 0.02)$ \\
\hline 152 & TIC & Neral & 35.38 & $0.075( \pm 0.04)$ & $0.033( \pm 0.02)$ & $0.110( \pm 0.01)$ & $0.041( \pm 0.01)$ & $0.022( \pm 0.01)$ & $0.043( \pm 0.03)$ \\
\hline 154 & 55 & 3-Decen-2-one & 35.56 & $0.005( \pm 0.01)$ & $0.022( \pm 0.01)$ & $0.004( \pm 0.01)$ & $0.006( \pm 0.00)$ & $0.003( \pm 0.01)$ & $0.013( \pm 0.01)$ \\
\hline 170 & 58 & C10 2,x-Diketone A & 36.83 & $0.033( \pm 0.04)$ & $0.080( \pm 0.03)$ & 0 & $0.065( \pm 0.02)$ & $0.060( \pm 0.02)$ & $0.099( \pm 0.03)$ \\
\hline 152 & TIC & Geranial & 37.49 & $0.149( \pm 0.10)$ & $0.098( \pm 0.06)$ & $0.195( \pm 0.12)$ & $0.102( \pm 0.03)$ & $0.080( \pm 0.04)$ & $0.116( \pm 0.07)$ \\
\hline 168 & TIC & Undecen-2-one A & 37.83 & $0.217( \pm 0.10)$ & $0.123( \pm 0.05)$ & $0.144( \pm 0.03)$ & $0.290( \pm 0.10)$ & $0.167( \pm 0.04)$ & $0.079( \pm 0.03)$ \\
\hline 168 & TIC & Undecen-2-one B & 38.06 & $0.029( \pm 0.04)$ & $0.064( \pm 0.02)$ & 0 & $0.059( \pm 0.03)$ & $0.066( \pm 0.01)$ & $0.062( \pm 0.03)$ \\
\hline 168 & TIC & Undecen-2-one C & 38.62 & $0.263( \pm 0.17)$ & $0.156( \pm 0.07)$ & $0.117( \pm 0.06)$ & $0.408( \pm 0.11)$ & $0.170( \pm 0.04)$ & $0.141( \pm 0.08)$ \\
\hline 168 & TIC & C10 2,x-Diketone B & 39.03 & $0.195( \pm 0.23)$ & $0.636( \pm 0.18)$ & 0 & $0.390( \pm 0.17)$ & $0.656( \pm 0.18)$ & $0.617( \pm 0.18)$ \\
\hline 170 & 58 & 2-Undecanone & 39.4 & $0.110( \pm 0.10)$ & $0.371( \pm 0.07)$ & $0.041( \pm 0.06)$ & $0.179( \pm 0.09)$ & $0.378( \pm 0.06)$ & $0.364( \pm 0.08)$ \\
\hline 172 & TIC & 2-Undecanol & 40.04 & $0.080( \pm 0.09)$ & $0.083( \pm 0.04)$ & 0 & $0.160( \pm 0.06)$ & $0.077( \pm 0.04)$ & $0.089( \pm 0.03)$ \\
\hline 166 & TIC & 69-98-41-81: A geranyl-related ketone & 40.83 & $0.300( \pm 0.13)$ & $0.058( \pm 0.04)$ & $0.419( \pm 0.03)$ & $0.181( \pm 0.05)$ & $0.061( \pm 0.02)$ & $0.055( \pm 0.06)$ \\
\hline 166 & TIC & 69-41-137-95-108--geranyl-related* & 41.62 & $0.087( \pm 0.05)$ & $0.002( \pm 0.01)$ & $0.133( \pm 0.02)$ & $0.040( \pm 0.01)$ & 0 & $0.004( \pm 0.01)$ \\
\hline 166 & TIC & 69-41-137-95-108--geranyl-related* & 42.27 & $0.060( \pm 0.04)$ & 0 & $0.097( \pm 0.01)$ & $0.023( \pm 0.02)$ & 0 & 0 \\
\hline 168 & 55 & 3-Undecen-2-one & 42.4 & $0.022( \pm 0.01)$ & $0.078( \pm 0.04)$ & $0.019( \pm 0.01)$ & $0.024( \pm 0.01)$ & $0.116( \pm 0.02)$ & $0.040( \pm 0.02)$ \\
\hline 184 & TIC & C11 2,x-Diketone A branched & 42.75 & $0.004( \pm 0.01)$ & $0.025( \pm 0.02)$ & 0 & $0.009( \pm 0.01)$ & $0.038( \pm 0.02)$ & $0.011( \pm 0.01)$ \\
\hline 184 & 58 & C11 2,x-Diketone B & 43.51 & 0 & $0.017( \pm 0.01)$ & 0 & 0 & $0.009( \pm 0.00)$ & $0.024( \pm 0.00)$ \\
\hline 184 & 58 & C11 2,x-Diketone C & 43.91 & $0.014( \pm 0.02)$ & $0.030( \pm 0.01)$ & 0 & $0.027( \pm 0.02)$ & $0.030( \pm 0.01)$ & $0.029( \pm 0.01)$ \\
\hline 182 & 43 & x-Dodecen-2-one & 44.3 & $0.036( \pm 0.03)$ & $0.028( \pm 0.01)$ & $0.022( \pm 0.01)$ & $0.050( \pm 0.03)$ & $0.038( \pm 0.01)$ & $0.018( \pm 0.01)$ \\
\hline & TIC & $\mathrm{x}$-Dodecen-2-one & 44.3 & $0.113( \pm 0.10)$ & $0.101( \pm 0.04)$ & $0.048( \pm 0.07)$ & $0.178( \pm 0.09)$ & $0.132( \pm 0.03)$ & $0.069( \pm 0.02)$ \\
\hline 172 & 55 & 1-Undecanol & 44.64 & $0.021( \pm 0.01)$ & $0.013( \pm 0.01)$ & $0.026( \pm 0.02)$ & $0.017( \pm 0.01)$ & $0.009( \pm 0.00)$ & $0.017( \pm 0.02)$ \\
\hline 184 & 58 & 2-Dodecanone & 45.84 & $0.014( \pm 0.02)$ & $0.062( \pm 0.01)$ & 0 & $0.027( \pm 0.02)$ & $0.061( \pm 0.01)$ & $0.062( \pm 0.01)$ \\
\hline 194 & TIC & Geranylacetone & 49.09 & $0.156( \pm 0.08)$ & $0.064( \pm 0.02)$ & $0.227( \pm 0.03)$ & $0.085( \pm 0.05)$ & $0.049( \pm 0.01)$ & $0.079( \pm 0.02)$ \\
\hline 198 & 58 & C12 2,x-Diketone A & 49.87 & $0.005( \pm 0.01)$ & $0.022( \pm 0.01)$ & 0 & $0.009( \pm 0.01)$ & $0.020( \pm 0.00)$ & $0.024( \pm 0.01)$ \\
\hline 196 & 58 & Tridecen-2-one A & 50.46 & $0.013( \pm 0.01)$ & $0.028( \pm 0.01)$ & $0.002( \pm 0.00)$ & $0.024( \pm 0.01)$ & $0.038( \pm 0.01)$ & $0.018( \pm 0.01)$ \\
\hline 186 & 55 & 1-Dodecanol & 50.97 & $0.042( \pm 0.02)$ & $0.028( \pm 0.01)$ & $0.044( \pm 0.03)$ & $0.040( \pm 0.01)$ & $0.026( \pm 0.01)$ & $0.030( \pm 0.01)$ \\
\hline 196 & TIC & Tridecen-2-one B & 51.19 & $0.027( \pm 0.04)$ & $0.088( \pm 0.04)$ & 0 & $0.053( \pm 0.03)$ & $0.116( \pm 0.03)$ & $0.059( \pm 0.04)$ \\
\hline 198 & 58 & 2-Tridecanone & 52.15 & $0.033( \pm 0.01)$ & $0.152( \pm 0.03)$ & $0.028( \pm 0.01)$ & $0.038( \pm 0.02)$ & $0.163( \pm 0.04)$ & $0.141( \pm 0.02)$ \\
\hline 200 & TIC & 2-Tridecanol & 52.72 & $0.012( \pm 0.02)$ & $0.054( \pm 0.02)$ & 0 & $0.025( \pm 0.03)$ & $0.056( \pm 0.02)$ & $0.052( \pm 0.03)$ \\
\hline 194 & TIC & 6,10-Dimethyl-3-undecen-2-one? & 53.57 & $0.005( \pm 0.01)$ & $0.090( \pm 0.04)$ & 0 & $0.010( \pm 0.01)$ & $0.116( \pm 0.02)$ & $0.063( \pm 0.04)$ \\
\hline 222 & TIC & Z-Nerolidol & 54.28 & $0.050( \pm 0.03)$ & $0.010( \pm 0.01)$ & $0.035( \pm 0.02)$ & $0.066( \pm 0.02)$ & $0.009( \pm 0.01)$ & $0.012( \pm 0.01)$ \\
\hline 196 & 55 & 3-Tridecen-2-one & 54.95 & $0.015( \pm 0.01)$ & $0.014( \pm 0.01)$ & $0.019( \pm 0.01)$ & $0.011( \pm 0.01)$ & $0.016( \pm 0.00)$ & $0.012( \pm 0.01)$ \\
\hline 222 & TIC & E-Nerolidol & 55.9 & $0.073( \pm 0.02)$ & $0.040( \pm 0.01)$ & $0.087( \pm 0.02)$ & $0.058( \pm 0.01)$ & $0.032( \pm 0.01)$ & $0.049( \pm 0.01)$ \\
\hline 200 & TIC & Dodecanoic acid* & 56.27 & $0.245( \pm 0.14)$ & $0.062( \pm 0.03)$ & $0.319( \pm 0.15)$ & $0.171( \pm 0.09)$ & $0.057( \pm 0.02)$ & $0.066( \pm 0.04)$ \\
\hline 210 & 55 & $\mathrm{x}$-Tetradecen-2-one & 56.91 & 0 & $0.009( \pm 0.01)$ & 0 & 0 & $0.014( \pm 0.00)$ & $0.004( \pm 0.01)$ \\
\hline 212 & 58 & 2-Tetradecanone & 58.05 & 0 & $0.025( \pm 0.01)$ & 0 & 0 & $0.031( \pm 0.01)$ & $0.019( \pm 0.01)$ \\
\hline 182 & TIC & Benzophenone & 59.21 & $0.017( \pm 0.02)$ & $0.022( \pm 0.02)$ & $0.031( \pm 0.03)$ & $0.003( \pm 0.01)$ & $0.011( \pm 0.00)$ & $0.033( \pm 0.02)$ \\
\hline 222 & TIC & x,y-Pentadecadien-2-one & 61.41 & $0.005( \pm 0.02)$ & $0.100( \pm 0.03)$ & 0 & $0.010( \pm 0.03)$ & $0.119( \pm 0.02)$ & $0.081( \pm 0.02)$ \\
\hline 226 & TIC & 2-Pentadecanone (branched) & 61.66 & 0 & $0.031( \pm 0.01)$ & 0 & 0 & $0.032( \pm 0.01)$ & $0.030( \pm 0.02)$ \\
\hline 224 & TIC & Pentadecen-2-one A & 62.07 & $0.003( \pm 0.01)$ & $0.046( \pm 0.02)$ & 0 & $0.007( \pm 0.02)$ & $0.054( \pm 0.02)$ & $0.037( \pm 0.02)$ \\
\hline 224 & TIC & Pentadecen-2-one B & 62.39 & $0.034( \pm 0.05)$ & $0.104( \pm 0.06)$ & 0 & $0.069( \pm 0.04)$ & $0.145( \pm 0.05)$ & $0.062( \pm 0.04)$ \\
\hline 226 & 58 & 2-Pentadecanone & 63.7 & $0.020( \pm 0.01)$ & $0.071( \pm 0.03)$ & $0.018( \pm 0.01)$ & $0.022( \pm 0.00)$ & $0.088( \pm 0.04)$ & $0.054( \pm 0.01)$ \\
\hline 228 & TIC & 2-Pentadecanol & 64.23 & 0 & $0.021( \pm 0.02)$ & 0 & 0 & $0.031( \pm 0.02)$ & $0.012( \pm 0.02)$ \\
\hline 228 & 60 & Tetradecanoic acid* & 67.25 & $0.078( \pm 0.03)$ & $0.032( \pm 0.02)$ & $0.090( \pm 0.02)$ & $0.065( \pm 0.03)$ & $0.021( \pm 0.01)$ & $0.044( \pm 0.02)$ \\
\hline 240 & TIC & 2-Hexadecanone & 69.05 & $0.002( \pm 0.01)$ & $0.019( \pm 0.02)$ & 0 & $0.004( \pm 0.01)$ & $0.030( \pm 0.01)$ & $0.008( \pm 0.02)$ \\
\hline 242 & 60 & Pentadecanoic acid* & 72.34 & $0.098( \pm 0.03)$ & $0.025( \pm 0.02)$ & $0.119( \pm 0.03)$ & $0.077( \pm 0.02)$ & $0.014( \pm 0.00)$ & $0.037( \pm 0.01)$ \\
\hline 252 & TIC & A heptadecen-2-one & 72.77 & 0 & $0.010( \pm 0.02)$ & 0 & 0 & $0.019( \pm 0.02)$ & 0 \\
\hline 254 & TIC & 2-Heptadecanone & 74.19 & $0.014( \pm 0.03)$ & $0.035( \pm 0.02)$ & $0.009( \pm 0.03)$ & $0.019( \pm 0.04)$ & $0.042( \pm 0.02)$ & $0.029( \pm 0.03)$ \\
\hline 256 & 60 & Hexadecanoic acid* & 77.5 & $0.230( \pm 0.08)$ & $0.092( \pm 0.05)$ & $0.276( \pm 0.04)$ & $0.183( \pm 0.08)$ & $0.056( \pm 0.01)$ & $0.128( \pm 0.04)$ \\
\hline 280 & 55 & Linoleic acid* & 85 & $0.131( \pm 0.06)$ & $0.068( \pm 0.04)$ & $0.134( \pm 0.06)$ & $0.128( \pm 0.07)$ & $0.042( \pm 0.01)$ & $0.093( \pm 0.05)$ \\
\hline 282 & 55 & Oleic acid* & 85.31 & $0.158( \pm 0.08)$ & $0.063( \pm 0.04)$ & $0.188( \pm 0.09)$ & $0.128( \pm 0.07)$ & $0.040( \pm 0.01)$ & $0.087( \pm 0.05)$ \\
\hline 284 & 55 & Octodecanoic acid* & 86.58 & $0.069( \pm 0.03)$ & $0.028( \pm 0.01)$ & $0.082( \pm 0.02)$ & $0.056( \pm 0.03)$ & $0.019( \pm 0.00)$ & $0.037( \pm 0.01)$ \\
\hline
\end{tabular}



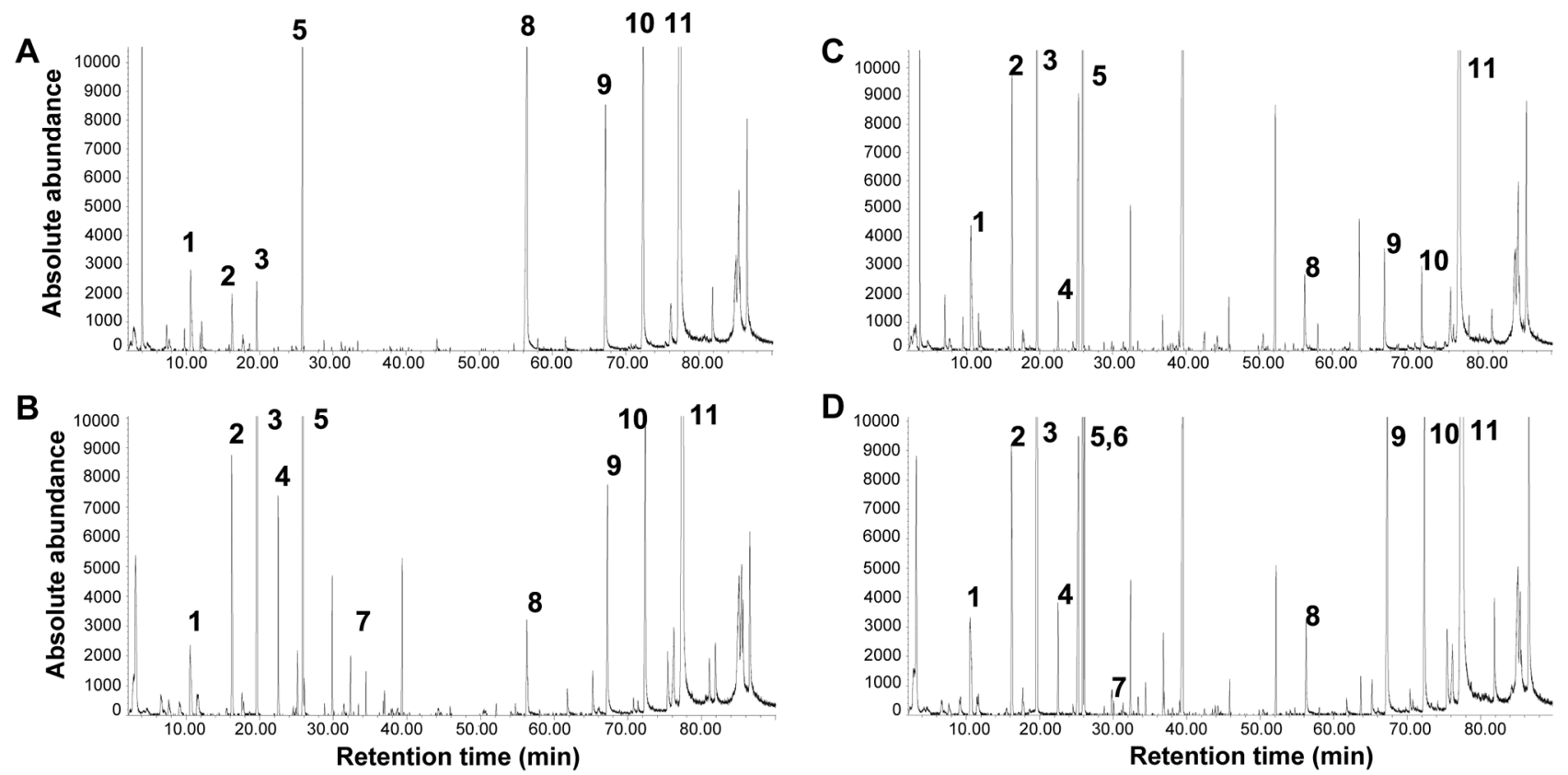

Figure 4. Representative ion $\mathrm{m} / \mathrm{z} 60$ trace with post-run selected ion chromatograms for thiazolines and carboxylic acids from preputial gland extracts of (A) Rattus fuscipes assimilis (QMJM 19152); (B) R. fuscipes coracius QMJM 19100; (C) R. leucopus cooktownensis QMJM 19131; and (D) R. leucopus leucopus QMJM 19060. Numbers above peaks identify specific compounds: (1) 2-methylthiazoline, $10.56 \mathrm{~min}$; (2) 2-ethylthiazoline, $16.04 \mathrm{~min}$; (3) 2-isopropylthiazoline, $19.59 \mathrm{~min}$; (4) 2-propylthiazoline, $22.49 \mathrm{~min}$; (5) 2-sec-butylthiazoline (SBT), $25.89 \mathrm{~min}$; (6) 2-isobutylthiazoline, $26.10 \mathrm{~min}$; (7) 2-butylthiazoline, $29.85 \mathrm{~min}$; (8) dodecanoic acid, 56.28 min; (9) tetradecanoic acid, $67.25 \mathrm{~min}$; (10) pentadecanoic acid, $72.34 \mathrm{~min}$; and (11) hexadecanoic acid, $77.50 \mathrm{~min}$.

C11 2,x-diketone B, x-tetradecen-2-one, 2-tetradecanone, 2-pentadecanone (branched), 2-pentadecanol, 7-methyl-2octanone, a heptadecen-2-one, and 2-isobutylthiazoline). One of these, 7-methyl-2-octanone, was only detected in a single sample. We also detected three compounds that were common across both $R$. leucopus subspecies but each was detected in only a single $R$. fuscipes sample and all in $R f_{c}$ (x,y-pentadecadien-2-one, 2-hexadecanone, and pentadecen2-one A). Of the eight compounds exclusive to R. leucopus, two were detected only in Rlc (7-methyl-2-octanone, a heptadecen-2-one) and one only in Rll (2-isobutylthiazoline). In contrast, we detected two geranyl-related sesquiterpene compounds at retention times $41.62 \mathrm{~min}$ and $42.27 \mathrm{~min}$ that, with the exception of a low abundance detection in a single $R l l$ sample, were exclusive to $R$. fuscipes. Sixteen compounds were detected in all subspecies except $R f a$ (4-methyl-2-6-heptanedione, C9-2-x-diketone-A (branched), C9-2-x-diketone-B, C9-2-X-diketone-B, 2-decanol, C102-X-diketone-A, undecen-2-one-B, C10-2-x-diketone-B, 2-undecanol, C11-2-x-diketone-C, 2-dodecanone, C12-2-xdiketone-A, tridecen-2-one-B, 2-tridecanol, 6-10-dimethyl3 -undecen-2-one, pentadecen-2-one-B). Among thiazoline compounds, 2-methylthiazoline, 2-ethylthiazoline, 2-isopropylthiazoline, 2-propylthiazoline, 2-butylthiazoline, and 2-secbutylthiazoline were found in all subspecies of $R$. leucopus and $R$. fuscipes. We detected 2-isobutylthiazoline in every sample of $R l l$ but did not detect it in any other subspecies. Comparative ion $\mathrm{m} / \mathrm{z} 60$ chromatograms for seven thiazolines and four carboxylic acids in representative samples of each subspecies with similar preputial gland masses (each about $100 \mathrm{mg}$ ) show substantial qualitative differences between species (Fig. 4).
Extensive quantitative differences in the composition of VOCs from preputial glands separated both species and subspecies of $R$. fuscipes and R. leucopus (Fig. 5). The two-dimensional multidimensional scaling (MDS) plot of the proportional abundance of total VOCs clearly separated species and subspecies with no overlap (Fig. 5A). The ANOSIM permutation analyses confirmed a significant effect of both species $(\mathrm{R}=0.75, \mathrm{p}<0.001)$ and subspecies $(\mathrm{R}=0.88, \mathrm{p}<0.001)$ on composition similarity compared to variation among individuals within species or subspecies (Fig. 5B). Our analysis of the subset of VOCs (thiazolines, carboxylic acids, and geranyl-related) produced similar patterns. Both species and subspecies are clearly separated in two-dimensional MDS space and outliers are less evident (Fig. 5C). However, sample points are more continuously distributed with less disjunct gaps among species and subspecies. This is reflected in the ANOSIM analyses of the subset data, which found a significant effect of both species $(\mathrm{R}=0.69, \mathrm{p}<0.001)$ and subspecies $(\mathrm{R}=0.86$, $\mathrm{p}<0.001)$ but with somewhat lower $\mathrm{R}$ values than with the total compound data (Fig. 5D). The SIMPER analyses identified 30 compounds that cumulatively explain $70 \%$ of the variation between species (Table 3). Among subspecies ten of these compounds explain a greater proportion of difference between sympatric taxa $(R f c / R l c)$ than between allopatric, conspecific subspecies $(R f c / R f a$ or $R l c / R l l)$. The SIMPER analyses found that four of the 17 compounds in our subset data contributed to differences among species or subspecies, whereas the remaining seven did not.

We also recovered a consistent pattern of increased chemical complexity in both species in sympatry. The 
Table 3. SIMPER analysis of relative contributions of chemical compounds to MDS differences between species and subspecies of Rattus fuscipes and R. leucopus. Compounds shown are those that contribute cumulatively $70 \%$ of the differences between species and are sorted by relative contribution to differences between species. Compounds with a greater relative contribution to differences between sympatric subspecies compared to allopatric, conspecific subspecies are highlighted in grey. Compounds included in our subset analyses are indicated with an asterisk. Superscript numbers indicate that a compound is depicted in Figs 3 or 4, and which figure.

\begin{tabular}{|c|c|c|c|c|}
\hline compound & $\begin{array}{l}\text { species } R \text {. leucopus } \\
\text { and } R \text {. fuscipes }\end{array}$ & $\begin{array}{l}\text { relative contribution t } \\
\text { sympatric subspecies } \\
R l c \text { and } R f c\end{array}$ & $\begin{array}{l}\text { fferences betwe } \\
\text { conspecifics } \\
R f c \text { and } R f a\end{array}$ & $\begin{array}{c}\text { conspecifics } \\
R l c \text { and } R l l\end{array}$ \\
\hline C10 2,x-Diketone B & $8.76 \%$ & $7.22 \%$ & $1.68 \%$ & $5.19 \%$ \\
\hline 2-Undecanone & $4.80 \%$ & $4.47 \%$ & $3.06 \%$ & $2.10 \%$ \\
\hline 69-98-41-81: A geranyl-related ketone & $4.52 \%$ & $2.73 \%$ & $4.88 \%$ & $1.79 \%$ \\
\hline 2-Nonanone & $3.65 \%$ & $2.91 \%$ & $1.82 \%$ & $2.74 \%$ \\
\hline Dodecanoic acid*,4 & $3.42 \%$ & $2.59 \%$ & $3.61 \%$ & $1.30 \%$ \\
\hline Undecen-2-one C & $2.97 \%$ & $5.33 \%$ & $5.95 \%$ & $2.93 \%$ \\
\hline Hexadecanoic acid*,4 & $2.66 \%$ & $2.90 \%$ & $2.34 \%$ & $2.68 \%$ \\
\hline Nonanal & $2.41 \%$ & $1.97 \%$ & $2.35 \%$ & $1.15 \%$ \\
\hline Octadecanoic acid* & $2.33 \%$ & $2.10 \%$ & $2.54 \%$ & $1.54 \%$ \\
\hline Furfuryl alcohol & $2.33 \%$ & $2.10 \%$ & $2.54 \%$ & $1.54 \%$ \\
\hline 2-Tridecanone & $2.18 \%$ & $2.79 \%$ & $0.37 \%$ & $1.25 \%$ \\
\hline Undecen-2-one A & $2.06 \%$ & $3.11 \%$ & $3.17 \%$ & $3.31 \%$ \\
\hline Oleic acid & $2.03 \%$ & $2.01 \%$ & $2.26 \%$ & $2.14 \%$ \\
\hline Geranylacetone & $1.92 \%$ & $1.09 \%$ & $2.92 \%$ & $1.09 \%$ \\
\hline 2-sec-Butylthiazoline (SBT)*,3,4 & $1.91 \%$ & $2.97 \%$ & $1.36 \%$ & $1.67 \%$ \\
\hline Geranial & $1.80 \%$ & $0.91 \%$ & $2.96 \%$ & $2.21 \%$ \\
\hline $\mathrm{x}, \mathrm{y}$-Pentadecadien-2-one & $1.75 \%$ & $2.43 \%$ & $0.21 \%$ & $1.43 \%$ \\
\hline Decanal & $1.74 \%$ & $1.47 \%$ & $2.17 \%$ & $1.49 \%$ \\
\hline $\mathrm{x}$-Dodecen-2-one & $1.71 \%$ & $1.95 \%$ & $2.96 \%$ & $2.39 \%$ \\
\hline 2-Decanone & $1.66 \%$ & $1.11 \%$ & $1.75 \%$ & $1.14 \%$ \\
\hline 2-Octenal & $1.63 \%$ & $1.44 \%$ & $1.78 \%$ & $1.23 \%$ \\
\hline 2-Undecanol & $1.59 \%$ & $2.18 \%$ & $3.27 \%$ & $1.44 \%$ \\
\hline 69-41-137-95-108: geranyl-related $(41.62 \mathrm{~m})^{*}$ & $1.57 \%$ & $2.73 \%$ & $1.92 \%$ & $2.26 \%$ \\
\hline 6,10-Dimethyl-3-undecen-2-one & $1.55 \%$ & $2.40 \%$ & $0.21 \%$ & $2.26 \%$ \\
\hline Pentadecen-2-one B & $1.53 \%$ & $1.81 \%$ & $1.40 \%$ & $3.29 \%$ \\
\hline Linoleic acid* & $1.47 \%$ & $1.96 \%$ & $1.44 \%$ & $2.30 \%$ \\
\hline Pentadecanoic acid*,4 & $1.35 \%$ & $1.43 \%$ & $0.97 \%$ & $0.89 \%$ \\
\hline Ethyl benzoate & $1.34 \%$ & $1.08 \%$ & $1.31 \%$ & $0.58 \%$ \\
\hline Tridecen-2-one B & $1.27 \%$ & $1.42 \%$ & $1.08 \%$ & $2.28 \%$ \\
\hline Acetophenone & $1.15 \%$ & $0.75 \%$ & $1.68 \%$ & $1.15 \%$ \\
\hline total & $71.04 \%$ & $71.37 \%$ & $65.96 \%$ & $58.73 \%$ \\
\hline
\end{tabular}

average number of chemical compounds $\left(\chi^{2}=27.10, \mathrm{p}\right.$ $<0.001)$ and the total abundance $\left(\chi^{2}=25.64, \mathrm{p}<0.001\right)$ of chemical compounds were both significantly different among subspecies. On average, $R l c$ males had more chemical compounds and higher total compound abundance than all other subspecies (Fig. 6A,B). Rfa males in contrast had fewer numbers of compounds and lower total compound abundance than all other subspecies. The two sympatric taxa, $R f c$ and $R l c$, both had significantly more compounds and significantly higher total compound abundance than their respective allopatric conspecific subspecies, $R f a$ (count, $\mathrm{Z}$ $=63.5, \mathrm{p}<0.001$; abundance, $\mathrm{Z}=62, \mathrm{p}<0.001$ ) and Rll (count, $Z=59.5, p=0.002$; abundance, $Z=64, p<0.001$ ).

\section{Discussion}

We identified and quantitated 78 and 69 volatile organic compounds (VOC) from preputial glands of Rattus leucopus and Rattus fuscipes, respectively. Most of these VOCs have been frequently reported in different mammalian gland secretions in different combinations and at different concentration levels. Here, we identified seven thiazoline compounds that are rarely detected in mammals but have been previously linked to sexual and social interactions in rodents or other mammals. Two of these compounds, 2-isopropylthiazoline and 2-sec-butylthiazoline (SBT), are under endocrine control and have been found in high concentrations in the urine of male house mice, Mus musculus (Schwende et al., 1986; Novotny et al., 2007), where they are involved in intermale aggression and are attractive to females (Jemiolo et al., 1985; Novotny et al., 1985; Schwende et al., 1986; reviewed in Petrulis, 2013). The chirality of 2-sec-butylthiazoline (Novotny et al., 1995; 
A

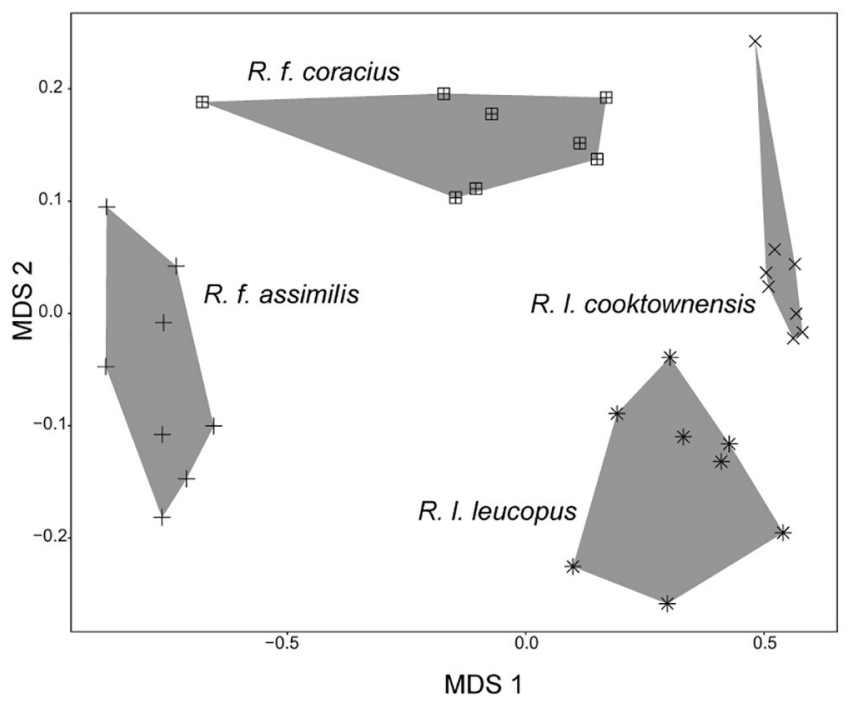

C

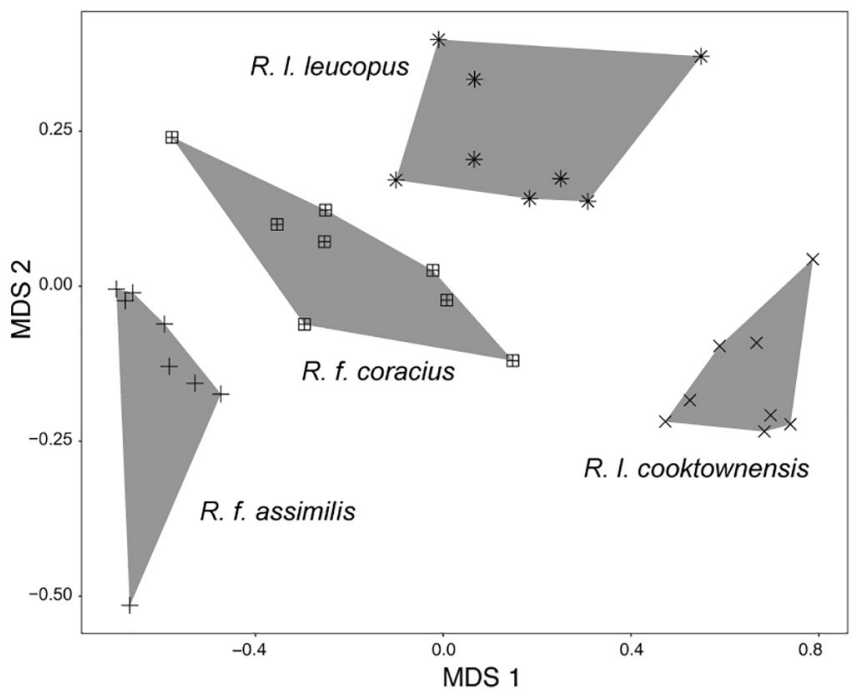

B

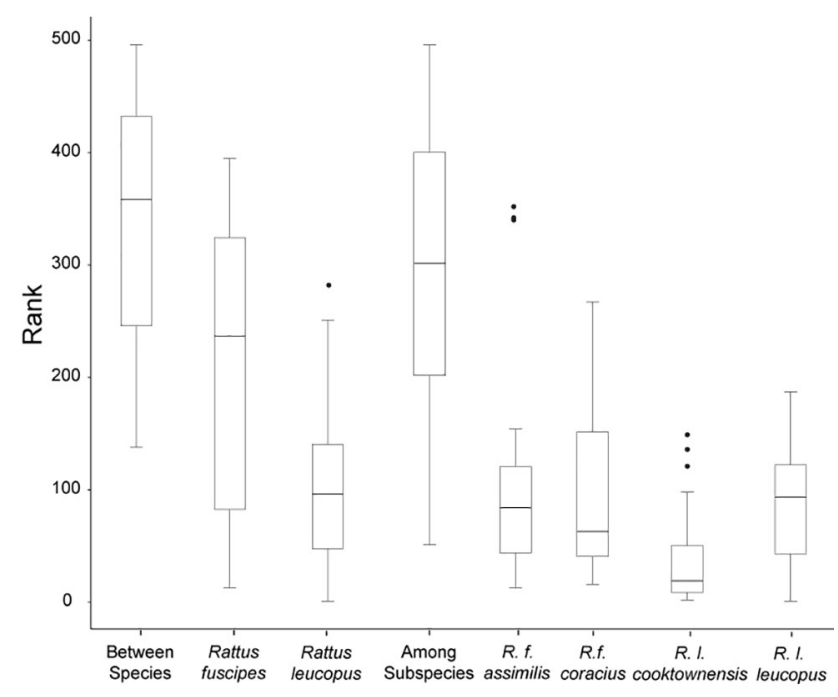

$\mathrm{D}$

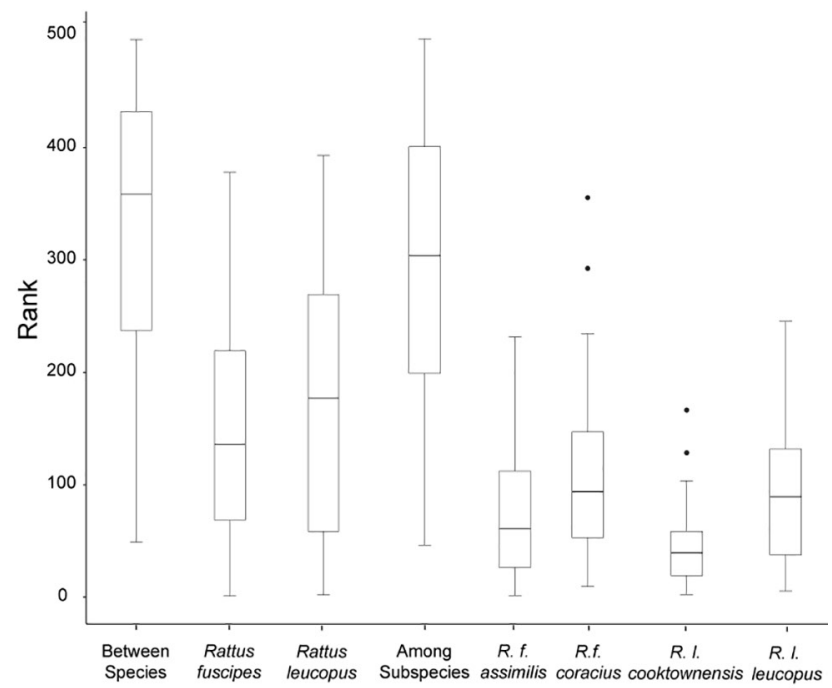

Figure 5. Variation in chemical composition of preputial glands among four subspecies of Rattus fuscipes and R. leucopus. (A) Twodimensional representation of chemical composition among individuals based on non-metric multidimensional scaling of all 80 quantitated compounds showing separation of species and subspecies (grey polygons represent grouping of samples using convex hulls). (B) Anosim plot of total compounds showing greater variation between than within species and among than within subspecies. $(C)$ Two-dimensional representation of chemical composition among individuals based on non-metric multidimensional scaling using subset of thiazoline, carboxylic acid, and sesquiterpene compounds showing separation of species and subspecies (grey polygons represent grouping of samples using convex hulls). (D) Anosim plot of subset of compounds showing greater variation between than within species and among than within subspecies.

Cavaggioni et al., 2003) may be important for efficient and specific binding to receptors. In M. musculus, racemic SBT activates vomeronasal neurons with high specificity, suggesting a primary role as a pheromone (Leinders-Zufall et al., 2000). Recently, SBT activity also has been linked to adult brain neurogenesis (Koyama et al., 2013; 2014) and induced cross-generational effects in M. musculus (Koyama et al., 2015) suggesting that this thiazoline is important in learning and the inheritance of learned behaviours, like mate choice. In M. musculus, SBT has been detected in preputial glands, urine, blood (Novotny et al., 2007) and saliva (Novotny \& Soini, 2008) suggesting that it is a systemic metabolite. The biosynthetic pathway of SBT includes the amino acids isoleucine and cysteine as precursors (Novotny et al., 1995). SBT is also known to be produced by $M$. musculus under alarm conditions and to activate neurons of the Grueneberg ganglion involved in alarm response (Brechbühl et al., 2013). SBT is structurally similar to another thiazoline, 2,3,5-trimethyl-3-thiazoline (TMT) that is found in predator feces, induces an alarm response, and also activates neurons of the Grueneberg ganglions in rodents (Vernet-Maury, 1980; review by Fendt \& Endres, 2008; Brechbühl et al., 2013). We also identified in R. fuscipes and $R$. leucopus two other thiazolines (2-isobutyl-1,3-thiazole and its 4,5-dihydro derivative) which are important in territorial marking in African antelopes (Sylvicapra grimmia and Cephalophus natalensis; Burger et al., 1988), and have not been reported previously in preputial gland secretions of rodents. The series of methylketones (2-ketones) identified in this study, including 2-heptanone, are known from 
A

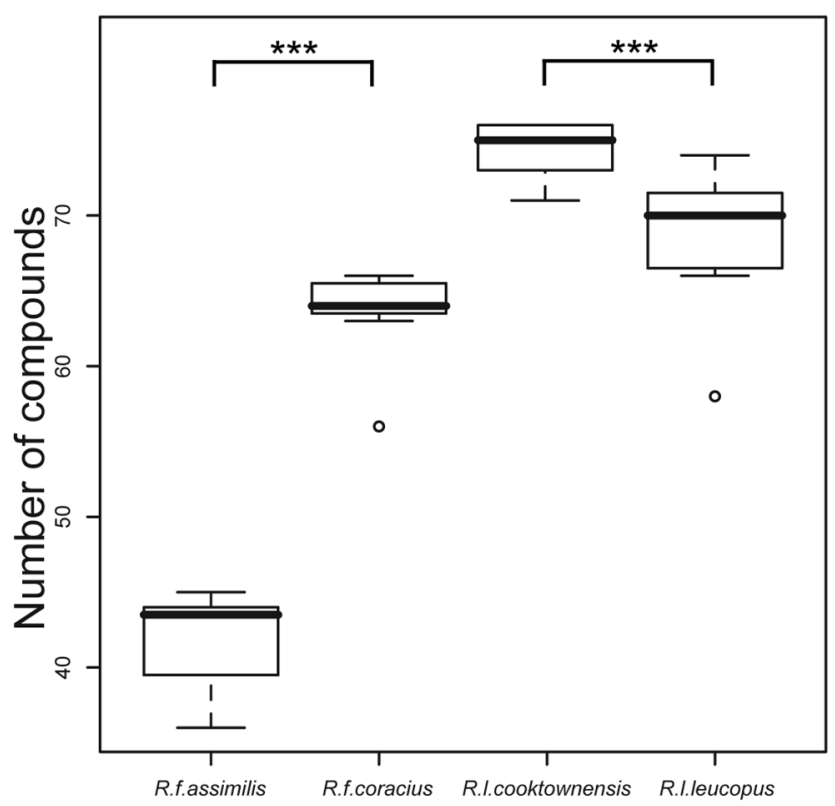

B

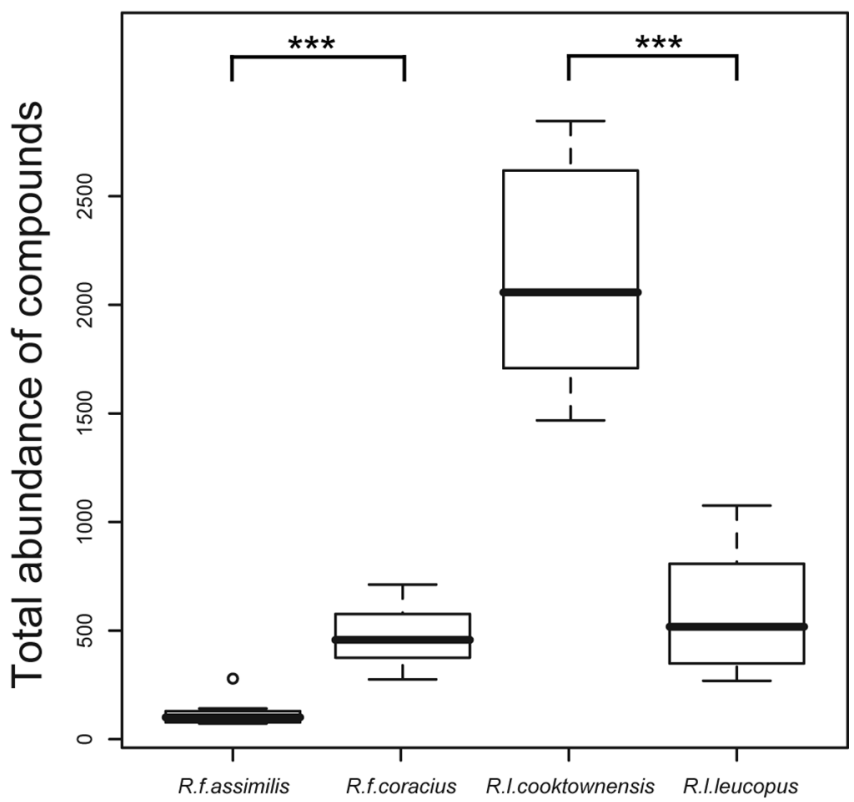

Figure 6. Variation in chemical complexity of preputial gland extracts among four subspecies of Rattus fuscipes and R. leucopus based on 80 quantitated compounds. $(A)$ Box and whisker plots of the number of chemical compounds detected in each subspecies. $(B)$ Box and whisker plots of the total abundance of chemical compounds detected in each subspecies. In both, asterisks above pairwise comparisons of conspecific subspecies indicate significantly higher values $(p<0.01)$ with a one-way Mann-Whitney U Test for all sympatric to allopatric comparisons.

urine of Mus musculus where they are involved in male effects on female estrus (Jemiolo et al., 1989) and activate specific vomeronasal organ neurons (Leinders-Zufall et al., 2000). 2-Heptanone also is known from preputial glands of Rattus norvegicus, where it is associated with social stress (Gutierrez-Garcia et al., 2006; Pohorecky et al., 2008). Notably, we did not detect farnesenes in $R$. fuscipes or $R$. leucopus. Farnesenes are sesquiterpenic compounds that originate in and are common components of rodent preputial glands, including in Mus musculus and Rattus norvegicus, where they signal social dominance (Harvey et al., 1989; Novotny et al., 1990; Pohorecky et al., 2008; Zhang et al., 2008). The partially identified geranyl-related sesquiterpenes observed in this study may have similar functions, replacing the farnesenes in $R$. fuscipes and $R$. leucopus. Two of these were detected only in $R$. fuscipes, but a third was detected in both $R$. fuscipes and $R$. leucopus.

Overall, our multidimensional analysis of chemical composition of preputial glands clearly separated Rattus fuscipes and Rattus leucopus. We found only a handful of compounds that are exclusive to each species, but the relative abundance of compounds was significantly different between species, suggesting that they are clearly differentiable by their chemical signatures. Several studies have demonstrated that the relative abundance of chemical compounds is often a reliable indicator of perceivable differences among sexes or species (Johansson \& Jones, 2007; Zhang et al., 2007, 2008a; Apps, 2013). However, our total analysis considered the entire pool of 80 VOCs quantitated by GC-MS, which might not all be perceivable or relevant to signalling in Rattus. Thus, we also analysed a subset of thiazolines, carboxylic acids, and geranyl-related sesquiterpenes that are known to be relevant in chemical signaling in mammals (Schwende et al., 1986; Zhang et al., 2008b). This subset of 17 compounds showed an equivalent pattern, with differentiation of species by their chemical composition, suggesting that odours of $R$. fuscipes and $R$. leucopus are reliably species-specific. These results are consistent with studies in other rodents, particularly in the genus $M u s$, that find clear compositional differences among species and genetic lineages (Smadja \& Butlin, 2009; Soini et al., 2009; Hurst et al., 2017).

In addition to differences among species, we uncovered substantial variation within species. First, the chemical composition among subspecies within both $R$. fuscipes and $R$. leucopus were as distinguishable as between species. One of the great challenges of taxonomy is to differentiate population-level or geographic variation (i.e. subspecies) from fixed differences among species. Indeed, we observed the highest number of fixed differences in chemical composition between subspecies of $R$. fuscipes, with 16 chemical compounds found in $R f c$ that were absent in $R f a$. If treated as taxonomic characters, these might suggest species boundaries within $R$. fuscipes that could be positively misleading. While species and subspecies are differentiable in our multidimensional analyses of chemical composition, subspecies of the same species are not clearly closer to each other in multidimensional space (Fig. 5). This is primarily because of the divergence of $R f a$ and $R f c$ from each other, whereas $R l c$ and $R l l$ are in close proximity. In addition to variation among subspecies, we also recovered considerable variation in chemical composition among individuals. This is not surprising given that chemical signals are used to identify individuals within populations and to communicate information about their gender, status, and condition (reviewed in Brennan \& Kendrick, 2006; Ferrero \& Liberles, 2009). In addition, many variables, not all chemical signals or indicators, contribute to the biochemical differences among individuals (Novotny et al., 2007, 2008; Zhang et al., 2008) 
Many factors contribute to the biochemical differences among species and individuals (Brennan \& Kendrick, 2006). A genetic basis for biochemical differences among species is evident in studies between and within species of rodents (Yamaguchi et al., 1981; Hurst et al., 2017). However, changes in species' metabolic systems also can alter their biochemical signatures (Zhang et al., 2007). Both $R$. fuscipes and $R$. leucopus are at the latitudinal limits of their respective ranges. Where they are sympatric, they co-occur at mid-elevations, with only $R$. fuscipes at the highest and only $R$. leucopus at the lowest elevations (Table S1, Rowe et al., 2020). These latitudinal and elevation differences are expected to underlie significant physiological differences between the species (Collins, 1973) that may affect their biochemical composition. In addition, ecological differences between species, including diet (Havlíček et al., 2019) and microbiotic community (Archie \& Theis, 2011; Davis et al., 2013), can change species' biochemical composition. For example, ketone-related compounds, some of which we detected exclusively in Rattus leucopus, are produced by bacteria in the uropygial gland of the songbird species Junco hyemalis (Whittaker et al., 2019).

Despite variation among subspecies and individuals there is some evidence that preputial gland chemical composition, whatever its source, is relevant to maintaining species boundaries between $R$. fuscipes and $R$. leucopus. For one, we found a consistent pattern of increased complexity of chemical composition in both species where they are sympatric with each other compared to allopatric populations. Both species have significantly more compounds and more abundance of compounds per gram of preputial gland in sympatry than their respective allopatric conspecifics (Fig. 6). We also detected a handful of compounds that are unique to $R$. leucopus $(\mathrm{n}=8)$ or $R$. fuscipes $(\mathrm{n}=2)$, and found in both subspecies of each, respectively. These species-specific compounds warrant further study to test if they have any function in intraspecific communication. The two partially identified geranyl-related sesquiterpenes in $R$. fuscipes may play an important role in social interactions, similar to farnesenes in other rodents (Gutierrez-Garcia et al., 2006; Pohorecky et al., 2008). In addition, we identified ten compounds that have the greatest contributions to chemical proportions differentiating both species (R. fuscipes and R. leucopus) and sympatric subspecies $\left(R f_{c}\right.$ and $\left.R f a\right)$ but with lower contributions to differences between allopatric conspecifics ( $R f c$ and $R f a, R l c$ and $R l l$; Table 3 ). One of these compounds, SBT, is an important social communication compound in Mus musculus, including signalling social status and for attracting females (Jemiolo et al., 1985; Novotny et al., 1985; Schwende et al., 1986). Its proportional contribution to chemical composition of the preputial gland is more than two times greater in $R$. fuscipes than in $R$. leucopus and is most different between sympatric subspecies $R f c$ and $R l c$ (Table 2). These patterns from sympatric congeneric species and from allopatric conspecific subspecies suggest that compositional differences in compounds could be used to identify and maintain species boundaries in wild Rattus.

Native Australian Rattus have one of the fastest rates of speciation reported for mammals but show limited morphological disparity among species (Rowe et al., 2011). Rattus fuscipes and Rattus leucopus occur in sympatry where they are difficult to distinguish based on external morphology (Taylor \& Calaby, 1988; Lidicker \& Laurance, 1991), but show no evidence of gene flow, which we confirmed here with allozymes. Our chemical analyses support the hypothesis that such phenotypically cryptic species are likely to rely on chemical cues for mating signals and to be distinguishable by the chemical composition of their primary secretory scent glands, the preputial glands. Rapid chemical evolution among closely related species may explain the rapid evolution of reproductive boundaries despite postzygotic reproductive compatibility (Higgie et al., 2000; Zozaya et al., 2019). However, three other species of Australian Rattus (i.e. $R$. sordidus, $R$. colletti, and $R$. villosissimus) are models for speciation via postzygotic incompatibilities caused by rapid chromosomal rearrangements (Baverstock et al., 1977, 1983). Notably, these three species have diverged from each other more recently than subspecies within $R$. fuscipes (Rowe et al., 2011). Thus, within the recent and rapid radiation of Australian Rattus, both premating and postmating mechanisms are likely to have evolved rapidly to maintain reproductive barriers among species. The chemical composition of preputial gland secretions from other Australian Rattus are entirely unknown. We would predict that chemical differences among species evolved rapidly to help them avoid incompatible matings with their closest relatives, especially in lineages that are sympatric such as $R$. fuscipes and $R$. leucopus or with strong postzygotic barriers to reproduction such as $R$. colletti, $R$. sordidus, and $R$. villosissimus. Our study highlights the rich diversity of chemical compounds in preputial glands of wild rodents and the qualitative and quantitative differences among species that warrant further examination across the tree of life.

ACKNOWLEDGEMENTS. This research was supported by the U.S. National Science Foundation, International Research Fellowship Program grant \#0502375 to KCR. The research was initiated and samples were collected while KCR was a postdoctoral fellow with Peter Baverstock at Southern Cross University, Lismore, and Craig Moritz at the University of California, Berkeley. I am deeply indebted to their support and insights into the development of this research and for all they did to foster my early career development. We are grateful to Santiago Ramirez for advice and guidance on multidimensional analysis of chemical signal information. We thank Donald Wiesler for the compound identifications and Craig Hollars for performing the preputial gland sample analyses at the Institute for Pheromone Research.

Special note from the first author: This manuscript and the enclosing volume is dedicated to the life and work of Dr Ken Aplin. Much like the chemical composition of Rattus in this study, Ken could identify and differentiate many of the most morphologically-similar vertebrates, from lizards to rats, often with the most fragmentary of material such as incisors from owl pellets. In my early career as an international postdoctoral fellow, Ken's generosity of time and knowledge allowed the success of several papers on rodents, particularly Australo-Papuan Rattus, that formed the foundation of my career in Australia. As an immigrant, blessed with a position at one of Australia's leading natural history collections, with a family raised in this country, and with a research program centred on the Australian continent, I am forever grateful to Ken for his early role in making that all possible for me. 


\section{Supplementary data}

Table S1 and Table S2 are published separately by the authors, see Rowe et al., 2020.

Table S1. Sample metadata, allozyme results and Genbank Accession numbers (Rowe et al., 2020: table S1).

https://doi.org/10.6084/m9.figshare.13058855

Table S2. Gas chromatography-mass spectrometry results for preputial gland extractions from Rattus fuscipes assimilis and $R$. f. coracius (Rfa-Rfc) and for $R$. leucopus cooktownensis and $R$. l. leucopus $(R l c-R l l)$. Compound identity verified by a standard; $\mathrm{S}$ and $\mathrm{N}$ verified by atomic emission detection; * ion 55 , ion 60 , etc. means that the peak area was integrated in the post-run single ion chromatogram (SIC); TIC = total ion chromatogram. Different molecular branching types denoted "A", "B", "C". For diketones " $\mathrm{x}$ " denotes unknown substitution site. QMJM is the Queensland Museum specimen number (Rowe et al., 2020: table S2).

https://doi.org/10.6084/m9.figshare.13058855

\section{References}

Aplin, K. P., S. G. Rhind, J. ten Have, and R. T. Chesser. 2015. Taxonomic revision of Phascogale tapoatafa (Meyer, 1793) (Dasyuridae; Marsupialia), including descriptions of two new subspecies and confirmation of P. pirata Thomas, 1904 as a 'Top End' endemic. Zootaxa 4055: 1-73.

https://doi.org/10.11646/zootaxa.4055.1.1

Apps, P. J., D. H. Gordon, H. W. Viljoen, and V. Pretorius. 1990. Chromatographic analysis of species-specific odor profiles in Mastomys natalensis and M. coucha (Rodentia: Muridae). Journal of Chemical Ecology 16: 2667-2676. https://doi.org/10.1007/BF00988077

Apps, P. J. 2013. Are mammal olfactory signals hiding right under our noses? Naturwissenschaften 100: 487-506.

https://doi.org/10.1007/s00114-013-1054-1

Archie, E. A., and K. R. Theis. 2011. Animal behaviour meets microbial ecology. Animal Behaviour 82: 425-436. https://doi.org/10.1016/j.anbehav.2011.05.029

Baverstock, P. R., C. H. S. Watts, and J. T. Hogarth. 1977. Chromosome evolution in Australian rodents. Chromosoma 61: 95-125.

https://doi.org/10.1007/BF00327396

Baltussen, E., F. David, P. Sandra, H. G. Janssen, and C. Cramers. 1999. Equilibrium sorptive enrichment on poly (dimethylsiloxane) particles for trace analysis of volatile compounds in gaseous samples. Analytical Chemistry 71: 5193-5198. https://doi.org/10.1021/ac990362t

Baverstock, P. R., M. Gelder, and A. Jahnke. 1983. Chromosome evolution in Australian Rattus-G-banding and hybrid meiosis. Genetica 60: 93-103.

https://doi.org/10.1007/BF00127495

Baverstock, P. R., M. Adams, and C. H. S. Watts. 1986. Biochemical differentiation among karyotypic forms of Australian Rattus. Genetica 71: 11-22. https://doi.org/10.1007/BF00123228

Bímová, B., T. Albrecht, M. Macholán, and J. Piálek. 2009. Signalling components of the house mouse mate recognition system. Behavioral Processes 80: 20-27. https://doi.org/10.1016/j.beproc.2008.08.004

Blows, M. W., and R. A. Allan. 1998. Levels of mate recognition within and between two Drosophila species and their hybrids. American Naturalist 152: 826-837.

https://doi.org/10.1086/286211
Brennan, P. A., and K. M. Kendrick. 2006. Mammalian social odours: attraction and individual recognition. Philosophical Transactions of the Royal Society B: Biological Sciences 361: 2061-2078.

https://doi.org/10.1098/rstb.2006.1931

Brennan, P. A., and F. Zufall. 2006. Pheromonal communication in vertebrates. Nature 444: 308-315.

https://doi.org/10.1038/nature05404

Bronson, F. H., and D. Caroom. 1971. Preputial gland of the male mouse: attractant function. Journal of Reproduction and Fertility 25: 279-282.

https://doi.org/10.1530/jrf.0.0250279

Brown, J. C., and J. D. Williams. 1972. The rodent preputial gland. Mammal Review 2: 105-147.

https://doi.org/10.1111/j.1365-2907.1972.tb00161.x

Burger, B. V., P. J. Pretorius, J. Stander, and G. R. Grierson. 1988. Mammalian pheromone studies, VII. Identification of thiazole derivatives in the preorbital gland secretions of the grey duiker, Sylvicapra grimmia, and the red duiker, Cephalophus natalensis. Zeitschrift für Naturforschung C 43: 731-736. https://doi.org/10.1515/znc-1988-9-1016

Burger, B. V. 2005. Mammalian semiochemicals. In The Chemistry of Pheromones and Other Semiochemicals II, pp. 231-278. Berlin: Springer-Verlag. https://doi.org/10.1007/b98318

Burgin, C. J., J. P. Colella, P. L. Kahn, and N. S. Upham. 2018. How many species of mammals are there? Journal of Mammalogy 99: $1-11$.

https://doi.org/10.1093/imammal/gyx147

Cavaggioni, A., C. Mucignat-Caretta, and G. Zagotto. 2003. Absolute configuration of 2-sec-butyl-4,5-dihydrothiazole in male mouse. Chemical Senses 28: 791-797. https://doi.org/10.1093/chemse/bjg073

Collins, B. G. 1973. The ecological significance of thermoregulatory responses to heat stress shown by two populations of an Australian murid, Rattus fuscipes. Comparative Biochemistry and Physiology Part A: Physiology 44: 1129-1140. https://doi.org/10.1016/0300-9629(73)90251-X

Davis, T. S., T. L. Crippen, R. W. Hofstetter, and J. K. Tomberlin. 2013. Microbial volatile emissions as insect semiochemicals. Journal of Chemical Ecology 39: 840-859. https://doi.org/10.1007/s10886-013-0306-z

Dayrat B. 2005. Towards integrative taxonomy. Biological Journal of the Linnean Society 85: 407-415. https://doi.org/10.1111/j.1095-8312.2005.00503.x

Fendt, M., and T. Endres. 2008. 2,3,5-Trimethyl-3-thiazoline (TMT), a component of fox odor-just repugnant or really fear-inducing? Neuroscience and Behavioral Reviews 32: 1259-1266.

https://doi.org/10.1016/j.neubiorev.2008.05.010

Ferrero, D. M., and S. D. Liberles. 2010. The secret codes of mammalian scents. Wiley Interdisciplinary Reviews: Systems Biology and Medicine 2: 23-33.

https://doi.org/10.1002/wsbm.39

Gutierrez-Garcia, A. G., C. M. Contreras, M. R. Mendoza-Lopez, S. Cruz-Sanchez, O. Garcia-Barradas, J. F. Rodriguez-Landa, and B. Bernal-Morales. 2006. A single session of emotional stress produces anxiety in Wistar rats. Behavioural Brain Research 167: $30-35$.

https://doi.org/10.1016/j.bbr.2005.08.011

Harvey, S., B. Jemiolo, and M. Novotny. 1989. Pattern of volatile compounds in dominant and subordinate male mouse urine. Journal of Chemical Ecology 15: 2061-2071. https://doi.org/10.1007/BF01207438

Havlíček, J., J. Fialová, and S. C. Roberts. 2019. How diet affects vertebrate semiochemistry. In Chemical Signals in Vertebrates, pp. 81-93. Springer, Cham. https://doi.org/10.1007/978-3-030-17616-7_7 
Higgie, M., S. Chenoweth, and M. Blows. 2000. Natural selection and the reinforcement of mate recognition. Nature 290: 519-521. https://doi.org/10.1126/science.290.5491.519

Hull, E. M., and J. M. Dominguez. 2007. Sexual behavior in male rodents. Hormones and Behavior 52: 45-55. https://doi.org/10.1016/j.yhbeh.2007.03.030

Hurst, J. L., R. J. Beynon, S. D. Armstrong, A. J. Davidson, S. A. Roberts, G. Gómez-Baena, C. M. Smadja, and G. Ganem. 2017. Molecular heterogeneity in major urinary proteins of Mus musculus subspecies: potential candidates involved in speciation. Scientific Reports 7: 44992. https://doi.org/10.1038/srep44992

Jackson, L. H. 1938. The preputial glands of British Muridae. Journal of Anatomy 72: 458-461.

Jemiolo, B., J. Alberts, S. Sochinski-Wiggins, S. Harvey, and M. Novotny. 1985. Behavioural and endocrine responses of female mice to synthetic analogues of volatile compounds in male urine. Animal Behaviour 33: 1114-1118. https://doi.org/10.1016/S0003-3472(85)80170-6

Jemiolo, B., F. Andreolini, T.-M. Xie, D. Wiesler, and M. Novotny. 1989. Puberty-affecting synthetic analogs of urinary chemosignals in the house mouse, Mus domesticus. Physiology and Behavior 46: 293-298. https://doi.org/10.1016/0031-9384(89)90270-9

Johansson, B. G., and T. M. Jones. 2007. The role of chemical communication in mate choice. Biological Reviews 82: 265-289. https://doi.org/10.1111/j.1469-185X.2007.00009.x

Johnston, R. E., and T. A. Robinson. 1993. Cross-species discrimination of individual odors by hamsters (Muridae: Mesocricetus auratus, Phodopus campbelli). Ethology 94: 317-325. https://doi.org/10.1111/j.1439-0310.1993.tb00448.x

Kamalakkannan, S., S. Achiraman, R. Rajkumar, K. Ramesh Kumar, and G. Archunan. 2006. Identification of sex-associated protein in the preputial gland of house rat (a new insight in rodent pest management). Acta Physiologica Hungarica 93: 145-152. https://doi.org/10.1556/APhysiol.93.2006.2-3.5

Kannan, S., and G. Archunan. 1997. Biochemical variations of male scent markers alter the attractiveness in the female rats, Rattus norvegicus. Acta Physiologica Hungarica 85: 175-181.

Kannan, S., K. Ramesh Kumar, and G. Archunan. 1998. Sex attractants in male preputial gland: chemical identification and their role in reproductive behaviour of rats. Current Science 74: 689-691.

Kotenkova E. V., and S. V. Naidenko. 1999. Discrimination of conand heterospecific odors in different taxa of the Mus musculus species group. In Advances in Chemical Signals in Vertebrates, pp 299-308. Boston: Springer.

https://doi.org/10.1007/978-1-4615-4733-4_25

Koyama, S., H. A. Soini, J. Foley, M. V. Novotny, and C. Lai. 2013. Stimulation of cell proliferation in the subventricular zone of brain by synthetic murine pheromones. Frontiers in Behavioral Neuroscience 7: 101. https://doi.org/10.3389/fnbeh.2013.00101

Koyama, S., H. A. Soini, J. Foley, M. V. Novotny, and C. Lai. 2014. Pheromone-induced cell proliferation in the murine subventricular zone. Biochemistry Society Transactions 42: 882-885. https://doi.org/10.1042/BST20140112

Koyama, S., H. A. Soini, J. Wager-Miller, W. R. Alley Jr, M. J. Pizzo, C. Rodda, J. Alberts, J. D. Crystal, J. Foley, C. Lai, and M. V. Novotny. 2015. Cross-generational impact of a male murine pheromone 2-sec-butyl-4,5-dihydrothiazole in female mice. Proceedings of Royal Society B: Biological Sciences 82: 20151074. https://doi.org/10.1098/rspb.2015.1074

Lane, R. P., J. Young, T. Newman, and B. J. Trask. 2004. Species specificity in rodent pheromone receptor repertoires. Genome Research 14: 603-608.

https://doi.org/10.1101/gr.2117004
Lassance, J. M., G. P. Svensson, M. V. Kozlov, W. Francke, and C. Löfstedt. 2019. Pheromones and barcoding delimit boundaries between cryptic species in the primitive moth genus Eriocrania (Lepidoptera: Eriocraniidae). Journal of Chemical Ecology 45: 429-439.

https://doi.org/10.1007/s10886-019-01076-2

Leinders-Zufall, T., A. P. Lane, A. C. Puche, W. Ma, M. Novotny, M. T. Shipley, and F. Zufall. 2000. Ultrasensitive and selective detection of putative pheromones by mammalian vomeronasal neurons. Nature 405: 792-796. https://doi.org/10.1038/35015572

Lidicker W. Z., and W. F. Laurance. 1990. Field identification of sympatric Rattus (Rodentia: Muridae) in north Queensland rainforest. Australian Mammalogy 13: 55-56.

Linn, C. R., and W. L. Roelofs. 1995. Pheromone communication in moths and its role in the speciation process. In Speciation and the Recognition Concept: Theory and Application, ed. D. M. Lambert and H. G. Spencer, pp. 263-300. Baltimore: The Johns Hopkins University Press.

Mallick, S. A. 1991. Observations on the preputial glands of three species of Rattus. Journal of Mammalogy 72: 198-201. https://doi.org/10.2307/1381998

Mammal Diversity Database. 2019. www.mammaldiversity.org. American Society of Mammalogists. Accessed 16 Dec 2019. https://www.mammaldiversity.org/

Moore, R. E. 1965. Olfactory discrimination as an isolating mechanism between Peromyscus maniculatus and Peromyscus polionotus. American Midland Naturalist 73: 85-100. https://doi.org/10.2307/2423324

Natynczuk, S. E., D. W. Macdonald, and F. H. Tattersall. 1995. Morphology and chemistry of brown rat, Rattus norvegicus, preputial and clitoral glands. Journal of Chemical Ecology 21: 247-260. https://doi.org/10.1007/BF02036655

Nevo, E., M. Bodmer, and G. Heth. 1976. Olfactory discrimination as an isolating mechanism in speciating mole rats. Experientia 32: $1511-1512$. https://doi.org/10.1007/BF01924423

Novotny, M., J. Jorgenson, M. Carmack, S. Wilson, E. Boyse, K. Yamazaki, M. Wilson, W. Beamer, and W. Whitten. 1980. Chemical studies of the primer mouse pheromones. In Chemical Signals_-Vertebrates and Aquatic Invertebrates, ed. D. MüllerSchwarze and R. M. Silverstein, pp. 377-390. New York: Plenum Press. https://doi.org/10.1007/978-1-4684-1027-3_23

Novotny, M., S. Harvey, B. Jemiolo, and J. Alberts. 1985. Synthetic pheromones that promote inter-male aggression in mice. Proceedings of the National Academy of Sciences USA 82: 2059-2061. https://doi.org/10.1073/pnas.82.7.2059

Novotny, M., S. Harvey, and B. Jemiolo. 1990. Chemistry of male dominance in the house mouse, Mus domesticus. Experientia 46: 109-113. https://doi.org/10.1007/BF01955433

Novotny, M. V., T. M. Xie, S. Harvey, D. Wiesler, B. Jemiolo, and M. Carmack. 1995. Stereoselectivity in mammalian chemical communication: male mouse pheromones. Experientia 51: $738-743$. https://doi.org/10.1007/BF01941272

Novotny, M. V. 2003. Pheromones, binding proteins and receptor responses in rodents. Biochemical Society Transactions 31: $117-122$. https://doi.org/10.1042/bst0310117

Novotny, M. V., H. A. Soini, S. Koyama, K. E. Bruce, and D. J. Penn. 2007. Chemical identification of MHC-influenced volatile compounds in mouse urine. I: Quantitative proportions of major chemosignals. Journal of Chemical Ecology 33: 417-434. https://doi.org/10.1007/s10886-006-9230-9 
Novotny, M. V., and H. A. Soini. 2008. Volatile mammalian chemosignals: structural and quantitative aspects. In Chemical Signals in Vertebrates 11, pp. 13-23. New York: Springer. https://doi.org/10.1007/978-0-387-73945-8_1

Novotny, M. V., and H. A. Soini. 2013. Analysis of volatile mouse pheromones by gas chromatography mass spectrometry. In Pheromone Signaling, pp. 29-45. Totowa: Humana Press. https://doi.org/10.1007/978-1-62703-619-1_3

Novotny, M.V., H. A. Soini, and Y. Mechref. 2008. Biochemical individuality reflected in chromatographic, electrophoretic and mass-spectrometric profiles. Journal of Chromatography $B$ 866: $26-47$.

https://doi.org/10.1016/j.jchromb.2007.10.007

Oksanen, F., G. Blanchet, M. Friendly, R. Kindt, P. Legendre, D. McGlinn, P. R. Minchin, R. B. O'Hara, G. L. Simpson, P. Solymos, M. Henry, H. Stevens, E. Szoecs, and H. Wagner. 2019. Vegan: Community Ecology Package. McGlinn Lab, College of Charleston.

Orsulak, P. J., and A. M. Gawienowski. 1972. Olfactory preferences for the rat preputial gland. Biology of Reproduction 6: 219-223. https://doi.org/10.1093/biolreprod/6.2.219

Padial, J. M., M. Aurélien, I. De la Riva, and M. Vences. 2010. The integrative future of taxonomy. Frontiers in Zoology 7: 1-14. https://doi.org/10.1186/1742-9994-7-16

Panhuis, T. M., R. Butlin, M. Zuk, and T. Tregenza. 2001. Sexual selection and speciation. Trends in Ecology and Evolution 16: 364-371. https://doi.org/10.1016/S0169-5347(01)02160-7

Patton J. L., D. G. Huckaby, and S. T. Álvarez-Castañeda. 2008. The evolutionary history and a systematic revision of woodrats of the Neotoma lepida group. University of California Publications in Zoology 135: 1-451.

https://doi.org/10.1525/california/9780520098664.001.0001

Petrulis, A. 2013. Chemosignals, hormones and mammalian reproduction. Hormones and Behavior 63: 723-741. https://doi.org/10.1016/j.yhbeh.2013.03.011

Phuong, M. A., M. C. Lim, D. R. Wait, K. C. Rowe, and C. Moritz. 2014. Delimiting species in the genus Otospermophilus (Rodentia: Sciuridae), using genetics, ecology, and morphology. Biological Journal of the Linnean Society 113: 1136-1151. https://doi.org/10.1111/bij.12391

Pillay N., K. Willan, J. Meester, and J. Cooke. 1995. Evidence of pre-mating isolation in two allopatric populations of the Vlei rat, Otomys irroratus. Ethology 100: 61-71.

https://doi.org/10.1111/j.1439-0310.1995.tb00315.x

Pillay, N., J. Eborall, and G. Ganem. 2006. Divergence of mate recognition in the African striped mouse (Rhabdomys). Behavioral Ecology 17: 757-764. https://doi.org/10.1093/beheco/arl014

Pohorecky, L. A., G. G. Blakley, E. W. Ma, H. A. Soini, D. Wiesler, K. E. Bruce, and M. V. Novotny. 2008. Social housing influences the composition of volatile compounds in the preputial glands of male rats. Hormones and Behavior 53: 536-545.

https://doi.org/10.1016/j.yhbeh.2007.12.006

R Core Team. 2019. R: A Language and Environment for Statistical Computing. Vienna, Austria: R Foundation for Statistical Computing.

Richardson B. J., P. R. Baverstock, and M. Adams. 1986. Allozyme Electrophoresis: A Handbook for Animal Systematics and Population Studies. Sydney: Academic Press. https://doi.org/10.1016/B978-0-12-587840-1.50009-5

Robins, J. H., M. Hingston, E. Matisoo-Smith, and H. A. Ross. 2007. Identifying Rattus species using mitochondrial DNA. Molecular Ecology Notes 7: 717-729.

https://doi.org/10.1111/j.1471-8286.2007.01752.x
Rowe, K. C., K. P. Aplin, P. R. Baverstock, and C. Moritz. 2011. Recent and rapid speciation with limited morphological disparity in the genus Rattus. Systematic Biology 60: 188-203. https://doi.org/10.1093/sysbio/syq092

Rowe, Kevin C., Helena A. Soini, Karen M. C. Rowe, Mark Adams, and Milos V. Novotny. 2020. Tables S1 S2-Rattus odorantssample metadata and chemistry data.xlsx. figshare. Dataset. https://doi.org/10.6084/m9.figshare.13058855

Schlick-Steiner, B. C., F. M. Steiner, B. Seifert, C. Stauffer, E. Christian, and R. H. Crozier. 2010. Integrative taxonomy: a multisource approach to exploring biodiversity. Annual Review of Entomology 55: 421-438.

https://doi.org/10.1146/annurev-ento-112408-085432

Schwende, F. J., D. Wiesler, J. W. Jorgenson, M. Carmack, and M. Novotny. 1986. Urinary volatile constituents of the house mouse, Mus musculus, and their endocrine dependency. Journal of Chemical Ecology 12: 277-296.

https://doi.org/10.1007/BF01045611

Shekelle, M., C. P. Groves, I. Maryanto, and R. A. Mittermeier. 2017. Two new tarsier species (Tarsiidae, Primates) and the biogeography of Sulawesi, Indonesia. Primate Conservation 31: 61-69.

Smadja, C., and G. Ganem. 2002. Subspecies recognition in the house mouse: a study of two populations from the border of a hybrid zone. Behavioral Ecology 13: 312-320.

https://doi.org/10.1093/beheco/13.3.312

Smadja, C., and G. Ganem. 2007. Divergence of odorant signals within and between the two European subspecies of the house mouse. Behavioral Ecology 19: 223-230. https://doi.org/10.1093/beheco/arm127

Smadja, C., and R. K. Butlin. 2009. On the scent of speciation: the chemosensory system and its role in premating isolation. Heredity 102: 77-97.

https://doi.org/10.1038/hdy.2008.55

Soini, H. A., D. Wiesler, R. Apfelbach, P. König, N. Y. Vasilieva, and M. V. Novotny. 2005. Comparative investigation of the volatile urinary profiles in different Phodopus hamster species. Journal of Chemical Ecology 31: 1125-1143. https://doi.org/10.1007/s10886-005-4252-2

Soini, H. A., D. Wiesler, S. Koyama, C. Féron, C. Baudoin, and M. V. Novotny. 2009. Comparison of urinary scents of two related mouse species, Mus spicilegus and Mus domesticus. Journal of Chemical Ecology 35: 580-589.

https://doi.org/10.1007/s10886-009-9628-2

Steiger, S., T. Schmitt, and H. M. Schaefer. 2011. The origin and dynamic evolution of chemical information transfer. Proceedings of the Royal Society B: Biological Sciences 278: 970-979.

https://doi.org/10.1098/rspb.2010.2285

Taylor, J. M., and J. H. Calaby. 1988. Rattus lutreolus. Mammalian Species 299: 1-7.

https://doi.org/10.2307/3503929

Theiler, G. R., and A. Blanco. 1996. Patterns of evolution in Graomys griseoflavus (Rodentia, Muridae). III. Olfactory discrimination as a premating isolation mechanism between cytotypes. Journal of Experimental Zoology 274: 346-350. https://doi.org/10.1002/jez.1402740602

Vazquez-Dominguez, E., D. Paetkau, N. Tucker, G. Hinten, and C. Moritz. 2001. Resolution of natural groups using iterative assignment tests: an example from two species of Australian native rats (Rattus). Molecular Ecology 10: 2069-2078. https://doi.org/10.1046/j.1365-294X.2001.01327.x

Vernet-Maury, E. 1980. Trimethyl-thiazoline in fox feces: a natural alarming substance for the rat. In Olfaction and Taste VII, ed. H. van der Starre, p. 407. Proceedings of the Seventh International Symposium on Olfaction and Taste and of the Fourth Congress of the European Chemoreception Research Organization, 22-25 July 1980, Noordwijkerhout, Netherlands.

Watts, C. H. S., and H. J. Aslin. 1981. The Rodents of Australia. Sydney: Angus and Robertson. 
Weber, M. G., L. Mitko, T. Eltz, and S. R. Ramírez. 2016. Macroevolution of perfume signalling in orchid bees. Ecology Letters 19: 1314-1323. https://doi.org/10.1111/ele.12667

Welsh, C. J., R. E. Moore, R. J. Bartelt, and L. L. Jackson. 1988. Novel, species-typical esters from preputial glands of sympatric voles, Microtus montanus and M. pennsylvanicus. Journal of Chemical Ecology 14: 143-158. https://doi.org/10.1007/BF01022538

Whittaker, D. J., S. P. Slowinski, J. M. Greenberg, O. Alian, A. D. Winters, M. M. Ahmad, M. J. E. Burrell, H. A. Soini, M. V. Novotny, E. D. Ketterson, and K. R. Theis. 2019. Experimental evidence that symbiotic bacteria produce chemical cues in a songbird. Journal of Experimental Biology 222: jeb202978. https://doi.org/10.1242/jeb.202978

Wilson, D. E., and D. M. Reeder, eds. 2005. Mammal Species of the World: A Taxonomic and Geographic Reference. Baltimore: The Johns Hopkins University Press.

Yamaguchi, M., K. Yamazaki, G. K. Beauchamp, J. Bard, L. Thomas, and E. A. Boyse. 1981. Distinctive urinary odors governed by the major histocompatibility locus of the mouse. Proceedings of the National Academy of Sciences USA 78: 5817-5820.

https://doi.org/10.1073/pnas.78.9.5817
Zhang, J. X., X. P. Rao, L. Sun, C. H. Zhao, and X. W. Qin. 2007. Putative chemical signals about sex, individuality, and genetic background in the preputial gland and urine of the house mouse (Mus musculus). Chemical Senses 32: 293-303. https://doi.org/10.1093/chemse/bj058

Zhang, J.-X., Y.-J. Liu, J.-H. Zhang, and L. Sun. 2008a. Dual role of preputial gland secretion and its major components in sex recognition of mice. Physiology \& Behavior 95(3): 388-394. https://doi.org/10.1016/j.physbeh.2008.07.002

Zhang, J.-X., L. Sun, J.-H. Zhang, and Z. Y. Feng. 2008b. Sex-and gonad-affecting scent compounds and 3 male pheromones in the rat. Chemical Senses 33: 611-621. https://doi.org/10.1093/chemse/bjn028

Zimmermann, Y., S. R. Ramírez, and T. Eltz. 2009. Chemical niche differentiation among sympatric species of orchid bees. Ecology 90: 2994-3008.

https://doi.org/10.1890/08-1858.1

Zozaya, S. M., M. Higgie, C. Moritz, and C. J. Hoskin. 2019. Are pheromones key to unlocking cryptic lizard diversity? American Naturalist 194: 168-182.

https://doi.org/10.1086/704059 


\title{
Expanding Population Edge Craniometrics and Genetics Provide Insights into Dispersal of Commensal Rats through Nusa Tenggara, Indonesia
}

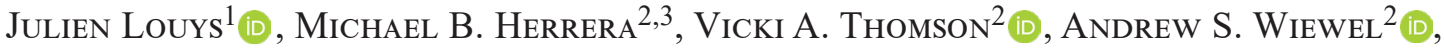 \\ Stephen C. Donnellan ${ }^{2,4}$ (D), Sue O’Connor ${ }^{5,6}$ (D), and Ken Aplin ${ }^{7} \dagger$ (iD \\ ${ }^{1}$ Australian Research Centre for Human Evolution, Griffith University, Brisbane QLD 4111, Australia \\ ${ }^{2}$ School of Biological Sciences, University of Adelaide, Adelaide SA 5005, Australia \\ ${ }^{3}$ Archaeological Studies Program, University of the Philippines, Diliman, Quezon City, 1101, Manila, Philippines \\ ${ }^{4}$ South Australian Museum, North Terrace, Adelaide SA 5000, Australia \\ ${ }^{5}$ Archaeology and Natural History, College of Asia and the Pacific, \\ The Australian National University, Acton ACT 2601, Australia \\ ${ }^{6}$ ARC Centre of Excellence for Australian Biodiversity and Heritage, \\ The Australian National University, Canberra, ACT 2601, Australia \\ ${ }^{7}$ Australian Museum Research Associate, 1 William Street, Sydney NSW 2010, Australia
}

\begin{abstract}
The Nusa Tenggara island chain consists of an archipelago that runs roughly east-west in eastern Indonesia. As part of Wallacea, it has never been connected to any continental landmass, and has been subject to a variety of biological invasions that have populated the islands. Here, we examine the craniometric and molecular genetic records of several species of Rattus sensu lato in the island chain. We use the predictions of expanding population edge phenotypic selection in an effort to understand the movement of Rattus rattus and Rattus exulans through the archipelago. We also examine the mitochondrial haplotype networks of $R$. argentiventer, $R$. exulans, and the $R$. rattus Complex $(\mathrm{RrC})$ and microsatellite allele frequency clustering patterns for the $\mathrm{RrC}$, to examine relationships within and between Nusa Tenggara populations, and those of Asia and the Pacific where relevant for each taxon. In the RrC LIV and $\mathrm{RrC}$ LII haplotype networks, 20 haplotypes with seven from Nusa Tenggara were observed for $\mathrm{RrC}$ LIV, and 100 haplotypes with seven from Nusa Tenggara observed for RrC LII. The top performing $\operatorname{RrC}$ craniometric model had a negative association between size and distance from the easternmost point of the samples from Nusa Tenggara, consistent with increasing size moving west to east. The cytochrome $b$ network for the $R$. exulans sequences comprised 14 haplotypes, with three observed from mainland Southeast Asia, one shared with Nusa Tenggara and regions further east, and another haplotype observed in Nusa Tenggara and in the Pacific. The $R$. exulans craniometric model selection produced four equally well performing models, with no migration scenario preferred. Finally, the haplotype network of $R$. argentiventer comprised 10 haplotypes, with six observed in Nusa Tenggara, including a relatively early cluster from the east of the archipelago. Our results are compatible with a polyphasic and polydirectional invasion of Nusa Tenggara by Rattus, likely beginning with $\mathrm{RrC}$ from the west to the east, an expansion of $R$. exulans from Flores, seemingly in no preferred overall direction, and finally the invasion of $R$. argentiventer from the east to the west. We find some support for the Dong Son drum maritime exchange network contributing to the distribution of the latter species.
\end{abstract}




\section{Introduction}

The expansion of species outside of their initial core range is associated with phenotypic and genotypic changes resulting from the dynamics of expansion (Chuang \& Peterson, 2016). Differences largely arise between edge and core demes (subpopulations) as a result of isolation, changing environmental gradients, and physiological, metabolic, and behavioural demands of dispersal (Chuang $\&$ Peterson, 2016). The most commonly observed dispersalpromoting phenotypic trait is related to larger size or better body condition (Chuang \& Peterson, 2016). Thus, a prediction from expanding populations edge studies is that individuals at the invasion front of a species will be bigger and better conditioned than those at the core. The classic example of this phenomenon is the cane toad in Australia, where individuals at the leading edge of the invasion are longer legged than at the core, thereby promoting further and faster dispersal through time (Phillips et al., 2006, 2007). Genetically, the most commonly expected result of dispersal into islands are reduced gene flow from core to the invasion front, resulting in the evolution of unique genetic markers in relatively isolated island populations. Arguably, one of the most important biological expansion events, at least from a human perspective (and other than our own), involved the genus Rattus.

Rattus is one of the most speciose mammalian genera, and one of the most impactful on human health and subsistence (Aplin et al., 2003). Despite this, its biogeographic and evolutionary history remains poorly known. While the general geographic origin of several of the most important commensal taxa have been relatively well established (Aplin et al., 2011; Thomson et al., 2014), how and in which directions they spread from their core areas, and how they interacted with each other is still poorly resolved. The Neolithic introduction of rodents through Southeast Asia and into the Pacific are probably the first and most wellstudied of these commensal invasions. They are thought to be part of an agriculturalist "package" that also included the introduction of chickens and pigs, the widespread adoption of agricultural practices, and involved species such as the Pacific Rat Rattus exulans and the Black Rat $R$. rattus (Thomson et al., 2018; Louys et al., 2018a; Leppard, 2018). The importation of pest species throughout the Asia-Pacific likely produced significant impacts on human subsistence and populations, particularly through raiding of crop stores, by acting as disease vectors, and destroying island ecosystems (Aplin et al., 2003, 2011; Leppard, 2018).

The islands of Nusa Tenggara provide an excellent region to study colonization and diversification of commensal rodents. The Nusa Tenggara archipelago represents a series of oceanic islands running in a roughly east-west orientation in the Wallacean region of island Southeast Asia (ISEA). Emerging probably sometime in the Pliocene, fauna dispersed to these islands in a series of colonization events, the most recent of which was tied to deliberate or unintentional introductions of commensals by humans. Invasions of rodents into the island chain continued into the Metal Age and possibly well into historic times (St Pierre, 2011). These islands are the likely point of origin for the Pacific Rat Rattus exulans (Thomson et al., 2014) and have been linked with each other through maritime trade networks since at least the Pleistocene (Reepmeyer et al., 2016), and with mainland Southeast Asia (MSEA) since the Neolithic (Bellwood, 2007). Several important commensal species are currently found on the islands; besides $R$. exulans they include the Black Rat $R$. rattus and the Ricefield Rat $R$. argentiventer.

Ecological studies of shifting population ranges have often studied biological invasions (Chuang \& Peterson, 2016). The introduction and dispersal of commensal rodents through Nusa Tenggara, even if anthropologically facilitated, might share ecological characteristics with these. We approached the question of movement into and through Nusa Tenggara through two independent but complementary approaches.

Firstly, we examined molecular genetic data of three rodent species belonging to Rattus sensu lato. The taxonomic identity of some commensal rodent taxa is beset with issues of unresolved taxonomic resolution in the natural range. In some cases these issues are amplified in the introduced range, due to multiple introductions from diverse source populations, and in some cases further confounded by subsequent introgression in the introduced range. The Rattus rattus Complex ( $\mathrm{RrC}$ hereafter) is one group where all of the above factors are present in several parts of the natural and introduced ranges (Aplin et al., 2011; Pages et al., 2013; Lack et al., 2012). In particular, mitochondrial lineages $\mathrm{RrC}$ LII and LIV co-occur in Indonesia and likely have dispersed there from MSEA and the Philippines (Aplin et al., 2011). While these lineages freely interbreed in Indochina (Pages et al., 2013) and show introgressive hybridization in the Philippines (Lack et al., 2012), their status as separate evolutionary entities in Indonesia is not known and could critically affect the interpretation of dispersal history in the archipelago. Thus, part of our study presents novel molecular genetic data informing on the identity of the $\mathrm{RrC}$ in Indonesia. Alongside $\mathrm{RrC}$, we also examine molecular genetic data on $R$. exulans and $R$. argentiventer.

Secondly, we examine the craniometrics of three species of Rattus to examine what changes, if any, can be observed between populations on different islands. We examine whether there is a trend in increasing size from the core to the population edge of a species in the commensal $R$. rattus and $R$. exulans, which may owe part or all their expansion to anthropogenic influence. Such a trend, if present, might relate to the selection effects of expansion. The two taxa are shared in common with the genetic analyses. We also included one wild taxon, $R$. hainaldi from Flores. Rattus hainaldi, although currently classified in Rattus, is phylogenetically associated with a group that includes Tarsomys, Limnomys, Diplothrix, Nesokia, and Bandicota, and revision of Rattus may necessitate the removal of hainaldi from this genus (Thomson et al., 2018). Nevertheless, it is important as an endemic rodent from Flores that, despite being found alongside $R$. exulans, has remained wild and has not dispersed beyond its island (Kitchener et al., 1991; Veatch et al., 2019). It thus provides an important indicator of cranial metric variation in a restricted island endemic. Finally, we discuss our results with a consideration of the archaeological record of maritime trade and human dispersal between Nusa Tenggara and the broader Asia-Pacific region. 


\section{Materials and methods}

\section{Mitochondrial DNA sequencing and analysis}

Building haplotype networks across an island chain and including extralimital samples can provide important insights into directions of gene flow, as unique haplogroups are traced through successive islands (or geographic regions). Such analyses have been used to inform on the movements of $\mathrm{RrC}$ through Southeast Asia (Aplin et al., 2011) and the likely direction of invasion for $\mathrm{RrC}$ into the Talaud islands (Louys et al., 2018a). The specimens used in this study included museum tissues and remains collected from surface finds (Table S1, see Louys et al., 2020). Genomic DNA was extracted from museum tissue samples using a salting-out method (Nicholls \& Austin, 2005). Surface remains were extracted in specialist ancient DNA (aDNA) laboratories of the Australian Centre for Ancient DNA (ACAD) at the University of Adelaide. DNA was extracted from each rodent incisor or bone element using the DNeasy Kit (Qiagen) with modification following the procedure described in Thomson et al. (2014).

A total of 380 samples were examined for cytochrome $b($ cyt $b)$ sequences across four taxa: $R$. argentiventer $(\mathrm{n}=$ 39), R. exulans $(\mathrm{n}=20)$; $\operatorname{RrC} \mathrm{LIV}(\mathrm{n}=49)$; and $\mathrm{RrC}$ LII ( =272). All other sequences were sourced from the literature (Table S1, see Louys et al., 2020). The PCR primers used to generate the mitochondrial $c y t b$ sequences are listed in Table S1, see Louys et al., 2020 (ACAD835, ACAD 1936, ACAD1937, and ACAD1877). PCR reactions were set up in $25 \mu \mathrm{L}$ volumes containing a final concentration of $1 \times \mathrm{HiFi}$ PCR buffer (Platinum Invitrogen), $200 \mu \mathrm{M}$ each dNTP, $3 \mathrm{mM}$ $\mathrm{MgSO} 4,1 \mathrm{mg} / \mathrm{mL}^{-1}$ Rabbit Serum Albumin (Sigma), $1 \mu \mathrm{M}$ of each primer, 1 unit of Platinum TaqHiFi DNA polymerase (Invitrogen), and $2 \mu \mathrm{l}$ of template DNA. Thermocycling included initial denaturation and enzyme activation at $94^{\circ} \mathrm{C}$ for 2 minutes, then 55 cycles of denaturing at $94^{\circ} \mathrm{C}$ for 30 seconds, primer annealing at $55^{\circ} \mathrm{C}$ for 30 seconds and extension at $68^{\circ} \mathrm{C}$ for 30 seconds, and a final extension $68^{\circ} \mathrm{C}$ for 10 minutes. Amplifications of extractions and PCR blank controls were also performed in all experiments to monitor for contamination. Amplicons were separated by electrophoresis on a $2.5 \%$ agarose gel. PCR clean-up, Sanger sequencing and capillary electrophoresis were conducted at the Australian Genome Research Facility Ltd (Australia).

The forward and reverse sequence chromatograms were aligned, visually inspected and edited using Geneious v. 7.1.2. (Biomatters) to obtain a consensus sequence. The newly generated sequences were aligned with published sequences (Table S1, see Louys et al., 2020) using MUSCLE alignment algorithm (Edgar, 2004) to form the cyt $b$ dataset. The evolutionary relationships among the haplotypes were characterized using median-joining (MJ) network analysis Popart v. 1.7.1 (Leigh \& Bryant, 2015).

\section{Microsatellite genotyping and analysis}

Prospective RrC microsatellite loci were identified by shotgun sequencing of two samples (RrC I-ABTC050177; RrC III-ABTC109244) on the GS-FLX platform (454 Life Sciences/Roche FLX) at AGRF-SA, following the protocol in Gardner et al. (2011). The resulting sequences were screened for microsatellite repeats using MSATCOMMANDER v. 1.0.8 (Faircloth, 2008) and checked for unique flanking sequences using MICROFAMILY (Meglécz, 2007), resulting in 395 potentially useful microsatellite repeats (194 dinucleotide, 79 trinucleotide, 109 tetranucleotide, 8 pentanucleotide, and 5 hexanucleotide). From this list, 30 microsatellite loci (1 dinucleotide, 7 trinucleotide, 21 tetranucleotide, and 1 hexanucleotide) were selected for primer development.

Primer3 (Rozen \& Skaletsky, 2000) was used to design microsatellite primers with Multiplex Ready Technology (MRT) tag sequences to facilitate flexible fluorescent labelling (FAM, NED, PET, and VIC) and post-PCR multiplexing (Hayden et al., 2008). These primers were evaluated to determine the reliability of PCR amplification and presence of polymorphism across multiple RrC lineages, and to determine the optimum primer concentration (10, 20,40 or $60 \mathrm{nM}$ ) for each primer pair, resulting in a final selection of 12 microsatellite loci (Table 1) that were pooled into two multiplexes.

Our 12 microsatellite loci were PCR amplified for 174 natural and introduced range $\mathrm{RrC}$ lineage II $(\mathrm{n}=79)$ and IV $(\mathrm{n}=95)$ samples in a volume of $12 \mu \mathrm{L}$ containing $2.4 \mu \mathrm{L}$ $5 \mathrm{X}$ MRT buffer $\left(1.2 \mu \mathrm{L}\right.$ Immolase buffer, $0.36 \mu \mathrm{L} \mathrm{MgCl}_{2}$ (50 mM), $0.096 \mu \mathrm{L} \mathrm{dNTPs}(100 \mathrm{mM}), 0.06 \mu \mathrm{L} \mathrm{BSA}(100 \mathrm{X})$, and $\left.0.684 \mu \mathrm{L} \mathrm{ddH}_{2} 0\right), 0.06 \mu \mathrm{L}$ Immolase $(5 \mathrm{U} / \mu \mathrm{L}), 0.09 \mu \mathrm{L}$ fluorescent-labelled forward tag $(10 \mu \mathrm{M}), 0.09 \mu \mathrm{L}$ unlabelled reverse tag $(10 \mu \mathrm{M}), 0.03-0.06 \mu \mathrm{L}$ of the locus-specific primer pair $(4 \mu \mathrm{M}), 7.3-7.33 \mu \mathrm{LddH}_{2} \mathrm{O}$, and $2 \mu \mathrm{L}$ template DNA (diluted to introduce 10-20 ng DNA) (Table 1). The MRT PCR thermocycling profile consisted of an initial denaturation step of $95^{\circ} \mathrm{C}$ for $10 \mathrm{~min}, 5$ cycles of denaturation at $92^{\circ} \mathrm{C}$ for $60 \mathrm{~s}$, annealing at $50^{\circ} \mathrm{C}$ for $90 \mathrm{~s}$, and extension at $72^{\circ} \mathrm{C}$ for $60 \mathrm{~s}, 20$ cycles of denaturation at $92^{\circ} \mathrm{C}$ for $30 \mathrm{~s}$, annealing at $63^{\circ} \mathrm{C}$ for $90 \mathrm{~s}$, and extension at $72^{\circ} \mathrm{C}$ for $60 \mathrm{~s}$, 40 cycles of denaturation at $92^{\circ} \mathrm{C}$ for $15 \mathrm{~s}$, annealing at $54^{\circ} \mathrm{C}$ for $60 \mathrm{~s}$, and extension at $72^{\circ} \mathrm{C}$ for $60 \mathrm{~s}$, and a final extension at $72^{\circ} \mathrm{C}$ for $10 \mathrm{~min}$. Two control samples were included in every 96-well plate to ensure consistent amplification between runs, and eight samples were repeated in reverse order within each plate to identify plate orientation errors and to calculate genotyping error rate.

Fluorescent-labelled PCR products from each multiplex were pooled by DNA sample with a ratio of 3 FAM: 2 NED: 4 PET: 2.25 VIC to account for differences in relative fluorescence of each dye, cleaned using MultiScreen ${ }^{\circledR}$ PCR cleanup filter plates (Millipore Corporation, Billerica, MA, USA), and analyzed using an ABI 3730xl DNA Analyzer (Applied Biosystems) at AGRF-SA. Microsatellite alleles were visualized and manually scored using GeneMapper v. 3.7 (Applied Biosystems), with a subset of genotypes confirmed by an independent party to minimize bias. One microsatellite performed poorly (amplification for c. $50 \%$ of samples) and was excluded from further analyses.

Microsatellite loci were tested for deviations from Hardy-Weinberg equilibrium and linkage disequilibrium using GENEPOP v. 4.1 (Rousset, 2008), with Bonferroni correction for multiple comparisons. Diversity statistics, including allelic richness (A), observed and expected heterozygosity $\left(\mathrm{H}_{\mathrm{O}}\right.$ and $\mathrm{H}_{\mathrm{E}}$, respectively), and inbreeding coefficient $\left(\mathrm{F}_{\mathrm{IS}}\right)$, were calculated in GenAlEx v. 6.5 (Peakall $\&$ Smouse, 2012). We investigated broad-scale genetic structure in our RrC lineage II and IV sample by conducting a principal coordinates analysis (PCoA) in GenAlEx v. 6.5 (Peakall \& Smouse, 2012). Finally, we used the Bayesian clustering approach implemented in STRUCTURE v. 2.3.4 
Table 1. Microsatellite locus name, primer sequences, fluorescent label, repeat motif, and amplicon size at primer testing.

\begin{tabular}{|c|c|c|c|c|}
\hline locus & primer sequence $\left(5^{\prime}-3^{\prime}\right)$ & label & repeat motif & size range $(b p)$ \\
\hline \multirow{2}{*}{ Rrat6 } & F: CACCAGTGTCCAATAACTATCCG & & & \\
\hline & R: TGAATTGCTATAAGTGGGTAAAAGA & FAM & $(\mathrm{AGAT})_{14}$ & 107 \\
\hline \multirow[t]{2}{*}{ Rrat8 } & F: AGGGCTTTTGTGGGTTTGTT & & & \\
\hline & R: GGACAACAGGAGGCCTTGTC & NED & $(\mathrm{AGAT})_{15}$ & 111 \\
\hline \multirow[t]{2}{*}{ Rrat11 } & F: CCAATGCCCAGCAAGATTTA & & & \\
\hline & R: ACATGGCTCAAGGCATACAT & VIC & $(\mathrm{ACAT})_{13}$ & 128 \\
\hline \multirow[t]{2}{*}{ Rrat15 } & F: TCCTTAGGTGTCAACAGCACTC & & & \\
\hline & R: TCTGCACTCTTGACTCCAACA & VIC & $(\mathrm{AGAT})_{13}$ & 152 \\
\hline \multirow[t]{2}{*}{ Rrat17 } & F: GAAGCCACATTTACCCCTGA & & & \\
\hline & R: GTTGCCTAGTTTGCCTTGGA & PET & $(\mathrm{AAAT})_{14}$ & 167 \\
\hline \multirow[t]{2}{*}{ Rrat21 } & F: CCAGCACTTGGGAGGTAAAA & & & \\
\hline & R: TGTTCAAACCAGCCTTCTCA & NED & $(\mathrm{AAGC})_{12}$ & 199 \\
\hline \multirow[t]{2}{*}{ Rrat24 } & F: GCGCCCTGTGTCTTACTGTT & & & \\
\hline & R: CCAGAAGCTAATATAGAAATGTGGC & FAM & $(\mathrm{AAAT})_{11}$ & 218 \\
\hline \multirow[t]{2}{*}{ Rrat25 } & F: TGTGCATGGAGTGCCTTCTA & & & \\
\hline & R: TTGTCAAGGTTAGTGACTACTTTCC & VIC & $(\mathrm{ACT})_{17}$ & 234 \\
\hline \multirow[t]{2}{*}{ Rrat26 } & F: TTTAACAGCGGAGGAGCAGT & & & \\
\hline & R: ACTAACTGCAATTCGTGGGG & PET & $(\mathrm{AAGC})_{11}$ & 234 \\
\hline \multirow[t]{2}{*}{ Rrat27 } & F: AGTCAGAAGCAAACCAGCGT & & & \\
\hline & R: GAAACCAATTCCAAAACACTCA & NED & $(\mathrm{AAAT})_{12}$ & 261 \\
\hline \multirow[t]{2}{*}{ Rrat28 } & F: GAGCTGCTGTCTTTCCATCC & & & \\
\hline & R: CCCATGAAATCTCAAAGGTATG & PET & $(\mathrm{AAC})_{15}$ & 281 \\
\hline \multirow[t]{2}{*}{ Rrat30 } & F: CCCAAGAACTGAGCAAGAGG & & & \\
\hline & R: TGAATGGCCTATAACCACAACTT & FAM & $(\mathrm{AGAT})_{9}$ & 316 \\
\hline
\end{tabular}

(Pritchard et al., 2000) to infer the optimal number of genetic clusters $(\mathrm{K})$ in our dataset and to assign individuals to those clusters. STRUCTURE simulations were parameterized to run 20 independent analyses of 1 million generations following a 500,000 generation burn-in for $\mathrm{K}=1$ to $\mathrm{K}=9$ (the total number of countries in our dataset) under the admixture model with correlated allele frequencies among populations. Convergence was determined by consistency of likelihood values and cluster assignment between duplicate runs. The optimal number of clusters was determined by calculating the mean $\ln \operatorname{Pr}(\mathrm{X} \mid \mathrm{K})$ and $\Delta \mathrm{K}$ values (Evanno et al., 2005) using Structure Harvester (Earl \& vonHoldt, 2012). STRUCTURE output for the optimal K were combined and summarized using 1000 random repeats of the greedy search algorithm in CLUMPP v. 1.1.2 (Jakobsson \& Rosenburg, 2007) on the CLUMPAK server (Kopelman et al., 2015).

\section{Craniometrics}

A total of 148 specimens across three taxa- $\operatorname{RrC}(57), R$. exulans (61), and $R$. hainaldi (30)—were examined in the craniometric analysis (Table S2, see Louys et al., 2020). We excluded juveniles and very old individuals, as well as those lacking locality information from our sampling. Thirty-eight cranial and mandibular measurements were taken to the nearest $0.01 \mathrm{~mm}$ using digital callipers (Mitsutoyo Co.) by the first author following Reutter et al. (1999) (basal length (BLL), basilar length (BRL), length of the bullae (BULL), condylobasal length (CBL), condylobasilar length (CBRL), length of the diastema (DA), length of the incisive foramina (FOR), length of the face (GES), length of the braincase (HKL), thickness of the incisor (ID), interorbital breadth (IOB), nasal length (NAS), nasal breadth (NASB), occipital breadth (OCB), occipital length (OCN), length of the upper molar row, alveoli (OZRA), length of the upper molar row, crown (OZRK), palatal length (PL), palatine breadth (PRL), rostral breadth (RB), rostral height (RH), breadth of braincase (SKB), height of braincase with bullae (SKH), and zygomatic breadth (ZYG)) and supplemented with further measurements of the crania (zygomatic plate (ZP), foramen magnum width (FMW), foramen magnum height (FMH), supraoccipital width at the occipital condyles (OCW), and supraoccipital height $(\mathrm{BH})$ ); the mandible (mandibular length (ML), mandibular depth (MD), mandibular toothrow length (crown) (MCL), mandibular alveoli length (MAL), thickness lower incisor (LID), minimum corpus length (CL), maximum mandibular height (MDL), mandibular diastema length (LAL), and mandibular depth at $\mathrm{M}_{1}$ (MID)). These are illustrated on Fig. 1.

Intra-observer error was determined by randomly selecting five skulls for each species and remeasuring them at least a day after first measurement. For each variable, the original and the re-measurement was compared using students t-tests, with the variable rejected if $p$ (same mean) $<0.95$. Outliers were determined by calculating the $25-75$ percent quartile length for each variable for each species, with values more than 3 times this length coded as missing values. In order to summarize the variables and to extract size for further analysis, we subjected the remaining metric variables to a Principal Components Analysis (PCA), using the variance-covariance matrix and disregarding species groupings. PCA was run in PAST v. 2.17c (Hammer et al., 2001). Missing values were treated via pairwise deletion. In PCA application to metric measurements, the first principal component is largely driven by size and can be considered a reasonable body-size proxy. 

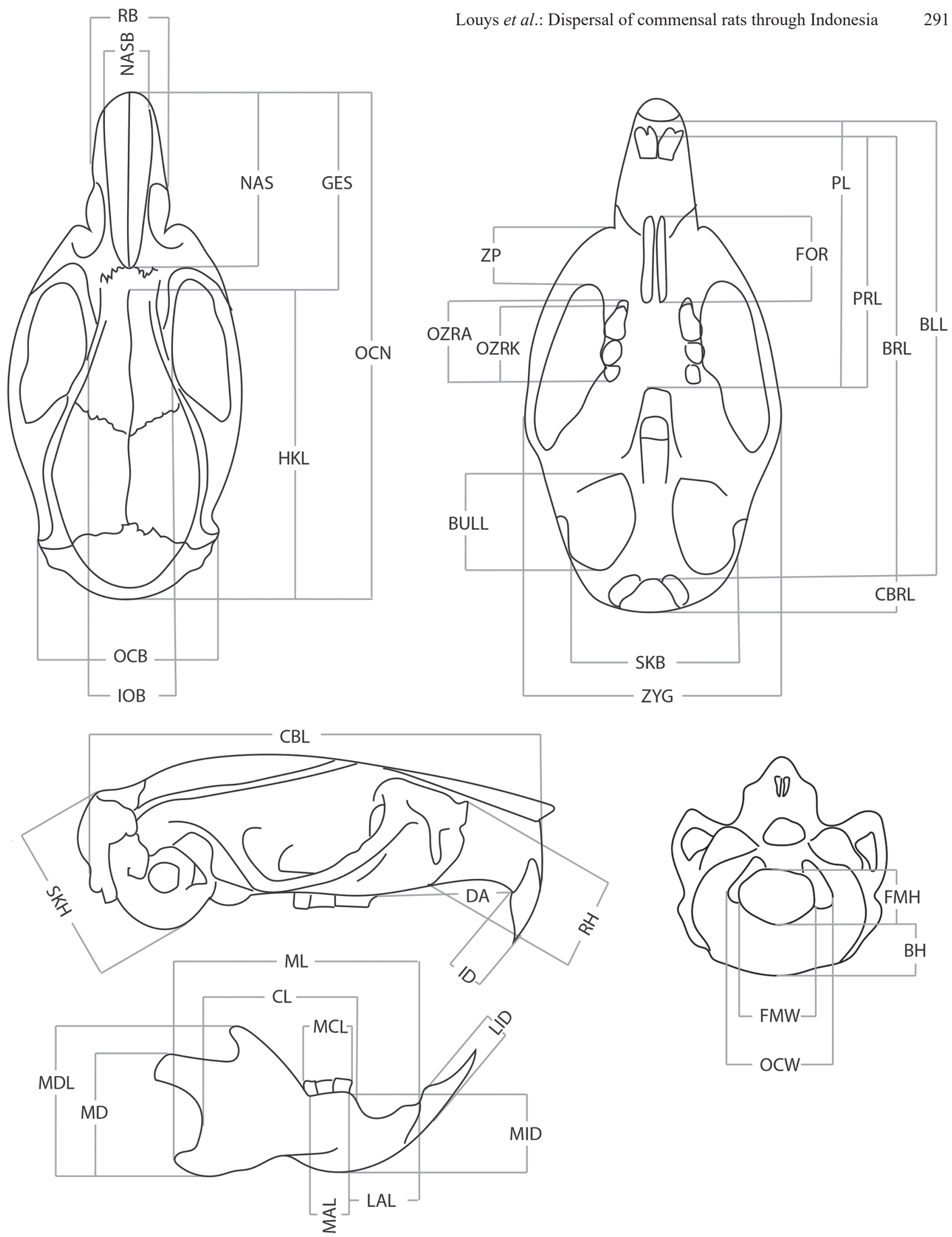

Figure 1. Cranial measurements taken for each specimen: supraoccipital height (BH), basal length (BLL), basilar length (BRL), length of the bullae (BULL), condylobasal length (CBL), condylobasilar length (CBRL), minimum corpus length (CL), length of the diastema (DA), foramen magnum height (FMH), foramen magnum width (FMW), length of the incisive foramina (FOR), length of the face (GES), length of the braincase (HKL), thickness of the incisor (ID), interorbital breadth (IOB), mandibular diastema length (LAL), thickness lower incisor (LID), mandibular alveoli length (MAL), mandibular toothrow length (crown) (MCL), mandibular depth (MD), maximum mandibular height (MDL), mandibular depth at $\mathrm{M}_{1}$ (MID), mandibular length (ML), nasal length (NAS), nasal breadth (NASB), occipital breadth $(\mathrm{OCB})$, occipital length $(\mathrm{OCN})$, supraoccipital width at the occipital condyles (OCW), length of the upper molar row (alveoli) (OZRA), length of the upper molar row (crown) (OZRK), palatal length (PL), palatine breadth (PRL), rostral breadth (RB), rostral height $(\mathrm{RH})$, breadth of braincase (SKB), height of braincase with bullae (SKH), zygomatic plate (ZP), zygomatic breadth (ZYG). 


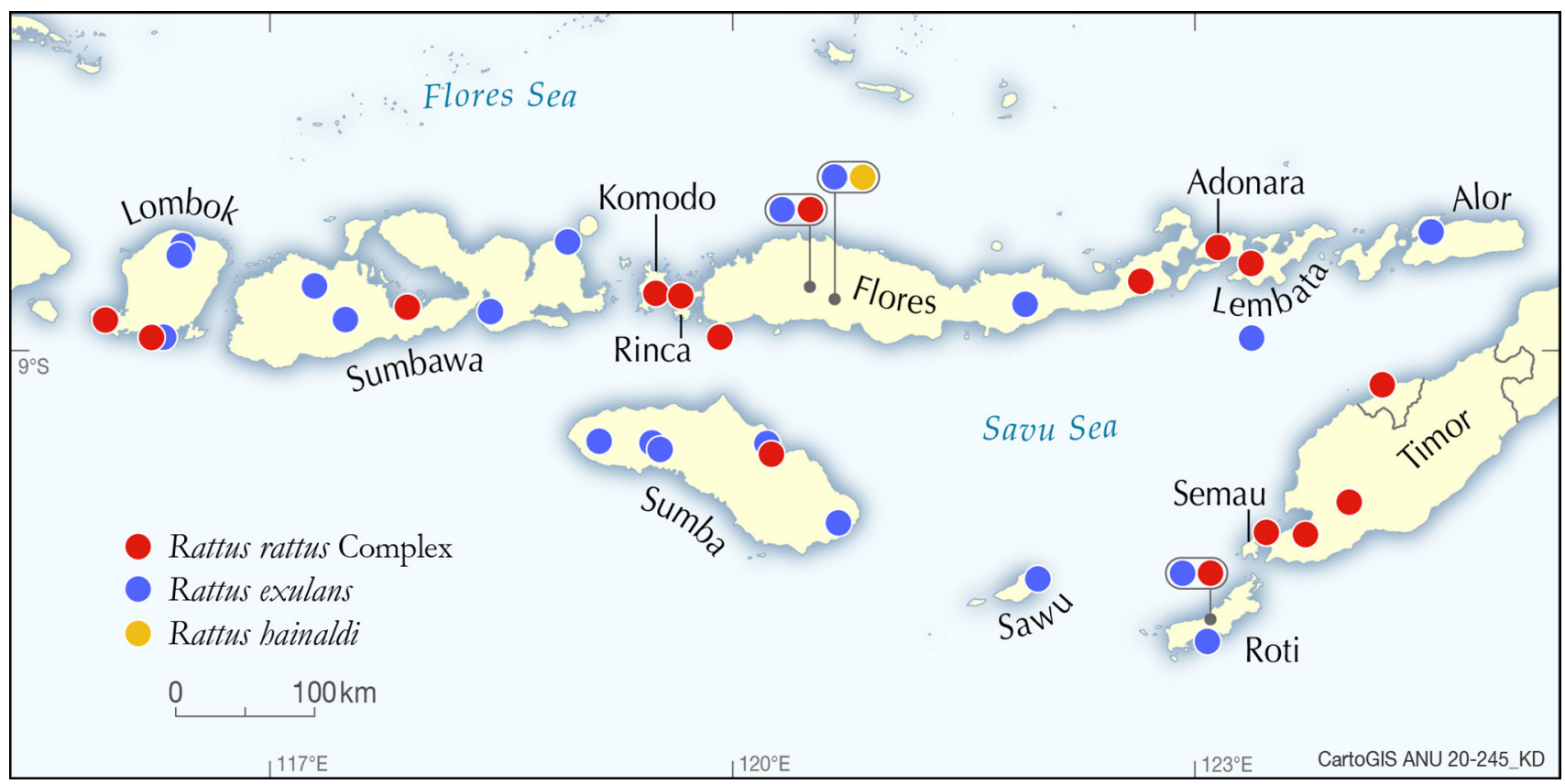

Figure 2. Sampling locations for skulls included in the craniometric analysis.

Because we were only interested in rats from Nusa Tenggara, we restricted distance analyses to rodents from Adonara, Alor, Flores, Komodo, Lembata, Lombok, Rinca, Roti, Sawu, Semau, Sumba, Sumbawa, and Timor (Fig. 2 ). We calculated three distance measures corresponding to our three hypotheses of invasion direction: (1) distance from easternmost point (in our dataset, Kalabahi, Alor); (2) distance from Flores $\left(8.7^{\circ} \mathrm{S}\right.$ and $\left.120.7^{\circ} \mathrm{E}\right)$; and (3) distance from westernmost point, (Pelangan, Lombok). Latitude and longitude information provided with each specimen was converted to decimal degrees and distance measures were calculated based on the cartesian distance equation.

Many ecological and environmental pressures can also produce significant changes in body size, particularly for island populations (Efford, 1976; Yom-Tov et al., 1999; Motokawa et al., 2004; Lomolino, 2005; Lomolino et al., 2012; Claude, 2013; van der Geer et al., 2018; Miszkiewicz et al., 2020). These pressures will be unique for each island, and in effect introduce non independence to quantitative data. These can be dampened by averaging values for each island; however, in order to maximize sample size across the entire biogeographical area, a linear mixed model approach that includes each island as a random effect was employed. We modelled the effects of dispersal distance across Nusa Tenggara on rat body size with Bayesian Linear Mixed-Effect Models (BLMEs), with model selection based on Akaike Information Criterion $\left(\mathrm{AIC}_{\mathrm{c}}\right)$ (Burnham $\&$ Anderson, 2002). Prior to analysis, all numerical values were centred and scaled. We fitted BLMEs using maximum likelihood parameter estimation criterion with functions implemented in the blme library (Dorie, 2015) of R (R Core Team, 2019). For each analysis, we included island as a random effect and the three distance measures as fixed effects. For the analysis examining all three Rattus species, we also included species identity as a fixed effect. To directly compare between models, we standardized input variables with the function available in the arm library (Gelman et al.,
2018). We generated the set of models for comparison using the function available in the MuMIn library (Bartoń, 2019) and restricted comparisons to models with at most one fixed distance measure included that fell within two $\mathrm{AIC}_{\mathrm{c}}$ of the best model in the set.

\section{Results}

\section{Genetics}

In the haplotype network for the $66 \mathrm{RrC}$ LIV samples, constructed from a common $376 \mathrm{bp}$ cyt $b$ fragment, 20 haplotypes were observed with seven of these found in Nusa Tenggara (Fig. 3). These include Haplotypes 1, 3, 4, 6, 8, 17, and 20, but only H6 is shared between MSEA and Nusa Tenggara. There are two star-shaped clusters originating from $\mathrm{H} 6$ and H20. The diversity within H6 "cluster" is found in MSEA and Nusa Tenggara. While the H20 "cluster" is found in the Philippines, Talaud Islands, Sulawesi, and from Lombok and Flores in Nusa Tenggara as well.

In the haplotype network for the $272 \mathrm{RrC}$ LII samples, constructed from a common $812 \mathrm{bp} c y t b$ fragment, 100 haplotypes were observed, with seven of these found in Nusa Tenggara (Fig. 4). There are four major clusters in the network, with $\mathrm{H} 1, \mathrm{H} 12$ and $\mathrm{H} 19$ forming the focal haplotypes of three of the clusters. These clusters comprise MSEA or East Asian samples only. The fourth cluster, with H6 as the focal haplotype, includes samples from MSEA, the Philippines, and Indonesia. Three further haplotypes, H8 (Sunda), H9(Sunda), H1 (Maluku), were found between the H12 and H19 clusters.

We assessed the relationships among populations of $\mathrm{RrC}$ using nuclear microsatellite genotypes at 12 loci (Table S3, see Louys et al., 2020). Genetic cluster analyses did not distinguish members of the $\mathrm{RrC}$ from MSEA or in their extralimital range in Indonesia on the basis of their mitochondrial lineage ancestry (Fig. 5). Our findings for 


\section{Rattus rattus Complex IV}
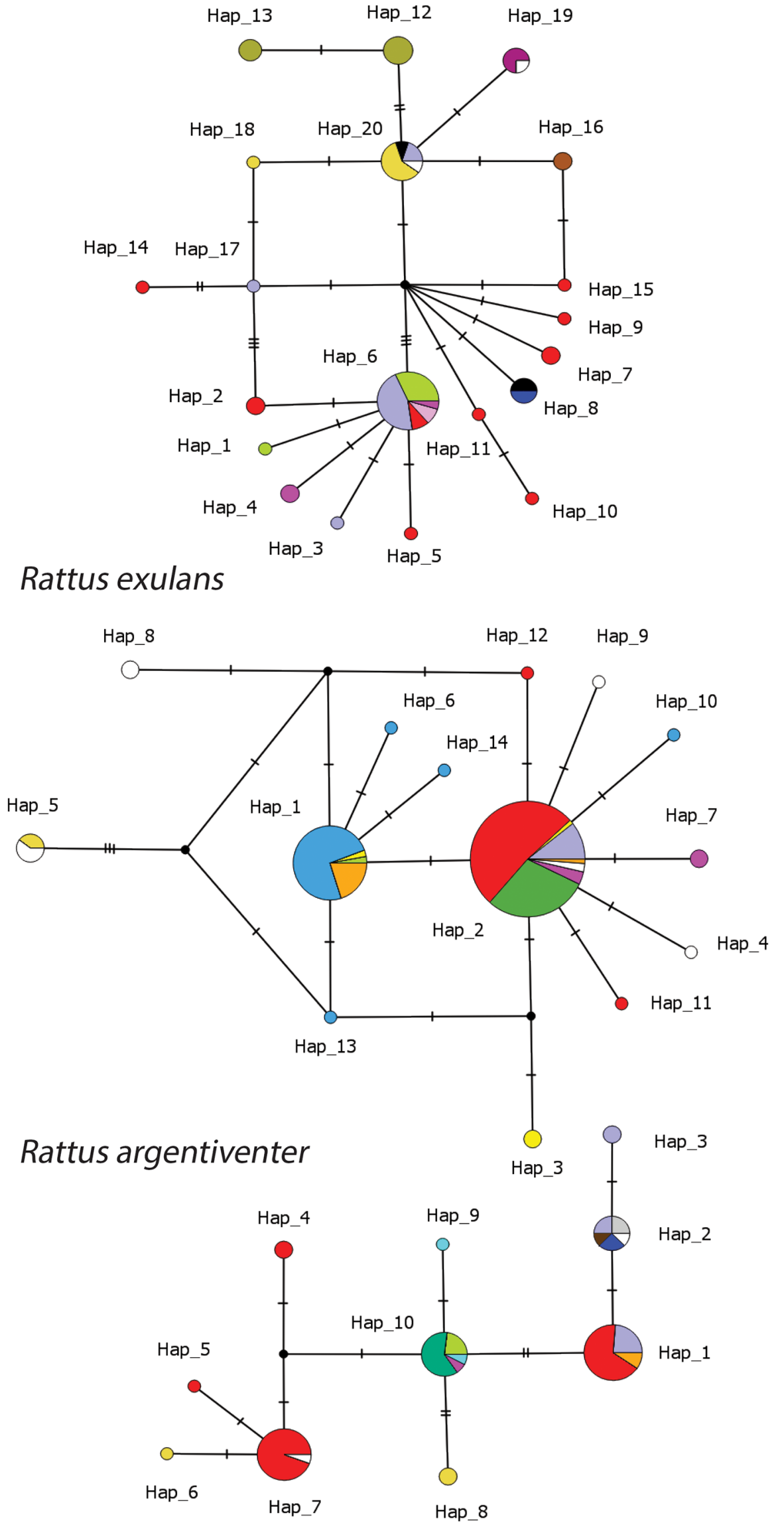

10 samples<smiles>C1CCCC1</smiles>

1 sample

Nusa Tenggara

Alor

Bali

Flores

Lombok

Pantar

Roti

Sumba

Sumbawa

Timor

\section{Other islands}

Talaud

Philippines

New Guinea

Sulawesi

Maluku

Regions

Sunda

Indonesia

Pacific

Mainland Southeast Asia (MSEA)

Figure 3. Haplotype networks for Rattus exulans, R. argentiventer, and Rattus rattus Complex LIV. Sunda refers to the islands of Borneo, Java, and Sumatra; the Indonesian sample (brown) lacks further collection information. 


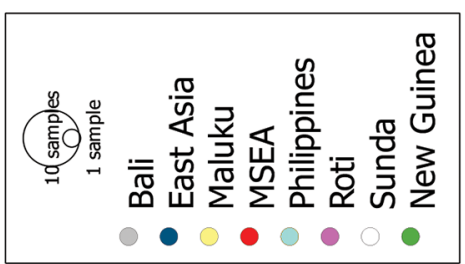

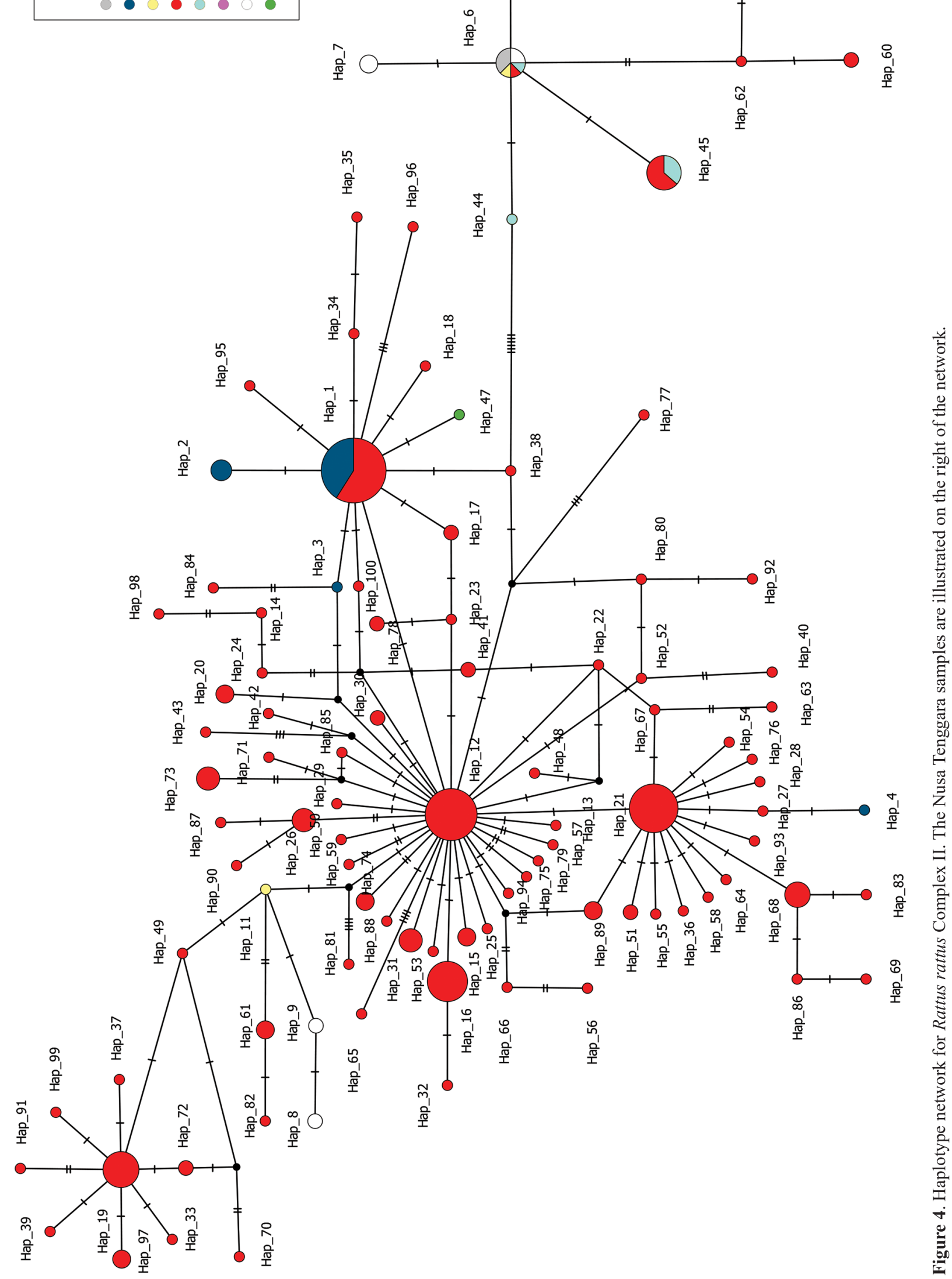




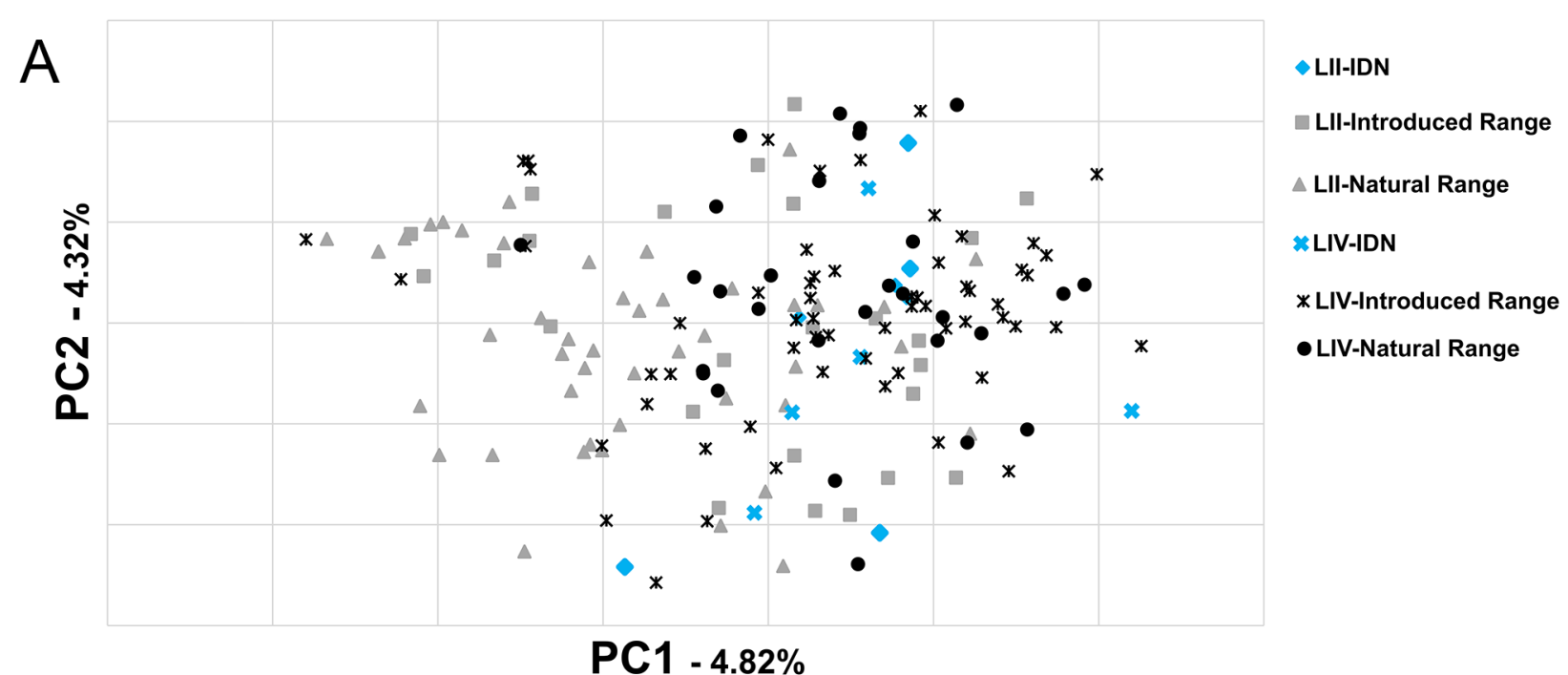

B

LII introduced range LIV IDN LIV natural range

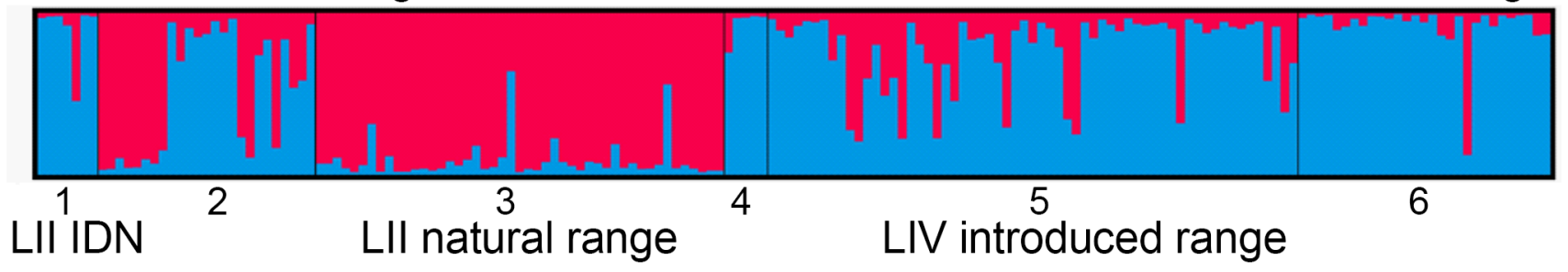

Figure 5. Genetic clustering based on allele frequencies of 12 microsatellite loci genotyped for Rattus rattus Complex samples from MSEA and extralimital distribution in Indonesia (IDN). (A) PCoA, (B) STRUCTURE barplot.

MSEA RrC are consistent with the findings of Pages et al. (2013) based on another set of eight microsatellite loci, i.e. the areas sampled for LII and LIV represent broadly introgressed populations.

The $c y t b$ network for the $139 R$. exulans sequences, constructed from the common $330 \mathrm{bp}$ fragment, comprises 14 haplotypes (Fig. 3). Three haplotypes (H2, H11, and H12) were observed from MSEA. However, only H2 is shared with Nusa Tenggara and regions further east such as Maluku and New Guinea. Haplotype 1 is observed in Nusa Tenggara and also in the Pacific, and is the predominant haplotype in the Pacific.

The haplotype network of the $R$. argentiventer cyt $b$ dataset, constructed from the common $312 \mathrm{bp}$ across all 69 individuals, comprises 10 haplotypes (Fig. 3). There were six $c y t b$ haplotypes observed in the Nusa Tenggara archipelago (H1, 2, 3, 8, 9, and 10). Haplotype 10 is unique to the region being found in Alor, Pantar, Roti, and Sumba. Only H1 is shared between MSEA and the Nusa Tenggara archipelago, i.e., Flores and Timor. Haplotypes 4, 5, and 7 occur in MSEA, but only $\mathrm{H} 7$ is observed in Sundaland (the Sundaic extension of the Asian continental shelf).

\section{Craniometrics}

Intra-observer error analysis resulted in the elimination of 19 variables: length diastema (DA), length of the incisive foramina (FOR), length of the face (GES), nasal length (NAS), length of the upper molar row (alveoli) (OZRA), length of the upper molar row (crown) (OZRK), length of the bullae (BULL), occipital breadth (OCB), nasal breadth (NASB), height braincase with bullae (SKH), thickness of incisor (ID), foramen magnum width (FMW), foramen magnum height $(\mathrm{FMH})$, supraoccipital width at the occipital condyles (OCW), supraoccipital height $(\mathrm{BH})$, mandibular depth (MD), mandibular alveoli length (MAL), mandibular diastema length (LAL), and thickness lower incisor (LID). Two values were removed from the dataset following outlier analysis, one from $R$. exulans (M33738: SKB) and another from $R$. hainaldi (M46412: HKL). Univariate statistics of the retained variables are summarized in Table $1 . \mathrm{RrC}$ had the largest variance, standard deviation, and coefficient of variation across all craniometric variables. Conversely, $R$. exulans and $R$. hainaldi had very similar values across all these statistics. These two species differ, however, predominately in range and skew, with $R$. hainaldi exhibiting larger ranges and more negative skew in most metrics.

The first principal component (PC1) explained 98\% of the variance (Table 2). All craniometric variables contributed positively to $\mathrm{PC} 1$, with the largest contributions from condylobasal length (CBL), basal length (BLL), basilar length (BRL), condylobasilar length (CBRL), occipital length $(\mathrm{OCN})$, and mandibular length (ML). Based on loglikelihood values, the "RrC BLME" model performed the best, followed by " $R$. exulans", then the "all rats" model (Table 4). The "all rats" model selection analysis produced two equally likely models. Both included species identity, indicating that species identity significantly impacts models, and implying that they should be treated separately. In the model selection analysis of the $\mathrm{RrC}$ only data, three models 
Table 2. Univariate statistics for the measurements $(\mathrm{mm})$ used in the craniometric analysis. Abbreviations in caption for Fig. 1. $\mathrm{CoV}-$ coefficient of variation.

\begin{tabular}{|c|c|c|c|c|c|c|c|c|c|c|c|c|c|c|c|c|c|c|c|c|}
\hline metric & species & $\mathrm{CBL}$ & BLL & BRL & CBRL & $\mathrm{OCN}$ & HKL & IOB & PL & PRL & $\mathrm{RB}$ & ZYG & $\mathrm{RH}$ & SKB & $\mathrm{ZP}$ & ML & MCL & $\mathrm{CL}$ & MID & MDL \\
\hline \multirow[t]{3}{*}{ number } & R. rattus & 57 & 57 & 57 & 57 & 55 & 57 & 57 & 55 & 55 & 57 & 51 & 56 & 57 & 57 & 57 & 57 & 57 & 57 & 46 \\
\hline & R. exulans & 60 & 60 & 60 & 60 & 58 & 60 & 60 & 56 & 56 & 60 & 52 & 60 & 59 & 60 & 58 & 60 & 60 & 60 & 38 \\
\hline & R. hainaldi & 29 & 29 & 29 & 29 & 29 & 28 & 29 & 28 & 28 & 27 & 29 & 28 & 28 & 27 & 27 & 27 & 27 & 27 & 26 \\
\hline \multirow[t]{3}{*}{ mean } & R. rattus & 37.51 & 35.04 & 32.13 & 34.59 & 39.80 & 24.06 & 5.97 & 21.73 & 18.80 & 6.77 & 18.68 & 6.52 & 11.51 & 4.01 & 21.33 & 6.24 & 13.14 & 5.79 & 11.18 \\
\hline & R. exulans & 28.70 & 26.57 & 24.23 & 26.34 & 30.93 & 19.66 & 4.79 & 16.15 & 13.91 & 5.21 & 14.30 & 4.81 & 8.92 & 2.98 & 15.62 & 4.85 & 9.58 & 4.18 & 8.30 \\
\hline & R. hainaldi & 32.18 & 29.89 & 27.26 & 29.45 & 34.74 & 21.36 & 5.15 & 18.29 & 15.74 & 6.06 & 16.82 & 5.76 & 10.24 & 3.21 & 17.95 & 5.38 & 10.98 & 5.07 & 9.61 \\
\hline \multirow[t]{3}{*}{ minimum } & R. rattus & 30.79 & 28.28 & 26.64 & 29.25 & 33.25 & 20.64 & 4.93 & 17.76 & 15.61 & 4.65 & 15.93 & 4.99 & 8.91 & 3.01 & 17.19 & 5.17 & 10.78 & 4.35 & 8.81 \\
\hline & R. exulans & 24.96 & 22.85 & 21.04 & 22.97 & 27.34 & 17.52 & 4.27 & 14.15 & 12.25 & 4.24 & 12.55 & 3.80 & 7.98 & 2.38 & 13.53 & 4.36 & 7.43 & 3.65 & 7.05 \\
\hline & R. hainaldi & 28.00 & 25.31 & 23.08 & 25.48 & 31.01 & 19.37 & 4.81 & 16.58 & 14.39 & 5.42 & 14.88 & 4.96 & 9.62 & 2.70 & 16.22 & 4.84 & 9.82 & 4.35 & 8.12 \\
\hline \multirow[t]{3}{*}{ maximum } & R. rattus & 43.66 & 40.59 & 37.99 & 40.92 & 45.38 & 26.99 & 6.88 & 25.91 & 22.87 & 8.30 & 22.85 & 8.34 & 13.66 & 5.04 & 26.51 & 7.35 & 15.91 & 7.18 & 14.09 \\
\hline & R. exulans & 31.62 & 29.74 & 27.28 & 29.21 & 34.49 & 21.92 & 5.43 & 18.15 & 15.66 & 5.93 & 15.45 & 5.86 & 10.24 & 3.42 & 17.43 & 5.65 & 10.66 & 4.69 & 9.61 \\
\hline & R. hainaldi & 35.03 & 32.86 & 30.05 & 31.91 & 37.02 & 23.02 & 5.48 & 20.04 & 17.11 & 6.62 & 18.50 & 6.66 & 10.97 & 3.70 & 19.74 & 5.91 & 12.10 & 5.75 & 10.90 \\
\hline \multirow[t]{3}{*}{ std. error } & R. rattus & 0.44 & 0.43 & 0.40 & 0.39 & 0.44 & 0.20 & 0.06 & 0.27 & 0.24 & 0.10 & 0.25 & 0.12 & 0.13 & 0.07 & 0.31 & 0.06 & 0.18 & 0.09 & 0.20 \\
\hline & R. exulans & 0.20 & 0.20 & 0.18 & 0.18 & 0.22 & 0.12 & 0.03 & 0.13 & 0.11 & 0.05 & 0.09 & 0.06 & 0.05 & 0.03 & 0.12 & 0.03 & 0.08 & 0.03 & 0.08 \\
\hline & R. hainaldi & 0.32 & 0.33 & 0.29 & 0.29 & 0.29 & 0.16 & 0.03 & 0.18 & 0.14 & 0.08 & 0.18 & 0.07 & 0.07 & 0.05 & 0.18 & 0.04 & 0.11 & 0.06 & 0.14 \\
\hline \multirow[t]{3}{*}{ variance } & R. rattus & 10.85 & 10.45 & 9.04 & 8.50 & 10.82 & 2.36 & 0.19 & 4.11 & 3.20 & 0.62 & 3.24 & 0.77 & 0.92 & 0.25 & 5.38 & 0.22 & 1.76 & 0.45 & 1.87 \\
\hline & R. exulans & 2.34 & 2.52 & 2.04 & 1.94 & 2.79 & 0.84 & 0.05 & 0.90 & 0.70 & 0.13 & 0.41 & 0.19 & 0.17 & 0.05 & 0.87 & 0.06 & 0.34 & 0.06 & 0.26 \\
\hline & R. hainaldi & 2.93 & 3.13 & 2.47 & 2.40 & 2.52 & 0.72 & 0.03 & 0.92 & 0.59 & 0.15 & 0.92 & 0.15 & 0.14 & 0.07 & 0.92 & 0.04 & 0.32 & 0.10 & 0.53 \\
\hline \multirow[t]{3}{*}{ standard deviation } & R. rattus & 3.29 & 3.23 & 3.01 & 2.92 & 3.29 & 1.54 & 0.44 & 2.03 & 1.79 & 0.79 & 1.80 & 0.88 & 0.96 & 0.50 & 2.32 & 0.47 & 1.33 & 0.67 & 1.37 \\
\hline & R. exulans & 1.53 & 1.59 & 1.43 & 1.39 & 1.67 & 0.92 & 0.22 & 0.95 & 0.84 & 0.36 & 0.64 & 0.43 & 0.42 & 0.23 & 0.93 & 0.25 & 0.59 & 0.24 & 0.51 \\
\hline & R. hainaldi & 1.71 & 1.77 & 1.57 & 1.55 & 1.59 & 0.85 & 0.16 & 0.96 & 0.77 & 0.39 & 0.96 & 0.39 & 0.37 & 0.26 & 0.96 & 0.19 & 0.57 & 0.32 & 0.73 \\
\hline \multirow[t]{3}{*}{25 th percentile } & R. rattus & 35.24 & 32.72 & 30.1 & 32.33 & 37.19 & 22.94 & 5.65 & 20.24 & 17.43 & 6.33 & 17.63 & 5.92 & 10.85 & 3.63 & 19.51 & 5.93 & 12.19 & 5.41 & 10.08 \\
\hline & R. exulans & 27.86 & 25.73 & 23.47 & 25.64 & 29.97 & 19.12 & 4.64 & 15.63 & 13.45 & 5.00 & 14.08 & 4.49 & 8.62 & 2.83 & 15.18 & 4.69 & 9.36 & 4.03 & 8.04 \\
\hline & R. hainaldi & 30.66 & 28.58 & 26.23 & 28.32 & 33.39 & 20.81 & 5.06 & 17.49 & 15.18 & 5.76 & 15.95 & 5.47 & 9.96 & 3.00 & 17.48 & 5.29 & 10.58 & 4.89 & 9.12 \\
\hline \multirow[t]{3}{*}{ 75th percentile } & R. rattus & 40.18 & 37.67 & 34.68 & 37.13 & 43.04 & 24.94 & 6.30 & 23.51 & 20.30 & 7.21 & 19.89 & 7.32 & 12.13 & 4.40 & 23.12 & 6.55 & 14.06 & 6.45 & 12.07 \\
\hline & R. exulans & 29.66 & 27.57 & 25.07 & 27.40 & 32.04 & 20.21 & 4.92 & 16.74 & 14.44 & 5.50 & 14.75 & 5.12 & 9.24 & 3.16 & 16.28 & 4.95 & 10.02 & 4.32 & 8.56 \\
\hline & R. hainaldi & 33.54 & 31.26 & 28.45 & 30.57 & 35.95 & 22.11 & 5.28 & 18.96 & 16.42 & 6.41 & 17.59 & 6.04 & 10.47 & 3.40 & 18.69 & 5.50 & 11.41 & 5.30 & 10.33 \\
\hline \multirow[t]{3}{*}{ skewness } & R. rattus & 0.03 & -0.08 & 0.00 & 0.11 & -0.01 & 0.22 & 0.04 & 0.01 & 0.05 & -0.16 & 0.40 & 0.03 & -0.27 & -0.16 & 0.20 & 0.25 & 0.07 & 0.04 & 0.20 \\
\hline & R. exulans & -0.14 & -0.20 & -0.20 & -0.11 & 0.02 & 0.41 & 0.47 & 0.08 & -0.06 & -0.10 & -0.81 & 0.09 & 0.27 & -0.24 & -0.29 & 1.09 & -1.09 & -0.23 & 0.22 \\
\hline & R. hainaldi & -0.60 & -0.77 & -0.86 & -0.86 & -0.57 & -0.41 & 0.07 & -0.29 & -0.29 & -0.06 & -0.52 & -0.16 & 0.34 & -0.11 & -0.20 & -0.15 & -0.36 & -0.02 & -0.24 \\
\hline \multirow[t]{3}{*}{ kurtosis } & R. rattus & -0.80 & -0.89 & -1.00 & -0.80 & -0.89 & -0.52 & -0.42 & -0.85 & -0.69 & 0.22 & -0.38 & -0.98 & 0.07 & -0.79 & -0.74 & -0.45 & -0.61 & -0.50 & -0.60 \\
\hline & R. exulans & -0.05 & 0.10 & 0.11 & 0.01 & -0.04 & 0.26 & 0.53 & -0.22 & -0.29 & -0.07 & 0.54 & -0.07 & 0.66 & -0.31 & -0.29 & 1.77 & 2.06 & -0.31 & 1.15 \\
\hline & R. hainaldi & -0.14 & 0.35 & 0.56 & 0.23 & -0.56 & 0.08 & -0.29 & -0.75 & -0.82 & -1.35 & -0.57 & -0.02 & -0.50 & -0.66 & -0.53 & 3.24 & -0.43 & 0.00 & -0.52 \\
\hline \multirow[t]{3}{*}{$\mathrm{CoV}$} & R. rattus & 8.78 & 9.23 & 9.36 & 8.43 & 8.26 & 6.38 & 7.29 & 9.33 & 9.52 & 11.65 & 9.63 & 13.42 & 8.34 & 12.48 & 10.87 & 7.58 & 10.10 & 11.55 & 12.24 \\
\hline & R. exulans & 5.33 & 5.97 & 5.89 & 5.29 & 5.40 & 4.66 & 4.59 & 5.86 & 6.02 & 6.88 & 4.49 & 8.96 & 4.69 & 7.61 & 5.97 & 5.23 & 6.11 & 5.71 & 6.18 \\
\hline & R. hainaldi & 5.32 & 5.92 & 5.77 & 5.26 & 4.57 & 3.97 & 3.16 & 5.23 & 4.87 & 6.45 & 5.70 & 6.72 & 3.61 & 8.00 & 5.33 & 3.51 & 5.16 & 6.33 & 7.59 \\
\hline \multirow[t]{3}{*}{ range } & R. rattus & 4.94 & 4.95 & 4.58 & 4.81 & 5.85 & 2.00 & 0.66 & 3.27 & 2.87 & 0.88 & 2.26 & 1.40 & 1.28 & 0.77 & 3.61 & 0.62 & 1.87 & 1.04 & 1.99 \\
\hline & R. exulans & 1.80 & 1.84 & 1.60 & 1.75 & 2.08 & 1.09 & 0.28 & 1.12 & 0.99 & 0.50 & 0.68 & 0.63 & 0.62 & 0.33 & 1.10 & 0.27 & 0.65 & 0.29 & 0.53 \\
\hline & R. hainaldi & 2.88 & 2.68 & 2.22 & 2.26 & 2.56 & 1.29 & 0.23 & 1.47 & 1.24 & 0.65 & 1.64 & 0.56 & 0.51 & 0.40 & 1.21 & 0.21 & 0.83 & 0.41 & 1.22 \\
\hline
\end{tabular}

performed equally well. Of these, the top performing model had a negative association between size and distance from the easternmost point. The third model had a positive association between size and distance from westernmost point. These results are consistent in indicating an increase in size moving west to east along Nusa Tenggara. The second model indicated no association between size and distance. The " $R$. exulans only" model selection analysis produced four equally well performing models, with all migration scenarios represented. Thus, for $R$. exulans it appears that size changes of the crania have not been influenced by distance.

\section{Discussion}

The haplotype networks of $\mathrm{RrC}$ indicate multiple dispersals and back dispersals from mainland Southeast Asia (MSEA) into Wallacea. The RrC LII network indicates an early dispersal into the Philippines, and hence into Maluku and Bali, judging by the significant distance between mainland Southeast Asian haplotype group 38 and the Philippine haplotype group 44. Only one RrC LII haplotype group
(H10) is recovered from Nusa Tenggara, which stems off from a haplogroup found in Bali and the Philippines. In $\mathrm{RrC}$ LIV, Haplotype group 6, which is represented in Alor, Flores, Pantar, Roti, and MSEA, shows considerable distance from the reconstructed core area indicating a single dispersal event followed by in situ production of genetic diversity (Fig. 3). This dispersal is thus also likely to be of considerable antiquity; however, it cannot be determined whether genetic diversity emerged mainly in MSEA with dispersal into Nusa Tenggara, or if dispersal was to Nusa Tenggara, with subsequent back-dispersal into MSEA. Given the additional diverging haplotypes from Haplotype group 6 into both MSEA and Alor, Roti, and Flores, considerable genetic exchange occurred during this period. A second, more recent dispersal of $\mathrm{RrC}$ through Southeast Asia is indicated by the fanning pattern of network connections with fewer haplotype substitutions from the reconstructed core. This dispersal was multidirectional, with several unique haplotypes now found in MSEA, Flores, and SumbawaLombok, Philippines-Sundaland-Lombok-Flores. The latter haplogroup gave rise to the Sulawesi and Talaud RrC LIV 
Table 3. Summary of Principal Components Analysis. Eigenvalues and amount of variance explained by each listed in columns on the left; loading of each cranial variable for the first two principal component (PC) scores on the right. Abbreviations in caption for Fig. 1.

\begin{tabular}{cccccr}
\hline PC & eigenvalue & \% variance & cranial variable & PC1 & PC2 \\
\hline 1 & 143.444 & 98.015 & CBL & 0.387 & -0.162 \\
2 & 0.591 & 0.404 & BLL & 0.375 & -0.276 \\
3 & 0.553 & 0.378 & BRL & 0.348 & -0.168 \\
4 & 0.392 & 0.268 & CBRL & 0.357 & -0.043 \\
5 & 0.263 & 0.180 & OCN & 0.389 & 0.091 \\
6 & 0.191 & 0.130 & HKL & 0.188 & 0.359 \\
7 & 0.142 & 0.097 & IOB & 0.047 & 0.034 \\
8 & 0.109 & 0.074 & PL & 0.242 & -0.116 \\
9 & 0.107 & 0.073 & PRL & 0.212 & 0.009 \\
10 & 0.074 & 0.051 & RB & 0.071 & 0.045 \\
11 & 0.061 & 0.041 & ZYG & 0.187 & 0.455 \\
12 & 0.059 & 0.041 & RH & 0.077 & -0.120 \\
13 & 0.051 & 0.035 & SKB & 0.108 & 0.203 \\
14 & 0.040 & 0.027 & ZP & 0.046 & 0.014 \\
15 & 0.032 & 0.022 & ML & 0.252 & 0.376 \\
16 & 0.027 & 0.019 & MCL & 0.054 & 0.135 \\
17 & 0.014 & 0.010 & CL & 0.154 & 0.100 \\
18 & 0.008 & 0.006 & MID & 0.069 & 0.089 \\
19 & -0.190 & -0.130 & MDL & 0.123 & -0.523 \\
\hline
\end{tabular}

haplogroups, suggested by Louys et al. (2018a) to belong to the Austronesian expansion of agriculturalists (Bellwood, 2007). This dispersal is likely tied to the one observed between Bali-Philippines and Roti in RrC LII. While introgression in Nusa Tenggara between RrC LII and RrC LIV may have occurred during this later dispersal, MSEA and other extralimital populations, e.g., the Philippines that comprise likely sources for dispersal into Indonesia, have highly admixed nuclear genomes.

The mtDNA history likely reflects dispersal episodes and sources but not the overall biological phenotype of rats arriving in Indonesia. Thus, we feel justified in treating the Indonesian material in the craniometric analysis as being derived from a single biological species. The name of this taxon remains uncertain. Robins et al. (2007) associated $R$. rattus diardii, the Malayan house rat, with $\mathrm{RrC}$ LIV and Musser \& Carlton (2005) list $R$. rattus diardii as synonymous with $R$. tanezumi, which in turn was considered part of $\mathrm{RrC}$ LIV by Denys et al. (2017). At present, the populations of LII and LIV mitochondrial ancestry rats are perhaps best viewed as "the Rattus tanezumi Complex" within the $\mathrm{RrC}$. We determined the mitochondrial haplotype for eight individuals, six were LIV and two were LII (Table S2, see Louys et al., 2020).

Our craniometric analysis provides further support for an earlier dispersal of $\mathrm{RrC}$ into Nusa Tenggara. The traits under evolutionary selection for species at the population front are likely multifaceted and would not necessarily be restricted to phenotypic changes (Chuang \& Peterson, 2016). Nevertheless, in this instance the craniometric analysis indicates an increase in the length of the skull associated with an eastern movement through Nusa Tenggara (Fig. 6). Increases in skull length are strongly correlated with increased body mass in rodents (Bertrand et al., 2016). Thus, body size of these rats increased through the archipelago, consistent with observations made for a range of demes at the population edge relative to the core (Chuang \& Peterson, 2016). This is inferred to be due to the physical exertion and

Table 4. Bayesian Linear Mixed-Effect Model summary statistics and Akaike Information Criterion (AICc) comparisons. $\operatorname{RrC}$, Rattus rattus Complex; $z-D$ (east) is the distance from the east fixed effect, $z-D$ (Flores) is the distance from Flores fixed effect, and $z-D$ (west) is the distance from the west fixed effect.

\begin{tabular}{lllcccccccc}
\hline model & intercept & species & z-D(east) & z-D(Flores) & z-D(west) & df & logLn & AIC $_{\mathrm{c}}$ & delta & weight \\
\hline all rats 1 & -0.82570 & + & - & - & - & 5 & -93.096 & 196.7 & 0 & 0.418 \\
all rats 2 & -0.82740 & + & -0.11950 & - & - & 6 & -92.756 & 198.2 & 1.52 & 0.195 \\
R. exulans 1 & -0.06516 & - & - & - & - & 3 & -82.830 & 172.1 & 0 & 0.259 \\
R. exulans 2 & -0.02467 & - & 0.6714 & - & - & 4 & -81.927 & 172.6 & 0.49 & 0.203 \\
R. exulans 3 & -0.06115 & - & - & 0.5819 & - & 4 & -82.350 & 173.4 & 1.34 & 0.133 \\
R. exulans 4 & -0.03825 & - & - & - & -0.4393 & 4 & -82.351 & 173.4 & 1.34 & 0.133 \\
RrC 1 & -0.04494 & - & -0.6587 & - & - & 4 & -54.671 & 118.5 & 0 & 0.285 \\
RrC 2 & -0.02832 & - & - & - & - & 3 & -56.248 & 119.2 & 0.68 & 0.203 \\
RrC 3 & -0.03502 & - & - & - & 0.49850 & 4 & -55.263 & 119.7 & 1.18 & 0.158 \\
\hline
\end{tabular}




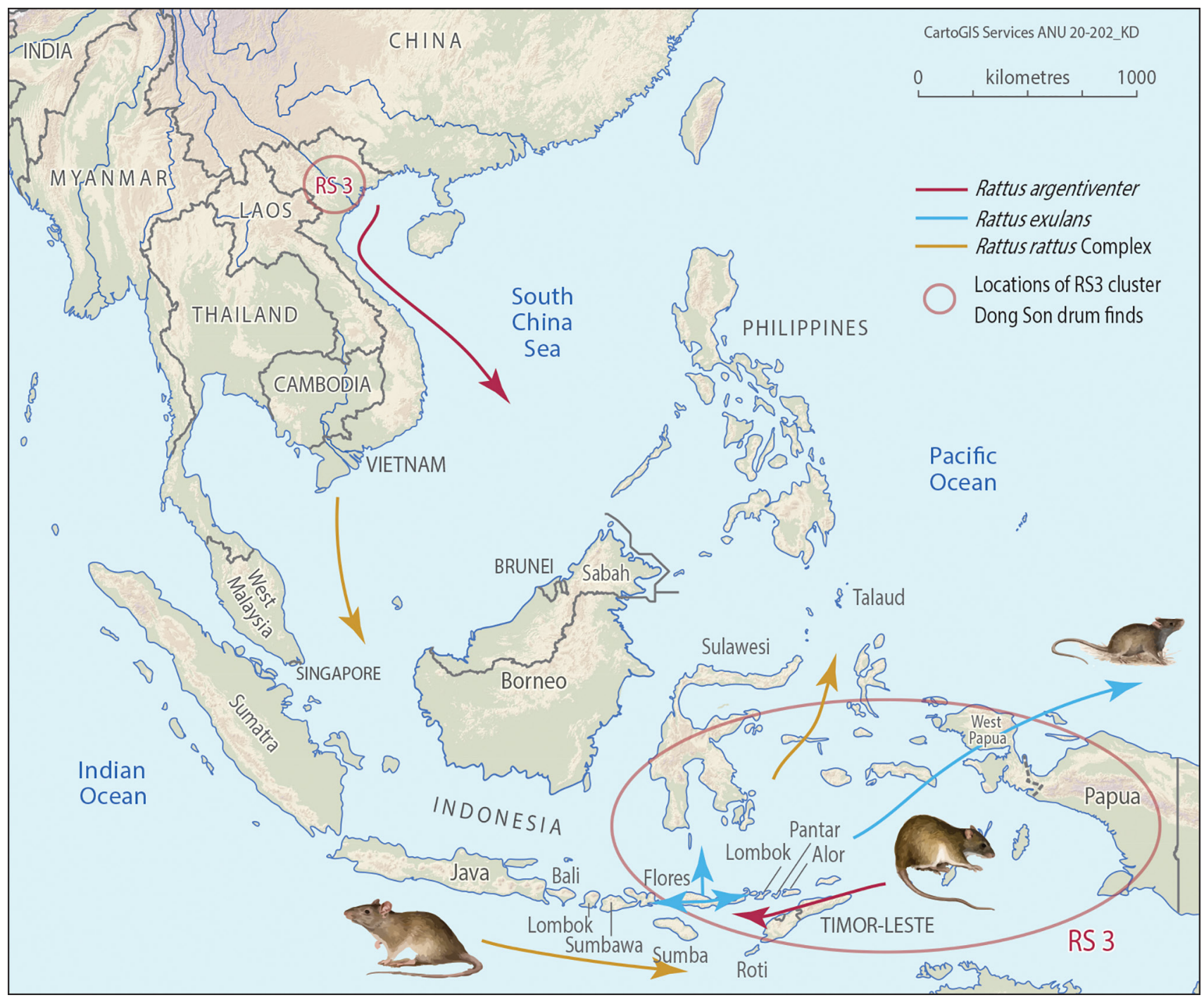

Figure 6. Summary of likely movements of the three commensal rodents through the Nusa Tenggara island chain. Rat illustrations redrawn and adapted from R. Budden, location of RS3 Dong Song drums from Calo (2014).

activity required by active dispersal. It suggests that at least one of the dispersals of $\mathrm{RrC}$ into Nusa Tenggara was an active one by the species as opposed to a passive translocation (e.g., as part of a Neolithic "package"). This active invasion could correspond to the more ancient dispersal event suggested by the haplotype network.

The $R$. exulans haplotype network largely mirrors that reported by Thomson et al. (2014) (see also Matisoo-Smith et al., 2014; Hingston, 2015; West et al., 2017). It shows a major haplotype group (centred on haplotype 2) with representatives currently found on MSEA, New Guinea, Roti, Sundaland, Timor, Flores, and the Maluku Islands, and a second major group (centred on haplotype 1) representing a major dispersal into the Pacific (Fig. 3). New sequences added by this study include an individual from Alor, a fossil specimen from Liang Luar cave, Flores, five specimens from Roti, and 14 specimens from archaeological deposits in Papua New Guinea (Panakiwuk, New Ireland; and Paleflatu, Sandaun Province). The Alor specimen belongs to the Pacific haplogroup, while the Liang Luar specimen corresponds to haplogroup 2, as was found by Thomson et al. (2014). All the specimens from Roti and New Guinea are also associated with this haplogroup, which is considered to include the source population of $R$. exulans. This was suggested to be Flores by Schwartz \& Schwartz (1967) based on the unique occurrence of the wild type white-belly phenotype on Flores and supported by Thomson et al. (2014) who observed the highest level of genetic diversity on that island. Our results do not contradict this conclusion. Archaeological records from Timor record the introduction of at least $R$. exulans on that island several thousand years before present (Glover, 1986), suggesting an initial Nusa Tenggara dispersal potentially co-eval or soon after the dispersal of $\mathrm{RrC}$ through the islands.

Unlike the $R$. rattus craniometric analysis, no one model of size change associated with distance was favoured by our $R$. exulans analysis. This was unexpected, as based on the dispersal of $R$. exulans out of Flores and eventually into the Pacific, we expected size to vary as a measure of distance from this island. It appears that size does not correlate with direction of travel throughout Nusa Tenggara, and in fact craniometric values for this species show similar statistics to the Flores-restricted endemic $R$. hainaldi. We interpret this result to indicate passive dispersal by this murid. Traits selected for at the expanding edge of this species, at least 
in Nusa Tenggara, are not discernible from their cranial measurements, and are instead more consistent with $R$. exulans belonging to a commensal Neolithic "package". Such a dispersal mechanism would more likely favour traits associated with higher neophilia (Chuang \& Peterson, 2016) and domestication (Leppard, 2018).

The zoogeographic history of $R$. argentiventer is largely unknown. Aplin et al. (2003) suggested a wetland or grassland origin for $R$. argentiventer based on its physiological link to the tillering stage of the rice crop. Its widespread distribution is attributed to human activities and unintentional transportation (Harrison, 1961). Musser (1973) suggested that the Sulawesi, Philippine, and New Guinea populations were likely recent anthropogenic introductions and remarked on its morphological uniformity throughout its range. Maryanto (2003), however, was able to distinguish four groups based on a craniometric analysis: a Java group, a Bali-Sulawesi group, a Sumba group, and a Kalimantan group. Maryanto (2003) agreed with Musser's (1973) conclusion that the Sulawesi population was likely a recent introduction. Our haplotype network analysis indicates that the Philippines populations were likely recent introductions from MSEA and Nusa Tenggara. Our haplotype groups 9-10 probably correspond to the Sumba group of Maryanto (2003), the single specimen from Kalimantan that we sampled belongs to haplogroup 7, a group otherwise represented in MSEA. Our single specimen from Sumatra belongs to haplogroup 2. Maryanto (2003) could not distinguish between Java, Sumatra, and Thailand specimens, and these populations are likely represented by our haplogroups 1-3. Interestingly, these also include specimens from Liang Luar cave in Flores. These are not represented in the better sampled Liang Bua deposits of Flores until the mid to late Holocene (Locatelli et al., 2015), indicating that haplogroups 1-3 represents a Neolithic or Metal Age dispersal. This cluster is separated from the "Sumba" group - actually representing a Nusa Tenggara Timur cluster-by two substitutions and is isolated from haplogroup 7. Because of this, we suggest that $R$. argentiventer dispersed directly from MSEA into eastern Nusa Tenggara, followed by a back dispersal into MSEA following a residence in Nusa Tenggara of sufficient duration to produce the haplotype diversity observed (Fig. 6).

Interestingly, the above model for the introduction of $R$. argentiventer matches well with the timing and distribution of the Metal Age maritime dispersal of Dong Son drums from mainland Southeast Asia into Nusa Tenggara. Dong Son drums (also known as Heger I drums) are large and elaborately decorated cast bronze drums made by the Dong Son culture of northern Vietnam/southern China in the last few centuries BC (Heger, 1902; Calo, 2014). These high prestige objects were traded along river and sea routes, including subsequent entry into maritime networks, and are found throughout MSEA and ISEA (Calo, 2014). A detailed study of Dong Son drums by Calo (2014) used the stylistic features and distributions of around 400 drums in Southeast Asia to derive distinct drum groups and trading clusters. One such group was found to characterize an eastern Indonesian dispersal (known as the RS3 cluster) whose homogeneity indicates a short and intensive distribution. RS3 drums have been found in many islands of the Nusa Tenggara archipelago and Maluku including Sangeang, Selayar, Alor, Roti, Timor, Leti, Luang, Tanimbar, Kei, Serua, Gorom, and Buru, and in western New Guinea (Calo, 2014; Oliviera et al., 2019).
A two-step process for the dispersal of the RS3 cluster was suggested, with drums initially moving from northern Vietnamese and Chinese production centres to the islands, via a direct maritime route, approximately 1850-1600 years ago (Calo, 2014). Inter-island maritime networks moved them into Nusa Tenggara and thence eastwards (Calo, 2014). This is thought to have begun after the fifth century AD and may have continued as late as the first millennium AD (c. 1600 years ago through to 1000 years ago).

The maritime networks that facilitated the movement of Dong Son drums into Nusa Tenggara may have had the unintentional consequence of also introducing $R$. argentiventer into the island chain. The establishment of this rodent species in the islands may not have been successful prior to this point owing to a lack of suitable habitat, specifically cultivated fields. Although it is currently unknown when rice cultivation in Nusa Tenggara began, Bellwood (2011) suggested the third phase of wet rice cultivation from China into Southeast Asia occurred after $500 \mathrm{BC}$ in regions of high population growth such as Java and Bali. However, in drier areas unsuitable for intensive wet rice cultivation, such as the Nusa Tenggara islands east of the Wallace Line, this may have occurred later, coincident with the Dong Son drum expansion detailed above. Importantly, the latter is also coincident with the extinction times of giant endemic rats from Sumba, Timor, and Alor, which have been associated with the widespread introduction of metal tools into Nusa Tenggara facilitating large-scale forest clearance (O'Connor \& Aplin, 2007; Louys et al., 2018b; Miszkiewicz et al., 2020). A later invasion into the western part of the island chain is suggested by the fossil record of Liang Luar, a natural Holocene assemblage from Flores, described by St Pierre (2011). In this sequence, invasive rodents including $R$. argentiventer and $R$. rattus do not appear until approximately the last 400 years (Rattus exulans is present from at least $2500 \mathrm{BP}$ ). St Pierre (2011) suggests that this rodent record is tied with the introduction of wet rice agriculture into Flores, possibly from Sumbawa or Sulawesi and temporally associated with changes in local governments and land use practices. However, our haplotype network (Fig. 3) suggest the Liang Luar haplotypes branch off from eastern Nusa Tenggara populations, thus potentially pre-dating these changes. It is possible the Liang Luar deposit records a local introduction event only. Sifting through these different scenarios will require more intensive sampling of the late Holocene rodent record of these islands, as well as more intensive genetic sampling.

\section{Conclusions}

Our analyses suggest the invasion of Nusa Tenggara by Rattus species occurred at different times and from different directions. The first introduction was likely by the Rattus rattus Complex from mainland Southeast Asia into the western parts of Nusa Tenggara and moving eastwards. Phenotypic changes associated with this migration include an increase in skull length, suggesting classic invasion effects selecting for larger and better-conditioned demes at the invasion front relative to the core. The movement of Rattus exulans from Flores is not associated with any craniometric changes in either direction, or from Flores as a point of origin. Instead, it is possible that this invasion 
favoured opportunistic individuals with a propensity for domestication. This dispersal may have occurred coeval with, or perhaps after the introduction of the Rattus rattus Complex into Nusa Tenggara. The invasion of $R$. argentiventer into Nusa Tenggara was likely the last of the three introductions considered here. Genetic analysis in combination with a consideration of major maritime exchange networks operating at the time suggests that it proceeded from the eastern parts of Nusa Tenggara westwards, required the establishment by people of open grasslands and cultivated fields starting from approximately 1500 years ago, and only established a population in the western part of the archipelago in the last 400 years.

ACKNOWLEDGEMENTS. This research was partially funded by an ARC Future Fellowship awarded to JL (FT160100450), an ARC Laureate awarded to SO (FL120100156), ARC Discovery grants (DP0988863 and DP140103650) awarded to SCD, KA, and Phil Piper, and the ARC Centre of Excellence for Australian Biodiversity and Heritage CE170100015. We thank Kay Dancey from CartoGIS ANU for the maps, Kenny Travouillon for facilitating access to the collections of the Western Australian Museum, and the Western Australian Museum, Jean-François Cosson, Chris Conroy, Lu Liang, Alexander Balakirev, Michael Kosoy, Nikhil Chakma, Shaoying Liu, Grant Singleton, Grace Yap for collection of genetic samples.

\section{Supplementary data}

Tables S1, S2 and S3 are published separately by the authors (see Louys et al., 2020).

Table S1. Sample information for murids included in the haplotype network analyses. PCR primers used for contemporary samples of Rattus exulans and $R$. argentiventer-A835/A1937; and for ancient samplesA1936/A1937 (Louys et al., 2020: table S1).

https://doi.org/10.6084/m9.figshare.12996851

Table S2. Murid crania data, raw measurements (mm). All specimens are registered in the Western Australian Museum. The mitochondrial lineage of eight $\mathrm{RrC}$ sequenced are indicated next to their registration number (Louys et al., 2020: table S2).

https://doi.org/10.6084/m9.figshare.12996851

Table S3. Nuclear microsatellite genotypes for RrC samples. https://doi.org/10.6084/m9.figshare.12996851

\section{References}

Aplin, K. P., T. Chesser, and J. ten Have. 2003. Evolutionary biology of the genus Rattus: profile of an archetypal rodent pest. In Rats, Mice and People: Rodent Biology and Management, ed. G. R. Singleton, L. A. Hinds, C. J. Krebs, and D. M. Spratt, pp. 487-498. ACIAR Monograph no. 96, 564 pp.

Aplin, K. P., H. Suzuki, A. A. Chinen, R. T. Chesser, J. ten Have, S. C. Donnellan, J. Austin, A. Frost, J. P. Gonzalez, V. Herbreteau, F. Catzeflis, J. Soubrier, Y.-P. Fang, J. Robins, E. Matisoo-Smith, A. D. S. Bastos, I. Maryanto, M. H. Sinaga, C. Denys, R. A. Van Den Bussche, C. Conroy, K. Rowe, and A. Cooper. 2011. Multiple geographic origins of commensalism and complex dispersal history of Black Rats. PLoS ONE 6(11): e26357. https://doi.org/10.1371/journal.pone.0026357

Bartoń, K. 2019. MuMIn: Multi-Model Inference. R package. Version 1.43.10.

https://cran.r-project.org/web/packages/MuMIn/index.html

Bellwood, P. 2007. Prehistory of the Indo-Malaysian Archipelago, revised edition. Canberra: ANU E Press. https://doi.org/10.26530/OAPEN 459472

Bellwood, P., 2011. The checkered prehistory of rice movement southwards as a domesticated cereal from the Yangzi to the equator. Rice 4: 93. https://doi.org/10.1007/s12284-011-9068-9

Bertrand, O. C., M. A. Schillaci, and M. T. Silcox. 2016. Cranial dimensions as estimators of body mass and locomotor habits in extant and fossil rodents. Journal of Vertebrate Paleontology 36: e1014905. https://doi.org/10.1080/02724634.2015.1014905

Burnham, K. P., and D. R. Anderson. 2002. Model Selection and Multimodel Inference: a Practical Information-Theoretic Approach. Ecological Modelling. New York: Springer Science \& Business Media.

Calo, A. 2014. Trails of Bronze Drums Across Early Southeast Asia: Exchange Routes and Connected Cultural Spheres. Singapore: ISEAS.

Chuang, A., and C. R. Peterson. 2016. Expanding population edges: theories, traits, and trade-offs. Global Change Biology 22: 494-512.

https://doi.org/10.1111/gcb.13107

Claude, J. 2013. Log-shape ratios, Procrustes superimposition, elliptic Fourier analysis: three worked examples in R. Hystrix, the Italian Journal of Mammalogy 24(1): 94-102. https://doi.org/10.4404/hystrix-24.1-6316

Denys, C., P. J. Taylor, and K. P. Aplin. 2017. Family Muridae (true mice and rats, gerbils and relatives). In Handbook of the Mammals of the World. Vol. 7 Rodents II, ed. D. E. Wilson, T. E. Lacher Jr, and R. A. Mittermeier, pp. 536-886. Barcelona: Lynx Edicions.

Dorie, V. 2015. blme: Bayesian Linear Mixed-Effects Models. R package. Version 1.0-4. https://cran.r-project.org/web/packages/blme/index.html

Earl, D. A., and B. M. Vonholdt. 2012. Structure harvester: a website and program for visualizing STRUCTURE output and implementing the Evanno method. Conservation Genetics Resources 4: 359-361. https://doi.org/10.1007/s12686-011-9548-7

Edgar, R. C. 2004. MUSCLE: multiple sequence alignment with high accuracy and high throughput. Nucleic Acids Research 32: $1792-1797$. https://doi.org/10.1093/nar/gkh340

Efford, M. 1976. Rattus exulans in Polynesia-a Case of Morphometric Divergence. Unpublished B.Sc. (Hons) thesis. Victoria University, Wellington, New Zealand. 
Evanno, G., S. Regnaut, and J. Goudet. 2005. Detecting the number of clusters of individuals using the software STRUCTURE: a simulation study. Molecular Ecology 8: 2611-2620.

https://doi.org/10.1111/j.1365-294X.2005.02553.x

Faircloth, B. 2008. MSATCOMMANDER: detection of microsatellite repeat arrays and automated, locus-specific primer design. Molecular Ecology Resources 8: 92-94. https://doi.org/10.1111/j.1471-8286.2007.01884.x

Gardner, M. G., A. Fitch, T. Bertozzi, and A. Lowe. 2011. Rise of the machines - recommendations for ecologists when using next generation sequencing for microsatellite development. Molecular Ecology Resources 11: 1093-1101.

https://doi.org/10.1111/j.1755-0998.2011.03037.x

Gelman, A., Y.-S. Su, M. Yajima, J. Hill, M. Grazia Pittau, J. Kerman, T. Zheng, and V. Dorie, V. 2018. arm: data analysis using regression and multilevel/hierarchical models. R package. Version 1.10-1.

https://cran.r-project.org/web/packages/arm/index.html

Glover, I. 1986. Archaeology in eastern Timor, 1966-67. Terra Australis 11. Canberra: Department of Prehistory, Research School of Pacific Studies, The Australian National University.

Hammer, Ø., D. A. T. Harper, and P. D. Ryan. 2001. PAST: paleontological statistics software package for education and data analysis. Palaeontologia Electronica 4(1), 9 pp.

Harrison, J. L. 1961. Ecology of the forms of Rattus rattus in the Malay Peninsula. Proceedings of the Ninth Pacific Science Congress 19: 19-24

Hayden, M. J., T. M. Nguyen, A. Waterman, and K. J. Chalmers. 2008. Multiplex-ready PCR: a new method for multiplexed SSR and SNP genotyping. BMC Genomics 9: 80. https://doi.org/10.1186/1471-2164-9-80

Heger, F. 1902. Alte metalltrommeln aus Südost-Asien. Leipzig: Kommissions-Verlag von Karl W. Hiersemann.

Hingston, M. 2015. Phylogeography of the Commensal Rattus exulans with Implications for its use as Bioproxy for Human Migrations. Unpublished Ph.D. thesis. University of Auckland.

Jakobsson, M., and N. A. Rosenberg. 2007. CLUMPP: a cluster matching and permutation program for dealing with label switching and multimodality in analysis of population structure. Bioinformatics 23: 1801-1806.

https://doi.org/10.1093/bioinformatics/btm233

Kitchener, D. J., R. A. How, and Maharadatunkamsi. 1991. A new species of Rattus from the mountains of West Flores, Indonesia. Records of the Western Australian Museum 15: 611-626.

Kopelman, N. M., J. Mayzel, M. Jakobsson, N. A. Rosenberg, and I. Mayrose. 2015. CLUMPAK: a program for identifying clustering modes and packaging population structure inferences across K. Molecular Ecology Resources 15: 1179-1191. https://doi.org/10.1111/1755-0998.12387

Lack, J. B., D. U. Greene, C. J. Conroy, M. J. Hamilton, J. K. Braun, M. A. Mare, and R. A. Van Den Bussche. 2012. Invasion facilitates hybridization with introgression in the Rattus rattus species complex. Molecular Ecology 21: 3545-3561. https://doi.org/10.1111/j.1365-294X.2012.05620.x

Leigh, J. W., and D. Bryant. 2015. Popart: full-feature software for haplotype network construction. Methods in Ecology and Evolution 6: 1110-1116. https://doi.org/10.1111/2041-210X.12410

Leppard, T. P. 2018. Rehearsing the Anthropocene in microcosm: the palaeoenvironmental impacts of the Pacific rat (Rattus exulans) and other non-human species during island Neolithization. In Multispecies Archaeology, ed. S. E. Pilaar Birch, pp. 47-64. Routledge.

https://doi.org/10.4324/9781315707709-4

Locatelli, E., R. Due, and L. W. van den Hoek Ostende. 2015. Middle-sized murids from Liang Bua (Flores, Indonesia): insular endemics, human introductions and palaeoenvironment. Palaeobiodiversity and Palaeoenvironments 95: 497-512. https://doi.org/10.1007/s12549-015-0204-1
Lomolino, M. V. 1985. Body size of mammals on islands: the island rule re-examined. American Naturalist 125: 310-316. https://doi.org/10.1086/284343

Lomolino, M. V., D. F. Sax, P. R. Palombo, and A. A. van der Geer. 2012. Of mice and mammoths: evaluations of causal explanations for body size evolution in insular mammals. Journal of Biogeography 39: 842-854.

https://doi.org/10.1111/j.1365-2699.2011.02656.x

Louys, J., M. Herrera, S. Hawkins, K. Aplin, C. Reepmeyer, F. Hopf, S. C. Donnellan, S. O'Connor, and D. A. Tanudirjo. 2018a. Neolithic dispersal implications of murids from late Holocene archaeological and modern natural deposits in the Talaud Islands, northern Sulawesi. In The Archaeology of Sulawesi: Current Research on the Pleistocene to the Historic Period, ed. S. O'Connor, D. Bulbeck, and J. Meyer, pp. 223-242, Terra Australis 48. Canberra: ANU E Press.

https://doi.org/10.22459/TA48.11.2018.14

Louys, Julien, Michael B. Herrera, Vicki A. Thomson, Andrew S. Wiewel, Stephen C. Donnellan, Sue O'Connor, and Ken Aplin. 2020. Supplementary data for craniometric and genetic analyses of commensal rats in Nusa Tenggara, Indonesia. figshare. Dataset.

https://doi.org/10.6084/m9.figshare.12996851

Louys, J., S. O'Connor, Mahirta, P. Higgins, S. Hawkins, and T. Maloney. 2018b. New genus and species of giant rat from Alor Island, Indonesia. Journal of Asia-Pacific Biodiversity 11: 503-510.

https://doi.org/10.1016/j.japb.2018.08.005

Maryanto, I. 2003. Taxonomic status of the ricefield rat Rattus argentiventer (Robinson and Kloss, 1916) (Rodentia) from Thailand, Malaysia and Indonesia based on morphological variation. Records of the Western Australian Museum 22: 47-66. https://doi.org/10.18195/issn.0312-3162.22(1).2003.047-065

Matisoo-Smith, E., J. H. Robins, and R. C. Green. 2004. Origins and dispersals of Pacific peoples: evidence from mtDNA phylogenies of the Pacific rat. Proceedings of the National Academy of Sciences USA 101: 9167-9172.

https://doi.org/10.1073/pnas.0403120101

Meglécz, E. 2007. MicroFamily: a computer program for detecting flanking region similarities among different microsatellite loci. Molecular Ecology Notes 7: 2611-2620.

https://doi.org/10.1111/j.1471-8286.2006.01537.x

Miszkiewicz, J. J., J. Louys, R. M. D. Beck, P. Mahoney, K. Aplin, and S. O'Connor. 2020. Island rule and bone metabolism in fossil murines from Timor. Biological Journal of the Linnean Society 129(3): 570-586.

https://doi.org/10.1093/biolinnean/blz197

Motokawa, M., L.-K. Lin, and K.-H. Lu. 2004. Geographic variation in cranial features of the Polynesian rat Rattus exulans (Peale, 1848) (Mammalia: Rodentia: Muridae). The Raffles Bulletin of Zoology 52(2): 653-663.

Musser, G. G. 1973. Zoogeographical significance of the ricefield rat Rattus argentiventer on Celebes and New Guinea and the identity of Rattus pesticulus. American Museum Novitates 2511: $1-30$

Musser, G. G., and M. D. Carleton. 2005. Family Muridae. In Mammal Species of the World: a Taxonomic and Geographic Reference, ed. D. E. Wilson and D. M. Reeder, pp. 894-1531. Baltimore: The Johns Hopkins University Press.

Nicholls, J. A., and J. J. Austin. 2005. Phylogeography of an east Australian wet-forest bird, the satin bowerbird (Ptilonorhynchus violaceus), derived from mtDNA, and its relationship to morphology. Molecular Ecology 14: 1485-1496. https://doi.org/10.1111/j.1365-294X.2005.02544.x

O'Connor, S., and K. Aplin. 2007. A matter of balance: an overview of Pleistocene occupation history and the impact of the Last Glacial Phase in East Timor and the Aru Islands, eastern Indonesia. Archaeology in Oceania 42(3): 82-90. https://doi.org/10.1002/j.1834-4453.2007.tb00021.x 
Oliveira, N., S. O’Connor, and P. Bellwood. 2019. Dong Son drums from Timor-Leste: prehistoric bronze artefacts in Island Southeast Asia. Antiquity 93: 163-180.

https://doi.org/10.15184/aqy.2018.177

Pages, M., E. Bazin, M. Galan, Y. Chaval, J. Claude, V. Herbreteau, J. Michaux, S. Piry, S. Morand, and J.-F. Cosson. 2013. Cytonuclear discordance among Southeast Asian black rats (Rattus rattus complex). Molecular Ecology 22: 1019-1034. https://doi.org/10.1111/mec.12149

Peakall, R., and P. E. Smouse. 2012. GenAlEx 6.5: genetic analysis in Excel. Population genetic software for teaching and researchan update. Bioinformatics 28: 2537-2539.

https://doi.org/10.1093/bioinformatics/bts460

Phillips, B. L., G. P. Brown, J. K. Webb, and R. Shine. 2006. Invasion and the evolution of speed in toads. Nature 439: 803. https://doi.org/10.1038/439803a

Phillips, B. L., G. P. Brown, M. Greenlees, J. K. Webb, and R. Shine. 2007. Rapid expansion of the cane toad (Bufo marinus) invasion front in tropical Australia. Austral Ecology 32: 169-176. https://doi.org/10.1111/j.1442-9993.2007.01664.x

Pritchard, J. K., M. Stephens, and P. Donnelly. 2000. Inference of population structure using multilocus genotype data. Genetics 155: 945-959.

Reepmeyer, C., S. O'Connor, T. Maloney, and S. Kealy. 2016. Late Pleistocene/early Holocene maritime interaction in Southeastern Indonesia-Timor Leste. Journal of Archaeological Science 76: $21-30$

https://doi.org/10.1016/j.jas.2016.10.007

Reutter, B. A., J. Hausser, and P. Vogel. 1999. Discriminant analysis of skull morphometric characters in Apodemus sylvaticus, A. flavicollis, and A. alpicola (Mammalia; Rodentia) from the Alps. Acta Theriologica 44: 299-308. https://doi.org/10.4098/AT.arch.99-28

R Core Development Team. 2019. R: a Language and Environment for Statistical Computing. Vienna, Austria: R Foundation for Statistical Computing.

Robins, J. H., M. Hingston, E. Matisoo-Smith, and H. A. Ross. 2007. Identifying Rattus species using mitochondrial DNA. Molecular Ecology Notes 7: 717-729. https://doi.org/10.1111/j.1471-8286.2007.01752.x

Rozen, S., and H. J. Skaletsky. 2000. Primer3 on the WWW for general users and for biologist programmers. Methods in Molecular Biology 132: 365-386.

https://doi.org/10.1385/1-59259-192-2:365
Rousset, F. 2008. genepop'007: a complete re-implementation of the genepop software for Windows and Linux. Molecular Ecology Resources 8: 103-106.

https://doi.org/10.1111/j.1471-8286.2007.01931.x

Schwarz, E., and H. Schwarz. 1967. A monograph of the Rattus rattus group. Annals Escuela Nacional Ciencias Biologicas 14: 79-178.

St Pierre, E. J. 2011. U-series Dating and Geochemical Analysis of Speleothems: Developing a Robust Chronological Tool for Cave Deposits and Assessing Late Holocene Human-Environment Interactions in Western Flores, Indonesia. Unpublished Ph.D. thesis. University of Queensland, Brisbane.

Thomson, V., K. P. Aplin, A. Cooper, S. Hisheh, H. Suzuki, I. Maryanto, G. Yap, and S. C. Donnellan. 2014. Molecular genetic evidence for the place of origin of the Pacific Rat, Rattus exulans. PLoS ONE 9(3): e91356. https://doi.org/10.1371/journal.pone.0091356

Thomson, V., A. Wiewel, A. Chinen, I. Maryanto, M. H. Sinaga, R. How, K. Aplin, and H. Suzuki. 2018. A perspective for resolving the systematics of Rattus, the vertebrates with the most influence on human welfare. Zootaxa 4459(3): 431-452. https://doi.org/10.11646/zootaxa.4459.3.2

van der Geer, A. A. E. 2018. Changing invaders: trends of gigantism in insular introduced rats. Environmental Conservation 45: 203-211. https://doi.org/10.1017/S0376892918000085

Veatch, E. G., M. W. Tocheri, T. Sutikna, K. McGrath, E. W. Saptomo, Jatmiko, and K. M. Helgen. 2019. Temporal shifts in the distribution of murine rodent body size classes at Liang Bua (Flores, Indonesia) reveal new insights into the paleoecology of Homo floresiensis and associated fauna. Journal of Human Evolution 130: 45-60. https://doi.org/10.1016/j.jhevol.2019.02.002

West, K., C. Collins, O. Kardailsky, J. Kahn, T. L. Hunt, D. V. Burley, and E. Matisoo-Smith. 2017. The Pacific rat race to Easter Island: tracking the prehistoric dispersal of Rattus exulans using ancient mitochondrial genomes. Frontiers in Ecology and Evolution 5: 52. https://doi.org/10.3389/fevo.2017.00052

Yom-Tov, Y., S. Yom-Tov, and H. Moller. 1999. Competition, coexistence and adaptation among rodent invaders of Pacific and New Zealand islands. Journal of Biogeography 26: 947-958. https://doi.org/10.1046/i.1365-2699.1999.00338.x 


\title{
Reproductive Biology of the Mice and Rats (Family Muridae) in New Guinea-Diversity and Evolution
}

\author{
William G. Breed ${ }^{1}$ iD, Chris M. Leigh ${ }^{2}$, And Eleanor J. Peirce² ${ }^{2}$ \\ ${ }^{1}$ School of Biological Sciences, Faculty of Sciences and Robinson Research Institute, \\ University of Adelaide, Adelaide SA 5005, Australia \\ ${ }^{2}$ Medical School, University of Adelaide, Adelaide SA 5000, Australia
}

\begin{abstract}
In New Guinea there are around 100 species of native rodents in the family Muridae that are members of two tribes, the Hydromyini and Rattini, and five divisions - the Hydromys, Uromys, Mallomys, Pogonomys, and Rattus divisions. Here we review their basic reproductive biology so far as it can be determined from the material available. We find that females of most species in the Hydromys and Uromys divisions have 4 nipples, most species in the Pogonomys division have 6, whereas in the Mallomys division nipple number across species ranges from 2 to 6 , and in the Rattus division from 4 up to 12 . The number of fetuses observed in pregnant individuals in species of all of the hydromyine divisions was generally between 1 and 3 but in three species in the Rattus division up to 6, or even occasionally more, occurs. In males, the relative testes mass (RTM) of most species in the Hydromys, Uromys, Mallomys, and Rattus divisions was usually between 1 and $3 \%$ of body mass, whereas in the Pogonomys division it varied markedly from only around $0.4 \%$ in Hyomys goliath up to $5 \%$ in two species of Pogonomys. The spermatozoa of species in the Hydromys and Uromys divisions, like in the Australian species of these divisions, contained a head with an apical hook together and two ventral processes, whereas in the Pogonomys and Mallomys divisions marked interspecific differences occurred with some having a sperm head with an apical hook and ventral processes but in others there were no ventral processes but a long apical hook. Sperm tail length of most species was generally between 90 and $130 \mu \mathrm{m}$ but Chiruromys and Xenuromys had sperm tail lengths of $150-153 \mu \mathrm{m}$. Male accessory sex glands were generally similar across the species except for that of the preputial glands which appeared to be absent in species of Pogonomys and Chiruromys but very large in Hyomys. The findings of large relative testes mass in Pogonomys and long sperm tails in Chiruromys and Xenuromys suggest selection for high levels of intermale sperm competition and hence multimale breeding systems in these species, whereas the variation in preputial gland size suggest interspecific differences in social organization.
\end{abstract}

\section{Introduction}

Australia, New Guinea and its adjacent land-bridge islands, Sahul, have a unique diversity of mammals with the original mammalian fauna being composed of marsupials and monotremes. However various groups of eutherian mammals also occur with murid rodents first arriving around 6 million years ago in the late Miocene or early Pliocene. Whereas there are, in Australia, around 60 species of native rodents in the family Muridae that make up around $20 \%$ of the current extant mammalian fauna, the number of species of mice and rats in New Guinea is still not known in detail 
although there appears to be at least 100 species (Tate, 1951; Menzies \& Dennis, 1979; Flannery, 1995a, 1995b; Musser \& Carleton, 2005; Aplin, 2006; Musser et al., 2008; Musser \& Lunde, 2009; Helgen, 2005a, 2005b; Helgen \& Helgen, 2009; Helgen et al., 2010; Aplin \& Ford, 2013; Rowe et al., 2008, 2019; Roycroft et al., 2020) with only a few species occurring in both Australia and New Guinea.

\section{Diversity of Australian rodents}

In Australia, there are two major groups of murid rodents - the "Old Endemics", tribe Hydromyini, and the more recently arrived genus Rattus, classified in the tribe Rattini. The Hydromyini are composed of around 10 genera most of which are classified in the Pseudomys and Conilurus "divisions" (use of divisions as a semi-formal taxonomic grouping follows Musser \& Carleton, 2005; Aplin \& Helgen, 2010; Rowe et al., 2019). They vary markedly in body mass from just a few grams in the Delicate Mouse, Pseudomys delicatulus, up to nearly $1 \mathrm{~kg}$ in the case of the Water Rat, Hydromys chrysogaster, and the Giant White-tailed Rat, Uromys caudimaculatus. These species are present in a variety of habitats (see Watts \& Aslin, 1981; Van Dyck \& Strahan, 2008; Breed \& Ford, 2007) although there are only a few species that occur in the rainforest environment with many species having adapted for living in semiarid or arid regions, with the most extreme arid-adapted species being members of the genus Notomys, or hopping mice. These old endemic hydromyine rodents include omnivores, herbivores, folivores, frugivores, and even two aquatic carnivores as in the case of the Water Rat $(H$. chrysogaster) and Water Mouse (Xeromys myoides) (Watts \& Aslin, 1981; Breed \& Ford, 2007; Van Dyck \& Strahan, 2008; Aplin \& Ford, 2013). Studies on the reproductive biology of females of these species have shown that, compared to many other murids, they have comparatively long pregnancies with females of nearly all species having only 4 nipples, which somewhat limits the number of pups that can be raised at any one time. By contrast, males vary greatly in their relative testes mass and thus in the numbers of sperm produced; a finding that suggests a considerable diversity across the species in the intensity of intermale sperm competition and hence breeding system (Kenagy \& Trombulak, 1986; Breed, 1997b; Breed \& Taylor, 2000). This is also suggested by the marked interspecific differences in quantity and quality of sperm produced (Breed, 1997a; McLennan et al., 2017).

In contrast to the "Old Endemics" the members of the genus Rattus include seven species which show much less diversity in body form (Rowe et al., 2011) though they occur in a variety of very different habitats. Females have much shorter gestation lengths than do those of the hydromyine rodents with considerable diversity in litter size, with species living in grasslands and deserts having the highest ovulation rates and potential litter sizes (see Taylor \& Horner, 1973; Breed, 1978; Yom-Tov, 1985; Taylor et al., 1990; Breed \& Ford, 2007; Geffen et al., 2011).

\section{Diversity of New Guinea rodents}

In previous studies of rodent diversity in New Guinea Lidicker (1968) and Lidicker \& Brylski (1987) suggested that there were five major tribes. These were the Hydromyini with species in the genera Hydromys, Leptomys, Paraleptomys, Mayermys, Neohydromys, Pseudohydromys, and Xeromys; the Uromyini, with species in the genera Uromys, Melomys, Coccymys,
Pogonomelomys, and Xenuromys; the Anisomyini which included the "residue" of the old Papuan group in the genera Anisomys, Hyomys, Lorentzimys, Mallomys, Pogonomys, Macruromys, and Chiruromys; the Conilurini with just two, largely Australian, genera, represented by Conilurus penicillatus and Pseudomys delicatulus; and the Rattini, with species of Rattus. Subsequently Watts \& Baverstock (1994) questioned the monophyly of the hydromyin and uromyin clades and included within their Hydromyini the various genera that had previously been placed in both of these groups. These authors suggested that "further clarification" (p. 303) of the position of Lorentzimys, Coccymys, and some Melomys species also needed to be investigated and they suggested that Mallomys "may be misplaced" (p. 303). In more recent decades, New Guinea murines have been subject to considerable clarifying taxonomic review and revision (e.g., Flannery, 1995a, 1995b; Menzies, 1996; Musser \& Carleton, 2005; Helgen, 2005a, 2005b; Musser et al., 2008; Helgen \& Helgen, 2009; Musser \& Lunde, 2009; Helgen et al., 2010), and murine tribes and divisions, including those of the New Guinea species, have been investigated extensively using molecular phylogenetic methods (e.g., see Lecompte et al., 2008; Smissen \& Rowe, 2018; Rowe et al., 2019; Roycroft et al., 2020). In the current study, we follow the systematic arrangement as detailed by Roycroft et al. (2020) which includes the following five divisions and two tribes in New Guinea and adjacent islands.

1 Hydromys division (tribe Hydromyini) with the genera Hydromys, Parahydromys, Baiyankamys, Crossomys, Xeromys, Leptomys, Paraleptomys, Microhydromys, Pseudohydromys, and Mirzamys. Helgen (2005a, 2005b), Helgen \& Helgen (2009), Helgen et al. (2010), and Musser et al. (2008) have recently expanded this division to include a number of new species; additionally Helgen (2005b) showed that Baiyankamys deserves generic recognition, and Helgen \& Helgen (2009) described a new genus, Mirzamys.

2 Uromys division (tribe Hydromyini) with the genera Uromys, Melomys, Paramelomys, Protochromys, and Solomys.

3 Pogonomys division (tribe Hydromyini) with the genera Pogonomys, Hyomys, Chiruromys, Anisomys, and Lorentzimys.

4 Mallomys division (tribe Hydromyini) which includes species in the genera Mallomys, Coccymys, Abeomelomys, Pogonomelomys, and Mammelomys. Musser \& Lunde (2009) revised the genus Coccymys and recognized an additional genus, Brassomys, which likely also belongs in this division.

5 Rattus division (tribe Rattini) with the various species of Rattus.

\section{Aims of current study}

In the current study an overview of the female and male reproductive biology of the rodents from New Guinea is presented. Since many of the species are poorly known, and only a very few have been bred in captivity, knowledge of their reproductive biology is, by necessity, very limited. For females some indication of reproductive potential can be determined from the number of nipples, and the number 
of fetuses found in utero of pregnant specimens, and these data are given here where known. For males an indication of intensity of intermale sperm competition, and hence the breeding system, can be inferred from their relative testes mass (RTM) (Harcourt et al., 1981; Kenagy \& Trombulak, 1986; Parker, 1993, 2016; Birkhead \& Møller, 1998; Gómez Montoto et al., 2011), as well as from some aspects of their sperm head morphology and sperm tail length (see Gomendio \& Roldan, 1991; Immler et al., 2007; Pitnick et al., 2009; Tourmente et al., 2011; Simmons \& Fitzpatrick, 2012; Šandera et al., 2013; Van der Horst \& Maree, 2014; McLennan et al., 2017; Pahl et al., 2018; Peirce et al., 2018). Thus the testes weight and body mass together with the testis organization and sperm morphology will be given here where known. Because the size and abundance of the various male accessory sex organs may also reflect the intensity of postcopulatory sexual selection (Ramm et al., 2005) and/or social organization (Bronson \& Caroom, 1971; Brown \& Williams, 1972; Zhang et al., 2008), these morphological traits are also summarized. Similarities and differences in the reproductive biology of the various species across the five divisions will be discussed and where the data suggest a potential breeding system it will be indicated.

\section{Materials and methods}

Specimens discussed here are vouchered in the mammalogical collections of the Australian Museum, Sydney (AM M.); the Australian National Wildlife Collection, CSIRO, Canberra (ANWC M); the Bernice P. Bishop Museum, Honolulu (BBM-NG); the Queensland Museum, Brisbane (QM JM); and the South Australian Museum (SAM M). Additional, non-vouchered specimens of Hydromys chrysogaster were wild caught in South Australia (see Leigh \& Breed, 2020).

Most of the material used in this study are specimens that had been fixed in formalin, most of which had their body cavity opened, with the consequent fixation of the reproductive organs. For examination the gastrointestinal tract was displaced to one side so that the reproductive tract could be visualized. If the individual was female the uterus was inspected for indication of the presence of fetuses and, when present, the number of swellings recorded.

In scrotal males, one or both testes and epididymides were removed, and testis weight of the individual determined. When one testis was obtained its weight was doubled to give the approximate total testis mass for the individual. To gain some insight into sperm production, histology of the testis was carried out on some individuals and, for this, small pieces of tissue were transferred to $0.1 \mathrm{M}$ buffered formaldehyde/ glutaraldehyde, dehydrated by passing the tissues through a series of alcohols and then embedding in epoxy resin. Sections were cut, at 0.5 to $1 \mu \mathrm{m}$ thickness, with an ultramicrotome and stained with toluidine blue in $0.5 \%$ sodium tetraborate. Some indication of the sperm production within the testes was then determined by ascertaining the relative proportion of seminiferous tubules to interstitial tissue in the testes cross sections by bright field light microscopy linked to an image analysis system.

From most of the males, spermatozoa were extruded from the cauda epididymides into $10 \%$ buffered formaldehyde and then observed by phase contrast or Nomarski optics light microscopy. If the sperm head had an apical hook and/ or ventral processes, the latter of which is a characteristic feature of most species of Australian hydromyine rodents, their approximate lengths were determined by measuring the distance from the base of the apical hook, and when present, the base of the ventral processes, to the tips of these processes as previously indicated in McLennan et al. (2017) and Pahl et al. (2018). The maximum length of the sperm tail was also recorded. Care was taken to only measure intact spermatozoa. Some spermatozoa were stained with $4^{1}-6^{1}$-diamidino-2-phenylindole dihydrochloride (DAPI), Sigma, for fluorescence microscopy using a UV filter performed to determine the shape of the sperm nucleus. Scanning electron microscopy of cauda epididymal spermatozoa from most species was also undertaken (Breed $\&$ Leigh, 2009). For this, sperm were attached to polylysine coated coverslips, dehydrated by passing the coverslips through a graded series of acetones, critical point dried, and coated with $10 \mathrm{~nm}$ of carbon and $5 \mathrm{~nm}$ of platinum. They were subsequently viewed at $20 \mathrm{kV}$ with a Philips XL20 SEM.

Male accessory sex glands from some individuals, including seminal vesicles, coagulating glands, ventral and dorsal prostates, and preputial glands, if present, were also dissected and camera lucida drawings of the accessory sex glands were made, indicating the relationships between the glands from anterior, posterior, and lateral perspectives. These drawings were then used to obtain measurements, when possible, of the maximum length and width of the seminal vesicles, coagulating glands, ventral prostates and preputial glands (Linzey \& Layne, 1969). Since the glands occur in pairs, measurements of each gland were obtained separately from anterior, posterior and/or lateral perspective and the values averaged to give a single measurement of the length and maximum width of the glands of each individual. For the seminal vesicles, measurements of length were taken from the attachment of the gland to the rest of the male reproductive tract, along the midline longitudinal axis, to its tip, following the gland's curvature. The width was taken as the average maximum width of the proximal, uncurved segment of the gland. For the coagulating glands and ventral prostates, the greatest length from the base to the tip, and width across the widest part of the gland, were recorded. Similarly, the size of preputial glands, when present, was also documented.

Male reproductive tracts used came from the following specimens:

\section{Hydromys division}

Hydromys chrysogaster (Hc38, Hc40, Hc41, Hc42, Hc61, Hc58, Hc100) (field numbers from Leigh \& Breed, 2020)

Leptomys elegans (AM M.18618)

Leptomys ernstmayri (AM M.14862)

Parahydromys asper (AM M.17319)

Paraleptomys rufilatus (BBM-NG 104629)

Pseudohydromys pumehanae (AM M.14827, AM M.15324)

Xeromys myoides (ANWC M10844)

\section{Uromys division}

Melomys leucogaster (AM M.14655)

Melomys lutillus (AM M.16396, AM M.18597, ANWC M29326, ANWC M29330, ANWC 
M29331)

Melomys rufescens (AM M.13485, AM M.15177, AM

M.19052, AM M.19053, AM M.21678)

Paramelomys lorentzii (AM M.32089, ANWC M35536)

Paramelomys mollis (ANWC M35526, ANWC M35509)

Paramelomys platyops (AM M.14671, AM M.14828, AM M.16168, AM M.18625, AM M.21682)

Paramelomys rubex (AM M.16252, AM M.24994)

Protochromys fellowsi (ANWC M10141)

Uromys caudimaculatus (AM M.16697, ANWC

M24354, ANWC M29303, QM JM2041)

Uromys anak (AM M.16695)

\section{Pogonomys division}

Anisomys imitator (AM M.13770)

Chiruromys forbesi (AM M.19956, AM M.29318)

Chiruromys lamia (AM M.28325)

Chiruromys vates (AM M.14658, AM M.17172, AM M.18590, AM M.18594)

Hyomys goliath (AM M.18452, AM M.18487)

Lorentzimys nouhuysi (AM M.13778, ANWC M35465, ANWC M35850)

Pogonomys championi (AM M.13463, AM M.13502, AM M.13719, AM M.17721)

Pogonomys loriae (AM M.13792, AM M.13828, AM M.15119, AM M.15126, AM M.15127, ANWC M35897, ANWC M35898)

Pogonomys macrourus (AM M.13802, AM M.15137, AM M.15149, AM M.24974, AM M.30295,)

Pogonomys sylvestris (ANWC M25472, AM M.2832, ANWC M29428, ANWC M29430, ANWC M29432)

\section{Mallomys division}

Abeomelomys sevia (AM M.13465)

Mallomys aroaensis (AM M.17362)

Mammelomys rattoides (ANWC M35847, BBM-NG 22308)

Mammelomys lanosus (BBM-NG 100148)

Xenuromys barbatus (AM M.17363, AM M.17703)

Coccymys shawmayeri (BBM-NG 100673)

\section{Rattus division}

Rattus leucopus (AM M.13934, AM M.14686, ANWC M35541, ANWC M35545, QM JM2388, QM JM974)

Rattus niobe (AM M.14710, AM M.14714, AM M.21689, ANWC M35545, ANWC M35541)

Rattus praetor (ANWC M35881, ANWC M35885)

Rattus sordidus (ANWC M29343, ANWC M29354, QM JM1392)

Rattus steini (AM M.14651, AM M.14880, ANWC M35887, ANWC M14880)

Rattus verecundus (ANWC M14832, SAM M15124)

\section{Results \\ Female reproductive biology}

The number of nipples recorded in the literature for each species is summarized in Table 1. The data show that there are considerable interspecific differences across the divisions in the number of nipples present (see Fig. 1).

Nearly all females of species in the Hydromys and Uromys divisions have 4 nipples, all of which were inguinally located, with the one exception being Pseudohydromys patriciae, which had only 2 inguinal nipples.

All species in the Pogonomys division have 6 nipples, with a pair of pectoral nipples in addition to the 2 pairs of inguinal nipples, except the species of Hyomys and Macruromys, which have 4, with 2 pairs of inguinal nipples.

The Mallomys division shows the greatest variation in nipple number. Species of Mammelomys have only 2 nipples. Abeomelomys and Pogonomelomys have 4. Species of Mallomys, Coccymys, and Xenuromys have 6, with a pair of pectoral nipples in addition to the 2 pairs of inguinal nipples.

Species in the Rattus division (genus Rattus), also showed marked interspecific differences in nipple number which ranged from 4 in Rattus vandeuseni, to 6 in R. leucopus, $R$. niobe, Rattus omichlodes, and $R$. verecundus, 8 in most species of New Guinea Rattus, and up to 12, with 3 pairs of pectoral as well as 3 pairs of inguinal, nipples in $R$. sordidus (see Table 1, Fig. 1). In R. steini and R. jobiensis the number reported varies from 6 to 8 (Flannery, 1995a, 1995b).

Is this difference in nipple number reflected in the number of fetuses in the uteri of pregnant individuals of these species? The results show that most pregnant individual members of the Hydromys and Uromys divisions had only 1 or 2 fetuses although in Melomys lutillus and M. rufescens, as well as $H$. chrysogaster, and the two Uromys species, 3 or even occasionally 4 , occurred (see Table 1, Fig. 2). In the Pogonomys division, amongst the species with 6 nipples, individuals of 3 species of Pogonomys and one species of Chiruromys species had up to 3 fetuses with a few others having just 1 or 2 , whereas only one fetus was present in the pregnant Mallomys and Hyomys individuals in spite of having 6 nipples. Similarly in the pregnant Mammelomys rattoides, which has 2 nipples, only a single fetus occurred. Rattus species with 6 or 8 nipples had an average of 2 to 4 fetuses, whereas in $R$. sordidus up to 9 fetuses have been recorded as being present although only 2 were present in the pregnant individual that we dissected (see Table 1, Fig. 2).

\section{Male reproductive biology}

Relative testes mass (RTM) in members of the Hydromys and Uromys divisions was generally similar across species and ranged from 0.8 to $2.9 \%$ of body mass (see Table 2 ). In the Pogonomys division a considerably greater range of RTM occurred across the species (see Fig. 3, Table 2), with small-bodied species like Pogonomys macrourus and $P$. championi tending to have a very large relative testes mass around $5 \%$ of body mass. By contrast, in a sexually mature Hyomys goliath specimen the RTM was just $0.4 \%$. In the Mallomys division RTM ranged from 0.8 to $2.4 \%$, and in the Rattus division from 1.1 to $3.0 \%$ (see Table 2, Fig. 3).

The percentage of the testis occupied by the sperm producing seminiferous tubules varied from $71-76 \%$ in Hydromys chryogaster and Mallomys aroaensis to over 


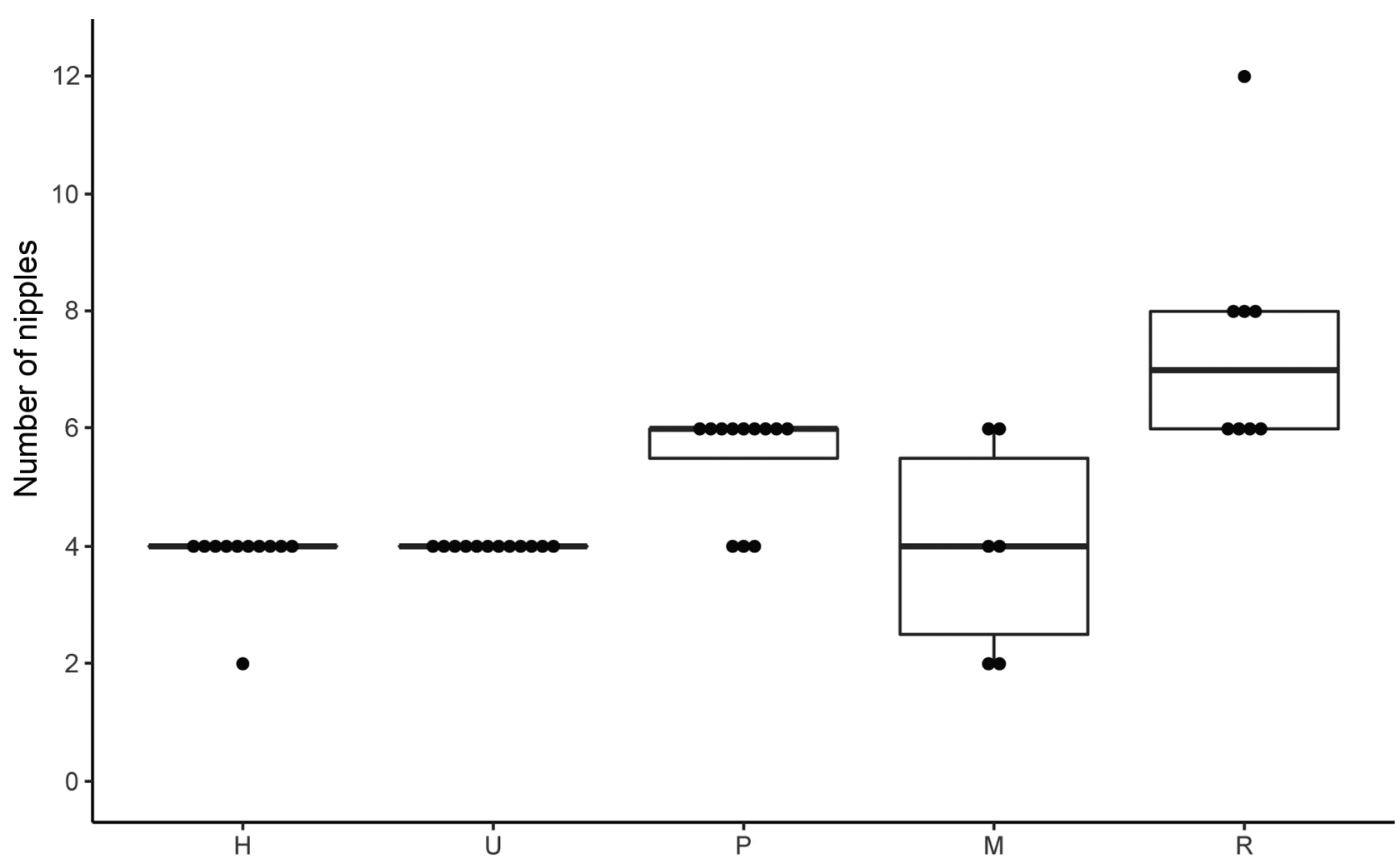

Figure 1. Boxplot showing nipple numbers for species in the divisions (H) Hydromys, (U) Uromys, (P) Pogonomys, (M) Mallomys, and (R) Rattus.

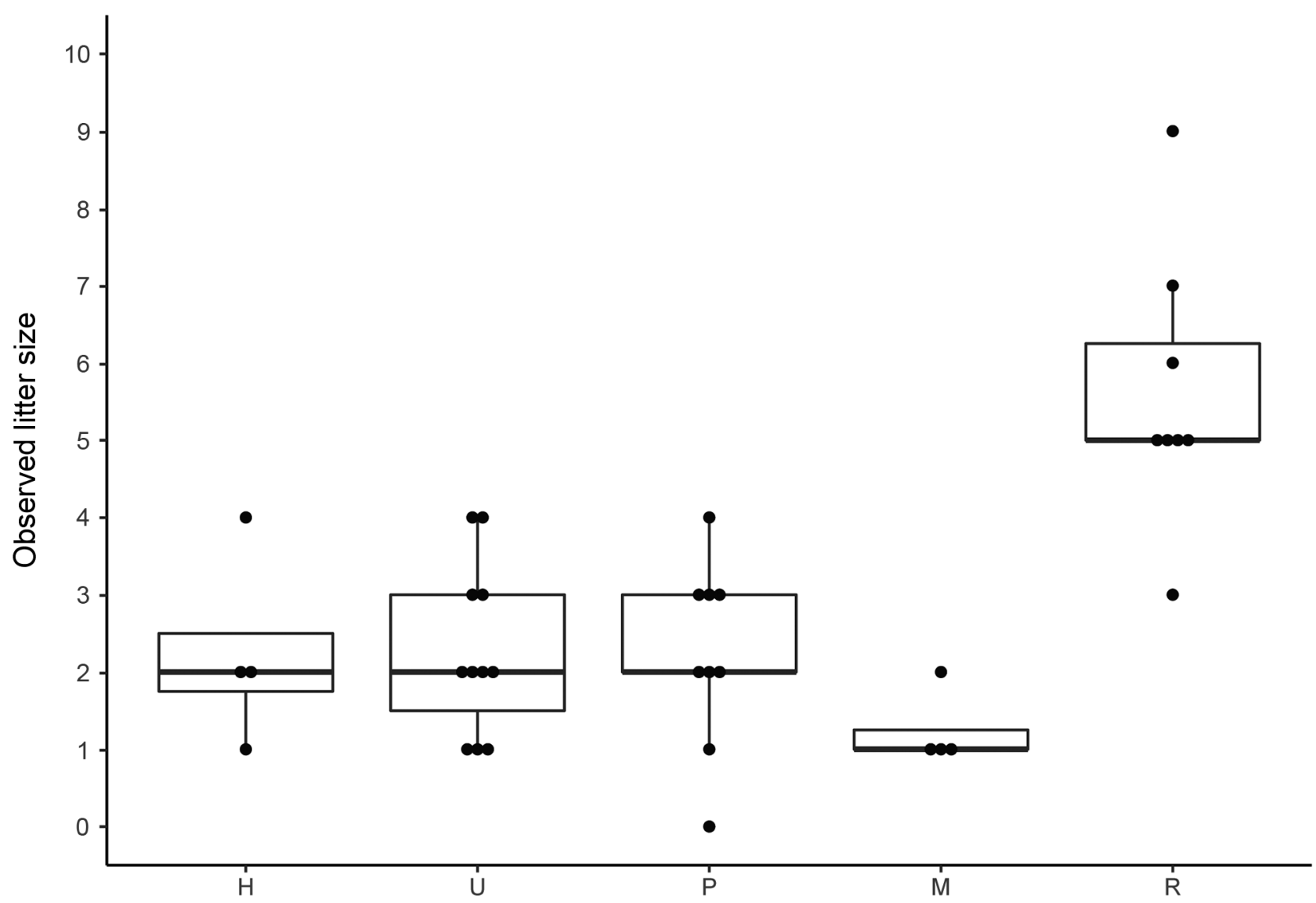

Figure 2. Boxplot showing maximum numbers of fetuses across the species in the divisions (H) Hydromys, (U) Uromys, (P) Pogonomys, (M) Mallomys, and (R) Rattus. 


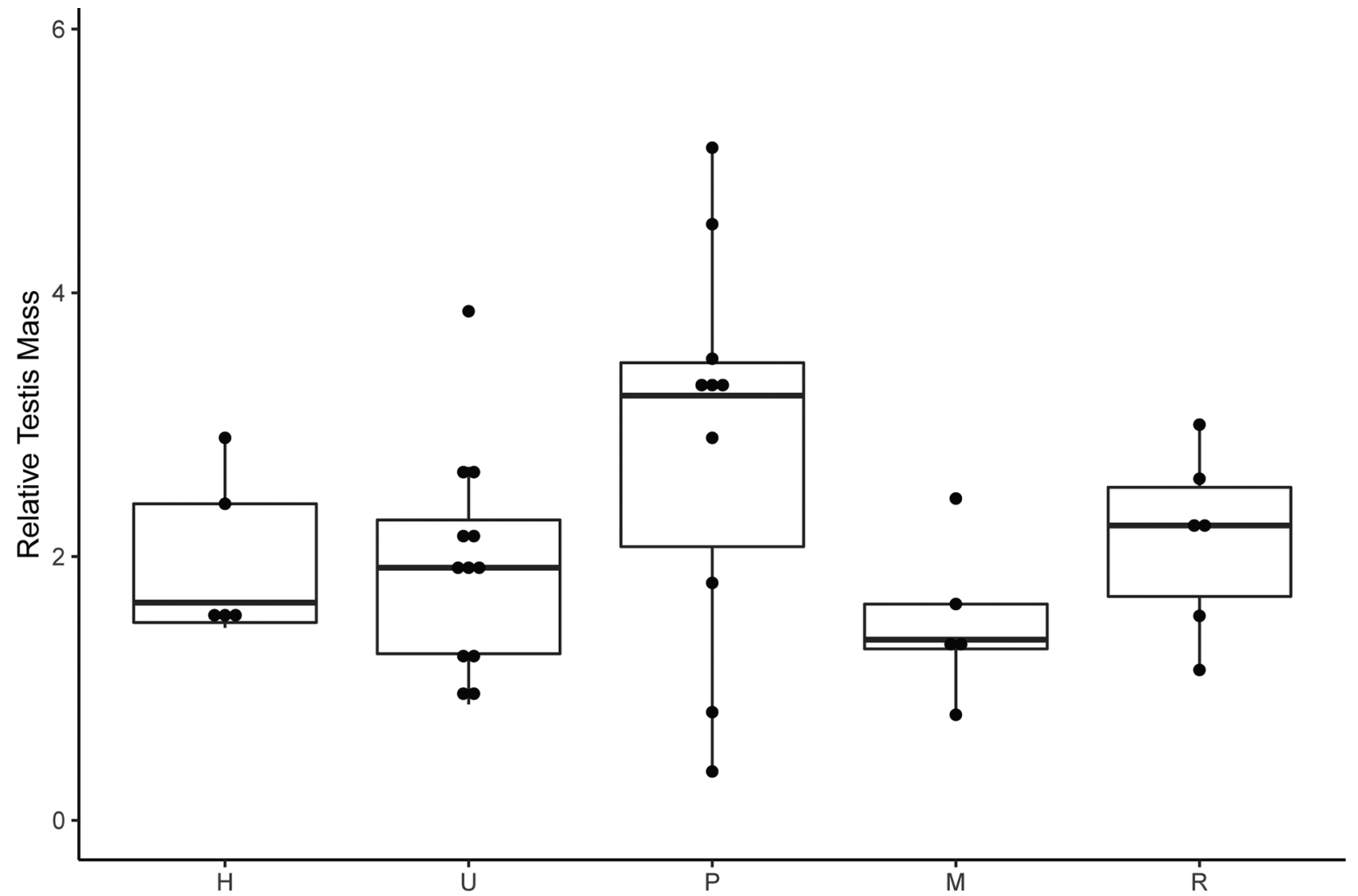

Figure 3. Boxplot of relative testes mass $(\mathrm{g})$ for species in the divisions (H) Hydromys, $(\mathrm{U})$ Uromys, (P) Pogonomys, (M) Mallomys, and (R) Rattus.

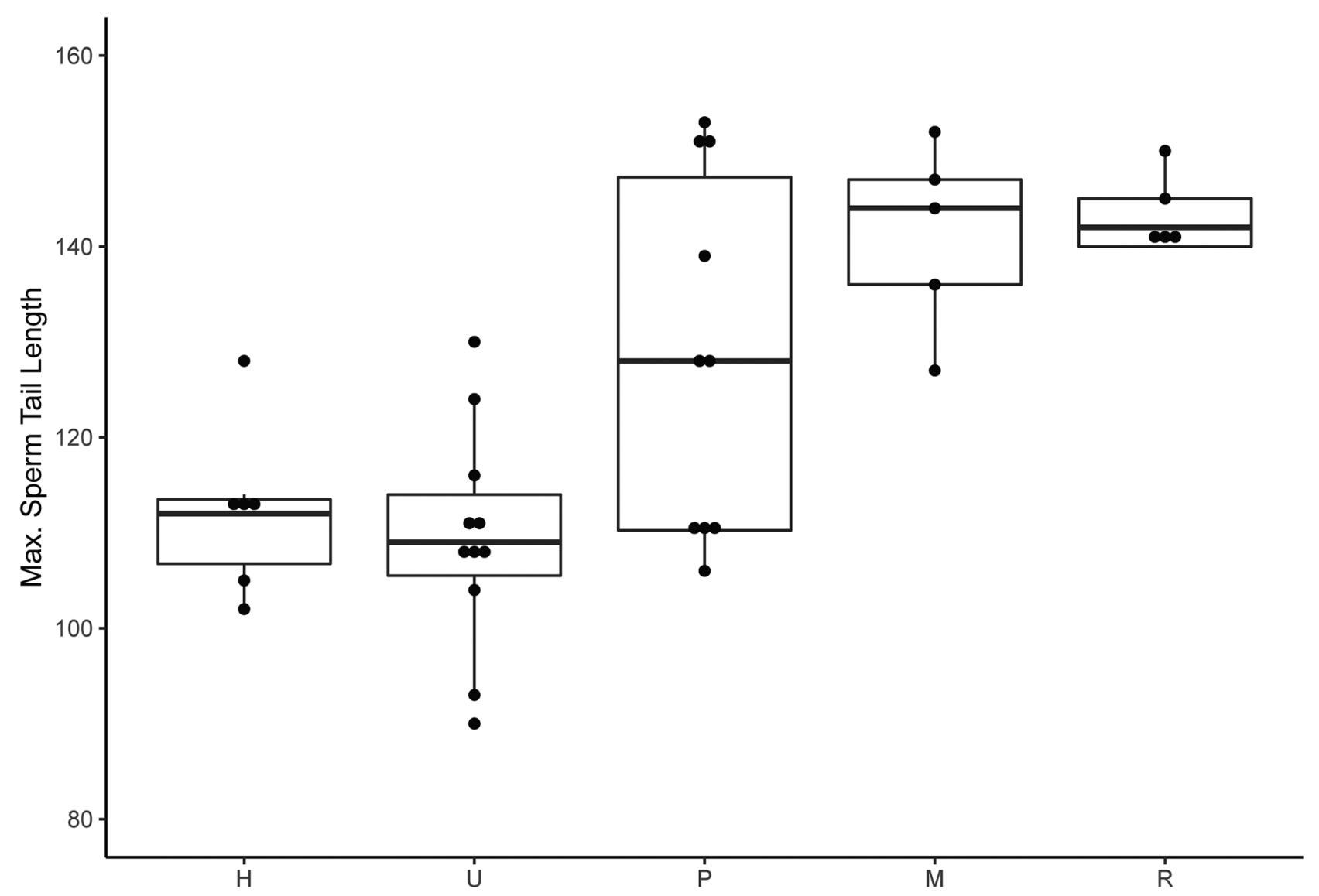

Figure 4. Boxplot of maximum sperm tail length $(\mu \mathrm{m})$ for species in the divisions (H) Hydromys, (U) Uromys, (P) Pogonomys, (M) Mallomys, and (R) Rattus. 
Table 1. Data on female reproductive morphology of New Guinea rodents. Average and range of body mass, number of nipples (with number of pairs of pectoral and inguinal nipples given in brackets), and female fetal number where known (as quoted in the literature). Data for number of fetuses of dissected specimens at the Australian National Wildlife Collection, Canberra (ANWC) and the South Australian Museum, given with specimen numbers (e.g., 2F- $=2$ fetuses).

\begin{tabular}{|c|c|c|c|c|c|}
\hline species & tribe & division & body mass $(\mathrm{g})$ & number of nipples & female fetal number \\
\hline Hydromys chrysogaster & Hydromyini & Hydromys & $700 \pm 14$ & $4(0+2)$ & up to 4,2 F-M35849 \\
\hline Parahydromys asper & Hydromyini & Hydromys & 540 & $4(0+2)$ & 2 \\
\hline Crossomys moncktoni & Hydromyini & Hydromys & 165 & $4(0+2)$ & - \\
\hline Microhydromys spp. & Hydromyini & Hydromys & - & $4(0+2)$ & - \\
\hline Baiyankamys shawmayeri & Hydromyini & Hydromys & $78 \pm 7.4$ & $4(0+2)$ & - \\
\hline Leptomys erstmayeri & Hydromyini & Hydromys & 42 & $4(0+2)$ & 1 \\
\hline Leptomys elegans & Hydromyini & Hydromys & $80,66-90$ & $4(0+2)$ & av. $1.75,1$ \\
\hline Pseudohydromys pumahanae & Hydromyini & Hydromys & $17 \pm 3$ & $4(0+2)$ & - \\
\hline Pseudohydromys patriciae & Hydromyini & Hydromys & 22 & $2(0+1)$ & - \\
\hline Mirzamys louiseae & Hydromyini & Hydromys & - & $4(0+2)$ & - \\
\hline Xeromys myoides & Hydromyini & Hydromys & 42 & $4(0+2)$ & - \\
\hline Melomys leucogaster & Hydromyini & Uromys & $65-156$ & $4(0+2)$ & 2 \\
\hline Melomys rufescens & Hydromyini & Uromys & c. $60,54 \pm 6$ & $4(0+2)$ & av. $2,(1-4)$ \\
\hline Melomys lutillus & Hydromyini & Uromys & $30-40$ & $4(0+2)$ & av. 2.2 , 3F-M29329 \\
\hline Protochromys fellowsi & Hydromyini & Uromys & - & $4(0+2)$ & - \\
\hline Paramelomys moncktoni & Hydromyini & Uromys & c. 100 & $4(0+2)$ & 2 \\
\hline Paramelomys mollis & Hydromyini & Uromys & $85,72-97$ & $4(0+2)$ & 1 \\
\hline Paramelomys lorentzii & Hydromyini & Uromys & $130-150$ & $4(0+2)$ & 1, 1F-M35529 \\
\hline Paramelomys platyops & Hydromyini & Uromys & $65-80$ & $4(0+2)$ & 1 \\
\hline Paramelomys rubex & Hydromyini & Uromys & c. $48,52 \pm 6$ & $4(0+2)$ & 2, 2F-M15119 \\
\hline Paramelomys levipes & Hydromyini & Uromys & $100-130$ & $4(0+2)$ & $1-2$ \\
\hline Uromys caudimaculatus & Hydromyini & Uromys & $450-695$ & $4(0+2)$ & av. 2.5 \\
\hline Uromys anak & Hydromyini & Uromys & 450 & $4(0+2)$ & 4 \\
\hline Chiruromys vates & Hydromyini & Pogonomys & $23-68$ & $6(1+2)$ & 1F-M15108, 2F-M15109 \\
\hline Chiruromys forbesi & Hydromyini & Pogonomys & - & $6(1+2)$ & $1-3,1 \mathrm{~F}-\mathrm{M} 2815$ \\
\hline Chiruromys lamia & Hydromyini & Pogonomys & $40-48$ & $6(1+2)$ & - \\
\hline Hyomys goliath & Hydromyini & Pogonomys & 882 & $4(0+2)$ & 1 \\
\hline Pogonomys loriae & Hydromyini & Pogonomys & $70-128$ & $6(1+2)$ & $2-3$ \\
\hline Pogonomys macrourus & Hydromyini & Pogonomys & $35-56$ & $6(1+2)$ & $1-3$ \\
\hline Pogonomys championi & Hydromyini & Pogonomys & $41-59$ & $6(1+2)$ & 2 \\
\hline Pogonomys sylvestris & Hydromyini & Pogonomys & $38 \pm 5$ & $6(1+2)$ & $2-3$ \\
\hline Macruromys elegans & Hydromyini & Pogonomys & - & $4(0+2)$ & - \\
\hline Macruromys major & Hydromyini & Pogonomys & 350 & $4(0+2)$ & - \\
\hline Anisomys imitator & Hydromyini & Pogonomys & $500-525$ & $6(1+2)$ & - \\
\hline Lorentzimys nouhuysi & Hydromyini & Pogonomys & $12-22$ & $6(1+2)$ & 2 \\
\hline Xenuromys barbatus & Hydromyini & Mallomys & 1000 & $6(1+2)$ & - \\
\hline Abeomelomys sevia & Hydromyini & Mallomys & $52,60-66$ & $4(0+2)$ & 1 \\
\hline Mallomys rothschildi & Hydromyini & Mallomys & $925-1500$ & $6(1+2)$ & 1 \\
\hline Mammelomys lanosus & Hydromyini & Mallomys & 112 & $2(0+1)$ & - \\
\hline Mammelomys rattoides & Hydromyini & Mallomys & $172-236$ & $2(0+1)$ & 1F-M35841 \\
\hline Pogonomelomys mayeri & Hydromyini & Mallomys & 110 & $4(0+2)$ & 2 \\
\hline Coccymys shawmayeri & Hydromyini & Mallomys & 26 & $6(1+2)$ & - \\
\hline Rattus niobe & Rattini & Rattus & $36-50$ & $6(1+2)$ & av. $2(1-3)$ \\
\hline Rattus verecundus & Rattini & Rattus & $55 \pm 6$ & $6(1+2)$ & av. $2.8(1-5)$ \\
\hline Rattus steini & Rattini & Rattus & $110-220$ & $8(2+2) \& 6(1+2)$ & av. $3.4(2-5)$ \\
\hline Rattus leucopus & Rattini & Rattus & $175-315$ & $6(1+2)$ & av. 3.5 (2-5), 4F-M29321 \\
\hline Rattus novaeguinae & Rattini & Rattus & 129 & $8(2+2)$ & av. $5(4-6)$ \\
\hline Rattus sordidus & Rattini & Rattus & c. 100 & $12(3+3)$ & av. 6 (2-9), 2F-M29339 \\
\hline Rattus jobiensis & Rattini & Rattus & - & $8(2+2) \& 6(1+2)$ & - \\
\hline Rattus vandeuseni & Rattini & Rattus & - & $4(0+2)$ & - \\
\hline
\end{tabular}

Data sourced from: Dwyer, 1975; Flannery, 1995a, 1995b; Helgen \& Helgen, 2009; Helgen, 2005a, 2005b; Helgen, 2007; Helgen et al., 2010; Jackson \& Woolley, 1993; McPhee, 1988; Menzies \& Dennis, 1979; Menzies, 1996; Musser \& Lunde, 2009; Musser et al., 2008; Olson, 1982; Taylor \& Horner, 1973 ; Taylor et al., 1990 ; and Woolley \& Furby, 1996.

90\% in several species with small body mass (Paramelomys platyops, P. rubex, Chiruromys vates, C. lamia, and Lorentzimys nouhuysi), all having at least $92 \%$ of the relative area of the testis occupied by seminiferous tubules (Table 2).

The morphology of the spermatozoon also differed markedly across the species in the various divisions (Figs 5-8). Nevertheless, in members of the Hydromys division it was very similar across the species with the sperm head having both an apical hook and two ventral processes extending from its upper concave surface which were a little longer in Leptomys and Paraleptomys (Fig. 5a, Table 2) with the length of the sperm tail ranging from $102-128 \mu \mathrm{m}$ (see Fig. 4, Table 2). In members of the Uromys division, similar sperm morphology with a sperm head having an apical hook and two ventral processes also invariably occurred with the length of the apical hook and ventral processes generally 
Table 2. Data on male reproductive morphology of New Guinea rodents. Abbreviations: $H$ - tribe Hydromyini or Hydromys division, $M$ - Mallomys division, $P$-Pogonomys division, $R$ - tribe Rattini or Rattus division, $U$ —Uromys division (see Roycroft et al., 2020). Data of Hydromys chrysogaster, Xeromys myoides, and Uromys caudimaculatus were from Australian specimens.

\begin{tabular}{|c|c|c|c|c|c|c|c|c|c|c|c|c|c|}
\hline \multirow[b]{2}{*}{ 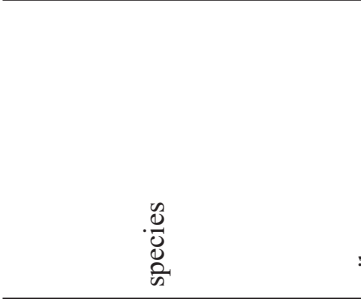 } & \multirow[b]{2}{*}{$\stackrel{8}{\Xi}$} & \multirow[b]{2}{*}{. } & \multirow{2}{*}{ 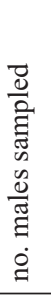 } & \multirow{2}{*}{ 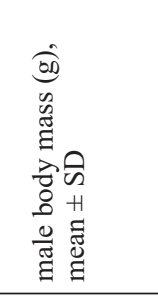 } & \multirow{2}{*}{ 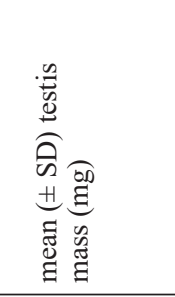 } & \multirow{2}{*}{ 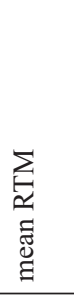 } & \multirow{2}{*}{ 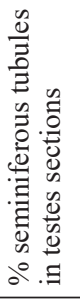 } & \multirow{2}{*}{ 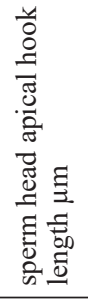 } & \multirow{2}{*}{ 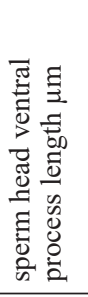 } & \multirow{2}{*}{ 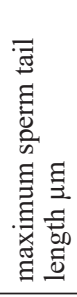 } & \multicolumn{3}{|c|}{$\begin{array}{c}\text { mean accessory sex glands, } \\
\text { length } \times \text { width }(\mathrm{mm})\end{array}$} \\
\hline & & & & & & & & & & & $\begin{array}{l}\text { seminal } \\
\text { vesicles }\end{array}$ & $\begin{array}{l}\text { coagulating } \\
\text { glands }\end{array}$ & $\begin{array}{c}\text { ventral } \\
\text { prostates }\end{array}$ \\
\hline Hydromys chrysogaster & $\mathrm{H}$ & $\mathrm{H}$ & 4 & $804 \pm 53$ & $13780 \pm 2320$ & 1.7 & 71.2 & 2 & 2 & 112 & - & - & - \\
\hline Parahydromys asper & $\mathrm{H}$ & $\mathrm{H}$ & 1 & 490 & 7152 & 1.46 & - & $2.5-3$ & $2.5-3$ & 112 & $32.7 \times 6.9$ & $12.5 \times 4.0$ & $7.4 \times 6.5$ \\
\hline Leptomys spp. & $\mathrm{H}$ & $\mathrm{H}$ & 2 & $61 \pm 12$ & $1432 \pm 271$ & 2.4 & - & 5 & 4 & 128 & $19.7 \times 4.6$ & $7.9 \times 3.0$ & $5.9 \times 4.0$ \\
\hline Paraleptomys rufilatus & $\mathrm{H}$ & $\mathrm{H}$ & 1 & 54 & 440 & 0.81 & 一 & 5 & 4 & 105 & - & - & - \\
\hline Pseudohydromys pumehanae & $\mathrm{H}$ & $\mathrm{H}$ & 2 & $19 \pm 2$ & $539 \pm 142$ & 2.9 & - & 2.5 & 2.5 & 114 & $24.0 \times 4.8$ & $5.7 \times 2.5$ & $5.5 \times 2.7$ \\
\hline Xeromys myoides & $\mathrm{H}$ & $\mathrm{H}$ & 1 & 34 & 568 & 1.65 & 89.6 & 3.5 & 2.5 & 102 & - & - & - \\
\hline Melomys leucogaster & $\mathrm{H}$ & $\mathrm{U}$ & 1 & 104 & 1102 & 1.04 & 87 & 3 & 3 & 104 & - & - & - \\
\hline Melomys rufescens & $\mathrm{H}$ & U & 5 & $71 \pm 15$ & $1341 \pm 521$ & 1.74 & - & 3 & 2.5 & 112 & $34.2 \times 7.6$ & $14.3 \times 5.0$ & $10.6 \times 5.1$ \\
\hline Melomys lutillus & $\mathrm{H}$ & $\mathrm{U}$ & 5 & $40 \pm 14$ & $806 \pm 131$ & 2.09 & - & 2.5 & 2.5 & 109 & $25.1 \times 5.2$ & $9.5 \times 3.6$ & $7.4 \times 5.5$ \\
\hline Paramelomys mollis & $\mathrm{H}$ & $\mathrm{U}$ & 2 & $118 \pm 42$ & $2386 \pm 48$ & 2.17 & 一 & 3 & 3 & 107 & - & - & - \\
\hline Paramelomys lorentzii & $\mathrm{H}$ & $\mathrm{U}$ & 2 & $129 \pm 9.2$ & $2476 \pm 746$ & 1.92 & - & 4 & 2.5 & 130 & $35.5 \times 10.4$ & $15.7 \times 5.9$ & $7.9 \times 4.3$ \\
\hline Paramelomys platyops & $\mathrm{H}$ & U & 5 & $90 \pm 14$ & $1670 \pm 447$ & 1.93 & 92.4 & 3 & 3 & 110 & $33.2 \times 6.2$ & $15.1 \times 5.7$ & $8.0 \times 4.1$ \\
\hline Paramelomys rubex & $\mathrm{H}$ & $\mathrm{U}$ & 2 & $80 \pm 28$ & $1847 \pm 35$ & 2.59 & 94.4 & 2.5 & 2.5 & 108 & $29.3 \times 6.1$ & $12.0 \times 5.7$ & $9.2 \times 4.4$ \\
\hline Protochromys fellowsi & $\mathrm{H}$ & U & 1 & 132 & 1600 & 1.21 & - & 3 & 2.5 & - & - & - & - \\
\hline Uromys caudimaculatus & $\mathrm{H}$ & U & 4 & $825 \pm 162$ & $7440 \pm 1445$ & 0.93 & 90 & 5 & 5 & 90 & $56.8 \times 9.1$ & $23.0 \times 6.9$ & $14.3 \times 5.9$ \\
\hline Uromys anak & $\mathrm{H}$ & U & 1 & 879 & 11592 & 1.31 & - & 3 & 2.5 & 93 & $76.4 \times 13.0$ & $31.1 \times 8.3$ & $13.7 \times 7.6$ \\
\hline Chiruromys vates & $\mathrm{H}$ & $\mathrm{P}$ & 4 & $45 \pm 3.5$ & $1557 \pm 187$ & 3.63 & 93.8 & 3 & 2.5 & 152 & $29.0 \times 5.3$ & $12.6 \times 5.0$ & $6.9 \times 4.6$ \\
\hline Chiruromys forbesi & $\mathrm{H}$ & $\mathrm{P}$ & 2 & $112 \pm 13$ & $2082 \pm 391$ & 1.8 & - & 2.5 & 2.5 & 150 & $34.5 \times 5.9$ & $15.1 \times 5.4$ & $6.0 \times 3.4$ \\
\hline Chiruromys lamia & $\mathrm{H}$ & $\mathrm{P}$ & 1 & 120 & 2292 & 1.91 & 93.1 & 2.5 & 2.5 & 153 & $24.0 \times 4.1$ & $10.4 \times 3.6$ & $5.3 \times 3.2$ \\
\hline Hyomys goliath & $\mathrm{H}$ & $\mathrm{P}$ & 2 & $1000 \pm 10$ & $3751 \pm 1091$ & 0.38 & 86.4 & 5.5 & 0 & 128 & $66.6 \times 9.6$ & $20.9 \times 5.6$ & $20.7 \times 8.5$ \\
\hline Pogonomys macrourus & $\mathrm{H}$ & $\mathrm{P}$ & 5 & $49 \pm 8.4$ & $2462 \pm 356$ & 5.14 & 88.7 & 3 & 3 & 110 & $32.5 \times 7.5$ & $10.6 \times 3.2$ & $7.7 \times 4.5$ \\
\hline Pogonomys championi & $\mathrm{H}$ & $\mathrm{P}$ & 2 & $53 \pm 1.4$ & $2097 \pm 117$ & 5.16 & - & 3 & 3 & 106 & $28.7 \times 6.9$ & $11.3 \times 4.2$ & $6.2 \times 3.4$ \\
\hline Pogonomys sylvestris & $\mathrm{H}$ & $\mathrm{P}$ & 4 & $50 \pm 7.4$ & $1556 \pm 239$ & 3.12 & 85.3 & 3 & 3 & 111 & $23.0 \times 4.5$ & $9.0 \times 2.9$ & $4.5 \times 2.5$ \\
\hline Pogonomys loriae & $\mathrm{H}$ & $\mathrm{P}$ & 6 & $104.8 \pm 11.4$ & $3483 \pm 657$ & 3.31 & 85.8 & 2 & 2 & 110 & $30.7 \times 6.8$ & $11.4 \times 3.8$ & $8.0 \times 4.6$ \\
\hline Anisomys imitator & $\mathrm{H}$ & $\mathrm{P}$ & 1 & 508 & 4167 & 0.82 & - & 5 & 0 & 139 & - & - & - \\
\hline Lorentzimys nouhuysi & $\mathrm{H}$ & $\mathrm{P}$ & 3 & $17 \pm 1.3$ & $403 \pm 82$ & 2.35 & 92.8 & 5 & 0 & 128 & $13.6 \times 2.9$ & $7.2 \times 2.5$ & $3.4 \times 2.4$ \\
\hline Abeomelomys sevia & $\mathrm{H}$ & M & 1 & 52 & 854 & 1.64 & - & 7 & 0 & 144 & - & - & - \\
\hline Mallomys aroaensis & $\mathrm{H}$ & M & 1 & 1087 & 14350 & 1.37 & 76.7 & 6 & 4 & 147 & $60.5 \times 14.0$ & $17.6 \times 4.3$ & $15.3 \times 8.2$ \\
\hline Mammelomys lanosus & $\mathrm{H}$ & M & 1 & 123 & 3004 & 2.44 & 83.6 & 6 & 0 & 136 & - & - & - \\
\hline Mammelomys rattoides & $\mathrm{H}$ & M & 2 & $216 \pm 1.4$ & $1621 \pm 30$ & 0.8 & - & 6 & 0 & 127 & $24.5 \times 4.7$ & $7.6 \times 3.2$ & $9.1 \times 5.5$ \\
\hline Xenuromys barbatus & $\mathrm{H}$ & M & 2 & $1000 \pm 141$ & $18941 \pm 14$ & 1.8 & - & 7 & 0 & 152 & $43.8 \times 10.2$ & $10.5 \times 6.0$ & $10.4 \times 5.7$ \\
\hline Coccymys shawmayeri & $\mathrm{H}$ & $\mathrm{M}$ & 1 & - & - & - & - & 5 & 0 & 124 & - & - & - \\
\hline Rattus niobe & $\mathrm{R}$ & $\mathrm{R}$ & 5 & $47 \pm 6$ & $1450 \pm 698$ & 3 & - & 6 & 0 & 140 & $25.8 \times 4.9$ & $10.6 \times 4.0$ & $8.9 \times 4.8$ \\
\hline Rattus verecundus & $\mathrm{R}$ & $\mathrm{R}$ & 1 & 100 & 1984 & 1.98 & & 6 & 0 & 145 & $25 \times 4.3$ & $10.7 \times 3.8$ & $7.4 \times 0$ \\
\hline Rattus steini & $\mathrm{R}$ & $\mathrm{R}$ & 3 & $88 \pm 22$ & $1045 \pm 334$ & 1.33 & - & 6 & 0 & 150 & - & - & - \\
\hline Rattus leuсориs & $\mathrm{R}$ & $\mathrm{R}$ & 4 & $146 \pm 51$ & $3289 \pm 922$ & 2.26 & - & 6 & 0 & 140 & - & - & - \\
\hline Rattus sordidus & $\mathrm{R}$ & $\mathrm{R}$ & 3 & $162 \pm 12$ & $2170 \pm 1204$ & 1.8 & - & 6 & 0 & 142 & - & - & - \\
\hline Rattus praetor & $\mathrm{R}$ & $\mathrm{R}$ & 2 & $193 \pm 7$ & $3094 \pm 1436$ & 1.55 & - & - & - & - & - & - & - \\
\hline
\end{tabular}

being $2.5-3.5 \mu \mathrm{m}$ (Figs $5 \mathrm{~b}, 6 \mathrm{~b}-\mathrm{d}$; Table 2) although a slightly longer apical hook and ventral processes of $5 \mu \mathrm{m}$ was present in Uromys caudimaculatus (Fig. 6e) whereas the sperm tail ranged from $90-130 \mu \mathrm{m}$ (see Table 2).

In members of the Pogonomys division there were, by contrast, marked interspecific differences in sperm head morphology as well as in sperm tail length. All species of Pogonomys and Chiruromys had, like the species in the Hydromys and Uromys divisions, a sperm head with two ventral processes as well as an apical hook (Figs 6f, 7a-d) with the overall shape of the sperm head being longer and narrower in Chiruromys vates than the others (Fig. 7a). Other species in this division such as Hyomys goliath (Fig. 7e), Anisomys imitator (Fig. 5f), and Lorentizimys nouhuysi (Fig. $8 \mathrm{a})$, had a sperm head that totally lacked the ventral processes although, in $H$. goliath, a short ventral spike extending from the lower ventral surface was evident (see Fig. 7e). The length of the sperm tail across these species was generally 106-130 $\mu \mathrm{m}$ but in the three Chiruromys species a longer sperm tail of $150 \mu \mathrm{m}$ to $153 \mu \mathrm{m}$ was present (Fig. 3, Table 2).

In the Mallomys division neither the sperm head of Mammelomys (Fig. 8b-c) nor those of Xenuromys barbatus (Fig. 8e), Coccymys shawmayeri (Fig. 8d), or Abeomelomys sevia (Fig. 5e) had ventral processes but the apical hook was generally longer than in species in the other divisions with the longest apical hook occurring in X. barbatus (Fig. 8e). In Mallomys aroaensis a uniquely shaped sperm head with a deep invagination at the site of sperm tail attachment occurred with the ventral extensions extending more caudally than in the other species (see Fig. 7f). The length of the sperm tails ranged from $124 \mu \mathrm{m}$ in Coccymys up to $152 \mu \mathrm{m}$ in Xenuromys (Fig. 4). 

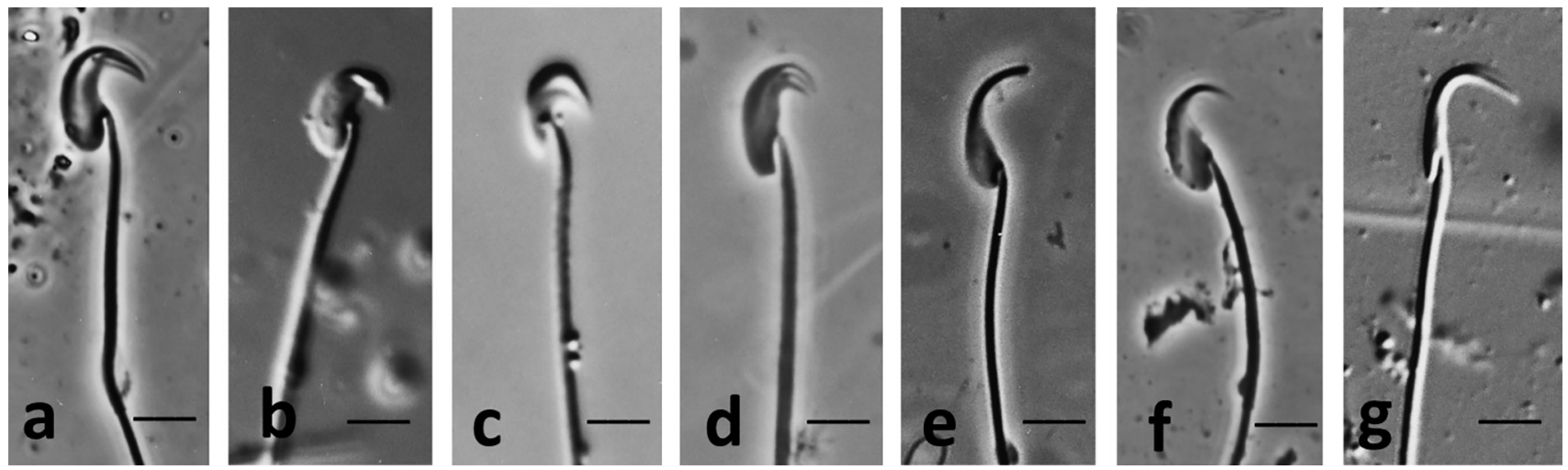

Figure 5. Light micrographs of spermatozoa from (a) Leptomys elegans, (b) Melomys rufescens, $(c)$ Pogonomys championi, $(d)$ Pogonomys loriae, (e) Abeomelomys sevia, $(f)$ Anisomys imitator, and $(g)$ Rattus steini. Scale bars $\mathrm{a}=4 \mu \mathrm{m}, \mathrm{b}-\mathrm{g}=5 \mu \mathrm{m}$.

All members of the Rattus division had very similar sperm head morphology with a single, comparatively long, apical hook of about $6 \mu \mathrm{m}$ (Fig. 8f) into which the nucleus extended whereas the length of the sperm tails ranged from $140-150 \mu \mathrm{m}$ (see Fig. 4, Table 2).

The accessory sex glands (Table 2) invariably included large saccular seminal vesicles together with coagulating glands lying along the inner curvature of the seminal vesicles with the distal region of the coagulating gland being embraced by a subterminal flexure of the seminal vesicle (Fig. 9a-b). However, uniquely, the seminal vesicles of Hyomys goliath appeared less saccular and the coagulating gland relatively short compared to those of the other species (Fig. 9c). Modestly developed ventral and dorsal prostates, ampullary glands, and bulbourethral glands appeared to be universally present (Fig. 9b, Table 2) and showed relatively little interspecific variability.

The accessory gland that lies either side of the glans penis, the preputial gland, showed marked interspecific differences
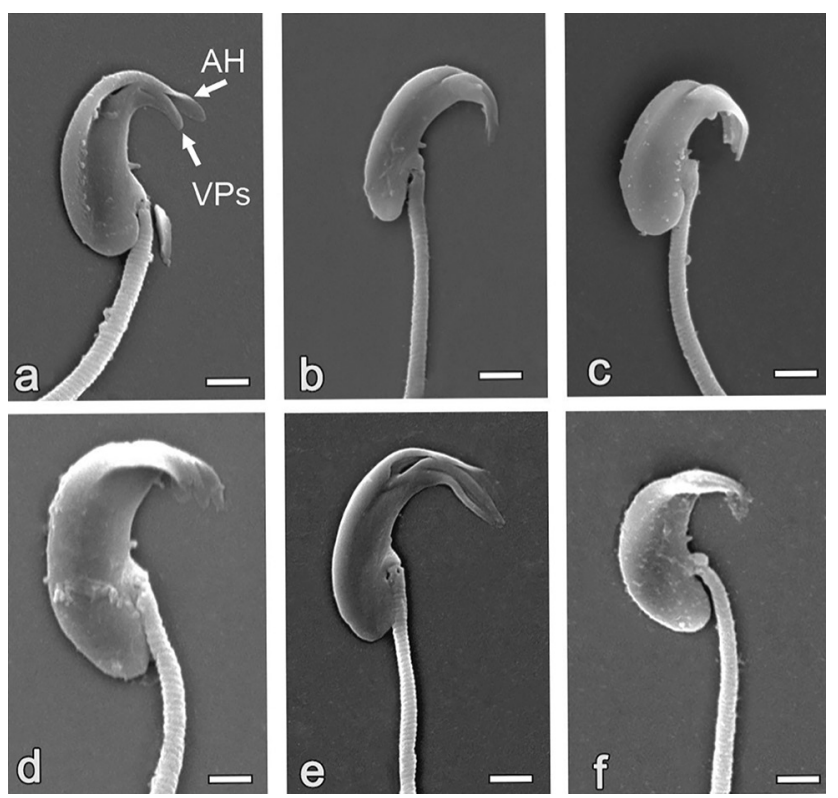

Figure 6. Scanning electron micrographs of spermatozoa from $(a)$ Pseudohydromys pumehanae, (b) Melomys lutillus, (c) Paramelomys platyops, (d) Uromys anak, (e) Uromys caudimaculatus, and ( $f$ ) Chiruromys lamia. $\mathrm{AH}=$ apical hook and VPs $=$ ventral processes of sperm head. Scale bars $\mathrm{a}=2 \mu \mathrm{m}, \mathrm{b}=1.3 \mu \mathrm{m}, \mathrm{c}=2 \mu \mathrm{m}, \mathrm{d}=1$ $\mu \mathrm{m}$, e and $\mathrm{f}=2 \mu \mathrm{m}$.
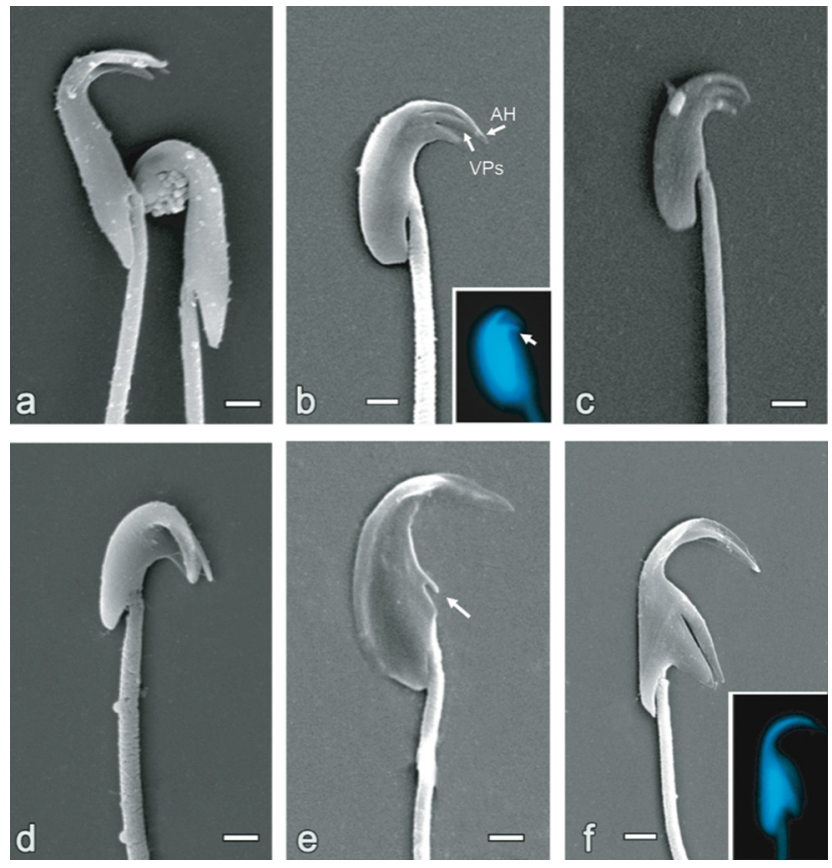

Figure 7. Scanning electron micrographs of spermatozoa from $(a)$ Chiruromys vates, (b) Pogonomys loriae with inset a fluorescent LM stained with DAPI showing nucleus, (c) Pogonomys macrourus, (d) Pogonomys sylvestris, (e) Hyomys goliath with arrow indicating ventral spike on sperm head, and $(f)$ Mallomys aroaensis inset fluorescent LM stained with DAPI showing nucleus. $\mathrm{AH}=$ apical hook and VPs $=$ ventral processes of sperm head. Scale bars a-d $=$ $0.7 \mu \mathrm{m}$, e and $\mathrm{f}=1.4 \mu \mathrm{m}$.

across the species. In some, for example, all four species of Pogonomys, two species of Chiruromys, and Melomys lutillus, it appeared to be very small or even absent, with species of the Hydromys division as well as Paramelomys rubex and Paramelomys platyops having small preputial glands. By contrast in Hyomys goliath the preputial gland was large and conspicuous (Fig. 9c).

\section{Discussion}

This comparative investigation shows considerable interspecific differences in both female and male reproductive anatomy across the various species of mice and rats from New Guinea with findings from a few species suggesting a polyandrous or promiscuous breeding system. 

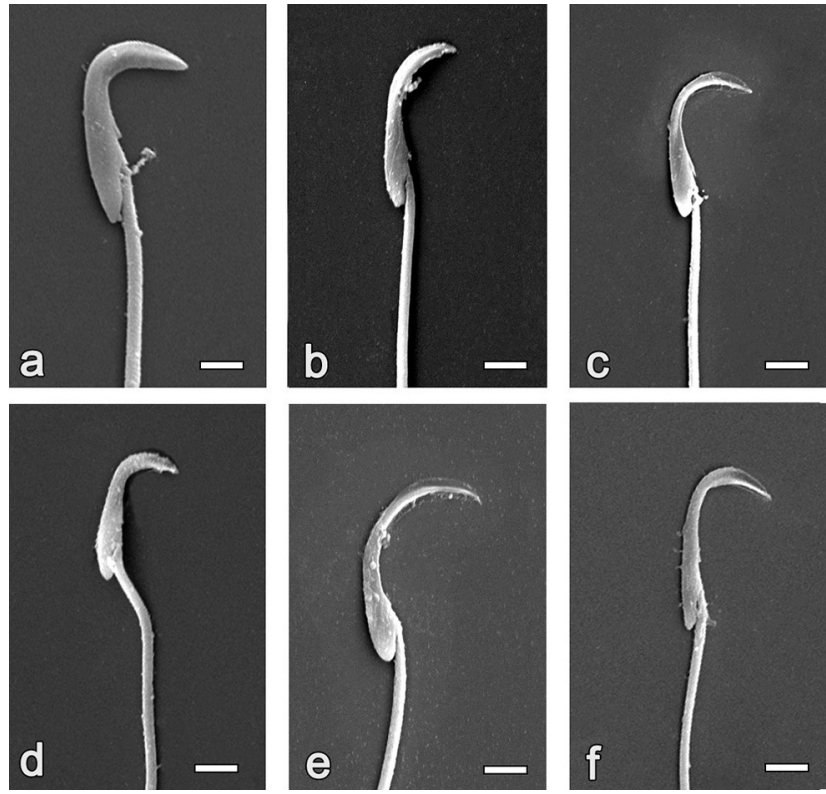

Figure 8. Scanning electron micrographs of spermatozoa from $(a)$ Lorentzimys nouhuysi, (b) Mammelomys lanosus, (c) Mammelomys rattoides, (d) Coccymys shawmayeri, (e) Xenuromys barbatus, and (f) Rattus niobe. Scale bars $\mathrm{a}=1.5 \mu \mathrm{m}, \mathrm{b}-\mathrm{f}=2.5 \mu \mathrm{m}$.

New Guinea clearly has a very diverse murid rodent fauna. The current study on female reproductive biology suggests, in general, similarity across the species in the Hydromys and Uromys divisions to those of the Australian members of these groups (e.g., Breed \& Ford, 2007; Van Dyck \& Strahan, 2008; Geffin et al., 2011), generally involving 4 nipples and a low number of fetuses in pregnant females.

Members of the Pogonomys and Mallomys divisions, by contrast, showed greater interspecific diversity in the nipple number which ranged from 6 in most species of the Pogonomys division to just 2 in Mammelomys, and with Mallomys aroaensis occasionally having 8 (Helgen, 2007a). Although individuals of several dissected animals of the species with 6 nipples had three fetuses, there was in general a low number of fetuses present in the pregnant females in the Pogonomys division even though most species had 2 additional nipples compared to the species in the Hydromyine and Uromyine divisions. These findings support the conclusion that, in general, the hydromyine rodents have a low fecundity in spite of the presence of 6 nipples in a number of species.

By contrast in the genus Rattus nipple number varied from 4 in $R$. vandeuseni up to 12 in $R$. sordidus (see also Taylor \& Horner, 1973; Breed, 1978; Taylor et al., 1990) indicating a high potential litter size in the latter species. There is a suggestion in the literature that females in some populations of $R$. steini and $R$. jobiensis have 6 nipples whereas others have 8 (Taylor et al., 1982, 1990; Flannery, 1995a, 1995b), a finding that suggests the possibility of a species complex (Helgen, 2007b; Robins et al., 2014; Rowe et al., 2020). That individuals of Rattus species with numerous nipples can sometimes have a large number of fetuses at the one time is indicated by the findings in $R$. sordidus where up to 9 fetuses have been recorded, although the litter size of $R$. niobe and $R$. verecundus appears to be no greater than that of many of the hydromyine rodents. The high number of fetuses in $R$. sordidus, which is a species that also occurs in northern Australia, is similar to that of two closely related Australian Rattus species R. colletti and R. villosissimus, which live in grassland or desert habitats (Taylor \& Horner, 1973; Yom-Tov, 1985; Breed \& Ford, 2007; Van Dyck \& Strahan, 2008) where rapid population increase during times of abundant resources sometimes occurs. By contrast the rainforest species $R$. leucopus has a lower number of nipples and lower number of fetuses (Dwyer, 1975; Taylor et al., 1990; Geffen et al., 2011). Clearly there is greater interspecific variability in ovulation rate, nipple number, and potential litter sizes across Rattus species than there is between species in the hydromyine tribe.

When it comes to interspecies differences in relative testes mass (RTM) it was found that none of the New Guinea species had such small relative testes mass as occurs in some of the semiarid and arid adapted Australian hydromyine rodents in the genera Notomys and Pseudomys (Breed, 1997b; Breed \& Taylor, 2000; Bauer \& Breed, 2008). Nevertheless, some differences between species in RTM are indicated for the rodents from New Guinea in the 40-100 g body weight range with two Pogonomys species, $P$. macrourus and $P$. sylvestris, having larger RTM than any of the species in the Hydromys or Uromys divisions of similar body mass. Evidence from observations of individuals of these species in the natural environment suggests that Pogonomys and Chiruromys may exhibit colonial or group-living behaviour, in either holes in trees or burrows underground (Dennis \& Menzies, 1979; Flannery \& Seri, 1990; Flannery, 1988, 1995a). The high RTM in these Pogonomys species, as well as in $C$. vates, suggest that considerable intermale sperm competition may at times take place with these species having potentially a polyandrous or promiscuous mating system.

Interspecies differences in the organization of the testis may also occur (e.g., Lüpold et al., 2009; Ramm \& Schärer, 2014; Peirce et al., 2018) and in the New Guinea species those with relatively small body mass, unlike the two species with large body mass such as Mallomys and Hyomys species, had at least $90 \%$ of the testes composed of seminiferous tubules. A finding that suggests greater numbers of sperm producing capacity of the testes are produced in these species.

So what is the significance of the interspecific differences in sperm morphology that have been found to occur? Previous studies on sperm morphology of Australian murids have shown clear differences between hydromyine rodents and Rattus species. Whereas all Rattus species have a sperm head with a single long apical hook and long tail, in most members of the Uromys and Hydromys divisions, as well as in most species in the Pseudomys and Conilurus divisions, a more complex sperm head with 2 ventral processes, in addition to the apical hook, occurs, with their angle, together with sperm tail length, correlating with relative testes mass (McLennan et al., 2017). Amongst the Rattus species from New Guinea the sperm also have a single apical hook like those of the Australian Rattus, whereas in species of the Uromys and Hydromys divisions the sperm head morphology is more complex and contains, in addition, two ventral processes similar to those of the closely related Australian species in the same divisions (Breed, 1984; Breed \& Aplin, 1994; Breed \& Leigh, 2010). Studies on spermatozoa of an Australian Pseudomys species have shown that the two ventral processes contain cytoskeletal proteins (Flaherty et al., 1983; Breed 

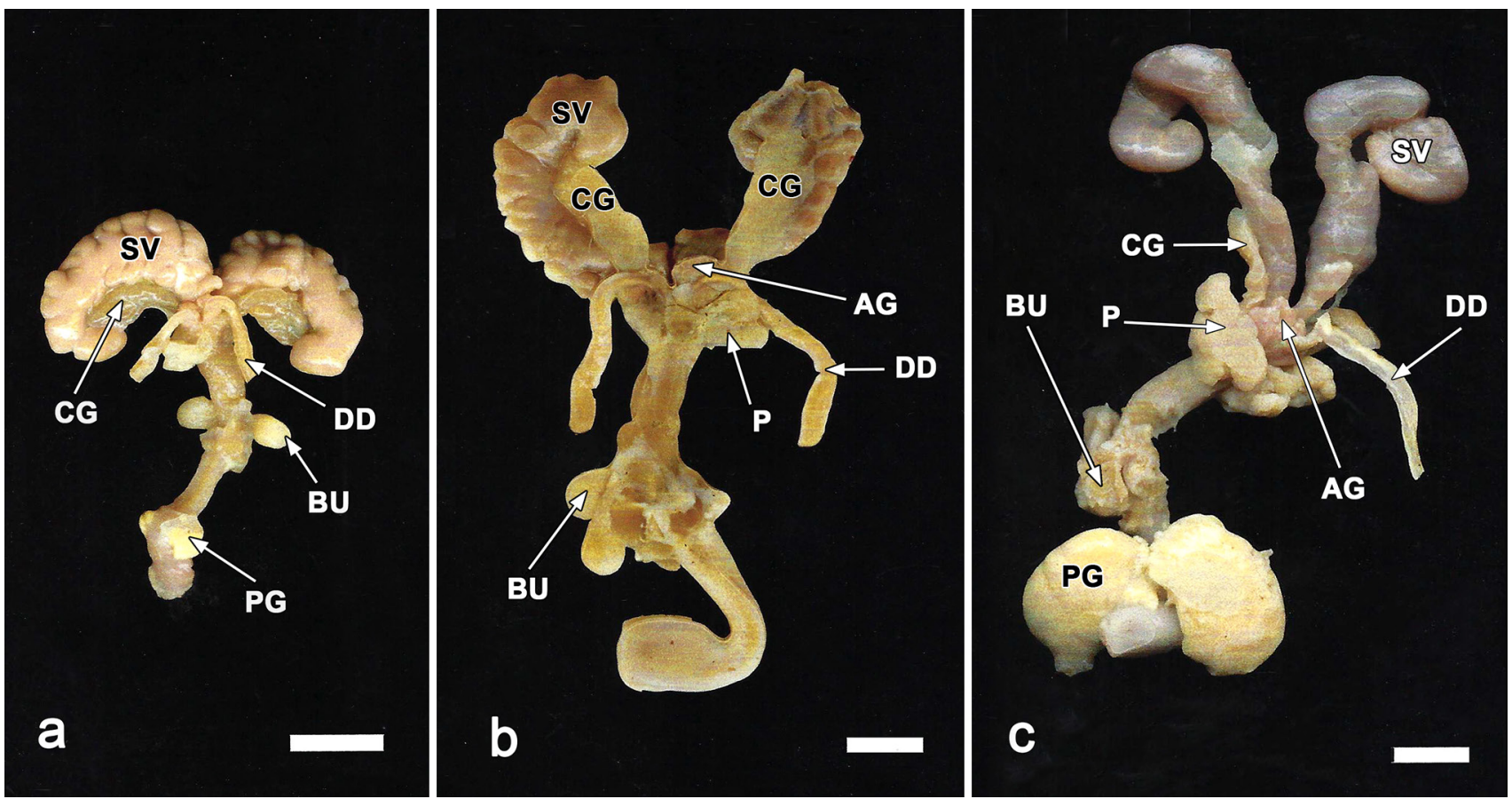

Figure 9. Dissected male reproductive accessory sex glands from (a) Paramelomys rubex, (b) Uromys caudimaculatus, and (c) Hyomys goliath. Note large sacculated seminal vesicles in $(a)$ and $(b)$ with coagulating glands on their inner curvatures; $H$. goliath has rather different gross morphology of seminal vesicles and coagulating glands and strikingly large preputial glands $(\mathrm{PG})$. $\mathrm{SV}=\mathrm{seminal}$ vesicles, $\mathrm{CG}=$ coagulating glands, $\mathrm{P}=$ prostate glands, $\mathrm{AG}=$ ampullary glands, $\mathrm{BU}=$ bulbourethral glands, $\mathrm{PG}=$ preputial glands, and $\mathrm{DD}=$ ductus deferens. Scale bars $\mathrm{a}-\mathrm{c}=10 \mathrm{~mm}$.

et al., 2009) with studies on spermatozoa of an Australian Pseudomys species having shown that these processes aid in the binding of the sperm head to the extracellular coat that surrounds the egg as well as to egg coat penetration at the time of fertilization (Breed, 1997a; Drew et al., 2014).

In members of the Pogonomys and Mallomys divisions the current findings clearly indicate marked differences in sperm morphology across the species albeit that there is generally similar sperm morphology between species within the same genus. In species of Pogonomys and Chiruromys the sperm head contains, like those in the Hydromys and Uromys divisions, two ventral processes extending from the upper concave surface with the three species of Chiruromys having somewhat longer sperm tails; a finding that supports the view, together with the fact that $C$. vates has a more streamlined sperm head (see Fig. 7a), that these species also have high levels of intermale sperm competition and multimale mating systems. In Mallomys a very different sperm head shape was found to occur with a more caudal orientation of the two ventral projections, with the divergent nature of these sperm suggesting the possibility of independent evolution of these structures, and perhaps a different function, from those of the species in the other genera.

Other species in the Pogonomys and Mallomys divisions in the genera Abeomelomys, Anisomys, Xenuromys, and Mammelomys, as well as that of Lorentzimys, have a sperm head in which the ventral processes are entirely absent but the apical process is generally longer than that of most other hydromyine rodents. The presence of a single apical process is similar to that of sperm morphology of various other genera of murid rodents that occur in Southeast Asia and the Philippines (Breed \& Yong, 1986; Breed \& Musser, 1991; Pahl et al., 2018; Breed et al., 2019) including species that are members of the Chrotomys division in the hydromyine tribe as well as members of the Maxomys, Dacnomys, and Bunomys divisions of the Rattini (Rowe et al., 2019).

The morphology of most of the accessory sex glands did not show marked differences across the species. In murids a full complement of accessory sex glands is considered to be the ancestral condition, with the seminal vesicles usually being the largest accessory sex gland (Linzey \& Layne, 1969; Voss \& Linzey, 1981). Its secretions, together with those from the coagulating glands, form a large intravaginal copulatory plug at time of mating, the main function of which may be a chastity enforcing device to protect the male's investment (Voss, 1979; Mangels et al., 2016), and/or to facilitate sperm migration through the highly fibrous cervix into the uterus (Carballada \& Esponda, 1992). In general, regardless of tribe or division, there was a similar complement of seminal vesicles, coagulating glands, and ventral and dorsal prostates albeit that in the one individual Hyomys goliath investigated divergent morphology occurred.

Unlike the other male accessory sex glands the size of the preputial glands differed markedly across the species with this gland being absent in some members of the Pogonomys division, whereas by contrast prominent preputial glands were evident in the male Hyomys goliath. The function of these glands may be to secrete pheromones that elicit sexual attraction in females, aggressive behaviour in male conspecifics, and/or possibly induce various other reproductive behaviours (Bronson \& Caroom, 1971; Brown \& Williams, 1972; Orsulak \& Gawienowski, 1972; Zhang et al., 2008; Rowe et al., 2020) with interspecific differences in preputial glands size suggesting differences in social organization across the species, although more data from $H$. goliath are needed to ascertain if the highly derived 
gland found in the one individual observed in this study is a characteristic feature of this species.

In conclusion this study indicates that, within the New Guinea Pogonomys and Mallomys divisions, marked interspecies differences have evolved in several aspects of both female and male reproductive anatomy. In the female there are species differences in number of nipples although the number of fetuses in the hydromyine rodents was generally low. In males interspecific differences in both relative testes mass and in sperm morphology were evident. The full functional significance of these differences has yet to be determined but the findings of large RTM in Pogonomys and the long sperm tails in Chiruromys, suggest that these species have high levels of intermale sperm competition and hence multimale breeding systems.

AcKnowledgements. This study would not have been possible without the numerous field trips to New Guinea made by Ken Aplin who collected much of the material used in this study. We thank Sandy Ingleby of the Australian Museum, Leo Joseph and Tonya Haff of the Australian National Wildlife Collection, Steve Van Dyck and Heather Janetzki of the Queensland Museum, and David Stemmer and Terry Reardon of the South Australian Museum for assisting us with the loans of the museum specimens and for their documentation. We thank Lyn Waterhouse and Lisa O'Donovan of Adelaide Microscopy for assistance with the scanning electron microscopy, Tavik Morgenstern for assistance in several ways and Martin Breed for assistance with the preparation of the figures. We thank Pat Woolley and James Menzies for their very helpful comments. A special thanks is given to Kristofer Helgen and to two referees, and in particular Kevin Rowe, for very extensive and extremely helpful comments on an earlier draft of this manuscript and to Harry Parnaby for his advice and assistance.

\section{References}

Aplin, K. P. 2006. Ten million years of rodent evolution in Australasia: phylogenetic evidence and a speculative historical biogeography. In Evolution and Biogeography of Australasian Vertebrates, ed. J. R. Merrick, M. Archer, G. M. Hickey, and M. S. Y. Lee, chapter 31, pp. 707-744. Oatlands, Sydney: Auscipub.

Aplin, K. P., and F. Ford. 2013. Murine rodents: late but highly successful invaders. In Invasion Biology and Ecological Theory: Insights from a Continent in Transformation, ed. H. H. T. Prins and I. J. Gordon, pp. 196-240. Cambridge: Cambridge University Press.

https://doi.org/10.1017/CBO9781139565424.012

Aplin, K. P., and K. M. Helgen. 2010. Quaternary murid rodents of Timor part I: new material of Coryphomys buehleri Schaub, 1937, and description of a second species of the genus. Bulletin of the American Museum of Natural History 341: 1-80. https://doi.org/10.1206/692.1

Bauer, M., and W. G. Breed. 2008. Testes mass of the Spinifex hopping mouse and its impact on fertility potential. Journal of Zoology (London) 274: 349-356. https://doi.org/10.1111/j.1469-7998.2007.00392.x

Birkhead, T. R., and A. P. Møller. 1998. Sperm Competition and Sexual Selection. San Diego: Academic Press. https://doi.org/10.1016/B978-012100543-6/50042-8

Breed, B., and F. Ford. 2007. Native Mice and Rats. Collingwood, Victoria: CSIRO Publishing.

https://doi.org/10.1071/9780643095595
Breed, W. G. 1978. Ovulation rates and oestrous cycle lengths in several species of Australian native rats (Rattus spp.) from various habitats. Australian Journal of Zoology 26: 475-480. https://doi.org/10.1071/Z09780475

Breed, W. G. 1984. Sperm head structure in the Hydromyinae (Rodentia: Muridae): a further evolutionary development of the subacrosomal space in mammals. Gamete Research 10: 31-44. https://doi.org/10.1002/mrd.1120100105

Breed, W. G. 1997a. Evolution of the spermatozoon in Australasian rodents. Australian Journal of Zoology 45: 459-478. https://doi.org/10.1071/Z097011

Breed, W. G. 1997b. Interspecific variation of testis size and epididymal sperm numbers in Australasian rodents with special reference to the genus Notomys. Australian Journal of Zoology 45: 651-669.

https://doi.org/10.1071/Z097010

Breed, W. G., and K. P. Aplin. 1994. Sperm morphology of murid rodents from New Guinea and the Solomon Islands: phylogenetic implications. Australian Journal of Zoology 243: $17-30$. https://doi.org/10.1071/ZO9950017

Breed, W. G., H. Hassan, M. Gonzalez, H. J. McLennan, C. M. Leigh, and L. R. Heaney. 2019. Interspecific diversity of testes mass and sperm morphology in the Philippine chrotomyine rodents: implications for differences in breeding systems across the species. Reproduction, Fertility and Development 31: 705-711. https://doi.org/10.1071/RD18278

Breed, W. G., and C. M. Leigh. 2010. The spermatozoon of the Old Endemic Australo-Papuan and Philippine rodents-its morphological diversity and evolution. Acta Zoologica 91: 279-294.

https://doi.org/10.1111/j.1463-6395.2009.00407.x

Breed, W. G., D. Idriss, C. M. Leigh, and R. J. Oko. 2009. Temporal deposition and spatial distribution of cytoskeletal proteins in the sperm head of an Australian rodent. Reproduction, Fertility and Development 21: 428-439. https://doi.org/10.1071/RD08187

Breed, W. G., and G. G. Musser. 1991. Sulawesi and Philippine rodents (Muridae): a survey of spermatozoal morphology and its significance for phylogenetic inference. American Museum Novitates 3003: 1-15.

Breed, W. G., and J. Taylor. 2000. Body mass, testes mass, and sperm size in murine rodents. Journal of Mammalogy 81: 758-768. https://doi.org/10.1093/jmammal/81.3.758

Breed, W. G., and H. S. Yong. 1986. Sperm morphology of murid rodents from Malaysia and its possible phylogenetic significance. American Museum Novitates 2856: 1-12. https://doi.org/10.1515/mamm.1985.49.1.105

Bronson, F. H., and D. Caroom. 1971. Preputial gland of the male mouse: attractant function. Journal of Reproduction and Fertility 25: 279-282. https://doi.org/10.1530/jrf.0.0250279

Brown, J. C., and J. D. Williams. 1972. The rodent preputial gland. Mammal Review 2: 105-147.

https://doi.org/10.1111/j.1365-2907.1972.tb00161.x

Carballada, R., and P. Esponda. 1992. Role of fluid from seminal vesicles and coagulating glands on sperm transport into the uterus and fertility in rats. Journal of Reproduction and Fertility 95: 639-648.

https://doi.org/10.1530/jrf.0.0950639

Dennis, E., and J. I. Menzies. 1979. A chromosomal and morphometric study of Papuan tree rats Pogonomys and Chiruromys (Rodentia: Muridae). Journal of Zoology (London) 189: 315-322.

https://doi.org/10.1111/j.1469-7998.1979.tb03965.x 
Drew, S., C. M. Leigh, and W. G. Breed. 2014. Spermatozoa of the old endemic rodents of Australia - the possible functional significance of their ventral processes. Reproduction, Fertility and Development 26: 1183-1187.

https://doi.org/10.1071/RD13162

Dwyer, P. D. 1975. Observations on the breeding biology of some New Guinea murid rodents. Australian Wildlife Research 2: 33-45.

https://doi.org/10.1071/WR9750033

Dwyer, P. D. 1984. From garden to forest: small rodents and plant succession in Papua New Guinea. Australian Mammalogy 7: 29-36.

Flaherty, S.P., W. G. Breed, and V. Sarafis. 1983. Localisation of actin in the sperm head of the plains mouse, Pseudomys australis. Journal of Experimental Biology 225: 497-500. https://doi.org/10.1002/jez.1402250318

Flannery, T. F. 1988. Pogonomys championi n. sp., a new murid (Rodentia) from montane western Papua New Guinea. Records of the Australian Museum 40(6): 333-341.

https://doi.org/10.3853/j.0067-1975.40.1988.159

Flannery, T. 1995a. Mammals of New Guinea, revised edition. Chatsworth, NSW: Reed Books.

Flannery, T. 1995b. Mammals of the South-West Pacific and Moluccan Islands. Chatsworth, NSW: Reed Books.

Flannery, T., and L. Seri. 1990. The mammals of southern West Sepik Province, Papua New Guinea: their distribution, abundance, human use and zoogeography. Records of the Australian Museum 42(2): 173-208. https://doi.org/10.3853/j.0067-1975.42.1990.114

Geffen, E., K. C. Rowe, and Y. Yom-Tov. 2011. Reproductive rates in Australian rodents are related to phylogeny. PLOS ONE 6(4): e19199.

https://doi.org/10.1371/journal. pone.0019199

Gomendio, M., and E. R. S. Roldan. 1991. Sperm competition influences sperm size in mammals. Proceedings of the Royal Society Series B: Biological Sciences 243: 181-185. https://doi.org/10.1098/rspb.1991.0029

Gómez Montoto, L., C. Magaña, M. Tourmente, J. Martin-Coello, C. Crespo, J. J. Luque-Larena, M. Gomendio, and E. R. S. Roldan. 2011. Sperm competition, sperm numbers and sperm quality in muroid rodents. PLOS ONE 6: e18173. https://doi.org/10.1371/journal.pone.0018173

Harcourt, A. H., P. H. Harvey, S. G. Larson, and R. V. Short. 1981. Testis weight, body weight, and breeding system in primates. Nature 293: 55-57. https://doi.org/10.1038/293055a0

Helgen, K. M. 2005a. A new species of murid rodent (genus Mayermys) from south-eastern New Guinea. Mammalian Biology 70: 61-67.

https://doi.org/10.1078/1616-5047-00176

Helgen, K. M. 2005b. The amphibious murines of New Guinea (Rodentia: Muridae): the generic status of Baiyankamys and description of a new species of Hydromys. Zootaxa 913: 1-20. https://doi.org/10.11646/zootaxa.913.1.1

Helgen, K. M. 2007a. A Reassessment of Taxonomic Diversity and Geographic Patterning in the Melanesian Mammal Fauna. Unpublished Ph.D. thesis. University of Adelaide.

Helgen, K. M. 2007b. A taxonomic and geographic overview of the mammals of Papua. In The Ecology of Papua, (Ecology of Indonesia series, volume VI, part 1), ed. A. J. Marshall and B. M. Beehler, pp. 689-749. Singapore: Periplus Editions.

Helgen, K. M., and L. E. Helgen. 2009. Biodiversity and biogeography of the moss mice of New Guinea: a taxonomic review of Pseudohydromys (Muridae: Murinae). Bulletin of the American Museum of Natural History 331: 230-313. https://doi.org/10.1206/582-8.1
Helgen, K. M., T. Leary, and K. P. Aplin. 2010. A review of Microhydromys (Rodentia: Murinae) with description of a new species from southern New Guinea. American Museum Novitates 3676: 1-22.

https://doi.org/10.1206/632.1

Immler, S., H. D. M. Moore, W. G. Breed, and T. R. Birkhead. 2007. By hook or by crook? Morphology, competition and cooperation in rodent sperm. PLoS ONE 2: e170. https://doi.org/10.1371/journal.pone. 0000170

Jackson, K. L., and P. A. Woolley. 1993. The diet of five species of New Guinea rodents. Science in New Guinea 19(2): 77-86.

Kenagy, G. K., and S. L. Trombulak. 1986. Size and function of mammalian testes in relation to body mass. Journal of Mammalogy 67: 1-22.

https://doi.org/10.2307/1380997

Lecompte, E., K. Aplin, C. Denys, F. Catzeflis, M. Chades, and P. Chevet. 2008. Phylogeny and biogeography of African Murinae based on mitochondrial and nuclear sequences, with a new tribal classification of the subfamily. BMC Evolutionary Biology 8: 199. https://doi.org/10.1186/1471-2148-8-199

Leigh, C. M., and W. G. Breed. 2020. A demographic study of the water-rat (Hydromys chrysogaster) on the River Torrens in Adelaide, South Australia. Australian Mammalogy 42: 277-282. https://doi.org/10.1071/AM19049

Lidicker Jr, W. Z. 1968. A phylogeny of New Guinea rodent genera based on phallic morphology. Journal of Mammalogy 49: 609-642.

https://doi.org/10.2307/1378724

Lidicker Jr, W. Z., and P. V. Brylski. 1987. The conilurine radiation of Australia, analysed on the basis of phallic morphology. Journal of Mammalogy 68: 617-641.

https://doi.org/10.2307/1381596

Linzey, A. V., and J. N. Layne. 1969. Comparative morphology of the male reproductive tract in the rodent genus Peromyscus (Muridae). American Museum Novitates 2355: 1-47.

Lüpold, S., G. M. Linz, J. W. Rivers, D. F. Westneat, and T. R. Birkhead. 2009. Sperm competition selects beyond relative testes mass in birds. Evolution 63: 391-402. https://doi.org/10.1111/j.1558-5646.2008.00571.x

Mangels, R., K. Tsung, K. Kwan, and M. D. Dean. 2016. Copulatory plugs inhibit reproductive success of rival males. Journal of Evolutionary Biology 29: 2289-2296. https://doi.org/10.1111/jeb.12956

McLennan, H. J., S. Lüpold, P. Smissen, K. C. Rowe, and W. G. Breed. 2017. Greater sperm complexity in the Australasian old endemic rodents (tribe: Hydromyini) is associated with increased levels of inter-male sperm competition. Reproduction, Fertility and Development 29: 921-930.

https://doi.org/10.1071/RD15425

McPhee, E. C. 1988. Ecology and diet of some rodents from the lower montane region of Papua New Guinea. Australian Wildlife Research 15(1): 91-102. https://doi.org/10.1071/WR9880091

Menzies, J. I. 1996. A systematic revision of Melomys (Rodentia, Muridae) of New Guinea. Australian Journal of Zoology 44: $367-426$. https://doi.org/10.1071/ZO9960367

Menzies, J. I., and Dennis, E. 1979. Handbook of New Guinea Rodents. Honolulu, Hawaii: Wau Ecology Institute Handbook, Bishop Museum Press.

Musser, G. G., and M. D. Carleton. 2005. Superfamily Muroidea. In Mammal Species of the World. A Taxonomic and Geographic Reference, 3rd edition, vol. 2, ed. D. E. Wilson and D. M. Reeder, pp. 891-1531. Baltimore, Maryland: The Johns Hopkins University Press. 
Musser, G. G., K. M. Helgen, and D. P. Lunde. 2008. Systematic revision of New Guinea Leptomys (Muridae, Murinae) with description of two new species. American Museum Novitates 3624: 1-60.

https://doi.org/10.1206/587.1

Musser, G. G., and D. P. Lunde. 2009. Systematic reviews of New Guinea Coccymys and "Melomys" albidens (Muridae, Murinae) with descriptions of new taxa. Bulletin of the American Museum of Natural History 329: 1-139.

https://doi.org/10.1206/635.1

Olson, P. D. 1982. Reproductive biology and development of the water rat, Hydromys chrysogaster, in captivity. Australian Wildlife Research 9: 39-53. https://doi.org/10.1071/WR9820039

Orsulak, P. J., and A. M. Gawienowski. 1972. Olfactory preferences for the rat preputial gland. Biology of Reproduction 6: 219-223. https://doi.org/10.1093/biolreprod/6.2.219

Pahl, T., H. J. McLennan, Y. Wang, A. S. Achmadi, K. C. Rowe, K. Aplin, and W. G. Breed. 2018. Sperm morphology of the Rattini-are the interspecific differences due to variation in intensity of intermale sperm competition? Reproduction, Fertility and Development 30: 1434-1442. https://doi.org/10.1071/RD17431

Parker, G. A. 1993. Sperm competition games: sperm size and sperm number under adult control. Proceedings of the Royal Society B: Biological Sciences 253: 245-254. https://doi.org/10.1098/rspb. 1993.0110

Parker, G. A. 2016. The evolution of expenditure on testes. Journal of Zoology (London) 298: 3-19. https://doi.org/10.1111/jzo.12297

Peirce, E. J., H. J. McLennan, J. Tuke, C. M. Leigh, and, W. G. Breed. 2018. Evolution of the testis and spermatozoon in mice and rats (subfamily Murinae) in the absence of sperm competition. Journal of Zoology (London) 306: 58-68. https://doi.org/10.1111/jzo.12573

Pitnick, S., D. J. Hoskin, and T. R. Birkhead. 2009. Sperm morphological diversity. In Sperm Biology: An Evolutionary Perspective, ed. T. R. Birkhead, D. J. Hoskin, and S. Pitnick, pp. 69-149. London: Academic Press.

https://doi.org/10.1016/B978-0-12-372568-4.00003-3

Ramm, S. A., G. A. Parker, and P. Stockley. 2005. Sperm competition and the evolution of male reproductive anatomy in rodents. Proceedings of the Royal Society B: Biological Sciences 272: 949-955.

https://doi.org/10.1098/rspb.2004.3048

Ramm, S. A., and L. Schärer. 2014. The evolutionary ecology of testicular function: size isn't everything. Biological Reviews 89: 874-888.

https://doi.org/10.1111/brv.12084

Robins, J. H., V. Tintinger, K. P. Aplin, M. Hingston, E. Matisoo Smith, D. Penny, and S. D. Lavery. 2014. Phylogenetic species identification in Rattus highlights rapid radiation and morphological similarity of New Guinean species. PLoS ONE 9(5): e98002.

https://doi.org/10.1371/journal.pone.0098002

Rowe, K. C., M. L. Reno, D. M. Richmond, R. M. Adkins, and S. J. Steppan. 2008. Pliocene colonization and adaptive radiations in Australia and New Guinea (Sahul): multilocus systematics of the old endemic rodents (Muroidea: Murinae). Molecular Phylogenetics and Evolution 47: 84-101. https://doi.org/10.1016/j.ympev.2008.01.001

Rowe, K. C., K. P. Aplin, P. R. Baverstock, and C. Moritz. 2011. Recent and rapid speciation with limited morphological disparity in the genus Rattus. Systematic Biology 60: 188-203. https://doi.org/10.1093/sysbio/syq092

Rowe, K. C., A. S. Achmadi, P.-H. Fabre, J. J. Schenk, S. C. Steppan, and J. A. Esselstyn. 2019. Oceanic islands of Wallacea as a source for dispersal and diversification of murine rodents. Journal of Biogeography 46: 2752-2768.

https://doi.org/10.1111/jbi.13720
Rowe, K. C., H. A. Soini, K. M. C. Rowe, M. Adams, and M. V. Novotny. 2020. Odorants differentiate Australian Rattus with increased complexity in sympatry. In Papers in Honour of Ken Aplin, ed. Julien Louys, Sue O'Connor, and Kristofer M. Helgen. Records of the Australian Museum 72(5): 271-286. https://doi.org/10.3853/j.2201-4349.72.2020.1721

Roycroft, E. J., A. Moussalli, and K. C. Rowe. 2020. Phylogenomics uncovers confidence and conflict in the rapid radiation of Australo-Papuan rodents. Systematic Biology 69: 431-444. https://doi.org/10.1093/sysbio/syz044

Šandera, M., T. Albrecht, and P. Stopka. 2013. Variation in apical hook length reflects the intensity of sperm competition in murine rodents. PLOS ONE 8: e68427. https://doi.org/10.1371/journal.pone.0068427

Simmons, L. W., and J. R. Fitzpatrick. 2012. Sperm wars-the evolution of male fertility. Reproduction 144: 519-534. https://doi.org/10.1530/REP-12-0285

Smissen, P. J., and K. C. Rowe. 2018. Repeated biome transitions in the evolution of Australian rodents. Molecular Phylogenetics and Evolution 128: 182-191. https://doi.org/10.1016/j.ympev.2018.07.015

Tate, G. H. H. 1951. The rodents of Australia and New Guinea. Bulletin of the American Museum of Natural History 97: 185-430.

Taylor, J. M., J. H. Calaby, and S. C. Smith. 1990. Reproduction in New Guinean Rattus and comparison with Australian Rattus. Australian Journal of Zoology 38: 587-602. https://doi.org/10.1071/ZO9900587

Taylor, J. M., J. H. Calaby, and H. M. Van Deusen. 1982. A revision of the genus Rattus (Rodentia, Muridae) in the New Guinean region. Bulletin of the American Museum of Natural History 173: 177-336.

Taylor, J. M., and B. E. Horner. 1973. Reproductive characteristics of wild native Australian Rattus (Rodentia: Muridae). Australian Journal of Zoology 21: 437-475. https://doi.org/10.1071/ZO9730437

Tourmente, M., M. Gomendio, and E. R. S. Roldan. 2011. Sperm competition and the evolution of sperm design in mammals. BMC Evolutionary Biology 11: 12. https://doi.org/10.1186/1471-2148-11-12

Van der Horst, G., and L. Maree. 2014. Sperm form and function in absence of sperm competition. Molecular Reproduction and Development 81: 204-216. https://doi.org/10.1002/mrd.22277

Van Dyck, S., and R. Strahan. 2008. The Mammals of Australia, 3rd edition. Sydney: Reed New Holland.

Voss, R. 1979. Male accessory glands and the evolution of copulatory plugs in rodents. Occasional Papers of the Museum of Zoology of the University of Michigan 689: 1-27.

Voss, R. S., and A. V. Linsey. 1981. Comparative gross morphology of male accessory glands among Neotropical Muridae (Mammalia: Rodentia) with comments on systematic implications. Miscellaneous Papers of the Museum of Zoology of the University of Michigan 159: 1-34.

Watts, C. H. S., and H. Aslin. 1981. The Rodents of Australia. Sydney: Angus and Robertson.

Watts, C. H. S., and P. R. Baverstock. 1994. Evolution in New Guinean Muridae (Rodentia) assessed by microcomplement fixation of albumen. Australian Journal of Zoology 42: 295-306. https://doi.org/10.1071/ZO9940295

Woolley, P. A., and C. B. Furby. 1996. Laboratory observations on the reproductive biology of Rattus (Stenomys) verecundus and Pogonomys sylvestris, murid rodents from New Guinea. Science in New Guinea 21: 115-122.

Yom-Tov, Y. 1985. The reproductive rates of Australian rodents. Oecologia 66: 250-256. https://doi.org/10.1007/BF00379862

Zhang, J.-X., Y.-J. Liu, J.-H. Zhang, and L. Sun. 2008. Dual role of preputial gland secretion and its major components in sex recognition in mice. Physiology and Behaviour 95: 388-394. https://doi.org/10.1016/j.physbeh.2008.07.002 


\title{
Evolutionary History of the Subgenus Mus in Eurasia with Special Emphasis on the House Mouse Mus musculus
}

\author{
Hitoshi Suzuki \\ Graduate School of Environmental Earth Science, Hokkaido University, \\ North 10, West 5, Sapporo 060-0810, Japan
}

\begin{abstract}
Elucidation of the evolutionary history of the subgenus Mus, including the House Mouse Mus musculus, is essential to understanding species diversification mechanisms in the Indomalayan region, which is a global biodiversity hotspot. In terms of interspecific relationships, the topography of India, Myanmar, and other Southeast Asian regions has been proposed to explain the speciation process and ecological niche diversification followed by range overlap after speciation. Recent research into mitochondrial DNA clocks has created the opportunity to reconstruct the detailed dynamics of $M$. musculus as affected by human activity. The resultant evolutionary scenarios are in good accordance with archaeological evidence observed in Asia, especially in China, Korea, and Japan.
\end{abstract}

\section{Introduction}

The evolution of murine rodents (subfamily Murinae) is the most successful example of species diversification in mammals (Musser \& Carleton, 2005). Over 560 species emerged within a short evolutionary time of several million years (Myr), with an unusual level of morphological diversity. The genus Mus, which includes the well-known model species, the House Mouse Mus musculus, is a species-rich group of murine rodents with unclear taxonomic diversity, probably due to substantial morphological similarity among species. Ken Aplin, a researcher who undertook extensive field studies in Southeast Asia to control pest rats and mice (Aplin, 2003), has expanded the network of researchers committed to resolving the taxonomic relationships of rats and mice and describing their evolutionary histories using genetic methods (e.g., Aplin et al., 2011). In this article, I focus on his findings in studies of Mus species over the last two decades, and review the recent progress of phylogenetic research into members of the subgenus Mus and phylogeographic studies of the widespread species M. musculus.

\section{Framework of species diversity in the subgenus Mus}

The genus Mus dominates the small granivore/omnivore niche in the Old World region from southern Africa to eastern Asia, and is now recognized as comprising more than 40 species (Musser \& Carleton, 2005; Shimada et al., 2010). In Eurasia, 20 species of Mus are known, which are grouped in the subgenus Mus. The taxonomy of this group was relatively stable until field surveys (2003-2007) of mice from Myanmar by Ken Aplin. He noticed taxonomic problems among the mice from Myanmar and conducted genetic studies to determine their phylogenetic backgrounds. In his research, populations previously known as Mus cervicolor and Mus booduga were found to have distinct evolutionary histories from mice referred to as Mus cervicolor from Thailand and Laos, and those called Mus booduga from India and Nepal, respectively. He demonstrated that the appropriate taxonomic names for these mice were instead Mus nitidulus Blyth, 1859 (Shimada et al., 2007a) and M. lepidoides Fry, 1931 (Shimada et al., 2010), respectively, characterizing them as 


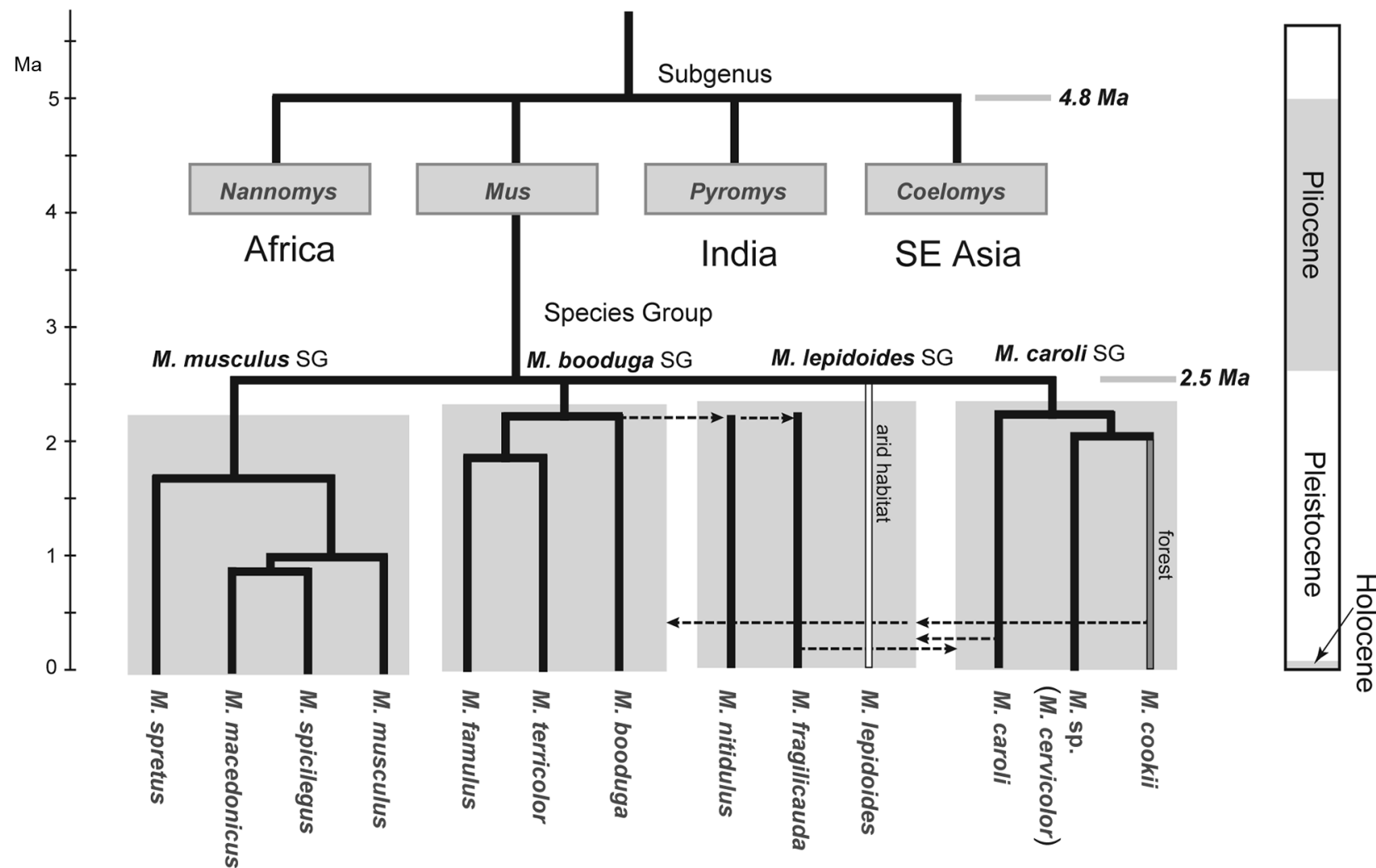

\section{Palaearctic India Myanmar SE Asia}

Figure 1. A sketch of the evolutionary patterns of lineage differentiation among species in the genus Mus based on molecular phylogenetic analysis of nuclear gene sequences (Suzuki et al., 2004; Shimada et al., 2010). The tree shows the four subgenera of the genus Mus and the four species groups (SGs) of the subgenus Mus: M. musculus, M. booduga, M. lepidoides, and M. caroli (previously termed as M. cervicolor SG), representing four geographic regions of the Palaearctic region, Indian subcontinent, Myanmar, and Southeast Asia, respectively. The taxon previously regarded as " $M$. cervicolor" in Thailand is here referred to as " $M$. sp.", due to uncertainty regarding the taxonomic status of the sampled specimens (see main text). The estimated divergence times for the subgenera and species groups are approximately 5 and 2.5 million years ago, respectively (Shimada et al., 2010). Specific habitat transitions from grasslands to forests and arid areas are marked for the species lineages of M. cookii and M. lepidoides. Predicted dispersal events between geographic regions are indicated with dotted arrows.

valid species endemic to Myanmar. The elucidation of these two additional species in the subgenus Mus from Myanmar led to two important findings. First, the region of Myanmar is an important zoogeographic area for understanding the species diversity of the subgenus Mus. Second, our current understanding of the taxonomy and phylogenetic status of the subgenus Mus and its distribution is incomplete, and therefore further intensive study is necessary.

A preliminary framework of the evolutionary history of the genus Mus, especially for members occurring in Eurasia, has been inferred based on molecular phylogenetic analyses (Fig. 1; e.g., Suzuki et al., 2004). The genus Mus is classified into four subgenera (Marshall, 1977), with equal evolutionary distances among all, including Southeast Asian (Coelomys), Indian subcontinent (Pyromys), African (Nannomys), and Palaearctic (Mus) lineages (Lundrigan et al., 2002; Suzuki et al., 2004; Chevret et al., 2005; Tucker et al., 2005; Veyrunes et al., 2005; Shimada et al., 2007a, 2010). The species-rich Eurasian subgenus Mus was found to have four distinct species groups (SGs): (1) the $M$. caroli SG (mainland Southeast Asian clade) including $M$. caroli, M. cervicolor, and M. cookii; (2) the M. musculus SG (Palaearctic clade) with M. musculus, M. spretus, $M$. spicilegus, and M. macedonicus; (3) the M. booduga SG (Indian clade) containing $M$. booduga, $M$. terricolor, $M$. famulus, M. nitidulus, and M. fragilicauda; and (4) the $M$. lepidoides SG, a monospecific clade endemic to Myanmar. The distribution pattern of the four species groups suggests origins in each of the four geographic regions of the Indomalayan Realm (Suzuki et al., 2014; Shimada et al., 2010). Their phylogenetic patterns can be characterized by two prominent divergence periods - for the four subgenera, and for the four species groups (Suzuki et al., 2004; Shimada et al., 2010; Suzuki \& Aplin, 2012). These two historical periods occurred 5-6 million years ago (Ma) and 2-3 Ma, respectively, based on molecular phylogenetic analysis and fossil evidence of rat and mouse bifurcation (at $12 \mathrm{Ma}$ ). These periods coincide with global environmental changes at the boundaries of the Miocene/Pliocene and Pliocene/ Pleistocene, respectively. Intermittent dramatic changes in the global environment played an important role in the diversification of Mus species (Fig. 1).

The distribution ranges of Eurasian mice remain poorly understood, especially those of the two recently recognized species (M. nitidulus and M. lepidoides) in Myanmar. A team from the University of Yangon, Myanmar, led by Thidalay 
Thwe performed a field survey to clarify the distribution ranges of mouse species in Myanmar, including M. nitidulus and M. lepidoides (Myat Myat Zaw et al., 2019). They found that $M$. nitidulus has a wide habitation zone along the Ayeyarwady River. Surprisingly, they observed $M$. fragilicauda in Pyay city, where it was restricted to the eastern side of the Ayeyarwady River. Myanmar is still expected to reveal new species of forest mice (subgenus Coelomys) and grassland mice (subgenus Mus). Moreover, an important finding of the field study is that no specimens of Mus from Myanmar were found to be genetically closely related to samples identified as $M$. cervicolor in studies of that species from Thailand, i.e. based on sequences of mitochondrial DNA (cytochrome $b, C y t b$ ) or nuclear DNA (melanocortin 1 receptor, Mclr) (Myat Myat Zaw et al., 2019). This finding does not support the view that Mus cervicolor, which was first described from Nepal, is distributed broadly from Nepal to Vietnam (e.g., Wilson et al., 2016). Little molecular phylogenetic or morphological analysis has been conducted with Nepalese mice, and thus Mus cervicolor from Thailand may not represent the original Mus cervicolor, first described from Nepal. Therefore, it is reasonable to treat these mice from Thailand temporarily as "Mus sp.", as the species identity is unclear.

\section{Reconstructing the diversification history of mouse species}

Here, I address the possible evolutionary scenarios and factors shaping the speciation events among the 13 species in the subgenus Mus (Fig. 1). The M. booduga SG consists of five species: $M$. booduga, M. terricolor, M. famulus, $M$. nitidulus, and $M$. fragilicauda. The ancestral lineage extended its range from a predicted home range on the Indian subcontinent into Myanmar around $2 \mathrm{Ma}$ (2 million years ago), creating the $M$. nitidulus species lineage. Simultaneously, the lineage further dispersed to the east, forming M. fragilicauda, somewhere in Southeast Asia. Mus fragilicauda currently has a fragmented distribution in Thailand, Laos, and Myanmar, within which lineage divergence is estimated to have occurred around 400,000 years ago (Myat Myat Zaw et al., 2018). This distribution pattern may be explained by dispersal following Pleistocene climatic fluctuation or fragmentation due to range extension of competing species as has been suggested in other studies on small mammals (e.g., Honda et al. 2019).

Mus lepidoides, the sole member of the M. lepidoides $\mathrm{SG}$, has been collected by Ken Aplin from the Central Dry Zone of Myanmar. To date, the full range of this species has not been reported, although it is likely within the arid region of central Myanmar. Future work must investigate the distribution of $M$. lepidoides and the biogeographic effects of the Ayeyarwady River, which flows through the centre of Myanmar, on the genetic differentiation of this arid-adapted species.

In Southeast Asia, the caroli SG diverged into three lineages, leading to the species $M$. caroli, M. cookii, and Mus sp. (formerly "M. cervicolor", found in Thailand), in Southeast Asia around 2.4 Ma. Mus caroli and Mus sp. may have evolved on the western and eastern plains of the Indochina peninsula, while $M$. cookii adapted to forest dwelling in more northern forested areas (Fig. 1), and extends as far west as the Himalayan foothills region of Pakistan (Bibi et al., 2017). The remaining species are grassland dwellers, and their speciation can be explained through geographic segregation, or stratification of shared distributions, after niche differentiation. Mus caroli has a wide range from Myanmar to Taiwan, containing several distinct geographic lineages (Shimada et al., 2007b). It may have extended its distribution westward during the Chibanian (c. 500,000-400,000 years ago), accounting for the level of genetic divergence among geographic groups (Fig. 1).

The musculus SG has four member species: M. spretus, M. macedonicus, M. spicilegus, and M. musculus, with estimated divergence in the period 1.7-1.4 Ma (Suzuki et al., 2013; Kodama et al., 2015). Aside from M. musculus, the other species are currently parapatric. This group may have expanded its range around 1.7 Ma and then diverged into the four species in different geographic areas, with M. musculus probably representing the easternmost part of the species group's range. Mus musculus has five main mtDNA lineages (Sakuma et al., 2016), with estimated divergence times of 400,000-500,000 years ago, but regional differentiation could have started at least one million years ago (Kodama et al., 2015). Hence, it is possible that M. musculus gained genetic diversity by occurring in multiple geographic regions at the beginning of the speciation process of the musculus SG.

\section{Widespread development of the mouse on the Eurasian continent during the prehistoric period}

Environmental changes during the Pleistocene had a great impact on the differentiation and spatial dynamics of Mus species. The last 15,000 years, including the terminal Pleistocene and Holocene, are characterized by an interglacial climate and widespread anthropogenic environmental impacts. Anthropological influences on evolution have been well documented, including on the dramatic spatial expansion and extensive hybridization events among the three subspecies groups of M. musculus (e.g., Nunome et al., 2010). A similar trend can be observed in the commensal species of Rattus (Aplin et al., 2011). The Brown Rat ( $R$. norvegicus) and Black Rat (Rattus rattus complex) are distributed widely in colder and warmer regions, respectively. Mus musculus is found in both ranges, and hence has been characterized as the most successful rodent due to its global distribution, with exceptions in urban areas and regions where congeneric species occur densely. The House Mouse may have special ecological traits that allow the species to inhabit human-made environments. For example, in addition to using underground spaces for their nests, they find suitable structures on the ground (e.g., timber gaps) for accommodation and use human houses for shelter from cold weather or competition from congeneric species. Here, I summarize the evolutionary history of $M$. musculus before and after the major human-associated range expansion events.

The original range of $M$. musculus is thought to be in the Middle East and Indian subcontinent (Boursot et al., 1993). This origin is supported by the presence of region-specific mtDNA lineages in Nepal and the southern tip of the Arabian Peninsula. Kodama et al. (2015) analysed genetic variation in seven linked nuclear gene sequences on chromosome 8 in mice collected from a broad area of Eurasia including India and Pakistan, within the native range (Figs 2-4), and found that M. musculus can be divided into three subspecies groups, 


\section{Mouse}

\section{Chromosome 8}

\section{2}

$\longrightarrow$, , Spire2

3

Mus caroli Mus terricolor
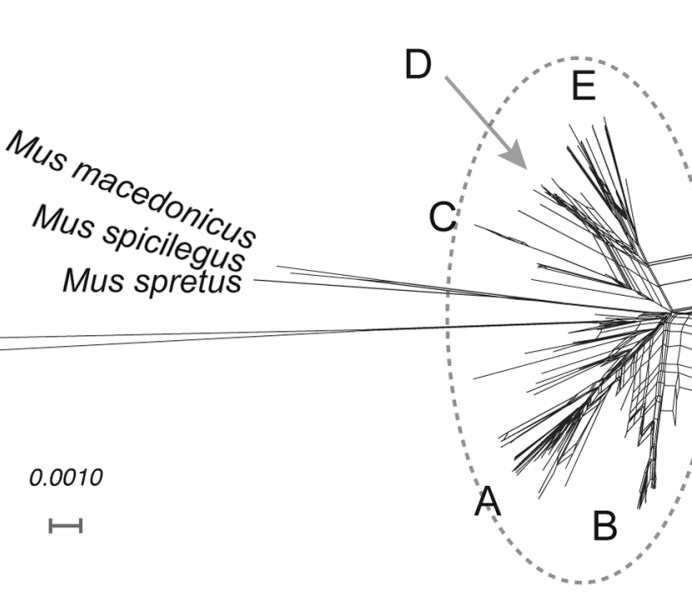

CAS

Mus musculus

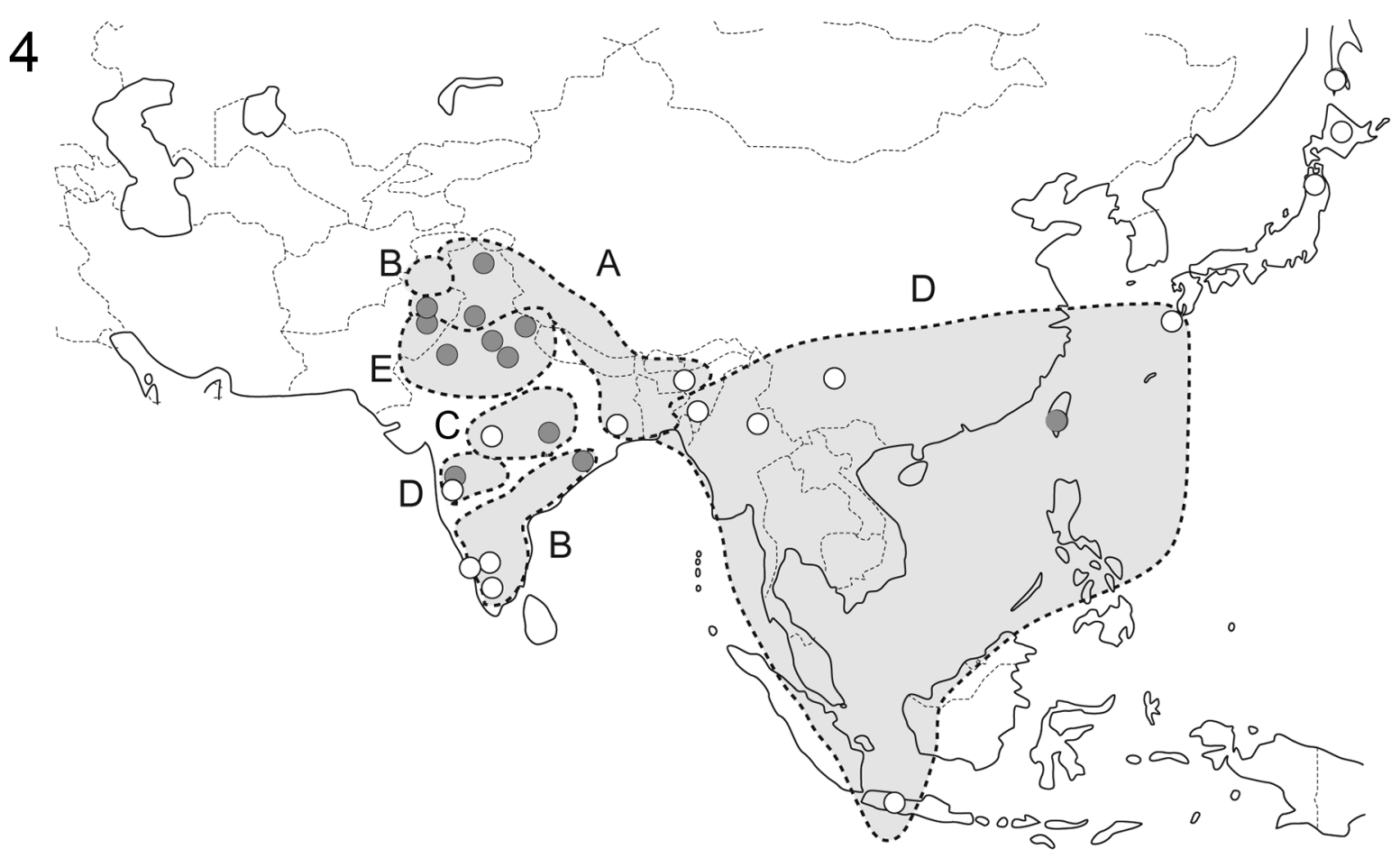

Figures 2-4. Assessment of population genetic structure using concatenated sequences (4302 bp) of seven nuclear genes. (2) Positions of the analysed regions (open triangles) in seven genes on murine chromosome 8 (Nunome et al., 2010; Kodama et al., 2013). (3) NeighbourNet network based on concatenated sequences from 98 Mus musculus, showing haplogroups representing the subspecies groups Mus musculus domesticus (DOM), Mus musculus castaneus (CAS), and Mus musculus musculus (MUS) as well as recombinant haplotypes (Re) (Kodama et al., 2013). In the network, the level of diversity of CAS is markedly higher than those of DOM and MUS, yielding five distinct phylogroups A-E. Scale bar indicates genetic divergence. (4) Approximate geographic ranges of the five subclusters of CAS. Localities where samples used in this analysis were collected are marked with open and filled circles, representing the mitochondrial haplogroup CAS-1 and all other types, respectively (Kodama et al., 2013). The phylogroups A-E of CAS showed rough geographical distributions and one of them, phylogroup D, comprised the haplotypes recovered from a large geographical area of Southeast Asia, south China, and Indonesia and can be characterized as the lineage dispersed with prehistoric human movement (arrow; Kodama et al., 2015). Note that subcluster D (arrow in Fig. 3) shows a broad distribution range in Southeast Asia and the southern part of East Asia. In the Neighbor-Net network, this subcluster exhibits limited divergence among haplotypes. 
M. m. domesticus (DOM), M. m. musculus (MUS), and M. m. castaneus (CAS). The levels of differentiation vary among the nuclear genes examined and some genes show more ancient divergence of allelic sequences than others, up to 1 Ma (Kodama et al., 2015). The three subspecies groups may have had genetic exchanges prior to their human-associated geographical expansion (Kodama et al., 2015). In addition, hybridization among subspecies groups has occurred due to secondary contact after long-distance dispersal, and hence the composition of the nuclear genome of M. musculus is complex (Nunome et al., 2010; Kuwayama et al., 2017). However, the rapidity of evolution of these nuclear genes allows reconstruction of this complexity of each subspecies group's range expansion events.

Of the three subspecies, DOM, which is currently found in Western Europe, showed a star-like structure in the network constructed from mtDNA sequences $(C y t b$, $1140 \mathrm{bp}$ ), indicative of rapid population expansion. The mode of the number of substitutions among the sequences $(\tau)$ is around 5.6 (Suzuki et al., 2013). The time (T) when expansion started can be calculated as 52,000 years ago $\left(\mathrm{T}=5.6 / 2 / 1140 / 4.7 / 10^{-8}\right)$ based on the time dependent evolutionary rate of 0.047 substitutions/site/Myr (see Hanazaki et al., 2017 for detail). During this period, major environmental changes have occurred, with rapid expansion of grasslands in the Northern Hemisphere. Moreover, a simultaneous population expansion of herbivorous rodents (voles, genus Myodes) has been observed in North America (Kohli et al., 2015), the Eurasian continent (Abramson et al., 2012), and the Japanese archipelago (Honda et al., 2019). The DOM subspecies group is believed to have expanded its geographic range into Western Europe approximately 15,000-10,000 years ago based on fossil evidence (Cucchi et al., 2005; Weissbrod et al., 2017). In my view, this range expansion event more likely occurred before this time range, with nucleotide diversity achieved prior to the human-associated expansion, if we accept that the generation of diversity began around 50,000 years ago in its original range. Notably, historical colonization is not always associated with development of an agricultural system and has also been achieved by human settlements without agriculture (Weissbrod et al., 2017). In modern times, DOM continues to be introduced to other parts of the world (e.g., Indonesia, Senegal, Somalia, Australia) (Suzuki et al., 2013). In contrast, Russian DOM populations have unique features and are suggested to have arisen from a different historical episode. In Japan, haplotype structure analysis of nuclear genes indicated that DOM has been introduced very recently, perhaps 50 years ago (Nunome et al., 2010; Kuwawama et al., 2017; Isobe et al., 2018). A DOM fragment of approximately $3-5 \mathrm{Mb}$ is embedded in the nuclear genome of Japanese mice, with an estimated transfer time several decades ago (Nunome et al., 2010; Kuwayama et al., 2017; Isobe et al., 2018).

The subspecies group MUS has a huge range in northern Eurasia. Notably, morphological features differ substantially between mice in Eastern Europe and East Asia (Marshall, 1998). Based on morphological characters and genetic analyses, the subspecies group can be subdivided further into two groups, MUS-I and MUS-II, represented by the traditional subspecies of "M. m. musculus" and "M. m. wagneri", respectively, which may have originated in separate geographic areas, such as the western and eastern sides of the Caspian Sea (see Suzuki et al., 2015). In mtDNA variation analysis, two phylogroups, termed MUS-1 and MUS-2, were recognized, with an estimated divergence time of 130,000 years ago (Suzuki et al., 2013). These phylogroups tend to be distributed in the southern and northern parts of Eurasia, respectively. Applying the timedependent evolutionary rate of 0.11 substitutions/site/Myr for inference of divergence times based on mtDNA sequences led to detailed reconstruction of M. musculus dynamics, as affected by human activity (Suzuki et al., 2013; Kuwayama et al., 2017). The resultant evolutionary scenarios are in good accordance with archaeological evidence observed in Asia, especially in China, Korea, and Japan (Li et al., 2020).

CAS contains three or four major mtDNA sub-lineages that diverged hundreds of thousands of years ago; among them, CAS-1 has spread over a wide area of eastern Eurasia (Figs 3C, 4). It extends to many regions of South and East Asia, including Pakistan, India, Southeast Asia, Indonesia, Philippines, south and northeast China, Primorye, Sakhalin, and Japan (Suzuki et al., 2013; Kuwayama et al., 2017; Bibi et al., 2017). The network drawn from CAS-1 haplotypes has a star-shaped structure, indicative of rapid population expansion events. The beginning of rapid expansion was calculated as 8000-7000 years ago (Suzuki et al., 2013; Kuwayama et al., 2017), based on the time-dependent mtDNA evolutionary rate of 0.11 substitutions/site/Myr. This date is consistent with early agricultural development in Asia (Fuller et al., 2010, 2014). In addition, a secondary expansion event occurred in south China, as observed in the basin of the Yangtze River including localities in Yunnan (Lijiang, Dali, and Kunming), as well as in Kyushu, Tohoku, and Hokkaido, in Japan (CAS-1a). The initiation of this expansion was estimated at around 4000 years ago. More detailed analysis, such as investigation of whole mitochondrial DNA sequences, is needed.

\section{Conclusion}

The direction of research on the taxonomic and molecular phylogenetic relationships of the murine subfamily in Southeast Asia was initiated by Ken Aplin twenty years ago. He constructed a framework of the phylogenetic relationships among species in the genus Mus (Shimada et al., 2010) and demonstrated the need for analysis of intra-species geographic variations through the examples of M. musculus (Suzuki et al., 2013) and M. caroli (Shimada et al., 2007). At present, the research that he began is being continued by his colleagues and progressing toward its goal, despite many aspects remaining unexplained. In particular, it is necessary to carefully examine the species status of "Mus cervicolor" throughout its putative range. In Myanmar, research addressing species assemblages is in progress and early signs suggest that new species exist, for which both morphological and molecular studies are necessary. Another important issue involves resolving the impact of humans on the diversity of rodents in the human era of the last 15,000 years. Such efforts will serve to clarify the concealed evolutionary history of these species in prehistory. Ken Aplin conducted a survey of the black rat, Rattus rattus complex, using mtDNA sequences and characterized the general movements of the species complex in Eurasia (Aplin et al., 2011). Ken Aplin also conducted surveys worldwide using nuclear markers for 
the $R$. rattus complex that are still currently being worked on. To attain a comprehensive view of the impacts of human history on rodent evolution, comparative studies should be conducted on other commensal rodents in addition to the $R$. rattus complex and M. musculus (Aplin \& Singleton, 2003), such as R. exulans (Thomson et al., 2014) and Bandicota species (Pagès et al., 2010). Clarification of evolutionary trends based on mtDNA markers is an important step toward reaching this goal.

ACKnowledgements. Ken Aplin was a constant source of encouragement, I greatly valued his professionalism, and his friendship. I also thank Kazuo Moriwaki, Hiromichi Yonekawa, Toshihiko Shiroishi, and Kimiyuki Tsuchiya for their time supervising my research. I wish to express my appreciation to Angela Frost, Alexey Kryukov, Thidalay Thwe, Sang-Hoon Han, Naoto Hanzawa, Hidetoshi Ikeda, Yoshifumi Matsushima, Pavel Munclinger, Peter Vogel, Sayaka Kodama, Nozomi Nakajima, Mitsuo Nunome, Takashi Kuwayama, Mie Terashima, and Daiki Usuda for their collaboration and support and to numerous collectors of mice for their kind help. I thank Jonathan Cramb, Kristofer Helgen, Julien Louys, and Vicki Ann Thomson for their comments, which helped to improve the manuscript. The study was supported by JSPS KAKENHI grant number JS18H05508.

\section{References}

Abramson, N. I., T. V. Petrova, N. E. Dokuchaev, E. V. Obolenskaya, and A. A. Lissovsky. 2012. Phylogeography of the gray redbacked vole Craseomys rufocanus (Rodentia: Cricetidae) across the distribution range inferred from nonrecombining molecular markers. Russian Journal of Theriology 11: 137-156.

Aplin, K. P., P. R. Brown, J. Jacob, C. J. Krebs, and G. R. Singleton. 2003. Field Methods for Rodent Studies in Asia and the IndoPacific. ACIAR Monograph no. 100, 223 pp.

Aplin, K. P., and G. R. Singleton. 2003. Balancing rodent management and small mammal conservation in agricultural landscapes: challenges for the present and the future. In Rats, Mice and People: Rodent Biology and Management, ed. G. R. Singleton, L. A. Hinds, C. J. Krebs, and D. M. Spratt, pp. 80-88. ACIAR Monograph no. 96, 564 pp.

Aplin, K. P., H. Suzuki, A. A. Chinen, R. T. Chesser, J. ten Have, S. C. Donnellan, J. Austin, A. Frost, J. P. Gonzalez, V. Herbreteau, F. Catzeflis, J. Soubrier, Y.-P. Fang, J. Robins, E. Matisoo-Smith, A. D. S. Bastos, I. Maryanto, M. H. Sinaga, C. Denys, R. A. Van Den Bussche, C. Conroy, K. Rowe, and A. Cooper. 2011. Multiple geographic origins of commensalism and complex dispersal history of Black Rats. PLoS ONE 6(11): e26357. https://doi.org/10.1371/journal.pone.0026357

Bibi, S., M. S. Nadeem, A. S. Wiewel, M. A. Beg, K. Hameed, M. Jabeen, and G. K. Raja. 2017. Mitochondrial genetic diversity and phylogeography of Mus musculus castaneus in Northern Punjab, Pakistan. Zoological Science 34: 490-497. https://doi.org/10.2108/zs170086

Boursot, P., J. C. Auffray, J. Britton-Davidian, and F. Bonhomme. 1993. The evolution of house mice. Annual Review of Ecology and Systematics 24: 119-152.

https://doi.org/10.1146/annurev.es.24.110193.001003

Cucchi, T., J. D. Vigne, and J. C. Auffray. 2005. First occurrence of the house mouse (Mus musculus domesticus Schwarz \& Schwarz, 1943) in the Western Mediterranean: a zooarchaeological revision of subfossil occurrences. Biological Journal of the Linnean Society 84(3): 429-445.

https://doi.org/10.1111/j.1095-8312.2005.00445.x
Fuller, D. Q., Y. I. Sato, C. Castillo, L. Qin, A. R. Weisskopf, E. J. Kingwell-Banham, J. Song, S.-M. Ahn, and J. van Etten. 2010. Consilience of genetics and archaeobotany in the entangled history of rice. Archaeological and Anthropological Sciences 2(2): 115-131.

https://doi.org/10.1007/s12520-010-0035-y

Fuller, D. Q., T. Denham, M. Arroyo-Kalin, L. Lucas, C. J. Stevens, L. Qin, R. G. Allaby, and M. D. Purugganan. 2014. Convergent evolution and parallelism in plant domestication revealed by an expanding archaeological record. Proceedings of the National Academy of Sciences USA 111: 6147-6152. https://doi.org/10.1073/pnas.1308937110

Isobe, M., M. Nunome, K. Katakura, and H. Suzuki. 2018. Evolutionary dynamics of copy number and meiotic recombination in murine 5S rDNA: possible involvement of natural selection. Journal of Molecular Evolution 86(5): 312-323. https://doi.org/10.1007/s00239-018-9848-6

Kodama, S., M. Nunome, K. Moriwaki, and H. Suzuki. 2015. Ancient onset of geographical divergence, interpopulation genetic exchange, and natural selection on the Mclr coat-colour gene in the house mouse (Mus musculus). Biological Journal of the Linnean Society 114: 778-794. https://doi.org/10.1111/bij. 12471

Kohli, B. A., V. B. Fedorov, E. Waltari, and J. A. Cook. 2015. Phylogeography of a Holarctic rodent (Myodes rutilus): testing high latitude biogeographical hypotheses and the dynamics of range shifts. Journal of Biogeography 42: 377-389. https://doi.org/10.1111/jbi.12433

Kuwayama, T., M. Nunome, G. Kinoshita, K. Abe, and H. Suzuki. 2017. Heterogeneous genetic make-up of Japanese house mice (Mus musculus) created by multiple independent introductions and spatio-temporally diverse hybridization processes. Biological Journal of the Linnean Society 122: 661-674. https://doi.org/10.1093/biolinnean/blx076

Li, Y., K. Fujiwara, N. Osada, Y. Kawai, T. Takada, A. P. Kryukov, K. Abe, H. Yonekawa, T. Shiroishi, K. Moriwaki, N. Saitou, and H. Suzuki. 2020. House mouse Mus musculus dispersal in East Eurasia inferred from 98 newly determined complete mitochondrial genome sequences. Heredity. https://doi.org/10.1038/s41437-020-00364-y

Marshall, J. T. 1977. A synopsis of Asian species of Mus (Rodentia, Muridae). Bulletin of the American Museum of Natural History 158: $173-220$.

Marshall, J. T. 1998. Identification and scientific names of Eurasian house mice and their European allies, subgenus Mus Rodentia: Muridae. Unpublished report, National Museum of Natural History, Washington.

Musser, G., and M. Carleton. 2005. Superfamily Muroidea. In Mammal Species of the World: A Taxonomic and Geographic Reference, volume 2, 3rd edition, ed. D. E. Wilson and D. M. Reeder, pp. 894-1531. Baltimore: The Johns Hopkins University Press.

Myat Myat Zaw, K., T. Taw, T. Shimada, S. Maung Maung Theint, K. M. Saing, S. Bawm, K. Katakura, and H. Suzuki. 2019. Molecular characterization of species of the subgenus Mus from Myanmar. Zoological Science 36: 299-305. https://doi.org/10.2108/zs180161

Nunome, M., C. Ishimori, K. P. Aplin, K. Tsuchiya, H. Yonekawa, K. Moriwaki, and H. Suzuki. 2010. Detection of recombinant haplotypes in wild mice (Mus musculus) provides new insights into the origin of Japanese mice. Molecular Ecology 19(12): 2474-2489.

https://doi.org/10.1111/j.1365-294X.2010.04651.X

Pagès, M., Y. Chaval, V. Herbreteau, S. Waengsothorn, J. F. Cosson, J. P. Hugot, S. Morand, and J. Michaux. 2010. Revisiting the taxonomy of the Rattini tribe: a phylogeny-based delimitation of species boundaries. BMC Evolutionary Biology 10(1): 184. https://doi.org/10.1186/1471-2148-10-184 
Prager, E. M, C. Orrego, and R. D. Sage. 1998. Genetic variation and phylogeography of Central Asian and other house mice, including a major new mitochondrial lineage in Yemen. Genetics 150: 835-861.

Sakuma, Y., M. C. Ranorosoa, G. Kinoshita, H. Shimoji, K. Tsuchiya, S. D. Ohdachi, S. Arai, C. Tanaka, H. Ramino, and H. Suzuki. 2016. Variation in the coat-color-controlling genes, Mclr and Asip, in the house mouse Mus musculus from Madagascar. Mammal Study 41: 131-140.

https://doi.org/10.3106/041.041.0303

Shimada, T., K. P. Aplin, P. Jenkins, and H. Suzuki. 2007a. Rediscovery of Mus nitidulus Blyth (Rodentia: Muridae), an endemic murine rodent of the central basin of Myanmar. Zootaxa 1498(1): 45-68.

https://doi.org/10.11646/zootaxa.1498.1.4

Shimada, T., K. P. Aplin, T. Jogahara, L. A. Lin, V. Herbreteau, J. P. Gonzalez, and H. Suzuki. 2007b. Complex phylogeographic structuring in a continental small mammal from East Asia, the rice field mouse, Mus caroli (Rodentia, Muridae). Mammal Study 32: 49-62. https://doi.org/10.3106/1348-6160(2007)32[49:CPSIAC]2.0.CO;2

Shimada, T., J. J. Sato, K. P. Aplin, and H. Suzuki. 2009. Comparative analysis of evolutionary modes in Mclr coat color gene in wild mice and mustelids. Genes and Genetic Systems 84: 225-231. https://doi.org/10.1266/ggs.84.225

Shimada, T., K. P. Aplin, and H. Suzuki. 2010. Mus lepidoides (Muridae, Rodentia) of central Burma is a distinct species of potentially great evolutionary and biogeographic significance. Zoological Science 27: 449-459.

https://doi.org/10.2108/zsj.27.449

Suzuki, Y., M. Tomozawa, Y. Koizumi, K. Tsuchiya, and H. Suzuki. 2015. Estimating the molecular evolutionary rates of mitochondrial genes referring to Quaternary Ice Age events with inferred population expansions and dispersals in Japanese Apodemus. BMC Evolutionary Biology 15: 1.

https://doi.org/10.1186/s12862-015-0463-5
Suzuki, H., T. Shimada, M. Terashima, K. Tsuchiya, and K. Aplin. 2004. Temporal, spatial, and ecological modes of evolution of Eurasian Mus based on mitochondrial and nuclear gene sequences. Molecular Phylogenetics and Evolution 33: 626-646. https://doi.org/10.1016/j.ympev.2004.08.003

Suzuki, H., M. Nunome, G. Kinoshita, K. P. Aplin, P. Vogel, A. P. Kryukov, M. L. Jin, S. H. Han, I. Maryanto, K. Tsuchiya, H. Ikeda, T. Shiroishi, H. Yonekawa, and K. Moriwaki. 2013. Evolutionary and dispersal history of Eurasian house mice Mus musculus clarified by more extensive geographic sampling of mitochondrial DNA. Heredity 111(5): 375-390. https://doi.org/10.1038/hdy.2013.60

Suzuki, H., L. V. Yakimenko, D. Usuda, and L. V. Frisman. 2015. Tracing the eastward dispersal of the house mouse, Mus musculus. Genes and Environment 37(1): 20. https://doi.org/10.1186/s41021-015-0013-9

Terashima, M., S. Furusawa, N. Hanzawa, K. Tsuchiya, A. Suyanto, K. Moriwaki, H. Yonekawa, and H. Suzuki. 2006. Phylogeographic origin of Hokkaido house mice (Mus musculus) as indicated by genetic markers with maternal, paternal and biparental inheritance. Heredity 96(2): 128-138. https://doi.org/10.1038/sj.hdy.6800761

Thomson, V., K. P. Aplin, A. Cooper, S. Hisheh, H. Suzuki, I. Maryanto, G. Yap, and S. C. Donnellan. 2014. Molecular genetic evidence for the place of origin of the Pacific Rat, Rattus exulans. PLoS ONE 9(3): e91356. https://doi.org/10.1371/journal.pone.0091356

Weissbrod, L., F. B. Marshall, F. R. Valla, H. Khalaily, G. Bar-Oz, J. C. Auffray, J.-D. Vigne, and T. Cucchi. 2017. Origins of house mice in ecological niches created by settled hunter-gatherers in the Levant 15,000 y ago. Proceedings of the National Academy of Sciences USA 114(16): 4099-4104. https://doi.org/10.1073/pnas.1619137114

Wilson, D. E., T. E. Lacher, and R. A. Mittermeier. 2016. Handbook of the Mammals of the World, Volume 6: Lagomorphs and Rodents I. Barcelona, Spain: Lynx Edicions. 



\title{
Litoria aplini sp. nov., a New Species of Treefrog (Pelodryadidae) from Papua New Guinea
}

\author{
Stephen J. Richards (iD and Stephen C. Donnellan (D) \\ South Australian Museum, North Terrace, Adelaide SA 5000, Australia
}

\begin{abstract}
We describe a new species in the Australopapuan pelodryadid frog genus Litoria from upper hill forest ( $940 \mathrm{~m}$ a.s.l.) on the northern slopes of Papua New Guinea's central cordillera. The new species is moderately small (male body length $=31.9-35.1 \mathrm{~mm}$ ) and slender (head width/body length $=0.29-0.30$ ), with extensive golden-yellow markings ventrally. It is most similar to Litoria iris, L. majikthise, L. ollauro, and $L$. verae but differs from them by a suite of morphological and colour features. The advertisement call is a series of short buzzes and clicks reminiscent of calls produced by both L. iris and L. ollauro. Phylogenetic analysis of mitochondrial ND4 nucleotide sequences shows that the new species is closest to $L$. iris and L. majikthise but shows a net sequence divergence of $14-15 \%$ from both of these taxa. The new species is unusual in being found calling from forest on limestone substrate where free-standing water is rarely encountered.
\end{abstract}

\section{Introduction}

Litoria is a morphologically and ecologically diverse assemblage of pelodryadid frogs confined almost entirely to the Australopapuan region (Tyler, 1999). Although there have been attempts to divide Litoria into informal species groups (Tyler \& Davies, 1978; King, 1981; Menzies, 2006), and into a number of genera (Duellman et al., 2016), relationships among many species remain poorly resolved, limiting the usefulness of proposed generic or species group concepts. One such example is Litoria iris and its relatives. Litoria iris is a small, brightly coloured, montane treefrog from mainland New Guinea, typically occurring at altitudes above c. $1500 \mathrm{~m}$ a.s.l. (Menzies, 2006) although there is a single record from $1000 \mathrm{~m}$ a.s.l. (Kraus \& Allison, 2006). Adults glue their large, green eggs to vegetation hanging over small pools in a wide range of pristine and degraded habitats (Menzies, 2006). Menzies (1972) and Tyler \& Davies (1978) included this species in the "Litoria nigropunctata Group" along with L. nigropunctata and $L$. vocivincens, two lowland species that differ markedly from L. iris in laying small pigmented eggs and in lacking bright colours ventrally (Menzies, 2006). Menzies (1993), in placing greater taxonomic emphasis on known or presumed reproductive strategies, included $L$. iris in an "L. iris group" along with six other species, four of them described as new: L. chloronota, L. havina, L. majikthise (as L. leucova), $L$. mucro, L. ollauro, and L. pronimia. Subsequently, Menzies (2006) expanded the "L. iris group" to include an additional three species, L. leucova, L. multiplica, and L. prora, creating a morphologically and ecologically heterogeneous assemblage defined by a single character: gluing large pale eggs on leaves above water. However, the reproductive strategies of five of the ten species in Menzies' " $L$. iris group" have not been documented as yet, and the striking morphological and ecological divergences evident among members of the group (see e.g., Menzies, 2006) suggest that it is unlikely to be monophyletic. 
Despite ongoing uncertainty about relationships among many members of the " $L$. iris group" as defined by Menzies (2006), several species within that assemblage, L. iris, L. majikthise, L. ollauro, share a suite of morphological, acoustic, and colour features that hint at a close relationship. These include moderately small size, enlarged tubercles along the outer margins of the limbs, bright colours in life ventrally and/or on the hidden surfaces of the thighs, and advertisement calls (where known) consisting of short chirps and buzzes. Three additional species, L. richardsi, $L$. singadanae, and $L$. verae, that were not included in the " $L$. iris group" by Menzies (2006) share these morphological and colour features, and two of them have similar calls; the call of $L$. singadanae has not been documented.

Discovery of a population of Litoria in Sandaun Province on the northern slopes of Papua New Guinea's central cordillera that exhibits characters typical of the "L. iris group" but differs consistently in a unique suite of morphological and acoustic features, led us to examine its molecular genetic relationships. Based on a combination of molecular genetic, morphological, and acoustic data we here describe the population from northern New Guinea as a new species.

\section{Materials and methods}

\section{Molecular genetics}

Frozen or alcohol preserved tissues were available from 25 Litoria from 20 locations (Appendix 1). Selection of taxa was based on the mitochondrial DNA sequence phylogenetic analysis of Rosauer et al. (2009) and a broader unpublished mitochondrial barcode survey of Melanesian pelodryadid frogs (Donnellan, Richards, and Mahony, unpublished). DNA was extracted using a Puregene DNA isolation kit (Gentra Systems, Minneapolis, MN, U.S.A.) following the manufacturer's protocol for DNA purification from solid tissue. A fragment of the mitochondrial $N A D H$ dehydrogenase subunit 4 (ND4) gene was amplified and sequenced using the forward primers 5'-TGACTACCAAAA GCTCATGTAGAAGC-3' with the reverse primer 5'-CATT TACTTTTTACTTGGATTTGCACCA-3'. Each PCR was carried out in a volume of $25 \mu \mathrm{l}$ with a final concentration of 1X GeneAmp PCR Gold buffer, 2-4 mM MgCl2, $200 \mathrm{M}$ of each dNTP, $0.2 \mathrm{mM}$ of each primer and $0.5 \mathrm{U}$ of AmpliTaq Gold DNA polymerase (Applied Biosystems, Foster City, CA, U.S.A.). Amplifications consisted of an initial denaturation step of $94^{\circ} \mathrm{C}$ for $9 \mathrm{~min}$, followed by 34 cycles of PCR with the following temperature profile: denaturation at $94^{\circ} \mathrm{C}$ for $45 \mathrm{~s}$, annealing at $55^{\circ} \mathrm{C}$ for $45 \mathrm{~s}$, and extension at $72^{\circ} \mathrm{C}$ for $1 \mathrm{~min}$, with an additional final extension at $72^{\circ} \mathrm{C}$ for $6 \mathrm{~min}$. The double-stranded amplification products were visualized on $1.5 \%$ agarose gels and purified using an UltraClean PCR clean-up DNA purification kit (Mo Bio Laboratories Inc., CA) before cycle-sequencing using the BigDye Terminator v3.1 cycle-sequencing kit (Applied Biosystems). The cycling protocol consisted of 25 cycles of denaturation at $96^{\circ} \mathrm{C}$ for $30 \mathrm{~s}$, annealing at $50^{\circ} \mathrm{C}$ for $15 \mathrm{~s}$, and extension at $60^{\circ} \mathrm{C}$ for $4 \mathrm{~min}$. All samples were sequenced on an Applied Biosystems 3700 DNA sequencer. Sequences were aligned with Muscle v6.814b (Edgar, 2004) implemented in Geneious Pro v8.1.4 (Kearse et al., 2012 ) and are deposited in GenBank (accessions numbers: MT268302-268326).
Bayes factors were used to assess all possible alternative partitioning strategies for four data subsets - 1 st, 2nd and 3rd codon positions and the tRNA in PartitionFinder v1.0.0 (Lanfear et al., 2012). The Bayes Information Criterion (BIC) was used to assess the best fit partition strategy and nucleotide substitution model for each data subset in the selected partition strategy. The data subset scheme comprised each of the codon positions as subsets with nucleotide substitution models $\mathrm{GTR}+\mathrm{I}+\mathrm{G}$ for the 1 st and 2 nd codon subsets and the GTR $+\mathrm{G}$ model for the 3rd codon position.

Sequences were analysed phylogenetically using Bayesian and maximum likelihood methods. Bayesian analysis was conducted using MrBayes v3.1.2 (Ronquist \& Huelsenbeck, 2003). The analysis was run with model parameters unlinked using default priors for ten million generations with two independent runs and two chains sampling every 1000 generations. Convergence was assessed as achieved when the average standard deviation of split frequencies was $<0.001$ and effective sample sizes (ESS) were $>3500$ as determined in TRACER v1.4.1 (Rambaut \& Drummond, 2007). The first $25 \%$ of sampled trees were discarded as burn-in. Partitioned maximum likelihood (ML) analysis was performed using RAxML v8.0 (Stamatakis, 2014) on the CIPRES Science Gateway (Miller et al., 2010).

Net average sequence divergence between lineages $(d A)$ was calculated in Mega v5 (Tamura et al., 2011) as: $d A=$ $d \mathrm{XY}-(d \mathrm{X}+d \mathrm{Y}) / 2$, where, $d \mathrm{XY}$ is the average distance between groups $\mathrm{X}$ and $\mathrm{Y}$, and $d \mathrm{X}$ and $d \mathrm{Y}$ are the within-group means (Table 1).

Molecular diagnostics. Following the recommendation of Renner (2016), we visually identified diagnostic SNPs within the mitochondrial ND4 gene in Geneious Pro v8.1.4. We selected the apomorphic SNPs that diagnosed the new species from its two closest relatives, using more distantly related members of the larger clade to assess character state polarity (Table 2).

\section{Morphology}

Measurements, terminology, and abbreviations follow Tyler (1968) and Oliver et al. (2019b). Measurements were made to the nearest $0.01 \mathrm{~mm}$ with callipers (SVL - body length from snout to vent, TL - tibia length from heel to outer surface of flexed knee, HL — head length, from tip of snout to posterior margin of tympanum, HW-head width at level of tympana) or a dissecting microscope fitted with an optical micrometer (all other measurements): EN—distance from anterior corner of eye to posterior margin of naris; $\mathrm{IN}$ - internarial distance, between medial margins of external nares; EYE-horizontal diameter of eye; TYM - horizontal diameter of tympanum including tympanic annulus; 3FD - transverse diameter of disc of finger III; 3FP - transverse diameter of penultimate phalanx of finger III; 4TD - transverse diameter of disc of toe IV and 4TP-transverse diameter of penultimate phalanx of toe IV. Measurements are presented as mean \pm SD and range. Sex was determined by examination of vocal slits, nuptial pads, the presence of eggs and by observation of calling. Calls were recorded using a Sennheiser ME66 microphone, K6 powering module, and a Marantz PMD-660 digital recorder. Calls were analysed using Avisoft-SASLab Pro (v4.34, available from Avisoft Bioacoustics: http://www.avisoft.com/ ).

Type specimens are deposited in the South Australian Museum, Adelaide (SAMA), and one will be repatriated to 
Table 1. Net average sequence divergence for the mitochondrial ND4 gene between species of Litoria. Bold values are between pairs of sister species.

\begin{tabular}{lccccccccccccccc}
\hline & aplini & iris & maj & sing & rich & viv & mucr & pron & ver & nigro & biak & bic & olo & cool & fall \\
\hline L. aplini & - & & & & & & & & & & & & & & \\
L. iris & 0.14 & - & & & & & & & & & & & & \\
L. majikthise & 0.15 & $\mathbf{0 . 1 5}$ & - & & & & & & & & & & & \\
L. singadanae & 0.21 & 0.22 & 0.23 & - & & & & & & & & & & \\
L. richardsi & 0.23 & 0.24 & 0.24 & $\mathbf{0 . 1 9}$ & - & & & & & & & & & \\
L. vivissimia & 0.23 & 0.24 & 0.25 & 0.22 & 0.24 & - & & & & & & & & \\
L. mucro & 0.21 & 0.23 & 0.22 & 0.24 & 0.25 & 0.19 & - & & & & & & & \\
L. pronimia & 0.23 & 0.23 & 0.24 & 0.22 & 0.23 & 0.19 & $\mathbf{0 . 1 5}$ & - & & & & & & \\
L. verae & 0.22 & 0.25 & 0.22 & 0.22 & 0.24 & 0.22 & 0.22 & 0.23 & - & & & & & \\
L. nigropunctata & 0.23 & 0.24 & 0.23 & 0.22 & 0.23 & 0.22 & 0.24 & 0.24 & 0.23 & - & & & & \\
L. biakensis & 0.22 & 0.23 & 0.23 & 0.20 & 0.23 & 0.23 & 0.21 & 0.22 & 0.23 & $\mathbf{0 . 2 2}$ & - & & & \\
L. bicolor & 0.21 & 0.22 & 0.22 & 0.23 & 0.23 & 0.21 & 0.20 & 0.21 & 0.24 & 0.21 & 0.20 & - & & \\
L. olongburensis & 0.20 & 0.21 & 0.22 & 0.21 & 0.21 & 0.22 & 0.22 & 0.24 & 0.21 & 0.22 & 0.21 & 0.20 & - & & \\
L. cooloolensis & 0.23 & 0.25 & 0.22 & 0.23 & 0.24 & 0.23 & 0.24 & 0.24 & 0.24 & 0.23 & 0.24 & 0.22 & 0.18 & - & \\
L. fallax & 0.21 & 0.23 & 0.22 & 0.22 & 0.24 & 0.23 & 0.22 & 0.25 & 0.20 & 0.21 & 0.20 & 0.21 & 0.16 & $\mathbf{0 . 1 1}$ & - \\
\hline
\end{tabular}

the Papua New Guinea National Museum and Art Gallery, Port Moresby (PNGNM). Specimens examined are listed in Appendix 1. Other comparisons were made from the relevant literature (Menzies, 1993; Johnston \& Richards, 1994; Günther, 2004; Kraus \& Allison, 2004; Richards, 2005; Dennis \& Cunningham, 2006).

\section{Taxonomy}

The new species described here is assigned to Litoria sensu Tyler \& Davies (1978) based on its molecular genetic relationships pending a phylogenetic based resolution of generic boundaries within Pelodryadidae (e.g., Kraus, 2018). Our genetic, morphological, and acoustic (where available) data support its distinctiveness and indicate that the new species' relationships lie with a small group of Litoria characterized by their moderately small size, crenulated skin folds or pale tubercles along the outer margins of the tarsi, and brightly coloured ventral surfaces and/or limbs. These are L. iris, L. majikthise, L. richardsi, L. singadanae, and

Table 2. Apomorphic nucleotide states in the mitochondrial ND4 gene diagnosing L. aplini from eight most closely related species.

\begin{tabular}{|c|c|c|c|c|c|c|c|c|c|c|c|c|}
\hline \multirow[t]{4}{*}{ taxon } & \multicolumn{12}{|c|}{ nucleotide position } \\
\hline & & & 2 & 3 & & 3 & & 3 & & & & \\
\hline & & & 3 & 1 & 3 & 5 & & 8 & & 0 & & \\
\hline & & 1 & 4 & 8 & 9 & 8 & & 4 & 2 & 7 & & \\
\hline L. $a_{1}$ & C & & G & A & A & A & & $\mathrm{C}$ & $\mathrm{T}$ & A & & \\
\hline L. iris & $\mathrm{C}$ & T & A & $\mathrm{T}$ & $\mathrm{C}$ & G & & $\mathrm{T}$ & $\mathrm{C}$ & G & $\mathrm{G}$ & A \\
\hline L. majikthise & G & $\mathrm{T}$ & A & $\mathrm{C}$ & $\mathrm{C}$ & G & A & $\mathrm{T}$ & A & G & $\mathrm{T}$ & $A$ \\
\hline L. richardsi & A & A & A & $\mathrm{C}$ & $\mathrm{C}$ & $\mathrm{C}$ & A & $\mathrm{T}$ & A & $\mathrm{T}$ & $\mathrm{T}$ & A \\
\hline L. sing & A & $\mathrm{T}$ & A & $\mathrm{T}$ & $\mathrm{T}$ & $\mathrm{C}$ & $\mathrm{T}$ & $\mathrm{T}$ & A & $\mathrm{T}$ & & \\
\hline L. vivissimia & A & $\mathrm{T}$ & A & $\mathrm{C}$ & $\mathrm{T}$ & $\mathrm{C}$ & $\mathrm{T}$ & $\mathrm{T}$ & G & $\mathrm{C}$ & $\mathrm{T}$ & \\
\hline L. muсro & A & A & A & $\mathrm{T}$ & $\mathrm{T}$ & $\mathrm{C}$ & $\mathrm{T}$ & $\mathrm{T}$ & A & $\mathrm{C}$ & $\mathrm{T}$ & A \\
\hline L. pronimia & A & $\mathrm{T}$ & A & $\mathrm{C}$ & $\mathrm{C}$ & $\mathrm{C}$ & $\mathrm{T}$ & $\mathrm{T}$ & A & $\mathrm{C}$ & $\mathrm{T}$ & A \\
\hline L. verae & A & $\mathrm{T}$ & A & $\mathrm{C}$ & $\mathrm{T}$ & $\mathrm{C}$ & $\mathrm{C}$ & $\mathrm{T}$ & A & $\mathrm{C}$ & $\mathrm{T}$ & A \\
\hline
\end{tabular}

L. verae. One other species, $L$. ollauro, is morphologically and acoustically similar to the new species and, although molecular genetic data were not available for $L$. ollauro, it is probably closely related.

\section{Pelodryadidae Günther, 1858}

\section{Litoria Tschudi, 1838}

\section{Litoria aplini sp. nov.}

urn:Isid:zoobank.org:pub:act:09663F46-325A-42B0-AB45-86517976962A

$$
\text { Figs 1-2 }
$$

Holotype. SAMA R71463 (Field number SJR12829), upper Sepik River catchment, West Sepik Province, Papua New Guinea $\left(4^{\circ} 38.637^{\prime} \mathrm{S} 141^{\circ} 40.747^{\prime} \mathrm{E}, 950 \mathrm{~m}\right.$ a.s.l.), 10 xii 2009, S. Richards. Paratypes. $(n=3)$ SAMA R71464 (Field number SJR12832), SAMA R71465 (Field number SJR12833), PNGNM (Field number SJR12834), same data as for holotype except collected 11 xii 2009.

Etymology. The species epithet is an honorific for Dr Ken Aplin, in recognition of his immense contributions to New Guinean herpetology and in gratitude for his friendship and selfless collaboration with the authors over many years. Ken's tremendous intellect, boundless energy, and unfailing humour in the field are sorely missed. We recommend the common name "Aplin's Treefrog" for this beautiful species.

Diagnosis. Litoria aplini sp. nov. is diagnosed morphologically from all congeners by the combination of body size moderately small (male SVL 31.9-35.1 mm); snout relatively broad $(E N / I N=0.79-0.84)($ Table 4$)$; presence of crenulated folds on outer edge of tarsi; webbing on hands extending to slightly past penultimate tubercle on fourth finger; presence of prominent ivory conical tubercles below vent and on ventral surfaces of thighs; and in the following colour in life traits - belly golden-yellow posteriorly, hidden surfaces of limbs predominantly blue with dark brown mottling except for discrete golden-yellow patch on posteroventral surface 
of thighs. The advertisement call is a short buzz normally followed by $1-7$ clicks, the latter most commonly comprising two pulses. From a genetic perspective, apomorphic nucleotide states at 12 sites in the mitochondrial ND4 gene reliably diagnose $L$. aplini from the eight most closely related species (Table 2).

Comparisons with other species (Table 3 and Fig. 3): Litoria aplini sp. nov. differs from other small (adult male SVL $<40 \mathrm{~mm}$ ), green or green and brown New Guinean Litoria as follows: from L. albolabris, L. longicrus, and $L$. mystax in having larger body size (male SVL $=31.9-35.1$ vs $<30.0 \mathrm{~mm}$ ), having prominent crenulated skin fold along outer margins of tarsi (vs absent), dorsum green and brown (vs uniform green), and lacking pale bar below eye (vs present).

Litoria aplini sp. nov. differs from members of the $L$. bicolor group (L. bibonius, L. chloristona, L. contrastens, $L$. eurynastes, L. lodesdema, L. viranula) in its larger size (male $\mathrm{SVL}=<31.6 \mathrm{~mm}$ in L. bicolor group; Menzies et al., 2008), having prominent crenulated skin fold along outer margins of tarsi (vs absent), dorsum green and brown (vs predominantly green), and venter golden-yellow (vs white); from L. bulmeri in having prominent crenulated skin fold along outer margins of tarsi (vs absent), dorsum green and brown (vs uniform green with broad black lateral stripe), and shorter limbs (TL/ $\mathrm{SVL}=0.59-0.66$ in L. bulmeri vs $0.56-0.57$ in L. aplini); from $L$. christianbergmanni in its larger size (male SVL = 26.9-31.2 $\mathrm{mm}$ in L. christianbergmanni), dorsum green and brown (vs uniform green with white, yellow or pale green spots), and lacking white bar below eye (vs present in $L$. christianbergmanni); from L. chloronota in having larger body size (males $27-32 \mathrm{~mm}$ in L. chloronota), narrower snout $(\mathrm{EN} / \mathrm{IN}=0.63-0.71$ in $L$. chloronota $\mathrm{vs} 0.79-0.84$ in L. aplini), having prominent crenulated skin fold along outer margins of tarsi (vs absent), dorsum green and brown (vs mottled pale and darker green with or without yellow spots), and venter posteriorly golden-yellow (vs cream) (Menzies, 1993); and from L. gasconi and L. multiplica by its smaller size (male $S V L \geq 36 \mathrm{~mm}$ in these species), and dorsum green and brown (vs uniform green with pale spots).

Litoria aplini sp. nov. differs from members of the $L$. gracilenta group (L. aruensis, L. auae, L. callista, L. elkeae, L. eschata, L. kumae, and L. robinsonae) in having prominent crenulated skin fold along outer margins of tarsi (vs absent), dorsum green and brown (vs plain green with or without pale or dark spots), and pale canthal and postocular stripes absent (vs present: Menzies \& Tyler, 2004; Kraus, 2013); from $L$. havina in having prominent crenulated skin fold along outer margins of tarsi (vs absent), dorsum green and brown (vs uniformly green or occasionally brown), and lacking a fleshy rostral spike in males (vs present); from L. nigropunctata in having prominent crenulated skin fold along outer margins of tarsi (vs absent), extensive golden-yellow on posterior of venter (vs absent in L. nigropunctata), grey (vs yellow) iris and extensive blue and dark brown mottling posterolaterally (vs absent); from L. rubrops in its larger size (male SVL = 21.4-25.2 $\mathrm{mm}$ in L. rubrops), having prominent crenulated skin fold along outer margins of tarsi (vs absent), dorsum green and brown (vs green, usually speckled with black or darker green), and iris grey with pale gold inner rim (vs iris red in L. rubrops); and from L. wapogaensis in having prominent crenulated skin fold along outer margins of tarsi (vs absent), dorsum green and brown (vs uniform green with or without pale spots), and hidden surfaces of thighs and groin golden-yellow (vs dark brown in L. wapogaensis).

Table 4. Measurements ( $\mathrm{mm}$ ) and ratios of the type series of Litoria aplini sp. nov. R71463 is the holotype. All specimens are adult males.

\begin{tabular}{lrrrrrr}
\hline trait & R71463 & R71464 & R71465 & SJR12834 & mean & SD \\
\hline SVL & 32.30 & 31.90 & 35.09 & 33.85 & 33.29 & 1.468 \\
TL & 18.08 & 17.80 & 20.15 & 19.08 & 18.78 & 1.067 \\
HL & 11.36 & 11.00 & 11.15 & 11.18 & 11.17 & 0.148 \\
HW & 9.85 & 9.81 & 10.16 & 9.90 & 9.93 & 0.158 \\
EYE & 4.20 & 4.20 & 4.30 & 4.10 & 4.20 & 0.080 \\
EAR & 1.90 & 1.90 & 2.10 & 1.90 & 1.95 & 0.100 \\
EN & 3.00 & 3.10 & 3.20 & 3.00 & 3.08 & 0.096 \\
IN & 3.80 & 3.70 & 3.90 & 3.80 & 3.80 & 0.082 \\
3FD & 1.60 & 1.50 & 1.70 & 1.50 & 1.58 & 0.096 \\
3FP & 1.10 & 1.10 & 1.30 & 1.00 & 1.13 & 0.126 \\
4TD & 1.50 & 1.40 & 1.50 & 1.30 & 1.43 & 0.096 \\
4TP & 1.10 & 1.00 & 1.10 & 0.90 & 1.03 & 0.096 \\
HL/SVL & 0.35 & 0.34 & 0.32 & 0.33 & 0.34 & 0.101 \\
HW/SVL & 0.30 & 0.31 & 0.29 & 0.29 & 0.30 & 0.107 \\
HL/HW & 1.15 & 1.12 & 1.10 & 1.13 & 1.13 & 0.937 \\
EYE/SVL & 0.13 & 0.13 & 0.12 & 0.12 & 0.12 & 0.065 \\
EAR/EYE & 0.48 & 0.49 & 0.50 & 0.48 & 0.48 & 0.853 \\
EAR/SVL & 0.06 & 0.06 & 0.06 & 0.06 & 0.06 & 0.056 \\
TL/SVL & 0.56 & 0.56 & 0.57 & 0.56 & 0.56 & 0.727 \\
EN/IN & 0.79 & 0.84 & 0.82 & 0.79 & 0.81 & 1.173 \\
IN/SVL & 0.12 & 0.12 & 0.11 & 0.11 & 0.11 & 0.056 \\
EN/SVL & 0.09 & 0.10 & 0.09 & 0.09 & 0.09 & 0.065 \\
4TD/4TP & 1.36 & 1.40 & 1.36 & 1.44 & 1.39 & 1.000 \\
3FD/3FP & 1.45 & 1.36 & 1.31 & 1.50 & 1.40 & 0.761 \\
\hline
\end{tabular}




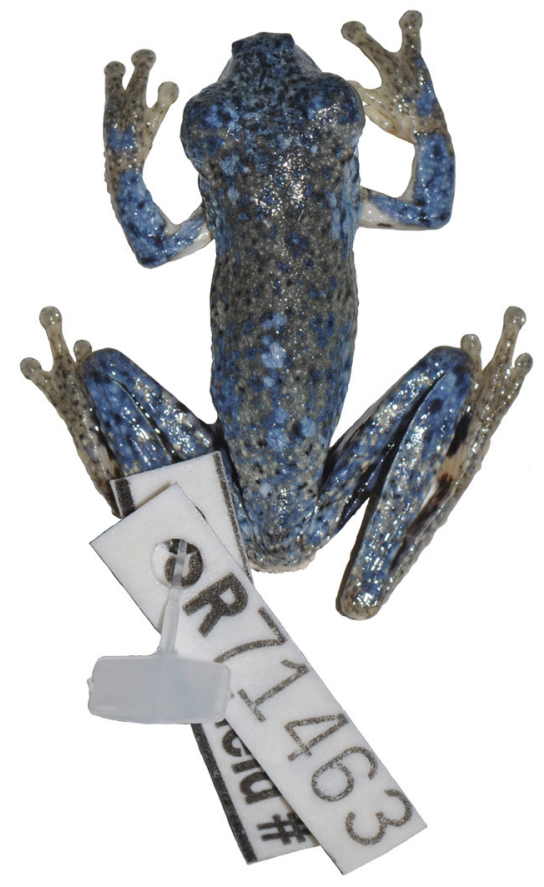

A

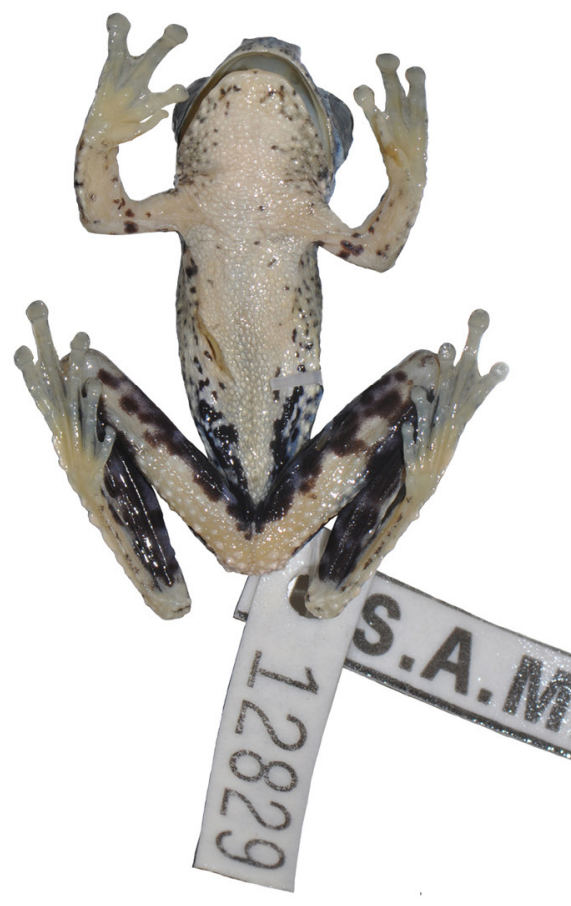

B

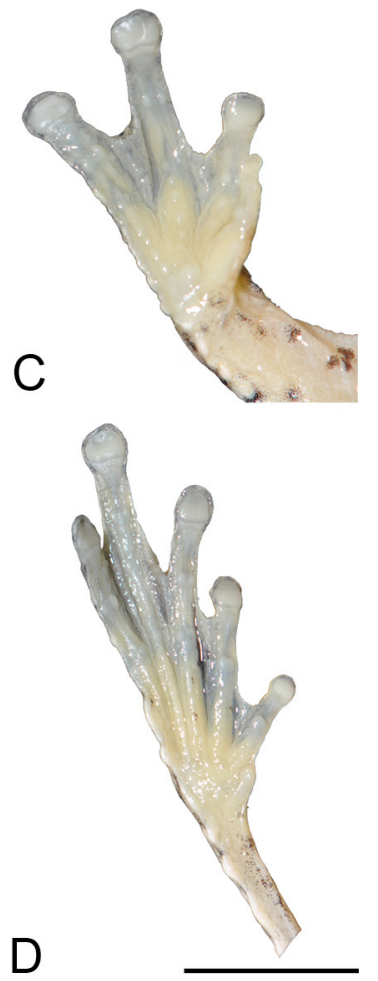

Figure 1. Views of Litoria aplini holotype (SAMA R71463) in preservative. $(A)$ dorsal; $(B)$ ventral (scale bar $=10 \mathrm{~mm}) ;(C)$ palmar; and (D) plantar surfaces (scale bar $=5 \mathrm{~mm})$.

In its moderate size (male SVL 30-35 mm), green and brown dorsal colour, extensively webbed fingers, and colourful ventrum and limbs in life, Litoria aplini most closely resembles the following six species: $L$. iris, $L$. majikthise, L. ollauro, L. richardsi, $L$. singadanae, and $L$. verae. It differs from all of these except $L$. singadanae and $L$. verae in having a prominent crenulated skin fold along outer margins of tarsi (vs a series of isolated pale tubercles along margins of tarsi). Litoria aplini can be further distinguished from $L$. iris by having posterior of belly and plantar surfaces golden-yellow (vs belly white and plantar surfaces without yellow), axilla without violet patch (vs present), posterior surfaces of thighs mottled blue and brown bordered ventrally by golden-yellow patch (vs posterior of thighs blue, red, or yellow, frequently blotched with white or purple); from $L$. majikthise by having posterior surfaces of thighs mottled blue and brown bordered ventrally by golden-yellow patch (vs uniform red), and by lacking a pearl-white post-ocular bar (vs present); from L. ollauro in having dorsum variably green and brown (vs uniform green or green with yellow spots), posterolateral surfaces of venter, ventral surfaces of tibiae, and hidden surfaces of thighs with extensive blue and dark-brown mottling (vs posterolateral surfaces of venter and hidden surfaces of thighs sky-blue without brown mottling, and ventral surfaces of thighs and tibiae uniform yellow); from $L$. richardsi in its larger size (males $31-35 \mathrm{~mm}$ vs $<27 \mathrm{~mm} \mathrm{SVL}$ ); dorsum without irregular black lines, and throat and finger and toe webbing without extensive black markings (vs present), and periphery of tympanic membrane not transparent (vs transparent); from $L$. singadanae in its larger size (males $31-35 \mathrm{~mm}$ vs $<30 \mathrm{~mm} \mathrm{SVL}$ ); in having posterolateral surfaces of belly and posterior surfaces of thighs with blue and brown mottling (vs posterior of venter and hidden surfaces of legs uniform orange), tympanum much smaller $(\mathrm{TYM} / \mathrm{EYE}=0.45-0.49$ vs $0.69-0.81)$, and pigmented (vs tympanic membrane transparent); and from $L$. verae in having posterolateral surfaces of belly and posterior surfaces of thighs with blue and brown mottling (vs posterior of venter and hidden surfaces of legs uniform yellow), feet dorsally with extensive areas of yellow (vs yellow absent) and dorsum without small brown spots aligned transversely (vs present). A summary of the major characters useful for distinguishing among these seven most similar species is presented in Table 3.

Molecular genetic comparisons. The final alignment for the mitochondrial ND4 gene comprised 694 bp. In a phylogram of relationships among mitochondrial ND4 sequences, the two sequences from $L$. aplini were the well supported sister group to a clade comprising $L$. iris and L. majikthise (Fig. $4)$. The net uncorrected sequence divergence $(d \mathrm{~A})$ for $N D 4$ between $L$. aplini and the two species in its sister clade was 0.14 for L. iris and 0.15 for L. majikthise (Table 1). $d \mathrm{~A}$ between sister species pairs ranged from 0.11 to 0.22 (Table 1).

Description of holotype. An adult male with right-lateral incision in abdomen. Vomero-palatines with two patches of small, poorly-defined teeth between internal nares. Vocal slits lateral, very long, extending from well behind angle of jaws to approximately $1 / 3$ distance between angle of jaws and front of mouth. Tongue oval with distinct posterior notch. Head moderately wide $(\mathrm{HW} / \mathrm{SVL}=0.30)$, slightly less than length $(\mathrm{HL} / \mathrm{SV}=0.35, \mathrm{HL} / \mathrm{HW}=1.15)$; loreal region steep, slightly concave; canthus rostralis rounded, distinctly curved; nostrils closer to tip of snout than to eyes; internarial distance greater than distance from external naris 

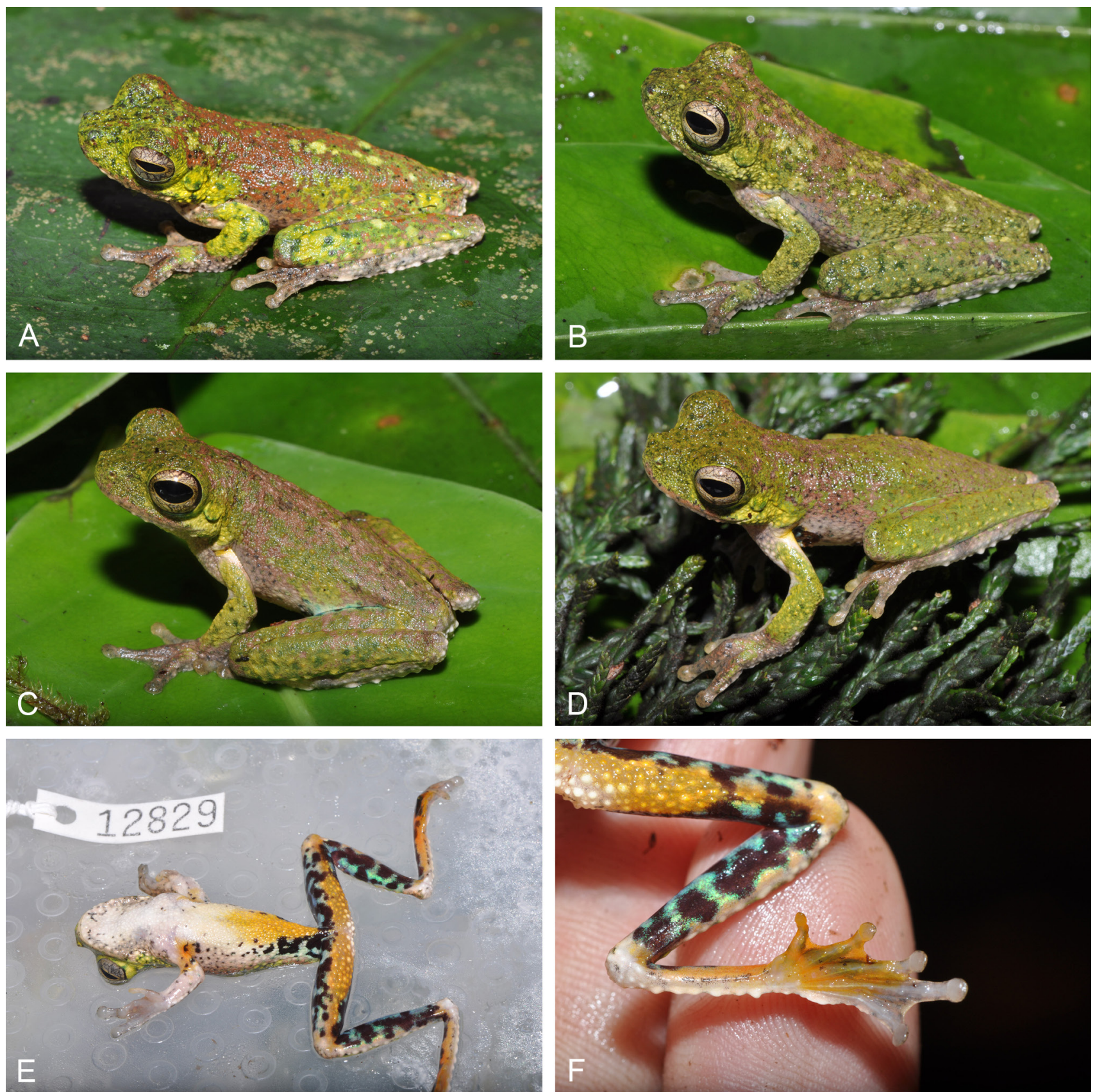

Figure 2. Type series of Litoria aplini in life: $(A)$ SAMA R71463; (B) SAMA R71465; (C) SAMA R71464; (D) SJR12834 (PNGNM); $(E)$ SAMA R71463, in ventral view; and $(F)$ SAMA R71463, ventral surfaces of hind limb.

to eye $(\mathrm{EN} / \mathrm{IN}=0.79, \mathrm{IN} / \mathrm{SVL}=0.12, \mathrm{EN} / \mathrm{SVL}=0.09)$; snout truncate when viewed from above, with slightly angular tip; steeply sloping when viewed from side; eyes large (EYE/ $\mathrm{SVL}=0.13$ ), prominent, protruding in dorsal and ventral views; tympanum prominent, raised above surrounding skin; tympanic ring distinct but top margin covered by thick supratympanic skin fold, horizontal diameter slightly less than half width of eye $(\mathrm{TYM} / \mathrm{EYE}=0.45)$.

Skin of dorsal and lateral surfaces including limbs, finely granular; ventral surfaces including limbs coarsely granular; patches of large ivory tubercles on ventral surface of thighs and around vent-largest around vent; a series of low tubercles along outer margin of tibiae and crenulated white skin fold on outer margin of F4 from proximal edge of disc extending along forearm to elbow, and prominent on outer margin of T5 from proximal edge of disc along tarsus to heel (Fig. 2F), patch of low ivory tubercles on heel.

Fingers moderately short with distinct lateral fringes, extensively webbed, webbing reaching slightly past penultimate tubercle on $\mathrm{F} 4$, to slightly below penultimate tubercle on outside of F3, and to level of penultimate tubercle on outside of F2; webbing between F1 and F2 greatly reduced; finger relative lengths $3>4>2>1$; tips of all fingers expanded into discs bearing circum-marginal grooves; disc on F3 approximately 1.4 times width of penultimate phalanx; palmar surfaces with numerous prominent tubercles (Fig. 1), subarticular tubercles at base of penultimate phalanx on F3-4 bilobed; first finger with elongate, brown nuptial 

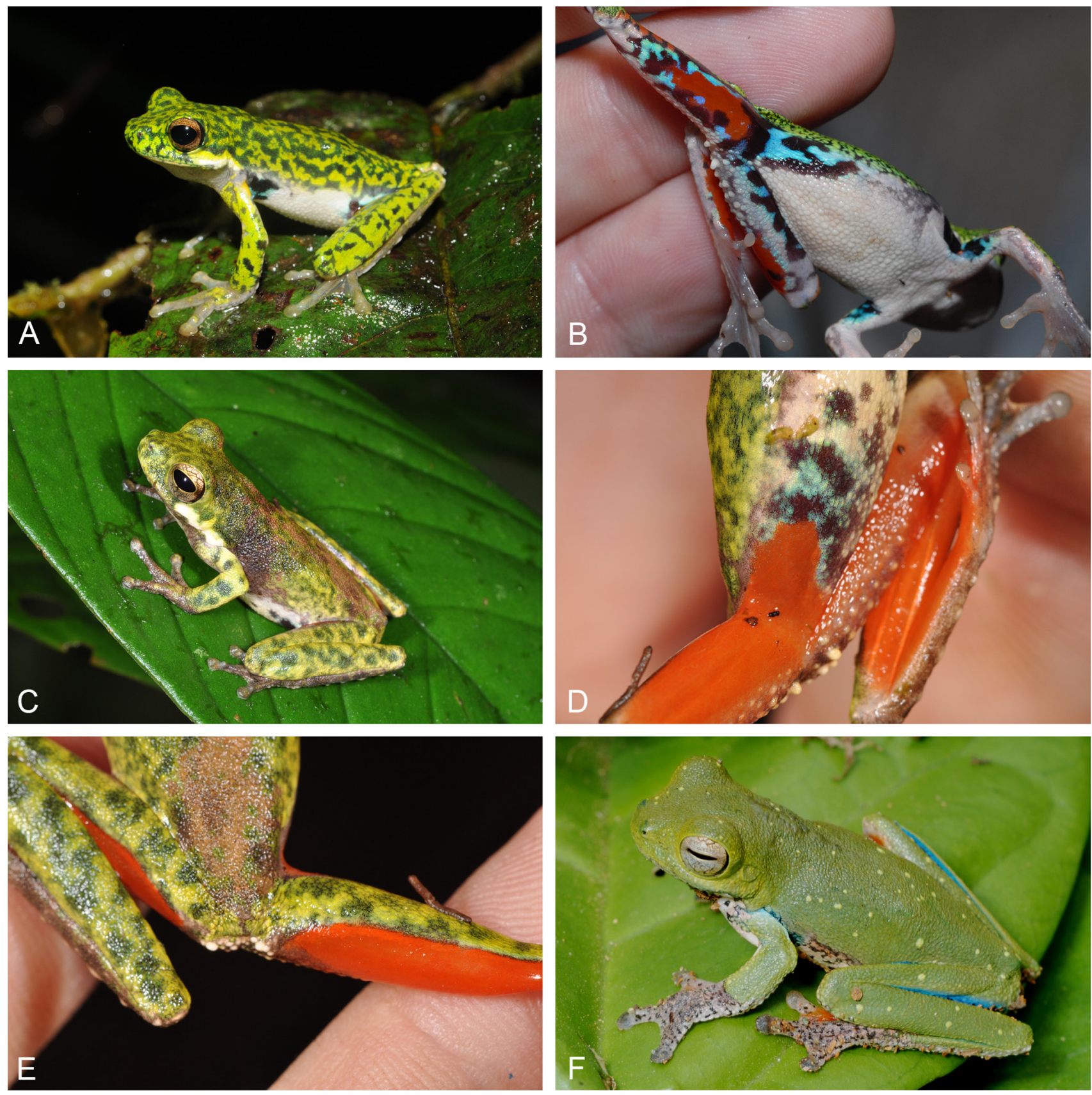

Figure 3. Closely related species that could be confused with Litoria aplini: (A) Litoria iris (SAMA R71615), adult male in life (Hindenburg Range, Western Province); (B) Litoria iris showing bright colours on hidden surfaces of the hind legs (unvouchered animal, Hela Province); (C) Litoria majikthise (SAMA R65042), in life, Muller Range, Western Province); (D, E) Litoria majikthise (SAMA R65042), showing colour ventrally and on hidden surfaces of hind limbs; and $(F)$ Litoria ollauro, Milne Bay Province, photo courtesy of Fred Kraus.

pad with narrow "handle" proximally, broadening distally at approximately mid-length $(1.7 \mathrm{~mm}$ long, $0.9 \mathrm{~mm}$ at widest point and $0.5 \mathrm{~mm}$ at narrowest point). Toes nearly fully webbed, web reaching to base of disc on T5, and on outside of T2 and T3, to base of penultimate phalanx on both sides of T4, and slightly beyond penultimate tubercle on T1 (Fig. 1); relative lengths $4>5=3>2>1$; tips of all toes expanded into discs with circum-marginal grooves; disc of T4 approximately 1.4 times wider than penultimate phalanx; subarticular tubercles at base of penultimate phalanx on T2-5 partially or completely bilobed; inner metatarsal tubercle elongate, bean shaped; outer absent. Hind legs moderately long $(\mathrm{TL} / \mathrm{SV}=0.56)$, with patch of small but prominent tubercles at heel.

Colour in life: body and limbs rufous brown dorsally and laterally, with small flecks of dark brown and large patches of green mottling posterolaterally and on arms, and pale green blotches on dorsum and limbs, most prominent being five blotches aligned anteroposteriorly on posterior half of mid-dorsum (Fig. 2A). Head predominantly pale green, mottled with flecks of dark green, green colouration extending laterally across tympanum to dorsal edge of axilla and on to forearms, blotch of green on dorsal surface of hand isolated from green on forearm. Iris pale grey with 


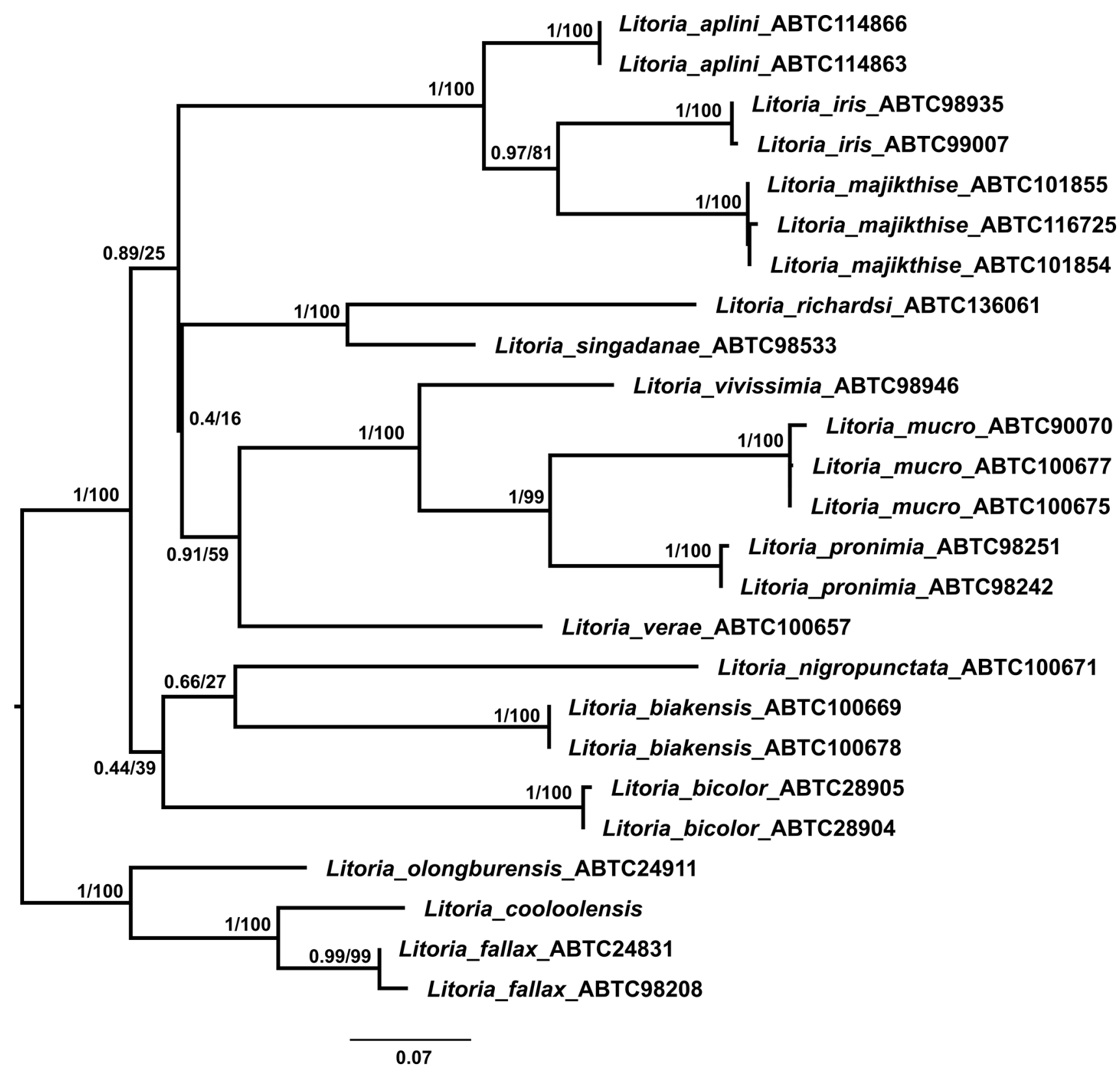

Figure 4. Maximum likelihood (ML) phylogram of relationships between mitochondrial ND4 nucleotide sequences of Litoria. Numbers at nodes are: left-Bayesian posterior probabilities, right-ML bootstrap proportions.

moderately dense dark-brown reticulations and pale gold inner rim without reticulations. Intensity and shade of dorsal green and brown colouration in life varied from beige to rufous brown depending on time of day, being darker (rufous brown, as shown in Fig. 2A) at night.

Ventrally white anteriorly with patches of grey laterally on throat, and small flecks and short reticulations of dark brown concentrated in a broad band around ventral edge of lower jaw; posterior half of venter and patch around axilla that extends on to base of arm golden-yellow; laterally darkbrown flecks extend from axilla to groin, these small and scattered anteriorly, becoming large interconnected blotches near groin. Anterior surfaces of thighs and tibiae pale blue, extensively mottled with deep brown; blue colouration extends anteriorly onto ventrolateral surfaces of belly but barely intrudes onto ventral golden-yellow patch. Posterior surfaces of thighs extensively mottled with blue and brown, bordered ventrally by broad band of golden yellow that narrows towards heel and incorporates patch of prominent tubercles of same colour. Ventral surfaces of tibiae pale iridescent blue with large dark-brown blotches; of tarsus suffused with golden-yellow, with peppering of fine darkbrown specks (Fig. 2E); plantar surfaces golden-yellow, except disc of T3, distal half of T4, and entirety of T5; these areas with, at most, light peppering of fine, dark-brown specks. Outer margins of limbs with pale crenulated skin folds, vent surrounded by patch of prominent pale tubercles, heel with cluster of small, ivory tubercles (Fig. 2F).

Colour in preservative: green markings have become shades of blue, large green dorsal blotches palest; background beige-brown has become mottled grey; dark-brown patches and flecks remain dark brown, but blue on limbs is darker and without iridescence; ivory of crenulated skin folds, and prominent tubercles around vent, have become more 


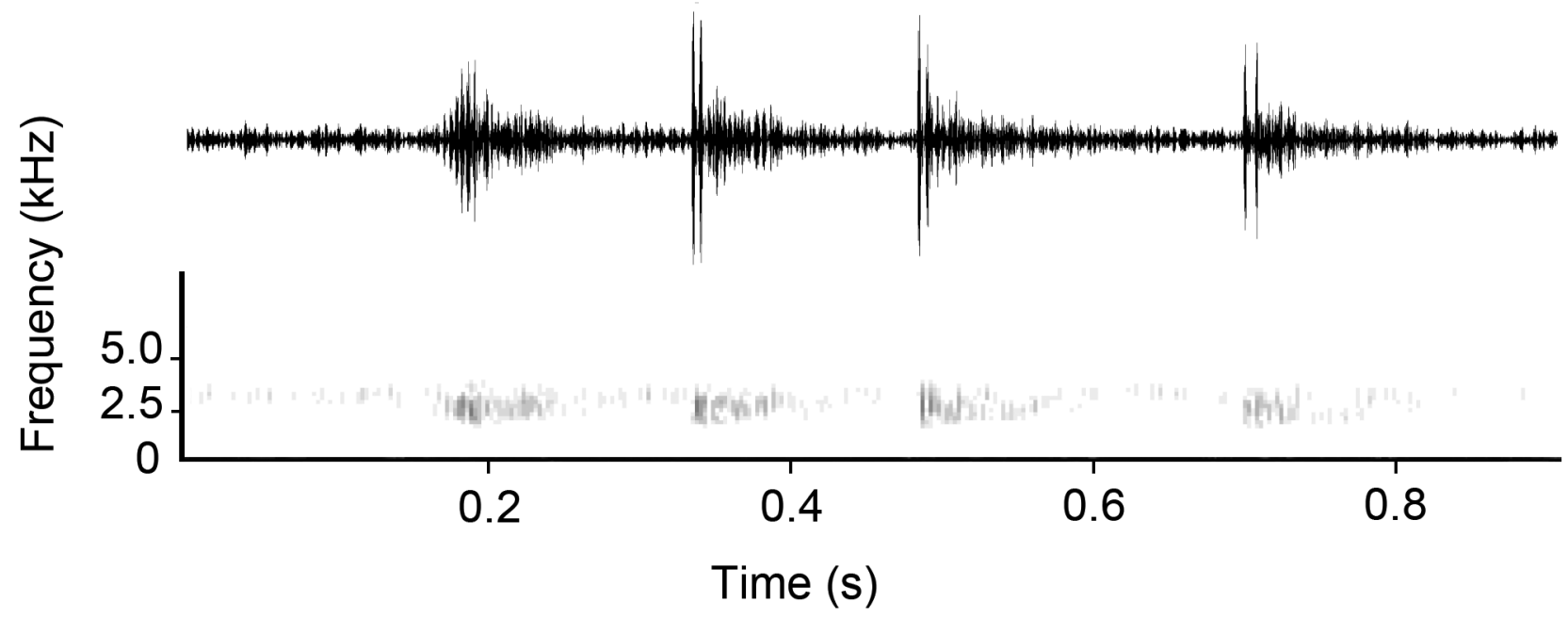

Figure 5. Advertisement call of the holotype of Litoria aplini (SAMA R71463), showing (top) wave form and (bottom) audiospectrogram of a four-note call recorded at $23.7^{\circ} \mathrm{C}$.

cream. Ventral surfaces predominantly cream, golden-yellow patches have disappeared except for slight suffusion on plantar surfaces and posterior of thighs.

Variation. The three paratypes are adult males; morphometric variation in the type series is limited (Table 4). The extent of green markings on the dorsum is variable (Fig. 2). All of the types have predominantly green heads and limbs, but in SAMA R71465 (Fig. 2B) brown on dorsum extends further anteriorly than in the other types, reaching to mid-way between eyes, and there are more extensive patches of mottled green, with more numerous pale green blotches dorsally; SAMA R71464 (Fig. 2C) is predominantly brown dorsally, with green restricted to dorsal surfaces of arms and legs, a large patch of mottled green posterolaterally, small, scattered patches of mottled green on dorsum and small green spot on each hand. SJR12834 (PNGNM) (Fig. 2D) is more uniformly green than the other specimens, lacking pale green spots and mottling. In life the three paratypes shared with the holotype a large golden-yellow patch posteriorly on the venter that was bordered by dark brown blotches; a large golden-yellow patch on the posteroventral surfaces of the thighs; and blue with dark brown blotches on the other hidden surfaces of the limbs. However, there is variation in the size, distribution, and connectivity of the brown blotches that border the ventral golden-yellow patch. In SAMA R71465 and SJR12834 (PNGNM) these are similar to the holotype, being interconnected to form a single large, irregular blotch, though the size of the blotch is variable; in SAMA R71464 the dark markings in the groin are not interconnected, instead forming a cluster of smaller, discrete blotches. Brown spotting on the anterior half of the venter is barely detectable in the holotype and two of the paratypes, but extensive in SAMA R71465.

Advertisement call. The advertisement call of L. aplini is a finely pulsed note (a "buzz") normally followed by one or more shorter clicking notes ("clicks") (Fig. 5). Twenty-two calls of the holotype recorded at an air temperature of $23.7^{\circ} \mathrm{C}$ were produced at a rate of 1.26 calls/s, lasted $0.16-1.21$ $\mathrm{s}$ (mean $=0.34, \mathrm{SD}=0.24, \mathrm{n}=20)$, and had a dominant frequency of $2150-3336 \mathrm{hz}($ mean $=2550, \mathrm{SD}=360, \mathrm{n}=$
18; however in most calls dominant frequency was between 2300 and $2400 \mathrm{hz}$ ). Most calls (20 of 22; 91\%) comprised a single buzz note lasting $0.026-0.062 \mathrm{~s}$ (mean $=0.046, \mathrm{SD}=$ 0.010 ), followed by one (13 of $22 ; 60 \%$ ) or up to seven, sharp multi-pulsed clicking notes lasting $0.005-0.020 \mathrm{~s}$ (mean $=$ $0.014, \mathrm{SD}=0.004, \mathrm{n}=29$ ). Note rate for multi-note calls was 3.98-6.99 notes/s (mean $=5.40, \mathrm{SD}=0.81, \mathrm{n}=17$ ). Pulses in buzz notes were produced too rapidly to count in all but one call, in which 15 pulses were produced at a rate of 272 pulses/s. Clicks consisted predominantly of two, but occasionally 1 or 4 , discrete pulses each lasting c. $0.005 \mathrm{~s}$. Pulse rate in click notes was much slower than in buzz notes, at around $166 \mathrm{pulses} / \mathrm{s}$. The distribution of energy in the two types of notes also differed, with amplitude in buzzes increasing gradually from the start of the call, and reaching maximum intensity near the end of the call before rapidly declining (Fig. 5); in contrast amplitude in the clicks was at or near maximum from the start of the call and then distributed uniformly until the end (Fig. 5). Although only one recorded buzz was not followed by one or more clicks, and only one recorded call was represented solely by a click, a number of additional calls comprising buzz and click calls produced in isolation were heard at the type locality.

Distribution and habitat. Litoria aplini is known from one location on the northern slopes of Papua New Guinea's central cordillera (Fig. 6), where it was collected from primary hill forest (Fig. 7A) at an altitude of $940 \mathrm{~m}$ a.s.l. The substrate at the type locality is limestone, and free-standing water was limited. The type series was collected from trees adjacent to a narrow, mostly dry gully where males called from perches up to five metres high over small $\left(<1 \mathrm{~m}^{2}\right)$, isolated pools of water in the base of the gully (Fig. 7B). However, no eggs or larvae were observed so the breeding strategy of this species remains unknown.

It is not known whether this species is endemic to forest on karst substrates, but there is increasing evidence for a suite of karst associated herpetofauna on the southern slopes of Papua New Guinea's central cordillera (Oliver et al., 2019a) so it is possible that a similar assemblage occurs in the much more poorly surveyed northern karst habitats. 


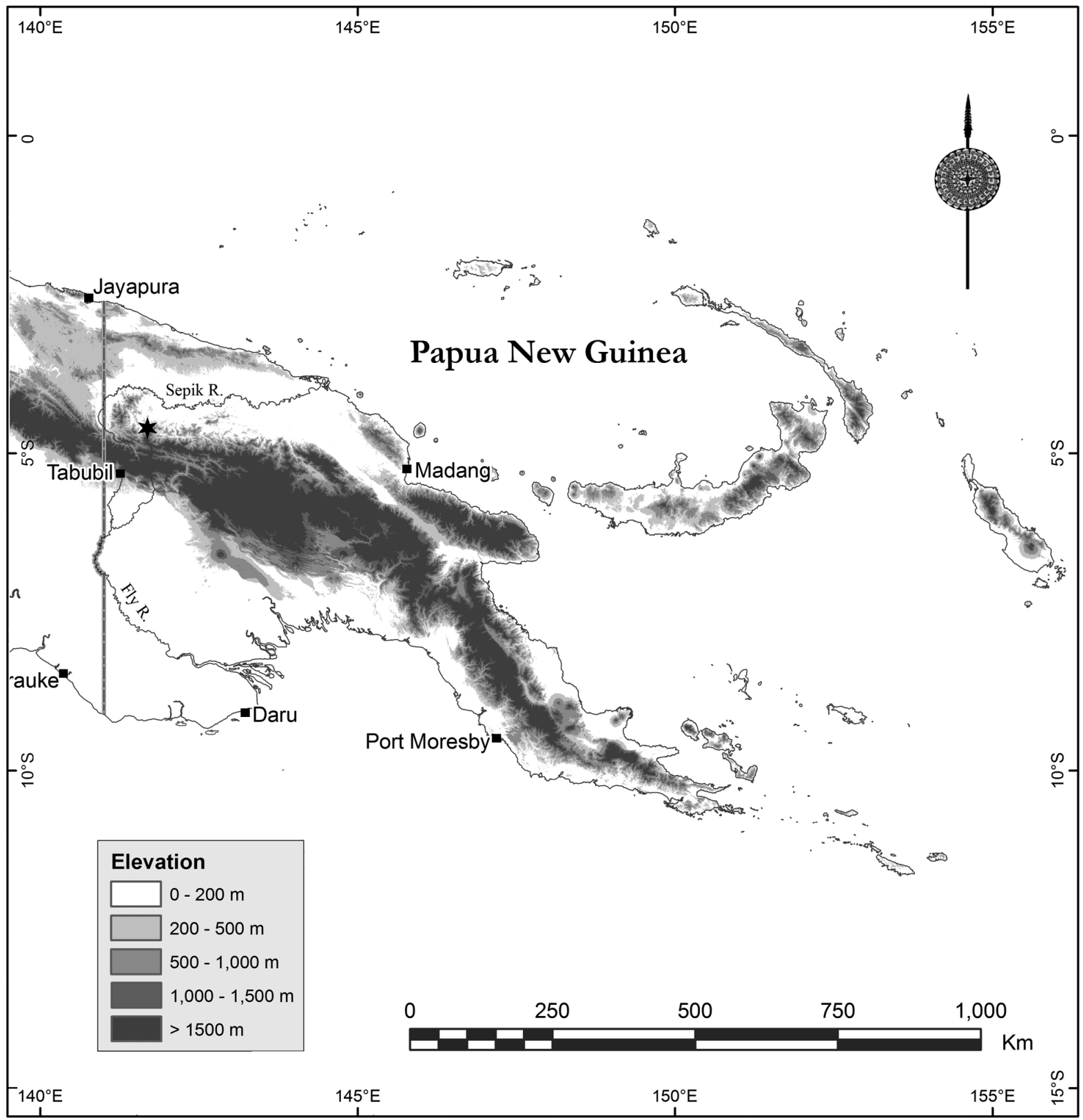

Figure 6. Map of Papua New Guinea showing the type locality of Litoria aplini.
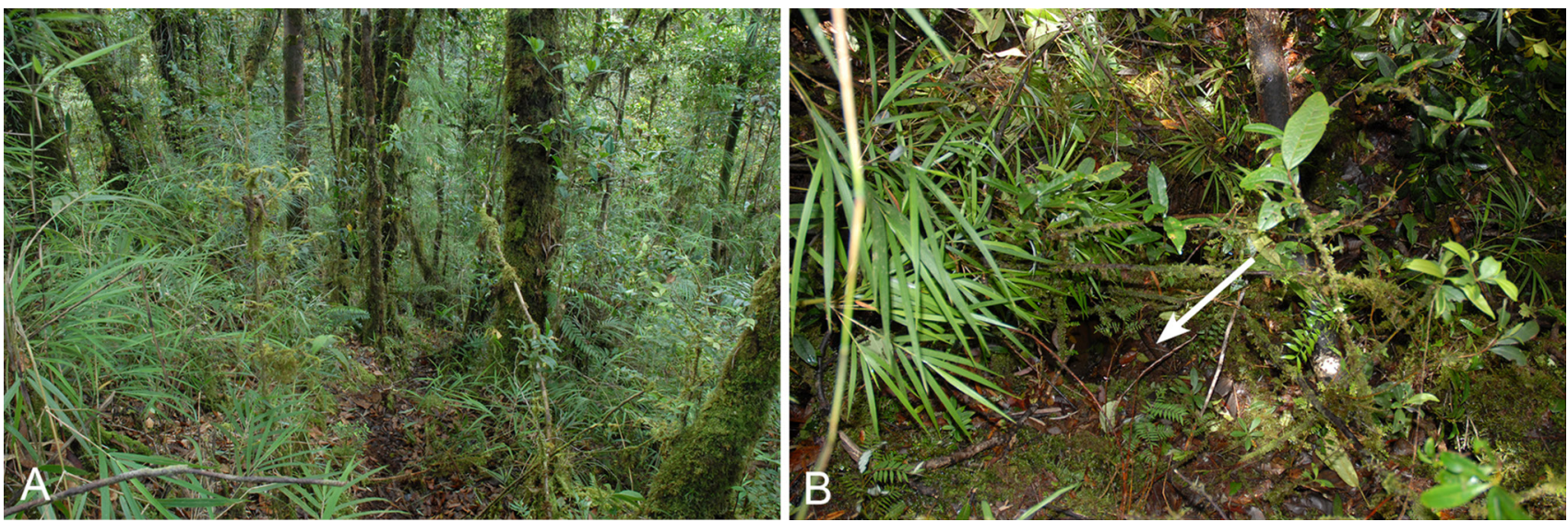

Figure 7. Habitat of Litoria aplini: $(A)$ forest interior at the type locality; and $(B)$ males were calling from trees over small pools (arrow) in the bed of a steep, narrow limestone gully. 
ACKnowledgements. Fieldwork in Papua New Guinea by SJR was approved by the PNG National Research Institute, and the PNG Department of Environment and Conservation (now the Conservation and Environment Protection Authority). Fieldwork in the Sepik River basin was supported by Frieda River Limited and SJR is particularly grateful to Michael Hawkins of FRL for his support. An ABRS Research and Capacity-Building grant (205-54) supported the nucleotide sequencing which was carried out by Luke Price and Leanne Wheaton. We thank Mark Hutchinson and Carolyn Kovach (South Australian Museum) for access to specimens in their care, Rainer Günther (Museum für Naturkunde Berlin) for providing valuable comparative tissue samples and Fred Kraus (University of Michigan) for providing images of Litoria ollauro. Lisa Capon kindly produced figures $1-3$ and 5-7 and Paul Oliver and Rainer Günther provided useful comments that greatly improved the manuscript.

\section{References}

Dennis, A. J., and M. J. Cunningham. 2006. Litoria richardsi sp. nov., a new treefrog (Anura: Hylidae) from New Guinea. Memoirs of the Queensland Museum 52: 65-69.

Duellman, W. E., A. B. Marion, and S. B. Hedges. 2016. Phylogenetics, classification, and biogeography of the treefrogs (Amphibia: Anura: Arboranae). Zootaxa 4104: 1-109. https://doi.org/10.11646/zootaxa.4104.1.1

Edgar, R. C. 2004. MUSCLE: multiple sequence alignment with high accuracy and high throughput. Nucleic Acids Research 32: $1792-1797$.

https://doi.org/10.1093/nar/gkh340

Günther, R. 2004. Two new treefrog species of the genus Litoria (Anura: Hylidae) from the west of New Guinea. Zoologische Abhandlungen (Dresden) 54: 163-175.

Johnston, G. R., and S. J. Richards. 1994. A new species of Litoria (Anura: Hylidae) from New Guinea and a redefinition of Litoria leucova (Tyler, 1968). Memoirs of the Queensland Museum 37: 273-279.

Kearse, M., R. Moir, A. Wilson, S. Stones-Havas, M. Cheung, S. Sturrock, S. Buxton, A. Cooper, S. Markowitz, C. Duran, T. Thierer, B. Ashton, P. Meintjes, and A. Drummond. 2012. Geneious Basic: an integrated and extendable desktop software platform for the organization and analysis of sequence data. Bioinformatics Applications Note 28: 1647-164. https://doi.org/10.1093/bioinformatics/bts199

King, M. 1981. A cytotaxonomic analysis of Australian hylid frogs of the genus Litoria. In Proceedings of the Melbourne Herpetological Symposium: The Royal Melbourne Zoological Gardens 19-21 May 1980, ed. C. B. Banks and A. A. Martin, pp. 169-175. Melbourne: Zoological Board of Victoria.

Kraus, F. 2013. A new treefrog of the Litoria gracilenta group (Hylidae) from Papua New Guinea. Proceedings of the Biological Society of Washington 126: 151-160. https://doi.org/10.2988/0006-324X-126.2.151

Kraus, F. 2018. Taxonomy of Litoria graminea (Anura: Hylidae), with descriptions of two closely related new species. Zootaxa 4457: 264-284. https://doi.org/10.11646/zootaxa.4457.2.3

Kraus, F., and A. Allison. 2004. A new species of Litoria (Anura: Hylidae) from southeastern New Guinea. Herpetologica 60: 97-103. https://doi.org/10.1655/03-07

Kraus, F., and A. Allison. 2006. Range extensions for reptiles and amphibians along the northern versant of Papua New Guinea. Herpetological Review 37: 364-368.

Lanfear, R., B. Calcott, S. Y. W. Ho, and S. Guindon. 2012. PartitionFinder: combined selection of partitioning schemes and substitution models for phylogenetic analyses. Molecular Biology and Evolution 29: 1695-1701.

https://doi.org/10.1093/molbev/mss020
Menzies, J. I. 1972. Papuan tree frogs of the Litoria nigropunctata group. Herpetologica 28: 291-300.

Menzies, J. I. 1993. Systematics of Litoria iris (Anura: Hylidae) and its allies in New Guinea and a note on sexual dimorphism in the group. Australian Journal of Zoology 41: 225-255. https://doi.org/10.1071/ZO9930225

Menzies, J. I. 2006. The Frogs of New Guinea and the Solomon Islands. Moscow: Pensoft.

Menzies, J. I., S. J. Richards, and M. J. Tyler. 2008. Systematics of the Australo-Papuan tree frogs known as Litoria bicolor (Anura: Hylidae) in the Papuan region. Australian Journal of Zoology 56: 257-280.

https://doi.org/10.1071/Z007068

Menzies, J. I., and M. J. Tyler. 2004. Litoria gracilenta (Anura: Hylidae) and related species in New Guinea. Australian Journal of Zoology 52: 191-214. https://doi.org/10.1071/ZO03008

Miller, M. A., W. Pfeiffer, and T. Schwartz. 2010. Creating the CIPRES Science Gateway for inference of large phylogenetic trees. In Proceedings of the Gateway Computing Environments Workshop (GCE), 14 November 2010, pp. 1-8. New Orleans, USA.

https://doi.org/10.1109/GCE.2010.5676129

Oliver, P., D. T. Karkkainen, H. Rösler, and S. J. Richards. 2019a. A new species of Cyrtodactylus (Squamata: Gekkonidae) from central New Guinea. Zootaxa 4671: 119-128.

https://doi.org/10.11646/zootaxa.4671.1.9

Oliver, P. M., S. J. Richards, and S. C. Donnellan. 2019b. Two new species of treefrog (Pelodrydidae: Litoria) from southern New Guinea elucidated by DNA barcoding. Zootaxa 4609: 469-484. https://doi.org/10.11646/zootaxa.4609.3.4

Rambaut, A., and A. J. Drummond. 2007. Tracer v1.4. http://beast.bio.ed.ac.uk/Tracer/

Renner, S. S. 2016. Return to Linnaeus's focus on diagnosis, not description: the use of DNA characters in the formal naming of species. Systematic Biology 65: 1085-1095.

https://doi.org/10.1093/sysbio/syw032

Richards, S. J. 2005. A new species of treefrog (Anura: Hylidae: Litoria) from the Huon Peninsula, Papua New Guinea. Zootaxa 1052: 29-39.

https://doi.org/10.11646/zootaxa.1052.1.3

Ronquist, F., and J. P. Huelsenbeck. 2003. MrBayes 3: Bayesian phylogenetic inference under mixed models. Bioinformatics 19: $1572-1574$.

https://doi.org/10.1093/bioinformatics/btg180

Rosauer, D., S. W. Laffan, M. D. Crisp, S. C. Donnellan, and L. G. Cook. 2009. Phylogenetic endemism: a new approach for identifying geographical concentrations of evolutionary history. Molecular Ecology 18: 4061-4072.

https://doi.org/10.1111/j.1365-294X.2009.04311.x

Stamatakis, A. 2014. RAxML Version 8: a tool for phylogenetic analysis and post-analysis of large phylogenies. Bioinformatics 30: $1312-1313$. https://doi.org/10.1093/bioinformatics/btu033

Tamura, K., D. Peterson, N. Peterson, G. Stecher, M. Nei, and S. Kumar. 2011. MEGA5: Molecular Evolutionary Genetics Analysis using maximum likelihood, evolutionary distance, and maximum parsimony methods. Molecular Biology and Evolution 28: 2731-2739.

https://doi.org/10.1093/molbev/msr121

Tyler, M. J. 1968. Papuan hylid frogs of the genus Hyla. Zoologische Verhandelingen 96: 1-203.

Tyler, M. J. 1999. Distribution patterns of amphibians in the Australo-Papuan region. In Patterns of Distribution of Amphibians: A Global Perspective, ed. W. E. Duellman, pp. 541-563. Baltimore: The Johns Hopkins University Press.

Tyler, M. J., and M. M. Davies. 1978. Species-groups within the Australopapuan hylid frog genus Litoria Tschudi. Australian Journal of Zoology, Supplemental Series 27(63): 1-47.

https://doi.org/10.1071/AJZS063 
Appendix 1. Specimens examined: ABTC-The Australian Biological Tissue Collection, South Australian Museum; $\mathrm{M}$ - morphological analysis; G-genetic analysis. Voucher origin (number of specimens in parentheses): BM-Natural History Museum, London; MJM-Michael J. Mahony field collection; MZB-Museum Zoologicum Bogoriense, Cibinong; QM-Queensland Museum, Brisbane; RMNH—Naturalis, Leiden; UP — University of Papua New Guinea Natural Sciences collection; SJR — Stephen J. Richards field collection; ZMB - Zoological Museum, Berlin.

\begin{tabular}{|c|c|c|c|c|c|c|}
\hline species & ABTC & voucher & locality & state/prov & country & comments \\
\hline L. albolabris & & SAMA R4947 M & Aitape & Sandaun & PNG & syntype \\
\hline L. aplini & ABTC114863 & SAMA R71463 ${ }^{\mathrm{G}}$ & Frieda River & East Sepik & PNG & holotype \\
\hline L. aplini & ABTC114866 & SAMA R71464 G & Frieda River & East Sepik & PNG & paratype \\
\hline L. auae & & $\mathrm{UP} 2490^{\mathrm{M}}$ & Purari River & Gulf & PNG & holotype \\
\hline L. auae & & SAMA R57262-3 ${ }^{\mathrm{M}}$ & Purari River & Gulf & PNG & paratypes \\
\hline L. biakensis & ABTC100669 & ZMB $67737^{\mathrm{G}}$ & Biak Is. & Papua & Indonesia & paratype \\
\hline L. biakensis & ABTC100678 & ZMB $68418^{\mathrm{G}}$ & Biak Is. & Papua & Indonesia & paratype \\
\hline L. bicolor & ABTC28905 & not found ${ }^{\mathrm{G}}$ & Black Point & NT & Australia & \\
\hline L. bicolor & ABTC28904 & not found ${ }^{\mathrm{G}}$ & Black Point & NT & Australia & \\
\hline L. chloronota & & BM1947.2.31.20 & Arfak Mtns & West Papua & Indonesia & syntype \\
\hline L. chloronota & & UP8380-8 ${ }^{\mathrm{M}}$ & Arfak Mtns & West Papua & Indonesia & \\
\hline L. contrastens & & SAMA R5845 M & Barabuna & Eastern Highlands & PNG & holotype \\
\hline L. contrastens & & SAMA R5847 (5) ${ }^{\mathrm{M}}$ & Noreikova & Western Highlands & PNG & paratypes \\
\hline L. cooloolensis & - & - & no locality & Qld & Australia & \\
\hline L. elkeae & & $\begin{array}{l}\text { MZB Amph.3866-9, } \\
\text { MZB Amph.3866-7, QM J7 }\end{array}$ & $\begin{array}{l}\text { Siewa } \\
0490-2 \text { м }\end{array}$ & Papua & Indonesia & paratypes \\
\hline L. fallax & ABTC24831 & MJM M008 G & Commissioners $\mathrm{Ck}$ & NSW & Australia & \\
\hline L. fallax & ABTC98208 & QM J72429 G & Littabella NP & Qld & Australia & \\
\hline L. havina & & UP $7281^{\mathrm{M}}$ & Ok Kam & Western & PNG & holotype \\
\hline L. havina & - & SAMA R69345-49 M & Ok Tedi headwaters & Western & PNG & \\
\hline L. iris & & BM $1961.1226^{\mathrm{M}}$ & Bamna & Chimbu & PNG & holotype \\
\hline L. iris & & SAMA R5423, 5874 M & Telefomin & Sandaun & PNG & \\
\hline L. iris & ABTC98935 & SAMA R71598 G,M & Gigira Ridge & Hela & PNG & \\
\hline L. iris & ABTC 99007 & SAMA R71599 G,M & Lake Tawa, Porgera & Enga & PNG & \\
\hline L. kumae & & UP3108 ${ }^{\mathrm{M}}$ & Tari & Southern Highlands & PNG & holotype \\
\hline L. kumae & & SAMA R52760-61 M & Tari & Southern Highlands & PNG & paratypes \\
\hline L. leucova & & SAMA R44091-2 & Mt Stolle & Sandaun & PNG & \\
\hline L. longicrus & & BM 1947.2.22.60-61 ${ }^{\mathrm{M}}$ & Wendessi & Papua & Indonesia & syntypes \\
\hline L. majikthise & ABTC116725 & SAMA R65042 G,M & Muller Range & Western & PNG & \\
\hline L. majikthise & ABTC101854 & SAMA R71600 G,M & Upper Strickland & Western & PNG & \\
\hline L. majikthise & ABTC101855 & SAMA R71601 G,M & Upper Strickland & Western & PNG & \\
\hline L. majikthise & & SAMA R44093 M & Tabubil & Western & PNG & holotype \\
\hline L. majikthise & & $\begin{array}{l}\text { SAMA R44094-44101, } \\
\text { UP } 6734,7305-9,8501-8,8\end{array}$ & $\begin{array}{l}\text { Tabubil } \\
602-3^{\mathrm{M}}\end{array}$ & Western & PNG & paratypes \\
\hline L. majikthise & & SAMA R65042-45 M & Muller Range & Western & PNG & \\
\hline L. mucro & & UP 2741-3, UP 2745-56 ${ }^{\mathrm{M}}$ & Rauit & East Sepik & PNG & paratypes \\
\hline L. muсro & ABTC90070 & SJR6187 G & Marina Valen & Papua & Indonesia & \\
\hline L. mucro & ABTC100675 & ZMB $70497^{\mathrm{G}}$ & Mt Waira, Yapen Is. & Papua & Indonesia & \\
\hline L. mucro & ABTC100677 & ZMB $70498^{\mathrm{G}}$ & Mt Amoman, Yapen Is. & Papua & Indonesia & \\
\hline L. mystax & & RMNH 4632 M & Moaif & Papua & Indonesia & holotype \\
\hline L. nigropunctata & ABTC100671 & ZMB $63977^{\mathrm{G}}$ & Mt Waira, Yapen Is. & Papua & Indonesia & \\
\hline L. nigropunctata & & SAMA R61799 M & Nr Konti, Yapen Is. & Papua & Indonesia & \\
\hline L. ollauro & & UP $4644^{\mathrm{M}}$ & Agaun & Milne Bay & PNG & holotype \\
\hline L. olongburensis & ABTC24911 & MJM $39700^{\mathrm{G}}$ & 20 km N Byron Bay & NSW & Australia & \\
\hline L. pronimia & АВTC98242 & SAMA R71131 G,M & Moran & SHP & PNG & \\
\hline L. pronimia & ABTC98251 & SAMA R71133 G,M & Gobe & SHP & PNG & \\
\hline L. richardsi & ABTC136061 & SAMA R71604 G, M & Upper Fly River & Western & PNG & \\
\hline L. richardsi & & SAMA R71602-3, 71605 & Upper Fly River & Western & PNG & \\
\hline L. richardsi & & SAMA R60283 M & Ok Tedi headwaters & Western & PNG & holotype \\
\hline L. richardsi & & MZB Amph.11823 M & Mamberamo Basin & Papua & Indonesia & paratype \\
\hline L. singadanae & ABTC98533 & SAMA R60172 ${ }^{\mathrm{G}, \mathrm{M}}$ & Surim & Morobe & PNG & holotype \\
\hline L. singadanae & & SAMA R60171, UP $9968^{\mathrm{M}}$ & Surim & Morobe & PNG & paratypes \\
\hline L. umarensis & & ZMB $62350^{\mathrm{M}}$ & Umar Bay & West Papua & Indonesia & paratype \\
\hline L. verae & ABTC100657 & ZMB $62384^{\mathrm{G}}$ & Wondiwoi Mountains & West Papua & Indonesia & \\
\hline L. vivissimia & АВТС98946 & SAMA R71127 G,M & Gigira & Hela & PNG & holotype \\
\hline
\end{tabular}





\section{INSTRUCTIONS TO AUTHORS}

Manuscripts must be submitted to the Editor. All manuscripts are refereed externally. Members of the Editorial Committee oversee the peer-review process and establish publication standards.

Only those manuscripts that meet the following requirements will be considered for publication.

Submit manuscripts and images separately and electronically; images should be high resolution TIFF or PSD (see below). Attach one summary file giving: the title, the name, address, email and ORCID of each author, the author responsible for checking proofs, a suggested running-head of less than 40 character-spaces, and the number of figures, tables and appendices. Manuscripts must be complete when submitted.

Tables and figures should be numbered and referred to in numerical order in the text. Authors should avoid excessive lay out or textual embellishments

All copy is manipulated within a Windows (not Mac) environment using Microsoft and Adobe software. Maps should be submitted as high resolution TIFF or PSD.

Maruscripts should be prepared using recent issues as a guide. There should be a title (series titles should not be used), author(s) with their institutional addresses, an abstract (should be intelligible by itself, informative not indicative), introduction (should open with a few lines for general, non-specialist readers), materials and methods, results (usually subdivided with primary, secondary and rarely tertiary-level headings), discussion, acknowledgments and references If appropriate, an appendix may be added after references.

In the titles of zoological works the higher classification of the group dealt with should be indicated. Except for common abbreviations, definitions should be given in the materials and methods section. Sentences should not begin with abbreviations or numerals, generic names should not be abbreviated if at the beginning of a sentence. Metric units must be used except when citing original specimen data. It is desirable to include geo-spatial coordinates, when reference is made to them, authors must ensure that their format precludes ambiguity, in particular, avoid formats that confuse arcminutes and arcseconds.

Label and specimen data should, as a minimum requirement, indicate where specimens are deposited, in addition to locality, date and collector. Original specimen data - especially that of type material-is preferred over interpreted data. If open to interpretation, cite original data between quotation marks or use "[sic]".

Rules of the International Code of Zoological Nomenclature must be followed; authors must put a very strong case if a Recommendation is not followed. When new taxa are proposed in works having multiple authors, the identity of the author(s) responsible for the new name(s) and for satisfying the criteria of availability, should be made clear in accordance with Recommendations in Chapter XI of the Code. A scientific name with more than two authors is unwieldy and should be avoided. Keys are desirable, they must be dichotomous and not serially indented. Synonymies should be of the short form: taxon author, year, pages and figures. A period and em-dash must separate taxon and author, except in the case of reference to the original description. Proposed ty pe material should be explicitly designated and, unless institutional procedure prohibits it, registered by number in an institutional collection.
Previously published illustrations will generally not be accepted. Colour is acceptable but only where necessary. All images must $(a)$ be rectangular or square and scalable to a width of $83 \mathrm{~mm}$ (= one text column) or $172 \mathrm{~mm}$ (= both text columns including central gutter) and any depth up to $229 \mathrm{~mm}$ (the number of lines in a caption limits depth), (b) have lettering similar to 14 pt, upper case, regular, sans serif/Helvetica or Arial, in final print, (c) have no unnecessary white or black space, and $(d)$ have vertical or horizontal scale bar(s) with the thickness approximately equal to an upper case $14 \mathrm{pt}$ letter " $\%$ ".

Digital images must be presented as TIFF, or as multilavered PSD files suitable for Adobe Photoshop. Halftone and colour images must be at a minimum resolution of 300 dpi at final size (at this resolution 2040 pixels $=$ printed-page width $=172 \mathrm{~mm}$ ) and all labelling must be sharp (with anti-alias active). Black and white line images (bitmaps) must be at a minimum resolution of 1200 dpi at final size (at this resolution, 8160 pixels = printed-page width).

When reference is made to figures in the present work use Fig. or Figs, when in another work use fig. or figs, the same case-rule applies to the words tables. Figures and tables should be numbered and referred to in numerical order in the text.

Authors should refer to recent issues of the Records of the Australian Museum to determine the correct format for listing references and to The Chicago Mamual of Style to resolve other matters of style. If EndNote is used, Chicago I6th B output-style closely approaces the required specification. CrossRef-minted DOI's are inserted automaticlly during copyediting (see crossref. org/SimpleTextQuery/); DOI minted by other agencies (e.g. DataCite) should be entered by authors.

Certain anthropological manuscripts (both text and images) may deal with culturally sensitive material. Responsibility rests with authors to ensure that approvals from the appropriate person or persons have been obtained prior to submission of the manuscript.

Stratigraphic practice should follow the International Stratigraphic Guide (second edition) and Field Geologist's Guide to Lithostratignaphic Nomenclature in Australia.

The Editor and Publisher reserve the right to modify manuscripts to improve communication between author and reader. Essential corrections only may be made to final proofs. No corrections can be accepted less than 10 days prior to publication without cost to the author(s). All proofs should be returned as soon as possible.

No duplicates or reprints are printed.

All authors, or the Corresponding Author on their behalf, must sign a Licence to Publish when a manuscript is submitted, and certify that the research described has adhered to the Australian Museum's Guidelines for Research Practice - or those of their home institution providing they cover the same issues, especially with respect to authorship and acknowledgment. While under consideration, a manuscript may not be submitted elsewhere.

More information and examples are frecly available at our website:

https://doi.org/10.3853/issn.2201-4349

Editor, Reconds of the Australian Susetum

Australian Museum Research Institute

Australian Museum, I William Street, Sydney NSW 2010, Australia editor@austmus.gov.au 


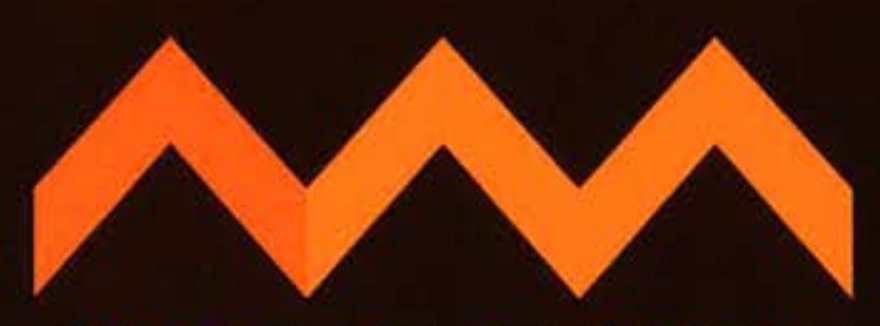

Australian Museum Research Institute

1 William Street, Sydney NSW 2010 scientific publications freely accessible at https://doi.org/10.3853/issn.2201-4349 ISSN 0067-1975 (print) 2201-4349 (online) 